\title{
Uurwerken en uurwerkmakers in Limburg, 1367-1850
}

Citation for published version (APA):

Mestrom, P. T. R. (1997). Uurwerken en uurwerkmakers in Limburg, 1367-1850. [, Maastricht University]. Universiteit Maastricht. https://doi.org/10.26481/dis.19971003pm

Document status and date:

Published: 01/01/1997

DOI:

10.26481/dis.19971003pm

Document Version:

Publisher's PDF, also known as Version of record

\section{Please check the document version of this publication:}

- A submitted manuscript is the version of the article upon submission and before peer-review. There can be important differences between the submitted version and the official published version of record.

People interested in the research are advised to contact the author for the final version of the publication, or visit the DOI to the publisher's website.

- The final author version and the galley proof are versions of the publication after peer review.

- The final published version features the final layout of the paper including the volume, issue and page numbers.

Link to publication

\footnotetext{
General rights rights.

- You may freely distribute the URL identifying the publication in the public portal. please follow below link for the End User Agreement:

www.umlib.nl/taverne-license

Take down policy

If you believe that this document breaches copyright please contact us at:

repository@maastrichtuniversity.nl

providing details and we will investigate your claim.
}

Copyright and moral rights for the publications made accessible in the public portal are retained by the authors and/or other copyright owners and it is a condition of accessing publications that users recognise and abide by the legal requirements associated with these

- Users may download and print one copy of any publication from the public portal for the purpose of private study or research.

- You may not further distribute the material or use it for any profit-making activity or commercial gain

If the publication is distributed under the terms of Article $25 \mathrm{fa}$ of the Dutch Copyright Act, indicated by the "Taverne" license above, 


\section{UURWERKEN EN UURWERKMAKERS IN LIMBURG, 1367-1850}

\section{PROEFSCHRIFT}

ter verkrijging van de graad van doctor aan

de Universiteit Maastricht, op gezag van de Rector Magnificus prof. mr. M.J. Cohen, volgens het besluit van het College van Dekanen, in het openbaar te verdedigen op vrijdag 3 oktober 1997 om 16.00 uur

door

P.TH.R. MESTROM 
Promotores: Prof. Dr. J.C.G.M. Jansen

Prof. Dr. Ir. C.A. Grimbergen (T.U. Delft, U. van Amsterdam)

Beoordelingscommissie:

Prof. Dr. A. Labrie (voorzitter)

Prof. Dr. W.E. Bijker

Prof. Dr. H.F.J.M. van den Eerenbeemt

(K.U.B. Tilburg)

Prof. Dr. R. van Uytven (U. van Antwerpen, K.U. Leuven)

Dr. J.C.M. Wachelder 


\section{Inhoudsopgave}

Lijst van grafieken, kaarten en tabellen ..................................IX

Lijst van geraadpleegde archieven .............................................

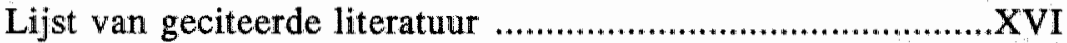

Lijst van gebruikte afkortingen ....................................XXIV

Inleiding XXXV

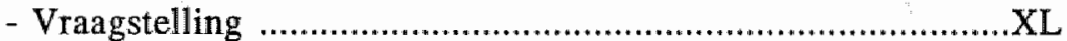

- Onderzoeksgebied ...............................................................

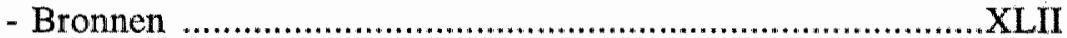

- Opzet van de studie ..........................................................XLV

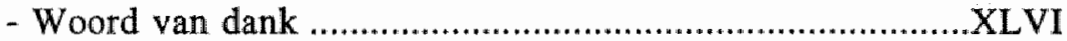

Hoofdstuk I. De ontwikkeling van het mechanisch uurwerk en de openbare tijdmeting 1

Hoofdstuk II. De openbare tijdmeting in Maastricht ................13

2.1. De stedelijke uurwerken .........................................14

2.1.1. Het uurwerk van de Lakenhalle .................................15

2.1.2. Het uurwerk van de Lanscroon ...................................19

2.1.3. Het uurwerk van het Dinghuis ..................................21

2.1.4. Het uurwerk van het stadhuis ..................................28

2.1.5. Het uurwerk van de Sint-Martinustoren .......................34

2.1.6. Het uurwerk van de Maasbrugtoren ............................. 35

2.2. De uurwerken aan kerkelijke gebouwen ....................37

2.2.1. Het uurwerk van het O.-L.-Vrouwekapittel ...............37

2.2.2. Het uurwerk van het Sint-Servaaskapittel ...................40

2.2.3. Het uurwerk van de Sint-Janstoren ...........................46

2.2.4. Het uurwerk van het Kruisherenklooster ....................49

2.2.5. Het uurwerk van het Minderbroedersklooster ..............50

2.3. De overige openbare uurwerken ...............................50

2.3.1. Het uurwerk van de Looierspoort ...............................50

2.3.2. Het uurwerk van kasteel Geusselt ............................51

2.3.3. Het uurwerk van kasteel Vaeshartelt .........................53

2.4. De stadsururwerkmakers van Maastricht .....................54 
Hoofdstuk III. De openbare tijdmeting in de Nederlands-

Limburgse steden Venlo, Weert, Sittard en Roermond .59

3.1. Venlo ....................................................................59

3.1.1. Het stadhuisuurwerk en de stadsuurwerkmakers ..........60

3.1.2. De andere stadsuurwerken .......................................70

3.1.3. De uurwerken aan Venlose kerken ............................71

3.2. Weert ....................................................................... 71

3.2.1. Het stadsuurwerk en de stadsuurwerkmakers ...............71

3.3. Sittard ...............................................................76

3.3.1. Het uurwerk van het gewanthuis en het stadhuis en de stadsuurwerkmakers ...........................................776

3.3.2. Het uurwerk van de Nederlands Hervormde kerk ........78

3.4. Roermond ............................................................80

3.4.1. Het stadsuurwerk in de Sint-Christoffeltoren en de stadsuurwerkmakers ...................................................80

3.4.2. Het uurwerk van de kapel van O.-L.-Vrouw in 't Zand

Hoofdstuk IV. De openbare tijdmeting in de Belgisch-Limburgse steden Hasselt, Tongeren, Sint-Truiden en Maaseik 89

4.1. Hasselt .................................................................89

4.1.1. De stadsuurwerken en de stadsuurwerkmakers ............90

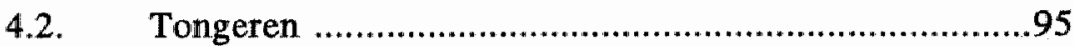

4.2.1. De stadsuurwerken en de stadsuurwerkmakers ...........96

4.2.2. Openbare uurwerken niet aan de stad behorend ...........99

4.2.2.1. Het uurwerk van de toren van de O.-L.-Vrouwekerk ...99

4.2.2.2. Het uurwerk binnen in de O.-L.-Vrouwekerk ............101

4.2.2.3. Het uurwerk van de Sint-Janskerk ............................102

4.2.2.4. Het uurwerk van de Begijnhofkerk ...........................102

4.3. Sint-Truiden .......................................................103

4.3.1. Het stadsuurwerk ...............................................103

4.3.2. De stadsuurwerkmakers .........................................108

4.4. Maaseik ................................................................110

4.4.1. De stadsuurwerken en de stadsuurwerkmakers .........110

Hoofdstuk V. De openbare tijdmeting in de kleine Limburgse steden

5.1. Belgisch-Limburg; inleiding 
5.1.1. Herk-de-Stad .......................................................115

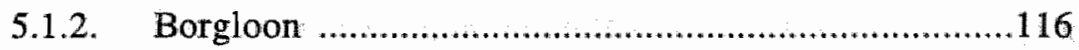

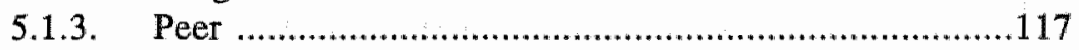

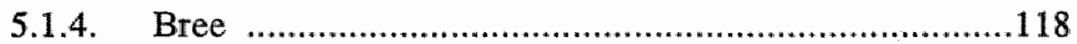

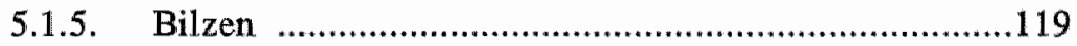

5.1.6. Hamont ...........................................................120

5.2. Nederlands-Limburg; inleiding ...............................121

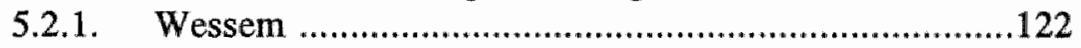

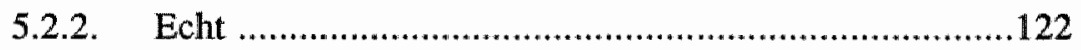

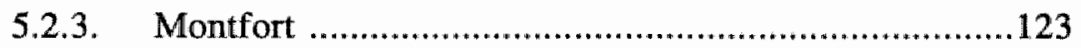

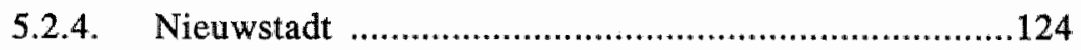

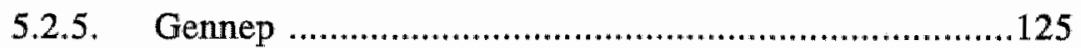

5.2.6. Valkenburg .................................................. 125

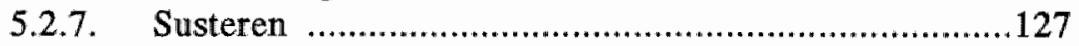

Hoofdstuk VI. De openbare tijdmeting in de Limburgse

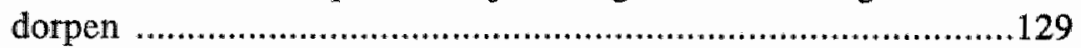

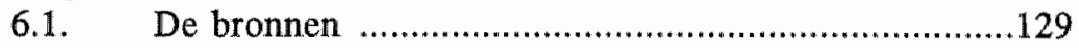

6.2. De spreiding van de openbare uurwerken .................135

Hoofdstuk VII. Technische aspecten van de Limburgse uurwerken .............................................................................143

7.1. Torenuurwerken ..................................................143

7.2. Huisuurwerken .....................................................149

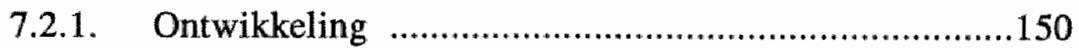

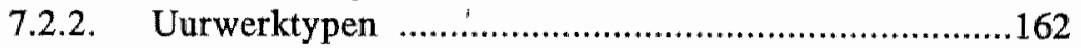

7.2.3. Kenmerken van het Limburgs huisuurwerk ...............166

7.2.4. Ontwikkeling van de wijzerplaat ............................ 180

7.2.5. De kasten van staande klokken: opbouw en decoratie ....................................................................193

7.2.6. Wandklokken: aantal, opbouw en vormgeving .........211

7.2.7. Luxe- en utilitaire producten .................................218

Hoofdstuk VIII. De Limburgse uurwerkmakers .....................223

8.1. De identificatie van de uurwerkmakers ....................223

8.2. De ontwikkeling van het vak .................................2224

8.2.1. De makers van torenuurwerken .............................224

8.2.2. De makers van huisuurwerken ...............................230 
8.3. De sociale positie van de uurwerkmakers 244

8.4. Joannes Brienen te Venray: enige aspecten van de bedrijfsvoering van een uurwerkmaker-winkelier eind 18 de eeuw

Hoofdstuk IX. De productie van Limburgse huisuurwerken ....257

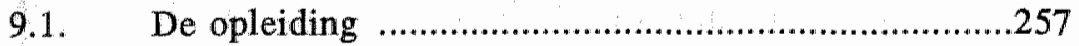

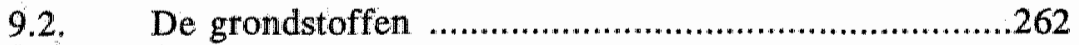

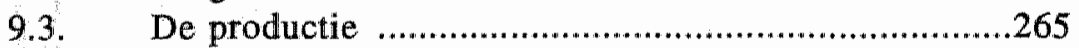

9.3.1. Werkplaats en gereedschap ...................................265

9.3.2. Zelfbouw of assemblage/toelevering? ......................267

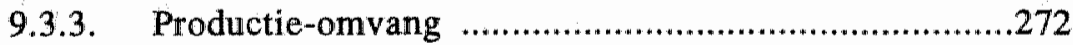

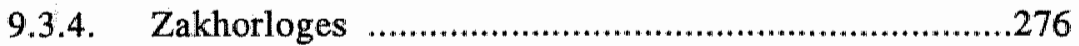

Hoofdstuk X. De verkoop en verspreiding van Limburgse

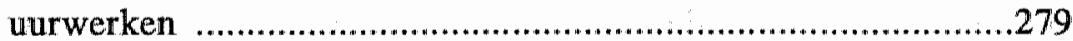

10.1. De sociale aspecten van de verspreiding ..................279

10.2. De prijs van een klokkast ......................................283

10.3. De verkoop van zakhorloges ..................................285

Hoofdstuk XI. Conclusies ..................................................291

11.1. Het openbare uurwerk ..........................................291

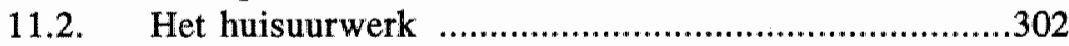

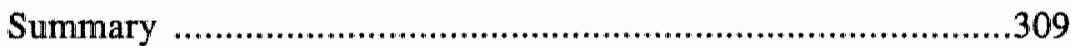

Appendix I. Lijst van uurwerkmakers per locatie chronologisch geordend

Appendix II. Alfabetische lijst van Limburgse uurwerkmakers; biografische gegevens en beschrijving van overgebleven uurwerken (zie bijgevoegde diskette) Appendix III. Documentatie betreffende de openbare tijdmeting in de Limburgse dorpen (zie bijgevoegde diskette) 


\section{Lijst van grafieken, kaarten en tabellen}

\section{Grafieken}

Grafiek 1. De variabele uren te Maastricht en Caîro ....................n................................6

Grafiek 2. Begin van de openbare tijdmeting in diwerse soorten plaatsen .................10

Grafiek 3. Hoogte wurwerken in mm tussen 1.720 en 1860 .................................170

Grafiek 4. Hoogte van wijzerplaten in mm tussen 1720 en $1860 \quad \ldots \ldots \ldots \ldots \ldots \ldots \ldots \ldots \ldots \ldots \ldots . . .190$

Grafiek 5. Verhouding hoogte wijzerplaathoogte urwerk tussen. 1720 en 1860 .....190

\section{Kaarten}

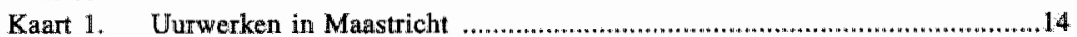

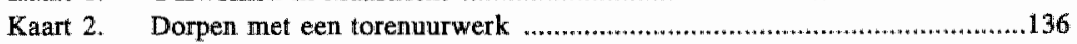

Tabellen

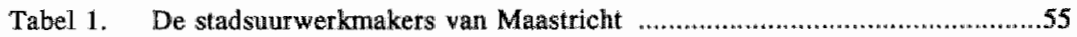

Tabel 2. De bezoldiging van de Maastrichtse stadsuurwerkmakers .........................57

Tabel 3. Aantal torenumerwen per tijdperk gesplitst naar bron ..........................135

Tabel 4. Unrwerkmakers en hom overgebleven en/of vermelde uurwerken ............163

Tabel 5. Hoogte wijzerplat in $\mathrm{mm}$ bij werschillende typen klokken $\mathrm{N}=83 \ldots \ldots \ldots \ldots . .189$

Tabel 6. Materiaal van de wijzers bij verschillende materialen van de

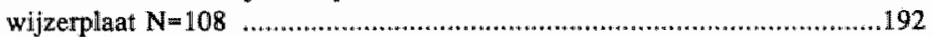

Tabel 7. Kasthoogte in mm bij verschillende typen Limburgse klokken $N=90$.....211

Tabel 8. Aantal vermelde Limburgse vurwerkmakers naar 25 -jarige periodes ......231

Tabel 9a. Aantal uurwerkmakers steden/platteland .............................................234

Tabel 9b. Uurwerkmakers in diverse steden .......................................................235

Tabel 10. Leningen aangegaan door Joannes Brienen, Venray ..............................252 


\section{Lijst van geraadpleegde archieven}

Algemeen Rijksarchief, "s-Gravenhage

Archief Ministerie wan Oorlog, archief van de kwartiermeester generaal en generale staf, inv.nr. 220-223: "Nombre des differentes especes d'artisans, tels que de menuisiers, de charrons, de marechaux, serruriers, fondeurs, maçons, boulangers, tailleurs, cordonniers etc." $[1815]$.

Archief der collegiale kerk van de H. Gummarus, Lier Acta Capitullaria 1700-1725.

Bedrijfsarchief Koninklijke Eijsbouts N.V., Asten.

Copy-boek nr. 5, copie nr. 42.

Verkoopboek over 1879-1906.

Domein Bokrijk

Inv.nir. B 57574.

Inv.nr. B69.1168.

Familiearchief Van Boom, privébezit Venlo

Aantekenboekje getiteld: "Over eenige weetenschappen die ik in de vremde bemerkt hebe als volgt. Hanover 3 Februa. 1799. C.I. van Boom".

\section{G.A. Echt}

Burgerlijke Stand.

\section{G.A. Gelinden}

Dorpsrekeningen 1755-1762.

\section{G.A. Gennep}

Stads Archief, inv.nr. 70/12, 87, 115/20.

G.A. 's-Gravenhage

H.M. Mensonides, Alfabetische lijst betreffende Haagse uurwerkmakers.

Notariele archieven, inv.nrs. 533, 535, 536, 712,732, 2184, 2629.

\section{G.A. Heerlen}

Landen var. Ovennaas, inv.nr. 6374, stukken betreffende de klokken, het luiden daarvan en het uurwerk der kerken van Heerlen en Voerendaal [en Welten].

\section{G.A. Heythwysen}

Burgerlijke Stand.

\section{G.A. Horst}

Burgerlijke Stand.

\section{G.A. Maastricht}

Archief van het arrondissement Maastricht en departement van de Nedermaas, inv.nr. 1044, inwonerslijst Maastricht van 1802 tot 1803 . 
Archief van het L.G.0.G., inv.nr. 86, J. de Beyer, tekening van het dorp Swolgen, 1741; Idem, inv.nr. 1021, J. de Beyer, tekening wan "de Kerck te Heel, een dorp int graefschap Hoorne, 1740".

Archief van het R.-K. Armenhuis, inv.nr. 1 .

Brabants Hooggerecht, criminele processen, 1783-1786, inv wr. 37 .

Brabants Hooggerecht, gichten 1700-1703, ongefolieerd, akte d.d. 18.11.1701.

Burgerboeken van Maastricht, Luikse zijde inv.nrs. 540 en 541 , Brabantse zijde inv.nrs. 916-922.

Burgerlijke Stand.

DTB-registers van alle parochies en gezindten.

Evacuatienummer 6995, gichten van de Vroenhof 1694-1697.

Fotoarchief, inv.nr. 367 (Dinghuis circa 1890) en inv.nr. 49343 (Vrijthof circa 1870).

Indivies Laaggerecht, voorlopig inv.nr. 3564, exhibitum 7 juli 1711.

Inwonerslijst Maastricht van 1802.

Laaggerecht Maastricht, Brabantse secretaris, inv.nr. 671.

Laaggerecht Maastricht, Luikse secretaris, inv.nr. 481.

Luikse gichten, reg.nir. 5526, inliggend vel tussen folio $205 \mathrm{vo}$ en $206 \mathrm{ro.}$

Modern archief inv.nr. 698, kiesregisters Maastricht, 1850.

NHG Lidmaten 1661-1691.

Notariële archieven, inv.nr. M 250a-b (notaris M.P.J.H. Jessé), inv.nr. 1146 (notaris L. de Vaulx), inv.nrs. 1175 en 1177 (notaris J.W. de Bombaijt), inv.nrs. 1236 en 1237 (notaris G. Bruysterbosch), inv.nr. 1276 (notaris Chr. Veestraten), inv.nrs. 1313 en 1314 (notaris J. Aussems), inv.nr. 1319 (notaris P. Bernardts), unv.nr. 1321d (notaris H. Schaepen),

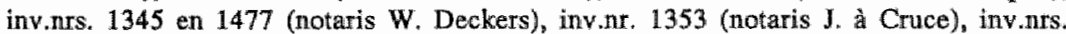
1374 en 1389 (notaris G. Demelinne), inv.nr. 1471 (notaris W. Costerus), inv.nr.. 1761 (notaris J.P.G. Veugen).

Oud-archief, Raadsverdragen, inv.nrs. 43-91.

Oud-archief, inv.nr. 72, p. 665, 21 maant 1703, verkoop van oud stadsuurwerk aan de choordeken van Lier.

Oud-archief, inv.nr. 151 (oud nr. 146), inhoudstafel op de Raadsnotulen der stad Maastricht.

Oud-archief, inv.nr. 212 (oud nr. 206), overeenkomst d.d. 17 januari 1685 van het stadsbestuur' met $J_{\text {. van }}$ Zutphen uit 's-Hertogenbosch voor de levering van een nieww torenuurwerk met speeltrommel voor het stadhuis.

Ond-archief, inv.nr. 218, ${ }^{H}$ Register der recessen, resolutien en ordonantien van de Ed. Mog. H.H. Commissarissen Deciseurs van beyde genadige Heeren en Princen deser stadt Maestricht begonnen MDCCLX"

Oud-archief, inv.nr. 300, "Discriptie van de horlogie", ongedateerd ${ }_{\text {" circa }} 1685$.

Oud-archief, inv.nr. 319, aanbesteding wan het onderhoud der stadsurumerken, fragnent van circa $1793 / 1794$.

Politieregister van Maastricht van het jaar 1825.

Prentcollectie, nr. 180.

Rekenboek der stad, 1590-1591, folio 90wo en 241 wo.

Rol van de bevolking der stad Maastricht opgemaakt in den maand maart 1816.

Tekeningen, plattegronden etc., inv.nr. 505 (tekering van het altarar van de Minderbroederskerk door Ph. van Gulpen) en inv.nr. 1133 (tekening van de Maasbrug door Ph. van Gulpen).

Volkstellingsregister van Maastricht 1816.

Zonder inv.nr., oud registratienummer 587R49, "Liste des docteurs et licenciés de l'une ou de plusieurs des quatre facultés de droit, médecine, sciences et belles lettres et des 
banquilers, agens de changê, négocians et marchands payant patente de l'une des deux premieres classes, domichlie a Maestricht", \pm 1811 .

\section{G.A. Nedenweer}

Burgerlijke Stand.

Gemeenterekeningen XVII-XX, 1782/83-1787/88.

Inwonerslijist, inw.nir: 1054 .

\section{G.A. Roermond}

Archief motarissen, inv.nr. 613, notaris H.A. Milliart.

Burgerlijke Stand.

Dossier 11.208.

DTB-registers.

Frans Archief.

Lijst van beroepsnamen circa 1850 -circa 1915 , inv.nr. 125 B 6.

Oud-archief, donderdagse protocollen, inv.nus. 1-60.

\section{G.A. Sittard}

Bevolkingsregister Sittard van 1847.

Burgerlijke Stand.

\section{G.A. Stevensweert} Bargerlijke Stand.

\section{G.A. Vaals}

Rapport der unterzeichnetenauf der vorigenordinaris Bancks Versamming wom 19 Junij 1792 angestellten Commission nebst 7 Beijlagen sub La $A, B, C, D, E, F, \&$.

Register der tesolutien genomen op de Bancksvergaderingen van Holset, Vaals en Vijlen, oud-archief, inv.nr. 2.

\section{G.A. Vernlo}

Archief wan het stadsbestuvir 1272-1814, inv.nrs. 1-930.

Beeld en Geluid, inv.nr. 710 ; afbeelding stadhuis Venlo, pen en penseel in klewr, 80 × 98 cm, toegeschreven aan J.G. Heldebeutel.

Burgerlijke Stand.

DTB-registers.

Knipselverzameling Müller, deel 2.

Oud-archief, burgerboeken, inv.nrs. 1448-1452.

Oud-archief, inv.nr. 640 .

Oud-archief, stadsrekeningen 1449-1458, inv.nrs. 68-77.

Parochiearchief Velden, 1713.

Schepenarchief Venlo, inv.nr. 2745.

Stadsrekening wan 1389 .

Volkstelling 1815.

\section{G.A. Venray}

Parochiearchief, doos 39.

Volkstellingsregister van 1812, voorlopig inv.nr. 215.

\section{G.A. Weert}

Burgerlijke Stand en Bevolkingsregister.

\section{XII}


Nieuw-archief, bevolkingslijst van 1839, inv.nr. 1196.

Nieuw-archief, inw.nt. 4.

Oud-archief, brief van de pastoor van de Sint-Martinuskerk aan de geneente, 1750 , inv.nr. 2729.

Oud-archief, magistraets resolutieboeck, inv.nus. 1-5.

Stadsrekening $1784 / 85$.

G.A. Yatton (G.B.)

Burgerlijke Stand.

G.A. Zaitbommel

Oud-archief, resolutiën van den magistraat d.d. 14.05.1733.

\section{G.A. Zonhoven}

Burgerlijke Stand.

General Staatsarchio Merseburg (D.)

Generaldirektorium Geldern, Titel CXXVII, nr. 2.

Hauptstaatsarchiv Düsseldorf (D.)

Roerdépartement, inv.nrs. 1710, 1711.

Roerdepartement, 1705 I, bevolkingslijst van Susteren uit 1799;1705 II; 1706 II.

Koninklijk Museum van Schone Kunsten, Brussel

Collectie Degrez inv.nr. 258, J. de Beyer, tekening wan de kerk te Grubbenworst, 1749.

\section{Parochiearchief, Gelinden}

Register 16: Computus fabricae et pauperum de Gelinden, folio 30 en 32.

\section{R.A. Hasselt}

Bocholt, gemeente, inv.nr. 35.

Bree, gemeente, inv.nrs. 93, 197, 198.

DTB-registers, bewolkingslijsten, Franse inwonerslijsten en Burgerlijke Stand van plaatsen waar nurwerkmakers werkzaam waren.

Familiearchieven, inv.nrs. 3875, 3729.

Fonds Hasselt.

Gelinden, rolregister 54 , folio 72 vo.

Kapittel Tongeren, kerkfabriek, inw.nrs. 426-445: rekeningen wan 1385 tot 1793 .

Notariaat Hasselt, nr. 5675A, 5677A, 5683A, 5684, 5692A.

Notariaat Maaseik, notaris Ignace Voss, microfilm nr. 1462343.

Notariaat Maaseik, inw.nrs. 2090, 2097, 3813, 4030, 4036, 4037, 4079, 4086, 4088-4089, $4102,4106,4583,5017,5022,5023,5787$.

Schepenbamk Maaseik, yaria zonder inventarisnummer.

Volkstelling Peer 1796, nr. 187.

\section{R.A. Maastricht}

Archief van de schepenbank Wijlre, bijlagen 1755-1756, nr. 7 en bijlagen 1791.

Archief van het kapittel van Onze-Lieve-Vrouw, Maastricht, voorlopig inv.nr. 422, protocollen van de kapittelvergaderingen $(1777-1786)$. 
Archief van het kapittell van Onze-Lieve-Vrouw, Maastricht, woorlopige inv.nrs. $915(37)$, 919(3) en 1157.

Archief van het Sint-Servaaskapittel, Liber privilegiorum et bonorum, fol. 37vo.

Archief van het Sint-Serwaaskapittel, Maastricht, I, folio CCCXVIverso.

Centrale huwelijksklapper, DTB-registers, bevolkingslijsten en Burgerlijke Stand van plaatsen waar uurwerkmakers werkzaam waren.

Frans Archief, inv.nrs, 1030-1062, inwonerslijsten uit 1796 van diverse plaatsen.

Frans Archief inv.nr. 1044, inwonerslijst van Maastricht, 1802.

Frans Archief, inv.nr. 4049, patentbelasting an VI therm. 8 (26 juli 1798)-an VII mess. 15 (3 juli 1799).

Frans Archief, inv.rur. 4091, etats nominatifs des patentables, 1811.

Frans Archief, inv.nr. 4320, decadaire rapporten van het kanton Meerssen 1798.

Handschriftencollectie, inv.nr. 100 , allbums met tekeningen van $\mathrm{M}$. Soiron $\mathrm{Jr}$.

Hof van Gelre te Venlo, inv.nr. 4, vonnissenboek.

Landen van Overmaas, inv.nrs. 273 en 274 (de staten van de kerken in de Staatse partages. van de Landen van Overmaas, opgemaakt in 1663).

Landen van Overmaas, inv.nr. 1321.

Landen van Overmaas, inv.nr. 7500, rapport van de bank-commissarissen alsmede de burgemeesteren van Ulestraten betreffende de kerkhorlogie en de schoolkamer te Meerssen.

Memories van successie.

Militieboeken.

Nieuw rechterlijk archief, invir. 891, Tribunal de le Instance, 1807.

Notariële archieven, inv.nr. 376, minuutakten vam notaris J.M. Lnijten te Geleen, 1816 (boedelverkoop van W.A. Wessels); inv.nr. 783, minutakten vam notaris J.F.R. van Halen te Heythuysen; inv.nr. 915, minuutakten wan notaris J.A.J. Kannegieter te Horst; inv.nr. 4411, minuutakten van motaris. J.J. Pingen te Venray.

Parochiearchief Oostrum (ongeordend) 1784.

Prentencollectie, inv.nt. 343.

R.K. Parochies, inv.nr. 14.C030, Horst inv.nr. 12.

Schepenbank Baarlo, inv.nr. 3121.

Schepenbank Venray, evacuatienummers $3871,3893,3956$.

R.A. Noord-Brabant, 's-Hertogenbosch

Kasteelarchief Heeze, stukken 1761 -1762.

\section{Rijksprentenkabinet, Amsterdam}

Inv.nr. 1921:48, tekening in pen en penseel van stadhuis te Venlo door Jan de Beyer, 1741 .

\section{S.A. Aachen}

Inv.nr. H 588, Chr. Quix, pentekening "Die Kirche zu Vijlen".

\section{S.A. Borgloon}

Archief O.C.M.W. van Borgloon, rekening van de armentafel van Jesseren, deels geïntegreerd in de rekeningen van de Administration d'assistance publique, eind 18e eeuw-1812. DTB-registers.

\section{S.A. Hasselt}

Burgerlijke Stand.

DTB-registers. 
Fonds Handel en nijverheid, augnstus 1852.

Inv.nr. 34/34/4\%, Recensement général de la population en 1814 ; tableau nomimatif des individus de chaque ménage.

Volkstelling van Hasselt, 1763, nr. 145.

Volkstelling van 1796, 1797, Luikerwijk.

\section{S.A. Maaseik}

Burgerlijke Stand.

\section{S.A. Sint-Truiden}

Bewolkingsregisters.

Burgerlijke Stand.

DTB-registers.

Inwonerslijst Sint-Truiden, 1796, ongenummerd.

Voikstelling Sint-Truiden 1808.

Zonder inv.nt., inwonerslijst van. Sint-Truiden uit 1796, lijstnummers 422-425.

\section{S.A. Tongeren}

Burgerlijke Stand.

Teylers Museum, Haarlem

Inv.nr. V 6, J. de Beyer, tekening van de kerk te Horst, 1738. 


\section{Lijst van geciteerde literatuur}

Abeler, J, Ullstein Uhrenbuch, Frankfurt a.M. 1975.

Abeler, J., Alt-Bergische Uhren und die Uhrmacherfamilien im Bergischen Land, Wuppertal 1976.

Abeler, J., Meister der Uhrmacherkunst, Wuppertal 1977.

Abeler, J., 5000 Jahre Zeitmessung dargestellt an den Uhren des Wuppertaler Uhrenmuseums und der J. u. G. Abeler Uhremwanderausstellung, Wuppertal 1978. (Tweede druk).

Ach lieve tijd: acht eeuwen Roermond en de Raermondenaren, Zwolle 1988-1989.

Ach lieve tijd: :wintig eeuwen Maastricht en de Maastrichtenaren, Zwolle 1994.

Adresboeken van Maastricht en Wijck: volgens officięle bronnen bewerkt, Maastricht 1875-1892.

Adresboek wan Roermond (1890), Roermond s.a.

Agt, J.F. van, Zuid-Limburg: Vaals, Wittem en Slenaken (De Nederlandse Monumenten van Geschiedenis en Kunst; 5), 's-Gravenhage 1983.

Alberts, W. Jappe, Geschiedenis van de beide Limburgen, (2 delen) (Maaslandse Monografieën; 15 en 17). Assen 1972 en 1974. (Deel I: tot 1632. Deel II: vanaf 1632 tot \pm i918).

Alberts, W. Jappe, Venlo in het midden van de vijftiende eeuw, in: "Van der Nyersen upwaert" : een bundel opstellen over Limburgse geschiedenis aangebaden aan drs. M.K.J. Smeets bij zijn afscheid als Rijksarchivaris in Limburg. Maastricht 1981, pp. $85-94$.

Andriesse, C.D., Titan kan niet slapen : een biografie van Christiaan Huygens, Ansterdam/Antwerpen 1994.

Art ancien au pays de Liège, $L^{\prime}$, Liège 1905. (Tentoonstellingscatalogus).

Asselberghs, V.J.J.M., De schatrekening van Horst over 1753, in: Horster Historiën / onder redactie van P.A.M. Geurts (et al.), (deel 2), Horst 1988, pp. 175-192. (Deel 2: Van heren en gemeentenaren).

Aus der Uhrzeit : die Uhrensammlungen des Musewms für Angewandte Kunst und des Kölnischen Stadtmuseuns / bearbeitet von Helmut Krieg, Köln 1987.

Bachiene, W.A., Vaderlandsche geographie, (deel V), Amsterdam 1779.

Baillie, G.H., Watchmakers and Clockmakers of the World, London 1974.

Baillien, $\mathrm{H}_{\text {, }}$ Inventaris van de fondsen van het O.-L.-Vrouwekapittel, de plebanie, de kerken van Sint-Jan, Sint-Niklaas, Sint-Gillis en Sint-Hubertus, Brussel 1967.

Bairoch, P., Europe's gross mational product: 1800-1975, in: The journal of European economic history, 5(1976), pp. 273-340.

Bassermann-Jordan, E. von en H. von Bertele, Oude klokken; vertaald door J. Zeeman, Haarlem/Antwerpen 1978.

Bastelaer, R. van Les estamper de Peter Bruegel l'Ancien, Bruxelles 1908.

Bax, W. (et al.), Gedenkboek der Nederlandsche Herwormde Gemeente van Maastricht, 1632-1932, Maastricht 1932.

Beckering Vinckers, J., Zalt Bommel, Amsterdam 1944.

Beekman, A.A., De Klokken van Delft, Zutphen 1887.

Beeson, C.F.C., English church clocks 1280-1850: their history and classification, London 1971 .

Beeson, C.F.C., Perpignan 1356 : the making of a tower clock and bell for the King's castle, London 1982. 
Bérgé, W., Heimwee naar de klassieken : de beelden van Mathieu Kessels en zin vijdgenoten, 1815-1840, Zwolle 1994. (Catalogus wan de gelijkramige tentoonstelling in het Noordbrabants Museum, 's-Hertogenbosch).

Bergen, W.H. van, Geleen in de Franse tijd, in: Geleen door de eewwen heen, Geleen 1989, pp. 56-79.

Bergevoet, M.J.J., Het voonmalig kerkhof aan de Ganzenstrat te Venlo (verwolg), in: Limburgs Tijdschrift voor Genealogie, 22(1994), pp. 102-107.

Berryer, A.M. et L. Dresse de Lëbioles, La mesare du temps à travers les agges anx musées royaux d'art et d'histoire, Bruxelles 1974 . (2e édition revue et complétée).

Beurden, A.F. van, [wordt geciteerd als Handelingen] De handelingen van den magistraat der stad Roermond wan het jaar 1596 tot en met 1792, in: Limburg's Jaarboek, 9(1903); pp. 3-261 (I); 10(1904), pp. 261-306 (II); 11(1905), pp. 231-268 (III); 12(1906), pp. 194-261 (V); 13(1907), pp. 3-55 (V); 14(1908), pp. 46-60 (VI).

Beurden, A.F. van, De stadshuishouding van Roermond in den ouden tijd : Ao 1579, in: Limburg's Jaarboek, 10(1904), pp. 122-136, 177-21.2.

Bieurden, A.F. van, Well en Bergen : extracten uit het resolutieboek vanaf 1767 , in: Limburg's Jaarboek, 11(1905), p. 323.

Beurden, A.F. van, Het "Verdrachsboek" der stad Roermond vanaf 1574-1656, in: Limburg's Jaarboek, 14(1908), pp. 137-178.

Beurden, A.F. van, Het burgerboek der stad Roermond wam af 1562-1793, Sittard s.a., pp. 19-46. (Overdruk vam. Limburg's Jaarboek 16(1910)).

Beurden, A.F. van, Roermonds ontwikkelingsgang: schetsen wit de stadsgeschiedenis, Sittard 1915.

Beurden, A.F. van, Gennepsche gildeleden, in: Limburg's Jaarboek, 23(1917), pp. 121 125.

Beurden, A.F van, Venlo en zijn stadhwis, in: Buiten : getlltustreerd weekblad aan her buitenleven gewijd, 17(1923) nr. 30(juli), pp. 356-358.

Beyers, J.G.Th.M., De beroepsstructuur van Zuid-Limburg in 1796, Melick 1980. (Scriptie nr. 140 van het Sociaal Historisch Centrum voor Limburg te Maastriclit).

Bilfinger, G., Die Mittelalterlichen Horen und die Modernen Stunden : ein Beitrag zur Kulturgeschichte, Stuttgart 1892. (Onveranderde herdruk Wlesbaden 1969),

Blitterswijk: Noord-Limburgs dorp met een rijke historie, Blitterswijk 1981.

Bloch, Marc, A vènement et conquêtes du moulin à eau, in: Mélanges historiques, (tome II), Paris 1963, pp. 800-821.

Bloemen, J., Matthijs Kessels, in: Limburg's Jaarboek, 15(1909), pp. 264-286.

Boekennieuws, in: De Maasgotw, 44(1924), pp. 22-23.

Boermans, H., Nogmaals: Venlo's klokkenmakers, in: Dagblad voor Noord-Limburg, 27 augustus 1964, p. 11, kolom 7 .

Bos, N., Lijst van Nederlands-Limburgers (1839-1845) die kozen woor de Belgische nationaliteit, in: Linuburgs Tidschrift voor Genealogie, 19(1991), pp. 60-64, 80-90; 20(1992), pp. 11-19.

Boschen, L., Die Annales Prumienses : ihre nähere wnd ihre weitere Verwandschaft, Düsseldorf 1972.

Boselie, P.H.M., Hoedemakers uit Lutterade, een familie van (hoef)smeden, "vecartsen" en boomkwekers in de 18 de-eeuwse Euregio , in: Historisch jaarboek voor het Land won Zwentibold, 14(1993), pp. 137-146.

Braudel, F., Beschaving, economie en kapitalisme (15de-18de eeuw), (deel I), Amsterdam 1987. (Deel I: De structuur van het dagelijks leven).

Britten, F.J, Old clocks and watches and their makers: being an historical and descriptive account of the different styles of clocks and watches of the past, in England and abroad, Woodbridge 1977. (Reprint of the 3d edition, 1911). 
Britten's Old clocks and watches and their makers, New York 1956.

Brockmans, C. Beringen, stad en buitingen, Paal s.a.

Broek, H. wan de, Uarwerknakers uit de 17 de en 18 de eeuw te Hamont, in: Limburg, 38(1959), pp. 66-70.

Broek, H. wan de, "Pontpenningen" in het land van Grevernbroek, in: Limburg, 46(1967), pp. 229-235.

Browwers, J, De klokken van Gelinden, in Limburg, 41(1962), p. 219.

Browwers, $J_{\text {. }}$ Reformatie van het Sint-Odulphuskapittel te Borgloon in 1613 door Nuntius Antonio Albergati, in: Het Oude Land van Loon : jaarbaek van de Federatie der Geschied-en Oudheidkundige Kringen van Limburg, 38(1983), pp. 5-25.

Brugmans, IJ., Statistieken wan de Nederlandse nijverheid wit de eerste helft der $19 \mathrm{e}$ eeuw (Rijks Geschiedkundige Publicatiën; grote serie nF. 98), 's-Gravenhage 1956.

Bijdrage tot de geschiedenis van Hamort, Hamont 1976.

Caluwaerts, G., Hasselt intra muros : Hasselt binnen de oude wallen : historiek van straten, pleinen, gebouwen en huizen zoals opgetekend door Jan Juliaan Melchior (1848-1920), Hassellt 1989.

Cameron, R., La France et le développenent économique de l'Europe (1800-1914), Paris 1971.

Carillon wan St. Serwaas, Het, in: De Maasgouw, 8(1886), p. 74.

Ceulemans, C. en J. Helsen, Het kunstpatrimonium van het O.C.M.W. van Tongeren, Tongeren 1991. (Fotoinventaris van het Belgisch kunstbezit Openbare Centra voor Maatschappelijk Welzijn provincie Limburg).

Chapuis, A., De horologisis in arte, Lausanne 1954.

Christaller, W., Die zentralen Orte in Süddeutschland : eine ökonomisch-geographische Untersuchung über die Gesetzmässigkeit der Verbreitung und Entwicklung der Siedlungen mit städtischen Funktionem, Jena 1933. (Herdruk Darmstađt 1980).

Cipolla, C.M., Clocks and culture, 1300-1700, London 1967.

Cipolla ${ }_{n}$ C.M. Before the industrial revolution: European society and economy, 10001700, London 1989. (2de druk).

Cittert-Eymers, J.G. wan en M.J. Hagen, Zonmewijzers aan en bij gebouwen in Nederland en enige astronomische (toren)uurwerken, Zutphen 1984.

Crasborn, P., De Thornse uurwerkmakers Schoufs, in: De Kroetwès : mededelingenblad van de Geschied-en Heemkundige Kring "Het Land van Thorn", 4(1990) nr. 2(oktober), pp. 43-49.

Creemers, $\mathrm{Ch}$, Bescheiden betreffende Gennep en zijn voormalige heerlijkheid, in: PSHAL, 32(1895), pp. 2-223.

Croonenberghs, J., De oude "stad en wrijheid" Stockheim, Mechelen aan de Maas 1896.

Damsma, D, J.M.M. de Meer en L. Noordegraaf, Statistieken van de Nederlandse nijverheid mit de eerste helft der 19 e eeuw : supplement (Rijks Geschiedkundige Publicatiën; grote serie nr. 168), "s-Gravenhage 1979.

Daniëls, M.J.M., Daniels : een geslacht uit het Overkwartier wan Gelre, in: Gens Nostra, 46(1991), pp. 154-182.

Daris, J., Histoire de la bonne ville, de l'église et des comtes de Looz: suivie de biographies lossaines, ( 3 delen), Liège 1864-1867.

Daris, J., Notices sur les églises du diocèse de Liège, (17 delen), Liège 1874-1899.

Davies, A.C., Rural clockmaking in eighteenth-century Wales: Samuel Roberts of Llanfair Caereinion, 1755-1774, in: Business History Review, 59(1985) 1(Spring), pp. $49-75$.

Deilos, J.G., Torenuurwerk te Gulpen, in: De Maasgouw, 17(1895), p. 23.

Dejong, A.A.M.N., Zwanezang van het Maastrichtse goud- en zilversmedenambacht, in: Miscellanea Trajectensia, Maastricht 1962, pp. 523-556.

Delhougne, E.M.A.H., Genealogieĕn van Roermondse geslachten, Maastricht 1956. 


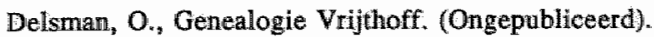

Derix, L., Oud Horst in het nieuws, (deel I), Horst 1990. (Deel I: 1843-1900).

Derry, T.K. and T.I. Williams, A short history of technology from the earliest times to A.D. 1900 , Oxford 1960 .

Dessureault, Chr., J.A. Dickinson and Th. Wien, Liwing standards of Norman and Canadian peasants 1690-1835, in: A.J. Schuurman and L.S. Walsh (eds.), Material culture: consumption, life-style, standard of living, 1500-1900, Milano 1994. (Proceedings eleventh International Economic History Congress, Milan, September 1994, B4).

Dicks, M., Die Abtei Camp am Niederrhein: Geschichte des ersten Cistercienserklosters in Deutschland (1123-1802), Moers 1915.

Dillis, E., L'ancien carillon et la vieille horloge de Saint-Jacques à Anvers, Anvers 1912.

Dohrn-van Rossum, G., Die Geschichte der Stunde : Uhren und moderne Zeitordnung, München/Wien 1992.

Doorman, G., Het Nederlandkch octrooiwezen der 19e eeuw, 's-Gravenhage 1947.

Doppler, P., Het carillon wan. St. Servass, in: De Maasgouw, 8(1886), p. 74.

Doppler, P., De uurwerken en klokkenspelen van St. Servaas kerk, in: De Maasgoww, 9(1887), pp. 129-130, 133-135.

Doppler, $\mathbb{P}$., Uurwerk op den kerktoren te Wyck, in: De Maasgouw, 16(1894), p. 19.

Doppler, P., Torenuurwerk te Helden in de XVIIle eeuw, in: De Maasgouw, 20(1898), p. 68.

Doppler, $\mathbb{P}$. Uurwerk en klokkenspel van de O.L.Vr. in de 17 de eeuw te Maastricht, in: De Maasgoum, 53(1933), deel 48, p. 57 .

Doppler, P., Schepenbrieven van het kapittel van O.L. Vrouw te Maastricht (1283-1767), s.1. s.a. (Overdruk uit PSHAL, LX, LXI, LXI, LXIII).

Dorren, Th., Akkoord over het maken eener klok, in: De Maasgouw, 22(1900), p. 67.

Dorsch, A.J., Statistique du departement de la Roer, Cologne An XII [1804].

Dowson, D., History of tribology, London/New York 1979.

Driessen, M., Zonnewijzers in Limburg, Herk-de-Stad 1979.

Dumont, B., Aux origines des communes : les communautés villageoises dans les pays de Dalhem et de Limbourg XVle-XVIIe siècle: genèse, structures, évolution, Bruxelles 1994.

Dijck, G.C.M. van, Bossche uurwerkmakers (Klokken en horloges in de $16 \mathrm{e}-17 \mathrm{e}$ eeuw), in: De Brabantse Leeww, 31(1982) 6(november/december), pp. 177-187.

Edwardes, E.L., Old weight-driven chamber clacks, 1350-1850, (IV volumes), Altrincham 1977.

Elzas, M., Het horloge in den loop der eeuwen, Zutphen 1935.

Emmel, $F_{\text {, }}$ Wilhelm Remmen in Luxemburg, in: Limburgs Tijdschrift voor Genealogie, 17(1989), p. 74 .

Emst, S.P., Histoire du Limbourg, suivie de celle des contes de Daelhem et de Fauquemont, des annales de l'abbaye de Roldac, (7 delen), Liège 1837.1852.

Escaille de Lier, H. I', Kroniek van Baarlo onder Maasbree (uit de Rekeningen opgemaakt), in: Limburg's Jaarboek, 16(1910), pp. 268-273.

Etains anciens Huy-Liège du XVWIème au XIXème siècle : millénaire 985-1985/catallogue par Maurice Lorenzi, s.l. 1985.

E[versen], J., Voorwaarden van aanbesteding en levering van het carillon der St-Servaaskerk te Maastricht, 14 Mei 1767, in: De Maasgouw, 5(1883), pp. 890-891.

Evrard, R, Dom Nicolas Spirlet, maître de forges à Poix, au Châtelet et au Fourneau Saint-Michel, Liège 1952.

Familie Poeijn, in: Limburg's Jaarboek, 6(1898/1899), p. 30.

Fehrmann, C.N., De Kamper klokgieters, hun naaste verwanten en leerlingen, Kampen 1967. (Dissertatie Amsterdam). 
Flament, A.J.A., Chroniek van de Heerlijkheid Weert, getrokken uit de stadsrekeningen, charters en andere oorspronkelijke bescheiden, in: PSHAL, 9(1892), pp. 131-276.

Flament, A.I.A., Oudheidkundige monumenten en voorwerpen te Urmond, in: De Macesgoww, 32(1910), p. 56 .

Flament, A.J.A., De gilden te Venlo, vooral onder het oogpunt van kunst en kunstnijverkeid, in: De Maasgoww, 35(1913a), pp. 57-59, 65-67.

Flament, A.J.A., Een belangmijke industrie in het dorpje Brunssum in de $18 \mathrm{e}$ eeuw, in: $D e$ Maasgouw, 35(1913b), pp. 81-82.

Flament, A.J.A., Inkomstenregistertjes der kerk, der pastorie, koster en armen van Montfort (L.), in: De Maasgouw, 36(1914), pp. 25-28, 34-36.

Flament, A.J.A., Chroniek wan Maastricht wan 70 na Chr. tot 1870 : witgegeven, met bijwogsels, verbeteringen, enz en geschiedkundige inleiding, Maastricht 1915. (Facsimile uitgave Maastricht 1980).

Forschelen, Jac., De armenzorg te Thorn in de negentiende eeuw, in: P. Crasborn (et al.) (red.), Opera Omnia: een verzameling geschied-en heemkandige opstellen, Thom 1990, pp. 50-77.

Gaier, C., L'Industrie et le commerce des armes dans les principautés belges du XIIIme a la fin du XVme siecle, Paris 1973.

Gedenkboek Geleen: van dorp tot Mauritsstad, Geleen 1952.

Gemessene Zeit: Uhren in der Kulturgeschichte Schleswig-Holsteins: Ausstellung zum 100 Jährigen Jubiläum 1875-1975, Schleswig-Holsteinisches Landesmuseum, Schleswig Schloß Gottorf 1975.

Genabeek, J. van, De afschaffing van de gilden en de voortzetting van hun functies, in: NEHA jaarboek, 57(1994), pp. 63-91.

Generale lyst der doctoren en andere personen in de provincie Limburg gevestigd, welke de onderscheidene takken der geneeskunde vermogen uitteoeffenen, zynde dezelve opgernaakt voor het jaar 1819, ingevolge het reglement gearresteerd by Zyner Majesteits resolutie van 31 mei 1818 , krachtens de wet wan 12 maart bevorens, in: Administratief Memoriaal, (1819) nr. 66, pp. 181-193.

Gerits, J., Uurwerkmakers in Vlaanderen XVIII, in: Ons Heem, 31(1977), pp. 18-19.

Gerits, J., Histarische steden in Limburg, s.1. [1989].

Gerits, J., Een nieuw torenuurwerk te Mielen-boven-Aalst (1857), in: Ons Heem, 47 (1993a) nr. 2, p. 108.

Gerits, I., Thomas Dekens van Tongeren maakte een uurwerk voor de kerk van Borgloon (1529), in: Ons Heem, 47(1993b) nr. 2, pp. 104-106.

Gerits, J., Uurwerken uit enkele Limburgse verzamelingen, in: Ons Heem, 47(1993c) nr. 2, pp. 106-107.

Gerits, J., Uurwerkmaker Antonius $\mathbb{J}$. Smeets van Hamont herstelde in 1784 het torenuur werk van Bocholt, in: Ons Heem, 47(1993d) nr. 2, pp. 102-103.

Gerits, J., Uurwerkmaker Gerard Smets van St.-Truiden werkte voor Borgloon, in: Ons Heem, $47(1993 \mathrm{e})$ nr. 2, p. 108.

Gerits, T.J., Losse aantekeningen over Limburgse uurwerkmakers uit de 18 de eeuw, in: Limburg, 41(1962), pp. 177-178.

Geschledenis yan Heusden: Heusden-Honeüken: twee Heren, eén Parochie, Heusden 1978.

Geuskens, P., De Rentelaershof te Vlodrop, in: Jaarboek van de Heemikundevereniging Roerstreek, 28(1996), pp. 63-89.

Gils, P.J.M. van, Kerkxekening van Stewensweert van 1578, in: De Maasgouw, 55(1935), pp. 25-27.

Gimpel, J., La révolution industrielle du Moyen Age. Paris 1975. 
Goole, F. en P. Severijns, Famille kroniek Aerts, krantenartikel in: Het Belang wart Limburg, 13.05.1992.

Grawwels, J., Dagboek van gebeurtenissen opgetekend door Christiacn Munters, 15291545 (Maaslandse Monografieën; 13), Assen 1972.

Grauwels, J., De parochiekerk wan Ordingen in de $17 \mathrm{e}$ en $18 \mathrm{e}$ eeuw, in: Het Oude Land van Loon: jaarboek van de Federatie der Geschied-en Oudheidkundige Kringen wam Limburg, 30(1975), pp. 159-175.

Grauwels, J., De aartsdiakenale visitaties van het dekenaat Beringen (1646-1726), in: Het Oude Land van Loon: jaarboek van de Federatie der Geschied-en Oudheidkundige Kringen van Limburg, 32(1977); pp. 33-190.

Grauwels, J., De aartsdekenale visitaties van Groot-Hasselt (1613-1763), in: Het Oude Land van Loon : jaarboek van de Federatie der Geschied- en Oudheidkundige Kringen van Limburg, 37(1982a), pp. 33-133.

Grauwels, J., De bouw van de Hasseltse laken-en vleeshalle in 1670, in: Het Oude Land wan Loon: jaarboek van de Federatie der Geschied-en Oudheidkundige Kringen van Limburg, 37(1982b), pp. 135-158.

Grauwells, J., Kroniek van Hasselt (1078-1914): grepen wit het dagelijks leven, Hasselt $1982 \mathrm{c}$.

Granwels, J., De aartsdiakenale visitaties van het dekenaat Maaseik (1646-1726), in: Het Oude Land wan Laon : jaarboek van de Federatie der Geschied-en Oudheidkundige Kringen van Limburg, 38(1983a), pp. 27-230.

Grauwels, $J_{*, \ldots}$ De visitaties van de kerk van Hoepertingen, in: Limiburg, 62(1983b), pp. $117-122$.

Groot, J. de, Zaitbommel, Zaltbommel 1979.

Guicciardijn, L., Beschryvinghe wam alle de Neder-landen: anderssins ghenoemt NederDuytslandt, Amsterdam 1612.

Gutmann, M.P., War and rural life in the early modern Low Conntries (Maaslandse Monografieën; 31), Assen 1980 .

Guye, S. et H. Michel, Mesures du temps et de l'espace : horloges, montres et instruments anciens, Fribourg 1970.

Haas, J.A.K., De verdeling van de Landen van Overmaas 1644-1662 : territoriale desintegratie van een betwist grensgebied (Maaslandse Monografieën; 27), Assen 1978.

Habets, I., Middeleeuwsche klokken en klokinschriften in het bisdom van Roermond, in: PSHAL, 5(1868), pp. 313-346.

Habets, J., Bijdragen to de geschiledenis van de voormalige stad Susteren en van de adellijke voormalige vrouwenabdij Sint Salvator aldaar, in: PSHAL, 6(1869), pp. 441567.

Habets, I., Chronijk der landen van Overmaas en der aangrenzende gewesten door eenen inwoner van Beek bij Maastricht (1275-1507), in: PSHAL, 7(1870), pp. 5-231.

Habets, J., Geschiedenis van het tegenwoordig bisdom Roermond en van de bisdommen. die het in deze gewesten zijn voorafgegaan, (4 delen), Roermond 1875-1927.

Hackeng, $\mathbb{R}_{.,}$Inventaris van de archieven van de parochie van de H.Petrus te St. Pieter, 1545-1954, Maastricht 1.987.

Hall, J.H.M.M, van, Enkele bijzonderheden over de koperfabricage te Eijsclen in de jaren 1612-1714, in." "Van der Nyersen upwaert" : een bundel opstellen over Limburgse geschiedenis aangeboden aan drs. M.K.J. Smeets bij zijn afscheid als Rijksarchivaris. in Limburg, Maastricht 1981, pp. 215-228.

Hamers, M.E.C., Inventaris van het archief van de schepenbank Horst 1501-1799, Malastricht 1985.

Hana, J., Klokken, Bussum 1961. 
Hansotte, G., Fays de fer et de houille, in: H. Hasquin (ed.), La Wallonie: le pays et les hommes : histoire, économies, societés, (tome I), s.1. 1975, pp. 269-294. (Tome 1: Des origines a 1830 ).

Hanssen, H., Inventaris van hef oud archief der stad, municipaliteit en gemeente Venlo, Venlo 1919.

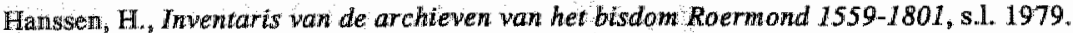

Hart van Zontoven, Het : album met commentaar, samengesteld naar aavileiding van 200 jaar Sint-Quintinuskerk en Gemeentehuis (1788), Zonhowen 1988.

Hasquin, $H_{r}$ (ed.), La Wallonie: le pays et les hommes : histoire, économies, sociétés, (tome I), s.L. 1975. (Tome I: Des origines a 1830).

Haye, $\mathbb{R}$ de la, De Mass over : 2000 jaar vaste oeververbindingen in Maastricht (Vierkant Maastrich; 4), Maastricht 1984.

Haye, R. de la, Inventaris van de archieven van de heerlijkheid en de schepenbank Wijle, 1464-1797 (1816) (Rijksarchief in Limburg; 49), Maastricht 1993.

Hekker, R.C., Het voormalige wakwerkhuis Putstraat 6 te Lutterade, in: Bulletin var de Koninklijke Nederlandse Oudheidkundige Bond, 64(1965), pp. 25-34.

Hendiicks, A., De kerk van Onze Lieve Vrouw Geboorte te Kessel : een overzicht van de geschiedenis van de twee oudst bekende kerkgebouwen, in: De Maasgouw, 114(1995), kolom 235-248.

Hendricks, A.J.G., "Het onderwijs is bij voartduring zeer voldoende". Een beschrijwing van het lager onderwijs te Kessel vanaf 1600 tot 1940, met tevens gegevens over personen gebouwen, cursussen, avondonderwijs en al die zaken, die direct of indirect met het anderwijs in deze periode te maken hebben gehad, aan de hand van stukken wit het parochie-, gemeente-en rijksarchief, verzameld in de jaren 1986, 1987, 1988, Kessel 1989.

Hendriks, H.H., Stamboom "Van de Port" Nederland: 1. Van Petrus wan de Grooteport naar Maria Wilhelmina van de Port" 2. Andere takken van dezelfde stam?. Tilburg 1989.

Hendriks, W., Adam en Eva keerden terug in het stadhuis van Venlo : meesterwerken uit begin achttiende eeuw, in: Dagblad voor Noord-Limburg 30 juli 1960.

Hendriks, W.Th.M., De burgerboeken van Venlo, in: Huldeblijk : bundel opstellen aangeboden aan de genealoog Jan J.M.H. Verzijl bij gelegenheid van zijn zeventigste verjaurdag op 25 maart 1967, Roermond 1967, pp. 97-133.

Henkens, $\mathrm{J}$. ., Weert in oude ansichten, Zaltbommel 1969.

Henkens, J. en J. van de Velden, Weert in ande ansichten, (deel 2), Zaltbommel 1975.

Henkens, M., Tussen Simon Symkens en Henri Symkens liggen meer dan 300 jaar familiegeschiedenis, in: Ter Euken : driemaandelijks kultureel tijdschrift Kessenich, 15 (1990) nu. 1(15 augustus), pp. 51-57.

Hermans, F, De parochie Geleen van 1605 tot 1654 : een beschrijving aan de hand van de cadex van Pastoor Leurs, Geleen [1989].

Hermans, F.J., De stadswording wan Venlo : een schets van facetten en antwikkelingen tot circa 1400 , Nijmegen 1985. (Doctoraalscriptie Universiteit Nijmegen).

Heylerhoff, M. van, Continuation de la description des monumens de la ville de Maestricht, avec indication des principaux souvenirs historiques qui $s^{\prime} y$ attachent, in: Annuaire de la province de Limbourg, Maestricht 1829, pp. 105-166.

Hinssen, J.P.P., Spin-off van streekhistorisch onderzoek, in: Limburgs Tijdschrift voor Genealogie, 21(1993) nr. 4, pp. 98-109.

Hoefer, F.A., Geschiedenis der openbare tijdaanwijzing, Leiden 1887.

Hoefer, F.A., Het klokkenspel van Sittard, in: PSHAL, 30(1893), pp. 153-164.

Hoogenboom, A.J., Uurwerkmakersfamilie Wessels te Geleen, in: Geleen door de eeuwen heen, Geleen 1989, pp. 109-117. 
Houben, G.M.M., Kwartierstaat van Louis P.J.H. Tonnaer, in: De Limburgse Leeuw, 10(1962) aflevering $1-2$, pp. 12-14.

Huybens, G. (red.), Beiacarden en torens in Belgü, Gient 1994.

Huygens, Chr., Horologium, Hagae Comitum 1658.

[Huygens, Chr.] Christiani Hugenii Zulichemii, Const. f., Horologium oscillatorium, sive, De motu pendulorum ad horologia aptato demonstrationes geometricae, Parisiis 1.673.

Huys, P., Uurwerkmakers in Vlaanderen XIX, in: Ons Heem, 32(1978), pp. 68-69.

Huys, P., Nog over uurwerkmakers, in: Ons Heem, 39(1985), pp. 18-20.

Huys, P., Nog urwerkmakers in. Vlaanderen, in: Ons Heem, 44(1990), pp. 199-201.

Indekeu, B., Uurwerkmakers te Lonmel omstreeks 1800, in: Te Lomelle op die Campine, $13(1987)$ nr. $1-2$, p. 44.

Israel, J.I., Dutch primacy in world trade, 1585-1740, Oxford 1990.

Jägers, G.J.M., Catalogus wan de handschriftcollectie van het Rijksarchief in Limburg (Rijksarchief in Limburg; 46), Maastricht 1991.

Jagger, C., Klokken en horloges, Alphen aan den Rijin s.a.

Jansen, J.C.G.M., Overheid en Joden in het huidige Limburg in de $18 \mathrm{e}$ en wroege $19 \mathrm{e}$ eeuw, in: Studies over de sociaal-economische geschiedenis van Limburg : jaarboek wam het Sociaal Historisch Centrum voor Limburg, XXIII(1978), pp. 1-62.

Jansen, J.C.G.M., Landbouw en economische golfbeweging in Zuid-Limburg 1250-1800 : een analyse van de opbrengst wan tienden (Maaslandse Monografieën; 30), Assen 1979.

Jansen, J.C.G.M., Jews and economic innovation in Southern Limburg 1690-1820, in: Studies on the history of Dutch Jewry, (volume 5), Jerusalem 1988, pp. 81-112.

Jansen, J.C.G.M., Crisis en herstructurering in en rond Maastricht (1560-1640), in: Bijdragen tot de geschiedenis, 73(1990), pp. 141-163.

Jansen, J.C.G.M., Landbouw rond Oirsbeek omstreeks 1800, in: Studies over de sociaaleconomische geschiedenis wan Limburg: jaarboek wan het Sociaal Historisch Centrum voor Limburg, XXXVII(1992), pp. 1-52.

Jansen, J.C.G.M., Economic and social vicissitudes in disad vantaged circumstances : Southern Limburg between 1780 and 1820, in: E. Aerts (et all) (eds.), Studia Historica Oeconomica : liber amicorum Herman Van der Wee, Leuven 1993a, pp. 127-144.

Jansen, J.C.G.M., Landbouw aan weerszijden van de Duits-Nederlandse grens, in: Economisch-en sociaal-historisch jaarboek, 56(1993b), pp. 150-182.

Jansen, J.C.G.M., Ouderenzorg in Maastricht : wijf eeuwen XII Apostelen (Vierkant Maastricht; 19), Maastricht 1993c.

Jansen, J.C.G.M., Ontsnappen aan economische achterstand: een bijzonder probleem, in: Het platteland in een veranderende wereld : boeren en het proces van modernisering : opstellen aangeboden aan Prof. Dr. H. de Vries bij zijn afscheid als hoogleratar in de Economische en Sociale Geschiedenis aan de Rijksuniversiteit te Leiden / onder redactie van Herman Diederiks, J. Thomas Lindblad en Boudien de Vries, Hilversum 1994, pp. 277-291.

Jansen, J.C.G.M., Economische geschiedenis van Limburg, 1800-1980, manuscript.

Jansen, M., Het stadhwis wan Venlo, in: De Maasgouw, 2(1880), pp. 253-254, 257-258, 261-262.

Janssen, A.M.P.P., Visitaties wan het Landdekenaat Susteren in de 17e eeww (Schriftenreihe des Kreises Heinsberg; 4), Heinsberg 1988.

Janssen, A.M.P.P., Custos et simul ludimagister : de koster-onderwijzer in Sittard en omgeving vanaf het Concilie van Trente (1545-1563) tot de Franse Tijd (1794), in: Magister Artium : onderwijs, kerk en kunst in Limburg : opstellen Br. Sigiswund Tagage aangeboden bij zijn zeventigste verjaardag. Sittard 1992, pp. 144-156. 
Janssen C.ss. $R_{x}, E$, Uit het verleden van het kerspel Ruregemunde in: Civitas Ruraemundensis : gedenkboek ter gelegenheid van het zevenhonderd-jarig bestaan van Roermond als stad, Roermond 1932, pp. 154-187.

Janussen, M., Het oud stadhuis van Sittard, in: De Maasgouw, 17(1895), pp. 38, 42, 46-47, $50-51,54-55,57-59$.

Jongen, J.J., Geschiedenis van Schaesberg : gedenkboek 1700-1950, ter gelegenheid wan het 250 jaar bestaan der parachie, Schaesberg 1950.

Joris, A et J.L. Kupper, Villes, bourgs et franchises en Wallonie de 1250 à 1477 , in: $\mathbf{H}$. Hasquin (ed.), La Wallonie: le pays et les hommes : histoüre, économies, sociètes, (tome I), s.1. 1975, pp. 131-159. (Tome I: Des origines à 1830).

Juwens-Geerkens, G., Familie Max, in: Tijdschrift wan de Geschied-en Heemkundige Kring De Reengenoten, Meeuwer, 2(1981-1982) nr. 1, pp. 22-41.

Keuller, $\mathbb{L}$., Roermond : de geschiedenis zijner westingwerken, monumenten en voorname gebouwen, in: Civitas Rurcenundensis: gedenkboek ter gelegenheid wan het zevenhonderd-jarig bestaan van Roermond als stad, Roermond 1932 "pp. 360-380.

Keyser-Schuurman, W.E.S.L., Het Kruisherenklooster (Maastrichts Silhouet; 17), Maastricht 1984,

Kisch, $\mathbf{H}_{n}$, Das Erbe des Mittelaliters, ein Hemmnis wirtschaftlicher Entwicklung: Aachens Tuchgewerbe vor 1790, in: Rheinische Vierteljahrsblätter, 30(1965), pp. 253-308.

Kleime atlas voor de geschiedenis van beide Limburgen / samengesteld door een redactiecommissie onder leiding van Drs. J.H.M. Wieland, Rijksarchivaris in de Provincie Limburg te Maastricht, Leeuwarden/Maastricht 1989.

Kleutghen, A., Een moorddadige roofoverwal op het Haspershoven in 1833 (in vier delen), in: Gemeentelijk Informatieblad [van Overpeit], 4(1986) mr. 3, ongepagineerd (deel 1); 5(1987) nr. 1 en nr. 2, ongepagineerd (deel 2 en 3); 6(1988) nt. 1, ongepagineerd (deel 4).

Knaepen, R, Lommel, de Vrijheid en het Teutendorp : een Kempense grenswlek verloren in de Heide : bijdrage van de Lommelse schepenprorocollen tot de kennis van de lokale en de economische toestanden tussem 1685 en 1808 , s.1. 1972.

Knaepen, R., Heden en verleden van de Lommelse markthuizen (1), in: Te Lomelle op die. Campine, 11(1985), pp. 72-90.

Koch, E.M.F., De kloosterpoort als sluitpost? : adelijke vrouwen langs Maas en Rijn tussen huwelijk en convent, 1200-1600 (Maaslandse Monografieèn; 57), Leeuwardem/ Mechelen 1994.

Koolbergen, H. van, Materiële cultuur: haisraad, kleding en bedrijfsgereedschap (Cahiers voor lokale en regionale geschiedenis; 2), Zutphen 1988.

Koreman, J.G.J., De stadsrekening van Maastricht over het jaar 1399-1400 (Maaslandse Monografieen; 7). Assen 1968.

Koreman, J.G.J., Rondom het Maastrichtse Dinghuis (Het Limburgse Monument; 2), Maastricht 1974.

Koreman, J.Gi.J., Geteeckent tot Maestricht, Maastricht 1981.

Krieg, H., Das Gehäuse der bergischen Uhr, in: Weltkunst, (1989), Teil $\mathbf{I}_{*}$ Heft 19, pp. 2764-2767; Teil III, Heft 23, pp. 3876-3881.

Kula, W., Measures and men, Princeton 1986.

Landes, D.S., Revolution in time: clocks and the making of the modern world, Cambridge Mass. 1983.

Last, A, Problemen op school, in: De Maaspost, 26 januari 1994. (Rubriek Archiefsprokkels).

Laugs, N.J.A., Echter klokken en Echter klokkenmakers, in: Echter Landj; heemkundige bijdragen over Echt en omgeving, 2(1989), pp. 40-43.

\section{XXIV}


Laveaux, N., Gekende Beerselse figuren .... Renerus Hubertus Voorter, geboren te Molenbeersel 7 october 1839, "Klokke-Neerke", in: Geef acht : soldatenblad, Milac, Molembeersel, (1954) nr. 10(september), pp.14-17, nr. 11(oktober), pp. 14-16, nr. 12 (november), pp. 14-17, nr. 13(december), pp. 9-11; (1955) nr. 15(februari), pp. 15-18, nr. 16 (maart), pp. 12-14.

Lavigne, E, Kroniek van de Abdij van Sint-Truiden : vertaling van de Gesta Abbatum Trudonensium, (deel 1) (Maaslandse Monografieër; 43), Assen/Maastricht 1986. (1ste deel: 628-1138).

Lecat, J.Ph., De Bourgondische uitdaging: bewogen leven in de Late Middeleeuwen, Amsterdam 1985.

Leemans, H., De Sint-Gummaruskerk te Lier (Inventaris van het kunstpatrimonium van de provincie Antwerpen; 2), Antwerpen/Utrecht 1972.

Leeuwen-Canneman, M.C. van, Inventaris van her archief van de familie Michiels van Kessenich en G.H.A. Venner, Inventaris wan archieven van overheidsfinctionarissen in het ambt Montfort, Maastricht 1995.

Le Goff, J., Au Moyen Age: temps de l'église et temps du marchand, in: Annales E.S.C., $15(1960)$, pp. $417-433$.

Le Goff, $\mathbb{I}_{.,}$L'Espace et le temps, in: L'Imaginaire médiéval : essais, Paris 1985, pp. 59119.

Lehr, A., Hemisferische bellen en het klokkenspell wan Born L., in: Klok en Klepel, (24) 1980 , juli, pp. 1-12.

Lehr, $\mathrm{A}_{* \mathrm{x}}$ De geschiedenis van het astronomisch kunstwurwerk: zijn techniek en muziek, Den Haag 1981a.

Lehr, A., Van paardebel tot speetklok: de geschiedenis van de klokgietkunst in de Lage Landen, Zaltbommel $1981 \mathrm{~b}$.

Lehr, A., De twee Klokkenspelen op het Nationaal Paleis te Mafra : een verslag van de huidige toestand, Asten 1984.

Leonard, C.S. and B.N. Mironow (eds.), Hours of work and means of payment: the evolution of conventions in pre-industrial Europe, Milano 1994. (Proceedings eleventh International Economic History Congress Milan, September 1994, B3b).

Leunis, J., De oudste Limburgse uurwerkmakers (14de-17de eeuw), in: Het Oude Land van Loon: jaarboek van de Federatie der Geschied-en Oudheidkundige Kringen van Limburg, 13(1958), pp. 273-298.

Limburg's Werleden : gexchiedenis van Nederlands Limburg tot 1815, (2 delen), Maastricht 1967.

Linssen, J., Over de wording van Roermond als stad, in: Historische opstellen over Roermond en omgeving, Roermond 1951, pp. 143-184.

Linssen, J., Roermond rond 1400, in: PSHAL, 101(1965), pp. 39-121.

Lintsen, H.W. (hoofdred.), Geschiedenis van de techniek in Nederland : de wording wan een moderne samenleving 1800-1890, (6 delen), Zutphen 1992-1995.

Lloyd, H.A., Some outstanding clocks ower seven hundred" years 1250-1950, London 1958.

Loeske, M., Heinrich Johann Kessels. Zu seinem 150sten Geburtstage am 15. Mai, in: Die Uhrmacher-Woche, (1931) nr. 19, pp. 336-338.

Loomes, B., Country clocks and their London origins, Newton Abbot [etc.] 1976a.

Loomes, B., Watchmakers and clockmakers of the world, (vol. 2), London 1976b.

Lorijn, H.G.A., De Mestreechter ambachte of een rechtshistorisch onderzoek naar met name de ambachtsreglementen en de gildenreglementen te Maastricht, Nijmegen 1980. (Gestencilde doctoraalscriptie Katholieke Universiteit).

Luijten, J. en F. Roebroeks, Calvariënberg (Maastrichts Silhouet; 26), Maastricht 1988.

Lux., M., Johann Heintich Kessels (1781-1849). Zu seinem 200. Geburtstag an 15. Mai, in: Alte Uhren, 2(1981), pp. 98-101. 
Luyn, P.B.N. van, Stadi Sittardt: een grensoverschrijdend verleden, Sittard 1993.

Macustrichts Zilver / onder redactie van LL. Szénăssy, Maastricht 1978.

Maes, S.F., De geschiedenis wan Bree, (deel 2), s.I. 1952. (Deel 2: De gemeente van de oudste tijden tot an de Franse revolutie).

Martens, N., Een ambachtsman wan Laak wit de Franse tijd, in: Limburg [Maøseik], 34(1955) 12(december), pp. 261-267.

Matthijssen, J.W. en J.H.J. Gulikers, Maastrichtse gevelstenen, in: De Maaspost, november $1975 \mathrm{t} / \mathrm{m} 31$ juli 1985.

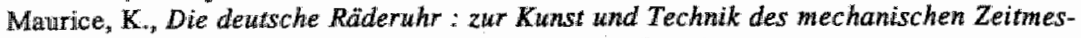
sers im deutschen Sprachraum, (2 Bände), München 1976.

Mayr, O., Authority; liberty and automatic machinery in early modern Europe (Iohns Hopkins studies in the history of technology; 8), Baltimore/London 1986.

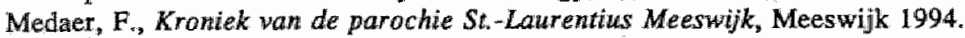

Meilink-Hoedemaker, L.J., Luidklokken en speelklokken in Delft: een cultuxt-historische studie over een Nederlands erfgoed, Delft 1985. (Proefschrift Utrecht).

Mélarges, in: LAncien pays de Looz, 6(1902), pp. 79-80.

Melis, H.C., Zonhoven, Zonhoven 1947.

Mertens, A.J. en J. Henkens, Schetsen uit de geschiedenis van het Land van Weert, Weert 1956.

Mertens, J. (met medewerking van R. Festraets en G. Beelen), De bevolking wan Zonhoven rijdens de 19de eeww: geboorten, huwelijken en overlijdens volgens de registers van de burgerlijke siand: met demografische inleiding, Zonhoven 1986.

Mesotten, I., Het kerkelijk leven in de parochie Diepenbeek in de 17de en I8de eeuw, Lenven 1981. (Licentiaatsverthandeling).

Mestrom, P.T.R., Limburgse klokken en klokkenmakers, in: Zuid-Limburg : kunst, ambacht en volksgebruiken, Baarn 1977, pp. 46-70.

Mestrom, P.T.R., Maastricht let op uw saeck, in: De Sint Servaas : tweemaandelijks restauratie-informatie bulletin, (1983) nr. 11-12(december), pp. 95-96.

Mestrom, P.T.R., De familie Wessels te Geleen en de klokkenmakerij op het Limburgse platteland van \pm 1750 tot \pm 1850 , in: Geleen door de eeuwen heen, Geleen 1989, pp. $118-129$.

Michelant, H. (ed.), Voyage de Philippe de Hurges à Liège et à Maestrect, Liège 1872.

Middeleeuwse kastelen in Limburg : verschijningswormen van het kasteel, zijt adellijke bewaners en hun personeel/ onder redactie van W.M.H. Hupperetz (et al.), Venllo 1996.

Miller, D.L. (ed.), The Lewis Mumford reader, New York 1986.

Miraeus, Aubertus, Opera diplomatica, et historica ...., (4 delen), Bruxellis 1723-1748. (Tweede editie).

Molemans, J. en J. Mertens, Zonhoven: historisch-naamkundige studie, Zonhoven 1982.

Molemans, J. en J. Mertens, Opglabbeek een rijk verleden, Opglabbeek 1984.

Molemans, J. en E. Paulissen, As in het verleden : een historisch, geografisch, socioekonomisch en naamkundig onderzoek, As 1976.

Momentopnamen langs de Maas : topografische tekenkunst uit Limburg 1600-1800/ ander redactie van J.M.C. Bruijnzeels en J.M.W.C.Schatorjé ; met medew. van E.P.M.Voermans, Maastricht 1989.

Morpurgo, E., Nederlandse klokken- en horlogemakers vanaf 1300, Amsterdam 1970.

Morreau, L.J., Bolwerk der Nederlanden : de vestingwerken wan Maastricht sedert het begin wan de 13 eeuw / met een inleiding over de militair-strategische betekenis van Maastricht door J.P.C.M. van Hoof en E.P.M. Ramakers (Maaslandse Monografieën (groot formaat); 2), Assen 1979.

Mosmans, H., Het Redemptoristenklooster Wittem, Roermond/Maaseik 1936. 
Mühe, R. und H.M. Vogel, Alte Uhren : ein Handbuch Europäscher Tischuhren, Wanduhren und Bodenstanduhren, München 1976.

Mulken., W. van, Inwentaris van de archiewen van de Gemeente Susteren, 1635-1948, Maastricht 1978.

Mumford, L., Technics and Civilization, New York 1934.

Mummenhoff, W., Die Bürgerrechtsverleilhungen in der Reichsstadt Aachen wăhrend der Jahre 1656 bis 1794 (1797), in: Zeitschrift des Aachener Geschichtsvereins, 68(1956), pp. 191-332.

Munier, W.A.J., Het simultaneum in de Landen van Overmaas : een uniek instituut in de Nederlandse kerkgeschiedenis (1632-1878), manuscript.

Nederlands Patriciaat, 's-Gravenhage 1978-1979.

Nederlands (ch)e Monumenten van Geschiedenis en Kunst, De, "s-Gravenhage 1912-..., deel V: de prowincie Limburg. Eerste stuk: De monumenten in de gemeente Maastricht, 'sGravenhage 1.926. Tweede stuk: Noord-Limburg, door J.H.A. Mialaret, "s-Gravenhage 1937. Derde stuk: Zuid-Limburg uitgezonderd Maastricht, dloor W. Marres en J.J.F.W. van Agt, 's-Grawenhage 1962.

Nederweerts verleden : het dorp en zijm heerschappen / onder redactie van Alfons Bruekers, Nederweert 1985.

Needham, J., Science and civilization in China, Cambridge 1954-....

Needham, J., Wang Ling and D.J. de Solla Price, Heavenly clockwork: The great astronomical clocks of medieval China, Cambridge 1986. (2de ed.)

NEHA-jaarboek woor economische, bedrijfs-en techniekgeschiedenis, (deel 57), Amsterdam 1994.

Nettesheim, Fr., Kroniek der stad Roermond wan 1562-1638, in: PSHAL, 7(1870), pp. 429m 487 ; $10(1873)$, pp. 97-344; $12(1875)$, pp. 249-386.

Nieuw Nederlandsch Biografisch Woordenboek, Leiden 1911. (Herdruk Amsterdam 1974).

Nieuwenhoven, H.J. van, Een klokkenspel te Born, in: Bulletin wan de Nederlandse Oudheidkundige Bond, 77(1978), p. 100.

Nieuwenhuizen, K., Zuid-Limburg in 19e eeuwse foto's, Amsterdam 1977.

Nissen, P., De herbouw van de St. Martinuskerk te Linne 1789-1790, in: Jaarboek van de Heemkundevereniging Roerstreek, 13(1981), pp. 119-128.

North, J.D., Montasticism and the first mechanical clocks, in: The study of time $I I$ : proceedings of the second conference of the International Society for the Study of Time/ eds. J.T. Fraser and N. Lawrence, New York 1975, pp. 381-398.

North, J.D., Richard of Wallingford: an edition of his writings, (3 delen), Oxford 1976.

Notermans, J., Onderwijs te Maastricht in de loop der eeuwen, in: 1902 Katholieke ondernemers Maastricht 1962, Maastricht 1962, pp. 41-71.

Oberndorff, Th. en M. Niesten, Meerssen: impressies uit het rijke verleden wan een jonge gemeente." Meerssen 1994.

Oirschot, A. van en F.J.A. Stender, Antiek kopen: klokken en pendules, Helmond 1969.

Oremus, J.M.S., De bouw van het Sittardse stadhuis van Pasqualini (1560-1570) en magistratenfamilies in de 16e en 17e eeuw (Monografieën uit het land van Sittard; 8), Sittard 1993.

Oremus, J.M.S., Sittardse stadsrekeningen 1588-1589 en 1628-1629 (Monografieën uit het land van Sittard" 1), Sittard s.a.

Orlers, J., Beschrijvinge der stad Leydem, Leyden 1614.

Ottema, N., Geschiedenis van de uurwerknakerskunst in Friesland, Assen 1948. (Tweede editie).

Oudheden in het Bonnefontenmuseun / catalogus onder redactie van I. Szenassy, Maastricht 1984 . 
Paquay, J., Béguinage Sainte-Catherine, in: Bulletin de la Société Scientifique et Littéraire du Limbourg, 31(1913), pp. 19-41.

Paquay, J, Bilsen voorheen : geschiedkundige schets, Bilisen 1924.

Pasleau, S., John Cockerill, itinéraire d'un géant industriel, Liège 1995.

Patart, C., Les cloches civiles de Namur, Fosses et Tourmai ax Bas Moyen Age, Bruxelles 1976.

P.D. Doppler, P.], Onderzoek vant het carillon van St. Servaaskerk te Maastricht, in: De Marisgouw, 56(1936), p. 23.

Peeters, G., Geschiedkundige beschrijwing van het aloude kerkspel Blerick bij Venlo, in: PSHAL, 7(1870), pp. 234-332.

Peeters, G., Chronologische beschrijwing van Tegelen, benevens aanteekeningen over Belfeld en Steijh, Roermond 1876.

Peters, G., Reparatie der torenklok van het kasteel Well in 1784, in: De Maasgauw, $41(1921)$, p. 62 .

Pex, R., Het mysterieuse torenuurwerk van het Maaseiker stadhuis, Maaseik 1996.

Philippe, J., Meubles, styles et décors entre Meuse et Rhin, Liège 1977.

Pholien, F, Lthorlogerie et ses artistes au pays de Liège, Liège 1933.

Pinchart, A., Archives des arts, des sciences et des lettres \$103: Horlogerie, in: Messager des Sciences historiques ou Archives des Arts et de la Bibliograhie de Belgique, Gand 1884 .

Plomp, R., Spring-driven Dutch pendulum clocks, 1657-1710, Schiedam 1979.

Pluymers, L., Oorlogsgruwelen te Heks, in: Limburg, 55(1976) nr. 5, p. 215.

Poell, G.M., Beschrijving van het hertogdom Limburg, Weert 1851.

Pol, A. van, Een klokkenmaker te St. Odiliënberg, in. Jaarboek van de Heemkundevereniging Roerstreek, 12(1980), pp. 120-122; deel II, in: 13(1981), pp. 143-144; deel III, in: 22(1990), p. 9; deel IV, im: 24(1992), pp. 98-99.

Pol, A. van en J. Ruyters, De klokkenmaker van St. Odiliënberg (5), in: Joarboek van de Heemkundevereniging Roerstreek, 25(1993), pp. 133-135.

Prak, M., Ambachtsgilden vroeger en nu, in: NEHA jaarboek, 57(1994), pp. 20-21.

Price, D.J. de Solla, Clockwork before the clock, in: Horological Journal, (1955), pp. 81081,4 en (1956), pp. 31-35.

Price, D.J. de Solla, Gears from the Greeks : the Antikythera mechanism - a calendar computer from ca. 80 B.C., in: Transactions of the American Philosophical Saciety, 64(1974) nr. 7, pp. 1-70.

Prowinciale Almanak voar Limburg, s.1. 1876.

Pryce, W.T.R and T. Alun Davies, Samuel Raberts clock maker : an eighteenth-century craftsman in a Welsh rural community, s.l. 1985.

Pubben, T.H.G., Van leem naar steen (Horster Historiën; 4), Horst 1993.

Pyls, C, Roermonds kloosterleven, in: Civitas Ruraemundensis: gedenkboek ter gelegenheid wan het zevenhonderd-jarig bestaan wan Roermond als stad, Roermond 19132, pp. 188-220.

Quaedvlieg, G.M.I., Klokken en klokkenspelen te Maastricht, in: Miscellanea Trajectensia, Maastricht 1962 , pp. 363-376.

Raadsverdragen wan Maastricht 1367-1428/bewerkt door M.A. van der Eerden-Vonk; m.m.w. W.J. Alberts en Th.J, van Rensch (Rijks Geschiedkundige Publicatiën; 218), "s-Gravenhage 1992.

Ramakers, E., Kerkklokken in de Petrus en Pauluskerk, in: A.W.A. van den Eelaart, Schaesberg in woord en beeld / met bijdragen van J.J. Jongen, Eygelshoven [1982], pp. 154-157.

Ramakers, E., De dekenale kerk van de H.H. Petrus en Paulus, Landgraaf-Schaesberg, s.1. 1989. 
Rats, J.C., De Lieve Vrouw in 't Zand : haar beeld, haar vereering, had wonderen, Roermond/Maaseik 1935.

Recueil der recessen, wegens beyde de genaedighe Heeren ende Princen, alhier geëna. neert inden jaere 1665, Maestricht 1680.

Remmen, N., De klokkenmakersfamilie Remmen te Well, in: De Madssouw, 109(1990), kolom 83-88.

Renes, J., Het cultuurlandschap van Noord-en Midden-Limburg : geschiedenis, kenmerken en waarden (DLO-Staring Centrum; rapport 192), Wageningen 1993.

Rensch, T.J. van, Inventaris der archieven van de parochie St. Lambertus te Horst, Horst 1979.

Rensch, T.I. van, Inventaris van het archief wan de Schepenbank Echt (Rijksarchief in Limburg; 23), Mastricht 1981.

Rensch, T.J. van, De Sint-Martinuskerk van Wyck, Maastricht 1983.

Reijnen, H.H.J., Heythaysen in oude ansichten, Zaltbommel 1973.

Richter, M.M.G.M., Het registre civique uit 1807 ; een genealogische bron woor Sint Odiliënberg, im: Jaarboek van de Heemkundevereniging Roerstreek, 25(1993), pp. 5664.

Ridder, M. de, De ondersteuningsfondsen van de Amsterdamse gilden in de achttiende eeuw, in: NEHA jaarboek, 57(1994), pp. 107-121.

Robertson, J.D. The evolution of clockwork, London 1931.

Romen, K., Roermond onder keizer Frans II tot het einde der Oostenrijksche regeering in 1794, in: Limburg's Jaarboek, 25(1919), pp. 46-57.

Rooijakkers, G.W.J., Hebben en houden te Horst : de materiële cultun van boeren onstreeks 1800, in Horster Historiën / onder redactie van G.F. Verheijen (et al.), (deel 3), Horst 1992, pp. 105-140.

Rooijakkers, G.W.J., Wooncultuur in de Westbrabantse Kempen : de arrangementen van anachronistische tijdgenoten, in: Brabants Heem, 46(1994) 3-4, pp. 107-119.

Rouhart-Chabot, J. et E. Hélin, Admissions à la bourgeoisie de la cité de Liège, 12731794 , Liège 1962.

Royer-Collard, F.B., Skeleton clocks, London 1972.

Rutten, W.J.M.J., De levensstandaard in Limburg van de Franse tijd tot aan de eerste wereldoorlog : een analyse van de lichaamslengte van Limburgse lotelingen, in: Studies over de sociaal-economische geschiedenis van Limburg : jaarboek van het Saciaal Historisch Centrum voor Limburg, XL(1995), pp. 123-160.

Rijswijck, A. van, De verwoeste kerken van Limburg, Roermond/Maaseik 1947.

Salie, J.W., Le guide impartial du voyageur à Maestricht ou indicateur général de la ville et des ses habitants, Maestricht 1855.

Schaaf, B., Schwarzwalduhren, Freiburg im Breisgan 1988. (2. Auflage).

S[chaepkens], A., Pièces concernant Sepperen et le Chapitte de St. Servais à Maastricht, in: $P S H A L, 1(1864)$, p. 103 .

Schaepkens van Riempst, J., Eenige bijzonderheden omtrent straten, pleinen en bewoners van het oude Tricht, in: PSHAL, 23(1907), pp. 39-358. (Een overdruk van dit artikel verscheen te Maastricht 1907).

Schaepkens van Riempst, J., Carillons en torenuurwerken te Maestricht, s.I. [1910].

Scheen, P., Lexicon Nederlandse Beeldende Kanstenaars, 1750-1950, Den Haag 1969.

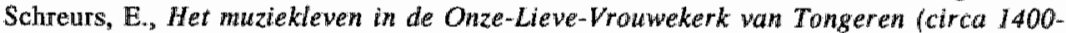
1797) : een archivalisch onderzoek naar het muziekleven wan een middelgrore kapittelkerk in het prinsbisdom Luik binnen haar stedelijke context, Leuven 1990. (Dissertatie Kathollieke Universiteit Lewen).

Schrijnemakers, A., Zonnewijzer aan de kerk(toren) van Geleen (1615), in: Tijdschrift Heemkundevereniging Geleen, 17(1996) 3, p. 51. 
Schunrman, A.J., Materiële cultuur en levensstijl : een onderzoek naar de taal der dingen op het Nederlandse platteland in de 19de eeww: de Zaanstreek, Oost-Graningen, OostBrabant (A.A.G. Bijdragen; 30), Wageningen 1989. (Proefschrift Wageningen. Tevens verschenen als deel XVII in de reeks HES Studia Historica, Utrecht 1989).

Seaby, W.A., James Wilson, clockmaker of Belfast, in: Antiquarian Horology, 14(1983), pp. 133-155.

Sellink, J.L., Dutch antique domestic clocks ca, $1670-1870$ and some related examples, Leiden 1973.

Sellink, J L.. A.F. Abbink en R.E. Wiggers, Achterhoekse klokken en uwrwerkmakers, s.1. [1990].

Servais, P., La rente contstituée dans le ban de Herve au XVIIL siècle, Bruxelles 1982.

Servais, P., "Kapitalisme" op het platteland: drie case-studies uit de 18 e eeuw in de streek van Verviers, in: Studies over de sociaal-economische geschiea'enis wan Limburg : jaarboek van het Sociaal Historisch Centrum woor Limburg, XXVIII(1983), pp. 1-18.

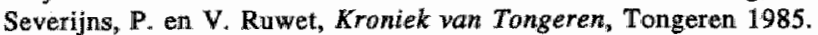

Seyn, E. de, Geschied- en aardrijkskundig woordenboek der Belgische gemeenten, Turnhout s.a.

Simenon, G., Visitationes archidiaconales archidiaconatus Hasbaniae in dioecesi Leodiensi ab anno 1613 ad annum 1763, Leodii 1939.

Simonis, A.H. (et al.), Sittard, historie en gestalte, Sittard 1971.

Sint-Truiden in de 18de eeuw, Sint-Truiden 1993.

Sivre, J.B., Bijdrage tot de geschiedenis der parochiale thans kathedrale kerk van dem $\mathrm{H}$. Christoffel te Roermond, in: Provinciale Almanak van Limburg, Roermond/Maastricht 1876, pp. 138-160.

Smeets, M., De kathedraal van Sint Christoffel te Roermond, Roermond 1953.

Smelik, Jaap, Uhren aus der Euregio Maas-Rhein, in: Schrifien der Freunde alter Uhren, Heft 20(1981), pp. 71-82.

Smith, A. (ed.), The Country Life International Dictianary of Clocks, s.1. 1979.

Snijders, D. en H.J. Geerkens, Ophoven en Geistingen door de eeuwen heen, Ophoven 1966.

Spanje, T. van, Hondboek voor den horlogiemaker, Amsterdam 1976. (Fotografische herdruk).

Spierdijk, C., Klokken en klokkenmakers: zes eeuwen uwrwerk 1300-1900, Amsterdam 1962.

Spierdijk, C., Horloges en horlogemakers, Amsterdam 1973.

Stinüssen, J., De ontwikkeling van de parochie Peer, met haar annex Wijchmaal, tot ca 1648, in: Het Oude Land vam Laon: jaarboek van de Federatie der Geschied-en Oudheidkundige Kringen wan Limburg, 45(1990), pp. 19-84.

Straven, $\mathrm{F}_{*}$, Inventaire analytique thronologique des archives de la ville de SaintTrond, (6 delen), Saint-Trond 1886-1895.

Stroobants, A. De Antwerpse horlogemakers, in: Ons Heem, 47(1993a) nr. 2, pp, 60-70.

Stroobants, A., De Brugse horlogemakers, in: Ons Heem, 47(1993b) nr. 2, pp. 71-82.

Stroobants, A., De Gentse horlogemakers, in: Ons Heem, 47(1993c) nr. 2, pp. 84-88.

Stroobants, A., De ordonnanties van de Brusselse horlogemakers, in: Ons Heem, 47 (1.993d) nr. 2, pp. 82-84.

Study of time II, The : proceedings of the second conference of the International Society for the Study of Time / eds. J.T. Fraser and N. Lawrence, New York 1975.

Synthese: twaalf facetten van cultuur en natuar in Zuid-Limburg, Heerlen 1977.

Sype, L. van de en A. Schroé (red.), De geschiedents van de stad Hamont, Hamont-Achel 1986.

Tardy, H., Dictionnaire des horlogers français, Paris 1951. 
Tardy, H., La pendule Française, (3 delen), Paris 1974.

Tessmar-Pfohl, C., Aktuelle Antiquitatten : die Wiener Kunst- und Antiquitätenmesse in der Hofburg, in: Parnass, 13(1993) 4 (November/Dezember), pp. 14-22.

Thiry, A., Dictionnaire des horlogers dans la principaute de Liege et périphérie, fon da XIVe au XXXe siècle : plus de 700 noms, Liège s.a. (Gestencild).

Thomassin, L.F. Mémoire statistique du departement de lourte (commencé dans le courant de l'année 1806), Liège 1879.

Thurlings, Th.L.M., De Maashandel van Venlo en Roermond in de 16e eeuw 1473-1572, Amsterdam 1946.

Thijs, Ch. Le chapitre N.D. à Tongres, in: Annales de l'Académie Royale d'Archélogie de Belgique, tomes XLIII, XLIV, XLV(1887-1889).

Tubee, $C_{\text {. }}$, De Weerter bewolking van 1839 in cijfers, in: Weert in woord en beeld : jaarboek woor Weert, Weert 1989.

Tijdmeting in Belgische verzamelingen, $D e$ / tentoonstelling georganiseerd door de Generale Bankmaatschappij 26-1/7-4-1984 te Brussel, Brussel 1984.

Ubachs, P.J.H., De Cellebroederskapel (Maastrichts Silhouet; 3), Maastricht 1980.

Ubachs, P.J.H., De burgerboeken van Maastricht, 1300-1795, in: PSHAL, 126(1990), pp. 22-50.

Ubachs, P.J.H., De Maastrichtse ambachten in de late middeleeuwen, in: PSHAL, 128(1992), pp. 232-245.

Ubachs, P.J.H., Nieuwe burgers van Maastricht : 14de eeuw-1795, Geleen 1993.

Ungerer, A., Les horloges astronomiques et monumentales les plus remarquables de l'antiquité jusqu'à nos jours, Strasbourg 1931.

Uyttenbroeck, H.H.H., De straten te Venlo, Venlo 1914 .

Van boterkleursel naar kopieersystemen : de ontstaansgeschiedenis wan Océ-van der Grinten, 1877-1956/ onder redactie van H.F.J.M. van den Eerenbeemt, Leiden 1992.

Vanhees, J., Pratestanten in Limburg (1518-1918): onderzoek naar het bestaan van protestanten en protestantse gemeenschappen im Belgisch Limburg tijdens de periode 1518-1918, Brussel 1993. (Dissertatie).

Vanheusden, $\mathbb{R}$, De urw werkmakers der abdijkerk te Munsterbilzen in de 16 de eeuw, in: Limburg, 52(1973), p. 270-273.

Vasari, $\mathbf{G}_{\text {, }}$, De levens wan de grootste schilders, beeldhouwers en architecten / gekozen en ingeleid door $\mathrm{H}$. wan Veen ; vertaald door Anthonie Kee, Amsterdam 1990.

Vehmeyer, H.M., Antieke wurwerken : een familiewerzameling, Utrecht 1.994.

Venme, J.M. van de, Geschiedenis wan Heer, Heer 1957.

Venne, I.M. van de, J.Th.H. de Win en P.A.H.M. Peeters, Geschiedenis wan Hoensbroek, Hoensbroek 1967.

Venner, G. (editor), Kroniek van de kerk van Susteren 1891-1900, inleiding, in: De Maasgouw, 110(1991), kolom 207-220; deel 2, in: De Maasgoww, 111(1992), kolom 215-222; deel 3, in: De Maasgouw, 111(1992), kolom 267-274.

Venner, G., Jan Michiel Dionisy (1794-1859), graveur te Roermond, in: De Maasgouw, 114(1995), kolom 1-12.

Venner, G.H.A. (red.), Roermond stad met verleden, Roermond 1985.

Venner, J.G.C., De beelldenstorm in Roemond, in: G.H.A. Venner (red.) Roermond stad met verleden, Roermond 1985, pp. 43-102,

Venner, J.G.C., Beeldenstorm in Hasselt 1567 : achtergronden en analyses van een rebellie tegen de prins-bisschop van Luik (Werken van de Bestendige Deputatie vant Limburg; 25, Maaslandse Monogafieën; 48), Leenwarden/Maastricht 1989. (Proef* schrift Katholieke Uniwersiteit Nijmegen).

Venner, I.G.C. (red.), Ter kerke in Grathem : parachiegeschiedenis ter gelegenheid van 750 jaar parochie Sint-Severinus, Grathem 1996. 
Verbois, R., Geschiedenis der kerken, kloosters en kapellen van Rekem, Rekem 1965.

Verlinden, G., Plaatsingslijst Schepenbank Venray. (Getypt).

Verslag van den toestand der gemeente Maastricht over het jaar 1910, Maastricht 1911.

Varzijl, J.J.M.H., Genealogieën wan Venlose schepenfamilies, 40: Van den Vaero, in: Limburgse Leeuw, 12(1964), pp. 125-128.

Vinckenroye, F, van, Pieter Hubert Creten 1823-1894, in: Het Oude Land van Loon: jaarboek van de Federatie der Geschied-en Oudheidkundige Kringen van Limburg, $45(1990)$, pp. $105-127$.

Vleeshouwers, J.M.E. Kraszonnewijzers op het St. Salviuskerkje van Limbricht, in: De Mansgouw, 109(1990), kolom 13-20.

Vols, J., De derde beiaard van Tongeren, in: Limburg, 33(1954) 12(december), pp 229230.

Vols, J., De Tongerse toren in de Franse tijd, in: Limburg, 34(1955) 5-6(meil-juni), pp. 108-113.

Voorloopige lijst der Nederlandsche monumemten van geschiedenis en kunst : deel VIII, de provincile Limburg, "s-Gravenhage 1926.

V.W., Oude klokkenmakers in het tegenwoordige Noorden van Limburg, in: De Maasgouw, 10(1888), p. 87.

Waddington, A., Histoire de Prusse, (vol. I), Paris 1911.

Walvis, J., Beschrijuing der stad Gouda, (2 delen), Gouda 1713.

Wee, H. van der, The growth of the Antwerp market and the European economy fourteenth-sixteenth centuries), (3 delen), The Hague 1963.

Weerd, $H$. van de, Geschiedenis van Eelen: parochie, heerlijkheid, gemeente, in: PSHAL, 46(1910), pp. 149-286.

Welters, A., Bijdragen tot de geschiedenis van de parochie Echt, in: PSHAL, 59(1923), pp. $1-269$.

Welters, A., Bijdragen tot de geschiedenis van de gemeente Ech, Echt/Maastricht 1926.

Welters, A., Uit Valkenburgs verleden: historische schetsen wan Ad. Welters verzameld ter gelegenheid van zijn 80e verjaardag 1888-13 april-1968 ("Oos Heim"-serie; 2), Valkenburg 1968.

Werveke, A. van, L'Horloge, in: La Dernière Heure, 25 maart 1932.

Weyns, J., Volkshuisraad in Vaanderen, (4 delen), Beerzel 1974.

White Jr., L., Medieval technology and social change, Oxford 1962.

Whitney, E., Paradise restored: the mechanical arts from antiquity through the thirteenth century, Philadelphia 1990.

Whitrow , G.J., Time in history : views of time from prehistory ta the present day $\mathrm{Ox}$ ford/New York 1988 .

Win, J.Th.H. de, Imventaris wan de archieven der gemeente Stevensweert, Maastricht 1940.

Win, J.Th.H. de, Inventaris en catalogus der archieven en bibliotheek van de parochie en basiliek van O.L. Vrouw te Maastricht, Maastricht s.a. (2 delen in typoscript).

Woodwards, D., The means of payment and hours of work in early modern England, in: C.S. Leonard and B.N. Mironov (eds.), Hours of work and means of payment: the evolution of conventions in pre-industrial Europe, Milano 1994, pp. 11-21. (Proceedings eleverth International Economic History Congress Milan, September 1994, B3b).

Woude, A van der and A. Schumrman (eds.), Probate inventories: a new source for the historical study of wealth, material culture and agricultural development : papers presented at the Leewwenborch Conference (Wageningen, 5-7 May 1980) (A.A.G. Bijdragen; 23), Wageningen 1980 .

Wouters, H.H.E., Historische gegevens over het carillon van het stadhuis te Maastricht. (Ongepubliceerd rapport). 
Wijnen, C., De lakennijverheid in de Staalse Landen ran Overmaas aan het einde van de achttiende eeuw: de activiteiten van Johann Amold won Clemont in Vaals en war de gebroeders Scheibler in Eijsden en Dalhem, in: Textielhistorische Bijdragen, 35(1.995), pp. 44-61.

Zanden, J.L. van, De economische ontwikkeling wan de Nederlandse landbown in de negentiende eeuw, 1800-1914, Utrecht 1985.

Zeeman, J, De Nederlandse stoelklok, Assen 1969.

Zeeman, J., De Nederlandse staande klok, Assen/Amsterdam 1977.

750 [zewenhonderdvijfig] jaar parochie St. Geertruid, s.L. s.a. [1973]. 


\section{Lijst van gebruikte afkortingen}

\begin{tabular}{|c|c|}
\hline cir. & confer \\
\hline DTE-Iegisters & Doop-, Troul-, Begraafregisters \\
\hline inv,tur. & inventarisnummer \\
\hline G.A. & gemeentearchief \\
\hline G.A.M. & gemeentearchief Maastricht \\
\hline G.A.R. & gemeentearchief Roermond \\
\hline G.A.V. & gemeentearchief Venlo \\
\hline G.A.W. & gemeentearchief Weert \\
\hline LGOG & Limburgs Geschied-en Oudheidkundig Genootschap \\
\hline N.A. & notarieel archief \\
\hline NMGK & Nederlands(ch)e Monumenten van Geschiedenis en Kunst \\
\hline PSHAL & Publications de la Société Historique et Archéologique dans le Limbourg \\
\hline R.A. & Rijksarchief \\
\hline R.A.H. & Rijksarchief Hasselt \\
\hline R.A.M. & Rijksarchief Limburg te Maastricht \\
\hline ro & recto \\
\hline s.a. & sine anno \\
\hline S.A. & Stadsarchief/Stadtarchiv \\
\hline S.A.St-Tr. & stadsarchief Sint-Truiden \\
\hline S.A.T. & stadsarchief Tongeren \\
\hline s.l. & sine loco \\
\hline s. v. & sub roce \\
\hline VNM & $\begin{array}{l}\text { voorloopige lijst der Nederlandsche monumenten wan geschiedenis en } \\
\text { kunst, deel VIII, de provincie Limburg }\end{array}$ \\
\hline wo & verso \\
\hline z.a. & e aldaar \\
\hline
\end{tabular}




\section{Inleiding}

De laatste zestig jaar verschenen talrijke publicaties over tijdmeting, uurwerken en uurwerkmakers. Een belangrijk deel was afkomstig van geïteresseerden in antiek, met name liefhebbers en verzamelaars van oude uurwerken. In fraai uitgevoerde en rijk geïllustreerde boekwerken bieden zij informatieve beschrijvingen en foto's van antieke uurwerken, soms een keur van details over de historie van gebouwen waarin een uurwerk was geplaatst en talrijke data over uurwerkmakers. ${ }^{1}$ Naarmate het onderzoek van deze auteurs gedetailleerder en nauwkeuriger werd, nam de waarde van hun werk toe. Vaak treft de onderzoeker in deze publicaties, vooral in de uitgebreide naamlijsten, ${ }^{2}$ zoals die van Britten, Tardy, Morpurgo en Abeler, een uiterst welkome aanvulling op zijn documentatie aan. Inzicht in de maatschappelijke betekenis van de mechanische tijdmeting en de verbreiding van de tijdmeetinstrumenten bieden deze publicaties niet, vooral omdat slechts een deel van de productie wordt behandeld dat geenszins aselect is gekozen.

Ook in kringen van lokale en regionale geschiedvorsers werd nu en dan aandacht aan uurwerken en uurwerkmakers geschonken, zij het niet altijd expliciet. Uit de meest onverwachte bronnen kunnen details over leven en werk van de uurwerkmakers boven tafel worden gebracht. Soms zijn de bevindingen samengevat in overzichtswerken die een hele regio beslaan, ${ }^{3}$ zij het niet in de beide Limburgen, uitgezonderd het artikel van J. Leunis over de vroegste uurwerkmakers in Belgisch-Limburg ${ }^{4}$ en mijn artikel over de klokken en klokkenmakers in Zuid-Limburg en Belgisch-Limburg. ${ }^{5}$ Gewoonlijk gaat het hiler om publicaties met een veel beperktere reikwijdte die slechts de lotgevallen van de torenuurwerken in een enkele stad of dorp - al dan niet fragmentarisch - beschrijven: hun aanschaf, het onderhoud en vooral de conflicten die ontstonden

\footnotetext{
"Enkele voarbeelden: H. Lloyd 1958; J. Sellink 1973; R. Mühe und H. Vogel 1976; H. Vehmeyer 1994.

2 F. Britten 1977; H. Tardy 1951; E. Morpurgo 1970; J. Abeler 1977.

${ }^{3}$ Onder anderen N. Ottema 1948 (Friesland); J. Abeler 1976 (Bergisches Land); B. Schaaf 1988 (Schwarzwald); W. Pryce and T. Davies 1985 (Wales); J. Sellink, A. Abbink en R. wiggers 1990 (Achterhoek).

"J. Leunis 1958.

${ }^{5}$ P. Mestrom 1977.
} 
wanneer het instrument niet naar behoren functioneerde, soms breed uitmetend of een of ander uurwerkmakersgeslacht onder de loep nemend. Voorzover dergelijke publicaties betrekking hebben op de regio die in dit boek wordt behandeld, is er dankbaar gebruik van gemaakt. Menig detail zou zonder de inbreng van de lokale en regionale historici nimmer zijn ontdekt. De op de beide Limburgen betrekking hebbende uitgaven van deze aard zijn dan ook nauwgezet getraceerd en in de literatuurlijst terug te vinden. De voor ons relevante publicaties bleken echter allerminst het gehele te onderzoeken terrein te behandelen. Theoretische achtergronden en verklaringen boden zij al helemaal niet.

Mede op basis van dergelijke publicaties zijn vervolgstudies verricht ten aanzien van tijdmeting en mechanische uurwerken. Diverse excellente wetenschappers hebben er hun krachten aan gegeven. Twee clusters dienen te worden onderscheiden: dat waarin de vraag naar het "hoe" centraal staat en dat waarin het in hoofdzaak gaat om het vinden van een antwoord op de vraag tot welke maatschappelijke of sociaal-economische consequenties de aanschaf van uurwerken in bepaalde historische tijdvakken aanleiding gaf.

Tot de "hoe"-publicaties dienen op de eerste plaats te worden gerekend de studies die zochten naar de oorsprong van het mechanisch uurwerk, het instrument dat het mogelijk maakte zich op de hoogte te stellen van het vorderen van de tijd, wanneer de veel oudere wateruurwerken en zonnewijzers het lieten afweten als gevolg van vorst of donkere wolken. De ene auteur heeft zich veel moeite gegeven te wijzen op het belang van de grote aandacht voor kalenderproblemen en dagindeling in monastieke kringen, ${ }^{6}$ een ander zocht naar een rellatie tussen de oude Chinese astronomische uurwerken en de mechanische uurwerken uit de westerse samenleving. ${ }^{7}$ Hun studies trokken breed de aandacht en gaven aanleiding tot omstandige discussies in wetenschappelijke kringen, maar behandelen slechts een deelprobleem, namelijk de vraag "hoe is Europa toch aan zijn eerste mechanische uurwerken gekomen?". Daarnaast bleek het mogelijk meer brede, als algemene samenvattingen van de geschiedenis van de tijdmeting gepresenteerde, studies te redigeren. Recent verschenen. werken van deze aard zijn

6. North 1975.

7 J. Needham 1954-; I. Needham, Wang Ling and D. de Solla Price 1986. 
van de hand van Edwardes ${ }^{8}$ en Maurice. ${ }^{9} \mathrm{Zij}$ bieden inzicht in de ontwikkeling van de tijdmeting, de typologieën van de uurwerken, de aard en voordelen van innovaties, geven kortom een gedegen geschiedenis van de uurwerkmakerstechniek en van de culturele betekenis van het uurwerk. Daar achterliggende vragen, zoals die naar de redenen om een uurwerk aan te schaffen en de betekenis van het uurwerk voor de organisatie van de samenleving of de economische vooruitgang worden niet of slechts marginaal aan de orde gesteld. Een gedeeltelijke uitzondering hierop vormen Whitrow ${ }^{10}$ en Dohrn-van Rossum ${ }^{11}$ die onder andere onderzoek deden naar de verandering in het tijdsbewustzijn van de westerse mens door de invoering van het mechanisch uurwerk. Het tweede cluster wordt gevormd door de publicaties van een groep wetenschappers die in het ontbreken van antwoorden op contextuele vragen aanleiding hebben gezien zich diepgaand met de tijdmeting bezig te houden. Een viertal, te weten Cipolla, Landes, Le Goff en Mayr, zullen we hier aanstippen, mede om te laten zien, hoe gemakkelijk bij dergelijke beschouwingen zich de wegen scheiden, vooral wanneer de documentatie niet al te ruim is en de auteur zich doorgaans baseert op data omtrent bijzonder luxe producten en technische hoogstandjes. Exhaustief kan men in het kader van een boek als het onderhavige in deze niet zijn. Het zou te veel op zijpaden voeren en de specifieke vragen eerder verduisteren dan verhelderen.

Cipolla werd getroffen doot de beschouwingen van Marc Bloch ${ }^{12}$ over de watermolens, een middeleeuwse vinding van mechanische aard die zich snel uitbreidde en leidde tot een sterke stijging van arbeidsproductiviteit bij bepaalde industriële productieprocessen, zodat streken met veel snel vlietend water lange tijd konden profiteren van serieuze kostenvoordelen bij de vervaardiging van bijvoorbeeld lakense stoffen en leer. Wellicht mede beïnvloed door Mumford, die al in 1934 poneerde dat "the clock, not the steam engine, is the key machine of the modern industrial age", richtte Cipolla zijn aandacht op twee toepassingen van vroege mechanica, de klokken en de vuurwapens. Beide zijn vindingen wan rond het

\footnotetext{
${ }^{8}$ E. Edwardes 1977.

${ }^{9} \mathrm{~K}$. Maurice 1976.

${ }^{19} \mathrm{G}$. Whitrow 1988 .

${ }^{11}$ G. Dohm-van Rossum 1992 .

12. M. Bloch 1963.
} 
begin van de 14 de eeuw. De eerste klokken zouden in Noord-Italië zijn opgedoken, in het bijzonder te Milaan. Binnen enkele decennia, in 1344 , slaagde $\mathrm{De}^{\prime}$ Dondi in Padua erin een uitermate gecompliceerd astronomisch uurwerk te bouwen. Voorshands was het mechanisch uurwerk weinig bedrijfszeker, maar toch kon het de clepsydra verdringen en de zonnewijzer naar een tweede plaats verwijzen omdat de storingen aan het uurwerk meestal van kortere duur waren dan de perioden van ongunstige weersomstandigheden als bewolking en vorst die de andere tijdmeters vaak wekenlang uitschakelden, althans volgens Cipolla. Veel belangrijker achtte deze auteur een tweede voordeel: het uurwerk heeft meer dan enige andere uitvinding de aandacht van de bevolking op de mogelijkheden van toepassingen van de mechanica gericht. Zich vergapend aan Jacquemarts en astronomische uurwerken en aandachtig luisterend naar de tonen van het carillon werd de Europeaan zich bewust van de mogelijkheden van de technologie. ${ }^{13}$ Het uurwerk legde in zijn visie mede de basis voor de westerse expansie.

Landes ${ }^{14}$ ging dit alles wat erg ver. Het mag zijn dat de uitvinding van het mechanisch uurwerk achteraf een revolutionaire gebeurtenis van beslissende betekenis was in Europa's opgang naar macht door middel van kennis en met behulp van technologie, zo betoogt hij, voor de Middeleeuwer stond deze doelstelling niet voorop. Voor hem ging het om een nuttig instrument dat op vele momenten behulpzaam kon zijn bij het regelen van alle zaken die door de aard van het biologisch ritme van de mens in een stedelijk milieu nu eenmaal gestructureerd moesten worden aangepakt en grondig georganiseerd: de arbeid, het genieten van maaltijden, de slaap, enzovoort. In het tweede deel van zijn studie weidt hij derhalve omstandig uit over de verbreiding van het uurwerk. In heel Europa vond hij er voorbeelden van. De talrijke problemen rond de nauwkeurigheid van het uurwerk en de degelijkheid van het instrument geven Landes aanleiding vervolgens nog vele bladzijden te wijden aan de uurwerkmakers die eeuwen nodig hadden om tot bevredigende oplossingen te komen. Het derde deel behandelt de economische geschiedenis van de horloge-industrie tot en met het massaal gefabriceerde quartzhorloge dat in beginsel iedereen de gelegenheid

${ }^{13}$ C. Cipolla 1967, passim; C. Cipolla 1989, pp. 181-182.

${ }^{14}$ D. Landes 1983.

\section{XXXVIII}


biedt jarenlang dezelfde tijd met zich mee te dragen als diegenen met wie hij afspraken heeft of van wie hij diensten wil ontvangen. Le Goff had toen al opgemerkt dat er wezenlijke verschillen bestonden tussen de behoefte aan inzicht in het tijdsverloop tussen verschillende sociale groepen. $\mathrm{Zij}$ die zich bezighielden met de rituele aspecten van de samenleving, de kerkelijke functionarissen, waren gedwongen ingewikkelde kalenderproblemen op te lossen om de paasdatum te kunnen bepalen en hun gecompliceerde metafysische en theologische discussies over de tijd, die min of meer berouwvolle zondaars moesten doorbrengen in het vagevuur, tot een goed einde te brengen. De kooplieden daarentegen ging het om efficiency. Voor hen was het uurwerk een instrument dat absoluut nodig was, wilden zij een kapitalistische samenleving gestalte geven. ${ }^{15}$ Aan de voet van het torenuurwerk ontmoetten zij elkaar. Daarna scheidden hun wegen. De kerkelijke overheid bracht de wijzerplaat hooguit naar het doxaal in de kerk om niet elke keer een lange wandeling te hoeven maken, de koopman had het tijdmeetinstrument het liefst duidelijk zichtbaar en hoorbaar nabij zijn werkplek op de markt. De een sloeg er slechts bij tijd en wijle acht op, de ander wilde het horologium liefst permanent bij de hand hebbben.

Mayr $^{16}$ wijst in een heel andere richting. De spectaculaire verbreiding van de uurwerken van de late Middeleeuwen tot in de $18 \mathrm{de}$ eeuw weerspiegelde zich zijns inziens in een zich steeds verder uitbreidend patroon van metaforen die de relatie tussen instrument, technologisch denken en cultuur in Europa onderstreepten. Wellicht werd de samenleving in de geschiedenis nooit zo sterk gefascineerd door een instrument als door het uurwerk. Literatoren, wetenschappers en in het bijzonder de Cartesiaanse wijsgeren ontleenden steeds vaker culturele beelden aan de klokken. Het zelfregulerend systeem ervan werd niet alleen het kenmerk van technologie, maar ook van de theorieën van denkers als Locke en Smith. De liberale opvatting van maatschappelijke orde, de economische wetenschap en hele politieke systemen werden gedomineerd door begrippen uit de uurwerktechnologie als balans en evenwicht, aantrekken en afstoten.

is. Je Goff 1960; J. le Gioff 1985 .

i6 O. Mayr 1986. 
Het gaat niet aan te betwijfelen of het wereldbeeld, het economisch handelen en de organisatie van de samenleving in de loop der eeuwen op diverse wijzen invloed hebben ondergaan van de mechanische inzichten die de basis vormen van het mechanisch uurwerk. Het is evenwel uitgesloten dat wie dan ook, die in de late Middeleeuwen of in de Nieuwe Tijd een forse som gelds neertelde voor een uurwerk, precies wist hoe de economie eeuwen later moest worden gereorganiseerd. Het mag zijn dat religieuze instituties op een andere wijze profiteerden van de uurwerken dan de handelaren, maar dit zijn constateringen achteraf. De in de literatuur ontwikkelde visies roepen vele vragen op. De "liefhebbers" hadden te weinig aandacht voor de verbreiding van het uurwerk en de sociaal-economische achtergronden van zijn verschijning. De lokale en regionale historici leverden gewoonlijk data die niet gemakkelijk met elkaar in verband zijn te brengen. De oudere algemene samenvattingen missen nog altijd de theoretische achtergrond en de verklaring. De belangwekkende conclusies van Cipolla c.s. slaan vele eeuwen over en hebben te weinig oog voor fundamentele wijzigingen die zich tussen de Middeleeuwen en de Moderne Tijd voordeden. Verbreiding, chronologie en nauwgezette analyse van de inbedding van het mechanisch uurwerk in de samenleving zullen onze aandacht in hoge mate nodig hebben. Wij zullen ons vooral moeten afvragen wat de Middeleeuwer verwachtte van het torenuurwerk en waarom drie eeuwen later huisuurwerken werden aangeschaft en hoe dat uurwerkbezit zich verbreidde.

\section{Vraagstelling}

Tal van specifieke vragen moeten worden bestudeerd: wie nam in de late Middeleeuwen het voortouw bij de openbare tijdmeting, de landsoverheid, de stadsbesturen, de kerkelijke leiding? Wat was het nut dat degenen die zo'n kostbare aanschaf deden ervan verwachtten? Ging het hen om status, om het oplossen van sociale en economische problemen of wilden zij slechts dat iedereen op tijd in de kerk was? Verandert daar in de loop van de tijd wellicht het een en ander aan? Hoe verbreidde het torenuurwerkbezit zich in geografisch opzicht: volgden de kleine nederzettingen, plattelandsstadjes en dorpen de lijnen uitgezet door hun grote broers? Hoe evolueert het torenuurwerkbezit in kringen met vooral een ritueel-

XL 
religieuze functie? Hoe gaat het bij de instituties van bestuurlijke aard? Wanneer gaat de particulier interesse tonen voor het bezit van een huisuurwerk? Waar gebruikt hij het voor? Hoe verbreidt het huisuurwerkbezit zich over de sociale lagen? Op deze vragen zal ons onderzoek zich toespitsen. Voor het oplossen ervan zullen wij ons op de realiteit moeten richten. Het gaat niet om ideeën, maar om feiten. Het zal gaan om de verklaring van geconstateerde feiten.

\section{Onderzoeksgebied}

De door de bestaande literatuur opgeworpen kwesties hebben deels betrekking op geografische aspecten, deels op sociale. Zowel de verbreiding van het uurwerkbezit over nederzettingen van verschillende grootte en aard, als die over de sociale strata, nodigen uit om het hele pakket kwesties te bekijken in een regio van beperkte omvang. Zo'n onderzoek naar verbreiding en benutting van mechanische uurwerken in een overzichtelijk geografisch gebied is nog nooit ondernomen. Ons voornemen is derhalve nieuw. Dit betekent dat er risico's aan vastzitten. Gesteld dat blijkt dat landsoverheden een grote rol speelden - vooraf weet de onderzoeker dit niet -, dan kan de keuze van het territorium vervelende gevolgen hebben. Indien men te maken heeft met een landsheer die op het terrein van openbare tijdmeting heel actief was of het daar juist lelijk liet afweten, zijn de conclusies allerminst significant. Hooguit gelden zij voor dit ene geval. In dat opzicht biedt onze keuze voor Limburg uitkomst. Bijna heel de bestudeerde periode door, behalve van 1795-1839, vormden de huidige Limburgen een politieke lappendeken, waarin grote (Boutgondië, Spanje, Oostemrijk, de Verenigde Provinciën en Pruisen) en kleine landsheren (de talrijke rijksheerlijkheden) het voor het zeggen hadden en zelfs grote (de prinsbisschop van Luik) en kleine kerkelijke bestuurslichamen (Thorn, de Maastrichtse kapittels) als suzerein optraden. De invloed van de bestuurlijke bovenlaag zal hier derhalve stellig aan de dag treden in wisselende vorm.

De regio is ook groot genoeg. Zij omvat weliswaar slechts één naar middeleeuwse maatstaven grote stad (Maastricht), maar wel een reeks kleinere steden en zelfs een heel palet aan mislukte stadsstichtingen. Het aantal dorpen loopt in de honderden. 
In sociaal opzicht verkeren wij wellicht niet in de allerbeste positie. Tegen het einde van de door ons bestudeerde periode vormden de beide Limburgen in economisch opzicht een wat achtergebleven gebied. Het besteedbaar inkomen per hoofd van de bevolking was er veel lager dan in Luik of West-Nederland. De hogere burgerij is spaarzaam vertegenwoordigd. Dit kan een voordeel zijn: de verbreiding van uurwerken over lagere sociale lagen zal nadrukkelijk aan de dag treden.

Omdat hier voor de eerste maal een regionaal precies begrensd onderzoek naar de boven gestelde vragen wordt beproefd en derhalve vergelijkingen en het benutten van comparatieve technieken uitgesloten zijn, zal uiterst zorgvuldig, stap voor stap, alle data, hoe minuscuul ook, precies wegend, moeten worden voortgeschreden. Dit stelt bijzondere eisen aan het bronnenmateriaal. Op de mogelijkheden daarvan dient in een afzonderlijke paragraaf te worden ingegaan.

\section{Bronnen}

De data nodig voor een boek als het onderhavige moesten moeizaam bijeen worden gesprokkeld. Het gaat gewoonlijk om details die in bronnen yan zeer verschillende aard zijn aangetroffen. Voor de torenuurwerken zijn we over het algemeen aangewezen op geschreven bronnen omdat er weinig oude exemplaren zijn overgebleven. Geschreven bronnen, waarin iets te vinden is over torenuurwerken, zijn er vele: stadsrekeningen, raadsverdragen, schepenbankarchieven, visitatierapporten, parochie-archieven, kasteelarchieven en notarisarchieven spreken er op onverwachte momenten over. Dat levert heuristieke problemen op. Het leven van de historicus is te kort om alle potentiële vindplaatsen te exploreren. Gelukkig bestaat er een overzienbare hoeveelheid secundaire literatuur, zoals stadsen dorpsgeschiedenissen en histories van instellingen. In deze literatuur komt gewoonlijk hier of daar wel een korte notitie voor betreffende een stads- of dorpsuurwerk, vaak met vermelding van bronnen, die opnieuw bekeken meer informatie bevatten dan de lokale historicus vermeldde. Leidt deze werkwijze tot volledigheid? Gedurende vele jaren werd getracht de literatuur zo compleet mogelijk na te kijken op uurwerkgegevens, maar tot het laatst toe stuitten wij op aanvullingen. Volledigheid kan niet worden gegaran- 
deerd. De diversiteit van het basismateriaal, het ontbreken van indices en vaak zelfs van archiefinventarissen hadden tot gevolg dat de zoektocht nooit voltooid kon heten. Het zelfvertrouwen groeit pas als blijkt dat nieuwe vondsten geen wezenlijke aanvulling meer bieden die tot andere inzichten nopen en dat andere ernstige onderzoekers tot identieke uitkomsten geraakten. Voor de vroege uurwerkmakers in Belgisch-Limburg werd dankbaar gebruik gemaakt van de studie die J. Leunis ${ }^{17}$ hierover heeft gepubliceerd. De data van Leunis konden, na consultatie van tientallen door hem niet benutte boeken, die deels verschenen nà de publicatie van zijn werk, en de raadpleging van heel wat archiefdossiers, slechts hier en daar worden aangevuld. Kennelijk mag men niet veel meer gegevens verwachten dan Leunis heeft gevonden. Hij deed zijn onderzoek van de Belgische steden nauwgezet. Jammer genoeg beperkte hij zich tot een deel van ons onderzoeksgebied.

Van meer belang is het antwoord op de vraag of de gevonden gegevens het schetsen van een in wetenschappelijk opzicht verantwoord beeld mogelijk maken. Met enige nuanceringen kan die vraag positief worden beantwoord. Er is over een dusdanig groot aantal uurwerken het een en ander gevonden dat tenminste in meerdere opzichten algemene kenmerken kunnen worden gepresenteerd op een wijze die statistisch redelijk relevant is. De gekozen regio biedt over een honderdtal torenuurwerken inlichtingen ten aanzien van aanschaf, plaatsing en onderhoud. Dit is hoogstwaarschijnlijk meer dan de helft van het totaal aantal torenuurwerken dat vóór 1820 in de beide Limburgen heeft bestaan. Voor wat de aspecten betreft waarover nagenoeg alle documenten spreken, de aanschaf, de opdrachtgever en de plaats waar het uurwerk werd opgesteld, kunnen schier definitieve uitspraken worden gedaan. Andere facetten, zoals die van meer technische aard, worden evenwell zo zelden in de akten aangeroerd dat daarover slechts mededelingen kunnen worden gedaan die het niveau van evenementele geschiedschrijving niet overstijgen.

Wat betreft de huisuurwerken is de aard van het bronnenmateriaal vergeleken met de torenuurwerken net omgekeerd: hier een groot aantal uurwerken (circa duizend exemplaren) en weinig documen-

I. J. Leunis 1958. 
ten. De uurwerken werden getraceerd via oproepen in kranten ${ }^{18}$ en in het televisieprogramma "Van gewest tot gewest". ${ }^{19}$ Mondelinge informatie bij bezoek aan uurwerkrestaurateurs en uurwerkbezitters leverde weer adressen op van andere uurwerkeigenaren. Hier lijken conclusies over de technische aspecten gemakkelijker te trekken dan over allerlei kwesties van organisatorische en financiële aard. Toch past voorzichtigheid. Bij de bewaard gebleven huisuurwerken moet in acht worden genomen dat aan veel huisuurwerken wijzigingen zijn aangebracht. $\mathrm{Nu}$ eens stond het uurwerk eertijds in een andere klokkenkast, vaak waren de wijzerplaat of het adresplaatje niet origineel, dan weer kreeg men te maken met regelrechte vervalsingen van delen of zelfs het geheel. Alleen het bestuderen van zoveel mogelijk exemplaren gaf op den duur het nodige onderscheidingsvermogen om vast te stellen wat wel en niet bij elkaar hoorde. Bij bezichtiging van uurwerken bij mensen thuis deed zich vaak een probleem voor, namelijk de omstandigheid dat het uurwerk niet uit de kast en zeker niet uit elkaar mocht worden genomen. Slechts bij ruim honderd exemplaren mocht dat wel, zodat deze nauwkeurig konden worden bestudeerd. Toch leverden ook de uurwerken die niet uit de kast mochten worden genomen veel gegevens op door ze goed van buitenaf te bekijken, op te meten en via de zijdeurtjes een blik op het binnenwerk te werpen: men kan dan tenminste het uurwerktype vaststellen, evenals het type echappement, het soort slagwerk, het aantal bellen en de aanwezigheid van een wekkerwerk. De wijzerplaat en de klokkast waren altijd van buitenaf goed te bekijken. Gezien de geschetste moeilijkheden was slechts af en toe een statistische analyse mogelijk. ${ }^{20}$ Vaak moest worden volstaan met beschrijving van waarnemingen, aangevuld met archivalische en literaire gegevens. ${ }^{21}$

Voor het vinden van biografische gegevens betreffende de uurwerkmakers werd een beroep gedaan op kerkregisters, inwonerslijsten uit de periode 1795-1813, de Burgerlijke Stand, memories van successie en notariële archieven. De naamlijsten van uurwerkmakers, zoals door Weyns en Pholien gepubliceerd, hadden weinig

\footnotetext{
${ }^{18}$ Dagblad "De Limburger"' d.d. 5 december 1975; "Dagblad woor Noord-Limburg" d.d. 5 februari 1992.

${ }^{19}$ N.O.S. "Van gewest tot gewest" d.d. 12 oktober 1977.

20 Zie hoofdstuk VII, tabellen 5-7 en grafieken 3-4.

21 Voor de beschrijving van 733 uurwerken zie appendix. II.
} 
waarde omdat ze vrijwel geen biografische gegevens bevatten en de door hen aangetroffen uurwerken niet werden beschreven, zodat zelfs niet duidelijk was of de vermelding een zakhorloge, een torenuurwerk dan wel een huisuurwerk betrof. ${ }^{22}$

Een bedrijfsarchief of zelfs maar een aantekenboekje van een Limburgse uurwerkmaker is niet gevonden, zodat we niet volledig zijn ingelicht over de productiewijze, de aantallen gemaakte uurwerken, noch over de gevolgde handelspraktijken. Wel bleken de boedelinventarissen van enkele Limburgse uurwerkmakers enig licht te werpen op genoemde aspecten. Ook konden enkele leercontracten worden opgespoord, die het beeld completeerden. Van belang was ook dat diverse uurwerkmakers hun producten niet alleen signeerden, maar ook van een volgnummer en een jaartal voorzagen, zodat de omvang van hun bedrijvigheid bij benadering kan worden bepaald. Door alle fragmentarische informatie te combineren kan een redelijk sluitend beeld worden geschetst en is het mogelijk tenminste de meest elementaire van de hiervoor genoemde vragen te beantwoorden. Wegens gebrek aan documentatie zullen niet alle vragen sluitend kunnen worden beantwoord, vooral ook omdat er onvoldoende mogelijkheden tot vergelijking zijn.

Zoals reeds werd aangestipt, zijn er in de beide Limburgen niet of nauwelijks tafelklokken en zakhorloges vervaardigd. Wel werden er van de laatstgenoemde heel wat verhandeld, waarbij de verkoper zich als maker voordeed door er zijn naam op te (laten) zetten. Het aantal zakhorloges dat zeker van eigen makelij is, bijvoorbeeld die van Johannes Vrijthoff den Jonge uit Maastricht, is zo klein, dat verdere beschrijving weinig zinvol is en daarom achterwege gelaten.

\section{Opzet van de studie}

De grote spreiding van de data, het vergaande verschil in hun aard en de overmaat aan details dwingt tot een opzet van deze studie die op het eerste oog heel evenementeel is. Elk gegeven dient nauwgezet te worden gewogen en in een context geplaatst. Pas na een beschrijving van enkele honderden pagina's, aan het einde van elk

\footnotetext{
${ }^{12}$ Voor de prosopografie van 434 uurwerkmakers zie appendix II. Voor een chronologische opsomming per plats zie appendix $\mathrm{T}$.
} 
hoofdstuk onderbroken door een korte samenvatting die de gevolgde redenering verheldert en laat zien voor de beantwoording van welke vragen het beschrevene relevant is, kan in een slothoofdstuk werk worden gemaakt van het trekken van conclusies.

$\mathrm{Na}$ een eerste hoofdstuk waarin bondig enkele hypothesen over het ontstaan en de verspreiding van het mechanisch uurwerk worden beschreven en een aantal kernbegrippen wordt uitgelegd, volgen vijf hoofdstukken over de openbare tijdmeting. De torenuurwerken horen voorop omdat zij eeuwen eerder in de beide Limburgen. werden aangetroffen dan huisuurwerken en zij voor een veel groter deel van de bevolking van belang waren dan de laatstgenoemde. Hoofdstuk II opent het gedeelte over openbare tijdmeting met beschouwingen over de torenuurwerken in Mastricht, in de Middeleeuwen en de Nieuwe Tijd veruit de grootste stad in de beide Limburgen. De hoofdstukken III en IV behandelen achtereenvolgens de aandacht die aan openbare tijdmeting is besteed in de kleinere Nederlands-Limburgse en Belgisch-Limburgse steden, voorzover die al vanaf de late Middeleeuwen als handels- of nijverheidssteden kunnen worden aangemerkt. Hoofdstuk V gaat in op de stadsstichtingen uit de Middeleeuwen die niet leidden tot een nederzetting die, althans in de eerste eeuwen in economische zin, de naam stad waard was, de grijze zone tussen stad en platteland. Hoofdstuk VI handelt over het platteland in Nederlands- en Belgisch-Limburg. Beide omvatten een zone met magere zandgronden en een andere met vruchtbare löss. Verschillen in welvaartsniveau tussen Noord en Zuid krijgen aandacht. De documentatie is in appendix III beschreven.

Hoofdstuk VII markeert de overgang van openbare tijdmeting naar het particulier bezit van huisuurwerken. Het gaat in op de technieken toegepast bij de bouw van beide soorten uurwerken. Hoofdstuk VIII spreekt over de uurwerkmakers. Hoofdstuk IX behandelt de productie in zijn vele facetten en hoofdstuk X bespreekt de afzet en verspreiding van de Limburgse uurwerken. Zoals reeds vermeld worden in het elfde hoofdstuk de conclusies getrokken.

\section{Woord van dank}

$\mathrm{Bij}$ de voorbereiding van dit boek werd veel steun ondervonden. De eigenaren van de uurwerken die toestonden hun bezit te bekijken 
zij veel dank gebracht. Zonder hun medewerking had dit boek nooit tot stand kunnen komen. Een aantal plaatselijke geschiedvorsers en archivarissen bleek tot heel bijzondere medewerking bereid. Met enige regelmaat meldden zij vermeldingen van uurwerkmakers en de aanschaf van uurwerken in archivalia die hen toevallig onder ogen waren gekomen. In het bijzonder zij met ere vermeld $M$. van Heyst te Maastricht, die mijn allereerste vraag over Limburgse uurwerkmakers zodanig beantwoordde, dat mijn belangstelling voor het onderwerp blijvend was gewekt. Gedurende vele jaren verschafte hij inlichtingen uit de notariële archieven. Ook J. Gulikers te Maastricht, M. Kunnen te Kinrooi en B. van Lieshout te SintMichielsgestel verschaften meermaals nuttige informatie.

L. Dohmen te Born en H. Royen te Cadier en Keer wisten in vele gesprekken de auteur tenminste zoveel uurwerktechnisch inzicht bij te brengen dat hij in staat was de technische onwikkelingen en verschillen bij de aangetroffen uurwerken te onderscheiden en te waarderen. $\mathrm{Zij}$ allen verdienen voor hun bereidwilligheid en diligentie grote dank.

Het Sociaal Historisch Centrum voor Limburg te Maastricht stelde werkruimte en faciliteiten beschikbaar, de Stichting Maaslandse Monografieën nam het boek op in haar reeks, de dames I.J.L. Frints, M.C. Mommers-Bakker en E.M. Muyres-Schilder maakten het manuscript persklaar. Ook hiervoor mijn grote dank. Er zijn nog velen die op de een of andere wijze hun bijdrage hebben geleverd aan deze publicatie. Het is schier onmogelijk iedereen te noemen, maar allen wil ik mijn dankbaarheid betuigen.

Tenslotte dienen de beide promotoren te worden genoemd. Prof. dr. J.C.G.M. Jansen heeft gedurende de vele jaren dat dit onderzoek heeft geduurd vele concepten en versies doorgelezen en met de auteur besproken. Door zijn niet aflatende bijsturing is, wat aanvankelijk soms een omgevallen kaartenbak leek, uitgegroeid tot een dissertatie. Prof. dr. ir. C.A. Grimbergen werd wat later bij het onderzoek betrokken. Als beoefenaar van de exacte wetenschappen en enthousiaste klokkenliefhebber heeft hij gelet op exacte formuleringen en aangedrongen op overzichtelijke tabellen en statistieken. Beiden spreek ik mijn grote dank uit.

Mijn zonen Pascal en Cyril dank ik voor hun begrip als ik weer eens op pad moest voor klokken of lange tijd bezig was de gegevens te verwerken. Ik betreur het dat mijn verongelukte zoon Maurice de voltooiing van dit werk niet mocht beleven. 



\section{Hoofdstuk I}

\section{De ontwikkeling van het mechanisch uurwerk en de openbare tijdmeting}

De openbare tijdmeting is al begonnen vóór het mechanisch uurwerk werd uitgevonden. Eeuwenlang werden voor dit doel het wateruurwerk en de zonnewijzer gebruikt. Na de komst van het mechanisch uurwerk heeft het wateruurwerk zich niet kunnen handhaven. De zonnewijzer daarentegen wel, hij bleef nodig om de mechanische klokken te kunnen controleren en op tijd te zetten, totdat het tijdsein per telegraaf en radio zijn intrede deed. Omdat het in deze studie gaat over mechanische uurwerken, wordt verder niet ingegaan op de andere tijdmeters.

Ten aanzien van de essentiële vragen "wanneer, waar, door wie en hoe is het mechanisch uurwerk uitgevonden?" bestaat onder wetenschappelijke onderzoekers nog altijd geen consensus. Hoewel het niet de bedoeling van een studie over de uurwerkmakerij in de beide Limburgen kan zijn hierop een definitief antwoord te geven lijkt het toch nuttig aan deze vragen aandacht te besteden omdat in deze streken een belangrijk deel van de zeer vroege Nederlandse uurwerken wordt aangetroffen. Een kort overzicht van de huidige kennis over de ontwikkeling van het mechanisch uurwerk zal daarom worden gepresenteerd.

De precieze ontstaansdatum van het mechanisch uurwerk is moeilijk vast te stellen omdat de terminologie in de vroege bronnen niet eenduidig is. Het woord "horologium" dat in Latijnse kronieken veelvuldig wordt gebruikt, betekent "urenteller", "tijdmeter" in het algemeen. Behalve mechanisch uurwerk kan het ook zonnewijzer en wateruurwerk betekenen. Ondanks deze onduidelijkheid zijn er aanwijzingen, dat het mechanisch uurwerk wellicht in het laatste kwart van de 13 de eeuw is ontwikkeld. Tot deze datering kan men komen op grond van de jaartallen betreffende het aanbrengen van uurwerken in Engelse kathedralen: Dunstable Priory in Bedfordshire (1283), Exeter Cathedral (1284), de oude Saint Paul's in Londen (1286), Merton College, Oxford, (1288?), Norwich Cathedral Priory (1290), Ely Abbey (1291) en Christchurch Cathedral, Canterbury 
(1292). ${ }^{1}$ Bij de genoemde Engelse voorbeelden gaat het vanwege de hoge kosten, die eraan werden gespendeerd, vrijwel zeker om (grote) mechanische uurwerken. Veel oudere handboeken noemen evenwel Italië als land van oorsprong van de mechanische klok. De eerste zekere vermelding van een mechanische klok daar dateert echter van 1309 (Milaan, San Eustorgio), Gezien de vroege Engelse vermeldingen is een ontstaan in Engeland of in Noordwest-Europa niet onwaarschijnlijk. Voor het ontstaan van het mechanisch uurwerk aldaar zijn argumenten aan te voeren. Immers hier was de behoefte aan een dergelijk instrument groter omdat zonnewijzers minder continu konden worden gebruikt dan in zuidelijke landen vanwege het geringere aantal zonne-uren, terwijl waterklokken er eerder bevroren. Het milieu waarin de uitvinding is gedaan, was mogelijk het monastieke. In de kloosters hield men zich voor het invullen van de kerkelijke jaarcyclus sinds eeuwen bezig met kalender- en tijdmeetproblemen. ${ }^{2}$ Hier was de technische en mathematische kennis aanwezig, nodig voor de bouw van een puur mechanisch raderuurwerk. Ook was hier voldoende geld. De monniken hadden baat bij signalen voor de aanvang van de diensten en gebeden, die op bepaalde tijden moesten worden gehouden. ${ }^{3}$ Dohrnvan Rossum zwakt de invloed van de kloosterorganisatie wat af, maar acht de kloosters toch de meest waarschijnlijke plaats van ontstaan van het mechanisch uurwerk. De tijdstippen voor de diensten moesten, vóór het mechanisch uurwerk bestond, worden bepaald met behulp van zonnewijzer, astrolabium of klepsydra. De signalen voor de diensten werden ten behoeve van de hele kloostergemeenschap gegeven door een daartoe aangewezen monnik of lekebroeder op één of meer luidklokken. 's Nachts werd de man niet vanzelf op tijd wakker, maar ook overdag was het handig dat hij op de juiste tijdstippen werd geattendeerd. Vóór de mechanische klok kan dit zijn gebeurd door een klepsydra die was verbonden met een door een gewicht aangedreven wekkerwerk. De rol van de eerste uurwerken was vergelijkbaar met die van de klepsydra, namelijk het uitlichten van het wekkerwerk. Dit impliceert dat het

\footnotetext{
J. North 1975 , pp. 381-398.

${ }^{2}$ T. Derry and T. Williams 1960 , p. 224 . De abdij van Prüm was een van de velle waar men zich bezig hield met kalendervragstukken. Zie L. Boschen 1972, pp. 13-75; G. Dohrn-van Rossum 1992, pp. 45-48.

${ }^{3}$ J. Noth 1975 , pp. 381-398; D. Landes 1983, pp. $53 \% 66$.

${ }^{4}$ G. Dohrn-van Rossum 1992, p. 50.
} 
door een gewicht aangedreven wekkerwerk al bestond vór het mechanisch uurwerk in zwang kwam. Daar zijn ook aanwijzingen voor. ${ }^{5}$

Het water van de klepsydra kon 's winters bevriezen en 's zomers verdampen. Daarbij kwam nog, dat viscositeitvariaties van het water een nauwkeurige tijdmeting verhinderden.

Een mechanisch uurwerk heeft deze nadelen niet. Evenals bij het wateruurwerk was de alarmeringsfunctie primair, de tijdsaanduiding secundair. De eerste mechanische uurwerken zullen daarom nog geen torenuurwerken zijn geweest, maar huisuurwerken, veel lijkend op de zogeheten kloosterwekkers, zoals er enkele zijn bewaard. Deze exemplaren dateren echter pas van circa $1400 .{ }^{6} \mathrm{Ze}$ hadden slechts een gaand werk met wekkerwerk. Meestal hadden zij een roterende wijzerplaat met 24-uurs indeling en gaatjes om een pen in te steken voor de wekkeruitlichting. Deze kloosterwekkers waren eenvoudige, kleine uurwerken, vandaar, wellicht, dat we er niets over lezen in de kloosterkronieken. Toen men uurwerken in torens ging plaatsen, die zelf het uur via een slagwerk op grote luidklokken sloegen, moesten er grote, zware instrumenten worden gebouwd. Daarover krijgen we wel herhaaldelijk informatie vanwege vermelde hoge kosten van aanschaf en onderhoud. Wellicht zijn de kloosterwekkers enige decennia vroeger te dateren dan de eerste vermeldingen van torenuurwerken.

Voor een mechanisch uurwerk is het ontsnappingsmechanisme of echappement, geregeld door een tijdsbepalend element, essentieel. Het zorgt ervoor dat de aandrijvingskracht van het gewicht in kleine stukjes kan ontsnappen. Deze stukjes worden door het raderwerk "geteld", waardoor een tijdsaanduiding ontstaat. Het oudst bestaande ontsnappingsmechanisme is de verticale spillegang met als gangregelaar de waag, ook foliot geheten: een horizontale balk met naar binnen en buiten verstelbare gewichtjes, die een alternerende beweging makt, waarbij het kroonrad telkens één tandje door draait (zie afbeelding 1). Over de ontwikkeling van het echappement is veel gespeculeerd. Er zijn zelfs enkele personen genoemd, die het ontsnappingsmechanisme zouden hebben uitgevonden, zoals aartsbisschop Pacificus van Verona, Gerbert van Aurillac - de latere paus Silvester II - en abt Wilhelm von Hirsau.

${ }^{5}$ L. White Jr. 1962 , p. 121.

${ }^{6}$ H. Lloyd 1958 , pp. 28-30, plaat 23. 


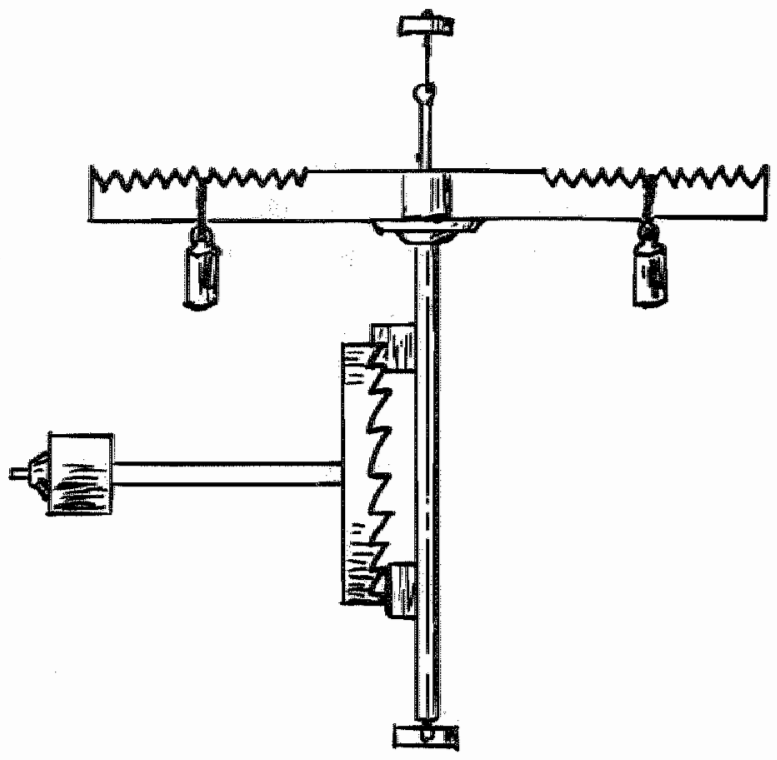

1. Spillegang met foliot of waag

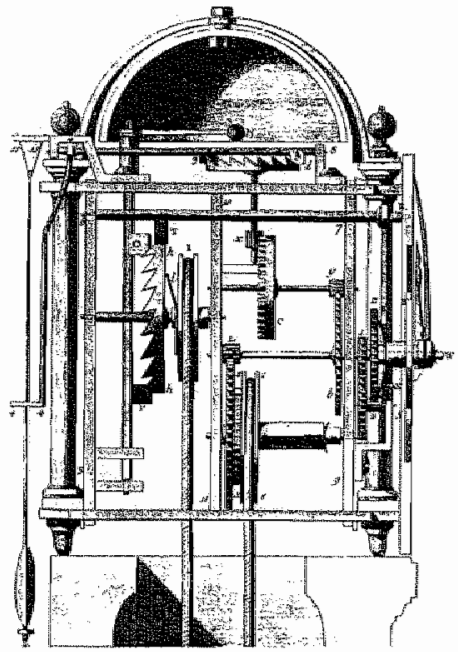

2. Wekkermechanisme: $h=$ wekkerrad, $N=$ bellhamer. De hamer beweegt heen en weer in een horizontaal wlak net zoals een foliot. Ook de vormgelijkenis van het wekkerrad en het ontsnappingsrad (d) van de spillegang is evident (Diderot/d'Alembert Encyclopédie, pl.no. 2c) 
Onderzoek heeft uitgewezen, dat zij met de genoemde uitvinding niet in verband kunnen worden gebracht. ${ }^{7} \mathrm{~J}$. Needham trachtte inspiratie voor de vinding vanuit China aannemelijk te maken. ${ }^{8} \mathrm{De}$ Solla Price is de mening toegedaan, dat de tijdmeting slechts een bijproduct is, een "fallen angel" van gemechaniseerde planetaria, wier oorsprong zou teruggaan op Chinese of - via de Arabische geleerden - antieke voorbeelden. ${ }^{9}$ Landes echter verwerpt de Chinese en "planetaire" invloed op naar het lijkt plausibele gronden. ${ }^{10}$ Ook Dohrn-van Rossum vindt Needhams en Price's theorie niet aanvaardbaar. "Op een veel voor de hand liggender mogelijkheid heeft Robertson al in 1931 gewezen. ${ }^{12}$ Hem was de frappante gelijkenis opgevallen tussen het wekkerrad met wekkerhamer en de verticale spillegang met waag (zie afbeelding 2 ). Hij veronderstelde daarom, dat het eerst bekende echappement is afgeleid van het wekkermechanisme. ${ }^{13}$

De foliot moest in hoge mate verstelbaar zijn, zolang er uren van ongelijke duur, de zogeheten temporaaluren, ${ }^{14}$ in zwang waren. Bij het systeem van temporaaluren werd de dag, dat wil zeggen de tijd tussen zonsopgang en zonsondergang, in twaalf gelijke delen verdeeld, die men uren noemde. De dag liep van zes tot zes uur. De nacht werd eveneens in twaalf uren verdeeld en liep van zes uur in de avond tot zes uur's morgens. Op de langste dag en de langste nacht van het jaar verschillen de daguren aanzienlijk in lengte van de nachturen. Wanneer op een zomerdag de zon opgaat om 04.30 uur en onder gaat om 19.30 uur, dan duurden de daguren in het temporaalsysteem dus $15: 12 \times 60$ minuten of 75 huidige minuten, de nachturen daarentegen 9:12×60 minuten of 45 minuten. Op de langste en kortste dag van het jaar waren de verschillen met de vaste uren op onze breedtegraad nog groter (zie grafiek 1).

\footnotetext{
${ }^{7}$ G. Dohrmwan Rossum 1992, pp. 57-58.

"J. Needham 1954-; J. Nedham, Wang Ling and D. de Solla Price 1986.

${ }^{9}$ D. de Solla Price 1955, pp. 810-814; Idem 1956, pp. 31-35; Idem 1974, pp. 1-70

${ }^{10}$ D. Landes 1983 , pp. 54-56.

"G. Dohrm-van Rossum 1992, pp. 85-88.

12. J. Robertson 1931, pp. 16-18.

${ }^{13}$ Zite ook C. Cipolla 1967, p. 38; G. Dohm-van Rossum 1992, pp. 102-103.

${ }^{14}$ Ook gerwemd temporele, variabele, ongelikke of seizoensuren.
} 
Grafiek 1. De variabele uren te Maastricht en Cairo

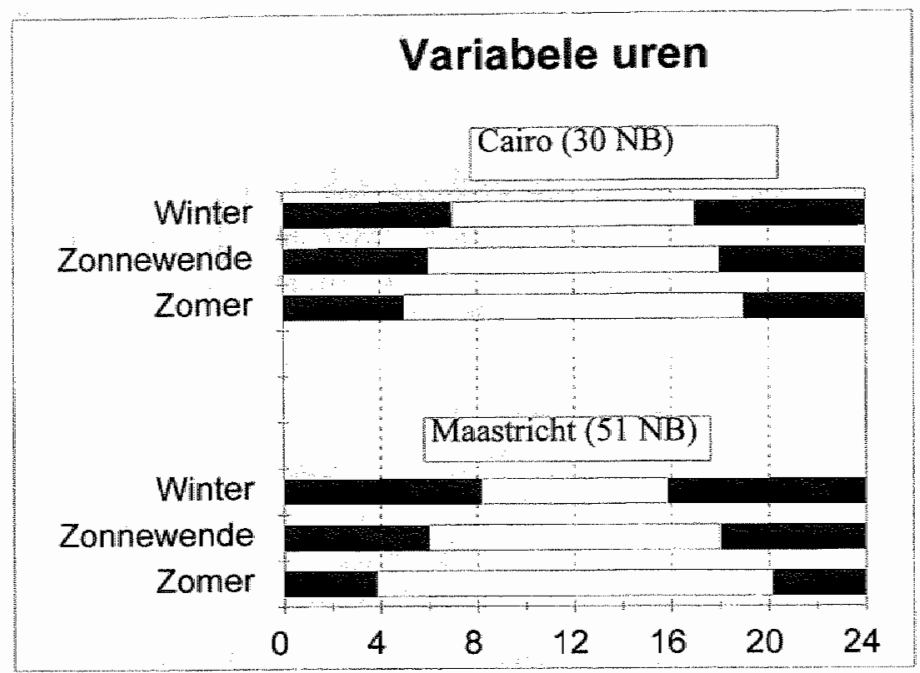

De opzichter van het uurwerk moest dus elke dag 's morgens en 's avonds de reguleringsgewichten van de foliot zo afstellen, dat de verschillende uren naargelang het jaargetijde juist werden afgemeten. Maar misschien gebruikte hij twee foliots, één voor de daguren en één voor de nachturen, net als de Japanners, die het systeem van de temporaaluren tot in de 19 de eeuw handhaafden.

Het systeem van de temporaaluren heeft het volgens Bilfinger ${ }^{15}$ na de opkomst van het mechanisch uurwerk met een automatisch, de uren tellend slagwerk niet lang meer uitgehouden. Dohrn-van Rossum dateert deze uurwerken met slagwerk rond 1335 . Ze zouden zijn ontwikkeld in Noord-Italië. Hij brengt de evenredige uren ermee in verband, hoewel hij toegeeft dat hier geen technische noodzaak voor is. ${ }^{16}$ Sociaal-economische redenen, zoals rechtvaardig verdeelde werktijd en daarmee samenhangende uurlonen, lijken er eerder mee in verband te staan. Hoe dan ook, rond het midden van de 15 de eeuw werden de ongelijke uren afgeschaft en kwamen de evenredige of equinoctiaaluren in gebruik. Als alternatief voor de foliot kon nu een wiel met dezelfde functie worden toegepast, het zogeheten balanswiel, gevormd net zoals de onrust in een

is G. Billfinger 1892, p. 157 .

16 G. Dohrn-wan Rossum. 1992, pp. 106-110. 
horloge, maar zonder spiraalveer. Het hoefde minder grote verstelmogelijkheden te hebben dan de foliot omdat de duur van een uur overdag en 's nachts, 's winters en 's zomers gelijk was. Alleen de invloed van temperatuurverschillen moest door het verschuiven van regelgewichtjes kunnen worden gecompenseerd. De nauwkeurigheid van de vroege mechanische uurwerken was naar onze maatstaven gering: de afwijking was tien tot dertig minuten per dag. De foliot en het balanswiel hebben geen van beide een eigen karakteristieke trillingstijd, zoals de slinger en het balanswiel met spiraal. De snelheid van het echappementsproces wordt bepaald door het traagheidsmoment van foliot of balanswiel samen met de aandrijvingskracht van gewicht of veer.

Ook liet de bedrijfszekerheid veel te wensen over, zoals men hierna veelvuldig kan vaststellen. Dit kwam vanwege de gebrekkige smeermiddelen $^{17}$ en ook omdat men nog niet het voordeel van stalen assen in bronzen lagerbussen had ontdekt. Men probeerde de assen èn de draaigaten juist zo "hard als stael" te maken. ${ }^{18}$ Vanwege de primitieve, met de hand gevijlde vertanding was men genoodzaakt zeer zware gewichten te gebruiken om de frictie te overwinnen. Dit eiste zijn tol in de vorm van tandbreuk en uitgelopen tapgaten. Behalve dat het vroege mechanisch uurwerk onnauwkeurig was, stond het ook vaak stil wegens een defect.

De vroegste torenuurwerken hadden vaak geen wijzers en evenmin een grote wijzerplaat op enige afstand van het uurwerk, hetzij binnen, hetzij buiten het gebouw, waarin het uurwerk was opgesteld. ${ }^{19}$ Men kon ze alleen horen: de tijd werd door het slagwerk verkondigd. Vermoedelijk is dit ook de reden, dat men een uurwerk "klok" ging noemen. Dohrn-van Rossum is de mening toegedaan dat het zelfslaande unrwerk een technische ontwikkeling was van circa 1336 in Italie . ${ }^{20}$ Door deze "sensationele" vernieuwing zou het mechanisch uurwerk zich snel in de steden hebben verbreid als

\footnotetext{
${ }^{17}$ Zie voor de geschiedenis van smeermiddelen D. Dowson 1979 .

18 Zie contract wan het Sint-Serwaaskapittel met Wennemekers anno 1544, hoofdstuk II, paragraar 2.2 .3

${ }^{19}$ De eerste toremunwerken moeten wel een wijzer met wijzerplaatje aan het uurwerk zelf hebben gehad, anders was gellijkzetten van het uurwerk en instelling van het slagwerk nauwelijks mogelijk.

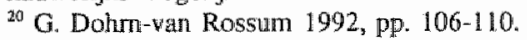


middel voor openbare tijdmeting. ${ }^{21}$ Mijns inziens moet het zelfslaande uurwerk ouder zijn, uit de tijd dat men urwerken in torens ging plaatsen. In Engeland gebeurde dit al in het laatste kwart van de 13 de eeuw. Het lijkt niet erg zinvol een uurwerk zonder wijzerplaten boven in een toren te zetten, als het uur toch door mensenhand moest worden geluid. De grote, niet aan het uurwerk zelf bevestigde wijzerplaat deed vrij laat zijn intrede. Pas in $1443 \mathrm{kreeg}$ het uurwerk in de dom van Florence een binnenwijzerplaat, geschilderd door Paolo Uccello. ${ }^{22}$ In $1455 \mathrm{kreeg}$ het uurwerk van het Gentse belfort een buitenwijzer. Dat bleek een verbetering die snel school maakte. In Maastricht werd op 16 april 1470 Heynric Mulart "de der stat oerclok geregiert ende gesat heet mitten wijser opt Dinckhuys" wegens ziekte vervangen. "Mitten wijser" werd uitdrukkelijk vermeld vanwege de nieuwigheid. ${ }^{23}$

De grote, dure uurwerken hadden waarschijnlijk niet alleen vanwege hun praktisch nut aantrekkingskracht op de kloosters en kapittels, maar ook vanwege hun statusverhogende waarde. Het toppunt van status waren wel de astronomische kunstuurwerken, zoals onder andere in de kathedralen van Straatsburg (1354), Wells (1392-1393) en Münster (1408) werden aangebracht. ${ }^{24}$ Voor de vervaardiging van zulk een wonderwerk liet abt Richard van Wallingford zijn abdij Saint Albans in Hertsfordshire bijna failliet gaan. Bij zijn dood in 1336 was het nog niet klaar, hoewel er al negen jaar aan werd gewerkt. ${ }^{25}$ Het astronomisch uurwerk had heel wat meer functies dan het torenuurwerk. Er zat een religieuze dimensie aan: de mechanische voorstelling van de regelmatige banen van zon en planeten kon bewondering wekken voor de Schepper van het geordende heelal (= machina mundi) en diende "ad majorem Dei gloriam". Daamaast waren de kosmologische aanduidingen op zulke uurwerken destijds nuttig voor astrologische bepaling van "de juiste tijd voor een aderlating, voor een operatie, voor het maken van kleren, voor het bewerken van het land, voor het ondernemen van reizen en voor andere dingen die nuttig zijn in deze wereld", zoals

a. Dohm-van Rossum 1992 geeft overzichten wan de verspreidling wan het mechanisch, openbaar aurwerk op pp. $125-128$ en p. 362 .

${ }^{22}$ G. Vasari 1990, p. 129 .

23 J. Koreman 1974, p. 11 .

${ }^{24}$ A. Ungerer 1931; A. Lehr 1981a.

25. J. North 1976. 
een Italiaanse uurwerkmaker in 1473 opmerkte. ${ }^{26}$ In de beide Limburgen zijn geen astronomische kunstuurwerken aangetroffen. In geen enkel document wordt erover gerept.

Voor de steden uit de 13 de en 14 de eeuw kwam het uurwerk in een cruciaal tijdsgewricht. Van groot belang was de regulerende functie ervan voor het stadsleven. Het maakte het verschil tussen stad en platteland op een pregnante manier duidelijk: in de stad regelde de dag zich naar het stadsuurwerk, dat de tijd akoustisch en later ook optisch aangaf, op den duur zelfs in evenredige uren. ${ }^{27}$ Het uurwerk makte een beperkte synchronisatie van werkzaamheden mogelijk, met name wat betreft de marktorganisatie en het wachtlopen door de burgerwacht: activiteiten die plaatsvonden op of vanaf de markt. Dat was ook de enige plaats, waar de stedelijke uurwerken goed zichtbaar en/of hoorbaar waren, wanneer het uurwerk tenminste functioneerde.

Daarentegen bleef het ritme ten plattelande bepaald door de zon en de seizoenen: 's zomers lange uren, 's winters korte, in de lente en de herfst gemakkelijk bewerkbare gronden. Het grootste gedeelte van het Limburgse platteland moest het nog eeuwen zonder openbaar uurwerk stellen: op het einde van de 18 de eeuw had volgens de bronnen nog slechts $30 \%$ van de dorpen een torenuurwerk ${ }^{28}$ Ook in de steden werden aanvankelijk de werktijden wel aan de lengte van de dag aangepast, maar niet automatisch, zoals op het platteland, waar de plantengroei in de herfst en de winter stagneerde en vanzelf de mogelijkheid op het land te werken minder werd en tensllotte helemaal ophield tot het volgende voorjaar.

Behalve de aspecten van regulering en efficiency sprak ook de steden het statusaspect aan. De trotse steden zochten in de late Middeleeuwen hun status te verhogen door ingenieuze torenuurwerken met uiterlijk vertoon als jacquemarts en automaten als ruiterspelen en apostelstoeten naast mechanische kalenders en astronomische aanduidingen. ${ }^{29}$ Deze toevoegingen waren blijkbaar gemakkelijker te realiseren en werden mogelijk meer gewaardeerd dan verbeteringen in precisie. Daarbij waren ze van nut om de lokale bevolking eraan te wennen acht te slaan op het uurwerk, ook wanneer dit niet

\footnotetext{
${ }^{26}$ De uurwerkmaket Bartolomeo Manfredi uit Mantua, geciteerd door C. Cipolla 1967, p. 42.

${ }^{27}$ Zie noot 15 en 16.

${ }^{28}$ Zie echter de opmerkingen over de betrouwbaarheid van de bronnen aan het einde van hoofdstuk VI.

${ }^{27}$ L. White Ir. 1962, p. 124.
} 
strikt noodzakelijk was. De torens van belforten, lakenhallen en stadhuizen vormden een uitgelezen punt voor de installatie van deze objecten van stedelijke status en bewustzijn. Het bezit van een stadsuurwerk lijkt in de 15 de eeuw een van de kenmerken van een succesvolle stad te zijn geweest naast de stadsrechten en de stadsmuren.

Dat de uurwerken zo"n snelle verspreiding vonden in de laat-middeleeuwse Europese steden (1275-1450) wordt waarschijnlijk verklaard door het sociaal belang en de statusverhogende werking. Daarbij komt nog - wat wij ons niet altijd realiseren -, dat de stedelingen in middeleeuws Europa openstonden voor mechanisering en technisch onderzoek. ${ }^{30}$

Ook in Limburg kan van een vlotte start worden gesproken, althans in steden van enige omvang en met een serieuze marktfunctie, zoals Maastricht, Venlo, Weert, Sittard, Roermond, Hasselt, Tongeren, Sint-Truiden en Maaseik. De verspreiding van het torenuurwerk over de kleine Limburgse steden en dorpen was daarentegen een uitermate langdurig proces dat grosso modo zo'n vijfhonderd jaar in beslag nam. De grote steden liepen voorop. Daar treft men al vanaf 1367 vermeldingen aan van mechanische uurwerken. De plattelandsstadjes volgden een, twee eeuwen later. In de dorpen waren kort vóór 1800 torenuurwerken nog zeldzaam. Slechts in één op drie gevallen werden zij vermeld, zoals wij zullen zien.

Grafiek 2. Begin van de openbare tijdmeting in diverse soorten plaatsen

\begin{tabular}{|c|c|c|c|c|c|c|c|c|c|c|c|}
\hline & & & & & ipe & & & & & & \\
\hline & & & & landss & & & & & & & \\
\hline & & steden & & & & & & & & & \\
\hline & & & & & & & inge & & & & \\
\hline 1300 & * & 1400 & * & 1500 & * & 1600 & * & 1700 & * & 1800 & * \\
\hline
\end{tabular}

De ontwikkeling van het mechanisch uurwerk is geschetst aan de hand van de literatuur. Vele vragen blijven open. De oorsprong wordt gezocht in kerkelijke kringen. De aandacht daar voor kalender- en tijdmeetproblemen, zeker vanaf Karolingische tijden, kreeg

30. Gimpel 1975, pp. $141-142$. 
naar het schijnt wel in Engeland een vervolg door het plaatsen van heel vroege torenuurwerken in of op kathedralen en grote abdijen, maar dat was in het Maasdal, zo zullen wij nog zien, allerminst het geval. Slechts zelden werd daar een uurwerk in de kerk geplaatst en dan was het ook nog bedoeld voor intern gebruik en niet als openbaar uurwerk. Er werden op vele plaatsen, kris-kras door Europa, vanaf het laatste kwart van de 13 de eeuw grote geldbedragen uitgegeven voor de aanschaf en het onderhoud van torenuurwerken, nog allerminst nauwkeurige en betrouwbare instrumenten. Omstreeks 1350 verstoutte men zich zelfs hier en daar monumentale kunstuurwerken aan te brengen die wonderen van techniek waren. De enige reden hiervoor kan toch niet zijn geweest, dat het zo vaak door de weersgesteldheid onmogelijk was op de zonnewijzer of op de clepsydra de tijd af te lezen. Tal van specifieke vragen moeten worden bestudeerd: wie nam in de late Middeleeuwen het voortouw bij de openbare tijdmeting, de landsoverheid, de stadsbesturen, de kerkelijke leiding? Wat was het nut dat degenen die zo'n kostbare aanschaf deden ervan verwachtten? Ging het hen om status, om het oplossen van sociale en economische problemen of wilden zij slechts dat iedereen op tijd in de kerk was? Verandert daar in de loop van de tijd wellicht het een en ander aan? Hoe verbreidde het torenuurwerkbezit zich in geografisch opzicht: volgden de kleine nederzettingen, plattelandsstadjes en dorpen de lijnen uitgezet door hun grote broers? Hoe evolueert het torenuurwerkbezit in kringen met vooral ritueel-religieuze functie? Hoe gaat het bij de instituties van bestuurlijke aard? Wanneer gaat de particulier interesse tonen voor het bezit van een huisuurwerk? Waar gebruikt hij het voor? Hoe verbreidt het huisuurwerkbezit zich over de sociale lagen? De geraadpleegde literatuur geeft over al deze vragen geen uitsluitsel, in het bijzonder omdat er nimmer een volledig onderzoek naar alle uurwerken aangetroffen in het in de publicatie onderzochte gebied aan ten grondslag ligt. De vragen die de literatuur op documentair vlak oproept, versterken de al in de inleiding verwoorde noodzaak het feitenonderzoek veel gedetailleerder en indringender uit te voeren. Eens te meer blijkt dat we terug moeten naar de feiten en ditmaal naar alle feiten voorzover ze een neerslag vonden in nog te raadplegen documenten. 


\title{
Hoofdstuk II
}

\section{De openbare tijdmeting in Maastricht}

Ontstaan uit een laat-Romeinse versterking bij een brug over de Maas groeide Maastricht uit tot de grootste stad in de huidige provincies Limburg. Het kreeg zijn eerste stadsmuren kort na 1229. Het herbergde binnen zijn muren twee belangrijke kapittels: het O.L.-Vrouwekapittel en het Servaaskapittel. Het eerste leunde sterk aan tegen de Luikse bisschop, het tweede stond onder bescherming van de keizer. Maastricht was tweeherig: het hoogste gezag werd uitgeoefend door de bisschop van Luik en door de hertog van Brabant, welke in rechte werd opgevolgd door de Staten-Generaal. De oudste vermelding van een torenuurwerk in de beide Limburgen stamt uit Maastricht: 1367. Maastricht is daarmee tevens een van de eerste steden in de Nederlanden met een torenuurwerk. Slechts Brugge en Brussel - belfort en paleis van de hertogen van Brabant aldaar - kunnen bogen op eerdere vermeldingen. Van de "zuster"steden Aken en Luik dateren de eerste vermeldingen van respectievelijk 1376 en 1523. De Luikse bron is overigens niet maatgevend, want de stedelijke archieven gingen er in 1476 vrijwel geheel verloren.

Voor de vroegste vermeldingen in de Nederlanden kan men het volgende lijstje opstellen:

Zuidelijke Nederlanden: (thans België)

\author{
Brugge, 1345 \\ Brussel, belfort, 1362 \\ Brussel, paleis van de hertogen van \\ Brabant, 1364 \\ Dendermonde, belfort, 1377 \\ Gent, belfort, 1377 \\ Kortrijk, vóór $1382 .{ }^{1}$
}

\footnotetext{
' Voor de Belgische steden zie A. Pinchart 1884, pp. 184-186; A. van Werveke 1932.
} 
Noordelijke Nederlanden: Maastricht, 1367

(thans Nederland)

Utrecht, 1369

Venlo, 1389

Amhem, 1395

Sluis (Zld.) verving vóór 1397 een in 1393 verbrand uurwerk

Aardenburg (Zld.) kreeg in 1397 een nieuw uurwerk tegen inruil van een oud. $^{2}$

Alleen in Vlaanderen en het Maasdal is in de 14de eeuw sprake van een lichte concentratie. Daar moeten de wortels van de openbare tijdmeting in de Nederlanden worden gezocht.

\subsection{De stedelijke uurwerken (zie kaart 1)}

Kaart 1. Uurwerken in Maastricht MAASTRICHT

1) Lakenhalle

2) Lanscroon

3) Dinghuis

4) Stadhuis

5) Sint-Martinus

6) Maasbrug

7) O.-L.-Vrouwe

8) Sint-Servaas

9) Sint-Jan

10) Kruisheren

11) Minderbroeders

12) Looierspoort

$\left[\begin{array}{ll}500 m \\ L\end{array}\right.$

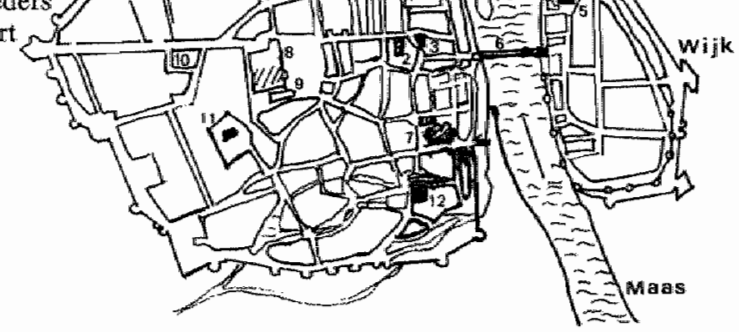

${ }^{2}$ Voor de Nederlandse steden zie F. Hoefer 1887 , pp. 24-26 en C. Spierdijk 1962, die op p. 69 ten onrechte vermeldt, dat Maastricht in 1373 zijn eerste uurwerk zou hebben gekregen; op p. 70 vermeldt hij het uurwerk van Dendenmonde, dat door ene Jan van Dilft zou zijn vervaardigd. 


\subsubsection{Het uurwerk van de Lakenhalle ${ }^{3}$}

De oudste vermelding van een stedelijk uurwerk te Maastricht dateert van 5 januari 1367 en betreft een schenking van veertig gouden denariën in mottoenen door de deken en het kapittel van Sint-Servaas aan het stadsbestuur van Maastricht voor het toen blijkbaar recent vervaardigde uurwerk. De tekst geeft weinig bijzonderheden en luidt als volgt: "Sculteti, Scabini et consules Trajectenses recognoscunt subsidium 40 denariorum aureorum ad mutunonem a Decano et capitulo S. Servatil ad fabricam horologii noviter facti, ex gratia et pura liberalitate et non de jure, traditum fuisse et impensum" . ${ }^{4}$ Ook een oude inventaris van het archief van het Sint-Servaaskapittel brengt ons niet verder. Het heet nu: "1367. 5 Januarij, liberalitas capituli pro horologio". 5

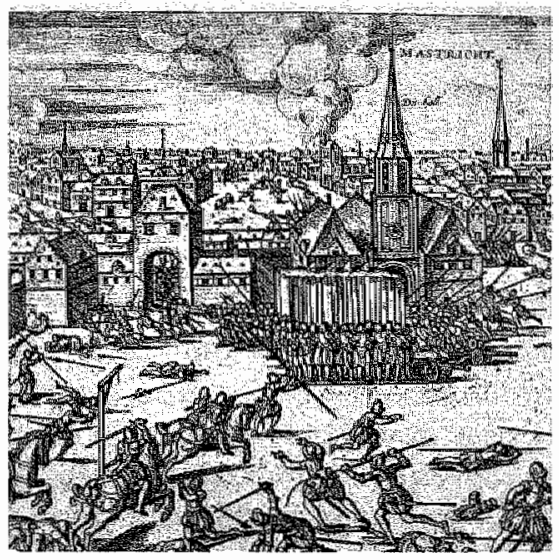

3. Toren van de lakerhlat $l_{\text {, }}$ met wijzerplaat, Maastricht (gravure Fr. Hogenberg, 1588) (reproductie J. Bonnet)

${ }^{3}$ De (Laken-)halle was een gebouw an de Markt, dat werd afgebroken bij de bouw van het huidige stadhuis.

4.A.M., Archief van het Sint-Servaaskapittel, Liber priwillegiorum et bononum, fol. 37vo. Vertald: "Schouten, schepenen en burgemeesters van Maastricht erkennen, dat cen bijdrage wan veertig gouden denariër in mottoenen door de deken en het kapittel van Sint-Serwaas voot. de bouw van het onlangs vervaardigde uurwerk is overgedragen en betald als gunst en pure vrijgevigheid en niet wegens enige juridische verplichting".

s. S[chaepkens] 1864, p. 103. Vertaald: "1367. 5 januari, vrijwillige bijdrage van het kapittell voor het unwerk". 
Helaas wordt niet vermeld wie het uurwerk heeft gemaakt, noc ${ }^{\text {th }}$ waar het werd geplaatst. Het meest waarschijnlijke is, dat het in de toren van de Lakenhalle op de Markt werd geplaatst. Hier immers kwam men bij elkaar voor stedelijke vergaderingen en proclamaties. Van hier vertrok op vaste uren, geslagen op de banklok in de Halletoren, de nachtwacht. Hier bewond zich ook de "scelle" of graanklokje, dat tot taak had de tijden aan te geven, waarop de diverse categorieën kopers op de markt graan mochten kopen. Aan een goede marktregeling hechtten de stadsbestuurders grote waarde om de graanprijzen in de hand te kunnen houden en zodoende volksopstanden wegens broodtekort te voorkomen. Een goed uur' werk in de buurt was daarom onontbeerlijk. Op een prent uit de 16 de eeuw ziet men op deze toren een grote wijzerplaat van een uurwerk en was er dus blijkbaar een uurwerk in de toren. ${ }^{6}$ Tot in de 17 de eeuw werd hij ook uurwerktoren genoemd (zie afbeelding 3). Sinds het midden van de 16 de eeuw bevond zich ook een klokkenspel in de toren. ${ }^{7}$ Schaepkens van Riemst $^{8}$ beweerde een eeuw geleden met stelligheid, dat genoemd uurwerk voor de Lakenhalle was bestemd, echter zonder motivatie. Leunis ${ }^{9}$ concludeerde ten onrechte, dat de bovenvermelde citaten betrekking hadden op een uurwerk voor de Sint-Servaas. De tekst en de termen "liberalitas" en "ex gratia" wijzen duidelijk op een uurwerk, dat de stad toebehoorde. Die had geen rechten op de kapittelkerk. De theorie van Le Groff over een tegenstelling tussen de "temps de l'église" en de "temps de marchand" 10 wordt door deze sponsoring van een stedelijk uurwerk door het kapittel niet bevestigd: men mag in de steunverlening een erkenning zien van het voordeel dat het kapittel zag in een door de stad verzorgde openbare tijdmeting. Het kapittel lijkt voornemens zich ernaar te richten en af te zien van een eigen tijdmeting. Het lijkt erop, dat het kapittel in 1367 koos voor een

"Prent van F. Hogenberg uit 1.588 betreffende de Spaanse Furie te Maastricht in 1576. G.A.M., Prentcolllectie, nr. 180. In het stadsprofiel bij de stadsplattegrond wan Bellomonte wordt de Halletoren aangeduid als "turris horologii"; op de kaart van Maastricht in vogelperspectief door Aveline, Mastric ou Maëstricht, wordt hij onder 11 "le Beffroy ou lHorloge". genoend.

${ }_{7}^{7}$ G. Quaedvlieg 1962 , p. 368 .

J. Schaepkens wan Riempst 1907 , p. 140.

9 J. Lennis 1958 , p. 275. Hij citeert hier het artikeltje van Alexander Schaepkens, zie noot 5 , warin sprake is van "liberalitas" 10. J. le Goff 1960, pp. 417-433. 
uniforme stedelijke tijdsaanduiding, hetgeen heel progressief zou zijn. Uit de voorbeelden die Le Goff aanhaalt blijkt dat er destijds niet alleen tijdsverschillen bestonden tussen de steden - dat zou nog tot in de 19 de eeuw blijven - maar zelfs binnen één en dezelfde stad.

In een Raadsverdrag van 13 december 1395 komt het stadsuurwerk opnieuw ter sprake. Nu wordt woor het eerst ook een stadsuurwerkmaker genoemd. ${ }^{11}$ Deze tekst luidt: "De magistro Willem, aurifaber (sic) de Zechen. Inden joere van XCV des XIII dahgs in decembri so waert verclaert inden gemeynen raet van meyster Willemme, goltsmeet indes Wolfsstrate, ende is ontfanghen weder inder stat dienst ende swoir voir die burgermeyster ende gesworen ten heylghen der stat in synen dienst holt ende getruwe te sijn ende syn ambacht wale halden. Ende is gevurwart mit home dat he van nuwenstof eyn nuwe erloye ${ }^{12}$ werck maken sal totter ure clocken op synen cost ende van synen stof. Ende weirt, dat home die stat ontsetten wolde ende eynen anderen in synen dienst setten, so sal home die stat weder keren synen cost ende arbeyt den he an dat weerck gelacht ende verdient hedde. Ende die stat sal home ter stont an synen rock gheven ende als dat werck genghe is vander ure clocken, so salmen home synen loen gheven also men vormoylz plaech".

Deze tekst laat de volgende conclusies toe: Willem van Zechen was als stadshorloger eerder ontslagen, want hij "... is ontfanghen weder inder stat dienst". Kennelijk was er een conflict ontstaan. Mogelijk was hij 28 jaar eerder de vervaardiger van het oudste uurwerk geweest. Op zijn minst had hij zijn taak verwaarloosd. Door zijn achteloosheid was het uurwerk onherstelbaar defect. Hij moest op zijn kosten een nieuw uurwerk maken en uit eigen zak de materialen betalen. Als het nieuwe uurwerk functioneerde ("als dat werck

\footnotetext{
${ }^{11}$ Raadsverdragen van. Maastricht $1367-1428,1992$, nr. 760 .

${ }^{12}$ Erloye=orloye $=$ horloge $<$ horologium: allemaal woorden woor unurwerk, tijdmeter, nooit woor luidklok. Andere woorden voor uurwerk: oerlament (Venlo) en "enghiene vanden ure" (in Vlaamse bronnen). Het woord horloge duidt op alle maten uurwerken, niet alleen op zakhorloges. Het wordt in die betekenis nog altijd gebruikt in het begrip "staand horloge". Ons woord klok voor uunwerk is ontstaan in de periode, dat uurwerken nog geen wijzerplaat hadden en de uren werden aangegewen door het slaan op een luidklok: de ureclock. In de verschillende volgende teksten kan men de overgang proeven: eerst betekent ureclock alleen de luidklok bij het uurwerk, later betekent het woord het geheel wan uurwerk + luidklok, daarna uarwerk tout court.
} 
genghe is vander ure clocken"), dan zou hij als vanouds weer zij ${ }^{n}$ salaris krijgen. Of Willem van Zechen voorgangers heeft gehad, is niet duidelijk. Wel is hij de eerst bekende stadsuurwerkmaker van Maastricht. Hij was niet alleen in staat een uurwerk te onderhouden, maar werd capabel genoeg geacht ook een nieuw te vervaar" digen. Het is merkwaardig, dat men zowel in Maastricht als in Venlo (zie onder Venlo) als eerste stadsklokkenmaker goudsmeden aantreft; men zou eerder een smid of slotmaker voor het onderhoud van de grote gesmede torenuurwerken verwachten dan een goudsmid. Wellicht hield men het erop dat goudsmeden beter geschikt waren voor precisiewerk dan grofsmeden omdat ze gewend waren kostbare materialen te verwerken. Het Maaslands voorbeeld staat niet op zich. Volgens Vasari werd de beroemde architect, beeldhour wer en schilder Filippo Brunelleschi (1377-1446) aanvankelijk in de leer gedaan bij een goudsmid "opdat hij het tekenen onder de knie zou krijgen". Eveneens in zijn jeugd "maakte hij eigenhandig enige uitstekende, prachtige klokken". ${ }^{13}$ Of Willem de opdracht om een nieuw uurwerk te maken, heeft volbracht, is niet bekend. We vernemen in de Raadsverdragen niets meer over zijn werk, ook niet dat het uurwerk op de markt ernstig defect was. Dat is - zoals nog zal blijken - in de 15 de en 16de eeuw bepaald opmerkelijk. Zeker is, dat er in de $16 \mathrm{de}$ en $17 \mathrm{de}$ eeuw een uurwerk in de toren van de Lakenhalle stond, waar het is gebleven tot de afbraak van de hal voor de bouw van een nieuw stadhuis. Het uurwerk in de Halle werd nog in 1555,1633 en 1656 gerepareerd en onderhouden. ${ }^{14} \mathrm{De}$ reiziger Philippe de Hurges heeft het daar nog in 1615 gezien. ${ }^{15} \mathrm{Hij}$ heeft het over "ceste halle ou Maison-de-Ville". Daarvan zegt hij: "elle est toute de pierre blanche, couverte d'ardoises, aiant une tour assez haute et bien bastie, laquelle sert de belfroy et contient $1^{\prime}$ horlogen ${ }^{n}$. Het uurwerk van de Halle moest ook dienst gaan doen in het nieuwe stadhuis, zo werd besloten. In 1659, tijdens de bouw van het stadhuis, werd het tijdelijk in de toren van de Sint-Matthijs-

${ }^{13}$ G. Vasari 1990 , p. 158 .

${ }^{14}$ G.A.M. , Oud-anchief, Raadsverdragen, Raadstesolutie 19 augustus 1555 , reparatie "oerclock. op de markt" 14 november 1633, "de horologien op den marck, dinghuis en brugge te stellen voor $36 \mathrm{gl}$ op het half jaar"; 1656, Raadsverdrag d.d. 25 juni 1656.

${ }^{15} \mathrm{H}$. Michelant 1872, p. 344. 
kerk opgesteld, totdat het nieuwe stadhuis klaar zou zijn. ${ }^{16}$ Daar werd het ook geplaatst. Stadshorloger Jan Muys vervoerde het op 16 juli 1668 naar het nieuwe stadhuis. Hier heeft het gefunctioneerd tot in 1686 een nieuw uurwerk met automatisch speelwerk werd geleverd door Jurriaan van Zutphen uit Den Bosch. Waarschijnlijk was het ook toen niet versleten. Ook het graanklokje vond een plaats in het nieuwe stadhuis, waar het nog hangt. In paragraaf 2.1.3 zal blijken dat er in 1703 door het stadsbestuur een torenuurwerk werd verkocht aan de koordeken van Lier, dat mogelijk het uurwerk was uit de Lakenhalle.

\subsubsection{Het uurwerk van de Lanscroon}

De Lanscroon was een pand aan de Grote Staat, waar nu het warenhuis Vroom en Dreesmann ligt, circa tweehonderd meter van de lakenhal verwijderd. Dit pand diende als stadhuis vanaf circa 1377 tot 7 juli 1664 , toen de eerste raadsvergadering in het nieuwe stadhuis werd gehouden.

Op 16 januari 1396, een maand na het bovenvermelde raadsbesluit over Willem van Zichen, de goudsmid uit de Wolfstraat, nam de raad het besluit "dat men der stat ureclocke opder Landscronen hanghen sal". ${ }^{17}$ De vraag doet zich voor, wat hier met "ureclocke" wordt bedoeld. Was dit alleen de luidklok, waarop het uur werd geslagen door een wachter, of bedoelde men een uurwerk met luidklok? In het besluit over het herstel van het uurwerk in de Halle noemde men beide componenten apart, namelijk: "erloye werck totter ureclocken". Als men de beide componenten scheiddle, dat wil zeggen, dat het uurwerk in de Halle bleef en de luidklok in de Lanscroon werd gehangen, werd men gezien de afstand en de bebouwing tussen Halle en Lanscroon onherroepelijk geconfrontreerd met de onmogelijkheid tijdmeting en signaal synchroon te laten verlopen. Hoe het zij, in november 1396 nam men een nieuw besluit. Men liet "dat erloye werck vander ureclocken maken" door

${ }^{16}$ G.A.M., Oud-archief, Raadsverdrag d.d. 19 mei 1659, een horlogie op St. Matthias thooren te stellen tot dat het stadtshuijs sal voltoijt weesen den 19 mey 1659. De koster van de SintMatthijskerk kreeg zolang wijftig gulden 's jaars voor het onderhoud, Raadsverdrag d.d. 20 maart 1662.

${ }^{17}$ Raadsverdragen van Maastricht 1367-1428, 1992, nrs. 762 en (762). 
meyster Heinric van Thoren. ${ }^{18}$ Helaas stal er niet bij, waar dit horloge moest worden geplaatst. Was het een tweede stadsuurwerk, bedoeld voor de Lanscroon? Het nieuwe door van Thoren te vervaardigen uurwerk was blijkbaar nogal kostbaar, want op 30 december 1398 werd door de Raad besloten om de tolgelden afkomstig van een nieuwe Maasdoorvaart aan de "ureclocken" te spenderen. ${ }^{19}$ Dat de kosten voor het nieuwe uurwerk zo hoog waren lag niet alleen aan het uurwerk zelf, maar ook aan het feit, dat men blijkbaar een nieuwe "thoren van der oyrclocken" heeft opgetrokken. Dit werk, dat deels werd uitgevoerd door meester Godart van Stockem, wordt uitvoerig vermeld in de stadsrekening van 1399. 1400. Men besteedde aan deze toren een bedrag ter grootte van ongeveer $2 \%$ van de totale stadsuitgaven in dat jaar. ${ }^{20}$ Blijkbaar is de begroting overschreden, want in het raadsverdrag van 20 september 1400 besloot men "..., dat men bi werckeluide die sich des verstain, bisien sal wes meyster Godart van Stochem meer gewarcht heet anden holtwercke da die ureclock inhanghen sal dan meyster Otte voirtijden verdenckt hadde..." ${ }^{21}$ Een andere post in genoemde rekening maakt melding van het feit, dat op kermisavond en de volgende dag op het feest van Maria Geboorte vier "pipere" en één "trompener" hebben "gespielt ende gepepen op den nuwen thoren". ${ }^{22}$ Het was dus een flink bouwwerk. Helaas wordt andermaal niet vermeld, waar de toren werd gebouwd. Mogelijk stond hij op de Lanscroon, misschien werd de toren van de Halle vernieuwd of werd hij gebouwd op de plek van het latere Dinghuis. Ook met behulp van de lokale topografie zijn deze vragen niet op te lossen.

In september 1400 was het uurwerk van Henric van Thoren bedrijfsklaar, want op 20 september 1400 werd hij benoemd tot stadsuurwerkmaker; hij moest toezien op de "ureclocke ende oirloe ende werck dat mit dat oirloe ghoin sal". ${ }^{23}$ Henric van Thoren genoot niet alleen faam als uurwerkmaker, hij wordt in de Raadsverdragen en in de stadsrekening ook meermalen genoemd in

\footnotetext{
I8 "Item des moendaighs XXVII daighe in novembri so wart uytgedragen inden gemeynen raet, dat meyster Heinric van Thoren dat erloye werck vander ure clocken maken sal." Raadsverdragen van Maastricht 1367-1428, 1992, nt. 802, d.d. 27 november 1396.

${ }^{19}$ Raadsverdragen van Maastricht 1367-1428, 1992, nr. 890.

${ }^{20} \mathrm{~J}$. Koreman 1968, pp. 133-134.

${ }^{21}$ Raadsverdragen van Mastricht 1367-1428, 1992, nr. 946.

江 J. Korreman 1968, p. 76.

${ }^{23}$ Raadsverdragen van Maastricht 1367-1428, 1992, nr. 946.
} 
allerlei andere functies. ${ }^{24}$ Zo was hij ook stadswerkmeester van het geschut ("vanden donre"). ${ }^{25}$ Henric van Thoren werkte ook buiten Maastricht. In 1389 leverde hij te Venlo het eerste stadsuurwerk aldaar. ${ }^{26}$

Verdere berichten over een uurklok of uurwerk op de Lanscroon werden niet aangetroffen. Als het uurwerk van Van Thoren op de Lanscroon heeft gestaan, is het wellicht kort vóór 1470 op het Dinghuis geplaatst.

\subsubsection{Het uurwerk van het Dinghuis}

Het Dinghuis, ook genoemd het oude stadhuis, werd kort vóór 1470 gebouwd op de huidige plaats, op de hoek van de Kleine Staat en de Jodenstraat (zie afbeelding 4). Het was de zetel van het Maastrichtse hooggerecht. ${ }^{27}$ Kort na de voltooiing is in het Dinghuis een uurwerk, mogelijk dat van de Lanscroon, geplaatst omdat dit gebouw veel hoger was dan de Lanscroon en voorzien van een torentje, waarop wachters waren gestationeerd. Die konden het uurwerk, dat intussen was voorzien van een wijzerplaat, opwinden en voor het dagelijks onderhoud zorgen. In een Raadsverdrag van 16 april 1470 is sprake van Aert van der Moelen, heer Aerts zoon, de opvolger van Heynric Mulart "de der stat oerclock geregiert ende gesat heet mitten wijser opt Dinchuis". "Gesat heet" hoeft niet te betekenen, dat hij het uurwerk in het Dinghuis heeft geplaatst, "setten" betekent in samenhang met klokken meestal: regelen, instellen, op tijd zetten. De toevoeging "mitten wijser" laat zien, dat het toen nog niet vanzelfsprekend was, dat een torenuurwerk ook een buitenwijzerplaat had. De oudste torenururwerken hadden dit niet, ze gaven de tijd door het slagwerk aan. ${ }^{28}$

\footnotetext{
2it Zie voor details appendix II onder Thoren, Hendrik van.

2s Raadsverdragen van Maastricht $1367-1428,1992$, nr. 759. Donre= donderbus. Zie ook hoofdstuk VIII, paragraaf 1, voor de combinatie uurwerkmaker geschutmeester.

${ }^{26}$ Men kan zich afvragen of Henri de Vic (Wic), die in 1370 het eerste grote openbare uurwerk te Parijs leverde, wellicht identiek is met Henric van "Thoren, als die tenminste in Wijck heeft gewoond!

${ }^{27} \mathrm{~J}$. Koreman 1974.

Zile hoofdstuk I, p. 7 .
} 


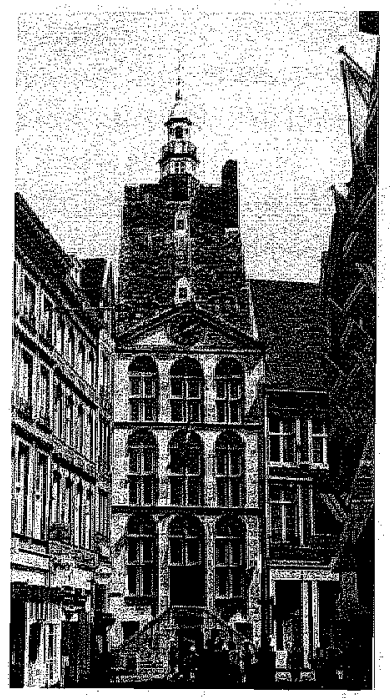

4. Het Dinghuis, Maastricht (zetel van het hooggerecht, gebouwd circa 1470)

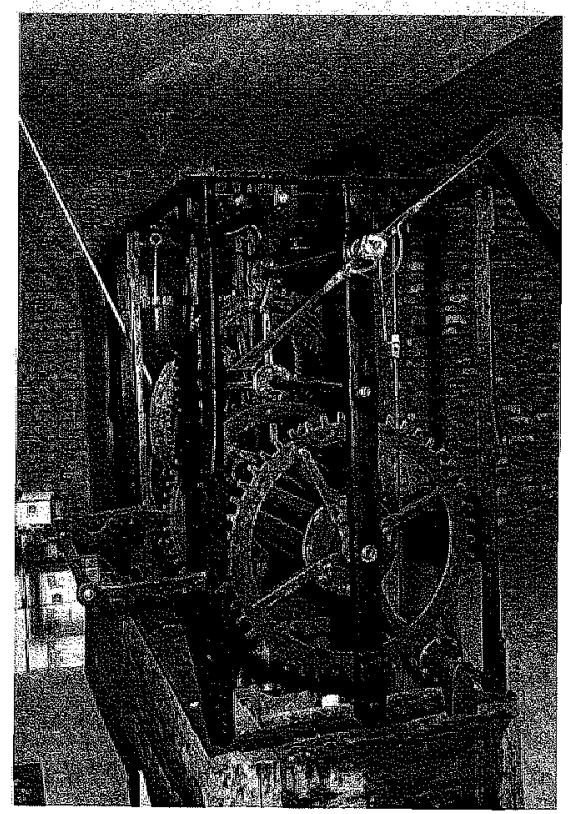

5. Torenuurwerk in het Dinghuis (mogelijk gemaakt door H. van Thoren, Maastricht, 1395-1400) 
Mogelijk is het uurwerk, dat nu in het Dinghuis staat, het uurwerk van Van Thoren, oorspronkelijk bestemd voor de Lanscroon (zie afbeelding 5). Als dat waar is, is het een van de oudste nog bestaande uurwerken in de Nederlanden, zoniet het oudste. Grote delen van het huidige uurwerk zijn kennelijk vroeg-15de-eeuws. In de loop der tijden is dit uurwerk, zoals bijna alle torenuurwerken, vele malen hersteld, aangepast, soms met weinig kennis van zaken en zonder enig historisch besef gemoderniseerd. Een nieuw uurwerk heeft het Dinghuis nimmer gekregen, althans in geen enkel document wordt gerept van de aanschaf van een nieuw uurwerk voor het Dinghuis.

Tegen de opvatting dat het wurwerk van Van Thoren nog altijd in het Dinghuis staat zou slechts kunnen pleiten, dat in de raadsnotulen tot twee keer toe sprake is van de verkoop van een stadsuurwerk. In beide gevallen ging het, bij nader onderzoek, evenwel niet om het uurwerk van het Dinghuis. In de "Inhoudstafel op de Raedsnotulen der stad Maestricht" staan onder het trefwoord "Horologien" beide verkopen van een stadsuurwerk vermeld. ${ }^{29}$ De eerste vermelding luidt: "vercoop van de oude horologie den 4 9-ber 1686. Ten selve is goedtgevonden bij affictie van bielletten alomme bekent te maecken dat men van meninge is het oudt orlogie aen den meest bijdende te vercoopen ten dage daartoe te praefigeren". Er wordt niet nader gepreciseerd om welk uurwerk het gaat. Het lijkt voor de hand te liggen, dat het oude uurwerk van de Halle werd bedoeld. Dit uurwerk was overbodig geworden omdat men zojuist het nieuwe uurwerk van Jurriaan van Zutphen had geïnstalleerd of daarmee bezig was. ${ }^{30}$ Of de verkoop in 1686 is gelukt, is zeer twijfelachtig gezien de tweede vermelding van een uurwerkverkoop. De inhoudstafel vermeldt dienaangaande: "die van het oudt stadtshuijs verkoght aen den choordeecken van Lier ad $650 \mathrm{gl}$. den 21 meert 1703". Het betreffende raadsbesluit luidt: "Op het rapport der Heeren Opperfabrijcquen geaccordeert hebbende met Henrick Morree in naeme van den heer choordeeken yan Lier het oudt stadtshorologie voor de somme van seshondert vijftich guldens

\footnotetext{
${ }^{29}$ G.A.M., Oud-archief, invnnr. 151 (oud nr. 146), p. 780 .

${ }^{39}$ Op 17 januari 1685 werd met Sr. Joost wan Zutphen, borgher van 's-Hertogenbosch, overeengekomen, dat hij binnen achttien maanden een nieuw uurwerk zou leveren voor de som van 2.800 rijksdaalders. G.A.M., Oud-archief, inv,nr, 212 (oud nr. 206). Waarschijnlijk is Joost een vergissing in deze conceptwakte en wordt Jurriaan bedoeld, zie noot 39.
} 
lichtgelt: is goetgevonden ende verstaen het genegotieerde der gemelte heeren $t^{\prime}$ approberen, haar Ed. naeders authoriserende om de bewuste kooppenninghen van $650 \mathrm{gld} \mathrm{t}^{\prime}$ ontfanghen ende over te reijcken aen de heeren bibliothequarissen om tot incoop van eenighe rare oude goede boecken te worden geappliceert ${ }^{m} .{ }^{31}$ Aangezien de functie van koordeken daadwerkelijk in Lier voorkwam, is hier waarschijnlijk de kerkelijke functionaris uit de stad Lier bedoeld, temeer omdat is onderhandeld via een tussenpersoon, Henrick Morree. In de archieven van het Liers kapittel werd (nog) geen document over deze transactie gevonden. Toch is het vrij zeker, dat een Maastrichts stadsuurwerk, waarschijnlijk dat van circa 1395 uit de Halle, naar Lier is verhuisd. Daar had men, eind 1702-begin 1703, juist behoefte aan een uurwerk omdat de torenspits van de collegiale Sint-Gummaruskerk met het carillon op 2 september 1702 door blikseminslag tot op het muurwerk was verwoest. ${ }^{32} \mathrm{De}$ schade was zo groot, dat men in 1703 voor 3.450 gulden eiken balken en ander houtwerk kocht. Daarenboven moest men bijna 2000 gulden aan de dakwerker betalen. ${ }^{33}$ Het is niet aannemelijk, dat er van het uurwerk, in 1612 door Hans de Voghelaar uit Brussel geleverd, iets bruikbaars was overgebleven, ook al schrijft Leemans: "Het oude mechanisme, dat ongetwijfeld nog ellementen bevatte van het gangwerk door Hans de Voghelaar geplaatst in 1612, werd een eeuw later, na de torenbrand van 1702, door Henricus Joltrain, uurwerkmaker te Antwerpen, - die ook voor de montering van de trommel instond; vergelijk trouwens de profilering van het geraamte van beide mechanismen - aangevuld en opnieuw gemonteerd voor het nieuwe torenuurwerk". ${ }^{34}$

Leemans heeft goed gezien, dat het raamwerk en verschillende tandraderen ouder zijn dan begin 18de eeuw, toen Joltrain zijn opdracht uitvoerde. Omdat zij niet op de hoogte was van de aankoop van het Maastrichtse uurwerk, heeft zij geconcludeerd dat de oude stukken resten waren van het uurwerk uit 1612. Als men het uurwerk dat nog in de toren staat, maar thans buiten gebruik is, goed bekijkt, dan vallen grote overeenkomsten op met het uurwerk in het Dinghuis te Maastricht. De overeenkomsten betreffen de

${ }^{31}$ G.A.M., Oud-archief, inv.nr. 72 , p. 665 .

32. E. de Seyn s.a., p. $774 ;$ H. Leemans 1972 , p. 39.

${ }^{33} \mathrm{H}$. Leemans $1972, \mathrm{p}_{4} 40$.

${ }^{34}$ H. Leemans 1972 , p. 483. 
hoekstijlen, de verbinding boven en onder door een plat ijzeren raamwerk bevestigd met latere (?) schroefdraad en moeren, de eigenaardige verbinding van de tussenstijlen aan het raamwerk (zie afbeelding 6) en de vierkante tanden van de grondraderen. Het uurwerk te Lier is iets groter dan dat van het Dinghuis, de afmetingen zijn circa $210 \mathrm{~cm}$ lang, $150 \mathrm{~cm}$ hoog, $55 \mathrm{~cm}$ breed. Op basis van het voorgaande is het waarschijnlijk dat Joltrain het Maastrichtse uurwerk weer gangbaar heeft gemaakt en verbonden met een nieuw door hem geconstrueerd automatisch speelwerk. Dit speelwerk draagt de opschriften "Henricus Joltrain Antwerpiae me fecit" en "17 S.P.Q.L. 12". Joltrain werkte in opdracht van het stadsbestuur omdat het kapittel de toren aan de stad had overgedragen vanwege de hoge kosten van herstel. Alexius Jullien goot de speeltrommel en het carillon. In de jaren twintig van deze eeuw heeft de Lierse uurwerkmaker Louis Zimmer moderniseringen aangebracht.

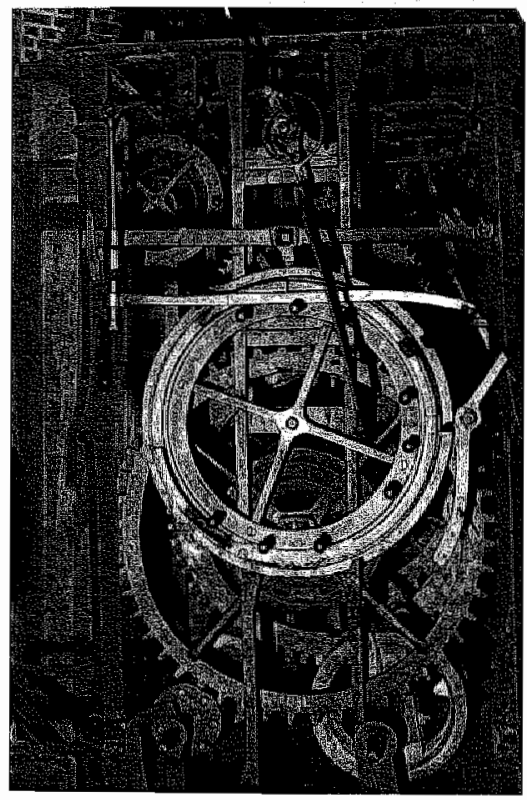

6. Torenurwerk in de Sint-Gummaruskerk, Lier (B). Mogellijk het voormalige uurwerk wan de lakenhal te Maastricht, eind 14 de eeww 
Er is nog een schijnbare moeilijkheid. Met nadruk dient te worden gewezen op de discrepantie tussen wat in de inhoudstafel op de Raadsverdragen wordt gesuggereerd, namelijk de verkoop van het uurwerk van het "oudt stadtshuijs" (dit wil zeggen het Dinghuis) en wat er feitelijk in de Raadsresolutie staat; die gewaagt slechts van de verkoop van "het oudt stadts horologie". De laat-18de-eeuwse indexeerder heeft wellicht aangenomen, dat de verkooppoging van 1686 succesvol was geweest en verondersteld, dat de tweede verkoopmelding betrekking had op het uurwerk van het oud stadhuis. Mijns inziens kan het echter niet om het uurwerk van het Dinghuis gaan en wel om de volgende redenen:

a. thans is nog altijd in het Dinghuis een uurwerk aanwezig, dat elementen bevat uit de $15 \mathrm{de}$ eeuw, te weten: de hoek-en middenstijlen, het slagwerk, het grondrad van het gaande werk en de as van het tussenrad met zijn draaipunt in een vierkante uitsparing voor de verticale spille-as, wat wijst naar een foliot. Het is geheel van gesmeed ijzer vervaardigd, behalve de hoekstijlen, die mogelijk zijn gegoten. Deze hoekstijlen hebben profileringen uit de gotiek en staan diagonaal ten opzichte van elkaar. Ze zijn onder en boven verbonden door jonger platijzer, dat met zijn platte zijde parallel aan de vloer is gemonteerd. De verbinding daarvan aan de hoek-en middenstijlen is zodanig, dat men moet concluderen, dat de verbindingen boven en onder eerst van rechtopstaand ijzer zijn geweest. De schroeven aan de boven- en onderkant van de hoekstijlen lijken er later opgezet. Het gaande werk heeft slechts twee assen, wat wijst op de aanwezigheid eertijds van een grote foliot met verticale spillegang. Zo'n grote foliot had een draaiperiode van circa elf seconden. Hij had een verstelmogelijkheid dat hij temporaaluren kon meten, dat wil zeggen 's zomers lange uren, 's winters korte uren. Rond 1470 is men in Europa overgeschakeld op het moderne systeem van even lange uren heel het jaar doot. Veel later ${ }^{35}$ is de verticale spillegang met foliot omgebouwd tot horizontale spillegang met slinger. De sluitschijf van het slagwerk bevindt zich tussen het

\footnotetext{
${ }^{35}$ Waarschijnlijk in 1712 door de stadskllokkenmaker Maurissen. Het horizontale spillerad was niet in de gewone vorm, zoals een wekkerrad, maar had rechtopstaande pennen. De slinger was bijna drie meter. Thans zijn een normaal spillerad en een slinger van een meter aangebracht.
} 
slagwerk en het gaande werk. Ook dit is een kenmerk van de eerste generatie uurwerken.

b. er is in heel de $16 \mathrm{de}, 17 \mathrm{de}$ en $18 \mathrm{de}$ eeuw geen vermelding te vinden van de aankoop van een ander uurwerk voor het Dinghuis, maar er was daar wel een uurwerk aanwezig, want

c. er is een vermelding uit 1585 en een besluit van 30 meil 1712 om "de horologien in St Marten, op de brugge en oudt stadthuijs te reparere".

d. er is een besluit van de Commissarissen Deciseurs uit 1760 , waarin sprake is van vier stadsuurwerken, te weten: "op den nieuwen en oude stadhuyse, van St. Marten en Maesbrugge" ${ }^{36}$

e. bij de beschrijving van het uurwerk van de Sint-Servaas zal worden aangetoond dat omstreeks 1870 niet, zoals wordt beweerd, een uurwerk van de Sint-Servaas naar het Dinghuis werd overgebracht.

Gezien het bovenstaande houd ik het erop, dat de verkoop van het oude uurwerk van de Halle in 1686 niet is gelukt en pas in 1703 plaats vond, waarna het in Lier terecht kwam.

Het huidige uurwerk van het Dinghuis betreft mogelijk dat van Henric van Thoren voor de Lanscroon uit de jaren 1396 tot 1400, met diverse aanpassingen in de loop der eeuwen. Het uurwerk is in 1986 gerestaureerd en voorzien van een automatische, electrische opwinding, zodat het nog dagelijks met zijn ene wijzer de tijd aanwijst. Het zou heel opmerkelijk zijn als er twee Maastrichtse torenuurwerken uit eind 14de eeuw - zij het met de nodige aanpassingen - bewaard zijn gebleven.

In de eerste vijftig jaar van de 15 de eeuw werd aan de stadsururwerken veel aandacht besteed. $\mathrm{Na}$ Henric van Thoren werd volgens een raadsresolutie van 26 augustus 1414 Godart meyster Godart Wittenson stadsuurwerkmaker. Hij was een zoon van Godart van Stokkem, die als timmerman had samengewerkt met Henric van Thoren. ${ }^{37}$ Godart Wittenson werd in 1427 opgevolgd door Dieric van Tongerloe, "der paymeister clercke". ${ }^{88}$ Godart en Dieric waren waarschijnlijk geen uurwerkmakers en deden alleen het regulaire

36. G.A.M., Ond-archief, inv.nr. 218, "Register der recessen, resolutien en ordonantien van de Ed. Mog. H.H. Commissarissen Deciseurs van beyde genadige Heeren en Princen deser stadt Maestricht begonnen MDCCLX", deel $\mathbb{I}_{\text {, }}$ nr. 7 .

${ }^{37}$ Raadsverdragen varn Maastricht 1367-1428, 1992, nr. 1111.

${ }^{38}$ Raadsverdragen van Maastricht 1367-1428, 1992, nr. 1112, d.d. 27 oktober 1427. 
onderhoud. Dat was, zollang er met een foliot temporaaluren werden gemeten en er slechts gebrekkige smeermiddelen bestonden, een tijdrovende, dagelijks terugkerende klus. Het ontbreken in de Raadsverdragen van opdrachten tot ingrijpend herstel toont aan dat Van Thoren een uurwerk van hoge kwaliteit had geleverd. Dat was lang niet altijd het geval. Willem van Zechen was, zoals hierboven verhaald, een voorbeeld van het tegendeel (voor een overzicht van de bekende stadsuurwerkmakers zie het einde van dit hoofdstuk, tabel 1).

\subsubsection{Het uurwerk van het stadhuis}

De ruwbouw van het huidige stadhuis, ontworpen door Pieter Post, kwam in 1662 gereed (zie afbeelding 7). De toren werd pas in 1684 voltooid. Men beschikte daarmee over een uitgelezen plaats om het reeds in 1668 bij Hemony gekochte carillon op te hangen. Tevens had men nu plaats voor een nieuw torenuurwerk met automatische speeltrommel vlakbij het klokkenspel. Het oude uurwerk van de Halle, dat men tot dan had benut, werd overbodig en men trachtte dit te verkopen. Voor het nieuwe uurwerk ging men te rade bij Jurrien van Zutphen te 's-Hertogenbosch. Over de naam en de herkomst van de maker van het stadhuisuurwerk bestaat in de literatuur nogal wat verwarring. Sellink, Abbink en Wiggers houden Jurriaan van Zutphen en Jurriaan (van) Spraeckel voor één en dezelfde persoon. ${ }^{39}$ Morpurgo noemt hem Joost, meent dat Spraeckel en Van Zutphen twee verschillende personen zijn en laat Van Zutphen in Tilburg wonen. ${ }^{40}$ De betrouwbaarste bron is duidelijk:

${ }^{39}$ J. Sellink, A. Abbink en R. Wiggers [1990] p. 7, afbeelding van een torenuurwerk uit 1696 te "s-Gravenmoer van Jurriaan van Zutphen (alias Spraeckel), pp. 11 en 12, afbeelding wan cen torenuurwerk van zijn hand te Dongen uit 1671 en p. 56: "Jurtiaan Spraeckel. Hij is vermoecelijk \pm 1615 geboren als zoon van de in 1637 overleden Jacob Sprakel uit Goor die waarschijnlijk eveneens torenuurwerkmaker was. Jurtian genoot een nationale bekendheid als bouwer en restaurateur van torenuurwerken en huisuurwerken, hij overleed $\pm 1690^{\prime \prime}$. Zie ook G. van Dijck 1982, pp. 184-185. Van Dijck gelooft, dat Spraeckel niet in Den Bosch woonde, matr telkens uit Zutphen overkwam onn. werkzaamheden te verrichten. Van Zutphen wordt in de owereenkomst met het Maastrichtse stadsbestuur "borgher wan "\$-Hertogenbosch" genoemd (zie noot 30). Ook in het verslag van hoogschout Groulardt van 4 december 1684 is in verband met Jurrien wan Zutphen sprake van "herwaarts te comen uijt "s-Hertogenbosch".

E. Morpurgo 1970, p. 146, k. 3, spreekt over Joost van Zutphen wit Tilburg (1); in de concept-overeenkomst staat: Sr. Joost wan Zutphen, borger tot 's-Hertogenbosch. Zie verder E. Morpurgo 1970, onder de naam Spraeckel op pp. 117-118. 


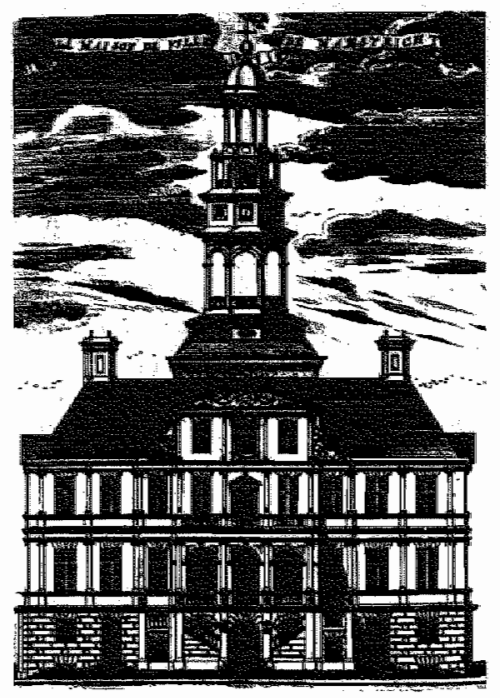

7. Stadhuis van Maastricht, ontworpen door Pieter Post. De toren met vier wijzerplaten kwam gereed in 1684. Er werd een urwwerk van Van Zutphen en een beiaard van Pieter Hemony in geplaatst (18de-eeuwse gravure)

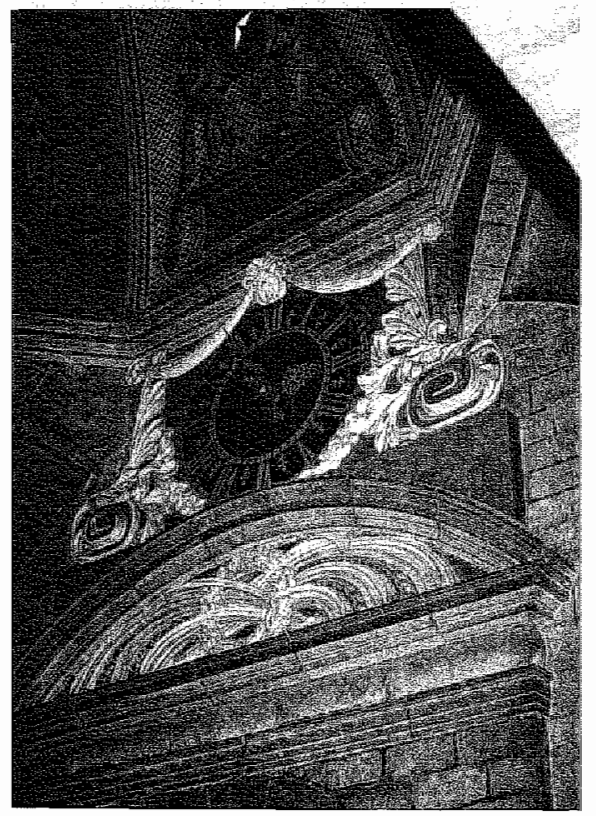

8. Binnenwijzerplaat boven de centrale hal, "het plein", wan het stadhuis, Maastricht 
in een verslag van de Maastrichtse hoogschout Groulardt van 4 december 1684 over een dienstreis naar den Haag staat: "ende eijndelijck dat versocht hadde seeckeren Mr. Jurrien van Zutphen een seer expert Orlogie Maker om herwaerts te comen uijt 's-Hertogenbosch op deze stadts costen, om het horlogie op het stadthuijs te veranderen en $t^{\prime}$ overlegghen hoe men hier bequaemst een goet orlogie en trom tot den voorslach soude maecken, het welck de Magistraet sich wel heeft laeten gevallen ${ }^{\prime \prime}{ }^{41}$ Het stadsbestuur kwam op 17 januari 1685 tot overeenstemming met Van Zutphen. Het contract leert ons de oorzaak van de verwarring over de voornaam. In de nogal slordig geschreven aanhef van het document staat: Sr. Joost van Zutphen. De handtekening luidt: J. van Zutphen. Gezien de Raadsresoluties hebben we echter zeker met Jurrien van Zutphen te maken. Maar hiermee is de vraag of Jurriaan Van Zutphen en Jurriaan Spraeckel één persoon zijn nog niet opgelost. Om deze kwestie op te lossen heb ik twee handtekeningen van J. van Zutphen vergeleken met een van J. Spraeckel. De handtekening van $\mathbf{J}$. van Zutphen onder een contract voor een torenuurwerk te Dongen (Noord-Brabant) uit 1671 en die onder het Maastrichtse contract lijken sterk op elkaar. De handtekening van J. Spraeckell onder een contract voor werkzaamheden aan een torenuurwerk te Harderwijk in 1663 wijkt sterk af van de twee eerder genoemde handtekeningen. De conclusie moet dan ook luiden, dat Jurriaan van Zutphen en Jurriaan Spraeckel twee verschillende personen waren.

In het Maastrichtse gemeentearchief is een ongedateerd en ongesigneerd document bewaard gebleven met het opschrift: "Discriptie van de horlogie". ${ }^{42}$ Dit stuk is een offerte voor een torenuurwerk. met slinger en speeltrommel. Er worden vier opties aangeboden met verschillende prijzen, van heel luxe "met 6 gedraaeide iseren calummen" en een speeltrommel met 68 gaten per maat tot een uitgeklede versie van alleen een speeltrommel, met eventueel 56 gaten, naast het bestaande te repareren uurwerk. De prijzen variëren van 3.000 rijksdaalders tot 1.600 rijksdaalders met eventueel nog een extra korting van 50 rijksdaalders. Wellicht is dit een offerte van Jurriaan van Zutphen. De handtekening "J. van Zutphen" onder het contract van 1685 lijkt sterk op het handschrift van de offerte.

41 G.A.M., Oud-archief, Raadswerdragen, inw.mr. 70, p. 554.

${ }^{42}$ G.A.M., Oud-archief, inv.nr. 300. 
Het stadsbestuur opteerde voor de luxeversie; wegende 13.000 pond, echter met een trommel van slechts 56 gaten per maat; waarbij de gewichten, katrollen, koorden en wijzerplaten voor rekening van de stad kwamen. Aldus kwam men op een prijs van 2.800 rijksdaalders, in termijnen te betalen. De stad had het geld er voor over om de standaardisatie van de stadstijd weer in eigen hand te nemen. Vanaf 1555 tot 1652 hadden de burgers zich gericht op het uurwerk van de Sint-Servaas. Dit liep in 1652 zeer slecht, maar het duurde tot 1679 eer het kapittel er iets aan liet doen. Dit wilde de stad niet meer. Van Zutphen moest het werk binnen achttien maanden opleveren. ${ }^{43}$ Het nieuwe uurwerk, dat in de loop van de tijd verloren is gegaan, kwam op 6 oktober 1687 onder de hoede van Jacob Maurissen, die de in dat jaar overleden stadshorloger Jan Muys was opgevolgd.

Als we de geschiedenis van het uurwerk verder volgen, komen we het volgende tegen. Volgens een Raadsresolutie van 20 januari 1710 moest een reparatie "aen de horlogie" worden onderzocht. Hier wordt waarschijnlijk het stadhuisuurwerk bedoeld vanwege een zes weken later genomen besluit een "horologiewijser op het pleijn ${ }^{44}$ van het stadtshuijs" te laten maken (zie afbeelding 8). Kennelijk is er dat jaar meer gebeurd. Pater Gerardus van Antwerpen, capucijn, verzocht de magistraat van Maastricht op 31 maart 1710 om Leonardus Mijnis als opzichter van het stadhuisuurwerk aan te stellen en hem gratis het burgerrecht en het smedenambacht te verlenen. Pater Gerardus had toen al aan het carillon gewerkt; hij deed het later nog eens: in 1723 heeft hij het volgens Notermans ${ }^{45}$ in acht maanden hersteld.

Leonard Mijnis werd inderdaad opzichter van het stadhuisuurwerk met carillon, terwijl de al 23 jaar in functie zijnde Maurissen de andere stadsuurwerken bleef verzorgen. Mijnis werd na zijn dood in de functie van opzichter van het stadhuisuurwerk opgevolgd door zijn broer Willem. In 1733, na het overlijden van Maurissen, werden alle stadsuurwerken aan Willem Mijnis toevertrouwd. Technisch gezien liep Willem niet achter, want op 9 april 1731 stelde

${ }^{43}$ G.A.M., Oud-archief, inv.nr. 212 (oud ar. 206).

* Het pleim is nog altijd de benaming van de grote hal wan het Maastrichtse stadhuis; de wijzer is dus binnen, niet buiten! G.A.M., Oud-archief, Raadsverdragen, besluit d.d. 17 maart 1710.

45. Notermans 1962 , p. 45, noemt geen bron. 
hij voor een compensatieslinger voor het stadhuisuurwerk te maken, "sodanigh dat door veranderinge van't weder geene de minste veranderinge aen hetselve horologie meer sal worden toegebrogt". De raad was hiermee accoord en verklaarde zich bereid vijftig rijksdaalders te betalen. Men had het er voor over om te bewerkstelligen, "dat dit horologie precies en accuraet gaet, vermits alle de andere horologien deser stad sigh daemae moeten reguleren". ${ }^{46}$ Voordien richtte men zich naar het uurwerk van de Sint-Servaas. Op 2 september 1652 richtte de raad zich via een deputatie van oud-burgemeesters tot het kapittel van Sint-Servaas om "... behoorlijck redressement van't horologie te versuecken", want "... die gehele gemeynte deser stadt haer reguleert nae de ureslach van de kercke van St. Servaes ende dat deselve tegenwoordich geheel confuselijck is gaende tot groot ongerief van eenyeder".

Nadat Willem Mijnis in mei 1737 was overleden, solliciteerden zes kandidaten naar de functie van stadsuurwerkmeester, te weten $\mathbf{N}$. Perrier, Croissier, Leemans (dit is waarschijnlijk Petrus Philippus Leemans, die sinds 12 februari 1731 beiaardier was van Maastricht $^{47}$ ), Van Gulpen, J.G. Ghilliot en Willem Mijnis. Deze laatste was een zoon van Leonardus Mijnis en stadsuurwerkmaker van Zaltbommel of was dat tenminste geweest. ${ }^{48} \mathrm{Hij}$ beriep zich op een "resolutie magistrael" van 19 augustus 1726, waarin was bepaald dat Willem Mijnis zijn broer Leonardus na diens overlijden opvolgde als opzichter van het stadhuisuurwerk en carillon, dat hij voor de kinderen van Leonardus zou zorgen en tenslotte, dat hij de functie van Leonardus zou overdragen aan een van diens kinderen, indien die in staat zou zijn haar uit te oefenen. Hoewel Willem Sr. het opzicht had gehad over alle stadsuurwerken, splitste de magistraat de functie weer. Op 20 januari $1738 \mathrm{kreeg}$ Willem Mijnis Jr. het opzicht over het carillon en de uurwerken van het huidige stadhuis en het Dinghuis. Perrier kreeg het onderhoud van de andere stadsuurwerken, te weten de Maasbrugtoren, de Sint-Martinuskerk en de "oude Leurenpoort". Dit laatste is echter doorgestreept en vervangen door "oud stadtshuijs" zonder dezelfde woorden bij

\footnotetext{
${ }^{46}$ G.A.M., Oud-archief, Raadswerdragen, Raadsnotulen d.d. 9 april 1731.

${ }^{47}$ G.A.M., Oud-archief, Raadswerdragen, Raadsresoluties d.d. 12.02.1731.

${ }^{48}$ Zie appendix II onder Mijnis, Willem Jr.
} 
Mijnis door te strepen. Het is onduidelijk hoe een en ander precies was geregeld.

Beiden hadden eerst een proef moeten afleggen: namelijk thet stellen van een air op het klockenspel van den nieuwen stadtshuijse soo voor het uijre als voor het halff uijre en quartier uijr". Het "air" was gecomponeerd door de "sanckmeester" van de O.-L.-Vrouwekerk, zekere Fricco. De proef werd door Mijnis matig, door Perrier slecht gedaan. De laatste beklaagde zich over het tekort aan noten. Dat dit geen smoesje was, blijkt uit de levering van vijfhonderd noten door Mijnis in $1739 .{ }^{49} \mathrm{Ze}$ werden echter toch aangesteld "besonder wegens de kunst van het horologiemaecken". In de resolutie wordt erop gewezen, dat Mijnis de Luikse nativiteit had en Perrier de Brabantse, zodat het principe van alternatie werd geobserveerd. ${ }^{50}$ Het traktement van beide stadsuurwerkmakers bedroeg 422 gulden en twee karren kolen per jaar. ${ }^{51}$ Willem Mijnis kreeg een week na zijn aanstelling een vergoeding van 120 gulden voor het waarnemen van de vacante functie van zijn oom. In 1741 verrichtte hij voor veertig rijksdaalders reparaties aan het carillon. ${ }^{52}$ Het laatste wat wij van Willem Jr. vernemen is, dat hij in het Cellebroedersklooster was opgenomen. De stad besloot op 28 november 1746 gedurende een kwartaal aan de broeders de verpleegkosten te betalen. ${ }^{53}$ Van Perrier vernemen we verder niets. Hij is waarschijnlijk in 1745 overleden, want toen werd François de Beefe zijn opvolger, in $1750 \mathrm{kreeg}$ hij ook de functie van Mijnis, namelijk het opzicht over het stadhuisuurwerk met carillon en het uurwerk van het Dinghuis. De 18de-eeuwse aanpassingen waren niet al te ingrijpend. Het werd in de 20ste eeuw anders. Het carillon werd in 1910 gerestaureerd door de firma B. Eijsbouts te Asten. "De restauratie was voor wat het drijfwerk (dat wil zeggen de speeltrommel met bijhorend mechaniek, R.M. ${ }^{54}$ ) betreft eene gehee-

\footnotetext{
4. G.M.M., Ond-archief, Raadsverdragen, Raadsresoluties d.d. 31.08.1739.

5il Het tweeherig bestuur van Maastricht impliceerde, dat er twee soorten burgers waren: Luikse en Brabantse. Sommige ambten en colleges bestonden daarom in tweevoud: Luiks en Brabants. Andere ambten moesten evenredig over Luikse en Brabantse burgers worden verdeeld, dat is de alternatie observeren.

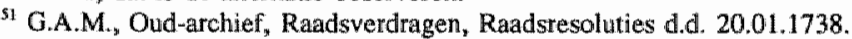

s: G.A.M., Ond-archief, Raadsverdragen, Raadsresoluties d.d. 11.09.1741.

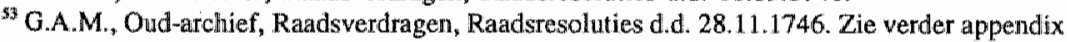
II onder Mijnis, Willem Jr.

st Bedrijfsarchief Koninklijke Eijsbouts N.V. te Asten, Copy-boek nr. 5, copie nr. 42, offerte
} 
le vernieuwing, terwijl de klokken konden behouden blijven, doch hunne plaatsing eene geheele verandering moest ondergaan..." De klokken werden meer aan de buitenkant wan de toren gehangen, zoals, naar men meende, vroeger ook het geval was geweest. Ook werd een nieuw klavier aangebracht, dat een persoonlijker en genuanceerder spel mogelijk maakte. ${ }^{55}$ Wat toen nog over was van het werk van Van Zutphen verdween vijftien jaar later. In 1925 leverde Eijsbouts een geheel nieuw torenuurwerk met twee slagwerken en elektrische opwinding. Thans rest in de toren alleen nog de speeltrommel van 1910 .

\subsubsection{Het uurwerk van de Sint-Martinustoren}

Ook in de uit 1450 stammende toren van de oude Sint-Martinuskerk, de parochiekerk van Wijck, het stadsdeel aan de andere zijde van de Maas, is een torenuurwerk opgesteld geweest. Zoals vaker voorkwam, was het uurwerk eigendom van de burgerlijke gemeente. Deze moest zorgen voor het onderhoud van toren, uurwerk en eventueel aanwezige banklok, terwijl andere kerkgedeelten ten laste kwamen van de kerkfabriek en/of de grote tiendheffer. Sinds wanneer er een uurwerk in de Sint-Martinuskerk was, is onbekend. Waarschijnlijk is het geplaatst nà 1585 , want in dat jaar is nog slechts sprake van twee stedelijke uurwerken, "opden Merckthoren ende opden Denckhuys-thooren", die door de stadsklokkenmaker Jan Thoens moesten worden onderhouden. ${ }^{56}$ Veel later dan 1585 kan het niet geplaatst zijn, want we weten dat de stad Maastricht in 1599 het plan opvatte "... te stellen een horologie bove op dye Maesbruggeporte tot gerieff van de gemeyne man soe te water als te land dese stadt passerende...". Hiervoor wilde men het uurwerk van de Sint-Maarten gebruiken. Omdat de pastoor en de parochianen niet veel moeilijkheden maakten over het wegnemen van "hun"

d.d. 1.2 maart 1910. Hierim is sprake wan "een geheel nieuw loopwerk... zoals door hem in 1907 te Weenen geleverd... te leveren... geheel klaar met het uurwerk in werking gesteld". Er wordt niet gerept over vervanging van het oude nurwerk. De toen geleverde speeltrommel draagt het opschrift: "Nederlandsche Fabriek van Torenuurwerken / B. Eijsbouts Asten / no. 360 anno $1910^{\prime \prime}$.

${ }^{55}$ Verslag van den toestand der gemeente Maastricht over het jaar 1910, 1911, p. 139.

${ }^{56}$ G.A.M., Oud-archief, Raadsverdragen d.d. 15 juli 1585. 
klok, gaf de stad voor de restauratie van de pastorie 300 mergelblokken uit Zichen en 16.000 bakstenen. ${ }^{57}$ Toch zou het nog tien jaar duren eer men "het urwerck, clocke ende wijser derselven kercke soude vandaer overdraegen ende stellen opder porte vande Maesbrugge". ${ }^{58}$ Sindsdien is sprake van "de drije horologien te onderhouden" ${ }^{59}$ Toch beviel het de Wijkenaren op den duur blijkbaar niet, dat er geen uurwerk in de Sint-Maartenstoren stond. Daarom werd er in september 1687 weer een uurwerk in de toren gehangen op kosten van de stad, die het geregeld onderhoud eveneens voor haar rekening nam. ${ }^{60}$ Wie het leverde is onbekend. In 1712 werd het gerepareerd samen met de uurwerken van de Maasbrug en het Dinghuis. ${ }^{61}$ In 1764 was een nieuwe herstelling nodig. die werd uitgevoerd door François de Beefe. ${ }^{62}$ De oude kerk werd in de 19de eeuw afgebroken en in de jaren 1855-1860 vervangen door een neo-gotische, ontworpen door dr. P.J.H. Cuypers. ${ }^{63}$ Het oude uurwerk kan bij die gelegenheid verloren zijn gegaan.

\subsubsection{Het uurwerk van de Maasbrugtoren}

Hierboven werd reeds verhaald, hoe er in 1609 een uurwerk op de Maasbrugpoort kwam. Deze poort met toren stond vanuit Maastricht gezien aan het einde van de stenen brug; daarachter kwam een houten overdekte boog naar Wijck ${ }^{64}$ (zie afbeelding 9).

Het uurwerk werd onderhouden op stadskosten, zelfs al vóór de brug in 1646 door het stadsbestuur van het kapittel van Sint-Servaas was overgenomen. In 1349 was er al een verdeelsleutel betreffende het onderhoud van de brug totstandgekomen: het kapittel van

\footnotetext{
${ }^{57}$ G.A.M., Oud-archief, Raadsverdragen d.d. 22 november 1599.

${ }^{58}$ G.A.M., Oud-archief, Raadsverdragen d.d. 3 augustus 1609.

59. G.A.M., Oud-archief, Raadsverdragen d.d. 29 november 1621 .

P. Doppler 1894 , p. 19. P. Doppler is één van de weinige archivarissen, zo niet de enige, die in de vorige eeuw en de eerste helft van deze eeuw aantekeningen over unwerken publiceerde.

G.A.M., Oud-archief, Raadsverdragen d.d. 30 mei 1712.

${ }^{62}$ P. Doppler 1894 , p. 19. De tekst van de overeenkomst van de stad met De Beefe wordt in het artikel afgedrukt.

63. T. vant Rensch 1983.

64 Afgebeeld op een tekening van Van Gulpen. G.A.M., Tekeningen, plattegronden, etc inv.nr. 1133 .
} 
Sint-Servaas zou een kwart betalen, de stad drie vierde deel. ${ }^{65}$ Men vindt vanaf 1621 in de Raadsverdragen vermeldingen van geregeld onderhoud en reparaties aan de "drije horologien" of de "horologien op den marck, dinghuys en brugge". ${ }^{66}$ Ondanks dit geregelde onderhoud viel er voor onze begrippen toch nogal vaak aan te sleutelen. Vermeldingen van grote reparaties aan het Maasbruguurwerk vinden we op 24 maart 1669: "de 3 horologien te doen hermaecken voor 120 gl" en op 2 mei 1678: "horologie op de brugge te repareren" door de stadshorloger Jan Muys, die voor twintig rijksdaalders "vier nieuwe raeders, grooter en swaerder als van te voorens" aanbracht. Op 18 september 1690 bracht stadsklokkenmaker Jacob Maurissen voor zestien pattacons een nieuw slingerwerck aan en verbuste hij het uurwerk. Op 30 mei 1712 lezen we "horologien in St. Marten, op dle brugge en oudt stadhuys te reparere". De Maasbrugtoren werd in 1801 wegens bouwvalligheid gesloopt. De onderdelen van het uurwerk werden overgebracht naar de prefectuur van het departement van de Nedermaas in Maastricht. ${ }^{67}$ De stad Maastricht heeft het uurwerk later teruggeëist, maar dit heeft er niet toe geleid, dat er een spoor van is overgebleven.

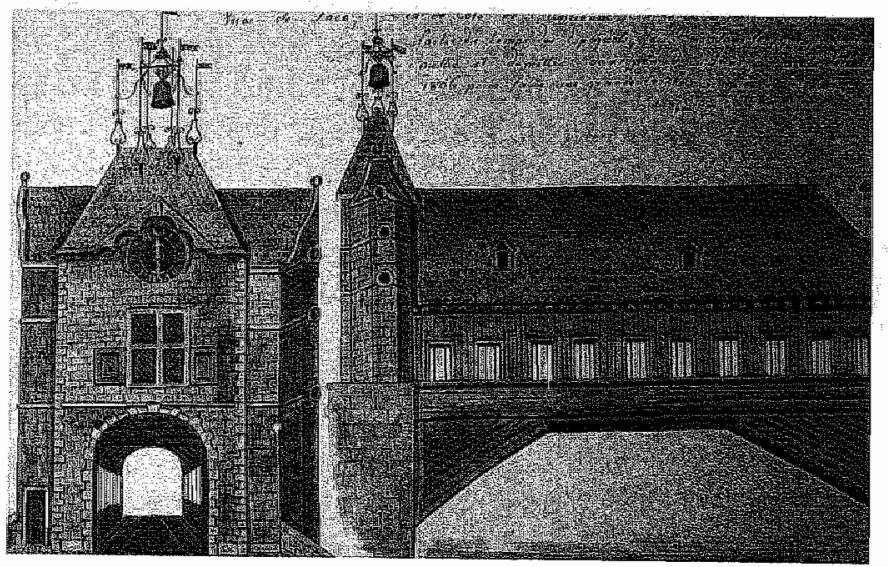

9. Toren met uurwerk op de Maasbrug, Maastricht (tekening door Van Gulpen, 19de eeuw)

Zie R, de la Haye 1984, p. 23.

G.A.M., Oud-archief, Raadsverdragen d.d. 29 november 1621, 14 november 1633, 26 juni 1634,26 juni 1656,24 maart 1669.

${ }^{67}$ R. de la Haye 1984 , pp. 38 en 39. 


\subsection{De uurwerken aan kerkelijke gebouwen}

\subsubsection{Het uurwerk van het O.-L.-V rouwekapittel}

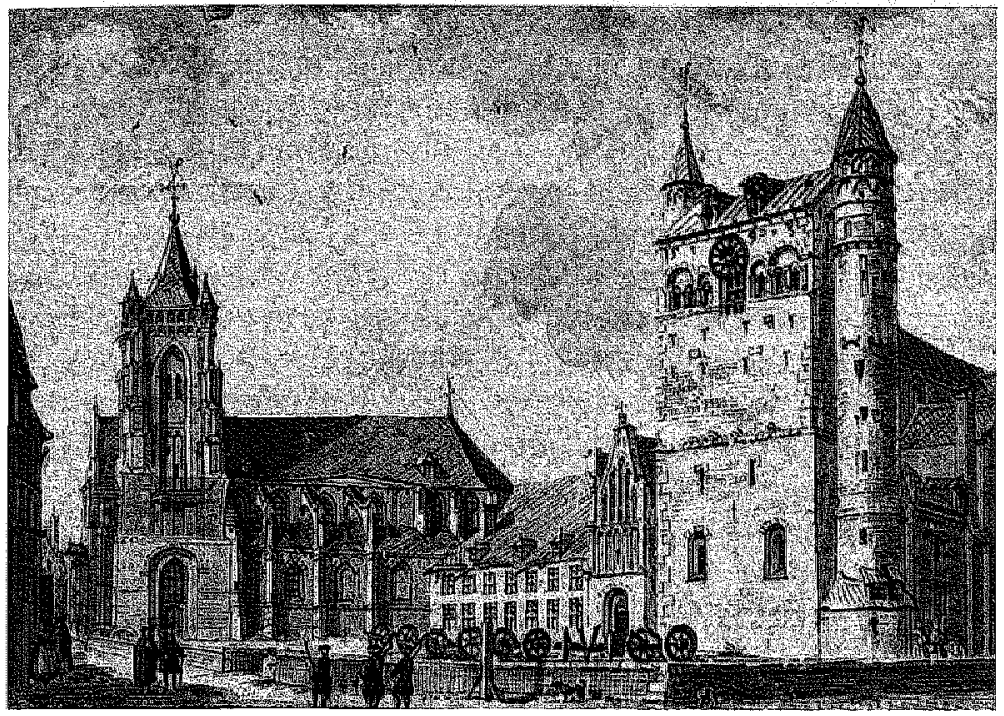

10. O.-L.-Vrouweketk, Maastricht (tekening J. de Beyer, 18de eeuw) (reproductie J. Bonnet)

De eerste vermelding van een uurwerk in de O.-L.-Vrouwekerk (zie afbeelding 10) stamt uit de eerste helft van de 15 de eeuw. In een 15 de-eeuwse staat van inkomsten en uitgaven van het O.-L.-Vrouwekapittel wordt aangetekend, dat Henricus Slotmeker een betaling had ontwangen "pro reformatione horologii". ${ }^{68}$ Er komt een Heynrick Johans zoon Slo(e)tmeker(s) voor in twee schepenbrieven van het O.-L.-Vrouwekapittel uit het jaar $1449 .{ }^{69} \mathrm{Hij}$ is blijkbaar in dat jaar of kort daarvóór overleden. Waarschijnlijk zijn Henricus Slotmeker en Heynrick Johans zoon Slo(e)tmeker(s) één en dezelf-

6. R.M.M., Kapittel van Onze-Lieve-Vrouw, voorlopig inv.nr, 1157. De tekst luidt: "Item ipso die beati Johannis Baptiste Henrico Slotmeker pro reformatione horologii XVII s...". Dank aan dr. J.A.K. Haas voor de attendering.

${ }^{69}$ P. Doppler s.a., nrs. 420 en 423 . Henricus Sloetmeker komt driemaal voor in de Raadsverdragen als gezworene voor de smeden: Raadsverdragen van Maastricht 1367-1428, 1992, nrs. 1161 (1415), 1221 (1419), 1264 (1423). Zijn vader Johannes Sloetmeker op den Alden Hoff, alias de Esden, was wolgens de Raadsverdragen therhaaldelijk gezworene voor de smeden tussen 1381 en 1406. 
de persoon. Hoe lang het uurwerk, waaraan Hendrik Slotmekers heeft gesleuteld, heeft gefunctioneerd, weten we niet. ${ }^{70}$ In 1640 namen de kanunniken het besluit om een nieuw uurwerk met caritlon te laten maken. De klokken voor het carillon bestelden zij bij meester Glaudius Plomere te Hoei. Voor het uurwerk werd op 4 januari 1642 een contract opgesteld met Arnold Moës en zijn vader Artus te Luik. ${ }^{1}$ Het werk vlotte niet erg; er is enige malen uitstel van leverantie verleend. Moës schijnt overleden te zijn vóór de voltooiing van de opdracht; in april 1644 was het nog niet af. ${ }^{72}$ Enige tijd later is het niettemin geplaatst. In 1734 repareerde Willem Mijnis het carillon dat toen uit 32 klokken bestond. ${ }^{73}$ Het moest niet alleen het volle en het halve uur kunnen slaan, maar ook het kwartier en zelfs het halve kwartier. ${ }^{74}$ Mijnis moest "Berghs" ijzer gebruiken en vijlen wat gevijld diende te zijn. De kosten beliepen 1.400 gulden Brabants Maastrichter koers.

Ruim veertig jaar later, in 1777 , moest de beiaard weer worden gereviseerd. Joannes Mertens uit Rosmeer, die dit werk op zich nam, moest ook "de geheele orlogie met het trommelwerk uijt malkander doen, hetselve schoonmaken en al wat daaraan manqueert herstellen, de trommel rond doen draijen en alle buijsen (bussen) die te wijt zijn met koper verbuijsen, alles op het best". Mertens moest ook het uurwerk zodanig veranderen, dat het maar tweemaal in plaats van driemaal in 24 uur hoefde te worden opgetrokken, dit alles voor 800 gulden Maastrichter koers. Hoewel het contract op 9 juli werd gesloten, moest het werk eind oktober klaar zijn op straffe van 200 gulden boete, als dit tijdstip niet zou wor-

\footnotetext{
${ }^{70}$ Mogelijk is er een uurwerk geweest tussen het door Slotmeker gerepareerde en 1640. We kennen het miet.

${ }^{71}$ Arnold Moës wordt al in 1598 wermeld. In 1612 werd hij een bekwaam slotenmaker genoemd. In 1620 maakte hij woor de Sint-Lambertkathedraal in Luik een torenuurwerk. Later maakte hij daarvoor nog een speeltrommel en in 1632 een halfuurslag. F. Pholien $1933_{1}$ p. 25. Zijn vader Artus wordt door Pholien niet vermeld. Voor andere unrwerkmakers uit de familie Moës zie noot 84.

${ }_{72}$ P. Doppler 1933, p. 57. Doppler baseerde zijn berichtje op protocollen van de kapittelvergaderingen. Omdat daar de contracten tussen het kapittel en Moës niet bij zijn gevoegd, kunnen. geen technische details over het uurwerk worden meegedeeld.

${ }_{73}$ R.A.M. ${ }_{*}$ Archief van het kapittel van Onze-Lieve-Vrouw, Maastricht, woorlopig unv.nr. 919(3), contract d.d. 17 februari 1734 tussen het O.-L.-Vrouwekapittel en Willem Mijnis. Of Willem Mijnis Sr. of Jr. dit werk verrichtte, is niet duidelijk. Dank aan dr. J.A.K. Halas voor de inzage tijdens de inventarisatie var dit archief.

${ }^{74}$ Het halve kwartier werd ook te Sint-Truiden, Hasselt en Lier op het carillon gespeeld.
} 
den gehaald.$^{75}$ De gestelde termijn werd inderdaad niet gehaald. In 1779 werd het werk afgekeurd door N. de Neve en P. Bovrie, de beiaardier van de O.-L.-Vrouwekerk. Op verzoek van Mertens werd het werk in 1783 opnieuw gekeurd door twee ongenoemde "horologeurs" en de eerder genoemde Bovrie. De uitslag van die keuring is niet bekend, maar zal niet ongunstig zijn geweest. In januari 1784 machtigde het kapittel tenminste enkele kapittelheren om de zaak af te wikkelen. Eindelijk op 26 februari $1785 \mathrm{kreeg}$ Jan Mertens de laatste termijn van 200 gulden uitbetaald. Toch was in juni 1786 weer een reparatie aan het klokkenspel nodig en moesten er enkele klokken worden verwijderd. ${ }^{76}$

In de Franse tijd, in 1797 , is het carilllon door de bezetters omgesmolten op de twee grootste klokken na, die ten dienste van het uurwerk werden gelaten. ${ }^{77}$ Het carillon bestond toen uit elf grote torenklokken en 25 kleinere klokjes. ${ }^{78}$ Blijkbaar was het gaandeweg enigszins uitgebreid. Hoewel het uurwerk door de Fransen ongemoeid werd gelaten, is het mogelijk door gebrek aan onderhoud tussen 1800 en 1837 verloren gegaan. De Fransen hadden de kerk aan de eredienst onttrokken en er een smidse, magazijn en paardenstal van gemaakt.

Toen in 1837 de O.-L.-Vrouwekerk parochiekerk was geworden, wilde het kerkbestuur weer een uurwerk installeren. Een carillon ambieerde men vanwege de hoge kosten niet. Men trad in overleg met het gemeentebestuur: aanvankelijk werd gevraagd om een uurwerk, dat geheel of tenminste voor twee derde deel door de gemeente werd betaald omdat het vanaf de Maas zichtbaar zou zijn. Het was immers dienstig om "zoveel ongemakken aan de scheepvaart op kanaal en Maas weg te ruimen". Onder voorwaarden wilde het gemeentebestuur een twee derde subsidie verlenen. Het kerkbestuur accepteerde deze voorwaarden echter niet. Op 5 november 1864 meldden Burgemeester en Wethouders een raadsbesluit om

\footnotetext{
${ }^{35}$ R.A.M., Archief van het kapittel van Onze-Lieve-Vrouw, Maastricht, voorlopig inv.nr. 915(37), contract d.d. 9 juli 1777 tussen het O.-L.- Vrouwekapittel en Joannes Mertens uit Rosmeer. Van Mertens is een staande klok bewaard gebleven, zie appendix II onder Mertens, Joannes.

${ }^{76}$ R.A.M., Archief wan het kapittel valn Onze-Lieve-Vrouw, Maastricht, voorlopig inv.nr. 422, protocollen van de kapittelvergaderingen d.d. $7.10 .1777,5.12 .1777,17.11 .1779,22.8 .1783$, 14.1.1784, 27.6.1786.

${ }^{77}$ A. Flament 1915, p. 145.

${ }^{78}$ G. Quaedvlieg 1962 , p. 368 , noemt eem aantal van 26 klokken voor het carillon.
} 
"het buiten dienst gestelde uurwerk van het Raadhuis" kosteloos aan de O.-L.-Vrouwekerk aan te bieden; de plaatsing en het onderhoud zouden voor rekening komen van de kerkfabriek. Een bijkomende voorwaarde was, dat de gang van het uurwerk zou moeten worden afgestemd op die van het Raadhuis. Als hieraan niet zou worden voldaan, moest het kerkbestuur alsnog 250 gulden betalen. Welk uurwerk de gemeente heeft aangeboden, is niet duidelijk. Dat van het oude stadhuis, het zogenaamde Dinghuis, of dat van het nieuwe stadhuis? Het kerkbestuur was niet enthousiast. Tweedehands spul was beneden de waardigheid van de O.-L.-Vrouwekerk. De knoop werd in 1865 doorgehakt door een geheel nieuw uurwerk met twee slagwerken (het rechter slagwerk is een zogeheten Angelusslag) en twee wijzerplaten te bestellen bij de Maastrichtse firma L. DopplerGadet om aan de westkant van de kerk te worden geplaatst. Het werd in 1866 geleverd voor $f 2.883,33$ en bevindt zich nog in de toren. Het is buiten werking gesteld, hoewel het nog voortreffelijk zou kunnen functioneren. ${ }^{79}$ Het echappement is een Grahamgang met verstelbare paletten in het anker. Uit de rekening van DopplerGadet blijkt, dat hij het zelf had gemaakt en niet van elders betrokken.

Of de Sint-Nicolaaskerk, de vroeger naast de O.-L.-Vrouwekerk staande parochiekerk, ooit een uurwerk heeft gehad, is niet duidelijk. Waarschijnlijk was dit niet het geval. De archieven spreken er niet van. Op afbeeldingen van de kerk is geen wijzerplaat te zien. Waarschijnlijk had een parochiekerk verbonden aan een kapittelkerk ook nooit een uurwerk. In paragraaf 2.2.3. zal blijken dat zulks tenminste bij Sint-Servaas en haar parochiekerk Sint-Jan het geval was.

\subsubsection{Het uurwerk van het Sint-Servaaskapittel}

De Sint-Servaaskerk was evenals de O.-L.-Vrouwekerk een kapitte1kerk. Tussen de beide kapittels heeft altijd een zekere rivaliteit bestaan. De kanunniken van Sint-Servaas konden op den duur ook op klokkengebied niet achterblijven bij hun collegae, die al rond 1450 een uurwerk bezaten.

${ }^{79}$ J. de Win s.a., nr. 663 en nr. 664. 
Toch vernemen we pas in 1544 iets over een groot torenuurwerk voor de Sint-Servaas. De kapittelheren zullen zich intussen hebben gerefereerd aan de openbare tijdmeting, die Maastricht rijk was. Aan de kosten voor het eerste stadsuurwerk hadden zij in 1367 royaal bijgedragen.

Rond het midden van de 16de eeuw wensten de kapittelheren een geavanceerd uurwerk, een dat meer dan alleen hele uren sloeg. In 1544, "den vierden dach Decembris", kwam een deputatie van het kapittel van Sint-Servaas met meijster Johan Dierix Wennemeker overeen "omme gemaeckt te hebben een goed oergewerck mijt den werck van eijnen voerslach met twelff schellen slaende dije halve ende geheele oeren, met geheelen en halven tonen, noet tegen noet dat men noempt conterpunt. Ende met drije wijsers, ende dat allet oprechtich ende goet staende durende werck, behalven oft aenden lepell ijet verslete, dat sal meijster Jan sijnen levenlanck onderhalden ter discretien van den Heren". ${ }^{80}$

Van Wennemeker wordt geen woonplaats vermeld, wat zou kunnen betekenen dat hij in Maastricht woonde. In dezelfde richting zou kunnen wijzen het feit, dat er geen bepalingen zijn opgenomen ten aanzien van eventuele reis- en verblijfkosten in verband met de levenslange garantie op het uurwerk. Ook in de borgstelling die Wennemekers moet geven, wordt geen plaatsnaam vermeld.

Dat de voorslag i.e. het carillon conterpunt moet kunnen spelen, verwijst naar de polyfone muziek van die dagen. De kapittelheren waren wel wat zuinig met hun twaalf schellen. Wennemekers wijst hen dan ook op de noodzaak van dertien schellen "omme altijd eijnen fa te hebben".

De tekst van de overeenkomst bevat alllerlei technische specificaties, zoals: "Ten eirsten moet het hebben verstaelde assen ende dije gaetten, daer dije assen ingaen sullen hard gemaeckt sijn gelijck stael". Daarna komt nog een hele opsomming van allerlei onderdelen die moeten worden verstaald. Wie dit leest, is niet meer verwonderd dat er zoveel onderhoud en reparaties waten aan de oude torenuurwerken. Pas tegen het eind van de 16de eeuw is men tot de bevinding gekomen, dat het beter is om harde assen te laten draaien in zachte bronzen bussen.

${ }^{80}$ P. Doppler 1887, pp. 129-130, vermeldt de volledige tekst wan deze overeenkomst. 
Het unrwerk moest uiterlijk in $1546 \mathrm{klaar}$ zijn en ongeveer 5.300 pond $(2,4$ ton) wegen. Wennemeker lijkt op tijd te hebben geleverd. Het carillon, groter dan eerst bedoeld, namelijk negentien klokken omvattend, werd echter pas in 1555 besteld bij Hendrik van Trier in A ken. Uurwerk en carillon werden in een middentoren geplaatst., die voor het carillon werd uitgebouwd tot een hoge houten toren. De wijzerplaten werden aan de oude stenen torens van de westbouw bevestigd. In december 1558 heeft ook de uurwerkmaker Lambrecht Blaesen uit Hasselt voor het kapittel gewerkt; wat hij heeft gedaan is niet duidelijk. ${ }^{81}$

Het uurwerk voldeed blijkbaar zo goed, dat het een tijd lang de lokale Maastrichtse standaardtijd aangaf, als we deze anachronistische uitdrukking mogen gebruiken. Deze situatie hing waarschijnlijk samen met de deplorabele toestand van de stadsfinanciën van 1580 tot 1640 ten gevolge van de inname van Maastricht in 1579 door Parma. De stad kon haar oude uurwerken nauwelijks onderhouden, terwijl de Servaas beschikte over een vrij recent uurwerk. Deze toestand duurde bijna een eeuw; toen was het SintServaasuurwerk zover versleten, dat er regelmatig moeilijkheden ontstonden. We kunnen dit afleiden uit het feit, dat het Maastrichtse stadsbestuur op 2 oktober 1652 besloot te streven naar een oplossing voor opdoemende problemen: "Alsoo naer oude gewoonte die gehele gemeynte deser stadt haer reguleert nae de ureslach van de kercke van St. Servaes ende dat selve tegenwoordigh geheel confuselyck is gaende tot groot ongerief van eenyeder sijn de heren oudtborgemeesters gediputeert om die heren Deeckens ende capittel hier over te spreecken ende behoorlijck redressement vant horologie te versuecken". ${ }^{82}$ Het zou nog drie en een half decennium duren voor de stad bereid was weer zelf de rol van tijdsbepaler te gaan spelen. In 1686 nam het uurwerk van het nieuwe stadhuis deze taak over.

Het onderhoud van het uurwerk werd aanvankelijk aan zijn maker toevertrouwd. Wie het daarna heeft onderhouden, is niet bekend. We kennen slechts één naam: Jan Reesen, woonachtig te Wijck "opten Poull". Deze verkreeg in 1569 voor drie jaar de tol van de Maasbrug. Hij vroeg meteen toestemming om gebruik te maken van

\footnotetext{
${ }^{* 1}$ R.A.M., Archief van het Sint-Servaaskapittel, Maastricht, I, folio CCCXVIvo d.d. december 1558.

kiz G.A.M., Oud-archief, Raadsverdragen d.d. 2 oktober 1652.
} 
de toren op de Maasbrug als woning en van het houten afdakje daartegen, dat hij met toestemming van het kapittel had laten bouwen. Voor dit vruchtgebruik moest Reesen zorgen voor het onderhoud van "die oerclock met allen die clockskens der selver oerclocken, mitz oeck der beyer clocken der voors. kerck van Ste. Servaes". Hij heeft het uurwerk met speelwerk en de luidklokken van de Sint-Servaas mogelijk onderhouden tot 1587 . In dat jaar werd in ieder geval in zijn plaats een andere tolgaarder aangesteld. ${ }^{83}$

De bovenvermelde klacht van de gemeente over het slecht lopen van het Servaasuurwerk heeft er ten langen leste toch toe geleid dat het kapittel de zaak grondig ging aanpakken. Dat gebeurde overigens pas tien jaar nadat de installatie van een nieuw uurwerk met slinger op het stadhuis duidelijk had gemaakt, dat het Sint-Servaasuurwerk de tijd hoogst onbetrouwbaar aangaf. Daarom sloot het kapittel op 3 juni 1679 een contract met "Maistre Lambert Moeuse, maistre horologier, bourgeois de la cité de Liège ${ }^{134}$ Hierin werd overeengekomen, dat Moeuse het uurwerk van de Sint-Servaas zo zou repareren dat het zo goed als nieuw zou worden ("... la rendre aussy bonne que neuffe"). Zeer interessant is, dat hij het uurwerk op slinger moest ombouwen: "faire le mouvement à pendules". Verder moest hij de speeltrommel reviseren, zodat deze recht zou draaien. Als cautie stelde Mr. Lambert onder meer zijn huis dat een uurwerk als gevelsteen had. Op 13 juni 1680 was Lambert nog niet met het werk klaar. ${ }^{85}$ Waarschijnlijk vond de levering kort nadien plaats: de notaris hoefde niet verder aan te dringen.

In de kapittelvergadering van 6 sèptember 1685 werd besloten een nieuw klokkenspel te laten maken omdat het bestaande sterk was versleten. Op 11 december 1686 bleek het echter noodzakelijk die aanschaf uit te stellen tot betere tijden. Die kwamen pas ruim honderd jaar later. Pas in 1770 was het nieuwe carillon met een nieuw uurwerk klaar. Het carillon werd geleverd door Andreas van den

\footnotetext{
${ }^{83}$ R. de la Haye 1984, p. 25.

${ }^{84}$ De naam Moeuse is waarschijnlijk identiek met Moës, dat wil zeggen dat Lambert tot een bekende unrwerkmakersfamilie behoorde. F. Pholien 1933, noemt Lambert Moeuse niet. Wel noemt hij op pp. 25 en 117 Amold Moes met de jaartallen 1598 en 1612 en Jean Moes met het jaartal 1.6...

${ }^{85}$ G.A.M., Notariele archieven, inv.nr. 1276, notaris Veestraten, d.d. 03.07.1679 en 13.06. 1680 .
} 
Ghein uit Leuven, ${ }^{86}$ het uurwerk met speeltrommel door François de Beefe, de stadshorloger van Maastricht van dat moment. Hij liet zien hoe zwaar verwaarlozing van een openbaar uurwerk werd gestraft. Het nieuwe uurwerk kostte 17.000 gulden. ${ }^{87}$ Het werd opgesteld onder de middentoren van het westwerk; er waren twee wijzerplaten, één aan iedere buitentoren van genoemd westwerk, de ene naar het noorden gericht, de andere naar het zuiden.

In de Franse tijd zijn het uurwerk en het carillon met moeite gered van de Franse smeltovens. Als "chef d'oeuvre de l'art" en vanwege de verknochtheid van de bevolking aan beide zaken zagen de Fransen af van versmelting. ${ }^{88}$ Uurwerk, speelwerk en carillon hebben, met de nodige moderniseringen en aanpassingen, gefunctioneerd tot de brand in de middentoren in september 1955. De speeltrommel met slagwerk en enige resten van het gaande werk zijn behouden gebleven en in 1994 gerestaureerd. Uit de sluitschijf bij de speeltrommel blijkt, dat de trommel elk kwartier in beweging kwam om op het carillon een wijsje te laten weerklinken. Het is een indrukwekkende constructie van tien kubieke meter omvang. Het ijzeren raamwerk, met messing kapitelen en basementen, heeft de afmetingen: hoogte $225 \mathrm{~cm}$, diepte $165 \mathrm{~cm}$, lengte $270 \mathrm{~cm}$. De messing speeltrommel, die in één keer is gegoten, heeft een doorsnede van $127 \mathrm{~cm}$ en een lengte van $140 \mathrm{~cm}$, zonder tandwiel. In de trommelwand zijn 120 rijen met 80 vierkante gaatjes gegoten en pas-gevijld. Op een dwarsverbinding boven de trommel staat het inschrift: "pensionné de cette ville may $1769^{\circ}$. De messing tandwielen hebben fraai gevorkte spaken. De assen draaien in bronzen lagers. De aandrijving van het geheel gebeurde door slechts één grondrad. Aan alles is te zien, dat François de Beefe uit een klokkenmakersfamilie stamde, die beroemd was vanwege haar torenuurwerken, vaak met speelwerk. ${ }^{89}$ Het geheel staat nu opgesteld in de zogeheten Kanunnikenkelder, als een indrukwekkend monument van ambachtelijk vakmanschap. Helaas is alles bij de restauratie gezandstraald, waardoor het brons eruitziet als karton (zie afbeelding 11).

\footnotetext{
36. E[versen] 1883, pp. 890-891.

${ }^{87}$ P. Doppler s.a., pp. 134-135.

8. Doppler 1886, p. 74.

${ }^{89}$ F. Pholien 1933, pp. 77-82; A. Lehr 1984, passim.
} 


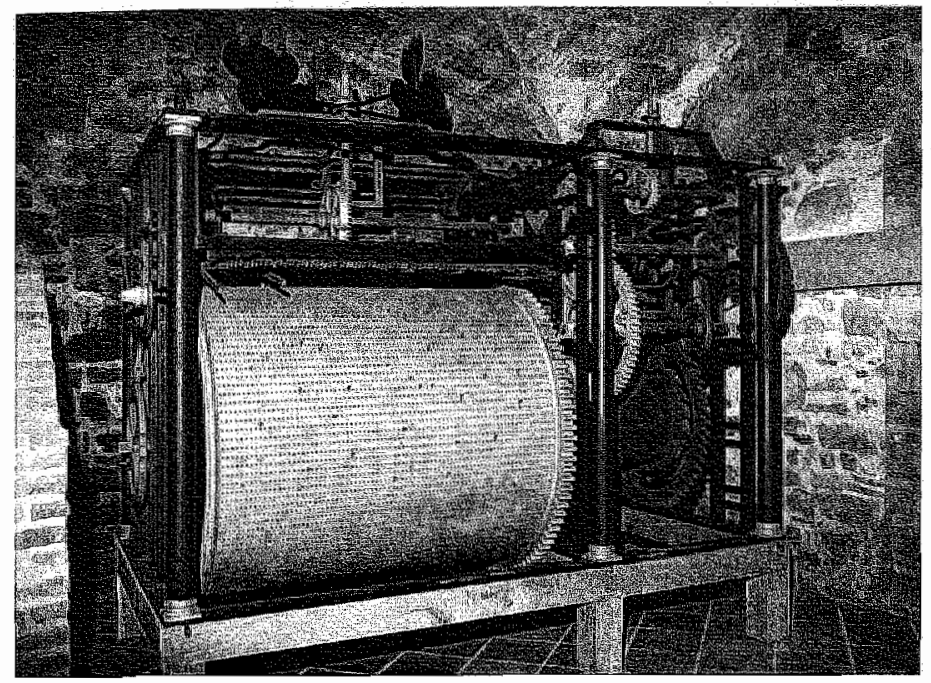

11. Speeltrommel met restanten van het uurwerk van de Sint-Servaaskerk, Maastricht (door Fr. de Beefe, Maastricht, 1770)

Behalve het grote uurwerk in de middentoren moet er ook een uurwerk zijn geweest boven de absis aan de Vrijthofkant. Immers, op veel afbeeldingen van de Sint-Servaas vanaf het Vrijthof is duidelijk een wijzerplaat te zien in de spitsboog van het venster boven het dak van de absis. Deze afbeeldingen bestrijken twee en een halve eeuw: van een tekening van Cantagallina ${ }^{90}$ uit 1612 tot omstreeks 1860 , toen dit detail nog werd weergegeven op een staalgravure naar Schüler van J. Poppel. Dat het geen artistieke fantasie was van de diverse kunstenaars, bewijst een foto van de absispartij, genomen vóór de restauratie door Cuypers, waarop duidelijk een wijzerplaat is te zien. ${ }^{91}$ De éne wijzer van deze wijzerplaat kan onmogelijk zijn aangedreven door het uurwerk in de middentoren van de westbouw vanwege de grote afstand. Over de bouw en de plaatsing van het oostelijk uurwerk werd geen enkel document gevonden. Of men er ooit in is geslaagd het uurwerk boven de absis synchroon te laten lopen met het uurwerk in de westbouw, is

\footnotetext{
Tekening van de Sint-Servaaskerk vanaf het Vrijthof gezien, toegeschreven aan R. Cantagal lina, gedateerd 1612, in bezit van het Koninklijk Museum voor Schone Kunsten te Brussel, afgebeeld in: J. Koreman 1981, p. 55, afbeelding 55.

91 K. Nieuwenhuizen 1977, omslagfoto.
} 
een vraag die waarschijnlijk ontkennend moet worden beantwoord. Vanwege de ene wijzer zal een verschil in aanwijzing echter $n^{\text {iet }}$ al te zeer zijn opgevallen.

Het absisuurwerk is verdwenen bij de restauratie van de oostzijde, toen het oorspronkelijke muurwerk, tijdens een afwezigheid van Cuypers, werd vervangen door het huidige, veel te rode steenwerk. In zijn restauratiejournaal vermeldde hij niets over uurwerk of wijzerplaat. In "Ach lieve tijd" wordt zonder bronvermelding beweerd, dat dit uurwerk werd verplaatst naar het timpaan van het Dinghuis. ${ }^{92}$ Nauwkeurige bestudering van de originele foto ${ }^{93}$ laat zien dat het uurwerk boven de absis eenwijzerig ${ }^{94}$ was. De wijzer eindigde in een Franse lelie. De wijzer van het Dinghuis ziet er heel anders uit. Hij heeft een brede "schoppen"-vorm met veel ajour zaagwerk, zoals ook huisuurwerken vaak hebben. Deze wijzer heeft ook een klein contragewicht dichtbij de wijzeras. Hij staat in deze vorm al op de oudste foto van het Dinghuis uit $1890 . .^{95} \mathrm{De}$ cijferringen lijken op elkaar, maar die van de Servalas is blijkens meting op de foto's groter geweest dan die van het Dinghuis. Als de verplaatsing inderdaad zou hebben plaatsgevonden, zou men hierover iets in de archieven van de gemeente moeten vinden omdat het Dinghuis eigendom is van de stad. De gemeentelijke jaarverslagen van 1865 tot 1890 reppen er echter met geen woord over, terwijl elk jaar de uitgaven voor de stadsuurwerken worden opgesomd. Een overplaatsing van het absisuurwerk naar het Dinghuis is onwaarschijnlijk.

\subsubsection{Het uurwerk van de Sint-Janstoren}

De hoge toren van de Sint-Janskerk (zie afbeelding 12), de parochiekerk naast de kapittelkerk van Sint-Servaas, zou volgens sommige auteurs al in 1373 een uurwerk hebben gehad. Flament schreef: "1373. Was er alhier zóó hevige storm, dat de toren van St. Janskerk omverstortte. Er was een uurwerk op dezen toren, en het

\footnotetext{
92 Ach lueve tijd 1994 , p. 5 in margine.

93 G.A.M., Fotoarchief, inv.n. 49343, datering $\$ 1870$.

verscheidene afbeeldingen van de oostbouw vam de Sint-Servaas en van het Dinghuis beelden wijzerplaten met twee(!) wijzers af.

95 G.A.M., Potoarchief, inv.nr. 367.
} 


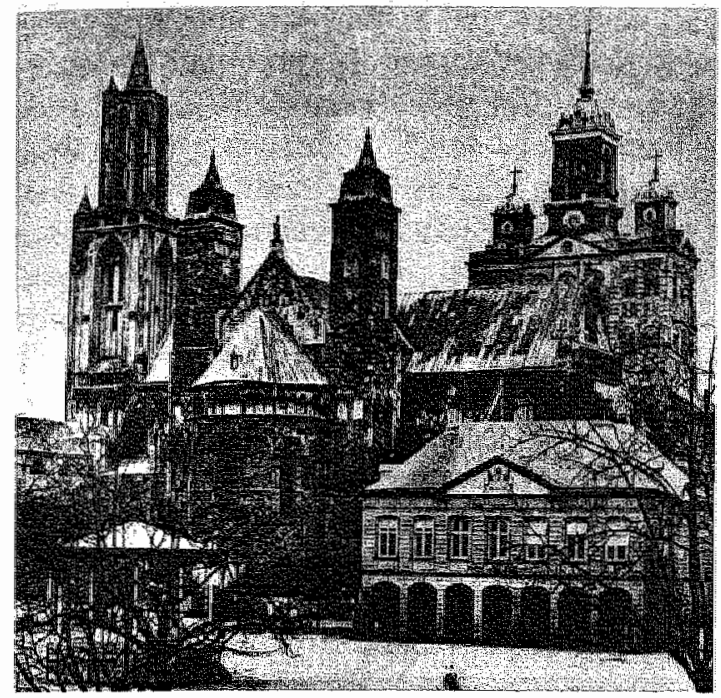

12. De Sint-Servaaskerk en de Sint-Janskerk, Maastricht. Let op de wijzerplaat boven de absis van de Sint-Servaaskerk

was een der eerste torens in deze streken die er een bezat (G.M. Poell, p. 83)". ${ }^{96}$ De passage van Poell, waarnaar Flament verwijst, luidt: "Deze kerk (uit de context blijkt, dat de Sint-Jan is bedoeld, R.M.) had vroeger eenen zeer hoogen toren, welke in 1373 door storm nederstortte. $\mathrm{Zij}$ pronkte toen reeds met een uurwerk, en was eene der eerste kerken van de Nederlanden, die zulks bezat... Lang, heeft men gewacht, om den nedergestorten toren door eenen anderen te vervangen. Zeker kronijkschrijver zegt, dat hij in het jaar 1450 is voltooid". ${ }^{97}$ Poell noemt geen bron voor zijn bewering, maar hij heeft waarschijnlijk een artikel van Van Heylerhoff uit 1829 benut. ${ }^{98}$ De volgende die gewag maakte van een uurwerk op deze toren was Habets. In een artikel over (luid-)klokken en klokinschriften uit 1868 wilde hij aannemelijk maken, dat er in 1180 reeds meerdere luidklokken in de Sint-Servaas hingen. Hij refereert daarbij in een yoetnoot aan de Opera diplomatica van Aubertus Miraeus, die spreekt van "cum signorum pulsatione" (onder gebeier

\footnotetext{
A. Flament 1915, p. 36.

${ }^{97}$ G. Poell 1851, p. 83.

${ }^{9}$ M. van Heylerhoff 1829 , pp. 122-123. Van Heylerhoff noemt geen bron voor zijn bewering.
} 
van klokken). In dezelfde voetnoot, pal achter de genoemde referentie, beweert hij: "Den 8 Junij 1373 werd de toren van St-Jan te Maastricht door eenen zwaren storm omwergestort. In dit gebouw hing eene klok die de uren sloeg. In de 14de eeuw bestonden uurwerken te Bologna, Straatsburg, Kortrijk en Spiers. In 1461 was de dorpsklok van Beek, bij Meerssen, reeds met een uurwerk voorzien". ${ }^{99}$ Omdat de bewering over de Sint-Janstoren pal achter de referentie naar Miraeus staat, lijkt het of dit feit bij Miraeus wordt vermeld. Daar staat echter alleen de reeds vermelde passage uit 1180 ! Habets noemde dus ook geen bron voor de instorting van de toren met uurwerk.

Het is zeer de vraag of al deze auteurs meer deden dan elkaars frasen overschrijven. In 1870 gaf Habets een 15de-eeuwse kroniek uit, die melding maakte van het feit, dat de Sint-Janskerk in 1390 afbrandde, behalve de toren. ${ }^{100}$ De kroniekschrijver, waarschijnlijk Peter Trecpoel, zegt het zo: "1390... brande synte Johans kyrcke te Trycht kael aff, sonder der thorn der bleyff staen". Bij de gebeurtenissen van 1393 schrijft dezelfde: "Item op hetselven jaer, des IX dachs in junio omtrent der middernacht vyel synt Johans thorn te Trycht, by synte Servaeskerk. Inde balde daernae soe waert erstwerf aengehoeffen inde begonnen der andere nuwe thorn die nu noch all daer steyt. Mer daer gynghe lange tyt toe er dat hee volmaekt waes". ${ }^{101}$ Twee dingen vallen hierbij op: 1 . er is géén sprake van een uurwerk; 2 . de instorting wordt gedateerd in 1393 na voorafgaande brand van de kerk in 1390 . Het omverwaaien van de toren, nadat hij vrij was komen te staan na de brand, is waarschijnlijker dan dat hij zomaar omwaaide. De datering 1393 voor deze catastrofe lijkt beter te passen dan 1373. Habets wijst overigens bij zijn uitgave van. Trecpoels kroniek op de verschillen in datering. ${ }^{102}$

We moeten concluderen dat contemporaine of vroege bronnen niet spreken over een uurwerk. Dit is geen bewijs dat er ook geen uurwerk was. Het is echter onwaarschijnlijk dat er ooit een in de Sint-Janstoren is geweest. De kapittelheren hadden liever een

\footnotetext{
J. Habets 1868 , p. 315 , voetnoot 2 .

100 J. Habets 1870 , pp. 5-231, met name p. 14.

101 J. Habets 1870 , p. 14.

${ }^{102}$ Habets wees ook een andere auteur in 1887 op de verkeerde datum 1373. Zie F. Hoefer 1887, p. 25, noot 7 .
} 
prestigieus voorwerp, wat een uurwerk lang is geweest, aan hun eigen kerk dan aan de parochiekerk. Een parallel geval deed zich voor bij het O.-L.-Vrouwekapittel: daar was het uurwerk aangebracht aan beide zijden van de westbouw wan de O.-L.-V rouwekerk en niet aan de ernaast gelegen toren van de Sint-Nicolaaskerk, hoewel deze hoger was en aan vier zijden een wijzerplaat kon hebben. De betere zichtbaarheid voor de stedelingen van wijzerplaten aan de Sint-Janstoren was kennelijk ook van geen belang voor de kapittelheren van Sint-Servaas. In 1544 vergrootte men liever de middentoren van de westbouw voor de plaatsing van een nieuw torenuurwerk met carillon, dan dat men de mogelijkheden van de Sint-Janstoren benutte.

Omdat de wijzerplaten aan de torens van het westwerk vanaf de stadszijde slecht af te lezen waren, heeft men later toch een uurwerk aan de Vrijthofkant geplaatst boven de absis van Sint-Servaas. Weer werd de Sint-Janstoren buiten beschouwing gelaten. Toen in de loop van de 17 de eeuw de Sint-Jan in protestantse handen kwam, kon men van de kapittelheren niets meer verwachten. De relatief kleine hervormde gemeente kon zich geen torenuurwerk veroorloven, zij had al genoeg moeite het gebouw te onderhouden. ${ }^{103}$ Het is al met al aannemelijk, dat de Sint-Janstoren nooit een uurwerk heeft gehad.

\subsubsection{Het uurwerk van het Kruisherenklooster}

Op het koor van het Kruisherenklooster, dat in 1459 werd voltooid, was een dakruiter geplaatst. Hierin bevonden zich al in het derde kwart van de 15de eeuw klokken en een uurwerk met slagwerk, geleverd door een zekere Antonius van Vise. ${ }^{104}$ Over hem noch over het uurwerk is verder iets bekend. In juli 1480 vernielde een hevige storm de dakruiter. Of bij de vernieuwing ervan weer een uurwerk is geplaatst, is niet duidelijk.

\footnotetext{
${ }^{103}$ W. Bax (et al. 1932, passim.

lot W. Keyser-Schumman 1984 , p. 19.
} 


\subsubsection{Het uurwerk van het Minderbroedersklooster}

Volgens een tekening van Philippus wan Gulpen was er in de Minderbroederskerk, de voormalige rechtbank aan de Minderbroedersberg, een uurwerk aangebracht bovenin het hoofdaltaar. ${ }^{105}$ Over de maker en het uurwerk is verder niets bekend. De afbeelding wijst op een 18 de-eeuws product. In aanmerking nemend dat de Minderbroeders na het befaamde verraad van 1634 uit hun klooster aan de Sint-Pieterstraat waren verdreven en zich pas rond 1700 aan de Minderbroedersberg vestigden, zou zo'n datering juist kunnen zijn. Het interieur van de kerk is inclusief het uurwerk verloren gegaan in de Franse tijd omstreeks 1795 of bij de verbouwing tot paleis van justitie en marechausseekazerne in 1825 .

\subsection{De overige openbare uurwerken}

Behalve stadsuurwerken en uurwerken in kerkelijk bezit waren er in Maastricht en directe omgeving nog enige uurwerken in bezit van corporaties of particulieren.

\subsubsection{Het uurwerk van de Looierspoort}

De Looierspoort, een van de hoofdpoorten uit de eerste stadsomwalling van circa 1250 , heeft een uurwerk gehad. Het hoorde toe aan het looiersambacht, dat zijn "leube" (verenigingslokaal) sinds 1502 had gevestigd in de Looierspoort. ${ }^{106}$ In het begin van de 18 de eeuw werd het uurwerk misschien van stadswege onderhouden. Mogelijk bleef het echter bij een plan. Immers in het Raadsverdrag van 20 januari 1738 betreffende de aanstelling tot stadsuurwerkmakers van Willem Mijnis Jr. en Perrier wordt aangetekend, dat Mijnis de uurwerken van het oude en nieuwe stadhuis krijgt te onderhouden en Perrier de uurwerken van de Maasbrug, de SintMartinuskerk en de "oude Leurenpoort". Dit laatste is echter bij de tweede vermelding doorgehaald en vervangen door "oude stadtshuijs". Hoe het ook zij, het uurwerk bleef intact. De poort

105 G.A.M., Tekeningen, plattegronden, etc., inv.nu. 505.

Lof L. Morreau 1979, p. 7, 11, 16, 22, 26, A. Flament 1915, p. 135; W. Bachiene 1779, p. 854. 
werd in 1772 gesloopt en het uurwerk werd in het front van het Rooms-Katholieke Armenhuis, thans Gemeentearchief, geplaatst. In de handgeschreven "Oorspronck en voortsganck vant Rooms Catholique Armenhuis etc." staat de schenking aldus beschreven: "Toen, in 1772, men de oude Poort der Looyers afbrak, verkregen de bestuurders van het armenhuis vanwege de opperhoofden van het ambacht der looyers het uurwerk, dat zich boven die poort bevond en plaatsten het aan de voorgevel van het gebouw" ${ }^{107}$. Inmiddels is het uurwerk evenwel verloren geraakt.

\subsubsection{Het uurwerk van kasteel Geusselt}

De toren van kasteel Geusselt (zie afbeelding 13) bevat een 18deeeuws torenuurwerk, dat in 1996 evenals het kasteel is gerestaureerd. Een foto van omstreeks 1930 laat een eenvoudige ronde wijzerplaat met één wijzer zien net onder de kroonlijst van de fronttoren. Thans is een rechthoekige, fel rode wijzerplaat aangebracht. Op de eerste verdieping is een ovaal raam in een gebeeldhouwde omlijsting met vruchtenornamenten en halve naaktfiguurtjes. Aan de bovenzijde daarvan heeft een vlak gehouwen steen waarschijnlijk dienstgedaan als zonnewijzer. Aan de onderzijde ziet men een cartouche met het devies "Recte et Fortiter" en het jaartal "ANNO 1657". ${ }^{108}$ Het uurwerk, dat achter de rechthoekige wijzerplaat boven het beschreven ovale venster staat, was vóór de recente restauratie sterk vervuild en verroest, maar nog vrijwel compleet. Alleen de slingerlens, de wijzer en de wijzerplaat ontbraken. Er is geen signatuur te ontdekken. Het is geheel van ijzer, behalve het ankerrad. Het raamwerk van bandijzer is $68 \mathrm{~cm}$ breed, $67 \mathrm{~cm}$ hoog en $40 \mathrm{~cm}$ diep. Het gaand werk heeft een terugwerkende ankergang met messing ankerrad. Het slagwerk heeft een grote sluitschijf met binnenvertanding en dubbele nokken voor de uur-en halfuurslag voluit. Ook de verstelinrichting van het slagwerk wijst erop dat op het halve en hele uur het volle aantal slagen werd gegeven op twee verschillende klokjes. De twee gewichten zijn van steen. Het uurwerk is te dateren omstreeks het tweede kwart van de 18de eeuw (zie afbeelding 14).

\footnotetext{
${ }^{109}$ G.A.M., Archief van het R.-K. Armenhuis, inv.nr. 1.

NMGK, deel V, derde stuk, W. Marres en J. van A.gt 1962, pp. 731-732.
} 


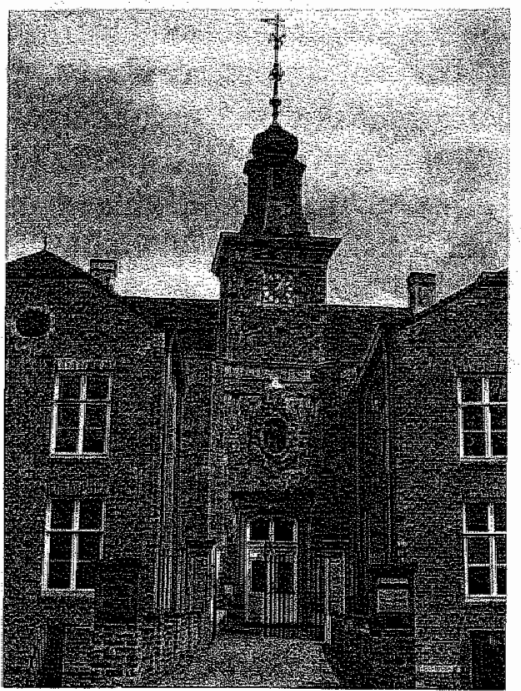

13. Kasteel Geusselt, Maastricht (toren 17de eeuw)

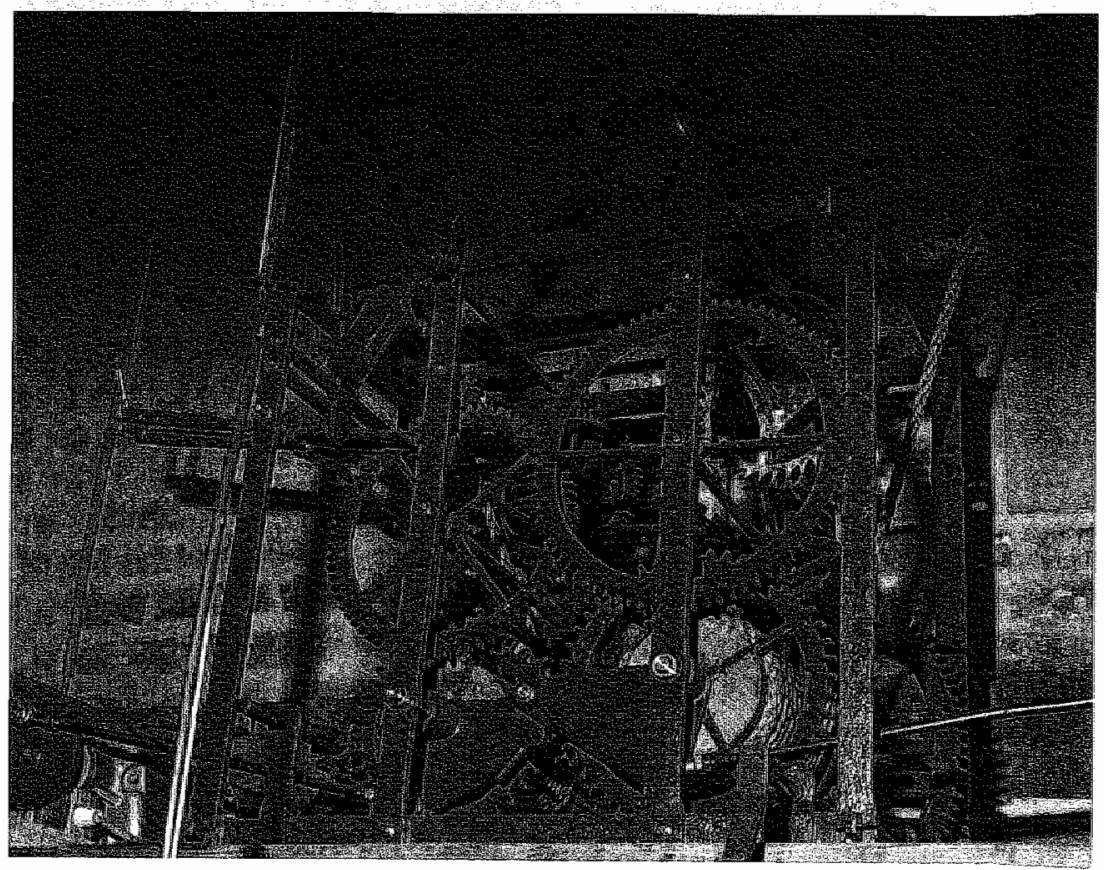

14. Torenuurwerk van kasteel Geusselt (18de eeuw, ongesigneerd) 
2.3.3. Het uurwerk van kasteel Vaeshartelt (zie afbeelding 15)

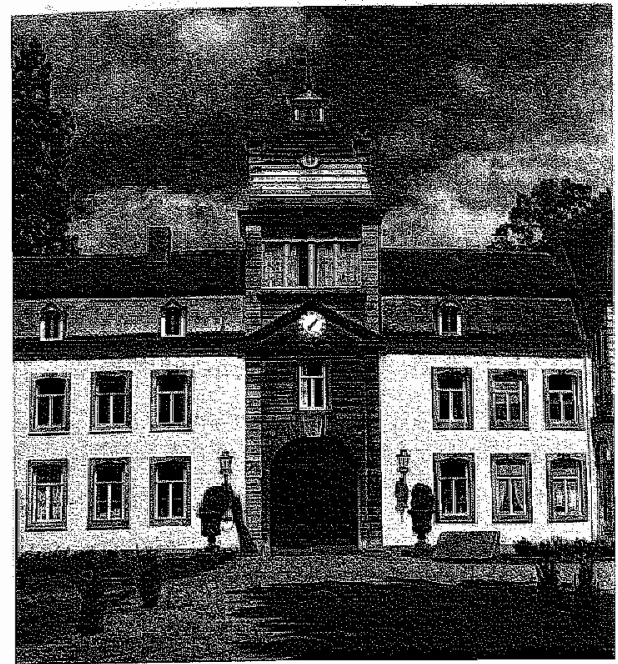

15. Kasteel Vaeshartell, Maastricht (18de, 19de eeuw)

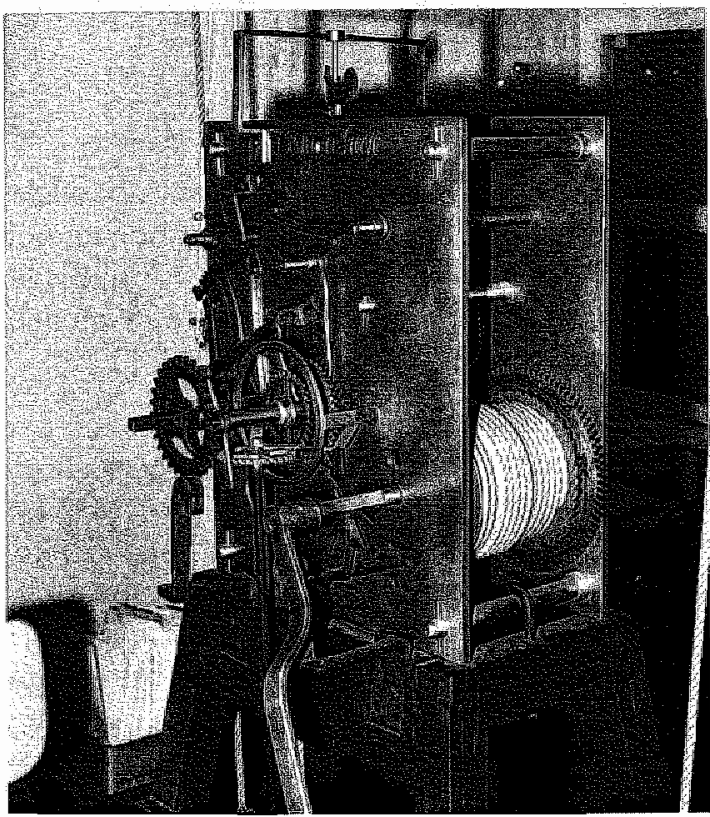

16. Torentnurwerk van kasteel Vaeshartelt (door L. Bay, Luik, circa 1800) 
Boven de hoofdingang in de toren van kasteel Vaeshartelt bevindt zich een torenuurwerk van omstreeks 1800 , gesigneerd "L. Bay" à Liège ${ }^{n}{ }^{109}$ Het is, net als het kasteel, recent gerestaureerd (1995) en teruggeplaatst op zijn oorspronkelijke plek. Het uurwerk heeft nessing platines van $\pm 45 \mathrm{~cm} \times 60 \mathrm{~cm} \times 1 \mathrm{~cm}$. Het heeft een dubbelzijdige schaargang; de benen van de "schaar" zijn verstelbaar via een fijnregulering. De slinger heeft mes-ophanging. Het zaagslagwerk slaat op twee klokjes, die in de dakruiter boven de toren hangen. Er is een halfuurslag met het aantal slagen van het komende uur op de kleinste klok; het volle uur wordt geslagen op de grootste klok. Ook is er een verschuivingsmechaniek in het slagwerk. De windvleugel heeft de vorm van twee vogeltjes. De metalen wijzerplaat was zwart geschilderd met witte Romeinse cijfers, thans is de wijzerplaat wit met zwarte cijfers. Er is van oudsher maar één wijzer. Blijkens de inscripties "G. Frencken. Echt. 1889" bovenop de rand van de slingerophanging en "G. Frencken. Echt" onderop dezelfde ophanging werd het uurwerk door Vrencken in $1889 \mathrm{ge}$ restaureerd en gemodificeerd: hij verplaatste de grondraderen en maakte een nieuwe binnenwijzerplaat ${ }^{110}$ (zie afbeelding 16).

\subsection{De stadsuurwerkmakers van Maastricht}

Hierboven werd herhaaldelijk melding gemaakt van de stadsuurwerkmakers, stadsklokkenmakers, stadshorlogers of hoe ze ook. werden genoemd. Onder hen waren vogels van diverse pluimage. Naast professionele klokkenmakers vindt men er goudsmeden, (slot)smeden en zelfs een stadsbeambte onder (zie tabel 1).

${ }^{109}$ Bay wordt zonder initialen of verdere bijzonderheden verneld door F. Pholien 1933, p. 121; A. Thiry s.a., p. 6: "BAY, Laurent, ouvrier horloger, rue Porte St.-Léonard 654, Liè ge, décédé le $19 / 5 / 1806$ à 22 ans".

${ }^{100} \mathrm{Bij}$ de recente restauratie werden deze ingeslagen signaturen zichtbaar. Voor Frencken zie appendix II. 


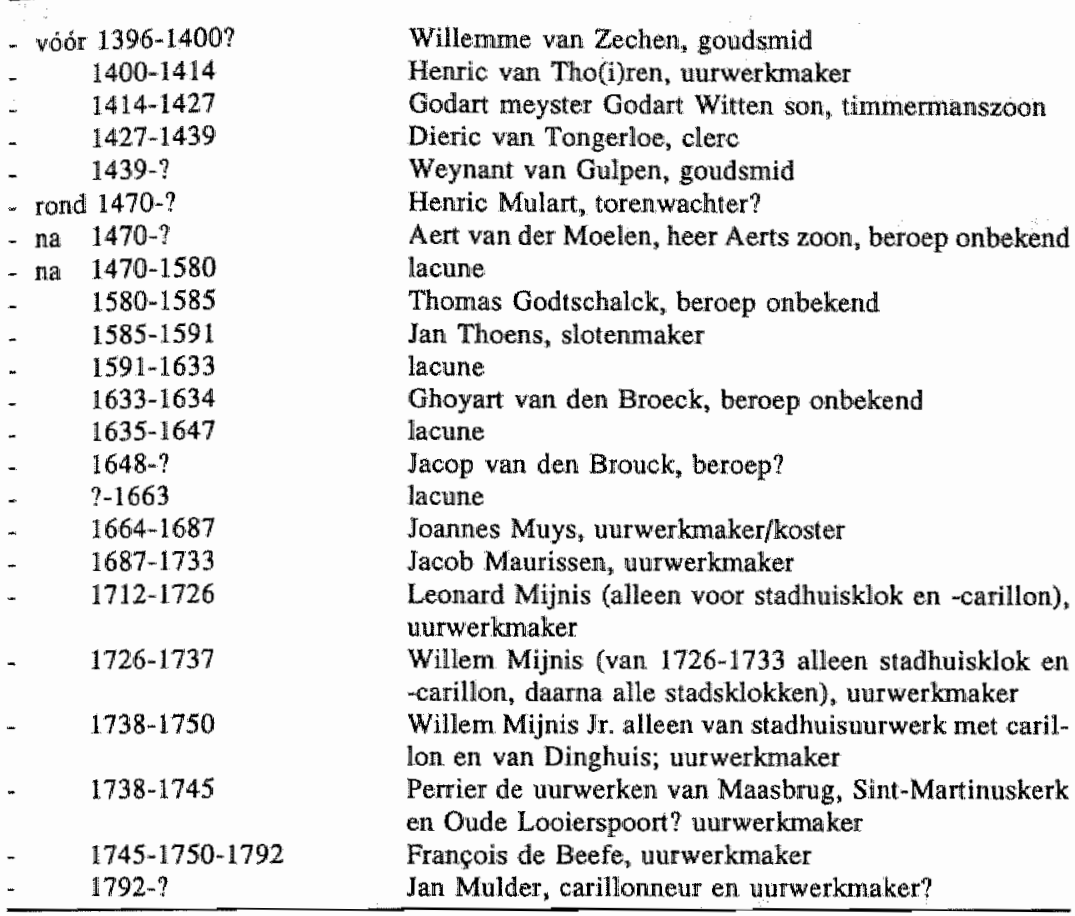

De hiaten in deze lijst omvatten de laatste decennia van de 15 de eeuw tot 1580 en daarna de perioden 1591-1633 en 1634-1664. Bijna twee eeuwen lang is er slechts incidentele informatie. Tussen de twee grote perioden, 1396-1470 en 1664-1792, waarover we redelijk zijn ingelicht, bestaat een opmerkelijk verschil. In de $14 \mathrm{de}$ en 15 de eeuw werden allerlei personen ingeschakeld. Slechts zelden ging het om een vakman. Dit was eigenlijk alleen het geval met Van Zechen en Van Thoren. Zij werden beiden in staat geacht een goed uurwerk te vervaardigen en te onderhouden. Van Van Thoren staat inmiddels vast dat hij inderdaad competent was. Ruim bezoldigd werden de uurwerkmakers voor het onderhoudswerk niet. Hun beroepsrisico was aanzienlijk, zoals bleek uit de affaire Van Zechen die het karwei op eigen kosten mocht overdoen. Onder die omstandigheden was het niet verwonderlijk dat men geleidelijk naar het 
amateuristische niveau afzakte met als gevolg - we zagen het al op de lange duur een reeks kostbare reparaties.

In de $18 \mathrm{de}$ eeuw werd een ander beleid gevoerd. Nu werden gespecialiseerde uurwerkmakers ingeschakeld, in de tweede helft van de $18 \mathrm{de}$ eeuw zelfs een met internationale reputatie, François de Beefe. Het valt te betwijfelen of men daardoor goedkoper uitkwam. Voor een klus die hem waarschijnlijk niet veel meer dan twee dagdelen per week kostte, ontving De Beefe een bedrag waarvoor men destijds drie à vier boerenknechten het hele jaar door aan het werk kon houden of om het anders uit te drukken: De Beefe verdiende niet veel minder dan het bedrag waarvoor men in de late $18 \mathrm{de}$ eeuw een compleet bejaardenhuis kon exploiteren! ${ }^{\text {111 }}$

Geen wonder dat de vertegenwoordigers van de Staten-Generaal en de prinsbisschop van Luik, die onder de naam CommisarissenDeciseurs het hoogste stedelijk bestuurslichaam vormden, er al vlug hun bekomst van hadden. Hun pogingen de kosten te reduceren hadden pas na lange tijd succes. De verlaging van alle salarissen van stedelijke ambtsdragers in 1760 ging pas in als er een functie vacant kwam. De Beefe zou nog meer dan drie decennia in functie blijven. De hoge overheid werd er nerveus van. Op 10 september 1778 namen de Commissarissen-Deciseurs het besluit het ambt van stadshorlogemaker af te schaffen. Het besluit luidde: "En naardien ons verder is voorgekomen dat het onderhoud van de vier stadshorologien voor een vrij minder jaarlijx somme zoude kunnen aanbesteed worden als voor de somme van $f 600$ zijnde de gagie van de toekomende stadshorologiemaker, hebbende eensgelijx goedgevonden de voorsz. bedieninge te mortificeeren, met authorisatie op de magistraat om nae dood van den actueele stadshorologiemaker omtrent de nodige vernieuwinge en het onderhoud der horologien tot stads laste staande, zodanige schikkingen te maken als met het grootste nut en voordeel van stadsfinantie zal overeenkomstig bevonden worden". ${ }^{112}$

\footnotetext{
11" J. Jansen 1993c, pp. 54-63. Daarbij moet wel worden opgemerkt, dat De Beefe uit zijn salaris de "opwinder" moest betalen en de "noten" voor het carillon moest leveren. Verder kwamen te zijnen laste alle reparaties, olie en licht.

112 G.A.M., Oud-archief, inv.nr. 218, "Register der recessen, resolutien en ordonantien van de Ed. Mog. H.H. Commissarissen Deciseurs van beyde genadige Heeren en Princen deser stadt Maestricht begonnen MDCCLX", deel II, nr. 7.
} 
$\mathrm{Na}$ de dood van De Beefe in 1792 werd het ambt openbaar verpacht. Opnieuw werd in 1794 nauwkeurig gestipuleerd wat de taken waren van de stadshorloger: "Den aanneemer sal op syne costen onderhouden en wanneer noodig vernieuwen de trommel, de staale nooten, de raaders, de coorden, sal sorgen voor het optrekken der horlogien, het stellen van de nieuwe airties op de carillion van het nieuwe stadhuys en voorts leeveren den olie, ligt en alles wat tot het behoorlijk onderhoud der klokken en carillion sal worden gerequireerd. Den aanneemer sal stellen behoorlijke cautie en in cas in gebreeke bleeve aan deese conditien exactelijk te voldoen sal hij vervallen van sijne aanneeming en het gebreckige van sijne kosten worden in staat gestelt ${ }^{\prime \prime} .{ }^{113}$ De boetebepalingen waren niet mals. Zij vormen zonder twijfel het meest opmerkelijke deel van deze instructie. Vakkennis bleef vereist.

In de loop van de 19de eeuw is het ambt van stadshorloger uitgestorven. Dit kwam niet alleen door de bezuinigingen van overheidswege, maar vond ook zijn oorzaak in de verbeteringen aan de torenuurwerken van metallurgische en smeertechnische aard. Hierdoor kwamen nog maar betrekkelijk weinig grote storingen voor, die men per keer kon laten repareren. Het normale onderhoud beperkte zich tot het opwinden en incidenteel het gelijkzetten. Laat in de 19 de en begin 20 ste eeuw vervielen ook deze activiteiten als gevolg van elektrische voorzieningen.

Tabel. 2. De bezoldiging van de Maastrichtse stadsurwerkmakers

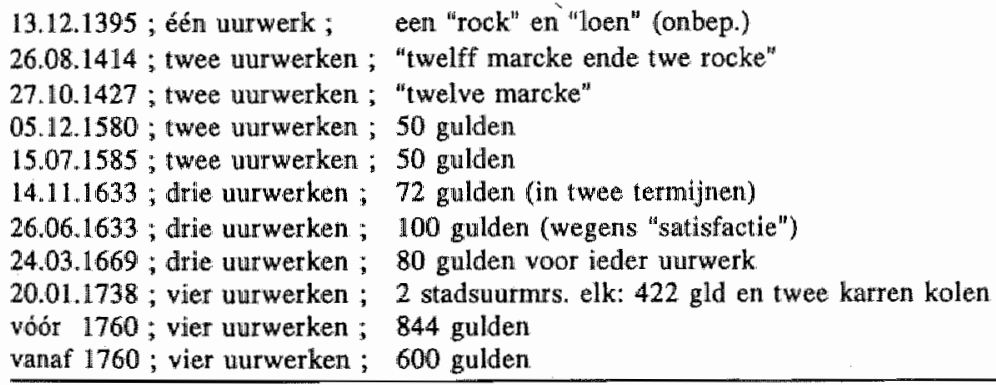

${ }^{113}$ G.A.M., Oud-archief, inv.nr. 319. Het is een fragment. 
Het gedetailleerde onderzoek naar de openbare uurwerken in Maastricht leert ons het een en ander dat voor de beantwoording van onze vraagstelling, zoals verwoord in de inleiding, van belang is. De beide landsheren, de prinsbisschop van Luik en de hertog van Brabant, later opgevolgd door de Staten-Generaal van de Republiek der Verenigde Nederlanden, hebben zich nooit met de tijdmeting bemoeid. Het stadsbestuur was de voornaamste initiatiefnemer. Het was buitengewoon vroeg, al in 1367, tot de aanschaf van een uurwerk, geplaatst in de buurt van een graanklokje, overgegaan en kreeg daarbij steun van een van de andere toezichthouders op handel en verkeer, het kapittel van Sint-Servaas. De geestelijkheid volgde met de aanschaf van torenuurwerken in het algemeen pas na lange tijd. Toen er stadsuurwerken ten getale van vier in de stad aanwezig waren, was het noodzakelijk een standaard te stellen. Voor het overige vertrouwden de geestelijken op hun luidklokken. Die riepen op tot deelname aan religieuze oefeningen, waarschuwden bij brand en dreigende calamiteiten, kondigden huwelijken en begrafenissen aan en gaven als de ochtend overging in de middag een signaal voor gebed en het neerleggen van de arbeid om het middagmaal te genieten.

De geschiedenis van de tijdmeting in Maastricht laat ook zien dat grote waarde werd gehecht aan een zo nauwkeurig mogelijke tijdmeting. Zowel bij de aankoop, als voor het onderhoud werden nog tot diep in de 17 de eeuw grote kosten gemaakt. Om de aandacht van de bevolking op het uurwerk te richten werden wijzerplaten aangebracht, kort nadat die voor het eerst rond 1450 werden toegepast. Het laat zich aanzien dat de scheiding tussen tijdsignalen van de overheid en die van de geestelijkheid fundamenteel was en lang in stand bleef, al werd soms, zoals in Maastricht, een pragmatische oplossing gevonden voor de vraag, wie de standaardtijd in de stad leverde. Gewoonlijk was de stad daarvoor verantwoordelijk, maar in de periode van 1580-1640, toen de stadsfinanciën in deplorabele toestand waren na de inname van de stad door Parma, nam het Servaaskapittel, dat sinds 1544 een nieuw uurwerk had, deze taak over. In 1686 nam de stad haar taak weer op met een nieuw uurwerk met speeltrommel en carillon. 


\section{Hoofdstuk III}

\section{De openbare tijdmeting in de Nederlands- Limburgse steden Venlo, Weert, Sittard en Roermond}

Een hele reeks plaatsen in Limburg beroemt er zich op in de Middeleeuwen stadsrechten te hebben gekregen of in de Nieuwe Tijd ooit door een overheid officieel als stad te zijn aangemerkt. Hier worden als criteria om stad genoemd te worden aangehouden dat de agglomeratie in 1796 enige duizenden inwoners telde en met enig recht mocht worden aangemerkt als een regionaal verzorgingscentrum met dicht opeengepakte bebouwing. Venlo, Roermond en Sittard voldoen met glans aan deze criteria. Het zeer uitgestrekte Weert met een krans van gehuchten rondom het verzorgingscentrum heeft het voordeel van de twijfel gekregen. De resultaten van het onderzoek naar de openbare tijdmeting in de genoemde steden worden in dit hoofdstuk gepresenteerd in chronologische volgorde van de eerste vermelding van een openbaar uurwerk.

De plaatsen die niet aan onze stadscriteria voldoen, worden behandeld in hoofdstuk V.

\subsection{Venlo}

Venlo kreeg pas in 1343 stadsrechten van hertog Reinoud II van Gelre, hoewel de Venlonaren zich al sinds 1272 oppidani (stedelingen) noemden. Door zijn gunstige ligging aan de Maas, op een plaats waar grotere schepen hun vracht voor havens stroomopwaarts moesten verbodemenen in kleinere schepen met minder diepgang en door zijn recht van opslag (schepen mochten op de rechter Maasoever tussen Venlo en Mook alleen in Venlo worden gelost) ontwikkelde Venlo zich voorspoedig tot een belangrijk handelscentrum. Er is dan ook al vroeg sprake van stadsuurwerken, namelijk in 1389. Over de geschiedenis van de Venlose stadsuurwerken zijn we goed geinformeerd omdat Venlo zijn stadsrekeningen bijna zonder lacunes vanaf 1380 heeft bewaard. Over uurwerken van kerken en kloosters kon niets worden achterhaald, behalve summie- 
re gegevens uit de 18 de eeuw betreffende de Sint-Martinuskerk en de H. Geestkerk.

\subsubsection{Het stadhuisuurwerk en de stadsuurwerkmakers}

Het oudst bekende stadhuis van Venlo was het zogeheten "Stenen Huis" aan de Lomstraat. De stad kocht het van ridder Gerhardt van Bocholdt en zijn vrouw Aleidt. Het diende zowel tot raadhuis en gerechtsgebouw als tot vleeshal. Het had dus een marktfunctie en lag ook aan de Markt. De magistraat voelde zich in de jaren tachtig van de 14 de eeuw al genoopt het van een uurwerk te voorzien. $O p$ 2 maart 1384 besloot de stad een uurwerk aan te schaffen, maar pas op 16 mei 1389 kwam een overeenkomst tot stand met de Maastrichtenaar Hendrick van Thoren. Eind mei van datzelfde jaar werd door Van Thoren een tijdelijk uurwerk geleverd. Het "oerlament", zoals het uurwerk in de 14de-eeuwse stukken heet, werd aangebracht op de nok van het stadhuis, waar voor de klok een speciaal torentje was gebouwd. Jan Goutsmeijt kreeg van meester Hendrick instructies, hoe het uurwerk moest worden onderhouden; hij werd de eerste stadsuurwerkmaker van Venlo. Van Thoren kreeg voor zijn werk zestien oude schilden betaald. ${ }^{1}$

Op 25 augustus 1389 bestelde het stadsbestuur van Venlo bij Van Thoren een nieuw "groet oerlament", dat op Goede Vrijdag van het daaropvolgende jaar werd afgeleverd. Meteen werd de "toyre van der oijrclocken" hoger opgetrokken. Ernaast werden twee kleine torentjes aangebracht. ${ }^{2}$ We kunnen slechts gissen naar de reden van de bestelling in twee fasen zo kort na elkaar. Misschien was het eerste te licht van constructie gebleken of was het een tweedehands uurwerk geweest, dat Van Thoren, in afwachting van de grote opdracht, had geleverd als service of proeve van bekwaamheid. Ongewoon was zoiets niet. Een geval van levering snel achter

\footnotetext{
${ }^{1}$ Hanssen 1919, inv.ni. 1194. Zỉe ook: M. Jansen 1880, pp. 253-254, 257-258, 261-262. H. Uyttenbroeck 1914 , p. 101 , schrijft, dat het eerste "oerlament" of uurwerk dagtekende van 1384 en dat in 1389 een groter werd gekocht. De stadstekeningen maken duidelijk dat Uyttenbroeck een verkeerde voorstelling van zaken geeft. Van Beurden nam zijn bewering echter over en voerde ook nog ene Jan van Thoren op. A. van Beurden 1923, p. 356.

${ }^{2}$ Hanssen 1919, inw.nr. 1194. F.J. Hermans 1985, p. 47, meent ten onrechte, dat met "oerlament" een ormament is bedoeld.
} 
elkaar van twee uurwerken heeft zich ook voorgedaan in Tongeren, waar M. Deeckens ze in de O.-L.-Vrouwetoren aanbracht.

Een andere verklaring zou kunnen zijn, dat men het eerste uurwerk ging gebruiken als torenwachtersururwerk, misschien in de stadstoren pal vóór de Sint-Martinuskerk, die als wachttoren werd benut en die in 1766 werd afgebroken. De dagbladen makten in 1939 melding van een "oud ijzeren stuk met veel raderwerk" dat in de toren van de Sint-Martinuskerk was aangetroffen. Volgens deskundigen was het een uurwerk uit de 14de eeuw. "Het moet een der eerste uurwerken met raderwerk zijn, die geluid gaven met een gewone bel, die heen en weer geslagen werd. Het uurwerk is bevestigd op een houten voet", zo heette het. ${ }^{3}$ Het werd waarschijnlijk niet gerestaureerd. Onderzoek in het parochie- en stadsarchief heeft geen foto van het uurwerk of gegevens over een restauratie opgeleverd. Mogelijk leek de werking van het uurwerk op die van een wandklok in het Mainfränkisches Museum te Würzburg, die wellicht van vóór 1350 dateert. Die heeft ook een heen en weer geslagen bel en een tandrad met twaalf gaten voor de wekkeruitlichting, zoals die in de berichtjes over de Venlose klok vermeld. ${ }^{4}$ Het Venlose uurwerk was echter geen wandklok, maar stond op een houten bok. Deken J.L.A. van Oppen liet het achter in de kerk opstellen bovenop het tochtportaal van de rechterzijbeuk. Waarschijnlijk is het niet verloren gegaan bij de verwoesting van de kerk op 11 november 1944. Zegslieden beweren, dat ze het uurwerk nog in 1945 in de kerk hebben gezien, maar dat het daarna spoorloos is verdwenen. $^{5}$

${ }^{3}$ C. Spierdijk 1962 , p. 54 . De primeur van de vondst had waarschijinlijk het parochieblaadje "Het klokje van Sint Martinus", 43(1939) nr. 40, d.d. 15 oktober. Dit berichtte over de vondst onder het kopje: "Uit den ouden tijd! Merkwaardige ontdekking!". Hetzelfde blaadje noemt het torenwachtersuurwerk nog eens in nr. 35 van 15 september 1940 in het stukje, getiteld: "De St. Martinustoren". De "Nieuwe Venloosche Courant" meldde de vondist op 16 oktober 1939, krant mr. 243, waarbij het berichtje uit het parochieblad wrijwell werd overgeschreven. ${ }^{4} Z$ Zie voor afbeelding: E von Bassermann-Jordan en $\mathrm{H}$. von Bertele 1978 , afbeelding 23. J Boernans liet in 1939 na de ontdekking van het torenwachtersurwerk een afbeelding van dit vurwerk nit de "Deutscher Uhmacherkalender", 1939, p. 133, zien om te bewijzen dat het gevonden tuig een zeer wroeg uurwerk was.

"Uurwerk Venlose torenwachter", artikel in: Dagblad voor Noord-Limburg, 25 april 1968, kolom 6 en 7. Volgens B. Boermans, juwelier te Venlo, heeft zijn oudere broer Jacques het uurwerk nog na de aorlog gezien op het tochtportaal. Tijdens het puizruimen in de kerk is het werdwenen. J. Boermans heeft er op verschillende stortplaatsen nog naar gezocht (nededeling B. Boermans, december 1995). 
Aan het onderhoud van het stadsuurwerk werd in Venlo veel aandacht besteed. De tweede stadsuurwerkmaker die we bij naam kennen is Peter Bartscherre. Hij wordt in de stadsrekeningen genoemd van 1449 tot en met 1456. Peter was waarschijnlijk een barbier die dichtbij de plaats woonde, waar het stadsuurwerk stond opgesteld; hij was geen klokkenmaker van professie. ${ }^{6}$

De laatste betaling aan Peter vond plaats op "Sonnendaighs na Sent Joerisdach" 1456,25 april. Terzelfdertijd zijn er vermeldingen van een zekere broder Jan ingher (soms uitgher) Gaesdonck, een dorp bij Goch, enkele tientallen killometers ten noorden van Venlo. De eerste keer wordt Jan genoemd in 1454, "des anderen daigs na Sent Mertensdach", 12 november. In 1455 voerde hij onderhoudswerkzaamheden en/of reparaties uit aan het uurwerk te Venlo. Later in dat jaar werd het oerlament per schip naar hem toegebracht. ${ }^{7}$ Wat er precies gebeurde is maar ten dele duidelijk, namelijk voorzover toeleveranciers werden ingeschakeld. Uit posten in de stadsrekening blijkt, dat er een nieuw touw in het stadsuurwerk kwam ("tot desen vurscreven oirwerck 1 lijne"); de schotteldreyer (=draaier van tinnen of houten schotels) draaide enkele onderdelen voor het uurwerk: "Item gegeven den schotteldreyer van eynen werck he totter oirclocken gemaict had, $4 \mathrm{kl}$." . Dezelfde ambachtsman wordt ook in 1456 vermeld: "Item gehat van den schoteldreyer tot desen oirwerck 12 pleyen dair die lijnen ynne gaen, elc pleije $2 \mathrm{kl}$. valet $24 \mathrm{kl} . " .8$

In 1455 heeft men Goirt den Meelre opdracht gegeven het uurwerk te schilderen. ${ }^{9}$ Blijkens de vermelding van allerlei bouwmateriaal, dat verwerkt werd "aen den heren huiss ende boven opter heren huyss dair dat oirwerck ynne steit", heeft hij ook groot onderhoud. aan het dak en de klokkentoren gepleegd. "Broder" Jan heeft het

G.A.V., Archief van het stadsbestuur, inwnrs. 68-75; G.A.V., Oud-archief, stadsrekeningen $1449-1456$.

${ }^{7}$ G.A.V., Oud-archief, stadsrekeningen 1449-1458, inw.nr. 74, stadsrekening 1455: "Item doe broder Jan vurscreven die uyrclock opten huse richtet ende sat, oem betailt 8 rijnsche gld. 1.5 $\mathrm{kl}$." Verderop in dezelfde rekening: "Item gegeven den dregeren van deser hoppen endle broit ende van den oirwerck int schiep te dtagen $7 \mathrm{kl}$.".

${ }^{8}$ G.A.V., Oud-archief, stadsrekeningen $1449-1458$, inv.nrs. 74 en 75 , stadsrekeningen 1455 en 1456.

${ }^{9}$ G.A.V., Oud-archief, stadsrekeningen 1449-1458, inv.nr. 74, stadsrekening 1455: "Item Gioirt den meelre gegeven van den oirwerck te maelen, 4 rijnsche gld.". 
uurwerk, na reparatie en de voltooiing van de werken aan het stadhuis, per kar uit Gaesdonk terug laten brengen. Hij verbleef geruime tijd te Venlo om het uurwerk te plaatsen, minstens zeven weken. Zijn verteringen liepen flink op: "Item broder Jan vurscreven opten huse vertert so voir so nae 2 rijnsche gld, $29 \mathrm{kl}$. 5 gr. 2 d." en "Item dieselve broder Jan vertert in Jans huse van Stalbergen 96 maeltijden, van elker maeltijt 1 albus, valet 4 rijnsche gld.". ${ }^{10}$ Van al zijn werkzaamheden weten we niet meer dan dat hij een "schelleken" aan het uurwerk heeft aangebracht.

En passant werd het uurwerk dat jaar ook nog verfraaid. Een zeer interessante post luidt: "Item gehat van Conraet Inghen Holt 2 dennen schechte dair die menneken op staen die op die oirclock slaen, dairvoir gegeven 4 stuver, valet $10 \mathrm{kl} .4 \mathrm{gr}$.". Hieruit is af te leiden dat er twee zogeheten jacquemarts waren aangebracht, die op de luidklok het uur sloegen. Mogelijk schafte Venlo tweedehands spul aan van matige kwaliteit, want in 1456 heeft Goirt die Meelre "eyn menneken tot desen oirwerck gemaict ende vermaelt". Het kan natuurlijk ook zijn dat een der jacquemarts niet stevig was vastgezet en naar beneden is gevallen. Daarmee was men nog niet klaar. In 1456 wordt aangetekend: "Item verdinckt eynen meister van den Bosche die urekloc te vermaicken voir 14 rijnsche gld." Dit slaat waarschijnlijk op de luidklok van het uurwerk. ${ }^{11}$ Wel duidelijk met het uurwerk heeft te maken de verzwaring van de wijzer om deze in balans te brengen. ${ }^{12}$ Drie kwart eeuw lang kon het uurwerk ertegen.

In de stadsrekeningen van 1532-1533 tot en met 1536-1537 wordt een zekere Wilhem Coster van Breij genoemd als stadsuurwerksteller. ${ }^{13} \mathrm{Hij}$ kon de algehele slijtage niet verhinderen. Het stadhuisuurwerk heeft nog gefunctioneerd tot 1538. Toen werd het door Goedert van Duesborch vervangen door een nieuw uurwerk van 606 pond. Hij kreeg als betaling het oude uurwerk van 200 pond alsme-

${ }^{16}$ G.A.V., Oud-archief, stadsrekeningen 1449-1458, inv.nr. 74, stadsrekening 1455, passim.

"II Voor de mogelijke werkzaamheild van Bossche klokgieters in Venlo zie: C. Fehrmann 1967, p. 32 e.v.

${ }^{12}$ G.A.V., Ond-archief, stadsrekeningen 1449-1458, inv.nr, 75, stadsrekening 1.456: "Ittem gehat wan Derick van Wachtendonck eyn vierdel myn dan 83 pont loetz dair men die seiger van den oirwerck myt gesweert heeft dat hondert $2 \frac{1}{2}$ rijnsche gld. 19 stuver voir den gld. valet 2 rijnsche gld, $10 \mathrm{kl}$. 3 gr.".

${ }^{13} \mathrm{~J}$. Hinssen 1993, p. 106. 
de 42 goudgulden en 16 stuivers Brabants. Toen het werk klaar was, wilde het stadsbestuur twee wijzerplaten zien aangebracht, één aan de Vleesstraatzijde en één aan de kant van de Lomstraat. Goedert ontving hiervoor nog eens vijftien gulden. Waar Van Duesborch vandaan kwam, kon niet worden achterhaald. Een halve eeuw lang bleef zijn product functioneren.

In 1582 moest het uurwerk grondig worden gerepareerd. Dit werd gedaan door Hendrik van Raey, die waarschijnlijk in Venlo woonde. Hij verplichtte zich het stadsuurwerk voor 22 gulden te herstellen en het, zolang hilj in goede gezondheid verkeerde, voor één daalder per jaar te onderhouden. Dat was niet duur, maar voorlopig voldoende. Bij de bouw van het nieuwe stadhuis in 1597 door Willem van Bommel uit Emmerik werd het bestaande uurwerk in de kleine linkertoren geplaatst. Misschien zijn de vroede vaderen van Venlo door hun zuinigheid van 1582 en 1597 evenwel bedrogen uitgekomen.

In 1607 moest Venlo een nieuw, iets zwaarder uurwerk aanschaffen. Het woog 628 pond en werd geleverd door Kerstiën (Christiaan) Kloecker uit Brachelen bij Aken (D). Hij ontving hiervoor $102 \frac{1}{2}$ rijksdaalders. Dit uurwerk met twee luidklokken werd in de grote toren geplaatst. Het moest eind 1625 reeds worden gerepareerd en men gaf daarvoor opdracht aan zijn maker Kloecker. Blijkens de bewaarde correspondentie nam Kloecker de tijd voor deze reparatie. Op 2 januari 1626 schreef hij aan de Venlose magistraat, dat hij niet eerder dan acht dagen na Driekoningen kon overkomen vanwege het krijgsrumoer. Ook wilde hij nog graag vijf of zes dagen lang graan laten dorsen en de vruchten opbergen. $\mathrm{Hij}$ had blijkbaar naast zijn klokkenmakerij een boerenbedrijf. De 12de juli 1626 schreef hij weer een brief aan de stad Venlo om zich te verontschuldigen, dat hij nog niet was komen opdagen. Hij had intussen een opdracht in het Land van Valkenburg uitgevoerd en nu was de oogsttijd aangebroken, zodat hij twee à drie weken lang geen tijd had voor Venlo. Op 13 oktober liet hij weten, dat hij nog niet was gekomen omdat het rond Brachelen onveilig was door allerlei krijgsvolk. Wanneer de reparatie werkelijk is uitgevoerd, is niet duidelijk. ${ }^{14}$

Rond het midden van de 17 de eeuw begon ook het Venlose stadsbestuur te zoeken naar mogelijkheden op het onderhoud aan het

${ }^{14}$ G.A.V., Knipselverzameling Müller, deel 2, pp. 66-67. 
uurwerk te bezuinigen. Verpachten en hier of daar een voorrechtje hielp geweldig. In 1651 werd het onderhoud van het stadsuurwerk publiek aanbesteed. Pasquier Janssen, een lokale smid, nam het aan voor twaalf rijksdaalders per jaar. Hij kreeg daarenboven vrijdom van inkwartiering tot 1665. Daarna is deze vrijstelling blijkbaar niet meer verleend, want in 1679 verzocht hij de magistraat om in zijn oude voorrecht te worden hersteld, daar bij hem een vuurgevaarlijk gezin was ingekwartierd. ${ }^{15}$

Het kon nog voordeliger. In 1705 werd Derick Terpoorten stadshorloger van Venlo. Hij kwam van Goch (D) en kreeg het burgerschap gratis, op voorwaarde dat hij zijn leven lang zou zorgen voor de klok van het stadhuis en voor die van het $\mathrm{H}$. Geestkerkje. ${ }^{16}$ Het bleek een goede keuze. Derick ter Poorten was een voortreffelijk uurwerkmaker. Hij vervaardigde in 1716 een monumentale klok voor de oude raadzaal van het Venlose stadhuis, de zo geheten Adam en Evaklok. Zij kostte 35 rijksdaalders, een koopje. Waarschijnlijk kwam dat deels omdat de Adam en Evaklok extern werd aangedreven. ${ }^{17}$ De klok werd aangesloten op het grote torenuurwerk van Kloecker.

De klok is zo bijzonder, dat zij een uitvoerige beschrijving waard is (zie afbeelding 17). De monumentale wijzerplaat bevindt zich in een hoek boven een deur in de raadzaal. Ze is blauw geschilderd en heeft een toogvorm, waarbij de twee bovenste hoeken zijn ingezwenkt. In de toog is een vergulde cijferring met de cijfers 1-31, waarop een vergulde wijzer de datum aanwijst. Binnen deze datumring is een venstertje, waarin de naam van de maand en het teken van de dierenriem zichtbaar zijn. Hieronder bevindt zich de iets grotere uurcijferring met Romeinse cijfers; de buitenste rand hiervan draagt de cijfers $1-60$ voor de minuten. Twee vergulde wijzers duiden de tijd aan. De binnenrand van de uurring draagt tweemaal de cijfers 1-12. Die zijn net zo klein gegraveerd als de minuutcijfers. Het middendeel tussen de uurring kan draaien en is beschilderd met een zon en sterren, waardoor de duur van dag en nacht kan worden aangeduid op de binnenring.

${ }^{15}$ G.A.V., Knipselverzameling Müller, deel 2, p. 67.

${ }^{1.5}$ G.A.V., Oud-Archief, stadsrekeningen 1449-1458, inv.nir. 1449a; W.Th.M. Hendriks 1967 , pp. 98 en 122 .

${ }^{37}$ Hanssen 1919, inv.nr. 1194: "Den Rentm(eester) J.A. van Tholl sal aen Derick ter Poorten horologiemaecker betalen vijfendertig Rijxdalders voor d'horologie op de Raedtcamer. Actum in senatu den 22 xbris $1716^{\text {th}}$. 


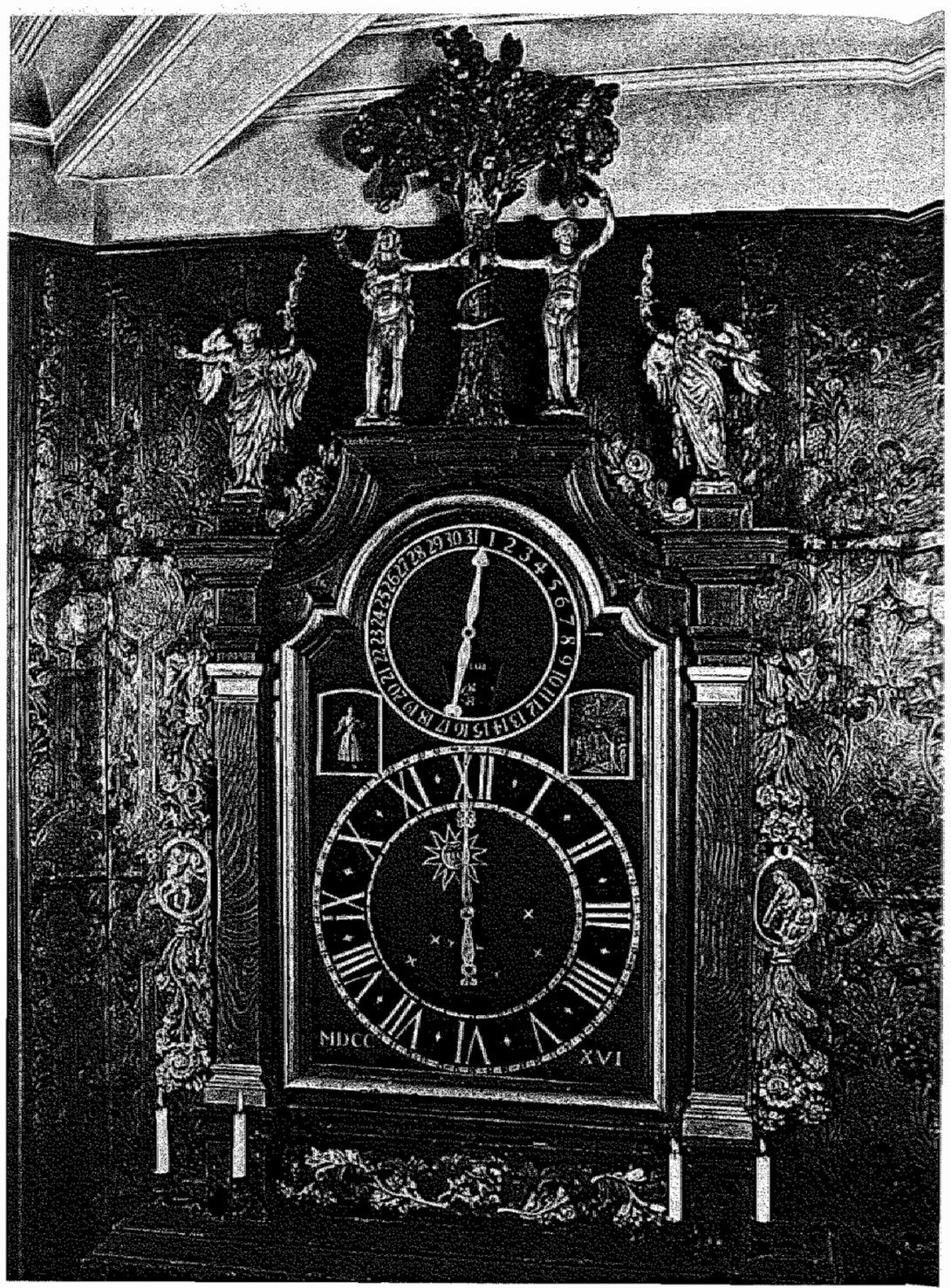

17. Adam en Evaklok in het stadhuis van Venlo (door Derick ter Poorten, Venlo, 1716). Boven de cijferring wordt de datum aangegeven met een wijzer. Een venster toonut de naam van de maand met het teken van de dierenriem. Bovenaan automaatfiguren van Adam en Ewa en twee engelen met een vlammend zwaard. In het medaillon onder de cijferring is een automatfiguur van Caïn die Abel doodt 
Tussen de datum- en de uurring zijn twee op koper geschilderde voorstellingen aangebracht van respectievelijk Justitia en het Laatste Oordeel. Deze zijn in 1745 vervaardigd door de Venlose kunstschilder Francis Wijrott. ${ }^{18}$ Onder de uurring staat de datering: MDCC XVI. De wijzerplaat is gevat in een monumentale barokke lijst in eikenkleur met aan weerszijden pilasters met vergulde bases en kapitelen. Daarnaast zijn vergulde guirlandes aangebracht met medaillons, die links de verdrijving uit het aards paradijs en rechts het werken voorstellen. Onder de wijzerplaat zijn twee vergulde takken uitgestoken met een medaillon met Caïn die Abel vermoordt. De moordhandeling is gemechaniseerd en vindt ieder eerste kwartier en half uur plaats. De bovenkant van de klok wordt afgesloten met zwaar inzwenkend lijstwerk. Hierop staat in het midden de Boom des Levens in natuurlijke kleuren met gouden appels en een gouden serpent. Aan weerszijden daarvan staan vergulde beeiden van Adam en Eva, ieder met een halve gouden appel. Op de hoeken staan twee engelen met vlammende zwaarden. Wanneer de klok het volle uur of het laatste kwartier aanwijst draait Eva zich een kwart slag op haar voetstuk en reikt zij Adam haar halve appel. Tegelijkertijd heft de engel aan haar zijde zijn vlammend zwaard. Wijst de klok het laatste kwartier of het halve uur aan, dan verrichten Adam en de engel aan zijn kant de genoemde handelingen.

De klok en de omlijsting werden door de Venlose kunstschilder Ftederik van Dheurne (of Dhurne) beschilderd. De omlijsting werd vervaardigd door de schrijnwerker Derick Deckers, die ook het pendant makkte voor de allegorie van het Twaalfjarig Bestand in de andere hoek van de zaal. De beelden van de boom, Adam en Eva, de engelen en de medaillons werden pas in 1719 vervaardigd door de "beeldsnijder" Franciscus Catelaen. ${ }^{19}$

In 1735 verrichtte Matthias van Pelt reparaties aan de Adam en Evaklok: "Op de raadzaal het werk tweemal afgenomen en van binnen uiteengedaan en de schuiven vermaakt met de lichters

\footnotetext{
${ }^{18}$ Hanssen 1919, inv.nr. 1194: "Betaelt aen francis Wijrott voor 't schilderen van 't Oordeel en de Rechtwaerdigheijt op twee copere platen...".

"Hanssen 1919, inv.nr. 1194: "12 Maij 1719 aen franciscus Catelaen voort maken en vergulden van vier beeldjes en eenig cieraet aen den kast van de horologie op de Raetskamer 72 gulden".
} 
veranderd en het serpent aan elkaar gemaakt, 6 rijksd.". ${ }^{20}$ Van Pelt werkte ook aan het torenuurwerk. In dit kader worden werkzaamh $e^{-}$ den aan de wijzerplaat genoemd, maar ook, wat zeer interessant is: "het stellen van de maan met drie spillen met de raderen allemaal vermaakt, met een dwarsijzer gemaakt, waarin de bol draait, ook een ijzer aan de "stelt" gemaakt, met het bekleden van de deuren, 6 rijksd." ${ }^{21}$ Hieruit blijkt dat een voorziening was aangebracht of de maanfasen te tonen en well door middel van een bolvormige maan. Jansen spreekt zelfs van het aanbrengen van "de standen onzer twee grote hemellichamen". ${ }^{22}$ Hij kan gelijk hebben. Een tekening in pen en penseel uit 1741 van Jan de Beyer ${ }^{23}$ laat de wijzerplaat zien met in de hoeken het jaartal 1736 (of 1735). Daaronder is de bolvormige maan afgebeeld tegen een blauwe achtergrond met goudkleurige sterren (zie afbeelding 18). Ook op een afbeelding van het stadhuis van omstreeks 1800, toegeschreven aan J.G. Heldebeutel, ${ }^{24}$ is onder de wijzerplaat een rechthoek te zien met een bol in het midden, waarschijnlijk de maan.

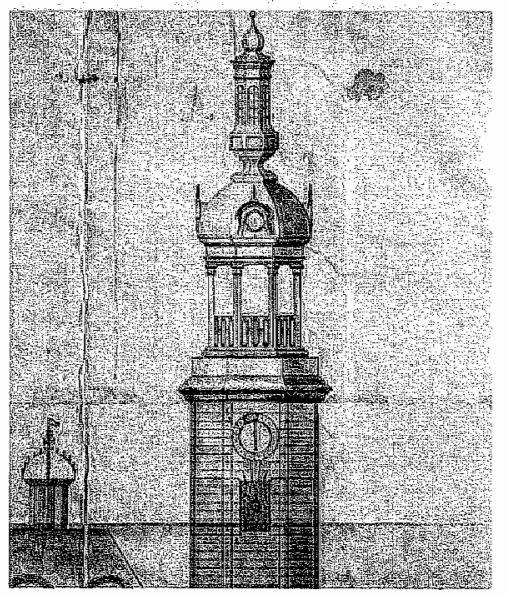

18. Wijzerplaat en maanbol aan de gevell van het Venlose stadhuis (aquarel van $\mathrm{G}$. Heldebeutel, 19de eeuw)

${ }^{20}$ G.A.V., Knipselverzameling Müller, deel 2, p. 67.

${ }^{21}$ G.A.V., Knipselverzameling Müller, deel 2, p. 67.

2.2 M. Jansen 1880 , p. 262 , noernt geen bron.

${ }^{23}$ Rijksprentenkabinet Amsterdam, inv.nr. 1921:48.

24 G.A.Y., Beeld en Geluid, inv.nr. 710, afbeelding stadhuis Venlo, pen en penseel in klenr. $80 \times 98 \mathrm{~cm}$, toegeschreven aan J.G. Heldebentel. 
Inmiddels was de waardering voor de stadsuurwerkmaker gestegen. Het stadsbestuur hechtte eraan opnieuw een vakman op die post te hebben en trok de beurs open. Op 14 maart 1745 werd Mathijs van Pelt aangesteld als stadsklokkenmaker voor zestien pattacons jaarlijks. ${ }^{25} \mathrm{Hij}$ werd in augustus 1749 opgevolgd door Bernardus Terpoorten. ${ }^{26}$ Onbekend is of deze Bernardus verwant was aan de eerder genoemde Derick Terpoorten. In 1794 werd een nieuwe stadsklokkenmaker aangesteld, Joannes Ferdinand van der Hoeven (1750-1812). ${ }^{27}$ In 1812 werd hij opgevolgd door Jozef Jacob Keuller (1779-1861). Die vroeg in 1822 een jaarwedde van honderd gulden. ${ }^{28}$ Mogelijk voorzag hij meer werk. In dat jaar werden de kappen van de beide torens geheel vernieuwd volgens een afwijkend model. ${ }^{29}$ Daarmee zullen de werkzaamheden aan het torenuurwerk verband houden die in 1823 door verschillende auteurs worden vermeld. ${ }^{30}$ De Adam en Evaklok zal hier bij betrokken zijn geweest. Waarschijnlijk zijn die werkzaamheden verricht door de stadshorloger J.J. Keuller zelf.

De opvolger van Keuller was zijn zwager Christiaan Josef van Boom (1774-1859). Hij werd omstreeks 1830 aangesteld, toen Keuller vrederechter werd. Van Boom repareerde in 1836 voor 1200 franken het stadsuurwerk. ${ }^{31}$ Daarna vernemen we niets meer van stadsklokkenmakers in Venlo. Waarschijnlijk is die functie er in die tijd evenals in andere steden overbodig geworden.

Het stadhuis kreeg op 1 mei 1903 een nieuw achtdaags uurwerk met twee slagwerken van de firma B. Eijsbouts te Asten. Over de Adam en Evaklok wordt bij die gelegenheid niet gesproken. ${ }^{32}$ Maar vanwege de koppeling aan het torenuurwerk zal men ook toen aan

${ }^{25}$ G.A.V., Archief van het stadsbestuur 1272-1814, inw.nr. 635 .

${ }^{26}$ G.A.V., Archief van het stadsbestuur 1272-1814, inw.nr. 636.

27 G.A.V., Archief van het stadsbestuur 1272-1814, inw, mr. 637, 1794-1809. Rekening van F. van der Hoeven over het opdraaien van het stadshorlogie.

${ }^{23}$ G.A.V., Atchief van het stadsbestuur 1272-1814, inw.nr. 639.

${ }^{20} \mathrm{M}$. Jansen 1880 , p. 262 . Jansen was zeer verbolgen over deze en andere veranderingen tan thet stadhuis.

31 "Paradijselijke scènes in Venlo"s raad; als straks de klok slaat", artikel in: Dagblad woor Noord-Limburg, 14 juli 1956; W. Hendriks, 30 juli 1960; G.A.V., Archief van het stadsbestuur 1272-1814, inw.nr. 638: "1822 - Conditiën van aanbesteding der reparatien aan het stadsuurwerk".

"G.A.V., Archief van het stadshestuur 1272-1814, inv.nr. 640 .

${ }^{32}$ Bedrijfsarchief Koninklijke Eijsbouts N.V., Asten, Verkoopboek over 1879-1906, 1 mei 1903: Venlo (stadhuis). Een nienw achtdaags uurwerk met twee slagwerken, No. $17 \mathrm{~b}$ v/d/ prijsc. op kogellagers fl. 1160,-. 
de Adam en Evaklok hebben moeten werken. In de jaren 1956-1960 is dit monumentaal uurwerk grondig gerestaureerd. ${ }^{33}$ Het bevin $\mathrm{dt}$ zich nog in de oude raadszaal van het Venlose stadhuis.

\subsubsection{De andere stadsuurwerken}

Over andere stadsuurwerken in Venlo is in de bronnen weinig of niets te vinden.

Het zogenaamde "torenwachtersuurwerk", dat in 1939 in de SintMartimustoren werd ontdekt, heeft waarschijnlijk in de stadstoren gestaan, een enorme wachttoren die vóór de Sint-Martinuskerk stond en in 1766 werd afgebroken. Het was waarschijnlijk ook een stadsuurwerk. ${ }^{34}$ Het heeft nooit een wijzer van een buitenwijzerplaat aangedreven. Het kon slechts dienst doen in de openbare tijdmeting als een wachter, na een signaal van het wekkermechanisme van het uurwerk, het uur verkondigde met signalen op een trompet of door slagen op een luidklok. $\mathrm{Na}$ de afbraak van de stadstoren is het blijkbaar in de Sint-Martinustoren terechtgekomen.

Mogelijk was er ook op de Helpoort een uurwerk aangebracht, althans een tijd lang. In de stadsrekening van 1451 staat immers het volgende: "Item gegolden tegen eynen vreemden mann, lach in Peter Huyskens huis, $133 \mathrm{lb}$. loetz dat verwracht is boven op die Helport op die vynsteren dair die papegeye doir geit ende op dat stijlken ende de vynsteren bij der oyreclocken". Latere vermeldingen van dit uurwerk zijn er niet. Mogelijk moet de geciteerde tekst worden gezien als een losse opsomming van wat men met een partij lood had gedaan en is er geen verband tussen de Helpoort en het "stijlken ende die vynsteren bij der oyreclocken". In dat geval gaat het allicht om het uurwerk op het stadhuis en is er dus geen sprake van een uurwerk op de Helpoort.

${ }^{33}$ W. Hendriks, 30 juli 1960; "Paradijselijke scènes in Vetnlo's raad; als straks de klok slaat", artikel in: Dagblad voor Noord-Limburg, 14 juli 1956.

${ }^{34}$ Zie dit hoofdstuk, paragraaf 3.1.1. 


\subsubsection{De uurwerken aan Venlose kerken}

Het uurwerk van de $\mathrm{H}$. Geestkerk is één keer vermeld ${ }^{35}$ Het werd in 1705 door de stad onderhouden en was hoogstwaarschijnlijk haar eigendom. Meer is er niet van bekend.

De hoofdkerk van Venlo, de Sint-Martinuskerk, had een uurwerk. Het is niet bekend sinds wanneer. In een visitatieverslag uit 1730 wordt betreffende de Sint-Martinuskerk aangetekend, dat het onderhoud van de toren en de luidklokken ten laste kwam van de stadsmagistraat, dat van de touwen en het uurwerk evenwel ten laste van de kerk. $^{36}$ Verdere berichten over uurwerken op de torens van kerken of in de kerkgebouwen zijn niet aangetroffen.

\subsection{Weert}

Weert lag temidden van uitgestrekte heidevelden op een punt waar de handelswegen uit het Rijnland via Venlo en Roermond samenkwamen en verder liepen naar Brabant en Vlaanderen. Door deze ligging en door de lakenhandel werd het een welvarende nederzetting. Het wolambacht, opgericht in 1378 , leverde grof laken naar meerdere plaatsen in heel West-Europa en had lakenhallen in Antwerpen en Bergen-op-Zoom. De heren, later graven, van Horne kregen Weert, eigendom van het Servaaskapittel in Maastricht, begin 13de eeuw in bezit en vestigden er hun verblijf in een sterke burcht. In 1414 kreeg Weert marktrecht of mogelijk stadsrecht van Willem IV van Horne. Het bleef een relatief kleine stad temidden van een krans gehuchten.

\subsubsection{Het stadsuurwerk en de stadsuurwerkmakers}

In de Chroniek van de Heerlijkheid Weert, een compilatie van A. Flament, ${ }^{37}$ treft men twee vermeldingen van uurwerken aan: één uit

\footnotetext{
${ }^{35}$ Zie noot 16.

${ }^{35}$ H. Hanssen 1979, inv.nr. 75: "magistratuí turris et campanarum, ecclesiae funium et horologiin".

${ }^{37}$ A. Flament 1892 , p. 158 (1516-1517): "voor het stellen der klok werd 2 gulden 8 stuivers gegeven", p. 164 (1555-1556): "Leen de organist kreeg voor een steen te houwen aan het uurwerk $4 \frac{1}{2}$ stuiver. Dit wurwerk was Zaturdag na Sacramentsdag 6 Juni aanbesteed. Hendrik
} 
1516-1517 en één bijna veertig jaar later uit 1555-1556. In beide gevallen gaat het om kleine betalingen. Zoals bij Flament gebruikelijk, betreft het ogenschijnlijk nauwelijks relevante informatie zonder enige bronvermelding. De gereleveerde betalingen hebben betrekking op een uurwerk dat werd onderhouden en hersteld ten laste van de burgerlijke gemeente. Maar waar stond het? Dat het uurwerk in het stadhuis was aangebracht, zoals Flament suggereert, is hoogst twijfelachtig. Waarschijnlijk stond het in de hoge kerktoren in het centrum van Weert. De toren van de Sint-Martinuskerk en het daarin geplaatste uurwerk kwamen nog heel lang ten laste van de burgerlijke gemeente, zoals in veel andere plaatsen het geval was. Die toren wordt in de Weerter stadsrekeningen en magistraatsresoluties zeer vaak "gemeyntethoren" genoemd. In Weert duurde deze toestand deels nog tot 29 december 1933 voort. Toen pas werd de toren van de Sint-Martinus door het gemeentebestuur in eigendom aan het kerkbestuur overgedragen. Het uurwerk bleef ook daarna nog eigendom van de gemeente.

Flaments mededelingen zetten ons wel op een spoor. Het ziet ernaar uit dat Weert in het midden van de 16 de eeuw een bekwaam uurwerkmaker in de arm had genomen, Hendrik van Hasselt. Daarmee wordt hoogstwaarschijnlijk Hendrik van Nuys(t) uit Hasselt bedoeld, een wijd en zijd befaamde uurwerkmaker, die zelfs aan steden als Delft en Gouda grote uurwerken leverde.

Het is de vraag of zijn uurwerk dadelijk in de Sint-Martinustoren of eerst in de toren van het stadhuis werd geplaatst. Voor het stadhuis zou in 1549 de eerste steen zijn gelegd door de latere koning Philips III. In de zijgevel van het oude stadhuis, thans Jacob van Horne-museum voor religieuze kunst, zijn nog resten te zien van laat-gotische vensters met accoladebogen. Het stadhuis had galerijen en een sierlijke toren. ${ }^{38}$ Deze werd in het begin van de 18 de eeuw na een brand hersteld, zoals blijkt uit de openbare aanbesteding van de heropbouw van de toren "op d'oude plaetse boven het stadtshuys, alwaer den voorigen door 't vier ende lesten brandt verslonden, heeft gestaen gehadt". ${ }^{39}$ Het bestek spreekt echter nergens van een weer aan te brengen uurwerk. Erg geschikt

van Hasselt, de meester die het maakte, kreeg voor godsperning $11^{1 / 2}$ stuiver".

38. Mertens en. J. Henkens 1956, p. 56.

${ }^{39}$ G.A.W., Oud-archief, magistraets resolutieboeck, inv.nr. 1, vergadering d.d. 14 april 1728 . 
voor een uurwerk was dit torentje ook niet. Het moest omtrent tien meter hoog worden.

De andere mogelijke plaats, de Martinustoren (zie afbeelding 19), was - ook al was hij vroeger beduidend lager dan thans - veel hoger dan de stadhuistoren. De theoretische mogelijkheid, dat er zowel in de stadhuistoren als in de Martinustoren een uurwerk stond, moet worden verworpen. Er is in de Weerter archieven nergens sprake van twee stadsuurwerken. Het zou ook weinig zin hebben twee uurwerken zo dichtbij elkaar te plaatsen. Het meest waarschijnlijk is, dat het uurwerk in 1555 werd aangebracht in de Martinustoren omdat er in 1516 - vóór de bouw van het stadhuis al een stadsuurwerk was en er nooit meer dan één is geweest. Wellicht heeft Hendrik van Nuyst het in 1516 vermelde uurwerk zelfs alleen maar aangepast of hersteld. De godspenning die hij ontving, was niet erg hoog.

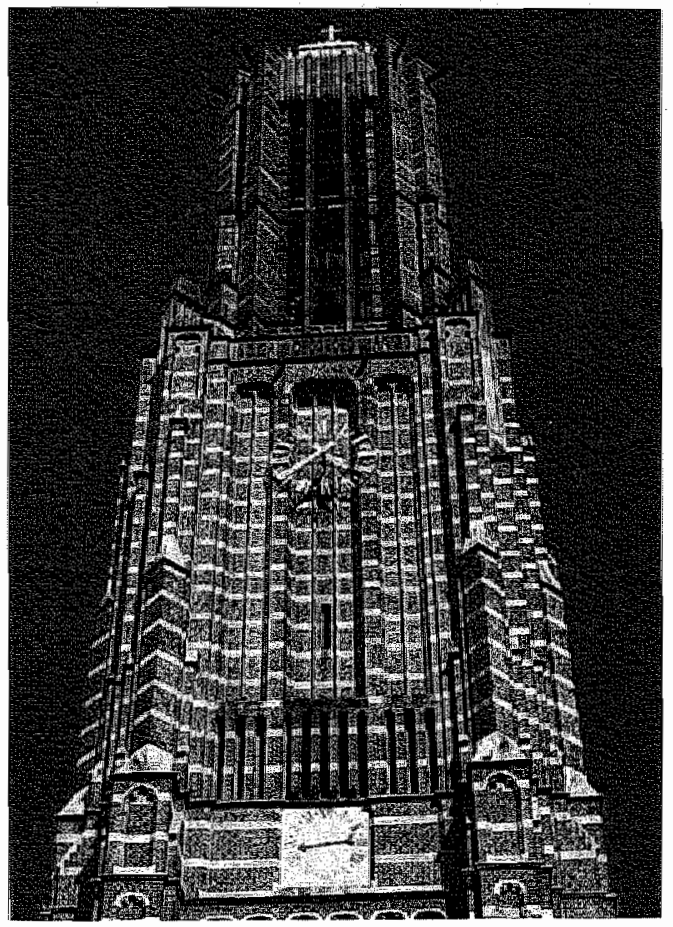

19. Toren van de Sint-Martinuskerk, Weert. Ver onder de huidige wijzerplaat is cen oudere te zien 
Rond 1750 was thet dak van de toren van de Sint-Martinuskerk njet in orde. Het lekte. Naar aanleiding daarvan schreef pastoor Janssen van de Sint-Martinuskerk een brief aan het stadsbestuur. Daarin vermelddle hij dat een "horlogiesteen", een stenen gewicht van het uurwerk, wit de toren was gevallen op het gewelf, waardoor neervallende delen van dit gewelf bijna een kerkganger hadden getroffen. De pastoor vroeg beter onderhoud van het dak, zodat ook de touwen van het uurwerk niet meer zouden wegrotten. ${ }^{40}$ Het valt te betwijfelen of dit verzoek effect sorteerde: in 1763 was de toren in zo'n slechte staat, dat hij ingrijpend moest worden gerestaureerd. Dit was zo kostbaar, dat de gemeente een collecte hield in de hele stad en op de buitenieën. De werkzaamheden werden door diverse ambachtslieden uitgevoerd. Een zekere Petrus Verschueren nam voor 290 gulden het vergulden van de torenhaan aan benevens "de nodighe herstellinge van de horologie in den thoren deser gemeijnte ende het maecken van drije nieuwe ijsere urewijsers te stellen op drije kanten van den thoren...". In het bestek staan precieze aanwijzingen voor het aanbrengen van wijzers en cijfers. De wijzers, één per wijzerplaat, moesten "seven voeten in diametre" zijn, de cijfers moesten van "roodt coper" zijn, "lanck elff duijmen en verguldt met fijn goudt". Het half-uur-teken "moet sijn eene ruijtte lanckwerpigh en vierkantigh van ontrent twee ende eenen halven duijm". Ook de vorm van de wijzers werd nauwkeurig voorgeschreven. Het uiteinde van de uurwijzer "sal gemaeckt worden op de forme van eene franse leelie". Uiteraard was de aannemer aansprakelijk voor de kwaliteit van zijn werk: "Den aennemer moet de wijsers aen den ganck helpen ende doen draeijen ende een geheel jaer goedt ende ganckbaer houden, oock de horologie schoon maecken; voorts deselve in volcomen staet stellen". 41 Van toen af werd het uurwerk behoorlijk onderhouden, na verloop van tijd door vakbekwame uurwerkmakers. De stadsrekening van $1784-1785$ vermeldt, dat aan de kundige Mathias van de Wyngaert ${ }^{42}$ negen gulden werd betaald voor het smeren van de stadsklok. ${ }^{43}$

40.A.W., Oud-archief, brief van de pastoor van de Sint-Martinuskerk aan de gemeente, 1750 , iny.nu. 2729.

${ }^{41}$ G.A.W., Ond-archief, magistraets resolutieboeck, inv.nut. 3, folio 49, d.d. 28 juli 1763.

" Zie voor meet gegevens over hem appendix $\Pi$ onder zijn naam.

${ }^{43}$ G.A.W., Stadsrekening 1784/85, folio 26, nr. 14. 
In 1792 verkeerde het stadsuurwerk blijkbaar opnieuw in slechte staat. Het stadsbestuur van Weert vroeg aan meerdere klokkenmakers offerte voor de reparatie. Mogelijk hield het zelfs een openbare aanbesteding. Het bestek, opgesteld door Petrus Andreas de Coster, van 14 september 1792 is bewaard gebleven. ${ }^{44} \mathrm{Hij}$ geeft daatin "GeExamineert hebbende de stads orlogie op de groote kerk alhier" een opsomming van alle werkzaamheden die moeten worden verricht, zoals het vernieuwen van praktisch alle rondsels in het gaande en slaande werk, het opvijlen van afgesleten tanden en het vervangen van enkele tandwielen. Twee punten zijn technisch interessant. Vooreerst werd voorgesteld "eenen nieuwen cillender ofte balansier(=slinger), lank over zeven voet, hebbende voor bol. $6 \frac{1}{2}$ pond" te maken en voorts "Het maken van een nieuw échapment bij forme van een anker, hetwelk eenen zeer zagten en gemakkelijken gank maeckt, ende dus zeer duursaem is". Hieruit blijkt dat het uurwerk tot dan toe een spillegang heeft gehad. Misschien kreeg het uurwerk er nu ook een minuutwijzer bij, maar hier wordt niet over gerept. Waar De Coster vandaan kwam, is niet bekend. Het feit dat De Coster een prijs in Kleefse guldens vroeg, is misschien een aanwijzing. Wellicht komt zijn identiteit te voorschijn bij onderzoek naar uurwerkmakers aan de Nederrijn. De opdracht werd hem gegund omdat zijn "besteck is minder wesende als dat van den orlogie maker van Thorn". ${ }^{45}$ Met deze concurrent is waarschijnlijk Joannes Schoufs bedoeld, die kennelijk nog drastischer wilde ingrijpen en in ieder geval duurder was.

De "zachte gank" heeft blijkbaar goed gefunctioneerd, want we vernemen in de 19 de eeuw weinig over herstellingen aan het uurwerk. Wel vermeldt een besluit van 26 oktober 1818 dat er dagelijks onderhoud werd gepleegd: "Een bediende voor de directie en opzigt van stads-horologie, drij en twintig guldens $s^{n}{ }^{46}$ De verdere lotgevallen van het uurwerk zijn onbekend.

${ }^{44}$ G.A.W., Ond-archief, magistraets resolutieboeck, inv.nr. 5, folio 51 e.v. Hoewell 100\% van de torenuurwerken op slinger zijn omgebouwd, vindt men slechts zelden zo'n uitvoerige beschrijving van de ombouw.

${ }^{45}$ G.A.W. Oud-archief, magistraets resolutieboeck, inv.nr. 5, folio 52 .

${ }^{40}$ G.A.W. Nieuw-archief, inv.nr. 4. 


\subsection{Sittard}

Sittard heeft zich ontwikkeld in de schaduw van een motteburcht met voorburcht van de heren van Valkenburg. De nederzetting kreeg in 1243 stadsrechten van Walram II, de Goede, Heer van Monschau en Sittard. Dit bleek een stimulans en al spoedig moest het stadsareaal worden aitgebreid. In het centrum binnen de nieuwe omwalling, die een tweemaal zo groot gebied als eerst omsloot, kwam een ruim marktplein. Hierop verrees waarschijnlijk al in 1326 een "gewanthuis", waarin allerlei handelsactiviteiten plaatsvonden. Dit werd in 1561 wegens bouwvalligheid afgebroken. Er kwam in 1570 een nieuw hertogelijk gebouw voor in de plaats. Het diende tot raadhuis en "schudhuis", dat wil zeggen korenopslagplaats. Het had een torentje waarin het stadsuurwerk stond.

In 1400 werd Sittard verkocht aan de hertogen van Gulik, zodat Sittard tot aan het einde van het Ancien Régime Guliks bleef. Pas na de Franse tijd, waarin het behoorde tot het departement van de Roer, werd Sittard in het Nederlandse staatsbestel opgenomen. ${ }^{47}$

\subsubsection{Het uurwerk van het gewanthuis en het stadhuis en de stadsuurwerkmakers}

Het "gewandthaus", de lakenhal, van Sittard wordt al in een akte van 1360 genoemd: "in domo pannorum opidi sittrensis"..$^{48}$ Daarin werd ooit een urrwerk geplaatst. ${ }^{49}$ Wanneer dit gebeurde en door wie dit uurwerk werd gemaakt, is echter niet bekend. Het kan niet later dan in de eerste helft van de 16de eeuw zijn gebeurd. Het gewanthuis werd zwaar beschadigd bij de verwoesting van Sittard in 1542 en vervolgens gesloopt. ${ }^{50}$ Het oude uurwerk werd in $1566-$ 1567 door Meester Gerhart van Maastricht gerepareerd en herplaatst

\footnotetext{
${ }^{47}$ P. van Luyn 1993, passim.

${ }^{4}$ A. Simonis (et al.) 1971, p. 40, ziet in "panmorum" een verklanking wan pan of ban en vertaait het begrip "domus pannorum" abusievelijk met pankuis (brouwhuis) of banhuis.

${ }^{49}$ P. van Luyn 1993, p. 60, stelt, dat er in Sittard aanvankelijk een raadhuis was en een gewanthuis in twee afzonderlijke gebouwen. Deze stelling wordt evenwel niet met duidelijke argumenten gestaaft.

9n A. Simonis (ef all) 1971, p. 41. De vernieling van het gewanthuis zal niet zo volkomen zijn geweest als Simonis ons wil doen geloven. Immers het unrwerk was nog bruikbaar.
} 
in het nieuwe raad- en schudhuis. ${ }^{51} \mathrm{Hij}$ is wellicht te identificeren met "Gereth naest dat Hoefyseren", alias Gereth van Hern, die werkzaam was als uurwerkmaker te Maastricht. De plaats, waar het uurwerk nu stond opgesteld, was lastig bereikbaar. De stadsmagistraat vroeg sleutels voor zichzelf of degenen die daartoe opdracht hadden, teneinde toegang tot de uurklok te hebben om deze bij mankementen te kunnen repareren, zonder dat zij daardoor toegang kregen tot de zolders, waar het graan was opgeslagen. ${ }^{52}$

Het uurwerk werd behoorlijk onderhouden, zoals blijkt uit een tweetal stadsrekeningen met specificaties. In 1588-1589 heette het: "Item Sijberten dem schlossmecher als verwehrer des uhrwercks vor und nach geliefert 3 pont kertz das pont $6 \frac{1}{2}$ stufer und 1 quart schmalz oder oelichs ad 18 st und 1 pint baumolichs ad $71 / 2$ st. facit 2 g. 5 st..". ${ }^{53}$ Op een andere pagina van dezelfde rekening staat: "Item noch allerleies am uhrwerck gemacht ad 2 g." ${ }^{54}$ En: "Item Seiberten dem schlossmecher von wegen dessen, das er der stat. uhrclock setzet und verwahrt, bezalt $18 \mathrm{~g}$." ${ }^{.5}$

In de stadsrekening van 1628-1629 komen de volgende posten voor: "Item weill derselb (Diederich Spielmans) der stadt uhrwerck auch regirt, derhalben bezahltt 18 g." 56 en: "Item Diederich Spielmans wachtmeister und regirer des stattuhrwerck auch machen lassen 3 par schuh jeder par $3 \mathrm{~g} 5$ st und fur seine fraw ein par schuh samen 12 g." ${ }^{57}$ In beide gevallen gaat het om normaal onderhoud. Enige tijd later vertoonde het uurwerk emstige gebreken. Bij besluit van 14 oktober 1644 voteerde het stadsbestuur een bedrag van 326 gulden en vier stuiver voor reparatie van het uurwerk. Aan het uurwerk was een klein carillon verbonden, want tevens werd besloten twee gebarsten klokken te laten hergieten en één nieuwe aan te schaffen. Het carillon werd spoedig daarna uitgebreid. Op 4 maart 1654 sloot de magistraal een contract met Johan van Neell uit Linnich (D) om het uurwerk van het stadhuis te repareren en het carillon van elf tot vijftien klokken uit te breiden. Eerst moest het

\footnotetext{
5. J. Oremus 1993 , p. 38.

\$. Oremus 1993, p. 5.

53 J. Oremus s.a., p. 36 (folio 21ro).

54 J. Oremus s.a. p. 45 (folio 29vo)

ss J, Oremus s.a., p. 46 (folio 31 ro).

${ }^{56}$ J. Oremus s.a., p. 121 (folio 63).

${ }^{37}$ J. Oremus s.a., p. 122 (folio 66).
} 
stadhuis echter worden opgeknapt, zodat Van Neell pas in 1659 kon beginnen. Op 20 mei $\mathbb{1} 660$ viel Van Neell, terwijl hij met zijn zoon aan het werken was, uit de toren. Hij werd ernstig gewond. Nadat hij was opgeknapt, hervatte hij het werk. Spoedig bleek dat hij het uurwerk grotendeels moest vernieuwen. Hij vroeg daarom meer geld dan was overeengekomen en kreeg het ook. ${ }^{58}$ Het duurde tot 1666 eer het werk klaar was en alle rekeningen vereffend. ${ }^{59}$

In 1677 bij de verwoesting wan Sittard door de Fransen vatte het stadhuis vlam. Zoals vaker bij dergelijke calamiteiten bleek het uurwerk niet onherstelbaar verwoest. Pas 35 jaar later, in 1712, werd het uurwerk door zekere Lenart Moris hersteld. Wie dit is geweest en waar hij vandaan kwam, bleek niet te achterhalen. ${ }^{60}$

Het stadhuis werd in 1755 afgebroken. Bij die gelegenheid is het uurwerk waarschijnlijk verloren gegaan ${ }^{61} \mathrm{Er}$ was ook geen plaats meer voor. Het stadsbestuur heeft tot 1874 zijn werkzaamheden verricht in verschillende lokaliteiten. Toen pas werd een nieuw stadhuis gebouwd.

\subsubsection{Het uurwerk van de Nederlands Hervormde kerk}

In dit kerkgebouw bevindt zich een mogelijk vroeg-17de-eeuws torenuurwerk (zie afbeelding 20). Het is geheel van smeedijzer. Dit geldt ook voor alle tandwielen. De vier hoekstijlen van het raamwerk zijn vierkant in doorsnee. Alle verbindingsstukken en overige stijlen zijn rechthoekig plat. Door middel van spieën zijn alle onderdelen nog zonder speling met elkaar verbonden. De vier hoekstijlen hebben een eivormige topversiering, verder is er geen decoratie. De afmetingen van het raamwerk zijn $56 \mathrm{~cm}$ lang, $45 \mathrm{~cm}$ breed en $61 \mathrm{~cm}$ hoog. Het gaande werk had een foliot. Het juk van de foliot-ophanging is nog aanwezig. Inmiddels is het uurwerk omgebouwd tot verticale spillegang met slinger als bij een stoelklok. De lengte van de slinger is $212 \mathrm{~cm}$, wat resulteert in een slingertijd van 1,5 seconde. Het uurwerk heeft één wijzer. Het slagwerk heeft een open sluitschijf met binnenvertanding. Het hele

\footnotetext{
M. Janssen 1895, pp. 54-55.

5. A. Simonis (et all.) 1971, p. 47.

50 M. Janssen 1895, p. 58.

6) De archiefstukken die betrekking hebben op het urwerk en het klokkenspel van het onde stadhuis te Sittard zijn in extenso gepubliceerd door F. Hoefer 1893.
} 
en het halve uur worden geslagen. Het grondrad van het slagwerk heeft zestien pennen voor de uitlichting van de belhamer. Gaand werk en slagwerk zijn in elkaars verlengde gemonteerd. Het is onduidelijk, wie dit uurwerk heeft gemaakt of gerepareerd. Op de voorzijde van de bovenrand van het raamwerk staat een inscriptie, die door ernstige putcorrosie bijna onleesbaar is. Mogelijk staat er: "[...] Sprakel [..B..] Anno 17(?)10". De letters vóór het naamdeel "Sprakel" zi.jn onleesbaar. Het jaartal 1710 is moeilijk te rijmen met de oorspronkelijke foliotgang, maar misschien duidt het de ombouw op slinger aan. Het is ook niet zeker, dat er 1710 staat. De 7 is nogal vreemd gevormd, 1610 zou gezien de constructie van het uurwerk veel beter uitkomen als jaar van vervaardiging. Als er inderdaad 1610 moet worden gelezen, kan het uurwerk oorspronkelijk ergens anders hebben gestaan en in 1683 samen met een luidklok aan de hervormde gemeente zijn geschonken. De luidklok kwam uit Den Bosch; Jurriaan Spraeckel was daar begin 18de eeuw werkzaam. Hij kan een oud uurwerk hebben gemoderniseerd.

Het uurwerk bevindt zich niet meer in de toren, maar is bij de laatste restauratie van de kerk in een halletje beneden opgesteld. Rond 1900 heeft het waarschijnlijk nog gefunctioneerd, want op foto's uit die tijd kan men aan de kerktoren een wijzerplaat ontwaren.

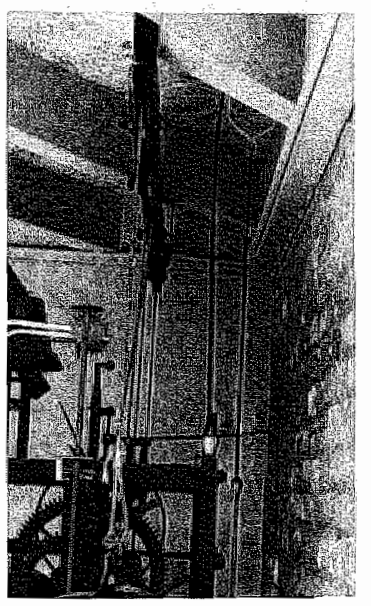

20. Torenuurwerk in de Nederlands Hervormde kerk, Sittard (begin 17 de eeuw), omgebouwd naar slinger volgens het "Scheweningse systeem": slinger los van het uurwerk opgehangen, lange "meenemer" aan de lepelas (zie oolk afbeelding 35) 
Roermond ontstond nabij de plek waar een handelsweg van het Rijnland naar Brabant en Vlaanderen de Roer en de Maas kruilste. Al in 1224 werd Roermond oppidum (stad) genoemd, hoewel de verlening van stadsrechten volgens de traditie pas in 1232 plaats vond. Vanuit de oudste kern Buitenop werd de stad in oostelijke richting uitgellegd. Er kwam een marktplein van zeventig bij honderd meter; de graaf van Gelre bouwde een waag, een zoutmaat en een lakenhal. De productie en verkoop van laken vormden naast andere handelsactiviteiten de pijlers van de Roermondse economie. De stad bezat aan de markt een belfort, later Grauwe Toren genoemd. Aan de rand van de stad stichtte de graaf de Munsterabdij, waarvan de kerk werd gebruikt als mausolleum voor het Gelderse gravengeslacht. Vanaf ongeveer 1350 trad Roermond op als hoofdstad van het Gelderse Overkwartier. Het inwonertal bedroeg in 1396 ruim zevenduizend, geestelijken en kloosterlingen niet meegerekend. Dit aantal nam in de 15 de en 16 de eeuw af door economische malaise en de stadsbrand van $1554 .^{62}$ Sinds 1569 was Roermond ook bisschopsstad.

Gezien zijn vroege status is het aannemelijk dat Roermond, evenals Venlo, lang vóór 1578 , de eerste vermelding van een uurwerk te Roermond, een stadsuurwerk had. Door het ontbreken van stadsrekeningen en raadsbesluiten van vóór 1578 weten wij over de openbare tijdmeting in Roermond in de $14 \mathrm{de}, 15 \mathrm{de}$ en een groot deel van de 16 de eeuw echter niets. In geen der vele kerken en kloosters, inclusief de machtige Munsterabdij, zijn uurwerken aangetroffen, behalve in de Kapel in 't Zand.

3.4.1. Het stadsuurwerk in de Sint-Christoffeltoren en de stadsuurwerkmakers

De eerste vermelding van een uurwerk te Roermond komt voor in de "Kroniek der stad Roermond van 1562-1638" van Jan van Rijckenroij. ${ }^{63}$ Volgens deze kroniek werd er in 1578 gewerkt aan het

6.2. Venner 1.985, pp. 44-46.

${ }^{63}$ Fr. Nettesheim 1873, p. 217: "In der seluer tyt heeft der overster lieutenant Vegersheim, dweil hy noch dat regiment deser stadt deur het vuytblywen des magistraets aen sich hielde 
uurwerk in de hoge toren van de Sint-Christoffelkerk. Tijdens de afwezigheid van de magistraat werd op gezag van een militair commandant de wijzer van de klok vervangen. Of het hier om een nieuwe wijzer gaat of om een herstelling is niet met zekerheid te zeggen, zodat wij ook niet weten of het gaat om de laatste fase van de plaatsing van een uurwerk of om het herstel van een ouder instrument. Het laatste is het meest waarschijnlijk. Uit de geciteerde bron en uit latere bronnen blijkt dat het uurwerk in de toren van de kathedraal een stadsuurwerk was. De toren was zeer geschikt voor de plaatsing van een uurwerk. Hij torent hoog boven de stad en het Maasdal uit en het uurwerk daarin was goed zichtbaar vanaf de nabijgelegen marktplaats. De Sint-Christoffelkerk is gebouwd na de afbraak in 1388 van de oorspronkelijke parochiekerk van Roermond, die buiten de muren in Buitenop lag, en werd pas begin 16de eeuw voltooid. De toren telde toen drie verdiepingen. Omstreeks $1604 \mathrm{kreeg}$ hij een vierde verdieping. Het uurwerk is tot in de 20 ste eeuw op de derde verdieping gebleven ${ }^{64}$ (zie afbeelding 21).

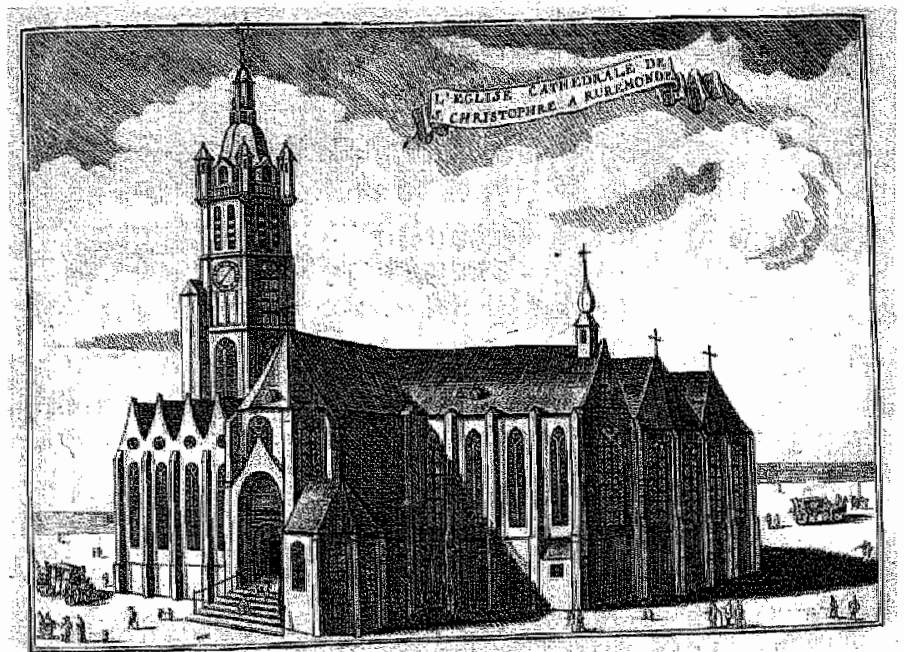

21. Sint-Christoffelkathedraal, Roermond (gravure $\mathbb{~ J . ~ H a r r e w i j n , ~ 1 8 d e ~ e e u w ) ~}$

ende der stadt accysen ende incompsten inbuerde, den vhrwyser aenden boogen thorri van 14 voeten... op der gemeynte costen doen maecken".

6. E. Janssen C.ss.R. 1932, pp. 154-187, met name pp. 167-176; M. Smeets 1953, p. 13 en pp. $19-20$. 
Vanaf het einde van de 16 de eeuw zijn we goed geïnformeerd over de zorgen, besteed aan het Roermondse stadsuurwerk. Aanvankelijk was het onderhoud een neventaak van de koster van de kerk. De stadsrekening van 1579 vermeldt: "Item den Custer vant uhrwerck 18 gl." " ${ }^{65}$ In 1588 werd Tilman Robijns op 29 november aangesteld als stadsuurwerkmaker van Roermond voor vijf gulden Brabants per jaar; tevens kreeg hij opdracht een reparatie aan het uurwerk uit te voeren voor achttien gulden Brabants. ${ }^{66}$ Van Tilman Robijns van Ruremunde wordt in het besluit gezegd: "Tegenwordig tot St. Stefens wehrde (Stevensweert) resideerende". Daar is hij blijkbaar blijven wonen. Op 1 januari 1600 wordt dan ook in het Verdrachsboek genoteerd, dat wegens het afsterven van meester Tilman van Sint-Stevensweert als toeziender op het uurwerk op den hoogen toren wordt aangenomen meester Derick van Vucht. Zijn jaarloon bedroeg zes gulden Brabants. ${ }^{67}$ Op 18 december 1603 werd genoteerd, dat het uurwerk "op den hoogen toren" voor vijftig gulden was gerepareerd en het "uurwerkske" op het raadhuis voor tien gulden. Daarbij gaf men nog drie gulden uit voor een touw. ${ }^{68}$ Wie de reparaties verrichtte wordt niet vermeld. Het uurwerk op het raadhuis was waarschijnlijk een huisuurwerk, dat binnen hing of stond. Het kan gaan om het uurwerk dat de stad had gekregen van de abt van Camp, waarover vijf jaar later commotie ontstond (zie hierna). Van een wijzerplaat aan de buitengevel is nooit een spoor gevonden.

Aan de klokkentoren der Hoogkerk werden niet nader gespecificeerde reparaties verricht in $1605{ }^{69}$ Een raadselachtige mededeling vinden we op 13 maart 1608: "Den rector Carolo Horstano voor de abdij van Camp gegeven het oude uurwerk, dat de Abt van Camp vroeger aan de stad schonk". ${ }^{70}$ De abdij van Camp (tegenwoordig

6s A. van Beurden 1904, p. 195.

${ }^{66}$ G.A.R., Oud-archief, donderdagse protocollen, "den naestleste Novembris" 1588; A. wan Beurden 1908, p. 144, maakt van dit besluit: "Tilman Robijns zal het uurwerk op de Hoichkerck voor $18 \mathrm{gl}$. Brab. onderhouden". Zie voor Tilman Robijns appendix II.

${ }^{67}$ G.A.R., Oud-archief, donderdagse protocallen, d.d. januari (zonder dagaanduiding) 1600 ; A. van Bewrden 1908, p. 149.

68 A. van Beurden, Handelingen 1903, p. 41.

69. A. van Beurden, Handelingen 1903, p. 43:26 mei 1605.

${ }^{70}$ A. van Beurden, Handelingen 1903, p. 52. De originele tekst luidt: "Den heere richter [sic!] Carolo Horstano op sijn supliceerent aenhalden ende om de redenen in sijne requeste verhaelt hebben mein heeren hen tot behouff der abdijen wan Campen geaccordeert ende vergunt het 
Kamp-Lintfort, bij Xanten) was de oudste cisterciënzerstichting in Duitsland. Zij heeft bestaan van 1123 tot 1802 . Het kan vreemd lijken, dat een zo ver van Roermond gelegen abdij de stad een uurwerk schonk. De zaak wordt begrijpelijker, wanneer we weten, dat de abt van Camp het recht van visitatie en biechthoren had van de Munsterabdij. ${ }^{71}$ De abt had bij de schenking bedongen, dat de stad een gebrandschilderd raam met zijn naam in de parochiekerk zou plaatsen. Dit was in 1608 nog niet gebeurd. De verhouding tussen Camp en de Munsterabdij verslechterde in de $17 \mathrm{de}$ eeuw zodanig, dat de taken van Camp werden overgenomen door de abt van Val-Dieu bij Aubel. Wanneer het uurwerk door Camp is geschonken en of de terugvraging verband hield met de losser wordende relatie met de Munsterabdij, weten we niet. Misschien is het feit dat de abdij Camp van eind 16de tot eind 17de eeuw verwoest was en de abten in Keulen resideerden de oorzaak geweest van de tijdelijke onderbrenging van het uurwerk in Roermond. $^{72}$

Op 11 juni 1609 inspecteerde volgens Van Beurden ${ }^{73}$ zekere Henrick den uhrwercker de uurwerken en kreeg daarvoor een malder rogge. In de originele tekst is echter sprake van Henrick der Uhrmecker, die betaling vraagt voor alle reparaties aan het uurwerk, waarmee hij bezig is. De stad gaf hem voorshands elk jaar een malder rogge. Hij moest hiervoor met ingang van juli 1609 het uurwerk regelmatig inspecteren en zonodig repareren, met andere woorden: hij werd stadsuurwerkmaker. De kerkmeesters willden het uurwerk in 1612 hoger plaatsen omdat de toren in 1604 een vierde verdieping had gekregen. ${ }^{74}$ Het voomemen is nooit uitgevoerd. 18 Januari 1618 nam het stadsbestuur het besluit "den custer Teunis

alde uhrwerck, soe eertijts der apt van Campen geschonken hadde aen deser stadt mit conditie, dat die stadt op dem naem van den abt voirsscreven een gelass inde moederkercken stellen sal, dwelck doch niet geschiet"

${ }^{7}$ C. Pyls 1932, pp. $190-191$.

${ }^{72}$ M. Dicks 1915, pp. 449, 481, 487, 499.

${ }^{73}$ A. van Beurden. Handelingen 1903, p. 56: "Henrick den uhrwercker voor het visiteeren der uurwerken een malder rogge". De originele tekst luidt: "Op requeste wan Mr. Henrick der Uhrmecker supplicerende on enig recompens veur die hij alle reparatien aen het urewerck is doende. Wordt denselven jaerlicx by provisie een malder rogge toegelacht, nu voorledig [?] Petri [feest van Petrus en Paulus] 1609 aenfangende mit die conditie dat hij suppliant het urewerck somwylens te visiteeren ende mits hij daarvan bevinden sall tot reparatien noodigh the repareeren gehalden. sall sijn".

${ }^{74}$ A. van Beurden, Handelingen 1903, p. 64, d.d. 5 april 1612. 
Wolfskeel" een hoger loon te betalen, mits hij goed voor het uurwerk zou zorgen. ${ }^{75}$

Soms werd voor speciale reparaties een buitenstaander aangetrokken. Op 28 februari 1625 goot Conrardus van Venlo, een telg uit het geslacht Clockegieters, alias Conraets, alias Janssen, "koperen rollen" voor het stadsuurwerk, tezamen 98 pond wegende. Hij ontving voor elk pond $41 / 2$ stuiver. $^{76}$ Waarvoor de rollen dienden, is niet duidelijk. Mogelijk werden zij op de opwindassen gemonteerd ter vervanging van houten exemplaren.

Ook als er geen vakman bij de hand was zorgde men ervoor dat het uurwerk bleef lopen. Op 3 augustus 1634 werd besloten: "Johan Berentsen van Thiel, custer van de Gereformeerde Kerk, zal s'avonds te 9 uur een half quartier lang trekken, en het uurwerk stellen. Hij krijgt 10 Rijksdaalder het eerste jaar; zal vervallen St. Bartholomeusdag $1635^{\prime \prime} .{ }^{77}$ De man deed zijn werk zo goed, dat pas na geruime tijd weer een deskundige werd ingeschakeld.

De magistraat van Roermond sloot op 6 september 1663 een overeenkomst met meester Tilman Hackhuyzen, horologiemaecker tot Maeseyck, waarin wordt bepaald, dat hij het stadsuurwerk in goede orde zall houden voor tien gulden 's jaars boven zijn mondkost. ${ }^{78}$ Midden 17 de eeuw werd het uurwerk uitgebreid met een kostbaar carillon. In 1664 schafte het Roermondse stadsbestuur een "beyaert in den toren der Cathedrale kerk" aan. De eerste octaaf werd geleverd door zekere Alphonse Hipper, die het burgerrecht kreeg en achthonderd rijksdaalders als vergoeding voor zijn werk. Daarmee was lang niet alles betaald: op 7 augustus 1664 krijgen de arbeiders aan de klokken 520 gl. en $17^{1 / 2}$ stuiver. Daar komen op 9 september van dat jaar nog vierhonderd rijksdaalders bij voor Rochus Grongnart voor het gieten van drie klokken om de "octaef te perficiëren". Aan tin voor de klokken werden nog eens twintig rijksdaalders uitgegeven. ${ }^{79}$

\footnotetext{
7 A van Beurden, Handelingen 1903, p. 73. Hij schrijft "Vuurwerk", terwijl in de tekst uurwerk staat. Ook lijkt er in het origineel Teuwis te staan, niet Teuris.

${ }_{76}$ A. van Beurden 1908, p. 161: "98 pond is \pm 44 kilo""

$"$ A. van Beurden, Handelingen 1903, p. 99.

${ }_{78}$ A. van Beurden, Handelingen 1903, p. 146.

19 A. van Beurden, Handelingen 1903, pp. 149-150. Hoe het met de beiaard is gegaan, is onbekend. Op 18 november 1700 is weer sprake van het oprichten van een beiaard. Men wilde daarvoor de gebroken klok gebruiken die in de parochiekerk lag en door de stad ooit was bekostigd. A. van Beurden, Handelingen 1904, p. 272.
} 
Vanzelfsprekend nam nu ook de aandacht voor het onderhoud toe: "1 maart 1668. De courwachter (torenwachter) zal voortaan voor het uurwerk zorgen. De koster deed zijn plicht niet ${ }^{k 8}{ }^{80}$ Het werd beter. De nieuwe stadsuurwerkmaker, Jan Geurts, kon later ten voorbeeld worden gesteld: "16 maart 1684. Steven Nicolaes zal het uurwerk stellen, zooals de torenwachter Jan Geurts dit heeft gedaan...". ${ }^{81}$

Een belangrijk besluit werd genomen op 4 mei 1688: "De magistraat komt overeen met Johan Lenssen van Well dat deze het uurwerk der stad zal maken voor 35 rijksdaalders, een half ton bier en twee schillingen drinkgeld voor den knecht. Het zal op kosten van den magistraat in 't marktschip en daarmede te Well gebracht worden. Hij zal na reparatie 4 jaar garantie moeten geven...". ${ }^{82}$ Wat in Van Beurdens weergave van het besluit niet wordt vermeld, is het belangrijke feit dat het niet om zo maar een reparatie ging, maar om de ombouw tot slingeruurwerk 32 jaar na Huygens' vinding. Tevens werd met Lenssen overeengekomen, dat hij het uurwerk zou onderhouden voor één ducaton per jaar. Johan Lenssen wordt ook Johan Remmen genoemd. Hij behoorde tot een bekende klokkenmakersfamilie. ${ }^{83}$

Het stadsbestuur besloot op 12 februari 1695 de Roermondse bevolking meer service te verlenen op het gebied van de openbare tijdmeting. Het stelde nachtwakers aan die de uren moesten aangeven, waarschijnilijk door luid te roepen in de trant van "Negen heit de klok, de klok heit negen"! Het bracht niet het verhoopte resultaat. Op 15 februari 1698 werden de twee nachtwakers weer ontslagen en moesten ze hun "stadsmantel" teruggeven. Men ging het nu kalmer aan doen. Daniël Jacobs, een veldschut, werd op 29 juli 1700 tevens belast met de nachtwakersdiensten ${ }^{84}$ Kort daarvoor had de stad het onderhoud van het uurwerk al gereorganiseerd. Op 14 januari 1699 nam zij het besluit: "In plaats van Steven Nicolaes en den horologiemaker van Well zal Philips Simon voor het stadsuurwerk zorgen". ${ }^{85}$ Voor het vergulden van het horologie en het witten

\footnotetext{
${ }^{80}$ A. van Beurden, Handelingen 1903, p. 165.

A. van Beurden, Handelingen 1903, p. 203

${ }^{82}$ A. van Beurden, Handelingen 1903, p. 216.

${ }^{3}$ Zie in appendix II de leden van de familie Remmen.

${ }^{84}$ A. wan Beurden, Handelingen 1903, p. 233; 1904, pp. 265, 271.

${ }^{85}$ A. van Beurden, Handelingen 1904, p. 270.
} 
van een deel van het kapwerk kreeg een zekere Joannnes Ermel op 31 mei 1723 vijf gouden Franse pistolen (muntstukken) uitbetaald. $\mathrm{Na}$ verloop van tijd besloot men het onderhoud weer in deskundige handen te leggen: " 22 juli 1734. Philip Simon, gewezen opzichter deser stadt horlogie overlijdt; Hermanus Beltiëns wordt daartoe aangesteld." Beltjens was een gerenommeerd uurwerkmaker, die onmiddellijk wees op ernstige gebreken. Die mocht hij herstellem. ${ }^{86}$ De tekst van de overeenkomst met Beltjens is gedateerd 5 augustus 1735 en luidt: "Geconvenieert met den horologiemaecker Hermanus Beltiens, dat denselven de stadshorologie in alles, het yserwerck aengaende, sal voorsien ende repareren ende de noodige vier raederen daerinne nieuw ende suffisant maecken, ende soodanigh reguleeren, dat deselve voor het toecommende precijs ende pertinent zije, daervoor den voornoemde horologiemaecker sal genieten eens achthien pattacons, onder verspraeck ende conditie dat hij deselve horologie voor de eygenste somme de daegen sijns levens sal houden in de noodige reparatien ende eijgenste precisitijt". ${ }^{87}$

Kort nadien heeft de stad ervoor gezorgd dat de tijd ook in de kerk kon worden afgelezen. Op 13 juli 1752 wordt een post vermeld van het vergulden van de uurwijzer op het nieuwe orgel van J.B. le Picard door Gerardus Verschuren. ${ }^{88}$ De stad bleef ook nadien het onderhoud aan uurwerk en orgel verzorgen. Op 24 mei 1757 liet zij het uurwerk op de toren herstellen omdat het in 1756 door bliksem en vuur was beschadigd ${ }^{89}$ In 1814 werd de wijzerplaat vernieuwd. ${ }^{90}$ Pas in de 19de eeuw werd het stadsbestuur van Roermond terughoudend. De schade die in 1892 door brand, in 1921 door storm en in 1944 door oorlogsgeweld ontstond kwam niet meer geheel voor stedelijke rekening. Tijdmeting was geen exclusieve taak meer van het stadsbestuur.

\footnotetext{
A. van Beurden, Handelingen 1906, op genoemde data,

${ }^{87}$ G.A.R.R Oud-archief, donderdagse protocollen, inv.nr. 29. torenuurwerk.

${ }^{89}$ A. van Beurden, Handelingen 1904, op genoemde data.

${ }^{90}$ L. Keuller 1932, p. 366.
}

Een uurwerk op het orgelfront treft men nog aan in de hervormde kerk te Vaals en in de proosdijkerk van Kornelimünster (D). Boven het grote renaissance-orgel in de Sint-Janskerk in Den Bosch is een uurwerk met exn automaat, namelijk een ronddraaiende "Totentan $z^{\text {"n }}$ voorstelling. Ook het orgel in de Sint-Sulpitiuskerk te Diest had zo'n uurwerk. Het hangt nu elders in de kerk. De ronde wijzerplaat is omgeven door een houten sculptuur van Vader Tijid en twee putti. Boven het orgel in de Sint-Quintinuskerk te Zonhoven bevindt zich een uurwerk in Louis XVI-stijl. Ook in de begijnhofkerk te Lier is zo'n voorziening, aangedreven door het 


\subsubsection{Het uurwerk van de kapel van O.-L.-Vrouw in ' $t$ Zand}

Van de vele kerken en kloosters binnen de stadsmuren van Roermond schijnt er geen een uurwerk te hebben gehad. De devotiekapel van O.-L.-Vrouw in ' $t$ Zand, één kilometer buiten de stad in een heidegebied gelegen, had er wel een. Rats deelt mee: "Behalve haar torenklok had de Kapel ook haar torenuurwerk of "horlogie", waarvan in de jaren 1700-1800 meermalen in de rekenboeken sprake is. In 1841 is er een nieuw voor in de plaats gekomen, geleverd door Jacob Kamps van Gerderath". ${ }^{91}$ Het stadsbestuur van Roermond, dat de patronaatstechten van de Kapel had, was wellicht ook eigenaar van het torenuurwerk. Het uurwerk was niet bedoeld voor de paar inwoners van de boerderijen, die op geruime afstand van de kapel lagen. Het zal vooral bedoeld zijn geweest om het marktgebeuren, dat rondom de kapel was ontstaan en dat zich niet beperkte tot devotionalia, te reguleren. Het stadsbestuur bemoeide zich hier uitdrukkelijk mee. Dat was uit de hand gelopen. De Donderdagse protocollen van 12 augustus 1744 bevatten een reces van de Tweede Kamer van het soevereine hof van Gelderland, mede namens de magistraat van Roermond, betreffende de kramen bij de Kapel in 't Zand die grote wanordelijkheden veroorzaakten. De kramen, waarin waslichten, kaarsen, wittebrood, fruit, hitsige wateren, haringen en andere levensmiddelen werden verkocht, mochten alleen nog staan bij het stenen kruis langs de bomen op de plekken aangewezen door de bode. De overtreders werd een halve goudgulden boete in het vooruitzicht gesteld benevens inbeslagname van de waren. ${ }^{92}$ Het uurwerk was ook nuttig om de tijden van de missen en plechtigheden aan te geven voor de grote scharen pelgrims. Er werden diensten gedaan vanaf vroeg in de morgen tot aan de middag en soms was het zo druk dat de gewapende macht eraan te pas moest komen om het gedrang te beteugelen. ${ }^{93}$ Op een foto van de oude kapel uit circa 1870 is de wijzerplaat te zien aan de basis van de dakruiter. ${ }^{94}$

9. Rats 1935, pp. 60-61. Ook in de Kapel was een nurwerk of klok, terwijl tot 1841 op het koor een pendule stond.

\$2 G.A.R., Oud-archief, donderdagse protocollen, inv.nt. 33.

${ }^{9}$ I. Rats 1935, p. 81.

* Ach lieve tijd 1988-1989, p. 167. 
Van de kleinere Nederlands-Limburgse steden met een bevolkings-omvang, die in de 14 de en 15 de eeuw iets beneden en soms mis:schien iets boven vijfduizend inwoners lag, was er slechts één, Venlo, waarvan wij met zekerheid weten, dat zij naar Nederlandsee begrippen vroegtijdig, laat-14de eeuw, een torenuurwerk aanschafte: In de andere gevallen hebben wij pas in de 16de eeuw zekerheidl. Het valt op dat het handels- en distributiecentrum Venlo, waar hett goederentransport op de Maas moest worden verbodemd, er zo vilugg bij was, mogelijk in tegenstelling tot steden die hun welvaart voorall ontleenden aan de nijverheden die er floreerden. We moeten im tegenstelling tot Landes en Le Goff bij de verklaring van hett fenomeen wellicht minder letten op de productiezijde in de economie en meer op de maatschappelijke invloed van handel en distritbutie in middeleeuwse steden. 


\section{Hoofdstuk IV}

\section{De openbare tijdmeting in de Belgisch- Limburgse steden Hasselt, Tongeren, Sint-Truiden en Maaseik}

De geschiedenis van de stadstichtingen in Belgisch-Limburg is een heel bijzondere. Tongeren ontwikkelde zich binnen de muren van een Romeins municipium; Sint-Truiden kreeg al vroeg in de Middeleeuwen allure omdat zich rond het oude, 7 de-eeuwse klooster van Sint-Trudo een pre-stedelijke kern ontwikkelde met een burgerij die al in de 12 de eeuw de twee lokale heren, de abt en de bisschop van Luik, handenvol werk bezorgde. Alle overige stadstichtingen in Belgisch-Limburg kwamen voort uit de bekommernis van de graaf van Loon om zijn territorium, dat in de 13 de en $14 \mathrm{de}$ eeuw voortdurend werd bedreigd, voldoende steunpunten te bezorgen. De grafelijke politiek werd meer door kwantitatieve overwegingen geleid dan door kwalitatieve. Van zijn talrijke stichtingen waren er slechts twee succesvol: alleen Hasselt en Maaseik werden steden in sociaal-economische zin, de rest kwam nauwelijks uit boven het niveau van het dorp met een streekfunctie voor omliggende gehuchten. ${ }^{1}$

\subsection{Hasselt}

Hasselt, gelegen in de Demervallei op de grens van de Kempen en de Haspengouw, overvleugelde Borgloon ${ }^{2}$ sedert de 13 de eeuw. Omstreeks $1200 \mathrm{kreeg}$ het van de graaf van Loon stadsrecht naar Luiks model, in 1232 bevestigd door graaf Arnold IV van Loon. In de 13 de eeuw kreeg Hasselt ook een omwalling en werd de Grote Markt aangelegd. Hierheen werden de oude Lakenhalle en de Broodhalle verplaatst. De nieuwe halle diende tegelijk tot vleeshuis, raadhuis en lakenhal. Hasselt groeide uit tot de hoofdplaats van het

'Zie J. Gerits [1989], passim; E. Lavigne 1986; R. Nouwen, conservator van het GalloRomeins Museum Tongeren, brief juni 1995.

2 Zie hoofdst uk $V$, paragraaf $5,1.2$. 
graafschap Loon. Het was gunstig gelegen midden in het graafschap aan enkele belangrijke handelswegen, met name aan een tak van de grote weg van Brugge naar Keulen. Naast de handelsactiviteiten die dit met zich bracht kende Hasselt in de 14 de en 15 de eeuw een bloei als regionaal centrum van lakennijverheid. Reeds in 1313 bestond er een weversambacht. Hoewel de lakennijverheid in de 17de eeuw teloor ging, bleef Hasselt een belangrijke marktplaats. De stad werd in 1839 de hoofdstad van Belgisch-Limburg.

\subsubsection{De stadsuurwerken en de stadsuurwerkmakers}

Op het dak van de lakenhal aan de Grote Markt was een torentje, waarin een stadsuurwerk stond met een luidklokje, waarop het uur werd geslagen. Tegen de gevel was een zonnewijzer aangebracht, zodat men bij tijd en wijle het uurwerk kon bijstellen. Bij de beschieting van Hasselt in 1567 werd het gebouw zwaar beschadigd. ${ }^{3}$ Het stadsbestuur was genoodzaakt naar een andere behuizing te vertrekken. Het kocht in 1580 voor 1.225 gulden de grote herberg "die Crone" aan de Jodenstraat om als raadhuis te dienen. ${ }^{4}$ Hier zetelde het tot 1779. Toen werd het huis aan de Groenplaats gekocht, dat thans nog als stadhuis dienst doet. Boven in het fronton van dit gebouw werd het uurwerk van de lakenhal geplaatst. Nadat het uurwerk enige tijd vervangen was geweest door het stadswapen werd het in 1863 weer teruggeplaatst. Wel heeft men toen het slagwerk uitgeschakeld omdat men er niet in slaagde de stadhuisklok en de kerkklok synchroon te laten slaan. ${ }^{5}$ Een tweede uurwerk, waarvan het onderhoud ten laste van de stad kwam, was geplaatst in de toren van de Sint-Kwintenskerk, de belangrijkste kerk van de stad (zie afbeelding 22).

Beide uurwerken stammen ten laatste uit de eerste helft van de $15 \mathrm{de}$ eeuw. Het kleine smeedijzeren uurwerkje, dat in het Beiaardmuseum in de toren van de Sint-Quintinuskerk wordt aangeduid als Stadhuisuurwerk, kan onmogelijk een stadsuurwerk uit de eerste

${ }^{3} G_{n}$ Caluwaerts 1989 , pp. 37-38. In 1670 werd de lakenhal gedeeltelijk afgebroken. De restanten werden tot in de Moderne Tijd voor verschillende doeleinden gebruikt.

' G. Caluwaerts 1989, p. 235.

${ }^{5}$ G. Caluwaerts 1989 , p. 235. 


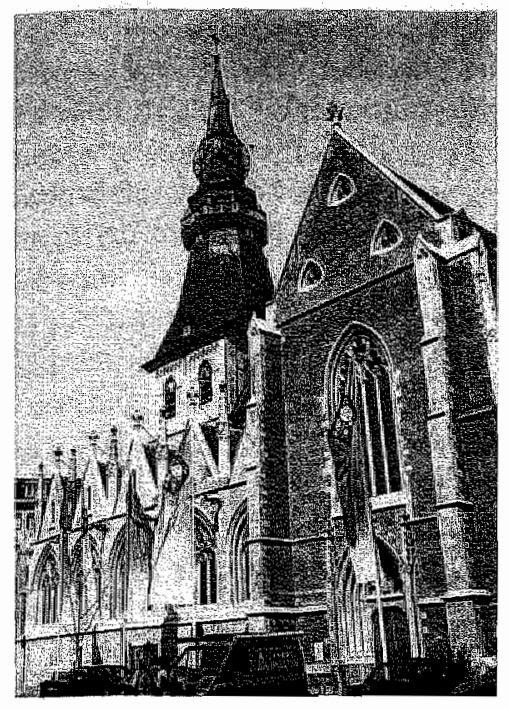

22. Sint-Quintinuskathedraal, Hasselt. De toren draagt vier cijferringen

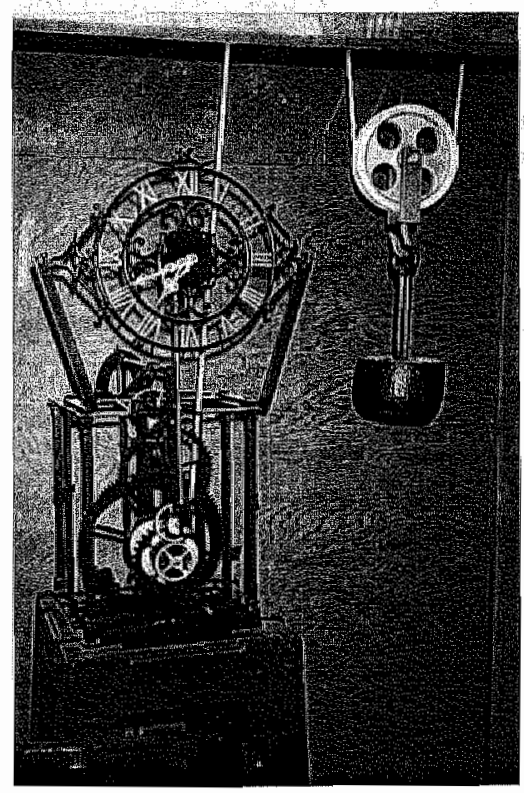

23. Zogenaamd stadhuisuurwerk met veel latere toevoegingen (in Beiaardmuseum, Hasseli). Het is te klein en te licht om als torenurwerk te kunnen hebben gediend (16de ceuw?) 
helft van de 15 de eeww zijn. Het is veel te klein en te licht uitgevoerd om een grote wijzer te kunnen aandrijven of een zware luidklok aan te slaan. Het volume van het uurwerkje valt in het niet bij dat van het stadsuurwerk van Maaseik, het uurwerk in het Dinghuis in Maastricht of het uurwerk van de Sint-Gommaruskerk in Lier. Zo'n uurwerkje als stadsuurwerk zou ver beneden de stand zijn van een stad als Hasselt met zoveel grote torenuurwerkbouwers (zie afbeelding 23).

Sedert het midden van de 15 de eeuw staan ons gegevens ter beschikking over onderhoud en herstel. De oudst bekende stadsuurwerkmaker was Bartholomeus Colen, alias Mewis Koelen. Hij was tenminste van 1451 tot 1494 in functie ${ }^{6}$ en had beide stadsuurwerken te onderhouden. Hij was een vooraanstaand ambachtsman. Binnen het smedenambacht bekleedde hij verschillende bestuursfuncties.

Hendrik van Diest volgde hem op een onbekend tijdstip op als stadsuurwerkmeester. Hij bleef tot 1498 in functie. In dat jaar nam Vaes Colen, wellicht een zoon van Mewis, het ambt over. Hij had trouwens al tijdens de ambtsperiode van Van Diest voor rekening van de stad herstellingen uitgevoerd. Van 1514-1520 en van 15271539 was Mewis Colen Jr., een kleinzoon van de eerdergenoemde Bartholomeus Colen, stadsuurwerkmaker. In 1529 leverde hij aan de stad de eerste voorslag voor het uur en het halve uur. ${ }^{7} \mathrm{Zijn}$ aanstelling werd onderbroken door de ambtstijd van Jan Blaesen, smid en slotenmaker, die van 1520 tot 1527 tevens stadsuurwerkmaker was. De herstellingen werden in die jaren nu eens door hemzelf, dan weer door Vaes Colen Jr. verricht. Deze Vaes Colen $\mathrm{Jr}_{\text {r. }}$ die zijn vader Mewis Colen $\mathrm{J}_{\mathrm{r}}$. van 1534 tot 1539 assisteerde, werd in 1539 de enige stadsurwerkmaker. Hij vervalde deze functie tot 1545 .

Dries Messmeickers, de opvolger van Vaes Colen Jr., werd reeds in 1548 als hersteller verdrongen door Willem Vossen, Lambrecht Blaesen en Hendrick van Nuyst. Gedurende het eerste half jaar van het boekjaar 1549-1550 was Lambrecht Blaesen de enige stadsuurwerkmeester. Hij was een belangrijk klokkenmaker, die torenuurwerken leverde aan verschillende steden, tot Antwerpen toe. ${ }^{8}$

\footnotetext{
J. Letunis 1958 , p. 292.

J. Granwels 1982 c, p. 29, nr. 178.

Zie appendix II onder Blaesen, Lambrectht.
} 
Eind 1549 of voorjaar 1550 werd hij opgevolgd door Hendrik van Nuyst, ook wel Van Nuest of Van Neuss genoemd. Van Nuyst was, hoewel hij in het smedenambacht slechts als messenmaker stond ingeschreven, een befaamd constructeur van torenuurwerken. Hij leverde zijn producten tot in Delft en Leiden. ${ }^{9} \mathrm{Hij}$ is de enige, die uitdrukkelijk als uurwerkmaker wordt vermeld, al is het maar één keer. In het smedenambacht bekleedde hij verscheidene bestuursfuncties.

Zijn opvolger was van 1580 tot 1582 Jaspar Sporckels. Hij was tevens beiaardier en stadsweger. Dat hij ook uurwerken vervaardigde, staat niet vast. $\mathrm{Na}$ het overlijden van Sporckels in 1583 nam Maarten Deeckens het ambt gedurende enkele maanden waar. Jarenlang was Deeckens stadsartilleriemeester. Hij heeft verschillende grote torenuurwerken geleverd en bekleedde vaak bestuursposten in het smedenambacht.

Spoedig, nog in 1583, nam Kerst Janssen, alias Christiaen der Smeet, het ambt van stadsuurwerkmaker op zich. Hij bleef in functie tot 1586 . Hij was eigenlijk slotenmaker van beroep.

Jan Minne was stadsuurwerkmaker van 1586 tot 1602 , het jaar van zijn overlijden. Hij verrichtte ook herstelwerkzaamheden. Huibrecht Liefsoens volgde hem op. Liefsoens moest ook haakbussen schoonmaken en herstellen. Hij bleef tot 1625 in functie. In 1612 leverde hij een nieuw uurwerk aan de stad.

Na het overlijden van Liefsoens werd Jan Noelmans stadsuurwerkmeester tot zijn overlijden op 3 april 1652. In 1618 en 1619 heeft hij haakbussen gerepareerd voor de stad.

Huibrecht Liefsoens Jr., zoon van eerdergenoemde Huibrecht, fungeerde als stadsuurwerkmaker van 1652 tot 1654 . Een zoon van Jan Noelmans, Frans, was van 1654 tot 1665 stadsuurwerkmeester van Hasselt.

De laatste uit de literatuur bekende stadsuurwerkmaker is Herman Braunts, alias Bronius. Hij werd in 1665 aangesteld en had reeds in 1658 samen met Frans Noelmans het stadsuurwerk hersteld. Hij wordt geregeld "smid" genoemd. Op 12 juli 1665 betaalde de stad zekere Alard van Tilborch voor een boek met liedjes voor het hele jaar om "het spelrat van die horologie op de toren te stellen". ${ }^{10}$ Sindsdien sluit de reeks niet meer. Uit de laatste decennia van de

\footnotetext{
${ }^{8}$ Zie appendix II onder Nuys(t), Hendrik yan.

10. Grauwels $1982 \mathrm{c}$, p. 88 , nr. 590 .
} 
17 de en de 18 de eeuw zijn slechts enkele namen van uurwerkmakers bekend: Ivo Ulrix, Wouter Loets, Richard van Intbrouck. Laatstgenoemde kreeg in 1740 opdracht de stadsuurwerken in orde te brengen. " Daarnaast traden op Jan Noelmans uit het Schuttershof, Deeckens van de Raamstraat, Jan-Jacob Lieffsoons uit Die Catte in de Joedenstraet en Leonard Joosten. De laatste had zich in 1794 vanuit Maseik in Hasselt gevestigd en was in het begin van de 19 de eeuw stadsuurwerkmaker van Hasselt. ${ }^{12}$

In 1751 kocht Hasselt voor de Sint-Kwintenskerk een nieuw uurwerk met speeltrommel bij Gilles de Beefve in Luik. Het koopcontract de dato 1 december 1751 is bewaard gebleven en bevat 32 punten. ${ }^{13}$ De bestelling werd in 1752 geleverd, zoals blijkt uit het opschrift op de speeltrommel: "Fait à Liège par Gilles de Beefe / et de son fils Nicolas Le 2 me 9 bre $1752^{\prime \prime} .{ }^{14}$ Het is een zogeheten "springtrommel", dat wil zeggen dat het trommelklavier, het onderdeel dat de "noten" op de trommel aftast, een paar centimeter kan verschuiven. Zo kunnen er meer wijsjes op worden gezet. De trommel heeft 17.920 gaatjes en is geplaatst in een ijzeren raamwerk met pilaren, bekroond door Ionische kapitelen van messing. Het raamwerk is $175 \mathrm{~cm}$ lang, $125 \mathrm{~cm}$ diep en $150 \mathrm{~cm}$ hoog. Het gaande werk en het slagwerk zijn verdwenen. De klok sloeg het hele en halve uur, het kwartier en waarschijnlijk ook het halve kwartier, net zoals het geval was in Sint-Truiden en Lier. Het geheel werd in 1862 gemoderniseerd door G. Creten en zonen uit Sint-Truiden ${ }^{15}$ (zie afbeelding 24). Na de verwijdering van het gaande werk werd de tijdmeting overgenomen door een uurwerk met "gravity escapement" zoals in de Big Ben in Londen. Het is een product van Michiels uit Leuven. Dit uurwerk is bewaard gebleven, maar niet meer in functie.

" J. Grauwels $1982 \mathrm{c}$, p. 114, nr. 766: "1740, 13 september. Richard van Intbroeck krijgt wan de stad opdracht alle stadsuurwerken "die langen tijt stil gestaen hebben oft qualyck gegaen" te herstellen".

${ }^{12}$ G. Caluwaerts 1989, p. 173, noot 23. Jammer genoeg geeft Calnwaerts geen bronnen en niet alle jaartallen.

${ }^{13}$ R.A.H., Fonds Hasselt.

14 De familie De Beefe heeft tot in Portugal toe gewerkt. Zie voor de twee grote uurwerken met carillon van de familie De Beefe te Mafra: A. Lehr 1984, p. 35. Hij citeert ook Prosper Verheyden, Triumphdicht over den nieuwe carlejon, 1752.

${ }^{15}$ Opschrift aan de achterkamt wan het trommelklavier: "Mis en rapport avec les progrès de l'art de lhorlogerie par $\mathrm{G}$. Creten et ses fils, horlogers à St.-Trond le 15rne Juillet 1862". 


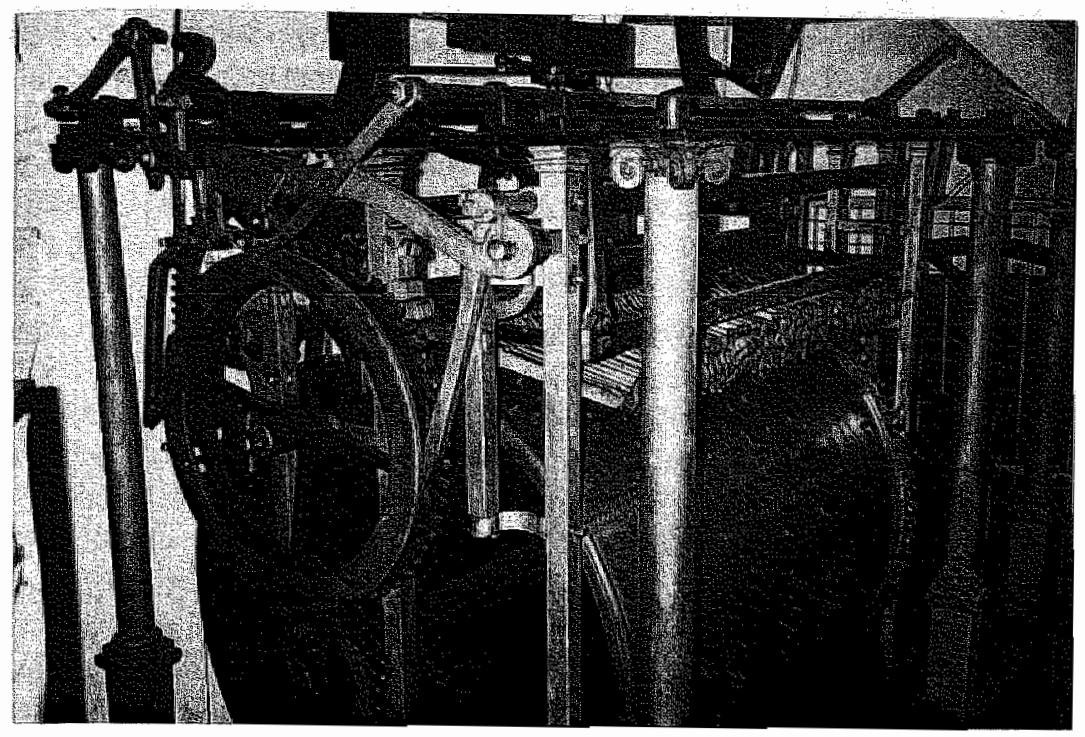

24. Torenuurwerk met speeltrommel, Sint-Quintinuskathedraal (uurwerk door Gilles de Beefe en zijn zoon Nicolas, Luik , 1752). Het gaande werk en het slagwerk ontbreken

Hasselt heeft, zoals uit het bovenstaande blijkt, meestal vakmensen als stadsuurwerkmaker in dienst gehad, soms zelfs zeer gerenommeerde. Slechts in het geval van Jaspar Sporckels ging het om een bijbaan van de stadsbeiaardier. Ook komt in Hasselt opvallend vaak de combinatie stadsuurwerkmaker met stadsgeschutmeester voor. In de 14 de en vroege 15 de eeuw waren die functies in grote delen van Europa in dezelfde hand geweest. ${ }^{16}$. Zelden bleef de combinatie zo lang bestaan als in Hasselt.

\subsection{Tongeren}

Tongeren is gelegen aan de Jeker, in het overgangsgebied van Droog en Vochtig Haspengouw. Reeds in de Romeinse tijd had Tongeren, Atuatuca Tungrorum geheten, allure. Tongeren bleef ook na de Romeinse tijd bewoond. In 980 werd het door keizer Otto II aan de prinsbisschop van Luik geschonken, waaraan het bleef

3ie voor meer voorbeelden en literatuur hierover hoofdstuk VIII, paragraaf 8.2.1. 
behoren tot de Franse tijd. De Tongerse stadsvrijheid, in de zin van stedelijk gebied, wordt voor het eerst in 1261 genoemd. De middeleeuwse stadskern kreeg een nieuwe ommuring, die omstreeks 1290 was voltooid. Aan de markt, het middelpunt van de stad en de handel, verrees op de plaats van het munthuis een vleeshal, waarin op de eerste verdieping de Raad vergaderde. Er was ook een schepenhuis aan de markt. Sinds 1250 wordt er een lakenhal in Tongeren vermeld, wat wijst op lakennijverheid. Vooral in de $12 \mathrm{de}-$ $13 \mathrm{de}$ eeuw, maar ook later, was Tongeren een bloeiend regionaal marktcentrum. Er was een vrije jaarmarkt, die veertien dagen duurde. In de nieuwe politieke constellatie na de aftocht van de Fransen kwam Tongeren tot de provincie Limburg te behoren.

\subsubsection{De stadsuurwerken en de stadsuurwerkmakers}

Het oude stadhuis had een uurwerk, want de oudst bekende Tongerse stadsuurwerkmaker, Thomas Dekens Sr. (Maes Dekens der alde), was van 1477 tot 1518 in dienst voor het onderhoud ervan. ${ }^{17} \mathrm{De}$ toren van de O.-L.-Vrouwekerk, de enige andere plaats waar ook een stadsuurwerk werd opgesteld, kreeg zijn eerste uurwerk pas in 1565 , zoals we nog zullen zien. ${ }^{18}$ De stadsmagistraat besloot in 1517 een nieuw "Raethuijs" te bouwen. De uitvoering van dit besluit liet echter op zich wachten tot 1558 , toen het oude inmiddels geheel was vervallen. ${ }^{19}$ Onduidelijk is of dit nieuwe stadhuis ook een nieuw uurwerk kreeg of dat het oude werd herplaatst. Tot dat moment werd het oude uurwerk nog verzorgd. Sinds 1518 gebeurde dit door Dekens' zoon Maezen Dekens der jonge, die het ambt waarnam tot 1529 . Thomas Dekens Jr. had blijkbaar een eigen atelier voor de bouw van torenuurwerken. Hij leverde in 1529 een uurwerk aan Borgloon, dat door kapittel en stad gezamenlijk werd betaald. ${ }^{20}$

De derde stadsuurwerkmaker die we kennen, is Ghijs Ho(e)len. Hij was nog in 1550 in dienst. Ook hij genoot faam vanwege zijn vakkennis. Hij verrichtte herhaldelijk herstelwerkzaamheden aan

\footnotetext{
${ }_{17}^{7}$ J. Leunis 1958, pp. 278, 282, 292.

E. Schreurs 1990, p. 192.

${ }^{19}$ P. Severijns en V. Ruwet 1985, nrs. 236, $286,290$.

I. Leunis 1.958, pp. 278, 282.
} 
het uurwerk van de abdij te Munsterbilzen, dat circa tien kilometer ten noorden van Tongeren ligt. ${ }^{21}$

Als vierde hebben we Salomon de Bochstey, alias meyster Salomon Boechten of Salomon in de Moriaen op de Pertsmerck. Hij was stadsuurwerkmeester rond 1560 en zorgde voor het uurwerk op het nieuwe stadhuis. Dat hij niet alleen dagelijks onderhoud kon verrichten, zoals Leunis ${ }^{22}$ suggereerde, maar heel wat meer kon, blijkt uit het feit dat hem in 1560 grote opdrachten voor het uurwerk van de abdij te Munsterbilzen werden verstrekt. ${ }^{23}$

Michiel Ho(e)len, waarschijnlijk een zoon van Ghijs, werd in 1565 de vijfde ons bekende Tongerse stadsurwerkmaker. Hij moest naast het uurwerk van het herbouwde stadhuis ook het nieawe uurwerk in de O.-L.-Vrouwetoren onderhouden, dat daar inmiddels door Lambrecht Blaesen uit Hasselt was geplaatst. Volgens een bron kostte het 179 Brabantse florijnen, volgens een andere 397 guldens. ${ }^{24}$ In 1566 vroeg Hoelen wegens verdubbeling van zijn werkzaamheden salarisverhoging. Die kreeg hij met terugwerkende kracht tot 1565. Men hechtte eraan dat beide uurwerken goed werden onderhouden, ook al stonden ze vlakbij elkaar. Hoelen werd bepaald genereus behandeld. Hij verdiende voortaan 110 gulden current, wat een verhoging van $450 \%$ betekende. ${ }^{25}$ Weldra ging het stadsbestuur bezuinigen. In 1580 wordt een nieuwe uurwerkmeester, Peter van der Eijcken, vermeld. Hij verdiende 98 gulden current. ${ }^{26}$ Dat was na twintig jaar inflatie merkelijk minder dan het salaris van zijn voorganger.

Rond 1585 kreeg de O.-L.-Vrouwetoren een carillon. ${ }^{27}$ Dit riep nieuwe problemen op: de beiaard moest worden bespeeld en de automatische speeltrommel vroeg van tijd tot tijd om nieuwe wijsjes. Wilde het carillon voldoen, dan moest het uurwerk in

\footnotetext{
${ }^{*}$ R. Vanheusden 1973, pp. 270-271.

${ }^{22}$ J. Leunis 1958 , p. 283.

${ }^{23} \mathrm{R}$. Vanheusden 1973 , pp. $271-272$.

${ }^{24}$ Volgens P. Severijns en V. Ruwet 1985 , p. 54, nr. 290, kostte het 179 florijnen. E. Schreurs 1990 , p. 192, noemt evenwel een prijs vam 397 florijnen en een gewicht van 3.012 pond.

${ }^{25}$ J. Leunis 1958 , p. 283.

${ }^{26} \mathrm{~J}$. Leunis 1958 , p. 283.

${ }^{27} \mathrm{Het}$ is onduidelijk of dit de eerste beiaard is. Op 7 juli 1500 besliste de stad de Romaanse toren wan de O.-L.. Vrouwe af te breken. De beiaard en de klokken moesten in de nieawe toren worden geplaatst. Vanwege de slechte financiën van de stad wend de afbraak niet aangepakt. Het probleem loste zich op, toen de toren in 1529 instortte. Zie P. Severijns en W. Ruwet 1985 , p. 42 , nr. 213 en p. 49 , nr. 258.
} 
perfecte staat zijn. Vanwege de speeltrommel was het immers nauw verbonden met het carillon. Men zocht daarom mensen die zowel muzikaal als technisch begaafd waren, personen die het uurwerk met speeltrommel en de beiaardconstructie konden onderhouden en tevens in staat waren de beiaard te bespelen en nieuwe wijsjes te versteken op de speeltrommel. Deze combinatie was in de eigen stad niet te vinden. Men trok Philip Innocet uit Rijsel (Lille) aan orn in één jaar tijd (1587-1588) een inwoner van Tongeren het beiaardspel te leren. Isbrandus Matthaei, een koster van de O.-L.Vrouw, werd de leerling van Innocet. Hij was waarschijnlijk meer musicus dan technicus. Voor de technische kant sloot het stadsbestuur daarom een contract met Jan Ingels uit Mechelen. Deze zou op afroep steeds onmiddellijk naar Tongeren afreizen voor reparaties. Hij was in feite stadsuurwerkmaker. Die moeizame constructie is tien jaar in stand gebleven. In 1598 bestelde Tongeren een torenuurwerk bij Thierry Friesnet te Bergen (Mons) omdat het oude na blikseminslag door brand was vernield. ${ }^{28}$ Friesnet bleek niet in staat het te leveren. Daarop wendde de stad zich tot Maarten Dekens in Hasselt. Deze bood onmiddellijk een oud uurwerk te huur aan in afwachting van het nieuwe dat hij in 1599 leverde. Afgesproken werd dat hij gedurende zes jaar (1599-1605) zou zorgen voor de nodige herstellingen. Zo werd hij de opvolger van Ingels. ${ }^{29}$

Inmiddels was er ook een nieuwe beiaardier gekomen. In 1594 was Matthei vervangen door Jan van Meldert, alias Mellarts. Hij zou tot 1638 in functie blijven. $\mathrm{Hij}$ verdiende vijftig gulden Brabants. Waarschijnlijk had hij enige technische feeling of werd hij bijgeschoold door Maarten Dekens. Volgens Schreurs was hij behalve beiaardier ook horlogemeester van de O.-L.-Vrouw. ${ }^{30}$

Ook zijn opvolger Jan Keyen combineerde beide functies. Bovendien was hij koster. Hij oefende deze taken uit van 1638 tot 1667. Vanaf 1667 tot 1672 was hij enkel nog beiaardier, maar met behoud van het volledige salaris, vijftig gulden Brabants. ${ }^{31}$

In het eerste half jaar van 1667 werd Keyen gedeeltelijk vervangen door zangmeester Henricus Pelsers. Het is niet duidelijk of deze

\footnotetext{
${ }^{23}$ P. Severijns en V. Ruwet $1985, p_{4} 60$, ni. 330 .

${ }^{29}$ J. Leunis 1958 , p. 284.

${ }^{301}$ E. Schreurs 1990 , p. 140 , tabel 18 .

10. J. Leunis 1958 , p. 284 ; E. Schreurs 1990 , p. 140, tabel 18.
} 
vervanging alleen betrekking had op de functie van horlogemeester of ook op die van koster. ${ }^{32}$

Sinds het tweede half jaar van 1667 fungeerde Hubertus Adams als stadsururwerkmeester. Het was zijn enige functie en dus kreeg hij slechts een wedde van 25 gulden Brabants. Hij bleef in functie tot 1677, het jaar van de fatale brand in Tongeren. In de rekeningen van 1675 wordt nog een betaling vermeld van 25 gulden Brabants aan vicaris Lambertus Wijnants. Het is niet duidelijk of hij beiaardier in vaste dienst was. Mogelijk was hij slechts tussenpersoon. ${ }^{33}$

\subsubsection{Openbare uurwerken niet aan de stad behorend}

\subsubsection{Het uurwerk van de toren van de O.-L.-Vrouwekerk}

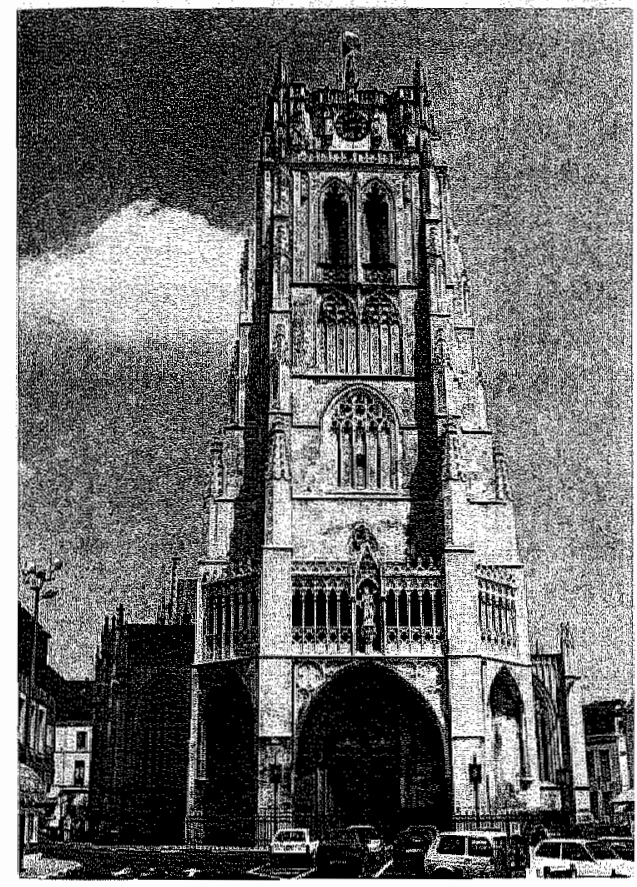

25. Toren var de O.-1.-Vrouwekerk, Tongeren

${ }^{32}$ J. Lemnis 1958 , p. 284 ; E. Schreurs 1990 , p. 140 , tabel 18 en voetnoot 432 .

${ }^{3}$ J. Leunis 1958 , p. 285 ; E. Schreurs 1990, p. 141, tabel 18 , voetnoot 433 . 
De stad Tongeren was niet in staat de in 1677 verwoeste toren van de O.-L.-Vrouwekerk (zie afbeelding 25) te herstellen en besloot op 24 december 1690 hem af te staan aan het kapittel. ${ }^{34}$ Van dat moment af werd de beiaardier door het kapittel betaald en sinds 1719 ook de "horlogemeester" ${ }^{35}$ In 1707-1708 kreeg de toren een nieuw uurwerk van Michel Beurquet uit Luik. Het werd in 1772 grondig gerenoveerd. ${ }^{36}$ Hoe het met de beiaard is gegaan, is niet helemaal duidelijk. In 1782 kwam er een nieuwe beiaard van 35 klokken, gegoten door François Chaudoir uit Luik. Er zijn vage aanwijzingen, dat men zich intussen heeft beholpen met een noodbeiaard of met de zeven resterende klokken van de oude beiaard. ${ }^{37}$ Dit zevental werd in de nieuwe beiaard opgenomen, zodat deze 42 klokken telde.

Het koppelen van de nieuwe beiaard aan het uurwerk vlotte niet erg. Op 2 april 1784 wilde men een akkoord sluiten met de Tongerse klokkenmaker Martinus Mertens om dit karwei uit te voeren. Men kwam niet tot overeenstemming en nam daarom contact op met zekere Fourneau en tenslotte met Gilles Rouma te Luik. De laatste bleek bereid het werk uit te voeren. Hij leverde en passant ook nog twee klavieren en een messing speeltrommel van 1.100 pond met 9.360 gaten voor 4.000 gulden. ${ }^{38}$ In 1787 kwam het kapittel met hem overeen, dat hij jaarlijks zowel het uurwerk als het klokkenspel zou onderhouden voor 78 gulden per jaar. ${ }^{39}$

Vanwege het ontbreken tot 1708 van een uurwerk vaceerde de functie van stadsuurwerkmeester van 1677 tot 1710 . Tussen 1708 en 1710 heeft Beurquet het onderhoud wellicht nog verricht. De eerste die de traditie voortzette, was Nicolaus Huysmans. Hij was in dienst van 1710 tot 1748 . In 1748 vervulde Johannes Huysmans, misschien een zoon van Nicolaus Huysmans, slechts één jaar lang de functie. Ook Hubertus Vrints was kort in dienst: van 1749 tot 1751 voor tachtig gulden Brabants per jaar.

Zijn opvolger Wilhelmus Gerets hield het langer vol, namelijk van 1751 tot 1776. Zijn salaris bedroeg honderd gulden Brabants, met inbegrip van de wedde als koster. Johannes Lambertus Petershem

\footnotetext{
${ }^{34}$ P. Severijns en V. Ruwet 1985, p. 77, nir. 435.

${ }^{35}$ E. Schreurs 1990, pp. 138 en 193.

${ }^{36}$ J. Leunis 1958, p. 285; E Schreurs 1990, p. 193; F. Pholien 1933, p. 117.

${ }^{37}$ E. Schreurs 1990, pp. 195-196.

${ }^{38}$ J. Vols $1954, \mathrm{pp} .229 .230$.

${ }^{39}$ E. Schreurs 1990, p. 200.
} 
combineerde van 1777 tot 1785 weer de ambten van horlogemeester en beiaardier. Dan houden de vermeldingen op. $\mathrm{Na}$ hem $\mathrm{kan}$ de functie zijn opgeheven, zoals later in andere steden ook gebeurde. Alleen groot onderhoud was nog aan de orde. Vols vermeldt zonder opgave van bronnen, dat in 1812 uurwerk en beiaard werden hersteld en dat einde oktober 1818 de stad - het kapittel bestond niet meer - een ijzeren wijzerplaat met vergulde letters liet aanbrengen tegen de voorzijde van de toren. ${ }^{40}$ In 1877 werd de torenspits veranderd en raakte de beiaard in onbruik tot $\mathrm{M}$. Michiels Sr. uit Doornik in 1913 het instrument herstelde. Rond 1920 herstelde P. Michiels nit Mechelen de speeltrommel, die elk half kwartier speelde. ${ }^{41}$ De trommel is thans buiten gebruik, maar staat nog in onttakelde toestand in de toren: de windvleugel en de wals met tandrad van het aandrijfgewicht liggen ernaast. Het is geen springtrommel, zoals L. Meilink-Hoedemaker beweert. ${ }^{42}$ De trommel is niet gesigneerd noch gedateerd. Zij lijkt niet ouder dan circa 19131920 en is mogelijk van M. of P. Michiels. In dezelfde ruimte als de trommel staat een eveneens onttakeld torenuurwerk van het "flatbed-type", waarvan alleen twee slagwerken over zijn. Het ongesigneerde uurwerk dateert eveneens van het begin van de 20 ste eeuw.

\subsubsection{Het uurwerk binnen in de O.-L.-Vrouwekerk}

Vóór het koor, mogelijk op het doksaal, een mooi gebeeldhouwde afscheiding tussen priesterkoor en schip van de kerk, ${ }^{43}$ bevond zich een uurwerk. In 1475 werd het "horologium ante chorum" hersteld door J. Decani, alias Johannes Dekens en in 1488 door Bartholomeus Colen Sr. uit Hasselt in opdracht van het kapittel. ${ }^{44}$ Dit uurwerk zal steeds eigendom zijn geweest van het kapittel, in tegenstelling tot het uurwerk in de toren, dat, althans tot 1690 , stadseigendom was. Verdere berichten over dit uurwerk werden niet aangetroffen.

J. Vols 1955, p. 112, voetnoot 14.

"G. Huybens 1994 , p. 148.

${ }^{42}$ L. Meilink-Hoedemaker 1985, p. 63.

${ }^{43}$ E. Schreurs 1990, pp. 311-312.

4. J. Leumis 1958 , pp. 282 en 292. 


\subsubsection{Het uurwerk van de Sint-Janskerk}

De Sint-Janskerk, die volgens Thys reeds in de 12 de eeuw bestond, had tenminste sedert 1488 een torenuurwerk. Uit dat jaar is een overeenkomst bewaard gebleven met koster Gyelys G(e)laesmekers in verband met het luiden, dienen, sluiten en openen van de kerk, het stellen van het uurwerk alsook de assistentie bij het zingen. ${ }^{45}$ Daarna horen wij er een halve eeuw lang niets meer van.

In 1543 werden enkele klokken gegoten voor de Sint-Jan, namelijk een grote klok, "scellen" en een uurklok. De laatste wijst op de aanwezigheid van een uurwerk. Dit uurwerk werd in 1555 hersteld aangezien het "ghebroken ende ontstelt" was. Wie de herstelling verrichtte, kon niet worden achterhaald. ${ }^{46}$

In 1606 stortte de toren in; hij werd in 1615 weer opgebouwd. Het kerkgebouw werd in 1752 afgebroken en daarna weer opgebouwd. Dit liet de toren onverlet. Hierin was blijkbaar na de wederopbouw weer een uurwerk geplaatst; door wie en wanneer wordt niet vermeld. Het werd vanaf de 17 de eeuw onderhouden door een "horlogemeester", die meestal ook de functie van blazer en/of onderkoster vervulde. In 1763 herstelden "horlogemeester" Henricus Maquoy en Johannes Wilhelmus Hausmans dit uurwerk voor 64 gulden. ${ }^{47}$

In de Franse tijd diende de Sint-Janskerk als vergaderplaats voor de Municipaliteit en als magazijn voor veevoeders. Daarna werd ze tot hulpkerk gedegradeerd en op 5 maart 1805 werden haar goederen en inkomsten aan de fabriek van O.-L.-Vrouwekerk overgedragen. In 1837 werd de Sint-Jan weer een zelfstandige parochiekerk. ${ }^{48}$ Over de lotgevallen van het torenuurwerk wordt nergens meer gerept.

\subsubsection{Het uurwerk van de Begijnhofkerk}

De Begijnhofkerk kreeg in 1709 een uurwerk. Of dit het eerste was of een vervangend exemplaar, is niet bekend. We lezen hierover: "Een ander Tongers uurwerkmaker, Nicolas Hausmans (alias Claus

\footnotetext{
${ }^{45}$ F. Schreurs 1990, pp. 318 en 324.

${ }^{46}$ F. Schreurs 1990, p. 324.

${ }^{47}$ E. Schreurs 1990, pp, 324-325.

4. Baillien 1967, p. 153 .
} 
Huysmans) geboren te Tongeren in 1672 en reeds vader in 1701, was eveneens smid. Hij leverde misschien in 1709 het uurwerk, dat in de gevel van de Begijnhofkerk werd aangebracht. Immers in december 1709 moest hij een kraag voor het Begijnhof hermaken en regelmatig moest hij de herstellingen aan het uurwerk uitvoeren. Het uurwerk stond in verbinding met twee klokjes.

De koster van de Begijnhofkerk, zekere Vlecken, onderhield het uurwerk van 1709 tot 1736 tegen een jaarwedde van 30 gulden". ${ }^{49}$ Verder vernemen we niets over het uurwerk van deze kerk.

\subsection{Sint-Truiden}

Sint-Truiden, in de Haspengouw gelegen, heeft zich in de schaduw van de Sint-Trudo-abdij uit de nederzetting Zerkingen (Sarchin̈um) tot stad ontwikkeld. In $1227 \mathrm{kwam}$ Sint-Truiden gedeeltelijk in bezit van de Luikse prinsbisschop, het andere gedeelte behoorde aan de abt toe. Sint-Truiden was als Maastricht een tweeherige stad. Het was een van de belangrijkste bedevaartplaatsen in de zuidelijke Nederlanden. Omdat het was gelegen aan de handelswegen Keulen-Boulogne en Brugge-Keulen ontstonden er handelsactiviteiten. In 1366 werd er op de markt een halle gebouwd, op de grens van beide jurisdicties. In de halle vergaderde ook de Raad. De halletoren of belfort is, met aanpassingen uit 1606-1607, nog bewaard als onderdeel van het stadhuis op de Markt. De nijverheid, lakenweven en bierbrouwen, was van lokaal belang; de markt had een regionale uitstraling.

\subsubsection{Het stadsuurwerk}

Sint-Truiden schijnt al vóór 1486 een stadsuurwerk te hebben gehad. Leunis ${ }^{50}$ laat zijn lijst van stadsuurwerkmakers beginnen met Jan Vrijmans, die vóór 1486 in stadsdienst was getreden. Het uurwerk was waarschijnlijk opgesteld in het belfort (zie afbeelding 26). Het stond met minstens één grote klok en vier schellen in

4. J. Leunis 1958, p. 285; E. Schreurs 1990 , p. 338, tabel 43, noemt een Lambertus Vlecken, die van 1706 tot 1737 koster was van de begijnhofkerk. Vergelijk 3. Paquay 1913, p. 25.

${ }^{30}$ J. Letains 1958 , p. 287. 


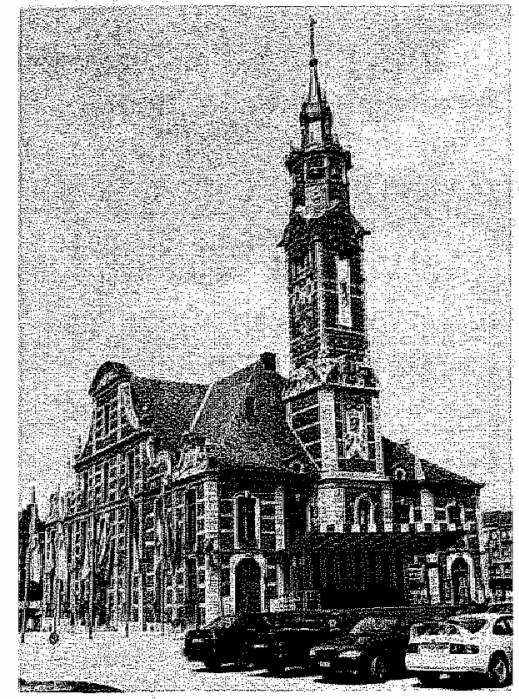

26. Stadhuis met belforttoren, waarin unwerk en beiaard, Sint-Truiden

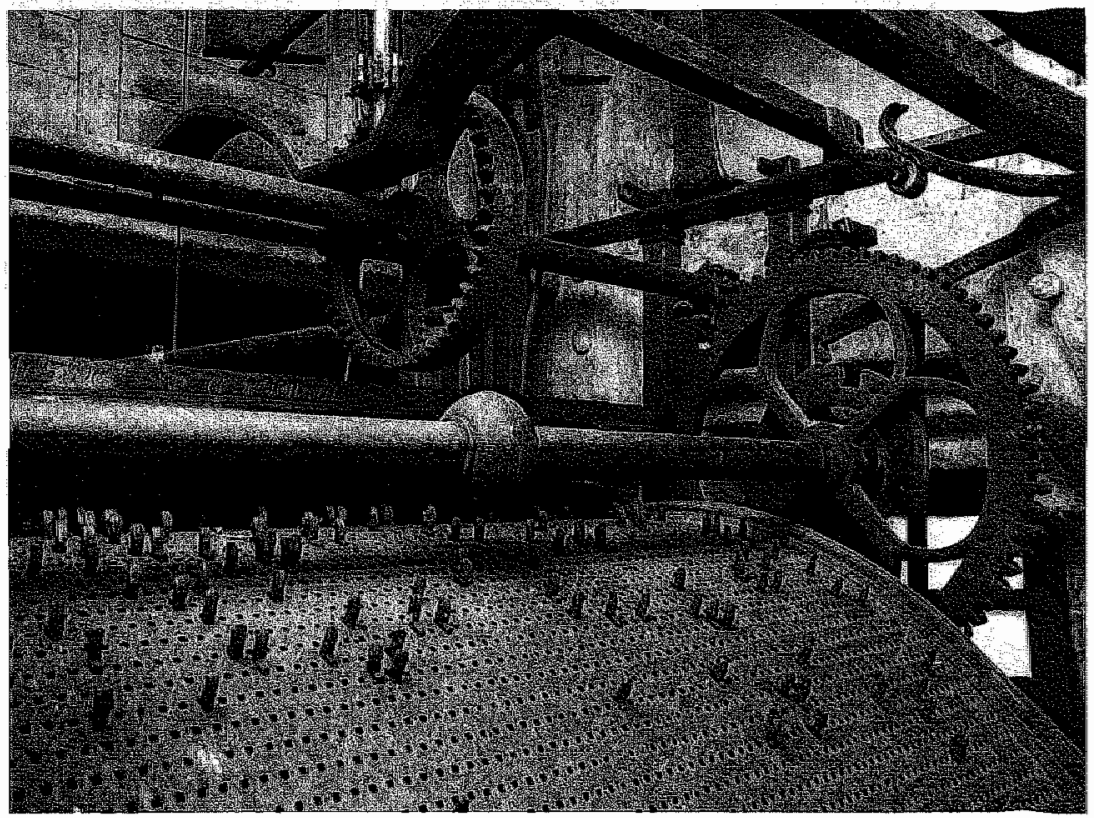

27. Torenuurwerk met speeltrommel in het belfort, Sint-Truiden (door Gilles en Nicolas. de Beefe, Luik, 1754) 
verbinding. In 1503 was enig herstel nodig. Vrijmans had er de assistentie van een smid, een schilder en een touwslager bij nodig. Het omstandig verslag in de stadsrekening wijst op de aanwezigheid van een foliot: "Meester Jan Vrijmans de orverckmester (stadsuurwerkmeester) clein verck ende 16 hocke (haken) totten viser (wijzer). Jan Cauwenberch voer den wijser te maken. Den schilder van Ludick van de wijsers te vergulden. Willem Van der Neyen gewerckt aen den wijser helpen te stellen 1 dag. Peter syn knape 1 dag voor 11 stuivers. Gheert Van der Hulst geleidt aen dat oergewerck aen dat groet gewicht twe zele (touwen) waegende $621 / 2$ pont. Der selve noch geleidt een cleyn seel aen die onrast (onust) 8 pont $t^{n} .^{51}$ De laatste zin duidt op het kleine touw, waarmee de foliot aan de galgvormige haak erboven werd bevestigd en waaraan hij heen en weer kon zwaaien in een horizontaal vlak.

Voor de levering van nieuwe noten voor de speeltrommel wendde Sint-Truiden zich in 1541 tot Peter Wanten, uurwerkmaker te Tienen, en in 1555 tot een niet nader genoemde uurwerkmaker te Hasselt. Hieruit blijkt dat Sint-Truiden al vóór 1541 een automatisch speelwerk had.

Nadat in 1602 een commissie van het stadsbestuur het uurwerk in de stadhuistoren had gevisiteerd, ${ }^{52}$ kreeg Martin Dekens uit Hasselt opdracht het uurwerk te herstellen. Daar dit onmogelijk bleek, vervaardigde hij een nieuw uurwerk voor 1.150 gulden Brabants. Als toegift ontving hij een zilveren kroes ter waarde van 25 gulden. Het uurwerk, met kwartier-, halfuur- en uurslag, was bestemd voor de nieuwe toren van het stadhuis. Daar de stad het uurwerk niet op tijd kon betalen, werd de schuld in 1612 omgezet in een lening van duizend gulden tegen een rente van $6 \% .^{53}$

Nadat op 3 april 1751 experts uit Luik en Leuven hadden geconstateerd dat de speeltrommel totaal was versleten, ${ }^{54}$ wendde men zich tot Nicolas le Gros, klokkengieter te Luik, die voor 8.600 gulden een carillon en uurwerk met speeltrommel zou leveren. $\mathrm{Hij}$ verplichtte zich het geheel gedurende zes jaar te onderhouden. ${ }^{55} \mathrm{De}$ nieuwe beiaard woog 8.530 pond, terwijl het stadsbestuur 8.566

1. Lewnis 1958 , p. 286.

${ }_{52}$ F. Straven 1886-1895, deel III, p. 246, d.d. 14 oktober 1602.

${ }^{53}$ F. Straven 1886-1895, deel WI, p. 319, d.d. 8 mel 1606; deel III, p. 280, d.d. 31 oktober 1612.

${ }_{\$ 4}$ F. Straven 1886-1895, deel V, p. 336.

${ }^{35}$ F. Straven $1886-1895$, deel VI, p. 416 , d.t. 24 aptil 1751. 
pond aan oude klokken had ingeleverd. Het verschil van 36 pond was van geen belang vergeleken met de zware exploitatielasten die volgden. Met het oog op de nieuwe beiaard werd op 27 juni 1752 Jean-Baptiste Kemna als beiaardier aangesteld met een jaarwedde van vierhonderd Brabants-Luikse guldens ofwel honderd gulden Brabants. Hij moest voor dat geld ook het uurwerk onderhouden. Als bijzondere gunst verkreeg hij het burgerrecht. ${ }^{56}$

De relatie met Le Gros was intussen grondig verstoord geraakt. $O p$ 9 maart 1753 weigerde hij het uurwerk te leveren. Wel was hij bereid de speeltrommel te leveren voor negenhonderd gulden en ook was hij genegen de beiaard te verbeteren, ${ }^{57}$ waarop kritiek was geleverd door Jean-Pierre Bouvrie, beiaardier van Maastricht en vooral door Jean de Decker, beiaardier van Diest. ${ }^{58}$ De ingrepen van Le Gros voldeden blijkbaar niet, want op 7 januari 1754 rapporteerde Andreas J. van den Gheyn dat er verschillende klokken moesten worden bijgestemd en sommige zelfs hergoten. $\mathbf{H i j}$ nam dit aan voor tweehonderd gulden. ${ }^{59}$ Toen Van den Gheyn klaar was, werd het carillon beoordeeld door de reeds genoemde $\mathrm{De}$ Decker uit Diest, die het nu goed vond behalve de twaalfde klok. Ook Philippe-Joseph Marechal, beiaardier van de abdij St.-Jacques te Luik, achitte de stemming goed, behalve die van de 21ste en $12 \mathrm{de}$ klok, maar hij vond de beiaard goed, wanneer men hem beneden beluisterde. ${ }^{60} \mathrm{Nu}$ het er naar uitzag dat de beiaard eindelijk in orde was, wilde het stadsbestuur een excellente beiaardier. Het besloot voor de functie een wedstrijd uit te schrijven, die in de kranten van Antwerpen en Luik bekend werd gemaakt. Arnold-M. Hoebrechts uit Tienen won de wedstrijd en werd beiaardier van Sint-Truiden. Naast zijn verplichtingen als beiaardier moest hij ook het uurwerk onderhouden. Bovendien moest hij elke zes maanden nieuwe melodieën op de speeltrommel zetten voor de voorslag van het hele en het halve uur. Hij kreeg een jaarwedde van vierhonderd gulden, die in 1758 echter werd verlaagd naar driehonderd gulden omdat $\mathbf{R}$. Martiny een deel van zijn taken overnam en voortaan voor het onderhoud van het uurwerk en het versteken van de speeltrommel

F. Straven $1886-1895$, deel V, p. 340 ,
F. Straven $1886-1895$, deel VI, p. 420 , d.d. 9 maart 1753 .
F. Straven $1886-1895$, deel V, 1.340 , d.d. 15 juli 1752 .
F. Straven $1886-1895$, deel VI, p. 422 .
F. Straven, $1886-1895$, deel VI, p. 422 , d.d. 7 januari, 9 juli en 10 jull 1754 . 
van het carillon zorgde. ${ }^{61} \mathrm{Hij}$ trad per 16 november 1754 in dienst, maar keerde in 1763 naar Tienen terug. ${ }^{62} \mathrm{Hij}$ werd voor één jaar opgevolgd door twee beiaardiers, te weten Jean Knapen de jonge en Arnold-Lambert van den Hove. ${ }^{63}$

Zoals reeds vermeld, wilde of kon Le Gros het uurwerk niet leveren. Kennelijk kwam die mededeling niet onverwacht. Vier dagen nadat Le Gros het bijltje erbij neer had gegooid, op 13 maart 1753, sloot de stad een contract met de befaamde Gilles de Beefe uit Luik. De kosten zouden bij hem 6.200 gulden bedragen. De Beefe gaf op het uurwerk een garantie van twee jaar. De stad beloofde voor hem een werkplaats in de toren in te richten, net zoals Hasselt dit had gedaan. ${ }^{64}$ Het werkstuk van De Beefe staat nog in de toren van het stadhuis. De signatuur op de balk van het trommelklavier luidt: "Fait par Gilles de Beefe et de son fils Nicolas le 25 Avril 1754 à Liège". De afmetingen bedragen: lengte $185 \mathrm{~cm}$, hoogte 150 $\mathrm{cm}$ en diepte $127 \mathrm{~cm}$. De breedte van de springtrommel inclusief het aandrijvingstandrad bedraagt $106,5 \mathrm{~cm}$. De ijzeren hoekstijlen hebben messing Ionische kapitelen en zijn door platijzeren strippen verbonden. Het gaande werk is gedeeltelijk verdwenen (zie afbeelding 27). Voor de tijdmeting werd een apart uurwerk aangeschaft. Thans staat er een Eysbouts-uurwerk uit het begin van deze eeuw. Het slagwerk is nog wel aanwezig. Het zorgde voor het slaan van hele en halve uren, van kwartieren en halve kwartieren. Om de voltooiing van het uurwerk te bespoedigen, lieten de burgemeesters in september 1754 door vier timmerlieden vier wijzers maken. ${ }^{65}$ Nog in dezelfde maand werden ze met vier wijzerplaten op de toren gemonteerd ${ }^{66}$ In oktober van hetzelfde jaar werden wijzerplaten en wijzers voor vijftien pistolen verguld. ${ }^{67}$ In 1822 werd blijkens de inscriptie op de balk van het trommelklavier de speeltrommel gerepareerd: "Restauré par J. Schoufs à St.-Trond le 15 Mars $1822^{\prime \prime}{ }^{68}$ In 1845 was weer een revisie nodig door Jacques van Ermen, die aan de andere kant van het trommelklavier de inscriptie

\footnotetext{
Fi. Strawen 1886-1895, deel VI, p. 424.

${ }^{62}$ F. Sirawen 1886-1895, deel VI, p. 423; deel V. P. 415.

${ }^{63}$. Strawen $1886-1895$, deel $V, p .419$, d.d. 13 augustus 1764 .

${ }^{34} \mathrm{~F}$. Strawen 1886-1895, deeil VI, p. 421 .

${ }^{65}$ F. Straven 1886-1895, deel V, p. 352, d.d. 12 september 1754.

F. Straven 1886-1895, deel VI, p. 423, d.d. 17 september 1754

${ }^{67}$ F. Straven 1886-1895, deel VI, p. 424.

Voor Jacobus Antonius Schoufs zie appendix II.
} 
aanbracht: "Jacques van Ermen horlogeur à St.-Trond 1845". ${ }^{69}$ Dertien jaar later is er weer aan gesleuteld. Op de sluitschijf van het slagwerk staat met enige trots vermeld: "Perfectionné et mis en rapport avec les progrès de l'art le 27 Juillet 1858 par G. Creten et fils et fille à St.-Trond sous la régence de..." (volgen namen van leden van het stadsbestuur) ${ }^{70}$ Blijkens een inscriptie, links naast die van Van Ermen, heeft de bekende Camille Festraets in 1937 het geheel geëlektrificeerd.

\subsubsection{De stadsuurwerkmakers}

Dankzij het speurwerk van Leunis kennen wij de namen van een aantal stadsuurwerkmakers." ${ }^{71}$ 1504: Jan Hubiert; 1511: Hendrik Hoetz; 1531: Henrico Tsoers of Soers; 1540: Ghielis Princen; 1558: Willem Prinsen; 1582: Willem Prinsen; 1614: Karel Prinsen; 1627: Karel Prinsen samen met Cristoffel Morren; 1628: Willem Briers. ${ }^{72}$ Van de meesten weten wij zeer weinig. Leden van de familie Prinsen overbrugden bijna een eeuw. $\mathrm{Zij}$ oefenden het onderhoud van het uurwerk echter niet allemaal als hoofdberoep uit: Ghielis Princen was één van de vijf stadsboden van Sint-Truiden. Als bode verdiende hij 12 gulden en 12 stuivers, als stadsuurwerkmeester kreeg hij meer: 21 gulden en 5 stuivers. Zijn taak als stadsuurwerkmaker was, vergeleken met die van stadsbode, bescheiden. Er waren luttele uren mee gemoeid. In tijd van nood riep men een vakman te hulp.

In 1557 vervaardigde of herstelde Lambrecht van den Borne twee raderen van het uurwerk, terwijl Ghielis Princen nog in functie was. Princen beperkte zich waarschijnlijk tot de elke dag voorkomende werkzaamheden, zoals optrekken, stellen en oliën. Zijn opvolgers deden niet veel meer. In 1602, toen Willem Prinsen de uurwerkmaker was, werkte Conrardt de Lamme één dag aan het uurwerk. Hij gebruikte staal, grofijzer en gruis (= gruisijzer?) dat hij bij drie verschillende ambachtslieden was gaan halen.

\footnotetext{
${ }^{69}$ Voor Van Ermen zie appendix II onder Vanermen, Jacques.

7w. Creten gebruilkte ongeveer dezelfde tekst op de speeltrommel in Hasselt. Zijn meewerkende dochter wordt ook vermeld op een uurwerk in Wittem. Zie appendix II onder Creten, $G$.

7. J. Leunis 1958 , p. 287.

${ }^{72}$ De jaartallen vóo de namen duiden het jaar van indiensttreding aan.
} 
Sedert het midden van de 17 de eeuw werden hogere eisen gesteld, zij het meer in artistiek dan in technisch opzicht. Op 6 juli 1665 vroeg Guillaume Briers om als beiaardier aangesteld te worden in plaats van $H$. Lascens. Hij kreeg de benoeming. ${ }^{73}$ In 1672 werd in de stad geklaagd over het slecht functioneren van uurwerk en voorslag. De magistraat belastte zangmeester Willem Briers voor één jaar met het onderhoud van uurwerk en carillon tegen een betaling van zestig gulden. Hij moest voor dat geld ook de beiaard bespelen en de speeltrommel van nieuwe wijsjes voorzien. ${ }^{74} \mathrm{De}$ organist Hubert Govaerts kreeg in 1673 de taak om vier- of vijfmaal per jaar de melodieën op de speeltrommel te wijzigen voor dertig gulden Brabants. ${ }^{75}$ Dezelfde taak nam in 1697 "le Sieur Roland Ceulers, curé de Gothem" op zich. Als vergoeding hiervoor kregen twee tantes van hem vrijstelling van enkele bellastingen. ${ }^{76}$ In 1700 gooide men het over een andere boeg: Laurent Roenen, ook wel Roonen genoemd, werd voor zes jaar aangesteld als stadsuurwerkmeester met een jaarwedde van 25 pattacons, in maandelijkse termijnen te betalen. ${ }^{77} \mathrm{Zijn}$ opvolger, Antoine de Levrie, trad pas in 1708 in dienst op dezelfde voorwaarden. Hoe lang De Levrie in dienst is geweest, is niet duidelijk, maar het kan een hele tijd zijn geweest, want de eerstvolgende stadsuurwerkmaker wordt pas in 1737 genoemd. Uit een contract van 31 januari 1737 blijkt dat Arnold Giles sinds Allerheiligen 1736 in dienst was als stadsuurwerkmaker voor 25 pattacons per jaar. Hij moest zorgen voor de voorslag, de wijzers, de noten, het koperdraad, de hamers, de hamerveren en de nodige olie. Slechts de touwen voor de gewichten kwamen ten laste van de stad. Als het uurwerk niet goed zou lopen, moest hij het op zijn kosten repareren. ${ }^{78}$ Op 19 augustus 1743 werd Gerard Smets op dezelfde condities aangesteld. ${ }^{79}$ Michel Spons werd op 10 augustus 1751 aangesteld voor zeventig gulden per jaar. ${ }^{80}$ In 1758 werd een zekere R. Martiny (alias Henri Marti-

${ }^{73}$ F. Straven 1886-1895, deel VI, p. 640. Waarschijnlijk betreft het hier een zoon van Willem Briers, die in 1628 deze functie bekleedde.

${ }^{74}$ F. Straven 188:6-1895, deel IV, p. 255, d.d. 1 februari 1672.

${ }^{75}$ F. Straven 1886-1895, deel IV, p. 267, d.d. 30 oktober 1673.

${ }^{76}$ F. Straven 1886-1895, deel V, p. 27, d.d. 2 augustus 1697.

"F. Straven $1886 \times 1895$, deel V, p. 60.

${ }^{7}$ F. Straven 1886-1895, deel V, p. 275.

${ }^{79}$ F. Strawen 1886-1895, deel V, p. 300.

${ }^{80}$ F. Strawen 1886-1895, deel V, p. 337. 
ny) aangesteld voor veertig schilden per jaar of veertig gulden per trimester. Hij zou in Sint-Truiden komen wonen en moest minstens twee keer per jaar de melodieën veranderen van de voorslag op het hele, halve en kwart uur. ${ }^{81} 14$ Mei 1761 werd Jean-Baptiste Molinet als stadsuurwerkmaker aangesteld onder gelijke voorwaarden. ${ }^{82}$ De stadsuurwerkmakers in Sint-Truiden waren geen echte vakmensen. De stad probeerde gewoonlijk de beiaardier ook het werk wan de stadsuurwerkmaker te laten opknappen. Ateliers voor torenuurwerken, zoals die in Hasselt bestonden, zijn in Sint-Truiden nooit van de grond gekomen.

\subsection{Maaseik}

Maaseik kreeg vermoedelijk tussen 1240 en 1243 zijn stadsbrief. Op het marktplein was tot het midden van de $18 \mathrm{de}$ eeuw het gewanthuys of heerenhuys gelegen. Het gebouw behoorde toe aan de landsheer. Het diende niet alleen tot commercieel centrum, maar ook tot raadhuis. Eveneens vergaderden er de ambachten en schuttersgilden ${ }^{83} \mathrm{Na}$ de afbraak van het gewanthuys werd in 1769 het huis "den Groenen Schilt" gekocht om als raadhuis te dienen. Het huidige stadhuis werd gebouwd in $1828-1829$ en in 1874 voltooid. ${ }^{84}$

\subsubsection{De stadsuurwerken en de stadsururwerkmakers}

Op de zolder van het huidige stadhuis aan de Markt bevindt zich een torenuurwerk met (laat-)gotische kenmerken (zie afbeelding 28): geprofileerde hoekstijlen, die onder een hoek staan van 45 graden ten opzichte van de lange en korte zijde van het uurwerk. De profielen maken de indruk er als losse stukken op geweld te zijn. Eén hoekstijl staat bijna haaks. De stijlen zijn boven en onder bevestigd aan een rechthoekig gesmeed raamwerk van plat ijzer. Alle verbindingen zijn van spieën voorzien. Links van het gaande

\footnotetext{
${ }^{81}$ F. Strawen, 1886-1895, deel VI, p. 424, d.d. 17 mei 1758.

${ }^{82}$ F. Straven, 1886-1895, deel V: p. 404.

3 J. Gerits [1989], pp. 152 en 155

I. Gerits [1989], p. 167 .
} 


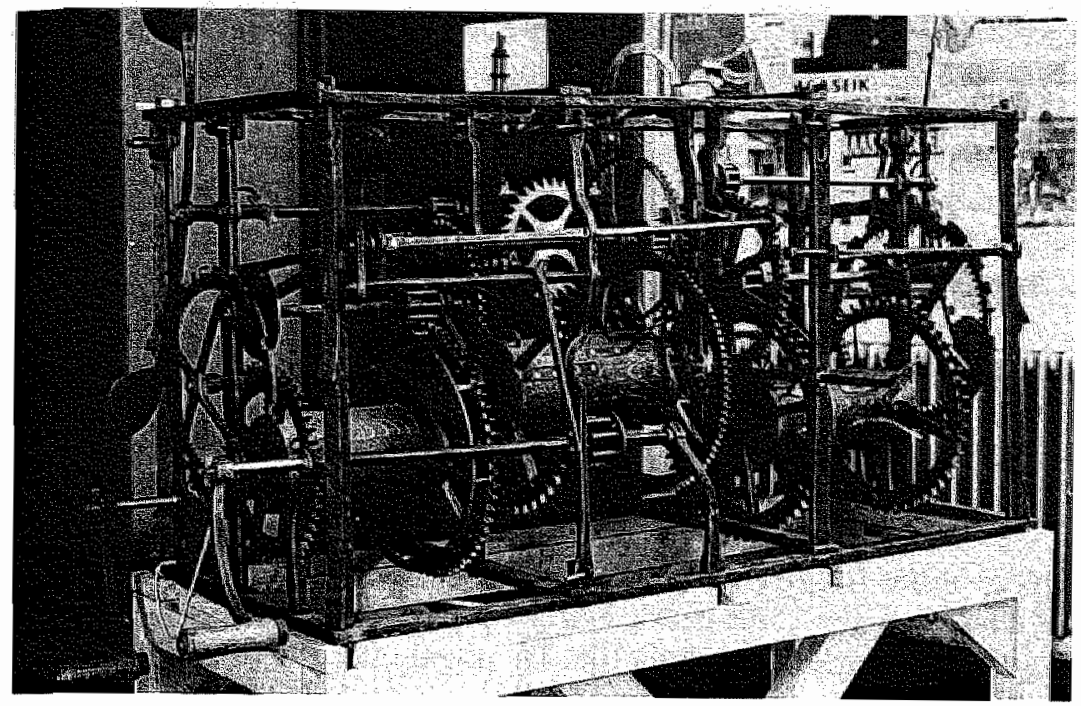

28. Torenuurwerk van het stadhuis, Maaseik (15de, 16de eeuw?). Links halfuurslag, midden gaand werk ongebouwd op ankergang, rechts slagwerk voor het hele uur

werk is een slagwerk, dat het halve uur voluit op een kleine klok slaat; rechts van het gaande werk is het slagwerk dat het volle uur slaat op een grotere klok. Mogelijk is het rechterslagwerk een latere toevoeging. Het uurwerk had oorspronkelijk een foliot en is later voorzien van een ankergang met een slinger van meer dan twee meter lengte. Het uurwerk is niet gemerkt of gesigneerd. De hoekstijlen en tussenstijlen zijn mogelijk 15de-eeuws. Andere onderdelen lijken jonger. Het is mogelijk afkomstig van het oude gewanthuis. Wanneer het werd geplaatst en door wie het werd gemaakt, is in nevelen gehuld. De afmetingen van het uurwerk zijn: hoogte $70 \mathrm{~cm}$, breedte $135 \mathrm{~cm}$, diepte $60 \mathrm{~cm}$. In de winter 1995 1996 is het volledig gereviseerd. ${ }^{85}$

Ook in de toren van de parochiekerk was een uurwerk geplaatst, dat werd onderhouden door de stad en waarvan we verder niets weten. De slechte toestand waarin het stedelijk archief zich tot voor enige tijd bevond, bemoeilijkte de consultatie zozeer dat geen auteur tot nu toe bijzonderheden vermocht te ontdekken, behoudens de namen van enkele stadsuurwerkmakers uit de 17 de en 18 de eeuw. De nog

\footnotetext{
${ }^{85}$ Zie de brochure van de restaurateur, R. Pex 1996.
} 
onvolledige $1 \mathrm{ijst} \mathrm{t}^{86}$ levert enkele namen op van personen die stuk voor stuk zeer lang in dienst schijnen te zijn gebleven. Het volgende beeld ontstaat:

- 1600 tot 1619 Pieter van Vucht, der Custer. Hij kreeg jaarlijks 25 gulden voor het beheer en onderhoud van de uurwerken van stadhuis en kerk,

- 1619 tot omstreeks 1650 Corst Alers. Hij verdiende 30 gulden;

- omstreeks 1650 tot 1688 Tilman Hackhuyzen. Hij kreeg 36 gulden voor het "uurgewerck boven het stadthuys". Tilman was ook stadshorloger van Roermond;

- 1688 tot 1720 Lambert Joosten;

-1720 tot \pm 1760 Michael Joosten. Hij kreeg voor het onderhoud van beide urwerken in totaal 42 gulden.

De grotere Belgisch-Limburgse steden bezaten alle vier in het midden van de 15 de eeuw een stadsuurwerk. Wanneer het werd geplaatst, is meestal onduidelijk. De nogal overvloedige documentatie die volgt op de eerste vermelding maakt het waarschijnlijk dat de uurwerken pas kort aanwezig waren op het moment dat er voor het eerst over werd gerept. Indien deze veronderstelling juist is, zouden de vier grote steden in het Loonse deel van het prinsbisdom Luik twee à drie generaties later dan Maastricht en Venlo een stadsuurwerk hebben gekregen, kort vóór of ongeveer tegelijk met de Nederlands-Limburgse steden die van nijverheid afhankelijk waren. Het gaat inderdaad ook in Belgisch-Limburg om steden die in de 15 de eeuw in belangrijke mate steunden op de vervaardiging van goederen voor markten, gelegen buiten het prinsbisdom, soms, zoals Hasselt en Sint-Truiden, steden met een flinke nijverheidstraditie. Juist in de twee laatstgenoemde steden ontwikkelden zich uurwerkmakersgeslachten die generaties lang zorg droegen voor de bouw en het groot onderhoud van uurwerken in de eigen stad en in steden in de verre omgeving. Met recht kan de vraag worden gesteld of de uurwerkmakerij een activiteit was die voortvloeide uit de aanwezigheid van een uurwerk in de stad. Op het moment dat de stad haar nijverheid zag bloeien, plaatste zij een torenuurwerk. De ambachtsman belast met het onderhoud maakte er zijn beroep van en legde er een eer in kwaliteit te leveren, vergelijkbaar met die van zijn collega's die de exportnijverheden van de stad richting gaven.

${ }^{86}$ Met dank aan Martin Boonen te Maaseik. 
Ook hier valt evenals bij de kleinere Nederlands-Limburgse steden op dat de interesse van de soms zeer vermogende kerkelijke instellingen en van de adel voor openbare tijdmeting heel beperkt was, althans tot het moment dat een ruimere aanwezigheid van huisuurwerken en zakhorloges de behoefte aan een lokale standaardtijd deed gevoelen. Allicht wilde men voorkomen dat velen op hun eigen tijd naar de kerk kwamen en zo de diensten ontregelden. 
114 


\section{Hoofdstuk V}

\section{De openbare tijdmeting in de kleine Limburgse steden}

\subsection{Belgisch-Limburg; inleiding}

Het graafschap Loon omvatte tijdens het hoogtepunt van zijn expansie het grootste deel van Belgisch-Limburg behalve Tongeren en Sint-Truiden, die van oudsher Luiks waren, en Halen, dat tot 1794 Brabants was. In de 13 de en 14de eeuw werd in het graafschap Loon kort achtereen een dozijn steden gesticht. De meeste stichtingen kwamen nauwelijks tot ontplooiing. ${ }^{1}$ Typerend daarvoor is wellicht mede de trage ontwikkeling van de openbare tijdmeting aldaar. Van Stokkem, Beringen en Halen kon niet worden vastgestell dat ze ooit een uurwerk kregen. Onder de overige is er slechts een enkeling die al in de $15 \mathrm{de}$ of $16 \mathrm{de}$ eeuw enige aandacht besteedde aan openbare tijdmeting. Hier zullen achtereenvolgens worden behandeld: Herk-de-Stad, Borgloon, Peer, Bree, Bilzen en Hamont.

\subsubsection{Herk-de-Stad}

Herk-de-Stad, van de 13 de tot de 18 de eeuw meestal Wuestherck geheten, had misschien al in de tweede helft van de 12 de eeuw stadsrechten. Vanaf 1334 is er sprake van "oppidum de Wustherke" en van "libertas oppidi de Wustherke". ${ }^{2}$ Aan de markt stonden behalve de kerk en het stadhuis het korenhuis, de lakenhal en het vleeshuis. Het stadje bezat sedert 1411 een viertal luidklokken, die eventueel de voorslag van een uurwerk konden vormen. In ieder geval was er kort vóór 1450 een openbaar uurwerk, zoals blijkt uit de aanwexigheid van een stadsuurwerkmaker.

De eerste als zodanig vermelde was Mathaeus Clingermans, die van 1446-1456 in functie was. Hij werd in natura betaald. Zijn jaarwed-

J. Gerits [1989], pp. 12-14.

2J. Gerits [1989], p. 135. 
de bedroeg één mud rogge, in 1450 verhoogd tot twee mudden. Anderhalve eeuw lang zwijgen vervolgens de bronnen. Dan vinden we Gerardus van den Bosch vermeld, die op 31 januari 1593 als stadsuurwerkmaker in dienst trad. Hij verdiende twaalf gulden per jaar.

Pieter Jaspers en Lambricht Joris worden in de 17 de eeuw meermaals genoemd. Zij herstelden gezamenlijk het uurwerk in 1664, 1665 en 1669 . Mogelijk waren het te Herk gevestigde uurwerkmakers. ${ }^{3}$

$\mathrm{Na}$ een bloeiperiode in de $14 \mathrm{de}$ en $15 \mathrm{de}$ eeuw, waarin Herk zelfs een muntatelier bezat, viel het stadje sindsdien terug tot een landelijke gemeente, die in 1796 nog slechts 480 inwoners telde. ${ }^{4}$

\subsubsection{Borgloon}

Borgloon, sinds de 11 de eeuw de hoofdstad van het graafschap Loon, had al vóór 1200 stadsrechten. Nadat de grafelijke burcht in 1179 was verwoest, werd het stadje spoedig overvleugeld door Hasselt, dat sinds de 13 de eeuw gold als hoofdstad van het graafschap. Borgloon verviel tot het niveau van een plattelandsstadje. De voornaamste gebouwen zijn de kapittelkerk van Sint-Odulfus, die dateert uit de 12de eeuw, en het stadhuis, daterend van 1668-1680. In 1529 kocht de stad Borgloon een nieuw uurwerk van zeshonderd pond bij Thomas Dekens Jr. uit Tongeren. De tekst van de overeenkomst is bewaard gebleven. ${ }^{5}$ Uit dit document blijkt dat de opdracht door het kapittel en het stadsbestuur samen werd gegeven. De prijs van het uurwerk was 48 rijnsguldens, die zij gezamenlijk zouden betalen. De leveringstermijn was ruim een half jaar. De maker moest zijn werkstuk na plaatsing nog een jaar lang gratis onderhouden. Daarna zou hij dat "werck metten wyser"16 levenslang moeten onderhouden voor een jaarlijkse vergoeding van één gelte Rijnwijn. Uit de overeenkomst blijkt ook dat Borgloon al eerder een uurwerk had, want er is sprake van "dat ouwe uurwerck". Verdere medede-

\footnotetext{
${ }^{3}$ J. Leunis 1958 , p. 287.

"J. Gerits [1989], pp. 141 en 148.

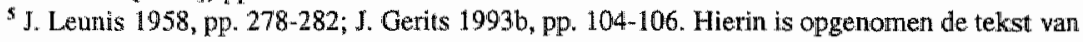
de overeenkomst tussen het kapittel van Borgloon en het stadsbestuur en Thomas Dekens.

"Nog altijid was het blijkbaar nodig aan te geven, dat het een uurwerk met wijzer was, die "het sy buyten der kercken oft binnen der kercken" was aangebracht.
} 
lingen daarover ontbreken. Het nieuwe uurwerk zou nog lang dienst doen. Het was in de toren van de Sint-Odulphuskerk geplaatst en niet op het stadhuis, zoals blijkt uit een verslag van muntius Antonilo Albergati, die in 1613 een reformatie van het Sint-Odulphuskapittel doorvoerde. Hij vermeldt daarin, dat de Sint-Odulphuskerk een klokkentoren had met klokken en een uurwerk. ${ }^{7}$ In 1749 werkte zekere Gerard Smets, uurwerkmaker te Sint-Truiden, aan het uurwerk van de Sint-Odulphuskerk. De onkosten werden ook ditmaal door het kapittel en de stad gezamenlijk gedragen ${ }^{8}{ }^{8}$ Het is niet waarschijnlijk, dat er ook een openbaar uurwerk was op het stadhuis: er zijn geen berichten over en het nog bestaande stadhuis vertoont geen sporen van een uurwerk.

\subsubsection{Peer}

Het kleine stadje Peer, halverwege tussen Hasselt en Weert, kreeg in 1367 een omwalling. Het had geen officiële stadsrechten, maar was sedert de 15 de eeuw toch als stad vertegenwoordigd in de Luikse Statenvergadering. ${ }^{9}$ De economische activiteiten waren vooral van agrarische aard. Op de markt werden vooral producten van akkerbouw en veeteelt verhandeld. Van de 14 de tot de $16 \mathrm{de}$ eeuw had de wol- en lakennijverheid enig belang. Maar reeds in de $16 \mathrm{de}$ en $17 \mathrm{de}$ eeuw verviel het stadje meer en meer tot een dorp, hoewel er in 1637 nog een fraai stadhuis annex markthal werd gebouwd. In 1823 leefden 160 van de 238 gezinnen van de landbouw, 40 gezinnen van handel en nijverheid. ${ }^{10}$

De parochiekerk van Peer kreeg ruim vóór 1589 een uurwerk. In dat jaar werd het voor dertig stuivers hersteld met bijlevering van nagels en lood door zekere Aert Nouten, mogelijk een slotenmaker. " Het ligt voor de hand dat het uurwerk in de kerktoren een stadsuurwerk was, want de stad betaalde het herstel.

\footnotetext{
${ }^{7}$ J. Brouwers 1983, p. 9.

*. Gerits 1993e, p. 108.

J. Gerits [1989], p. 171 .

10. Gerits [1989], pp. 182 en 184 .

${ }^{11}$ J. Stiruissen 1990, p. 69.
} 


\subsubsection{Bree}

De inwoners van Bree, vijftien kilometer ten oosten van Peer, worden in een oorkonde van 9 april 1282 voor het eerst opidani, stedelingen, genoemd. Mogelijk heeft Bree een vrijheidsbrief gekregen van graaf Arnold IV van Loon, die overleed in 1273. ${ }^{12}$ Het stadje werd al in de 14de eeuw omwald en ontwikkelde zich tot een klein regionaal marktcentrum met een gewanthuis. Maar zoals de meeste stadsstichtingen van deze Loonse graaf ontwikkelde Bree zich niet erg voorspoedig. Het had het uitzicht en het karakter van een plattelandsgemeente. In 1796 telde het slechts 961 inwoners. ${ }^{13}$ Van openbare tijdmeting vernemen we er pas iets aan het einde van de 16 de eeuw.

Tussen 1587 en 1592 werd te Bree een nieuw stadhuis gebouwd. Nog vóór 1591 leverde Lambrecht Bla(e)sen uit Hasselt een stadhuisuurwerk, dat met een raadsklokje in verbinding stond. In 1634 werd het stadsuurwerk hersteld door Jan Thonis. Op den duur bleek een uurwerk nodig, dat van veraf beter zichtbaar was. Michel Pingen vervaardigde in 1661 een nieuw stadsuurwerk, dat in de kerktoren werd geplaatst. Het was $5^{1 / 2}$ voet breed en 5 voet hoog. Het kostte vijfhonderd gulden, twee amen bier en vier rijksdaalders voor de knecht. Pingen schijnt in Bree een uurwerkmakersatelier te hebben gehad. In 1666 bevestigde hij een zonnewijzer aan het stadhuis van Bree. Dat kan erop wijzen dat het stadhuisuurwerk inmiddels buiten gebruik was gesteld, maar kan ook het tegendeel beduiden, namelijk dat men de gang van het uurwerk goed in de gaten hield en wenste dat het gelijk liep met de zonnetijd.

Claes Willerns uit Bree herstelde in 1705 het uurwerk van Pingen. In 1743 werden grondige herstellingen uitgevoerd door Joannes Joosten uit Maaseik. Een volgende reparatie werd in 1784 verricht door Antonius Jacobus Smeets uit Hamont. ${ }^{14}$ Beiden genoten als uurwerkmakers renommée. Het uurwerk was nog altijd eigendom van de stad.

\footnotetext{
12 J. Gerits [1989], p. 65 .

is J. Gerits [1989], pp. 71-72.

${ }^{14}$ Ontleend aan I. Leunis 1958, p. 288; S. Maes 1952, p. 61.
} 


\subsubsection{Billzen}

Bilzen behoort tot de Loonse steden, gesticht vóór 1200, maar ook deze plaats ontplooide zich ternauwernood. Aan één van de voorwaarden voor het functioneren van een stad in economische $\mathrm{zin}$, het bezit van een openbaar uurwerk, voldeed het pas zeer laat. Het bleef een klein regionaal handelscentrum met een uitgesproken landelijk karakter, hoewel het ommuurd was. De plaatselijke ambachten ondersteunden voornamelijk de agrarische sector. In 1846 telde Bilzen 3.456 inwoners.

Bilzen bestelde op 25 augustus 1654 voor 550 gulden Brabants een uurwerk bij Jean Moës te Luik. Waar hij het plaatste is voorshands onduidelijk. Dat het voor het nieuwe stadhuis was bedoeld, zoals Leunis beweert, is onwaarschijnlijk, want dat werd pas in 1685 door Lambert Derick uit Antheit gebouwd. Evenmin kon het bestelde dadelijk in de kerktoren worden geplaatst. De gemeente bouwde de kerktoren, die tot 1876 gemeentebezit bleef, ${ }^{15}$ pas in $1667 .{ }^{16}$ Later kwam het uurwerk wel in de kerktoren terecht. Wanneer men het daar plaatste is niet bekend. Het kan door een lokaal uurwerk-

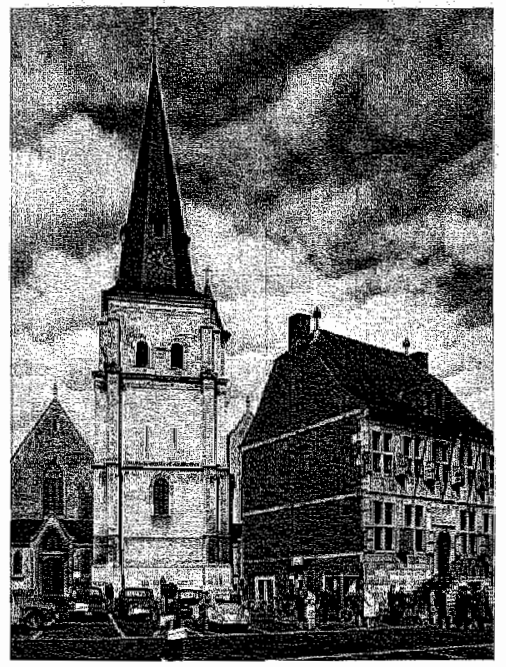

29. Stadhuis en parochiekerk van Bilzen

\footnotetext{
15. Paquay 1924 , p. 89.

${ }^{15}$ J. Paquay 1924 , p. 35; I. Leunis 1958, p. 288.
} 
maker zijn gebeurd. Die was voorhanden. In 1662 herstelde immers een uurwerkmaker uit Bilzen het torenuurwerk van het nabijgelegen dorp Beverst. ${ }^{17}$ Zijn naam is niet overgeleverd (zie afbeelding 29). De Franse administratie eiste in 1796 de vier klokken van Bilzen op. Voor de uurslag kreeg Bilzen van het departementsbestuur in 1798 één klok terug, afkomstig uit een andere plaats. Die wisseling ging gepaard met flinke kosten: "A même jour l'horloger Peters a réparé l'horloge mise à la dite cloche. Cet ouvrage a coûté 59 florins 76 sous 2 liards". ${ }^{18}$ Opnieuw moeten vraagtekens worden geplaatst. Welke Peters is bedoeld? In aanmerking komen Thomas Peters (1732-1806) uit Zutendaal en Matthias Peters (1772-1848), die aanvankelijk in Zutendaal en later in Opglabbeek woonde. Laatstgenoemde komt het meest in aanmerking, gezien de opdrachten die hij in ieder geval uitvoerde aan het torenuurwerk te Opglabbeek.

\subsubsection{Hamont}

Hamont kreeg relatief laat stadsrechten, namelijk in 1401; het heeft zich nooit kunnen ontwikkelen tot een heuse stad. Het had een bescheiden regionale handelsfunctie, maar die ging reeds in de tweede helft van de 16 de eeuw sterk achteruit. Het stadje had geen ambachtsgilden. Wel waren er in de tweede helft van de 18 de eeuw verscheidene uurwerkmakers werkzaam. ${ }^{19}$ Het was toen ook een belangrijke kern van Teuten, reizende handelaren. In 1796 waren er op een beroepsbevolking van circa negenhonderd personen zestig Teuten. ${ }^{20}$

Gegevens over een stadsuurwerk aldaar zijn uitermate schaars. Zij stammen pas uit de 18de eeuw en melden niets over de aanschaf. Jan Smeets, ${ }^{21}$ smid en constructeur van toren- en huisuurwerken, was zeker vanaf 1724 stadsuurwerkmaker van Hamont. ${ }^{22}$ Zijn zoon,

\footnotetext{
$1 \%$ Zie appendix I ad Beverst.

18 J. Paquay 1924, p. 84.

"19 Zie in appendix II Jan en Antonins-Jacobus Smeets, Theodore Mertens, J.J. Simons, $\mathbf{H}_{\text {. }}$ Bins, Charles en Jacques Streel.

201. Gerits [1989], p. 104.

21 Zie appendix II onder Smeets, Jan, Hamont.

${ }^{22} \mathrm{H}$. van de Broek 1959, p. 66 .
} 
de "orologiemaker Antonius Jacobus Smeets", ${ }^{23}$ wordt sinds 1769 herhaaldelijk in de stadsrekeningen vermeld in verband met werkzaamheden aan het uurwerk. ${ }^{24}$ Beiden waren in goede doen. Vader en zoon Smeets waren verscheiden keren burgemeester van $\mathrm{Ha}$ mont.

Waar het stadsuurwerk zich bevond, in het stadhuis van 1624 of in de toren van de Sint-Laurentiuskerk, is onduidelijk. De reconstructietekening van het stadhuis, vervaardigd door J. Dijkmans, laat geen wijzerplaat zien. ${ }^{25}$ Een afbeelding van de toren van de Sint-Laurentiuskerk, zoals die er uit zag van begin 19 de eeuw tot 1851 , toont een wijzerplaat met één wijzer. Wellicht mogen we hieruit concluderen dat het stadsuurwerk van oudsher in de kerktoren was opgesteld.

\subsection{Nederlands-Limburg; inleiding}

Even treurig als in Belgisch-Limburg was het gesteld met de openbare tijdmeting in de plattelandssteden in Nederlands-Limburg, dat tijdens het Ancien Régime een staatkundige lappendeken was. De voortdurend verschuivende gezagsverhoudingen in dat conglomeraat, dat tussen 1795 en 1839 werd omgevormd tot de huidige provincie Limburg, waren in hoge mate aansprakelijk voor de pogingen van allerlei gezagsdragers langs de Maas een stad te stichten. Vaak mislukte het. Van Wanssum, Blitterswijk en Neeritter staat vast dat de stadsverheffing tot niets leidde, zeker niet tot de installatie van een openbaar uurwerk. Elders, zoals te Valkenburg en Gennep, was tenminste tijdelijk sprake van een vesting met stevige omwalling. De openbare tijdmeting kwam er niet of nauwelijks op gang. De bevolking kon zelfs in de 18 de eeuw soms slechts aan de stand van de zon nagaan hoe laat het bij benadering was. Zeven plaatsen, Wessem, Echt, Montfort, Nieuwstadt, Gennep, Valkenburg en Susteren, vergen enige toelichting. ${ }^{26}$

\footnotetext{
${ }^{23}$ Zie appendix II onder Smeets, Amtonius-Jacobus, Hamont.

${ }^{2} \mathrm{H}$. van de Broek 1959, p. 67.

${ }^{25}$ Bijdrage tot de geschiedenis van Hamont 1976, p. 14.

${ }^{26} \mathrm{~W}$. Altherts 1972 , passim.
} 
Wessem, tien kilometer ten zuidwesten van Roermond aan de Maas gelegen, wordt door Jappe Alberts, waar hij spreekt over plaatsen die vór 1200 stedelijke privileges ontvingen genoemd onder de "oudere vestigingen". ${ }^{27}$ De pre-stedelijke kern heeft zich niet kunnen ontwikkelen tot een echte stad, hoewel ze meer allure had dan de omringende dorpen. Hier dateert de publieke tijdmeting van het einde van de 16de eeuw. De Sint-Medarduskerk had sedert 1594 een uurwerk van Meister Wijman Herbeinc(?) uit Weert. ${ }^{28}$ Door de verwoesting van de kerk in de nadagen van de Tweede Wereldoor$\log$ is er niets meer van over. Het onderhoud van toren, uurwerk en kleine klokken kwam ten laste van de gemeente, zoals een kerkvisitator in 1766 aantekende. ${ }^{29}$

\subsubsection{Echt}

Of Echt ooit stadsrechten heeft gekregen, en zo ja wanneer, is onzeker. De plaats was van 1397 tot circa 1600 versterkt en had een gewandthuys (lakenhal) en een gasthuis. ${ }^{30}$

Welters haalt in zijn publicatie ${ }^{31}$ verschillende malen passages uit de gemeenterekeningen aan over een uurwerk. Zij dateren zonder uitzondering uit de 18 de eeuw. De wereldlijke gemeente moest, evenals in veel andere plaatsen, de kerktoren en het daarin geplaatste uurwerk onderhouden. De rest van de kerk kwam ten laste van de Munsterabdij in Roermond.

Uit een kwitantie van 1 oktober 1705 blijkt dat een zekere Frencken het uurwerk onderhield voor vijftien gulden Luiks per jaar. ${ }^{32}$ Op 1 september 1756 vond de levering plaats van een "nieuw horologie-koorde ofte seel". ${ }^{33}$ Wilhelmus Wessels uit Geleen heeft in

\footnotetext{
${ }^{27}$ W. Alberts 1972, p. 69.

24 VNM 1926, P. 553.

29) H. Hanssen 1979, inw.nr. 76: "reparatio turris et horologii et parvarum campanarum communitali".

30 T. van Remsch 1981, pp. 7-9.

31 A. Welters 1923 , pp. 1-270.

32 A. Welters 1923, p. 90.

33 A. Welters 1923 , p. 92 .
} 
1757 aan het uurwerk gewerkt. Hij bracht nieuwe onderdelen aan. ${ }^{34}$ De reparatie was wat zuinig uitgevoerd. Dit zou nog een paar keer gebeuren. In 1764 waren wederom grote reparaties nodig. "Den horologiemaecker van Postert" nam ze aan voor acht pattacons. Hij zou het uurwerk voor dat geld ook een jaar lang onderhouden. ${ }^{35}$ Met de horlogemaker van Postert wordt waarschijnlijk Hendrik van den Borgh uit Posterholt bedoeld (zie appendix II). Hij wordt korte tijd later uitdrukkelijk vermeld. Op 1 augustus $1767 \mathrm{kreeg}$ Van den Borgh een croon voor het onderhoud. Het was zijn laatste activiteit in Echt. Hij is mogelijk kort nadien overleden. Reeds in december 1767 liet men Michiel Joosten uit Maaseik komen voor verdere reparaties. ${ }^{36}$ Het bleef evenwel sukkelen. In februari 1770 klaagde de koster over het uurwerk en men liet Joosten weer een reparatie uitwoeren, ditmaal een flinke voor liefst 29 pattacons en 4 schillingen. ${ }^{37}$ In april 1772 waren er andermaal klachten over het niet op tijd lopen van het uurwerk. Deze keer kreeg de koster de schuld. ${ }^{38}$ Ook de kerk was in een slechte conditie omdat de abdis van de Munsterabdij te Roermond er niets aan liet doen, hoewel zij als grote tiendhefster daartoe verplicht was. Echt spande daarom een rechtsgeding aan bij het hof van Gelre in Venlo. Dit hof verplichtte de abdis bij vonnis van 21 maart 1782 de kerk te Echt te herstellen "mitsgaders den tooren horologie".$^{39}$ Daarmee raakte het gemeentebestuur onverwacht een schadepost kwijt, waaraan geen eer te behalen was geweest. We vinden er dan ook geen raadsbesluiten meer over. Het oude uurwerk is in 1872 verloren gegaan bij de afbraak van de Romaanse kerktoren.

\subsubsection{Montfort}

Hoewel Montfort, tussen Roermond en Echt gelegen, vanaf 1271 stadsrechten had en sinds 1312 hetzelfde stadsrecht als Roermond, ${ }^{40}$ heeft er nooit enige stedelijke ontwikkeling plaats gegrepen. Het

\footnotetext{
A. Welters 1923, p. 26.

A. Welters 1923, p. 29.

A. Welters 1923, p. 30 .

$\$ 7$ A. Welters 1923, pp. 30 en 31 .

38 A. Welters 1923 , p. 31 .

3.A.M., Hof van Gelre te Venlo, inv.nr. 4, vonnissenboek, vonnis d.d. 21.03.1782.

40 Limburg"s Verleden 1967, deel $\mathbb{M}$, p. 111.
} 
bleef een dorp in de schaduw van een machtige burcht, waar de drossaard zetelde, de hoogste bestuurder van het Ambt Montfort, dat het zuidelijk gedeelte van Opper-Gelre omvatte. Over een uurwerk in de Sint-Catharinakerk horen we pas iets in 1618, als de kerkrekening vermeldt: "Aen den custer vant urwerck 2 gulden". Deze post komt in de daaropvolgende jaren telkens terug, evenals allerlei onderhoudskosten, onder andere voor smout en boomolie. In 1626 had de schrijnwerker de uurwijzer vermaakt, Peter de Smit had aan de "hamer des urwerx" gewerkt, ook werden twee "seylen tot het gewicht" gekocht. Dit gaat zo door tot de rekening van 1639, de laatste die is bewaard. ${ }^{41}$ In een "Descriptio redituum pastoratus", een inkomstenregister van de pastoor, lezen we betreffende het jaar 1712 over de inkomsten van de koster: "Noch heeft den custer van het horlogie te stellen seven guldens van de Gemeynte en dry van de Kercke-renten" . ${ }^{42}$ Ook uit het visitatieverslag van 1749 blijkt dat de koster, die tevens schoolmeester was, voor het stellen wan het uurwerk werd betaald, ${ }^{43}$

\subsubsection{Nieuwstadt}

Nieuwstadt, een Gelderse enclave in Guliks gebied, kreeg in 1213 stadsrechten, ${ }^{44}$ mogelijk om te concurreren met Sittard. Het ontwikkelde zich niet tot een echt stedelijk centrum. Er werd een fraai stedebouwkundig plan ontworpen, dat in feite slechts werd gevuld met een klein aantal boerderijen. De parochiekerk van Sint-Johannes de Doper had in 1751 een uurwerk, dat door de kerk werd onderhouden. ${ }^{45}$ "Den horologiemaecker" ontving hiervoor jaarlijks twee gulden en tien stuiver. ${ }^{46}$

\footnotetext{
${ }^{41}$ M. van Leemwen-Canneman en G. Venner 1995, inv.nr. 1460.

12 A. Flament 1914, p. 36 .

${ }^{43}$ H. Hanssen 1979, inv.nr. 78, nr. 9: "Custos est Theodorus Coenen; (ludimagister) est idem custos; (reditus:) quatuor uggera agronm pro dono et horologio ponendo quatuor imperiales solidum et dinidium, ex qualibet domo decem libras panis".

44 Limburg's Verleden 1967, deel I, p. 111.

${ }^{45} \mathrm{H}$. Hanssen 1979 , inv.nr. 76, nr. 9: "horologii ex praxi ecclesiae".

${ }^{46}$ M. van Leeuwen-Canneman en G. Venner 1995, inv.nr. 1694.
} 
Gennep kreeg in 1376 stadsrechten van de graaf van Gelder. ${ }^{47}$ In 1441 kwamen stad en heerlijkheid Gennep aan de hertog van Kleef; in 1614 raakte Gennep met heel het hertogdom Kleef in Brandenburgs-Pruisische handen. Over de openbare tijdmeting in Gennep is weinig bekend. De enige berichten stammen uit de tijd van het Pruisisch bestuur, dat zich veel moeite gaf zijn aanzien te verbeteren. Dat was in het bijzonder nodig in de bezittingen vlakbij de Republiek. Die waren voor het eigen Rijk wel van weinig belang, maar men kon het niet langer over zijn kant laten gaan in de eerste helft van de 17 de eeuw afhankelijk te zijn geweest van subsidies van de Staten-Generaal. De grote keurvorst begon zich als eerste te manifesteren. ${ }^{48}$ Het huidige stadhuis werd omstreeks 1659 gebouwd. ${ }^{4 i j n}$ fraaie toren zal wellicht vanaf het begin een torenuurwerk hebben geherbergd. De wijzerplaat is immers mooi in het metselwerk ingewerkt. Op een gravure uit 1758, getiteld "het raadhuys te Gennip", van Paul van Liender naar Jan de Beyer is aan de stadhuistoren duidelijk een éénwijzerig uurwerk te zien. Ook zijn de zonnewijzers aan twee zijden van deze achthoekige toren goed zichtbaar.

De enige stadsuurwerkmakers die we kennen, zijn Cornelis Remmen, die deze post rond 1728 vervulde, en Willem Camps. Hij wordt vermeld in de "Staat der bezoldigde personen van stadswege en hunne bezoldigingen" uit 1748. De bezoldiging van Camps als stadsuurwerker beliep één rijksdaalder per jaar, ${ }^{50}$ niet bepaald een bedrag, waarvoor men veel inspanningen mag verwachten, gezien de salarissen die andere steden in het Maasland destijds aan hun stadsurwerkmaker betaalden.

\subsubsection{Valkenburg}

Ook in Valkenburg, dat wan circa 1300 tot 1672 was ommuurd, zijn we slecht geïnformeerd over eventuele openbare uurwerken. Hier

\footnotetext{
${ }^{47}$ Limburg's Verleden 1967, deel II, p. 111.

A. Waddington 1911, pp. 470-471.

Ch. Creemers 1895, pp. 2-203.

${ }^{50}$ Zie voor Cormelis Remmen en Willem. Camps appendix II.
} 
dateren de oudste gegevens van 1812. In dat jaar zond de Franse prefect de volgende mededeling aan het kerkbestuur: "Ik observeere ten opzichte van de klokken, dat die dewelcke toegewijt is aen den dienst van de ure-klok, alsook de ure (uurwerk) zelfs (zelf) moeten onderhouden worden uyt de gemeentegelderen, aangezien dat dit aen de meyers in rekeninge als eenen artikel van uitgave, die den dienst betreft gepasseerd is".$^{11}$ In 1816 ontstond tussen het kerkbestuur en de stad onenigheid over de kosten van het uurwerk. Pastoor P.G. de Guasco schreef op 29 november 1816 aan burgemeester F.W. Quaedvlieg:

"Vernoomen hebbende dat UED. voor het vervlooten jaar alleenlijk 15 francs tot onderhoud en afdraging van de kerkuur gepasseerd heeft, zoo bidde UED. te overwegen

1e so dat de kerkklock niet tot den Godsdienst maar tot het gemak van de gemeente dienende ook van dezelve hoort betaalt te worden.

$2 \mathrm{e}$ dat den koster 4 croonen voor het dagelijks optrekken bekomt.

3e dat jaarlijks een halve kan beste boom-olie van 5 francs de $\mathrm{kan}$, tot 't smeeren nodig is.

4e dat jaarlijks een ofte tweemaal eenen uurmaeker van Maastricht uyt komende van 10 tot 30 , zelfs tot 40 francs verdient heeft, welk tesaamen getrokken zijnde de alloneerde ${ }^{52}$ somme wel haast driemaal zal overtreffen, waarom UED. nogmaals verzoeke van een billigere somme te willen accordeeren, of waarin gaarne wil toestemmen. Indien den achtbaren raad der gemeente het goed oordeelt de klock tot Uw bestuur over te neemen, vermits het niet geoorlooft is de tot den godsdienst geofferde penningen elders te verwenden". ${ }^{53}$

Hoe het allemaal afliep, onttrekt zich voorshands aan onze waarneming.

\footnotetext{
${ }^{\$ 1}$ Kennelijk werd uitgegaan van cen verdeling van kosten, gemoeid met het instandhouden wan de toren en de daarin aanwezige apparatuur.

\$2 Aldus A. Welters 1968. Bedoeld wordt alloweerd, toegekend.

${ }^{43}$ A. Welters 1968, pp. 183-184.
} 


\subsubsection{Susteren}

Susteren, dat in 1276 stadsrechten kreeg van de graaf van Gelre, ${ }^{54}$ behoorde later tot het Guliks gebied. ${ }^{5 s}$ Een stedelijke ontwikkeling is in Susteren niet op gang gekomen, het was meer een versterkt dorp dan een stadje. Of de stad een uurwerk heeft gehad, is onbekend, maar niet aannemelijk. Susteren herbergde binnen zijn aarden wallen en grachten tot aan de Franse Revolutie het oudste vrouwenklooster van Nederland: het adellijke stift Sint-Salvator. ${ }^{56}$ De kerk van deze abdij is behouden en dient tegenwoordig als parochiekerk. Daarnaast heeft tot in 1789 een aparte parochiekerk gestaan. ${ }^{57}$ Het is niet onwaarschijnlijk, dat de abdij ooit een torenuurwerk heeft gehad, maar we vernemen er niets over (zie afbeelding 30 ).

Pas in de 19de eeuw zijn er berichten over een torenuurwerk te Susteren. In de Kroniek wan de kerk van Susteren 1891-1900 wordt onder 1892 gemeld: "10 april. Het uurwerk met de wijzerplaat is

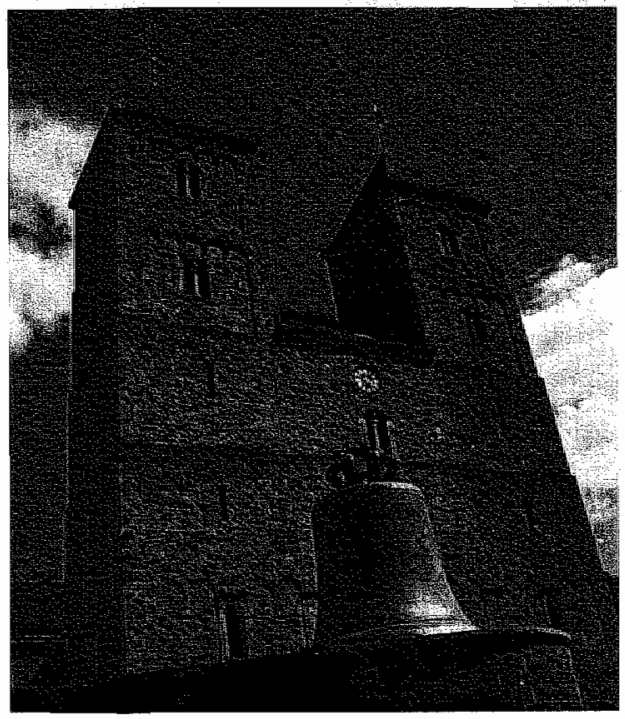

30. Voormalige abdijkerk, thans parochiekerk van de H. Amelberga, Susteren

\footnotetext{
${ }^{54}$ Limburg's Verleden 1967, deel II, p. 111.

${ }^{35}$ Limburg's Verleden 1967, deel II, p. 111.

${ }^{56}$ J. Habets 1869 , p. 442.

" J. Habets 1869 , p. 489 .
} 
naar beneden gekomen door onvoorzichtigheid". Dit uurwerk zat blijkens een foto van vóór 1890 in de linkertoren, die rond 1850 een bekroning had gekregen ${ }^{58}$ op de Romaanse muren. Misschien is toen het uurwerk aangebracht, maar het kan ook zijn dat men een vroeger uurwerk had gehandhaafd. Het onderhoud was tenminste deels een gemeentelijke aangelegenheid. In 1893 werd op de gemeentebegroting een post van tweehonderd gulden uitgetrokken voor een uurwerk aan de kerk. ${ }^{59}$ Het bleek niet voldoende. In 1894 werd het "oude uurwerk der kerk door G. Vrencken uit Echt weder in orde gebracht voor 150 gld." en in 1895 noteerde de plaatselijke chroniqueur: "12 mei. De pastoor heeft mij gezegd dat het uurwerk op de toren 165 gld. heeft gekost. De bijkomende kosten, 45 gld., dus samen $210^{\prime \prime} .{ }^{\circ 0}$ De pastoor had flink moeten toeleggen. Het is onduidelijk of Vrencken het oude gevallen uurwerk heeft gerepareerd of dat met gemeentesubsidie een nieuw uurwerk werd gekocht.

De kleine steden kregen gewoonlijk pas heel laat een torenuurwerk. De ermee verband houdende hoge uitgaven waren kennelijk pas verantwoord nadat de technische ontwikkeling in de $16 \mathrm{de}$ eeuw, bronzen lagers, en de uitvindingen van Huygens, de slinger, en Clement, de ankergang, in de 17 de eeuw de bedrijfszekerheid en nauwkeurigheid van het uurwerk aanzienlijk hadden verbeterd en de onderhoudskosten zeer hadden gereduceerd. Gelijktijdig kwam het huisuurwerk steeds meer op en ontstond er behoefte aan een lokale standaardtijd. Gewoonlijk droeg de plaatselijke overheid de kosten van het openbare uurwerk. In enkele gevallen werden ze met de kerkelijke overheid gedeeld of na verloop van tijd door het kerkbestuar overgenomen. In de 17 de eeuw lijkt de interesse van stadsbesturen voor openbare uurwerken nog groter dan die van de kerkelijke instellingen. Landsheren leggen hoegenaamd nergens enige belangstelling aan de dag, maar dat was ook al het geval in de grotere steden.

${ }^{4}$ G. Venner 1991, inleiding, kolom 213, foto kolom 214.

${ }^{39} \mathrm{G}$. Venner 1992, deel 2, kolom 222; zie ook W. van Mulken 1978, inv.nr. 1597.

6. Venner 1992, deel 3, kolom 269 en kolom 271. Voor Vrencken zie in appendix II onder Vrencken, $\mathrm{G}$. 


\section{Hoofdstuk VI}

\section{De openbare tijdmeting in de Limburgse dorpen}

\section{I. De bronnen}

Het is niet eenvoudig de toestand van de openbare tijdmeting ten plattelande in de greep te krijgen. Dorpsgeschiedenissen zijn er vele vervaardigd. Nog altijd verschijnen zij in Limburg jaar in jaar uit in tot de verbeelding sprekende aantallen. Evenwel, over openbare tijdmeting reppen zij zelden. Sinds anderhalf, twee eeuwen is het zo gewoon dat er op de kerktoren een uurwerk staat, dat de lokale historieschrijvers er zelden een punt van aandacht van maken. Zelfs het niet gering aantal auteurs dat de hoogst denkbare vorm van lokale geschiedschrijving ziet in het vermelden van elk in hun fichesbak terechtgekomen detail, is meestal over het torenuurwerk zwijgzaam. Dat geeft te denken. Erger is, dat als zij al een opmerking maken, het gewoonlijk een toevallige archiefvondst betreft, een reparatienota, een onderhoudscontract of iets dergelijks dat ons niet wijzer maakt over de plaatsing van het eerste uurwerk op de kerktoren of op een ander hoog punt in het dorp.

Noodzakelijkerwijze moest een toevlucht worden genomen tot seriële bronnen, al ontstonden die gewoonlijk pas vrij laat. Gedoeld wordt op dekenale, aartsdiakenale en bisschoppelijke visitaties die pas sinds het midden van de 17 de eeuw met enige regelmaat werden "gehouden", al had het Concilie vàn Trente het houden van visitaties al in het midden van de 16de eeuw verplicht gesteld. Deels zijn ze gepubliceerd, deels in een archief tertig te vinden. ${ }^{1}$ Verslagen van de visitaties die om de twee jaar door de landdeken werden gehouden, kunnen zich hier of daar nog in parochie-archieven bevinden. Dat houdt in dat op 355 plaatsen fragmenten kunnen voorkomen. Nog niet de helft van die archieven bevindt zich in een

${ }^{1}$ G. Simenon 1939 (A); J. Grauwels 1977, pp. 33-190 (B); J. Grauwels 1983a, pp. 27-230 (C); de originele verslagen van de kerkvisitaties in het bisdom Roermond, te weten de inv.nrs. 71 tot 129 van de inwentaris van $H$. Hanssem 1979 (D); de visitaties van het dekenaat Susteren, gepubliceerd door A. Janssen 1988 (E). Voor verklaring van de letters tussen haakjes, zie hierna, tabel 3. 
openbaar depot, vaak ongeïnventariseerd. Een systematisch onderzoek is onmogelijk.

Gewoonlijk waren er voor de visitatoren twee of drie redenen in hun verslag gewag te maken van de aanwezigheid van een uurwerk. Vooreerst dienden zij inzicht te geven in de financiële positie van de parochie die zij bezochten. Een torenuurwerk was een regelmatig terugkerende, dikwijls niet onaanzienlijke kostenpost, die vermelding verdiende, wanneer zij voor rekening kwam van de parochie. Vootts zagen wij reeds dat in nogal wat gevallen de onderhoudskosten aan kerkgebouw en zijn aanhorigheden, zoals de toren, waren verdeeld over meerdere partijen dan wel ten laste van specifieke inkomstenbronnen moesten worden gebracht: dorpsgemeenschap, parochiegemeenschap en lokale clerus moesten vaak elk bepaalde kosten betalen. De tienden, de stipendia, de collectes, de opbrengsten uit deze of gene bezitting moest men dan aanwenden voor specifieke uitgaven. Her en der was het een bron van conflicten, die de aandacht vroeg van de visitator.

In de Landen van Overmaas deed zich nog een specifiek probleem voor. In 1632 waren delen van Nederlands-Zuid-Limburg, de huidige provincie Luik (B) en het Regierungsbezirk Aachen (D) onder Staats gezag gekomen. De Staten-Generaal probeerden er het calvinisme te introduceren. $\mathrm{Na}$ tal van verwikkelingen werd er een simultaneum ingevoerd. Dominee en pastoor mochten elke zondag de kerk een aantal uren gebruiken. De inkomsten werden ten gunste van de hervormden geconfisqueerd. Hier en daar ontstonden rond deze regeling flinke rellen. Over en weer werden diensten en plechtigheden verstoord. ${ }^{2}$ Overal werd gekrakeeld over de kosten van onderhoud van de kerk en haar inventaris. Onder die omstandigheden was het hoogdringend precies te noteren wat ieders verplichtingen waren. In 1663 stelden de hervormden daartoe lijsten op; ${ }^{3}$ kort daarna stuurde de bisschop van Roermond hiervoor zijn vicaris op pad. ${ }^{4}$

Helaas brengen de seriële bronnen niet overmatig veel duidelijkheid. In het huidige Nederlands- en Belgisch-Limburg hadden de

\footnotetext{
${ }^{2}$ W. Munier, manuscript.

${ }^{3}$ R.A.M., Landen van Overmaas, inv.nrs. 273 en 274. Nr. 274, folio 13ro, bevat de staat van de kerken in de Staatse partages van de Landen van Overmaas, opgemaakt in 1663 en de "Nieuwe Lastenverdeling" uit 1764 op folio $16 \mathrm{vo}$.

${ }^{4} \mathrm{H}$. Hanssen 1979, inv.urs. 71-129. De visitaties bestrijken het tijdvak 1656 tot 1787. (Onder rubriek D verantwoord.)
} 
hervormden maar in enkele dorpen rechten, terwijl de katholieken een organisatie uit de dagen van koning Philips II handhaafden, die in het Maasdal aan drie bisschoppen jurisdictie verleende: Roermond, Luik en Keulen. De een visiteerde duidelijk frequenter dan. de ander; van sommige visitaties is het verslag eenvoudig te raadplegen, maar andere zoekt men tevergeefs. En dan nog, volstrekte zekerheid brengt de bron niet. Sommige visitatoren zwijgen in alle toonaarden over uurwerken, als de tot betaling verplichte instantie keurig aan zijn verplichtingen voldeed en de parochie niet meebetaalde. In zulke gevallen brengen soms secundaire bronnen uitkomst.

Ruim 50\% van de uurwerken die vóór 1650 waren geplaatst, is achterhaald uit vermeldingen in gedenkschriften en dorpsgeschiedenissen. Dat is niet verwonderlijk. De visitatieverslagen beginnen pas te lopen rond 1660. De oudere uurwerken moesten wel uit andere bronnen worden gehaald, tenzij de visitator een retrospective gaf. Ook van de uurwerken in de 17 de en 18 de eeuw is nog een aanmerkelijk percentage uit secundaire literatuur gehaald. In tabel 3 zijn de uurwerken uit de secundaire bronnen samengebracht in kolom $\mathrm{F}$.

Lang niet elk uurwerk wordt door de visitator vermeld, zoals reeds is opgemerkt. Enkele voorbeelden mogen de situatie verduidelijken. Epen (Nederlands-Limburg) bezit nog altijd een 17 de-eeuws torenuurwerk. In de visitatieverslagen wordt geen uurwerk vermeld. Ordingen (Belgisch-Limburg) had volgens Grauwels in de $17 \mathrm{de}$ en 18de eeuw een uurwerk. ${ }^{5}$ Toch zwijgen de visitatieverslagen hierover. Soms staat er onder het kopje "turris" (toren) in het visitatieverslag niets over een torenuurwerk, maar wordt in de rubriek "matricularia" (kosterij) wel gesproken over een vergoeding voor het onderhoud van het uurwerk. In zo'n geval moet er een uurwerk zijn geweest. Voorbeelden daarvan zijn As en Borlo, beide gelegen in Belgisch-Limburg. Wanneer het visitatieverslag een uurwerk vermeldt, is dit stellig niet verzonnen. Ook wanneer er uitdrukkelijk wordt gezegd dat er geen uurwerk is, zal dit op waarheid berusten. De lezer van de verslagen krijgt de indruk dat het uurwerk bij voorkeur wordt genoemd, als er iets te klagen was over het onderhoud, dat valak ten laste kwam van de burgerlijke gemeenschap, die in verreweg de meeste gevallen de eigenaar was van toren, uurwerk

S. Granwels 1975 , pp. 159-175. 
en banklok en dat nog tot diep in de 19 de eeuw of zelfs tot in de 20ste eeuw ${ }^{6}$ zou blijven. Die dorpsrekeningen zijn dus de eerst aangewezen bron voor informatie over de dorpsuurwerken. Helaas zijn ze voor een groot deel verloren gegaan of ontoegankelijk, want niet geinventariseerd, zodat het onontkoombaar was oneigenlijke bronnen als visitatieverslagen te raadplegen. In de loop van de $19 \mathrm{de}$ eeuw zou de financiële bemoeienis van de gemeente zich zelfs gaan uitstrekken tot het hele kerkgebouw, de pastorie en soms de kapelanie?

Al met al mag tabel 3 geen aanspraak maken op volledigheid. Dat slechts in $31 \%$ van de plattelandsparochies een uurwerk voorkwam, moet niet letterlijk worden genomen. In feite kon slechts wan $31 \%$ van de dorpstorens worden aangetoond dat zij een uurwerk hadden, van de resterende $69 \%$ staat de afwezigheid van een uurwerk bepaald niet vast. Slechts van zestien parochies ${ }^{8}$ weten we absoluut zeker dat zij omstreeks 1800 geen uurwerk hadden. Wel was de steekproef in hoge mate aselect. De spreiding zal redelijk correct zijn weergegeven. Dit betekent dat een zeer aanzienlijk deel van de uurwerken op de dorpstorens pas laat werd geplaatst, gewoonlijk in de loop van de 18 de eeuw. $75 \%$ Van de plattelandsparochies die een uurwerk hadden kreeg het pas ná 1650 . Het percentage late plaatsingen zal bij eventuele voortzetting en intensivering van het onderzoek waarschijnlijk zelfs nog hoger worden dan de tabel aangeeft. Daar zijn technische oorzaken voor aan te voeren. Vóór 1650 geplaatste torenuurwerken waren uitermate storingsgevoelig. $\mathrm{Zij}$ vergden als gevolg van het ontbreken van een slinger frequent gelijkzetten. De gebrekkige smeermiddelen en de toegepaste materialen veroorzaakten veel en kostbaar onderhoud. Met name op het platteland zal het zelden mogelijk zijn geweest een plaatselijke coryfee al de nodige werkzaamleden naar genoegen te laten uitvoeren. Gewoonlijk zal men iemand van buiten hebben moeten laten komen. Bij de bespreking van de diverse Limburgse steden zagen we al dat een dergelijk besluit omstandig werd voorbereid. Hoe ouder een uurwerk, hoe meer kans op een dossier over ingrijpend

\footnotetext{
${ }^{6}$ Bijvoorbeeld Weert, toren van de Sint-Martinuskerk.

"Zie bijvoorbeeld de kerkelijke politiek in de kerkdorpen van de gemeente Meerssen. Th. Obemdorff en M. Niesten 1994, pp. 178-183, 194-195, 246-247.

${ }^{8}$ Dit zijn: Ambij, Amstenrade, Bingelrade, Brunssum, Bunde, Geulle, Hulsberg, Itteren, Klimmen, Merkelbeek, Nuth, Oirsbeek, Oud-Valkenburg, Schimmert, Schin op Geul, Spaubeek.
} 
en kostbaar herstel. Zulke dossiers bleven in de steden relatief vaak bewaard, zo vaak zelfs dat zij de conclusie rechtvaardigen dat om de 50 à 75 jaar elk openbaar uurwerk een ingrijpende beurt nodig had. In de dorpen zal het niet anders zijn gegaan. De kans dat van een twee- à driehonderd jaar oud uurwerk geen schriftelijk spoor is overgebleven, is vele malen kleiner dan dat een laat-18de-eeuws uurwerk aan onze aandacht is ontsnapt (zie afbeelding 31 en 32). Ook in een ander opzicht geeft de tabel relevante informatie. De visitatievoorschriften waren in de drie betrokken diocesen tamelijk uniform. De visitatoren noteerden grosso modo dezelfde gegevens. Wanneer hierachter wordt uiteengezet dat zij in sommige delen van de beide Limburgen bijna nooit een openbaar uurwerk vermeldden en in andere delen er relatief waak vermeldden, dan zal dat betekenen dat de ene regio ook in werkelijkheid veel vaker was gezegend met een torenuurwerk dan de andere. Met andere woorden, dat de aanwezigheid van torenuurwerken regional was bepaald.

Tabel 3 toont de aangetroffen uurwerken naar tijdperk en bron. Het totale aantal parochies dat in een bepaalde bron wordt beschreven staat in de onderste rij. Het getal 17 in kolom $\mathrm{E}$, bijvoorbeeld, duidt het aantal Limburgse plaatsen aan in de Luikse dekenaten Susteren en Wassenberg. De getallen in kolom $F$ betreffen de uurwerken in parochies, die in de bronnen A-E aan de orde komen zonder vermelding van een uurwerk, maar die blijkens andere bronnen toch een openbaar uurwerk hadden. Van de 27 dorpstorens waar een uurwerk van vóót 1650 werd aangetroffen, lagen er dertien in de Haspengouw, ${ }^{9}$ goeddeels rond Hasselt. Daarbuiten vinden we veertien vermeldingen verspreid over de rest van het onderzoeksgebied. ${ }^{10}$ Het gaat bij de dorpen met relatief oude uurwerken zeker niet om dorpen met een centrumfunctie. Integendeel, vooral de Haspengouwse dorpen met een torenuurwerk waren vaak zeer klein. Wel gaat het om dorpen met een compacte bebouwing. Het zou tenminste tot 1700 zo blijven: het dorpsbestuur investeerde niet in een torenuurwerk, tenzij nagenoeg alle dorpelingen er plezier van hadden. De bebouwing mocht niet te ver van de kerk afliggen. Typisch langgerekte straatdorpen, zoals die in de

\footnotetext{
"Beverst, Borlo, Diepenbeek, Herderen, Jesseren, Kozen, Munsterbilzen, Ordingen, Overrrepen, Schalkhoven, Stevoort, Wintershoven, Zichen-Zussen-Bolder.

${ }^{10}$ As, Baarlo, Beek (bij Maastricht), Dieteren, Grathem, Gulpen, Kessemich, Hoensbroek, Middelaar, Nederweert, Neeroeteren, Oostham, Stevensween, Zonhoven.
} 


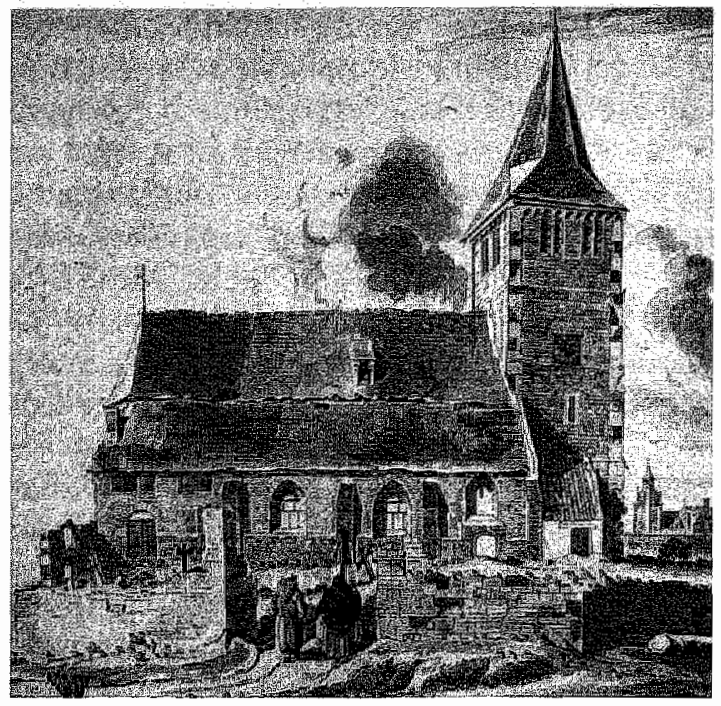

31. Dorpsgezicht van Heel (tekening J. de Beyer, 1740, archief L.G.O.G., nummer 1021 )

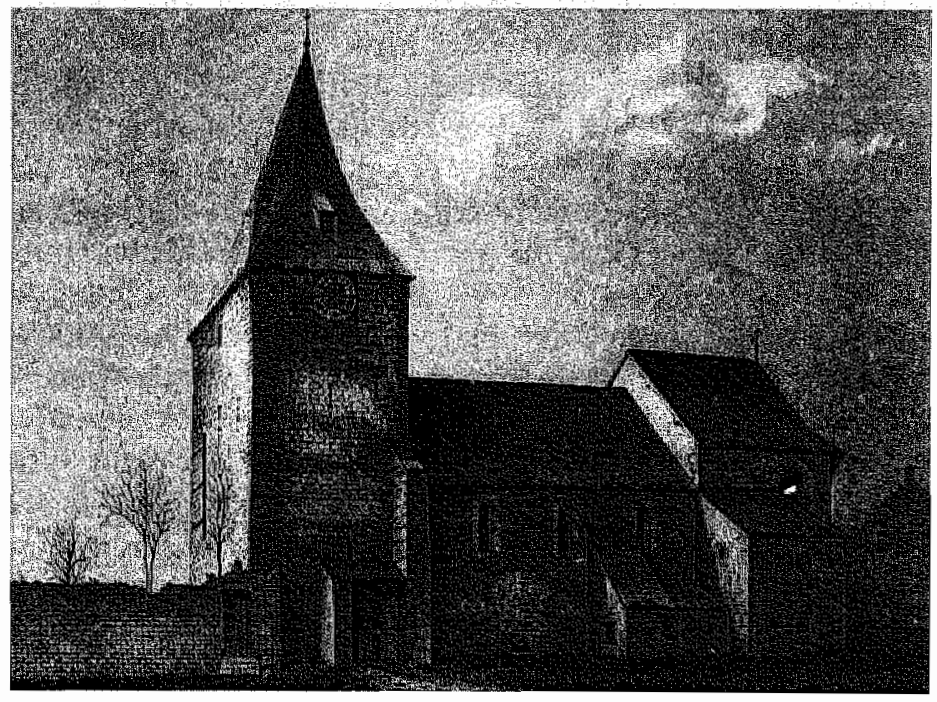

32. Kerk van Mesch (lithografie J. Brabant, privé-bezit) 
Landen van Overmaas worden aangetroffen, of dorpen met daaromheen een krans van gehuchten, vanwaar uit men de tijdsaanduiding op de kerktoren niet kon lezen, kregen voorshands geen torenuurwerk. Het dorpje Ulestraten, op drie kilometer afstand van Meerssen gelegen, was in 1792 en waarschijnlijk nog vijftig jaar later aangewezen op het uurwerk van Meerssen. ${ }^{11}$ Omdat het onmogelijk was vanuit Ulestraten de wijzerplaat in Meerssen af te lezen, moest men zich behelpen met de uurslag, die men kon horen als de wind gunstig stond.

Tabel 3. Aantal torenuurwerken per tijdperk gesplitst naar bron

\begin{tabular}{lrrrrrrrr}
\hline Broni2 $^{\mathrm{i2}}$ & A & B & C & D & E & $F^{13}$ & Totaal & $\%$ \\
\hline$<1650$ & 9 & - & - & - & & 18 & 27 & 7,6 \\
$<1700$ & 10 & 1 & 1 & - & & 10 & 22 & 6,2 \\
$<1750$ & 11 & - & 4 & 11 & & 17 & 43 & 12,1 \\
$>1751$ & 2 & - & - & 1 & & 15 & 18 & 5 \\
\hline Somma & 32 & 1 & 5 & 12 & & 60 & 110 uurwerken 31 \\
\hline Aanial & & & & & & & \\
parochies & 172 & 26 & 64 & 76 & 17 & - & 355 parochies \\
\hline
\end{tabular}

\subsection{De spreiding van de openbare uurwerken}

Wanneer we de vermelde dorpsuurwerken intekenen op een kaart blijkt dat er regionaal enorme verschillen bestonden (zie kaart 2).

- Er is een concentratie van openbare uurwerken van vóór 1700 rond Hasselt met een zuidelijke uitloper naar de streek tussen Sint-Truiden en Tongeren, de Limburgse Haspengouw. Mogelijk is dit te verklaren als een uitstraling van de Hasseltse klokkenateliers, die van de 15 de tot de 17 de eeuw hun top bereikten. Enige samenhang met welvaart mag ook worden verondersteld. Die was in de Haspengouw relatief hoog.

\footnotetext{
"R.A.M., Landen van Overmaas, inv.תr. 7500.

${ }^{12}$ Zie dit hoofdstuk, noot 1 .

"Diverse monografieën en tijdschriftartikelen in het literatunuoverzicht ${ }_{\text {. }}$ geciteerd bij het desbetreffend dorp in appendix III.
} 
Kaart 2. Dorpen met een torenuurwerk

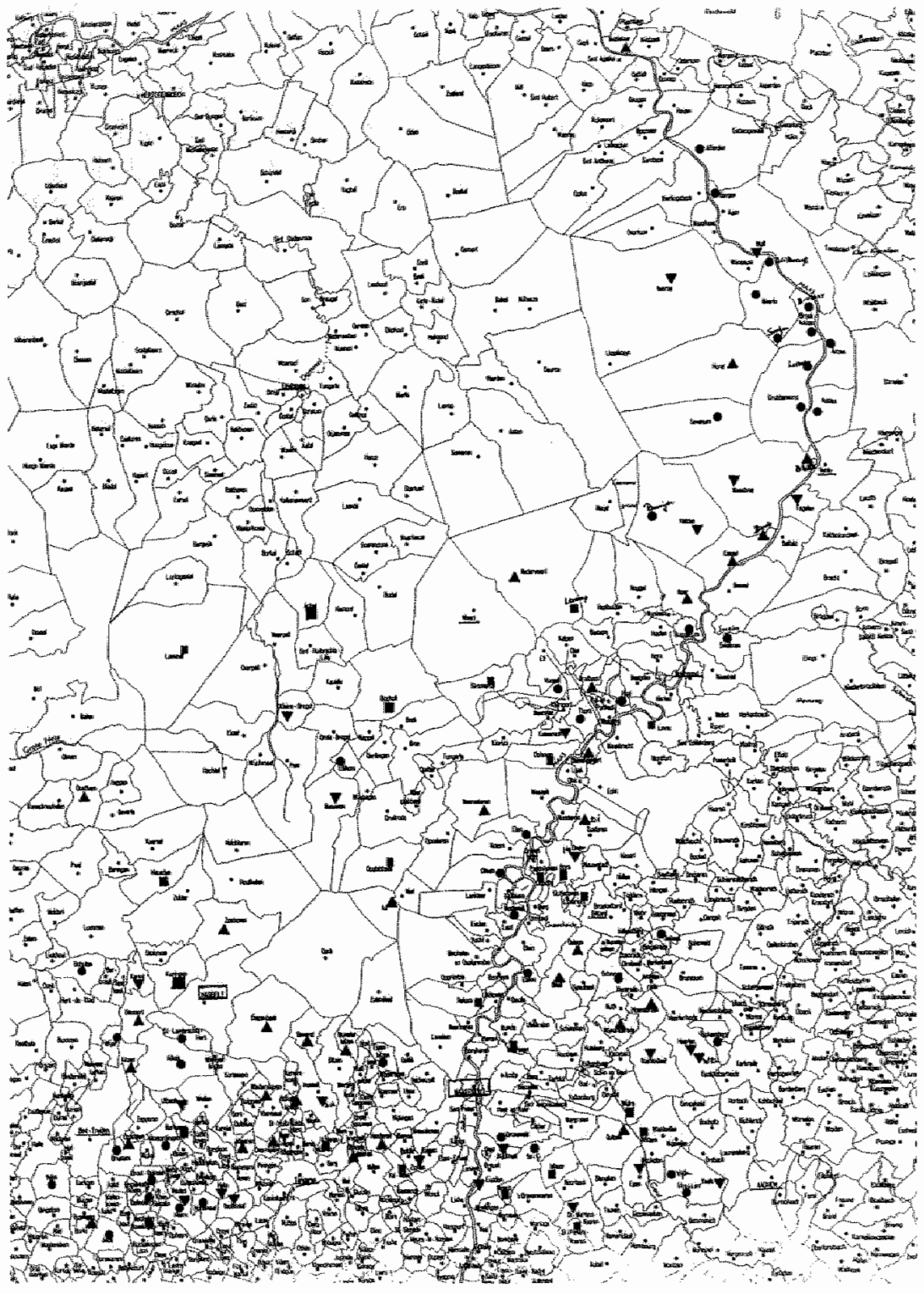

Legenda: vóór $1650 \Delta ; 1651-1700 \nabla ; 1701-1750$; na $1751 \mathbf{0 .}$ 
- In het dekenaat Beringen, dat zich uitstrekte over de Kempen, zijn weinig openbare uurwerken. Het beeld wordt hier overigens mede bepaald door het feit dat de visitatieverslagen van Beringen slechts tot 1726 zijn overgeleverd. Juist in de periode 1720-1749 komen er in de andere gebieden veel uurwerken bij. Dat kan ook in dit dekenaat zijn gebeurd. Men zou dan zijn afgestapt van het bezwaar dat de verspreide bebouwing en de aanwezigheid van talrijke gehuchten op kilometers afstand van de kerk opriep.

- Een kleine concentratie doet zich voor rond Maastricht aan de oostkant van de Maas van Beek over Geleen naar Gulpen en Gronsveld, in een lus rond de kern van het Nederlands-Limburgse lössgebied. Mogelijk hangt dit voor wat het noordelijk gedeelte betreft samen met de metaalnijverheid (gereedschappen, vooral sloten) in Beek, Spaubeek, Geleen, Brunssum en voor het overige met de afzet van veeteeltproducten op de nabijgelegen grote markten van Maastricht en Aubel.

- Opmerkelijk is het geringe aantal, de bijna afwezigheid, van openbare uurwerken in de kern van het Zuid-Limburgse lössgebied, de Landen van Overmaas. De afwezigheid is even pregnant in de Spaans-Oostenrijkse partage als in de Staatse. De veronderstelling, dat het ontbreken van torenuurwerken zou samenhangen met het simultaneum werd niet bewaarheid. Het zijn niet alleen de simultaankerken waarop het torenuurwerk ontbreekt. Van meer belang lijkt dat we hier met straatdorpen hebben te maken. In de Landen van Overmaas blijft de openbare tijdmeting een zeldzaam verschijnsel.

- De concentratie van toremuurwerken in Nederlands-Noord-Limburg uit de 18 de eeuw is te danken aan de activiteiten van de klokkenmakersfamilie Remmen te Well en de stimulansen die uitgingen van het Pruisische bestuur. Dat was er voortdurend op uit de economie in het hertogdom Kleef en in Pruisisch OpperGelder een bredere basis te verschaffen. Vooral de lokale nijverheid moest worden uitgebouwd, al was het maar in de vorm van huisnijverheid. De combinatie van ambachtelijke en agrarische activiteiten in één gezin leverde vanzelfsprekend problemen op bij de indeling van de werkdag. In de omgeving van Horst en Venray kan als gevolg van een opbloei van een overigens kleinschalige 
plattelandsnijverheid in de late 18 de eeuw behoefte aan torenuur werken zijn ontstaan. ${ }^{14}$

- In de Roerstreek werden geen gegevens betreffende openbare uurwerken aangetroffen, hoewel er enkele oude parochies zijn als Herkenbosch met een 13de-eeuws gotisch koor aan de parochiekerk, Vlodrop en Melick. Hoewel de kerk van Sint-Odiliënberg een tijdlang kapittelkerk is geweest, wijst ook daar niets in de richting van een torenuurwerk. Posterholt is een vrij jonge parochie en daarbij een typisch langgerekt straatdorp, zodat daar tenminste de afwezigheid verklaarbaar is. Voor het overige zijn we voor een raadsel geplaatst. In de 18 de eeuw woonden in deze streek bekwame uurwerkmakers, waarvan er één hiervoor werd genoemd als hersteller van het torenuurwerk van Echt. In eigen omgeving was aan zijn vakmanschap geen behoefte.

Gezien het betrekkelijk kleine aantal openbare dorpsuurwerken, dat ons bekend is, en de aard van onze bronnen, waardoor we niet met absolute zekerheid weten of een bepaalde plaats al dan niet een openbaar uurwerk had, moeten we zeer voorzichtig zijn met onze conclusies. $\mathrm{Zij}$ zouden kunnen luiden: maatschappelijke behoefte alleen biedt geen afdoende verklaring voor de aanwezigheid van torenuurwerken. De aanwezigheid van uurwerktechnische kennis in de omgeving vormt soms, maar ook weer niet steeds een bijkomende factor van betekenis.

Particuliere bezitters van torenuurwerken waren ten plattelande heel zeldzaam. Van slechts drie abdijen en kloosters zijn gegevens over uurwerken boven water gekomen. Het beste zijn we ingelicht over Munsterbilzen dankzij een artikel van Vanheusden. ${ }^{15}$ Of dit uurwerk goed zichtbaar was vanaf de straat, en dus een echt openbaar uurwerk was, is evenwel de vraag. Het uurwerk van de abdij in Thorn was volgens de tekening van De Beyer goed zichtbaar voor de dorpelingen. Het klooster Keizerbos bij Neer beschikte in 1507 over een uurwerk, ${ }^{16}$ maar over de plaats waar het was angebracht weten we niets. Enige samenhang met een behoefte de religieuze diensten op vaste tijdstippen te laten plaatsvinden, kan hieruit niet worden afgeleid.

\footnotetext{
14. J. Jansen 19936 , p. 154.

15 R. Vanheusden 1973, pp. 270-273.

${ }^{16}$ E. Koch 1994, zie bijlagen op diskette: Keizerbosch urs. 30 en 121.
} 
Een achttiental kastelen beschikt thans nog over een torenuurwerk. of er meer zijn geweest, is onduidelijk, maar onwaarschijnlijk. De meeste van deze torenurwerken stammen uit de $18 \mathrm{de}$ eeuw, drie zijn ouder, vier jonger. Enkele kastelen met torenuurwerken lagen vlakbij wegkruisingen. Mogelijk gaat het hier om maatschappelijke dienstverlening, niet alleen om status.

Een heel ander aspect wordt belicht door de onderhoudsplichten na te gaan. De verantwoordelijkheid voor het onderhoud van de uurwerken, die in de tabel voorkomen, vertoont een caleidoscopisch beeld. In de 18de eeuw konden onderhoudsplichtig zijn" de hogere overheid (bijvoorbeeld de Staten-Generaal), de lokale gemeenschap, de plaatselijke heer, de grote tiendheffer, de kerk(fabriek), de armenkas, ieder voor zich of tezamen met één of meer van de andere genoemde instanties. Soms werden de onkosten de facto door de Kerk of armenkas gedragen, terwijl anderen de jure aansprakelijk waren. De visitators fulmineerden hier tegen. Overigens weten we in heel wat gevallen niet wie verantwoordelijk was. De gevallen waarover wel informatie beschikbaar is, vertonen het volgende beeld. De lokale gemeenschap alléén was verantwoordelijk in 22 gevallen, vooral in de Kempen en Nederlands-Noord-en Midden-Limburg. Daar komen acht gevallen bij, waarbij de lasten door gemeenschap en Kerk samen werden gedragen, in één geval aangevuld door de armentafel. Ook die werden voornamelijk aangetroffen in de genoemde regio's. In de Haspengouw kwam het onderhoud in dertien gevallen ten laste van de kerk(fabriek), vijf keer aangevuld met geld uit de armenkas. Dit laatste tot ongenoegen van de visitators. In Nederlands Noord-Limburg deden zich ook zeven gevallen voor, waarin de kerk(fabriek) alléén voor het onderhoud opdraaide. In drie gevallen werd dit door de visitator verboden. In één geval was de grote tiendheffer alleen onderhoudsplichtig, in één ander geval de Kerk met de plaatselijke heer. $\mathrm{Na}$ de verdeling van de Landen van Overmaas ${ }^{17}$ namen de Staten-Generaal in toenemende mate de onderhoudslasten van torens en kerken in hun gebieden op zich. In de staat van kerken, opgemaakt in 1663, worden zij tweemaal als onderhoudsplichtige opgevoerd; in de "Nieuwe Lastenverdeling" van 1764 nemen zij de lasten van elf

17. Haas 1978, passim. 
torens en/of kerken op zich. ${ }^{18}$ Overigens neemt in genoemde "Nieuwe Lastenverdeling" het aantal lokale gemeenschappen met onderhoudsplicht ook toe van tien naar twaalf. De gemeenten krijgen steeds meer financiële lasten op hun bord. Voor een groot deel waren zij daarvan zelf de schuld, zoals Dumont aantoonde. Sedert het midden van de 17 de eeuw trachtten de lokale dorpsgemeenschappen zich te ontworstelen aan de druk van de schepenbanken die door vreemdelingen werden bezet, de landsheer en de parochie. Mits zij wat meer zeggenschap kregen, waren zij bereid in de buidel te tasten, hetgeen hen aanvankelijk mondjesmaat werd toegestaan, maar gaandeweg toch leidde tot groeiende lokale autonomie. ${ }^{19}$ Regionaal zijn er op dit vlak grote verschillen, maar voorshands is volstrekt onduidelijk waarom Haspengouw een andere weg ging dan de Landen van Overmaas en Opper-Gelder. De abdijen en kloosters betaalden zelf voor hun uurwerk.

De grote diversiteit ten plattelande biedt perspectieven voor beschouwingen over de spreiding en de functie van de openbare uurwerken. Met wat we over de Limburgse steden hebben gevonden, wordt ons inmiddels de mogelijkheid geboden enige duidelijkheid te scheppen rond vragen naar de diffusie van het torenuurwerk, de instanties die verantwoordelijk waren voor de instandhouding ervan en de samenhang met de sociaal-economische ontwikkeling van de steden en het platteland in de late Middeleeuwen en de Nieuwe Tijd. Het torenuurwerk verbreidde zich zeer traag, eerst over de steden met een handelsfunctie, vervolgens over die met overwegend nijverheid en pas veel later over de streekcentra en het platteland. De burgerlijke overheid is voor plaatsing en instandhouding de eerst verantwoordelijke. Als mogelijke verklaring voor de functie van het torenuurwerk geldt dat het in de 14 de-15de eeuw vooral met de handel en het gebeuren op de markt was verbonden en allicht een beperktere rol speelde dan in de late $17 \mathrm{de}$ en de $18 \mathrm{de}$ eeuw, toen de organisatie van bedrijven ten plattelande, die meerdere vormen van bedrijvigheid combineerden, in het geding was. Wij zullen er hierna in hoofdstuk XI op terugkomen. Het beeld kan wellicht wat duidelijker worden wanneer eerst nog de technische aspecten en de verspreiding van de huisuurwerken worden behan-

\footnotetext{
${ }^{18}$ Zie noot 3. In de genoemde staten wordt helaas niet expliciet melding gemaakt van nurwerken.

${ }^{19}$ Zie B. Dumont 1994.
} 
deld. Het is immers niet onwaarschijnlijk dat hun verschijnen het torenuurwerk een nieuw of misschien een tweede functie bezorgde: het leveren van een standaardtijd. 
142 


\section{Hoofdstuk VII}

\section{Technische aspecten van de Limburgse uurwerken}

De oudste uurwerken in de beide Limburgen waarover we gegevens hebben zijn torenuurwerken. Over hun functie in de openbare tijdmeting in steden en dorpen is in de voorafgaande hoofdstukken nitvoerig gesproken. De instrumenten zelf, hun opbouw en specifieke kenmerken, dienen thans aan de orde te komen. Het is niet gemakkelijk ze in detail te beschrijven omdat we van de meeste slechts weet hebben via documenten betreffende hun onderhoud, terwijl de meeste torenuurwerken zelf verloren zijn gegaan.

Beter ingelicht zijn we over de huisuurwerken, althans over de producten uit de 18de en de eerste helft van de 19 de eeuw. In totaal konden 634 huisuurwerken worden bekeken, waarvan er 109 nader konden worden bestudeerd en opgemeten. Op grond van de analyse van deze collectie en subcollectie zal in dit hoofdstuk worden gepoogd de specifieke kenmerken van de Limburgse huisuurwerken te omschrijven.

\subsection{Torenuurwerken}

Slechts een viertal torenuurwerken uit de vroegste periode, $14 \mathrm{de}-$ 15 de eeuw, is deels bewaard gebleven. ${ }^{1}$ De gegevens van de bewaarde exemplaren combinerend met de gegevens uit de archivalia en de horologische literatuur kunnen we ze als volgt omschrijven. Het waren grote constructies van gesmeed ijzer, aanvankelijk zonder (buiten-) wijzerplaten. De raderen, eveneens van smeedijzer,

${ }^{1}$ De uurwerken van respectievelijk de Sint-Gummaruskerk in Lier, waarschijnlijk wit de lakenhal te Maastricht afkomstig (rond 1396?), het Dinghuis in Maastricht (rond 1400?), het stadhuis van Maaseik (1.5de eeuw?) en de parochiekerk in Overrepen (tegen 1500?). Men moet niet uit het $00 \mathrm{~g}$ verliezen dat genoemde uurwerken eeuwenlang in gebruik zijn geweest en dat ar am de ongeveer vijftig jaar ingrijpende vernieuwingen plaatsvonden. In het algemeen zijn slechts de hoekstijlen, de tussenstijlen en wellicht de grondraderen uit de tijd van ontstaan. De datering van de zeer vroege toremurwerken staat nog in de kinderschoenen. Er zijn geen duidelijke en eensluidende dateringscriteria voorhanden, zoda" er onder de "experts" veel discussie is over tegenstrijdige dateringen. 
waren gevat in een raamwerk, waarvan de vier hoekstijlen diagonaal waren geplaatst en van Gotische profileringen voorzien (zie afbeelding 33). De gangregeling was een foliot (zie afbeelding 1), het echappement was een verticale spillegang, het slagwerk werkte met een telrad, meestal sluitschijf genoemd. Torenuurwerken uit dezelfde periode in andere streken en landen vertonen hetzelfde beeld. De Limburgse uurwerken van die tijd weken niet af van het algemeen gangbare type; er zijn geen typische regionale of "nationale" kenmerken te achterhalen, zij het wellicht slechts bij gebrek aan voldoende vergelijkingsmateriaal. Er zijn, niet alleen in de beide Limburgen, maar in heel Europa, slechts heel weinig torenuurwerken van vóór 1500 overgeleverd. $\mathrm{Zij}$ zijn gewoonlijk gemaakt door rondtrekkende vaklieden, ${ }^{2}$ net zoals bij het gieten van luidklokken het geval was. ${ }^{3}$ Meestal kennen we hun namen niet. Deze anonimiteit verdwijnt geleidelijk vanaf het einde van de 14 de eeuw. Van het uurwerk van het vroegere stadhuis, de Lanscroon, weten we dat het tussen 1396 en 1400 werd vervaardigd door de Maastrichtenaar Henric van Thoren. ${ }^{4}$ In 1389 had Van Thoren al twee uurwerken aan de stad Venlo geleverd. ${ }^{5}$ In de 15 de eeuw neemt het aantal met name bekende Limburgse torenuurwerkmakers toe. $\mathrm{Zij}$ waren hoofdzakelijk werkzaam in Hasselt. ${ }^{6}$

Ook de overgebleven torenuurwerken uit latere tijden vertonen geen typische kenmerken. Wel volgen zij de technische en stilistische ontwikkelingen van hun tijd. Zo ging men omstreeks 1600 bronzen of messing bussen toepassen als lagering, zodat minder slijtage optrad. Rond het midden van de 16 de eeuw verdwenen de gotische stijlkenmerken om plaats te maken voor renaissancevormen: klassieke zuilvormen op hoge basementen (zie afbeelding 34). Na het bekend worden van de revolutionaire slingertoepassing door Huygens, dus na de publicatie van zijn brochure "Horologium"7 uit 1658, gevolgd door het doorwrochte boek "Horologium oscillatori-

\footnotetext{
Zile hoofdstuk VIII, paragraaf 8.2.1.

${ }^{3}$ A. Lehr 1981b, p. 105 .

4 Zie hoofdstuk II, pargraaf 2.1.1 en voor Van Thoiren appendix II.

"Zie voor deze uarwerken hoofdstuk III, paragraaf 3.1.1.

${ }^{6} \mathrm{~J}$. Leunis 1.958, pp. 273-298; zie ook hoofdstuk IV, paragraaf 4.1 en hoofdstuk VIII, paragrataf 8.2.1.

${ }^{7}$ Uitgegeven te "s-Graverihage (Hagae Comitum) door Adriaan Vlacq in 1658. In de Oeuvres complètes is het opgenomen in volume 17, pp. 41-73. Het boekje werd oorspronkelijk in het Latijn geschreven en is later in het Frans vertaald.
} 


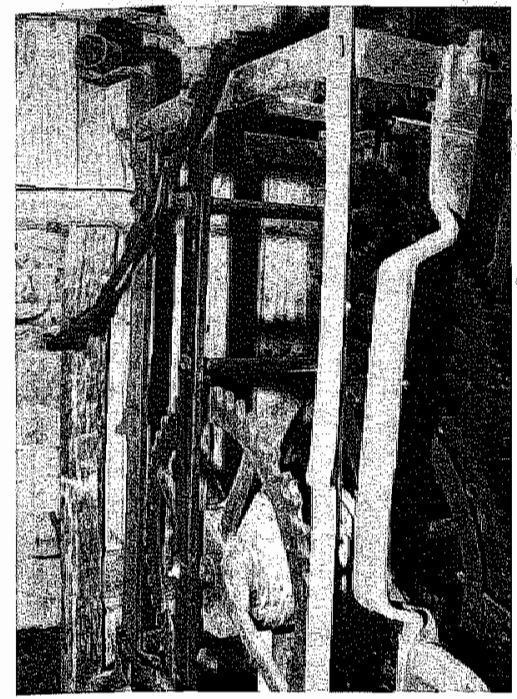

33. Details van gotisch torenuwrwerk in de kerk van Overrepen (circa 1500). Gotische hoekstijlen onder een hoek wan 45 graden geplaatst. Links slagwerk, rechts gaand werk op ankergang omgebouwd

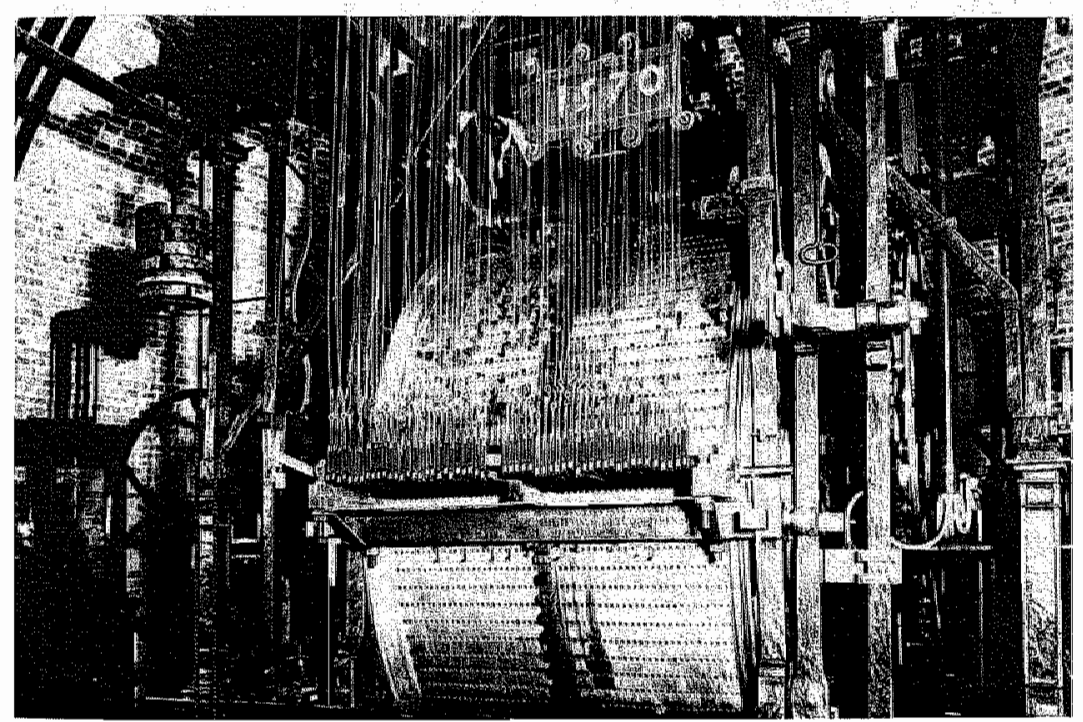

34. Torenuurwerk in de Nieuwe Kerk, eertijds un stadhuis te Delft (uurwerk $\mathbb{H}_{\text {. }}$ van Nuyst, Hasselt, 1570; speeltrommel is een vervanging door Hemony en Van Call, 17 de eeuw). Foto Gemeentearchief Delft 
um"8 uit 1673 , werden bestaande uurwerken meestal omgebouwd naar het nawweurigere slingersysteem. De foliot werd vervangen door een slinger; het uurwerk werd daartoe aangepast, waarvoor men twee mogelijkheden had. Vooreerst kon men de verticale spillegang behouden door een lange meenemer aan de foliot-as te

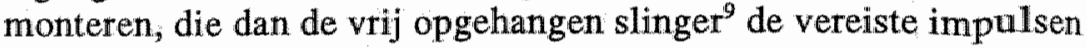
kon geven. Dit is het zogeheten "Scheveningse systeem", een oplossing door Huygens voor het eerst uitgeprobeerd in de kerk van Scheveningen (zie afbeelding 35).

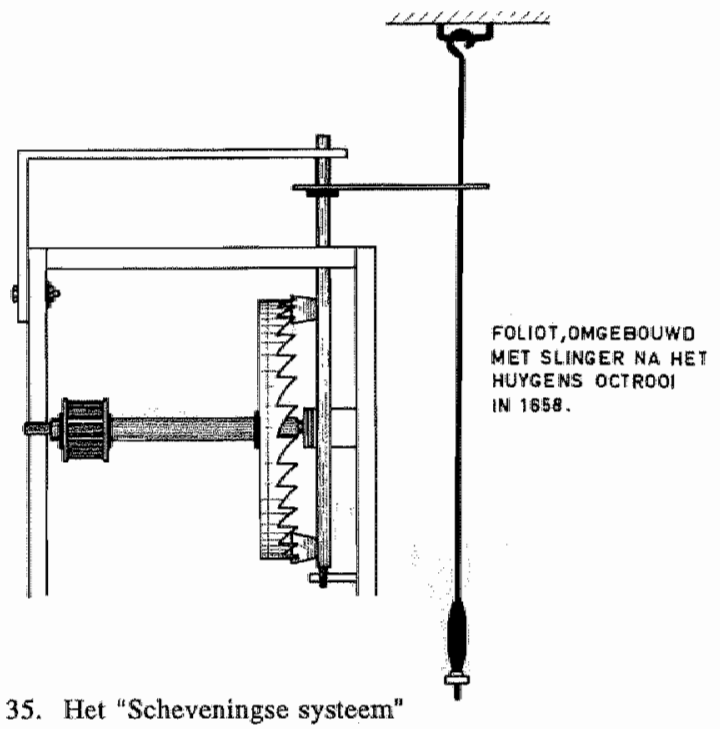

De andere manier was de verticale spillegang te vervangen door een horizontale. De slinger werd dan opgehangen aan het uurwerk. Het uurwerk van het Dinghuis in Maastricht werd op deze manier omgebouwd, mogelijk in $1712 .{ }^{10}$ Later werd de spillegang vaak vervangen door een ankergang, zoals in 1792 gebeurde met het uurwerk van de Sint-Martinuskerk in Weert door P.A. de Coster. ${ }^{\| 1} \mathrm{Het}$

\footnotetext{
"De volledige titel luidt: "Horologium oscillatorium sive de motu pendulorum ad horologia aptato demonstrationes geometricae". Het werd uitgegeven te Parijs bij F. Muguet in 1673. "Dit wil zeggen: niet opgehangen aan het uurwerk, maar aan een balk of aan de zoldering dichtbij het unurwerk.

${ }^{10}$ Zie hoofdstuk II, paragraaf 2.1.3.

${ }^{" 1}$ Hoofdstuk III, paragraaf 3.2.1.
} 
kwam voor, dat voor zo'n modernisering specialisten uit andere plaatsen werden uitgenodigd. Verschillende slingerophangingen van torenuurwerken, die in Limburg in de 18 de eeuw werden omgebouwd, dragen de initialen I.H., soms omgeven door een cirkel van kleine rondjes (kasteel Wijnandsrade en het afgedankte torenuurwerk van de kerk van Gronsveld). Dit wijst mogelijk op ombouw door Joannes $\mathrm{Ha}(\mathrm{e}) \mathrm{rtmans}$ (1735-1807) uit Beek (zie afbeelding 36).

In de loop van de $18 \mathrm{de}$ eeuw kwamen ook bij torenuurwerken messing tandwielen in zwang. Wat betreft de vormgeving volgden de Lodewijkstijlen elkaar op. Deze salonstijlen kwamen over het algemeen niet zo pregnant voor aan torenuurwerken als aan meubels en architectuur. Met enige moeite kan men drie voorbeelden van de Louis XVI-stijl aanwijzen: de uurwerken met speeltrommel van de Sint-K wintenskerk in Hasselt en in het stadhuis van SintTruiden, beide door Gilles de Beefe en zijn zoon Nicolas uit Luik, ${ }^{12}$ en het uurwerk met speeltrommel voor de Sint-Servaas te Maastricht door François de Beefe uit Maastricht ${ }^{13}$ (zie afbeelding 11, 24 en 27). De drie genoemde instrumenten zijn incompleet bewaard: geen heeft nog zijn gaande werk. Vaak blijft in de 18 de eeuw de versiering beperkt tot gesmede krullen bovenaan de hoekstijlen, zoals bij het uurwerk van Cornelis Remmen uit Well voor kasteel Arcen (zie afbeelding 37), of blijft zij helemaal achterwege, zoals bij het uurwerk van het museumkerkje te As en dat van kasteel Geusselt te Maastricht (zie afbeelding 14).

Ook uit de concentratie van torenuurwerkmakers in bepaalde steden mogen wij geen specifieke Limburgse kenmerken afleiden. Daarvoor verplaatsten de zwaartepunten zich te snel. In de $1.5 \mathrm{de}$ en $16 \mathrm{de}$ eeuw was Hasselt een centrum voor torenuurwerkbouw met leden van de families Co(e)len, Blaesen, Deeckens en Van Nuys $(t) .{ }^{14}$ In de 17 de, maar vooral de 18 de eeuw nam Luik deze rol over met onder anderen de families Moës en De Beefe. In de $18 \mathrm{de}$ eeuw werden in het noorden van de beide Limburgen concentraties van torenuurwerkmakers aangetroffen, namelijk het atelier Smeets in Hamont en het atelier Remmen in Well.

\footnotetext{
${ }^{12}$ Zie hoofdstuk IV, paragraaf 4.1.1. en 4.1..3.

${ }^{13}$ Het uurwerk werd blijkens een inscriptie boven de speeltrommel in 1769 gebouwd en in 1770 geplaatst. Zie hoofdstuk II, paragraaf 2.2 .2 .

14 J. Leunis 1958 , pp. $273-298$.
} 


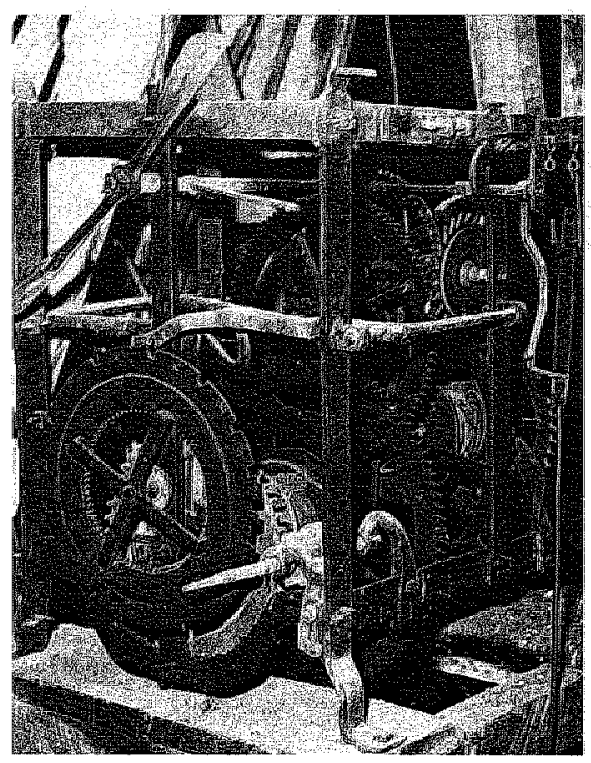

36. Torenunurwerk in kasteel Wijnandsrade (eerste helft 17 de eeuw). Links op de foto het slagwerk, rechts de 18 de-eeuwse slinger met de signatuur "I.H." op de ophanging

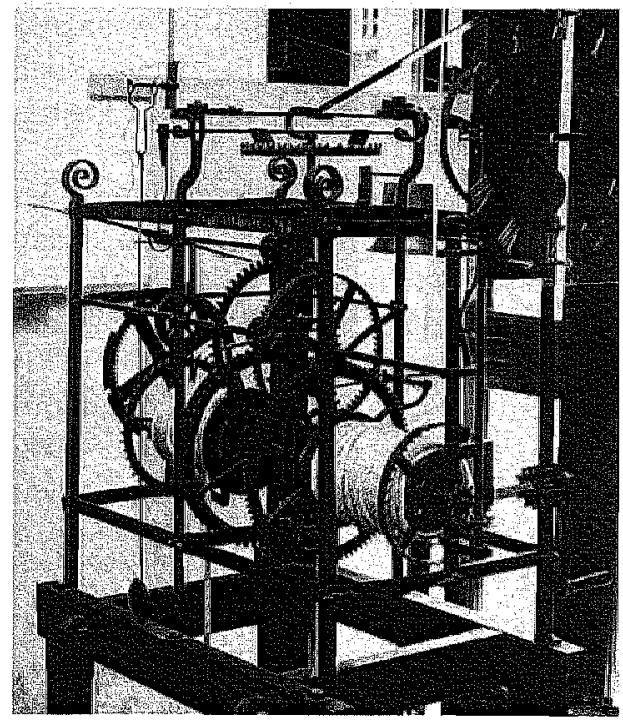

37. Torenuurwerk in kasteel Arcen (Cornelis Remmen, Well, 1748). Niet meer in functie; bel en cijferring zijn toegevoegd 
In de 19de eeuw werden soms uurwerken gebouwd door "mecaniciëns", zoals L. Doppler-Gadet in Maastricht ${ }^{15}$ en J.B. Premeren in Ninove, die werkte volgens aanwijzingen van de uurwerkmaker Jan Arnold Bielen uit Zonhoven. ${ }^{16}$ In het laatste kwart van de $19 \mathrm{de}$ eeuw komen er steeds meer industrieel vervaardigde torenuurwerken in gietijzeren frames van buiten Limburg. Het is seriewerk van goede kwaliteit, maar zonder de charme van het unieke, ambachtelijk vervaardigde product.

\subsection{Huisuurwerken}

De behoefte aan een (verplaatsbaar) "huisuurwerk" deed zich al vroeg gevoelen. De hertogen van Bourgondië trokken in de $15 \mathrm{de}$ eeuw door hun landen met in hun gigantische tros een uurwerk, begeleid door een Vlaamse of Hollandse uurwerkmaker om het aan de gang te houden. ${ }^{17}$ Men wilde de tijd aflezen, ook daar waar geen torenuurwerk in de buurt was. De uurwerkmakers konden na verloop van tijd aan deze vraag tegemoetkomen na de ontwikkeling van de opwindveer rond het midden van de 15 de eeuw. Toen werd het mogelijk verplaatsbare en draagbare uurwerken te produceren, zoals tafelklokken en halshorloges. Dit waren aanvankelijk uitermate kostbare apparaten met een zeer beperkte verspreiding. Pas veel later vond het enige verbreiding. Weldra ontstond nu een regionale specialisatie.

Bij de Limburgse torenuurwerken waren, zoals wij zagen, geen regionale of nationale kenmerken te ontdekken. Heel anders werd het bij de bouw van kleine huisuurwerken, die mogelijk in de 15de eeuw was begonnen en laat in de 17 de eeuw in de beide Limburgen opbloeide. Hierbij ontwikkelde zich laat in de 17 de eeuw, nadat een reeks innovaties gemeengoed was geworden, een technisch geheel met eigen kenmerken, dat anderhalve eeuw stand hield. Het opmerkelijke zit niet in de technische complicaties of sierlijke uitvoering van de uurwerken, maar vooral in de eenvoudige, samenhang vertonende implementatie van vernieuwingen die van anderen

\footnotetext{
${ }^{\text {is }}$ Uumwerk voor de $0 .-L_{-}-$Vrouwekerk, Maastricht, 1850. Zie appendix II onder Doppler, Lambertus Nicolaus.

${ }^{115}$ Uurwerk voor de kerk wan. Mielen-boven-Aalst, 1857. Zie J. Gerits 1993a, p. 108.

17. Lecat 1985 , p. 60 .
} 
werden overgenomen. Het Limburgse huisuurwerk is eenvoudig en goedkoop van opbouw, maar oerdegelijk, secuur lopend en op tijd wekkend.

Hoe is dit alles totstandgekomen en wat zijn de specifieke kenmerken van het Limburgs huisuurwerk? Deze vragen kunnen slechts worden beantwoord door een korte schets te geven van de technologische ontwikkeling die het huisuurwerk in de $16 \mathrm{de}$ en $17 \mathrm{de}$ eeuw doormaakte.

\subsubsection{Ontwikkeling}

Het huisuurwerk heeft zich aanvankelijk parallel aan de torenuurwerken ontwikkeld. Dat wil zeggen dat verworvenheden als slagwerk, wijzerplaat met wijzer, balansrad en automatenfiguren in beide genres klokken toepassing vonden. Hoewel toren- en huisuurwerk beide mogelijk voortkwamen uit de bescheiden kloosterwekker, ontwikkelden zij zich al snel in heel verschillende richting. Het torenuurwerk werd een steeds groter en ingewikkelder apparaat met als hoogtepunt het astronomische kunstuurwerk. Bij het huisuurwerk zocht men naar miniaturisering en verplaatsbaarheid. Hier lag het hoogtepunt in het draagbare zakhorloge, mogelijk geworden door de ontwikkeling van de veer voor de aandrijving in het midden van de 15 de eeuw in Vlaanderen of Bourgondië. Waarschijnlijk zijn er geen zakhorloges, zeer luxeproducten in die tijd, in de Limburgen vervaardigd. Er zijn althans geen sporen van overgebleven. Wellicht zijn er wel al vroeg huisuurwerken geproduceerd, maar zekerheid hieromtrent hebben we niet. Documenten omtrent uurwerkbouw in de 16 de eeuw werden in onze contreien nog niet aangetroffen. Er zijn geen huisuurwerken bewaard, waarvan vaststaat dat zij hier zijn gebouwd vóór 1650. Nieuwe ontwikkelingen en vindingen in de uurwerktechniek in de 15 de en 16 de eeuw zullen tot de Limburgen maar langzaam zijn doorgedrongen, net als elders het geval was. Heel de Nieuwe Tijd door werden technische en technologische ontwikkelingen gekenmerkt door traagheid van diffusie. ${ }^{18}$ Volgen wij het proces op de voet.

De eerste huisuurwerken waren de zogeheten gotische huisuurwerken. Dat waren wandklokken, die men, waar ze ook zijn gepro-

${ }^{18}$ F. Braudel 1.987, pp. $420-425$. 
duceerd, kan onderverdelen in twee hoofdtypen: a. het type, dat in een ijzeren beugel met een hoekige c-vorm het uurwerk bevat (zie afbeelding 38) en $b$. het type, waarbij het gaande werk en het slagwerk achter elkaar tussen hoekstijlen en onder- en bovenplaat zijn gemonteerd (zie afbeelding 39). Ze waren helemaal van ijzer vervaardigd en hadden gewichtsaandrijving. Er is geen gotisch huisuurwerk bewaard gebleven, dat aantoonbaar in de Limburgen is gemaakt.

Rond 1500 begon men veel meer messing in klokken te verwerken. Tandwielen, platines en allerlei andere onderdelen werden in dit materiaal gemaakt. Niet alleen was het messing gemakkelijker te bewerken dan het ijzer, het bood een nog groter voordeel: minder frictie in het raderwerk. Men ontdekte dat er minder wrijving en slijtage optrad, wanneer men een messing tandwiel in een ijzeren rondsel liet ingrijpen. Ditzelfde geldt voor ijzeren assen die in messing platines of bronzen bussen (lagers) draaien. Deze afwisseling van messing en stalen onderdelen bleef tot heden het standaardconstructieprincipe. Het vormt een der grondslagen voor degelijkheid van het product. Ook in de torenuurwerken ging men dit principe toepassen.

De productie van (huis-)uurwerken werd op den duur gemakkelijker door de ontwikkeling van de draaibank en later van de verdeelschijf en de radersnijmachine. Een andere vernieuwing binnen de uurwerkmakerskunst was het gebruik van de schroef. Beide innovaties vereenvoudigden de miniaturisering, verkortten de bouwtijd, verhoogden de precisie en boden mogelijkheden tot serievervaardiging van onderdelen. Het huisuurwerk werd aanzienlijk minder kostbaar. Nieuwe markten kwamen langzaam maar zeker open te liggen. In de loop van de 18 de eeuw werd het huisuurwerk bereikbaar voor plattelanders.

Door de ontwikkeling van de aandrijfveer kwam naast het reeds genoemde horloge het genre der veeraangedreven tafelklokken tot ontwikkeling. ${ }^{19}$ Hierin zijn twee types te onderscheiden: één met een verticale opbouw, zoals de torentjesklokken (Türmchenuhren). Het andere type met horizontale platines in platte ronde, vierkante of veelhoekige "dozen" van edele metallen of verguld messing gemaakt. Versiering en vormgeving beantwoordden aan de renaissancistische smaak. Ze werden vooral vervaardigd in Augsburg en

${ }^{19}$ C. Jagger s.a., pp. $90-93$ 

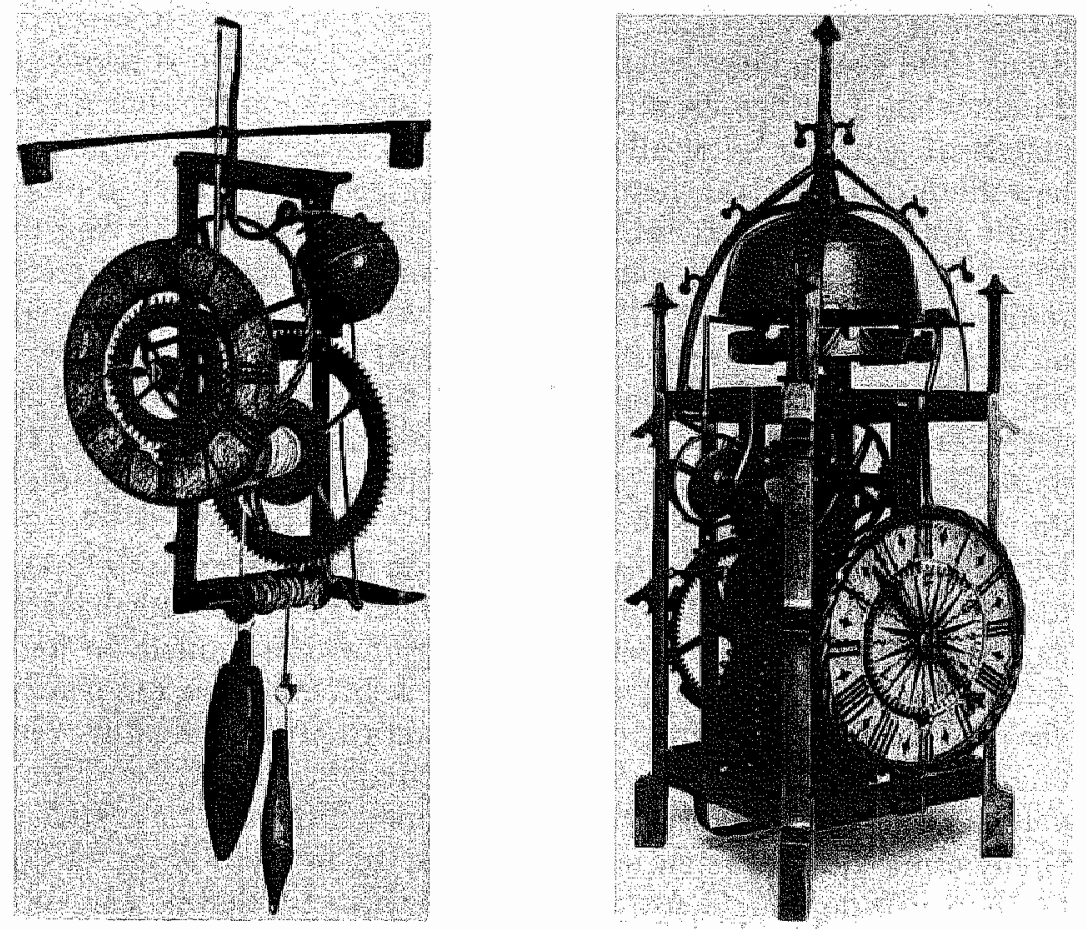

38. (1.) Vroeg huisuurwerk, torenwachterstype (14de eeuw). Het frame bestaat uit vier strippen

39. (r.) Gotisch huisuarwerk (1460-1470). Het frame heeft vier hoekstijlen met gotische profielen, verbonden door verticale banden aan boven- en onderzijde 
Neurenberg, maar ook wel in Vlaanderen en Brabant. Het bleven zeer kostbare instrumenten die bepaald niet voor een breed publiek waren weggelegd, net zo min als de automatenfiguren van de vorstelijke tafelopschik. Deze dierfiguren en tafelschepen zaten boordevol uurwerkachtige mechaniek ${ }^{20} \mathrm{Zij}$ hebben ongetwijfeld bijgedragen aan kennis van de mechanica en verfijnde productiemethoden, ook bij de uurwerkmakers. Het valt zeer te betwijfelen dat er in de arme Limburgse gebieden dergelijke luxe-objecten zijn vervaardigd. De veeraandrijving vond daar geen toepassing: men hield zich aan de gewichtsaandrijving. Limburgse uurwerken met veeraandrijving zijn op de vingers van één hand te tellen: een "Haags klokje" (circa 1685) van Joannes Vrijthoff den Jonge, een tafelklokje (circa 1775) van Jacobus Joosten, een tafelklokje (circa 1785) van Joannes Reinerus Beltjens, een consoleklok (circa 1780) van Arnold de Nève, enkele consoleklokjes (circa 1780) van François de Beefe en een reisklokje van C.J. van Boom (circa 1810). Het gotische huisuurwerk tussen hoekstijlen met gewichtsaandrijving evolueerde laat in de $16 \mathrm{de}$ eeuw tot de renaissancistische lantaarnklok, zo genoemd naar zijn lantaarnvorm. Hiervan is een exemplaar uit Limburg bewaard gebleven, namelijk een klok uit 1653 wan Joannes Muys te Maastricht. ${ }^{21}$ Deze klok heeft astronomische aanduidingen, zoals: aanduiding van de tijd waarop de maan de meridiaan passeert en van de maanfasen; verder worden aangegeven de dag van de week en de leeftijd van de maan. De klok bevindt zich in de collecties van het British Museum (zie afbeelding $40 \mathrm{a}$ en b). Wanneer we een Limburgs daguurwerk vanaf omstreeks 1700 bekijken, zien we dat het een qua decoratie vereenvoudigde en qua techniek gemoderniseerde afgeleide is van het gotische huisuurwerk tussen hoekstijlen met gewichtsaandrijving via de renaissancistische lantaarnklok (zie afbeelding 41).

Het huisuurwerk was rond het midden van de 17 de eeuw een technisch hoogontwikkeld product geworden, waaraan evenwel nog de nauwkeurigheid ontbrak. De nauwkeurigheid kwam er door de toepassing van de slinger door Christiaan Huygens in 1656.

${ }^{20} \mathrm{C}$. Jagger s.a., pp. 78-81 en afbeelding op p. 89.

${ }^{21}$ Voor nadere gegevens over Muys zie appendix II onder Muys, Joannes. 

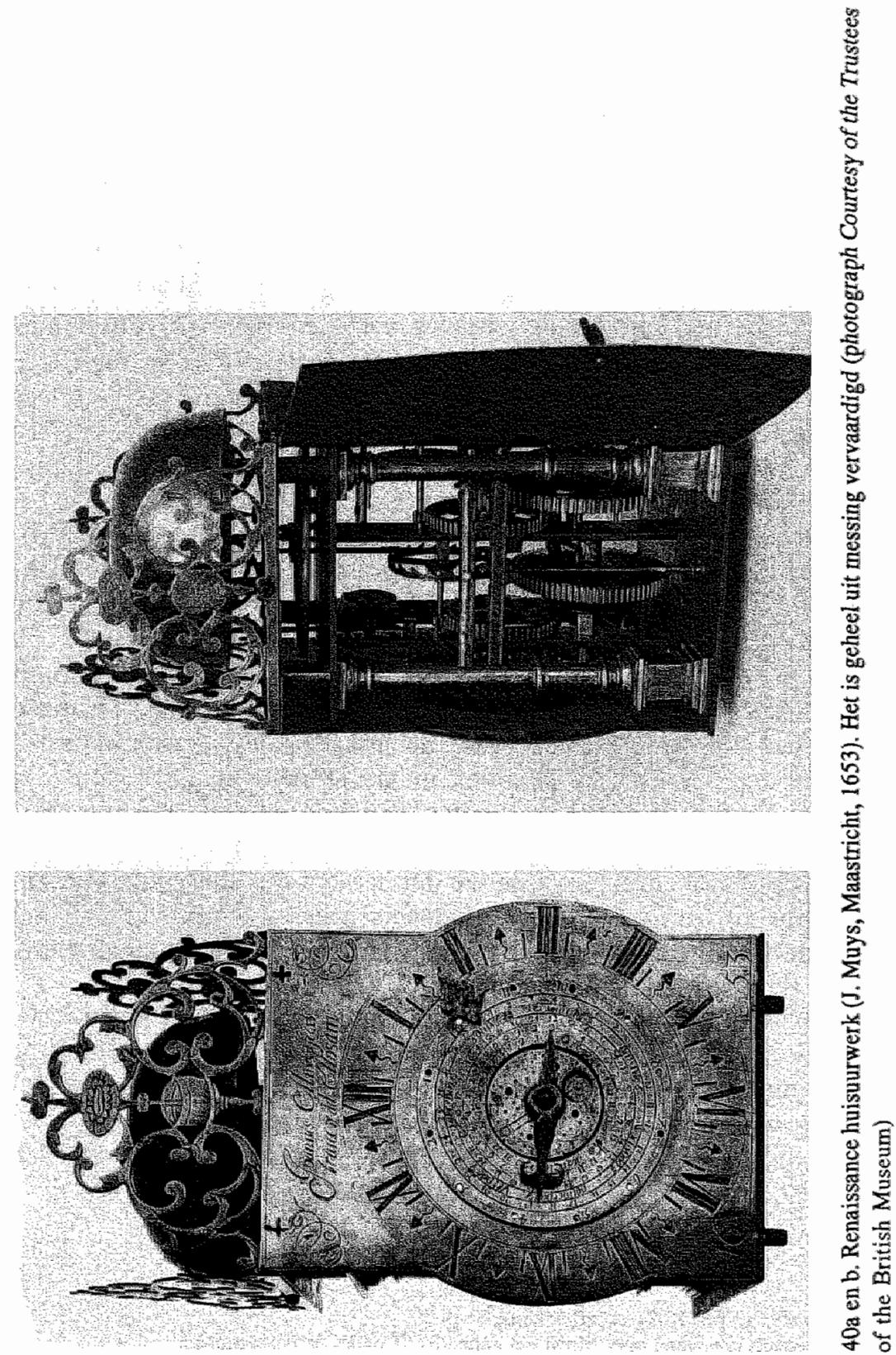
De eerste huisuurwerken, uitgerust met een spillegang en korte slinger tussen cycloïdale boogjes, zijn de zogenaamde Haagse klokjes. ${ }^{22}$ Van dit genre zijn twee in Maastricht gemaakte exemplaren bewaard gebleven. Ze werden gemaakt door Johan Vrijthoff den Jonge (1651-1716). Slechts van één van deze twee uurwerken is de verblijfplaats bekend. Het bevindt zich in het Bonnefantenmuseum te Maastricht (zie afbeelding 42). Volgens de criteria van Plomp ${ }^{23}$ moet het dateren uit circa 1685. Dat een Maastrichtse uurwerkmaker zo wroeg een "Haags klokje" realiseerde, is niet zo verwonderlijk als het op het eerste gezicht lijkt. De frequente contacten tussen Den Haag, als regeringscentrum, en Maastricht, als belangrijke Staatse vestingstad in het zuiden, brachten regelmatig personenverkeer met zich mee tussen deze steden. Het is denkbaar, dat daardoor nieuws met betrekking tot de toepassing van de slinger Maastricht snel bereikte. Johan Vrijthoff den Jonge is in ieder geval naar Den Haag getrokken, waar de uurwerkmakers werkten die voor Huygens opdrachten uitvoerden. Dit waren na de dood van Salomon Coster in 1659 vooral Pieter Visbach de Oude en Johannes van Ceulen de Oude. Deze laatste was volgens Morpurgo ${ }^{24}$ afkomstig uit Maastricht en had zich in 1677 gevestigd op het Plein in Den Haag tegenover het woonhuis van Huygens. Vrijthoff bleef meerdere jaren in Den Haag. Blijkens notariële akten woonde Johan Vrijthoff $(* 1651)$ daar in de jaren 1671 tot 1680 . Mogelijk waren er onderbrekingen in zijn verblijf in Den Haag; in ieder geval hield hij regelmatig contact met zijn verwanten in Maastricht. ${ }^{25}$ Ook uit processtukken blijkt, dat Johan Vrijthoff regelmatig in Den Haag

\footnotetext{
"Voor de "Haagse klokjes" zie R. Plomp 1979, passim.

${ }^{23}$ R. Plomp 1979, p. 249.

24 E Morpurgo 1970, p. 25, kolom 3. Voor deze Maastrichtse afkomst heb ik geen bewijs gevonden in de Mastrichtse archieven.

${ }_{25}$ Johan Vrijthoff komt woor in Haagse notariële akten van 1671 tot 1680, te weten Gemeentearchief "s-Gravenhage, Notariële Archieven (verder afgekort N.A.), inv.nr. 712, f. 117 (15.04.1671); N.A., inv.nr. 732, f. 150 (21.10.1678). Hierin is sprake van Johlan Vrijthoff, Mr. horologiemaecker inwoonder alhier. Hij geeft procuratie aan zijn broers Lambertus en Hermanus en aan zijn zuster Catharina, allen womend te Maastricht. N.A., inv.nr. 533, f. 543 (25.11.1678); N.A., inv.nr. 533, f. 599 (07.12.1678); N.A., inv.nr. 533, f. 667 (19.12.11678); N.A., inv.nr. 535, f. 53 (13.07.1679); N.A., inv.nr. 536, f. 162 (04.03.1680); N.A., inv.nr. 536, f. $311(03.05 .1680)$; N.A., inw.nr. 536, f. 345 (20.05.1680). Uit de akte N.A., inv.nr. 536, f. 337 (15.05.1680), blijkt dat Margaretha Vrijthoff in Dem Haag was, maar eigenlijk woonachtig was in Maastricht, net zoals haar oom Johan en haar broer Lambertus, aan wie zij procuratie verleent. Dank aan de heer J.A. Leopold, Londen, voor de gegevens over deze Haagse notarisakter.
} 


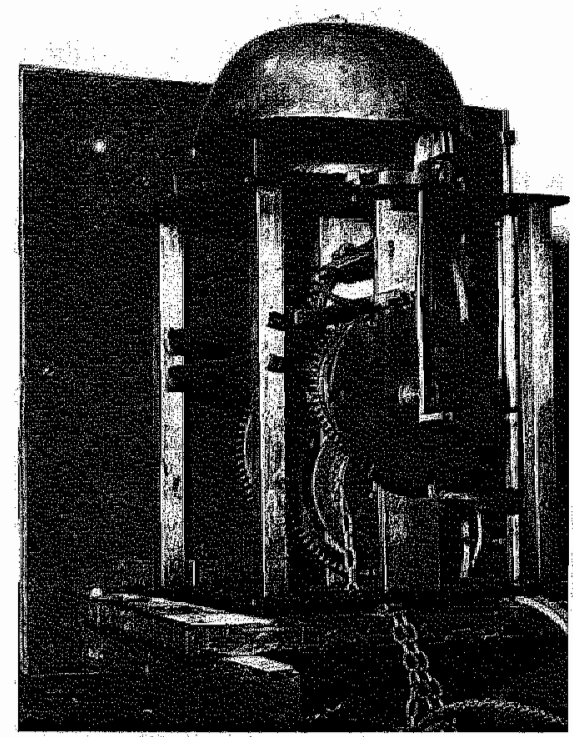

41. Limburgs eendaags uurwerk uit een staande klok (circa 1770). Gaand werk met ankergang; daarachter slagwerk met sluitschijf; wekker haaks ten opzichte van de andere tandraderen gemonteerd

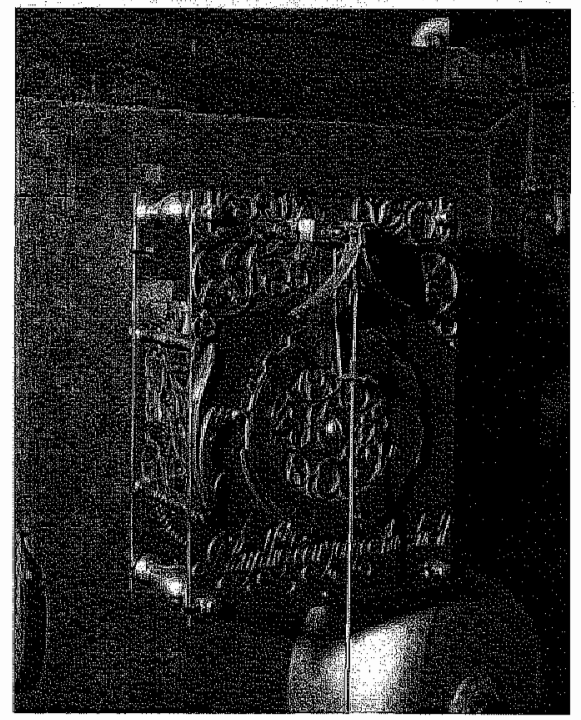

42. Unrwerk gebonwd op de wijze van de Haagse klok (Jean Vrijthoff le Jeune, Maastricht, circa 1685) 
was. ${ }^{26}$ Het lijkt niet te veel gezegd, dat Johan Vrijthoff en zijn familie een spilfunctie hebben vervuld bij de kennisoverdracht van de slingertechniek naar het zuiden, net zoals de Fromanteels dat hebben gedaan naar Engeland.

De Haagse klokjes werden tussen platines gebouwd. Deze bouwwijze tussen platines werd later in het Limburgse bijna uitsluitend voor weekwerken gebruikt. Sporadisch komen ook daguurwerken tussen meestal ijzeren platines voor, evenals er een enkele keer weekwerken tussen hoekstijlen vórkomen. Het normale patroon in de beide Limburgen is echter: dagwerken tussen hoekstijlen naar gotisch/renaissancistisch gebruik, weekwerken tussen platines naar Haags voorbeeld.

Door de grotere nauwkeurigheid ten gevolge van de slinger kreeg het zin de klok van een minuutwijzer en zelfs een secondewijzer te voorzien. De voordelen die deze vorm van precieze tijdsaanduiding met zich meebracht, werden in de Limburgen hooggewaardeerd. Eenwijzerige huisuurwerken zijn in de beide Limburgen zeldzaam, terwijl ze in Engeland nog tot in de 19de eeuw werden geproduceerd.

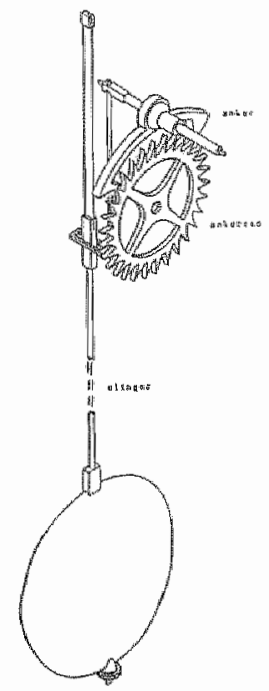

43. Ankergang met lange slinger

${ }^{25}$ Zie onder Vrijthoff, Johan den Jonge, in appendix II; G.A.M., Laaggerecht Maastricht, Luikse secretaris, inv.nr. 481 . 
Nog een andere nieuwigheid werd rond 1700 in Limburg owergenomen. Circa 1672 construeerde William Clement in Engeland de terugwerkende ankergang met lange slinger, waardoor de cycloïdale boogjes in onbruik raakten en nog betere gangresultaten konden worden bereikt (zie afbeelding 43). Praktisch alle Limburgse huisuurwerken, ook de oudst bekende, behalve de beide reeds vermelde zogeheten "Haagse klokjes" van Vrijthoff en het lantaarnklokje van Johan Muys, zijn voorzien van dit echappement. Daaruit blijkt eens te meer dat de Limburgse uurwerkmakers in het laatste kwart van de 17 de eeuw en de eerste jaren van de 18 de eeuw openstonden voor technische vernieuwingen en niet schroomden deze toe te passen. Hoe snel de "Limburgers" de ankergang hebben overgenomen, is niet met zekerheid te zeggen. Tussen de uitvinding van de ankergang circa 1672 en de oudst bekende Limburgse uurwerken met ankergang, de staande klok, genoemd onder $a_{\text {. }}$ van Leonardus Mijnis ${ }^{27}$ uit Maastricht, en de staande klok van Lambertus Joosten, ${ }^{28}$ beide van circa 1715 , zit een tijdsverloop van ruim veertig jaar. Dat is een relatief korte periode. De Friese klokkenmakers begonnen pas omstreeks 1750 de ankergang met lange slinger toe te passen, waardoor later de staartklok kon ontstaan.

Andere echappementsvormen, zoals de Grahamgang ${ }^{29}$ stammend uit omstreeks 1730 en de pennengang van Amant ${ }^{30}$ uit 1741, werden in de Limburgen nauwelijks toegepast. De Limburgse klok representeert heel de $18 \mathrm{de}$ eeuw door tot in het eerste kwart van de 19 de eeuw het technisch niveau van omstreeks 1700 .

De lange slinger vroeg als het ware om bescherming tegen stoten. Zo ontstond de staande klok of staand hotloge. Men neemt aan, dat er aanvankelijk een soort hekwerkje rondom de slinger (en de gewichten) van een wandklok werd gezet om deze voor stoten te behoeden. Het stoten tegen de slinger kan de goede gang van de klok verstoren en zelfs de slingerophanging beschadigen. Bij de vroegere wandklokken met foliot of balansrad hoefde men overigens voor dit laatste niet bang te zijn: als men tegen de gewichten van zo'n klok stootte bleef ze gewoon door\open. Genoemd hekje evolueerde tot een gesloten kastrormig omhulsel. De hier beschre-

\footnotetext{
${ }^{27}$ Zie appendix II onder Mijnis, Leonardus.

t. Zile appendix II onder Joosten, Lambertus.

20 Fen rustende gang, ontwikkeld door de Engelsman George Graham (1673-1751).

${ }^{30}$ Of sehaargang. De Fransman Louis Amant was werkzaam te Parijs van omstreeks 1730 tot 1749. Een precisiependule van Wilmotte, Maastricht (zie appendix II), heeft deze gang.
} 
ven ontwikkeling kan mogelijk worden geïllustreerd door de hierbij afgebeelde, weliswaar 19de-eeuwse klok uit Horst van een zekere Schampers. Deze timmerman heeft onbewust de voorloper van de staande klok nog eens uitgevonden ${ }^{31}$ (zie afbeelding 44).

Een zeer vroeg voorbeeld van een staande klok zien we in de als nummer 45 afgebeelde monumentale klok met een beschilderde klokkast met datering 1687 in het Sint-Dympna gasthuis te Geel, even over de grens van Limburg en Antwerpen. Het uurwerk met houten speelwals, Jacquemarts, ruiterspel en mechanische Annunciatievoorstelling, dat mogelijk uit de abdij Corsendonk komt, is laatgotisch en veel ouder dan de kast. De kast herbergt vier zware gewichten plus een slinger. Mogelijk heeft men de kast gemaakt ter bescherming van de slinger, nadat deze in 1687 was aangebracht bij de ombouw van het uurwerk tot slingeruurwerk.

De oudste bewaard gebleven Limburgse staande klokken zijn, zoals hierboven reeds vermeld, de als nummer 46 afgebeelde klok van Leonard Minis uit Maastricht van circa 1715 en die van Lambertus Joosten uit Maaseik uit ongeveer hetzelfde jaar (zie afbeelding 47). Helaas is er na driehonderd jaar te weinig aan uurwerken en schriftelijke documentatie over om het ontstaansproces van het Limburgse uurwerk in detail te kunnen volgen. Vooral producten uit de aanloopperiode rond 1700 ontbreken omdat zij waarschijnlijk slechts in kleine aantallen zijn geproduceerd en wellicht verloren zijn gegaan omdat er nog te veel gebreken aan kleefden.

Hoe het ook zij, eind 17 de eeuw kwam de bouw van een naar toenmalige begrippen zeer modern uurwerk in Limburg in zwang, precies op het moment dat de pre-industriële economie behoefte had aan zo'n instrument omdat werkgevers hun arbeidskrachten meer en meer per uur gingen betalen en in het kader van de combinatie van industriële en agrarische activiteiten nauwkeuriger gingen. controleren, onder meer om beter zicht te krijgen op de kosten van hun ambachtelijk-industriële productie. ${ }^{32}$ In die omstandigheden was het niet zo verwonderlijk dat er vraag ontstond naar uurwerken die zo'n arbeidsproces mogelijk maakten. Vooral op het platteland, waar door de wijde verbreiding van het putting-out-systeem de

\footnotetext{
${ }^{31}$ In het Musée de l'histoire ef de l'histoire d'Art te Luxemburg zijn hiervan drie voorbeelden te vinden van eind $18 \mathrm{de}$ tot begin $19 \mathrm{de}$ eeuw.

${ }^{32}$ D. Woodwards 1994, pp. 11-21, vooral pp. 13 en 1.4: "The hours worked by day-labourers were closely controlled. They worked by the clock and not by the task...".
} 

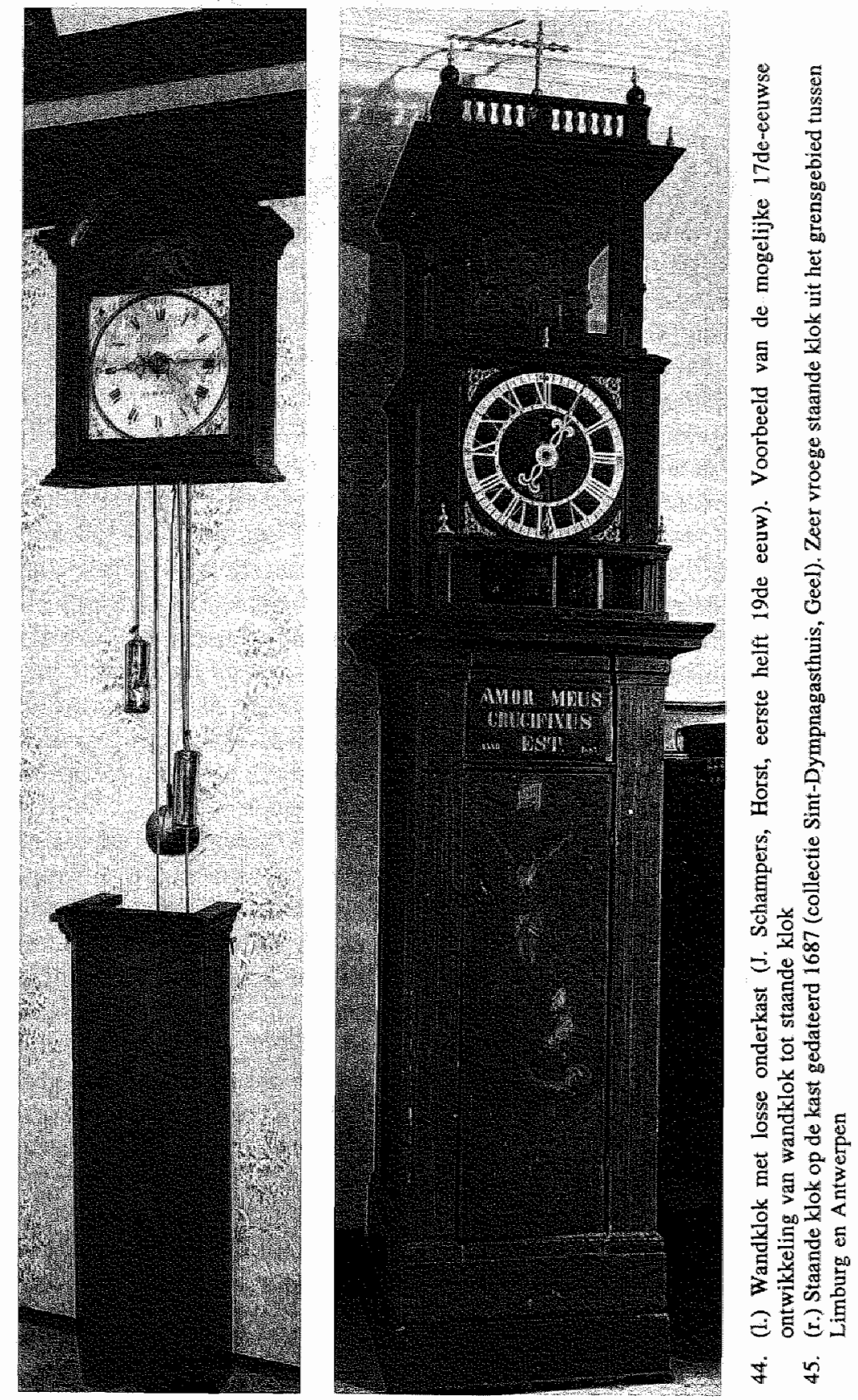


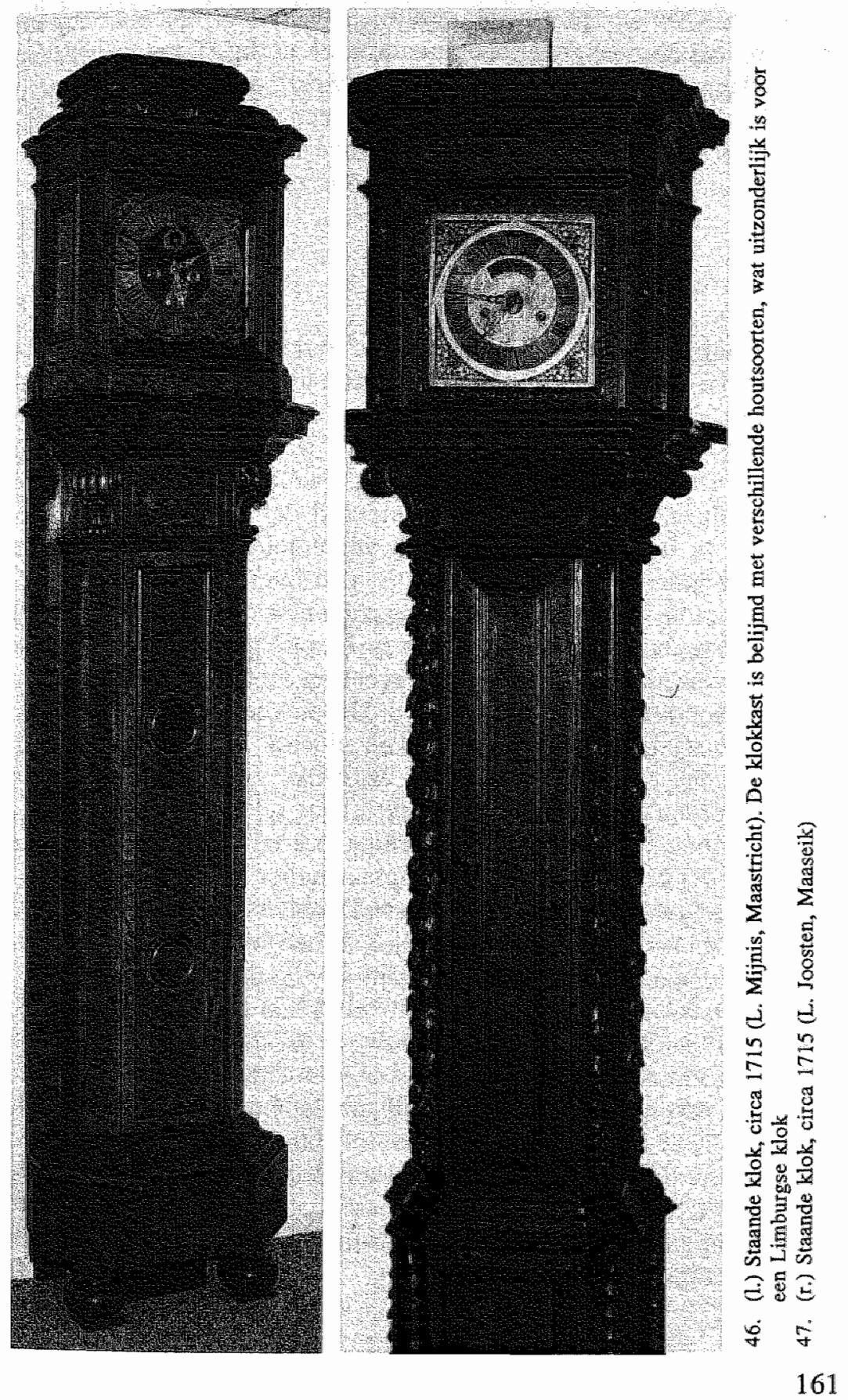


ambachtelijke en proto-industriële activiteiten geconcentreerd raakten, had de werkgever een huisuurwerk nodig. Torenuurwerken waren daar, we zagen het al, zelden aanwezig en als zij er al waren kon men vanwege het ontbreken van een minuutwijzer de tijd slechts globaal aflezen, als de waarnemer al niet moest vaststellen dat het torenuurwerk weer eens still stond omdat het defect was.

\subsubsection{Uurwerktypen}

De popularisering van het huisuurwerk en de geleidelijke wijziging in de typen kan slechts worden afgelezen uit gegevens omtrent het bouwjaar van bewaard gebleven exemplaren en hier en daar een document, waarin de bouw of verkoop van een uurwerk wordt vermeld. Dat leidt hoe dan ook tot vertekening. Jonge exemplaren werden uiteraard frequenter overgeleverd dan oude. Uit de gegevens die in het onderzoek werden verzameld, werd omdat geen andere benaderingswijze mogelijk is, een overzicht samengesteld, waaruit om de vertekening nog enigszins te reduceren, slechts valt af te lezen, hoeveel uurwerkmakers er per periode van 25 jaar konden worden achterhaald en hoeveel en welke soort uurwerken van hen konden worden opgespoord. Uit de onderstaande tabel kan men niet afleiden, welke uurwerken slechts worden vermeld in archivalische of gedrukte bronnen en welke zijn overgebleven en in situ werden bestudeerd. Dat blijkt uit de tekst en kan met name in de alfabetische lijst van uurwerkmakers en hun producten (zie appendix II) exemplaar voor exemplaar nader worden bekeken.

Het totale aantal Limburgse uurwerkmakers dat is gevonden, bedraagt 434 . Gemiddeld is van elk van hen niet eens 1,7 uurwerken achterhaald. Uit de begintijd zijn gewoonlijk alleen de namen van de uurwerkmakers bekend en ontbreekt van hun producten inmiddels zelfs elk spoor. Zo kennen we uit de 15 de eeuw dertien namen van uurwerkmakers, maar is er geen enkel uurwerk bewaard gebleven dat kan worden gekoppeld aan één van deze namen. In de $16 \mathrm{de}$ en $17 \mathrm{de}$ eeuw is dit maar weinig anders. Tot $1725 \mathrm{zijn}$ er grotere aantallen makers dan uurwerken bekend. Dit komt omdat de namen via relatief goed bewaarde archivalische bronnen konden worden opgespoord, maar slechts weinig uurwerken de tand des tijds zo lang doorstonden. 
Tabel 4. Uurwerkmakers en hun overgebleven en/of vermelde nurwerken

\begin{tabular}{|c|c|c|c|c|c|c|c|c|c|}
\hline Periode & Makers & Ntur & Nwk & Nsk & Nhor & Ntak & Nem & Nlu & Totaal \\
\hline Vóór 1400 & 2 & 4 & . & . & . & . & . & . & 4 \\
\hline $1400-1425$ & 2 & . & . & . & . & . & . & . & 0 \\
\hline $1425-1450$ & 4 & . & . & . & . & . & . & . & 0 \\
\hline $1450-1475$ & 4 & . & . & . & . & . & . & . & 0 \\
\hline $1475-1500$ & 3 & . & " & . & . & . & . & . & 0 \\
\hline $1500-1525$ & 6 & $\mathbb{1}$ & . & . & . & . & . & . & 1 \\
\hline $1525-1550$ & 7 & 6 & . & . & . & . & . & . & 6 \\
\hline $1550-1575$ & 11 & 8 & . & . & . & . & . & . & 8 \\
\hline $1575-1600$ & 1.7 & 1 & . & . & . & . & . & . & 1 \\
\hline $1600-1625$ & 7 & . & . & . & . & . & . & . & 0 \\
\hline $1625-1650$ & 8 & . & . & . & . & . & . & . & 0 \\
\hline $1650-1675$ & 18 & 2 & 4 & $\mathbb{1}$ & 2 & 1 & . & . & 10 \\
\hline $1675-1700$ & 10 & 2 & 1 & 2 & . & . & . & . & 5 \\
\hline $1700-1725$ & 17 & . & . & 6 & $\mathbb{1}$ & . & 1 & . & 8 \\
\hline $1725-1750$ & 22 & 11 & 4 & 61 & . & 5 & . & . & 81 \\
\hline $1750-1775$ & 48 & 2 & 20 & 132 & . & 3 & 3 & . & 160 \\
\hline $1775-1800$ & 75 & . & 6 & 152 & 3 & 6 & 5 & 3 & 175 \\
\hline $1800-1825$ & 70 & 1 & 11 & 142 & 7 & 14 & 3 & 1 & 179 \\
\hline $1825-1850$ & 48 & 2 & 10 & 29 & 10 & . & 1 & . & 52 \\
\hline $\mathrm{Na} 1850$ & 55 & 2 & 9 & 25 & 4 & 1 & . & 2 & 43 \\
\hline Totaal & 434 & 42 & 65 & 550 & 27 & 30 & 13 & 6 & 733 \\
\hline Percentage & & $6 \%$ & $9 \%$ & $75 \%$ & $4 \%$ & $4 \%$ & $2 \%$ & $1 \%$ & \\
\hline
\end{tabular}

Legenda: makers=aantal uurwerkmakers; Nto=aantal torenuurwerken; $N$ wk=aantal wandklokken; Nskmaantal staande klokken; Nhor=aantal zakhorloges; Ntak=aantal tafellklokken; Ncm=combinatiemeubels; Nlu=aamtal losse urwerken.

Bron: Appendix II.

De getallen in de tabel duiden niet alleen op bewaard gebleven uurwerken, maar ook op vermeldingen van uurwerken. De weinige uurwerken van vóór 1700 die zijn overgebleven, zijn bijna allemaal torenuurwerken die in het algemeen niet zijn gesigneerd en ook niet op een andere wijze zijn te relateren aan een bepaalde uurwerkmaker. Tot de huisuurwerken van vóór 1700 die bewaard zijn gebleven, behoren de reeds vermelde wandklok van Joannes Muys uit 1653 en enkele werkstukken van Joannes Vrijthoff den Jonge uit de tweede helft van de $17 \mathrm{de}$ eeuw. Pas over de bloeitijd wan de Limburgse uurwerkmakerij, 1725-1825, zijn we ook middels objecten goed geïnformeerd. Uit dit tijdvak zijn 215 uurwerkmakers bekend, waarvan niet minder dan 595 objecten zijn overgebleven, iets minder dan drie per bouwer. Evenwichtig verdeeld is het niet. Van 
sommige unwerkmakers zijn wel tien of meer uurwerken over, terwijl we van diverse andere uurwerkmakers zelfs helemaal niets meer aantroffen. Jammer is dat de groep Belgisch-Limburgse uurwerkmakers zo slecht is gerepresenteerd. Dit vindt zijn oorzaak in het feit dat door Weyns in zijn klokkenmakerslijst 57 uurwerken van Belgisch-Limburgse uurwerkmakers zonder enig nader detail worden opgesomd, zodat we zelfs niet weten of hij een torenuurwerk, staande klok, wanduurwerk, dan wel een zakhorloge heeft gezien. ${ }^{3.3}$ Daarom zijn deze vermeldingen onbruikbaar voor verdere analyse. In de nadagen van de Limburgse uurwerkmakerij, de jaren na 1825 , moest de uurwerkbouwer concurreren tegen het industrieel vervaardigde uurwerk, in het bijzonder het Schwarzwald-uurwerk en de Franse pendule. Tot het uiterste moest op kosten worden bespaard: soberheid was troef, de kwaliteit nam af. Niet alleen de productie liep terug, ook de overlevingskans werd slechter. Het aantal met name bekende uurwerkmakers overstijgt weer het getal bewaard gebleven uurwerken, zij het nipt: 103:95. Dit alles dwingt tot voorzichtigheid met uitspraken op microniveau. Alleen globale uitspraken zijn mogelijk.

Kijken we allereerst meer in detail naar de perioden, waarin in Limburg uurwerkmakers optraden, dan valt op dat na een opleving in de $16 \mathrm{de}$ eeuw, in de eerste helft van de $17 \mathrm{de}$ eeuw een forse daling intrad. Het herstel na 1650 is nog lang beperkt van omvang. Tot 1750 overstijgt het getal met naam en toenaam bekende uurwerkmakers dat uit het laatste kwart van de 16de eeuw nauwelijks. Daar zijn twee kanttekeningen bij te maken:

1. Tot 1650 kennen we in de beide Limburgen uitsluitend torenuurwerkmakers, de meesten uit de periode $1525-1575$. Rond laatstgenoemd jaar waren de beide Limburgen in een diepe economische crisis geraakt. Vele stadsbesturen slaagden er slechts met moeite in hun instrument lopende te houden. Van 1575-1650 werden heel wat onderhoudscontracten afgesloten met allerlei lieden, waarvan men hoopte dat zij de magistraat voor weinig geld uit de brand konden helpen. Nieuwe uurwerken werden hoegenaamd niet besteld. Van 32 uurwerkmakers troffen wij geen enkel uurwerk aan.

2. De opleving tussen 1650 en 1750 had slechts in heel beperkte mate betrekking op de torenuurwerken. Het aantal van twintig vermeldingen van torenuurwerken uit de jaren 1367-1600 kon 
slechts met vijftien nieuwe exemplaren worden aangevuld. Daarentegen werden wel nieuwe markten verkend. Men probeerde het tussen 1650 en 1700 met wandklokken (5), staande uurwerken (3), zakhorloges (2) en tafelklokken (1).

Alleen het staand uurwerk werd een commercieel succes, zij het pas na 1725. Uit de kwart eeuw 1725-1750 bleven er niet minder dan 61 bewaard. Nog driekwart eeuw lang zou het staand uurwerk de markt, voorzover we haar uit bewaard gebleven specimina kunnen reconstrueren, volledig domineren. Was tussen 1367 en 1650 het torenuurwerk het "pièce de résistance" van de Limburgse uurwerkmakers geweest, vanaf 1725 was dit het staand horlogie. Van de overgebleven historische uurwerken afkomstig uit Limburg zijn $75 \%$ staande uurwerken. Het aantal wandklokken (9\%), tafelklokken ( $4 \%$ ) en combinatiemeubels $(2 \%)$ valt daarbij in het niet. Opvallend is in onze tabel het kleine aantal zakhorloges: 27. Daarin was zeker tegen het einde van de 18 de eeuw een levendige handel, ook in Limburg. Heel wat bleef bewaard, maar het gros was niet gesigneerd, dan wel aantoonbaar afkomstig uit den vreemde. Van een Limburgs atelier dat met enige regelmaat horloges bouwde is geen spoor gevonden. Zelfs het merendeel van de horloges met een signatuur, die naar Limburg verwijst, dankt zijn inscriptie aan een wederverkoper.

Het thans meest aangetroffen type Limburgse klok is, zoals reeds is opgemerkt, de staande klok. Of dit altijd zo nadrukkelijk het geval was, is niet helemaal zeker. Mogelijk hebben wij een enigszins vertekend beeld omdat we moeten afgaan op de bewaard gebleven exemplaren. Een defecte staande klok werd omdat ze een mooi meubelstuk bleef, waarschijnlijk eerder bewaard en hersteld dan een kapotte wandklok, die, zodra ze niet meer functioneel was, voor weinig geld kon worden vervangen. Dit zou één van de redenen kunnen zijn, dat er zoveel meer staande klokken zijn bewaard gebleven dan wandklokken. Het verschil is echter zó groot - de verhouding is 8,5:1 - dat het niet waarschijnlijk is dat er van deze laatste, hoewel aanzienlijk goedkoper, in Limburg meer zijn geproduceerd dan van staande klokken. Er zijn andere streken die precies het omgekeerde laten zien. Schuurman beweert in een onderzoek over de Zaanstreek, Oost-Groningen en Oost-Brabant, dat de staande klok nooit populair is geweest vanwege haar hoge 
prijs. $^{34}$ De prijs is mijns inziens echter niet de enige of zelfs maar de belangrijkste verklaring voor de populariteit van een bepaald kloktype. Traditie, mode en type van huizenbouw spelen in dezen een grote, misschien wel de grootste rol. Dat Schuurman zoveel meer wandklokken aantrof in de boedelinventarissen, waarop zijn onderzoek is gebaseerd, vindt zijn verklaring in de keuze van de regio's die hij onderzocht. De Zaanstreek is beroemd voor haar Zaanse klokken, luxe uitgevoerde en kostbare wandklokken; OostGroningen zal zich voor klokkenaanschaf hebben gericht op het naburige Friesland, ook al een streek waar praktisch alleen wandklokken werden geproduceerd, in eenvoudige en luxe-uitvoeringen. Oost-Brabant tenslotte grenst aan Noord-Limburg, juist de streek waar meer wandklokken werden vervaardigd dan in de rest van de provincie. Daarbij komt dat de lage huizen in de Zaanstreek en Oost-Brabant meer geschikt zijn voor wandklokken dan voor staande klokken.

\subsubsection{Kenmerken yan het Limburgs huisuurwerk}

De specifieke technische kenmerken van Limburgse huisuurwerken, gebouwd van het einde van de 17 de eeuw tot het midden van de 19 de eeuw - over de klokken vóór 1700 in Limburg is te weinig bekend om gefundeerde uitspraken te kunnen doen - zijn aan de hand van een statistische analyse te bepalen. De percentages zijn significant. $\mathrm{Zij}$ zijn, indien niet anders vermeld, berekend over het totale aantal van 691 huisuurwerken.

a. Het zijn bijna altijd (95\%) dagwerken, dat wil zeggen uurwerken die circa dertig uur lopen na het optrekken van het gewicht. Platine-uurwerken met een loopduur van een week tot tien dagen maken $5 \%$ uit.

b. Het mechanisme van de dagwerken is gevat in een "kooi", bestaande uit een onder-en bovenplaat, verbonden door rechthoekige ijzeren stijlen op de vier hoeken zonder enige versiering. In het midden tussen deze stijlen zijn drie platte stijlen aangebracht, waarin de messing tandwielen draaien (zie afbeelding 48). Het gaande werk is vóór het slagwerk geplaatst $(100 \%)$.

${ }^{34}$ A. Schuurman 1989 , p. 115. 


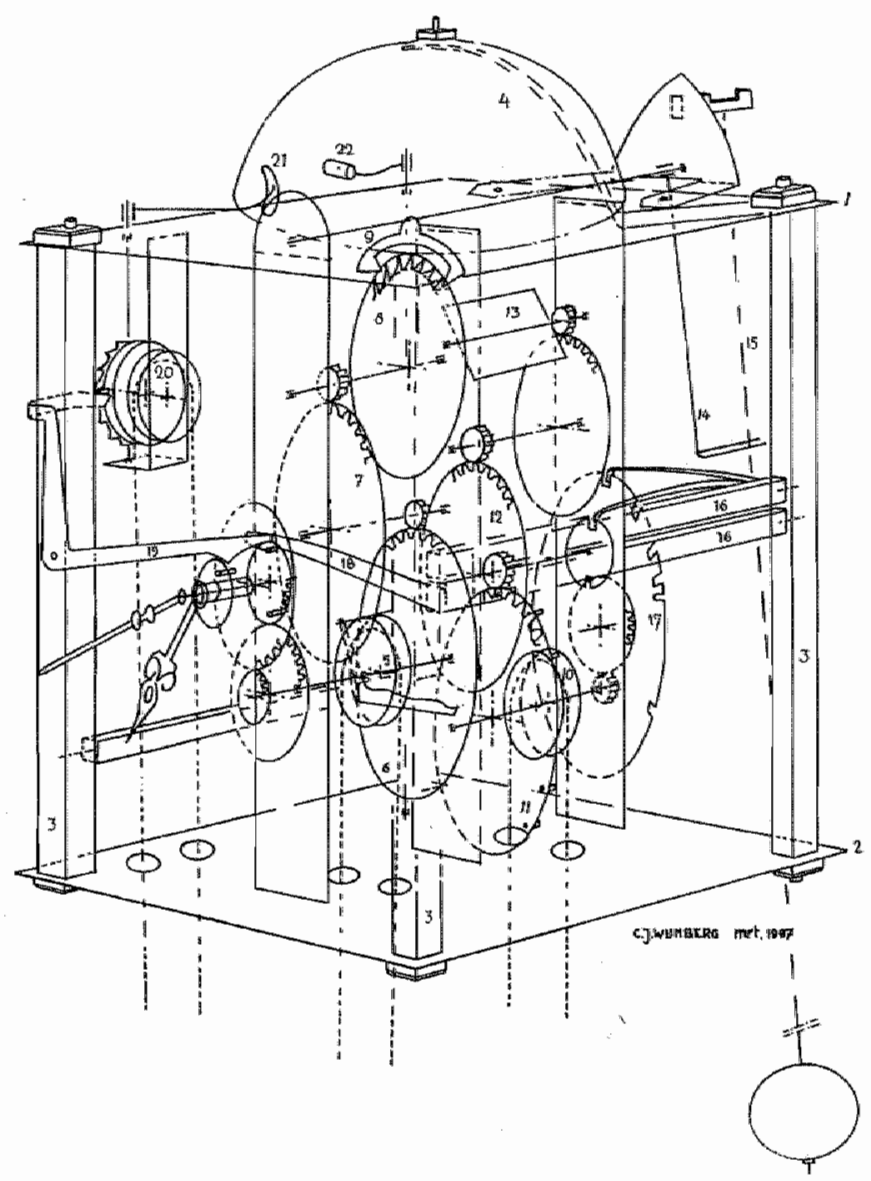

1 bosendod

2: carondphal

6. grondrad thirwerk

7 lussenrad

3 stellingood

8 onkernod

9 arkeras en anker

II Grandrod stcon werk

12 lussen rod slagherik, 17 shits schijl

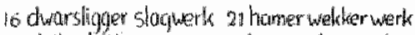

4 bel

to spoorrad siogwerk

1.3 wind wengel is thich slaguerk

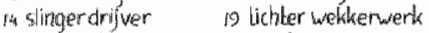

s spocrad cantwerk

is slingerstoon

20 witktherwerk

48. Opbouw van een Limburgs daguurwerk (tekening C. Wijnberg) 
c. Het echappement is een "terugwerkende" ankergang (99\%), dat wil zeggen: als men nauwkeurig naar de grote wijzer kijkt, ziet men deze bij elke slingerbeweging even terugwijken voordat hij verder gaat in de klokrichting. In de zeldzame gevallen dat een Limburgse klok een secondewijzer heeft $(5,5 \%)$, kan men dit terugwerken ook bij deze wijzer zien. Deze gang is minder gunstig dan de later ontwikkelde rustende gangen, waarbij de wisselwerking tussen aandrijving en tijdsbepalend element, de slinger, veel geringer is, bijvoorbeeld de Grahamgang en de pennengang. Toch zijn de gangresultaten van de terugwerkende ankergang bij een goed geconstrueerde en onderhouden klok met gewichtsaandrijving voor huiselijk gebruik uitstekend te noemen.

d. Ze hebben een lange secondeslinger van draadijzer, waaraan een messing met lood verzwaarde slingerlens (99\%). De slinger is opgehangen aan een slingerveer (99\%).

e. Ze hebben meestal ( $95 \%$ ) een slagwerk, in $91 \%$ met sluitschijf, in $9 \%$ een zaagslagwerk, met één $(87 \%)$ of twee $(13 \%)$ bellen en met één of twee belhamers. Er werd slechts één uurwerk met een speelwerk aangetroffen, namelijk een uurwerk van M. Raetsen Jr. uit Heythuysen. ${ }^{35}$ De zogenaamde meidenklok of wekkerklok heeft geen slagwerk, maar op de plaats daarvan, dus achter het gaande werk, een wekkermechanisme.

f. Ze hebben meestal (98\%) een wekkermechanisme (gehad), dat haaks (zelden parallel, $1,75 \%$ ) ten opzichte van de andere tandwielen is gemonteerd. Deze klokken konden dus op een bepaald tijdstip aflopen, net als onze losse wekkers. Het wekkerschijfje, dienend om de tijd van aflopen van de wekker in te stellen, is meestal (99\%) van messing.

g. Ze hebben één gewicht aan een koord of ketting, die als een eindeloze lus volgens het principe van Huygens is aangebracht. De wekker heeft uiteraard zijn eigen gewichtjes. De platinewerken (5\%) hebben praktisch altijd twee gewichten aan darmsnaren.

Deze algemene technische kenmerken hebben een zekere ontwikkeling van de bouwwijze niet uitgesloten. Kijken we allereerst naar de kooiconstructie. Men kan constateren dat de dikke hoekstijlen en dito tandwielen vanaf de $17 \mathrm{de}$ eeuw naar het midden van de $19 \mathrm{de}$ eeuw toe steeds dunner worden. De hoekstijlen gaan van $\pm 15 \mathrm{~mm}$ naar $\pm 3 \mathrm{~mm}$, de tandwielen van $\pm 12 \mathrm{~mm}$ naar $\pm 1,5 \mathrm{~mm}$. I $k$ heb

${ }^{35}$ Zie appendix II onder Raetsen, Matthias Jr., klok a. 
slechts één klokkenmaker gevonden die ronde, messing hoekstijlen gebruikte zonder versiering, behalve een paar ingefraisde ringetjes, namelijk A.J. Smeets te Hamont. Eén uurwerkmaker, Gerard Trommar in Horst, paste meestal rechthoekige messing hoekstijlen toe; één uurwerk van hem heeft echter ronde, als een Friese klok geprofileerde hoekstijlen. De hoekstijlen zijn meestal aan de bovenen onderplaat gesmeed. M. Raetsen Sr. uit Heythuysen is éen van de weinigen die daarvoor soms $(33 \%)$ geschroefde verbindingen gebruikte (zie afbeelding 49).

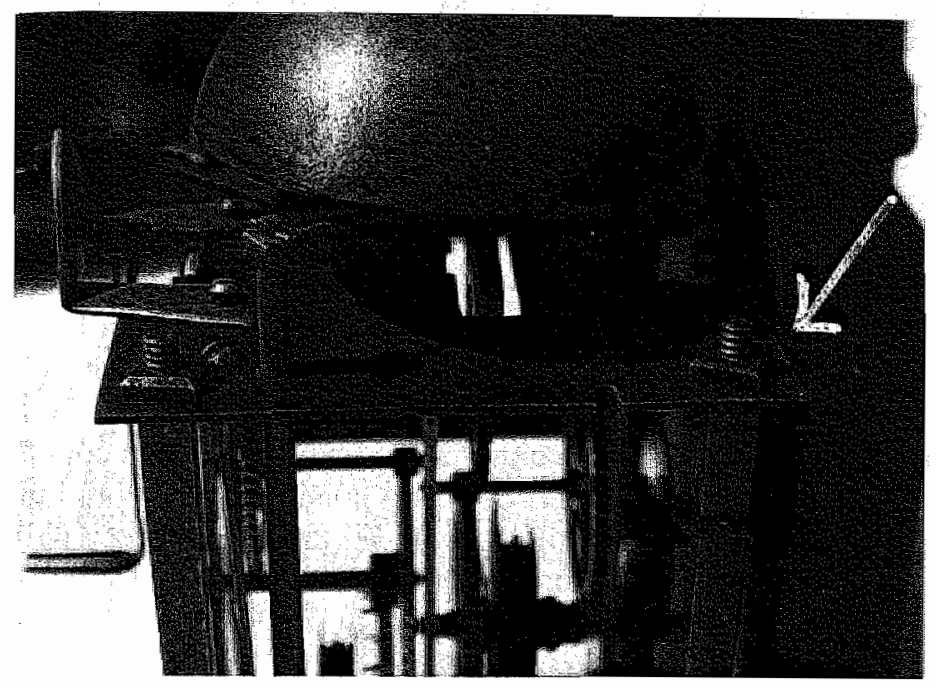

49. Limburgs daguurwerk, waarvan de hoekstijlen niet aan boven- en onderplaut zijn geklonken, maar geschroefd, zie pijl, gedateerd 1781 (M. Raetsen, Heythuysen)

De afmetingen van de "kooi" zijn variabel, ook bij klokken van dezelfde klokkenmaker. De gemiddelde hoogte van de aangetroffen uurwerken met slagwerk bedraagt $17,3 \mathrm{~cm}$, de gemiddelde breedte $13,8 \mathrm{~cm}$ en de gemiddelde diepte $11,25 \mathrm{~cm}$. Er is bij wandklokken een tendens waarneembaar dat de uurwerken kleiner worden naar 1850 toe (zie grafiek 3). Bij wekkerklokken is de gemiddelde hoogte $14 \mathrm{~cm}$, de gemiddelde breedte $10,75 \mathrm{~cm}$ en de gemiddelde diepte $8,5 \mathrm{~cm}$. 


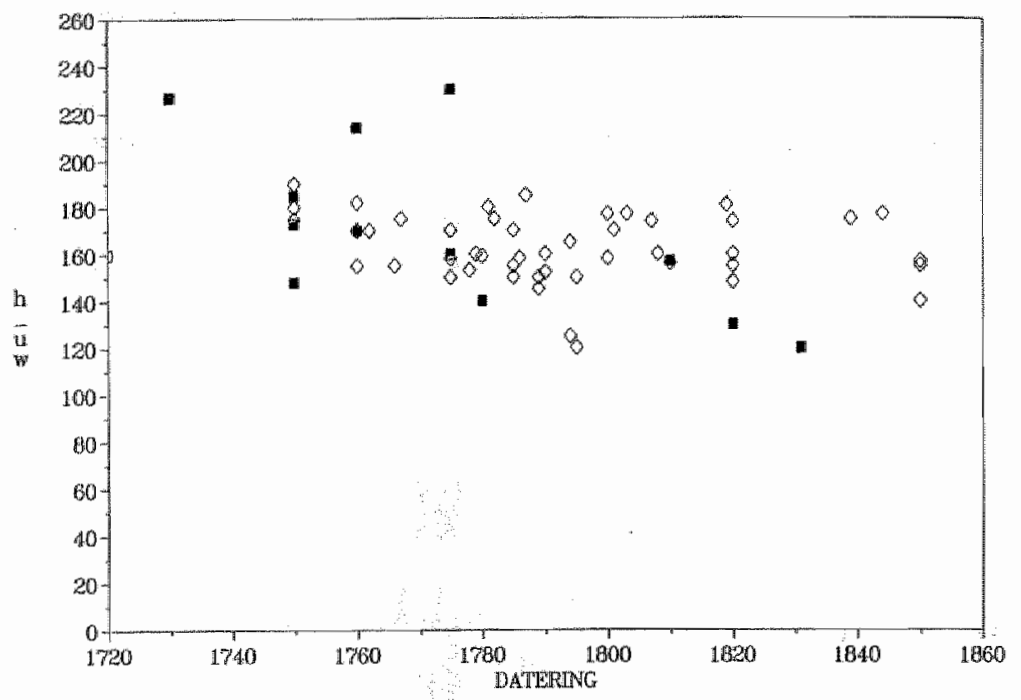

$\mathrm{sk}=$ staande klok, $\mathbf{w} \mathrm{w}=$ wandklok

Ten aanzien van de looptijd kan worden opgemerkt dat men in 35 gevallen, ongeveer $5 \%$ van de huisuurwerken, een tiendaags uurwerk tussen platines aantreft (zie afbeelding 50). Ruim de helft daarvan (twintig) heeft een datumaanwijzing en een kleine secondewijzer. Enkele keren (zes) is er ook een maanfasenaanduiding, waarbij één keer een bolvormige maan is aangetroffen. ${ }^{36}$ Nog zeldzamer dan de weekwerken tussen platines zijn de weekwerken tussen hoekstijlen. De enige drie $(0,4 \%)$ die in de beide Limburgen werden aangetroffen, zijn een staande klok uit omstreeks 1800 van Dionisy te Roermond, ${ }^{37}$ die zich in het Gemeentemuseum te Roermond bevindt, een staande klok, daterend van rond 1840 , van H.R. Beltjens uit Roermond in particulier bezit ${ }^{38}$ en een staande klok, gesigneerd "Joannes Augustinus horlogeur Eustageus Beelen $1786^{\prime \prime} \cdot{ }^{39}$ Sporadisch zijn ook daguurwerken tussen ijzeren platines aangetroffen. Dit is met name het geval bij Joannes Trommar Sr. en diens gelijknamige neef te Horst.

\footnotetext{
36. Staande klok met uurwerk van J. Beeckman in Meldert. Zie in appendix II.

"s7 Zie appendix II onder Dionisy. T.F., klok a.

35: 'Zie appendix II onder H.H.H. Beitjens, Roermond, klok * b.

29. Zie appendix II onder Augustinus, Joannes.
} 


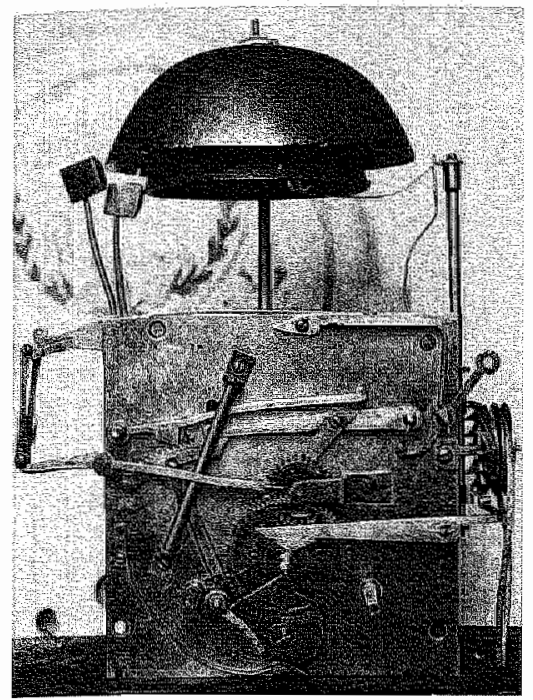

50. Limburgs wurwerk tussen platines met zaagslagwerk, cirea 1830 (T.F. Dionisy, Roermond). De meeste platinewerken hebben een looptijd van éen week. Rechts is het wekkerrad zichtbaar

Ten aanzien van het slagwerk valt op dat de sluitschijf een ontwikkeling laat zien van groot naar klein, van ijzer naar messing, van gesloten naar gespaakt. Ook hier weer kleine moderniseringen, heel geleidelijk ingevoerd in het tempo van het Ancien Régime, bijna onmeetbaar traag ${ }^{40}$ (zie afbeelding 51a en b).

Dit alles betekent niet dat de uurwerken geen wezenlijke technische verschillen vertonen. Talloze varianten in de wijze, waarop de hamer tegen de bel slaat, kan men in Limburgse uurwerken aantreffen: de meest voorkomende $(86 \%)$ is één hamer met lange steel, die even boven de onderplaat scharnierend de bel aanslaat in een verticaal vlak, van buiten naar binnen bewegend. Minder vaak treft men een hamer met korte steel aan, die aan de rand van de bovenplaat scharniert en daar wordt geveerd $(22 \mathrm{x}$ of $3,2 \%)$; de impuls van het pennenrad/slagrad wordt via een trekstangetje naar de hamer overgebracht, die in een verticaal vlak de bel aanslaat. Deze constructie is normaal voor G. Janssen te Sint-Odiliënberg. Dezelfde constructie wordt ook wel eens $(0,6 \%)$ aangetroffen bij een dubbele bel, waarbij dan twee hamertjes worden toegepast. Daar-

${ }^{40}$ F. Braudel 1987, pp. 420-425. 

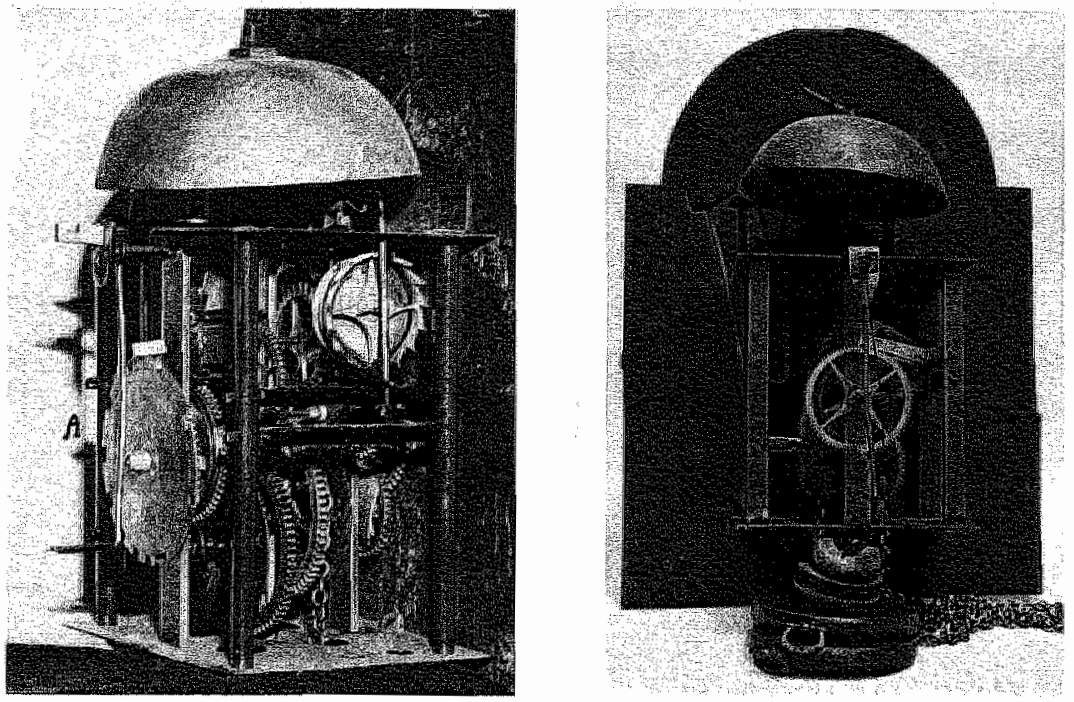

51a. (1.) Gesloten sluitschijf (heel usr voluit, half uur één slag)

51b. (r.) Gespaakte sluitschijf (heel wur woluit, half vour én slag)

naast vindt men, vooral in uurwerken van vóór 1775 , de hamer met lange steel, die in de bodemplaat draait en de bel in een horizontaal vlak aanslaat $(0,6 \%)$; met name komt deze constructie voor bij uurwerken, waarbij de bel boven op het dak van de kop is geplaatst. Een andere variant, die men vooral in Noord-Limburg, onder andere bij Remmen aantreft (1\%), is de hamer met lange steel, die verticaal zwaaiend van binnen naar buiten de bel aan de binnenkant aanslaat (zie afbeelding 52).

Voor het aanslaan van twee bellen heeft men ook allerlei systemen bedacht: het meest voor de hand ligt $(5,1 \%)$, dat dit gebeurt met twee hamers van verschillende lengte aan één of twee kanten van het uurwerk, verticaal of horizontaal bewegend. Daarnaast is het systeem met twee korte hamers op de bovenplaat toegepast, dat boven reeds werd vermeld $(0,6 \%)$. Vernuftiger zijn de systemen met één hamer voor twee bellen: er is een systeem, waarbij de twee bellen zo kunnen kantelen, dat één bel wordt aangeslagen, namelijk de grote op het volle uur en de kleine op het halve uur $(0,4 \%)$. Bij een ander systeem wordt de enige hamer opgetild of neergelaten $(1,4 \%)$. Weer een ander systeem houdt in dat het bovenstuk van de 


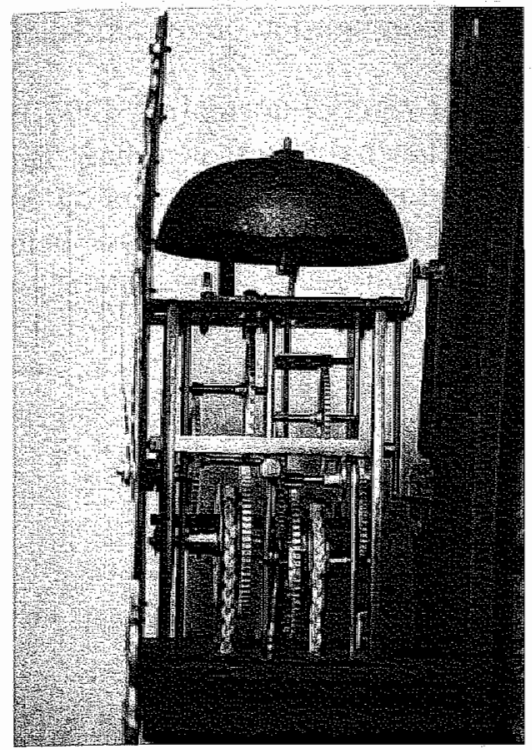

52. Slagwerk met én bel

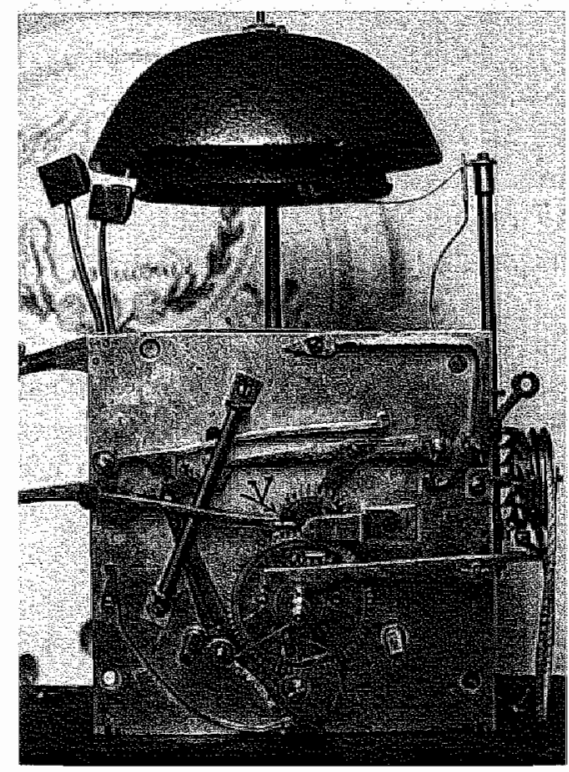

53. Slagwerk met twee bellen en twee korte belhamers. Het inschakelen van de ene of de andere hamer gebeurt door een schuin oplopende tlens op rad $\mathrm{V}$ 
hamer kan scharnieren en naar believen kan worden opgetrokken of neergelaten $(0,6 \%)$ (zie afbeelding 53 ).

De wijze van slaan is bij uurwerken met één bel normaliter (99\%): op het volle uur het aantal uren en op het halve uur één slag. Bij uurwerken met twee bellen bij het volle uur het aantal uren op de grote bel, bij het halve uur het aantal slagen van het volgende hele uur op de kleine bel ( $99 \%$ ), ofwel bij het halve uur: afwisselend op de kleine en grote bel het aantal slagen van het volgende uur $(0,4 \%)$. Dit is het zogeheten "Nederlandse slagwerk". De kwartierslag komt af en toe voor $(1,7 \%)$; Matthieu Peeters, eerst te Zutendaal, later te Opglabbeek gevestigd, past hem nogal eens toe. Zeer zelden, namelijk één keer, werd de angelusslag aangetroffen en wel bij een klok van Gielissen uit Neeritter.

Zoals vermeld hadden de meeste (98\%) Limburgse huisuurwerken behalve het slagwerk ook een wekkerwerk, dat kon aflopen op een bepaald tijdstip, net als onze losse wekkers. Door het zogeheten wekkerschijfje met de cijfers 1-12 rond de wijzeras kon men het tijdstip van aflopen instellen. Als de wekker om zeven uur moet aflopen, moet men het schijfje zo draaien, dat het cijfer 7 staat tegenover het uiteinde van de kleine wijzer, die in een scherpe lange punt uitloopt (zie afbeelding 54). Meestal (98\%) is de ontgrendeling van het wekkerraadje haaks gemonteerd op de wekkerlichter. Deze draait om een nok, links onder het wekkerraadje (zie afbeelding 55). Cornelis Remmen monteerde echter de wekkerlichter links en de ontgrendeling rechts van het wekkerraadje op een scharnierend stuk platijzer tussen de hoekstijlen (zie afbeelding 56). De standaardwekkeruitlichting bij Limburgse klokken is die, waarbij de wekkerlichter omhoog wordt geduwd door een stift op de wekkerschijfas. Van Hermannus Beltiëns uit Roermond is evenwel één wekkerklok bekend in een staartklokkast ${ }^{41}$ met een afwijkende uitlichting. ${ }^{42}$ De hamersteel wordt geblokkeerd door een rechtopstaande pen, die op een metalen strip is gemonteerd. Deze strip rust aan een kant op een lichter met een nok, die op een flens van de wekkerschijfas rust. In deze flens is een inkeping. Als de lichternok in deze inkeping valt, komt de blokkeerpen vrij en kan

${ }^{41}$ Uurwerk en kast lijken bij elkaar te horen, al is het staartgedeelte door de vader van de huidige bezitter omstreeks 1.925 vernieuwd wolgens het onde model. Bij navraag vertelde een Roermondse antiquair, dat hij wel vijf van dergelijke "Limburgse" staartklokken had werhandeld. Hij kende echter de huidige verblijfplaats niet en had geen foto's.

${ }^{32}$ Zie appendix II onder Beltiëns, Hermannus, klok $\mathrm{f}$. 


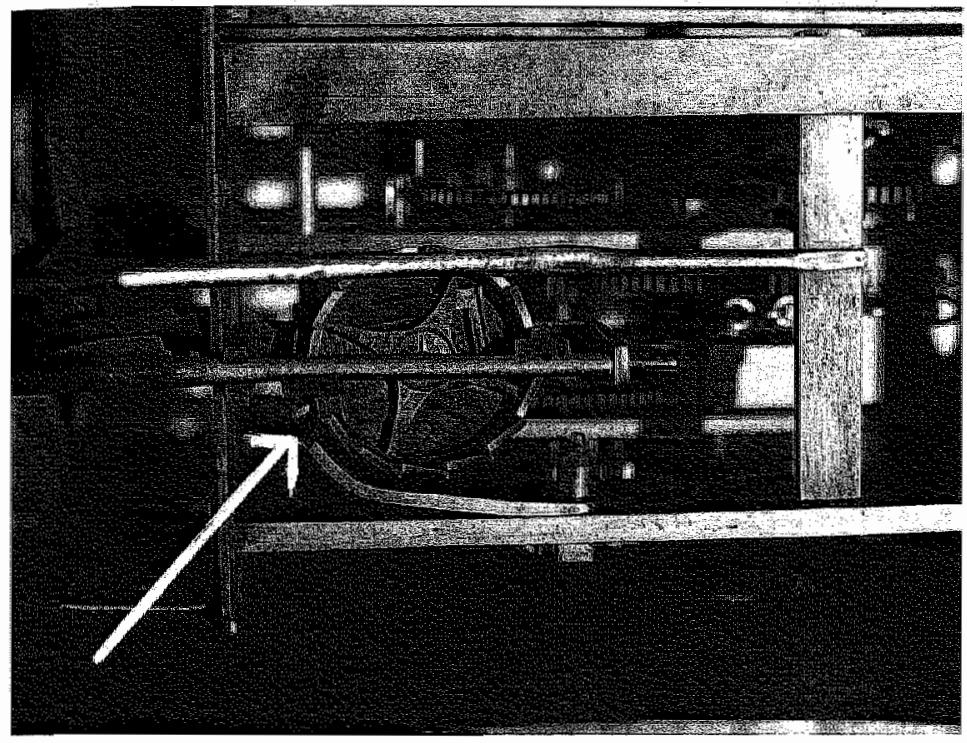

3
3
0
0
0
0
0
0
0
0
0

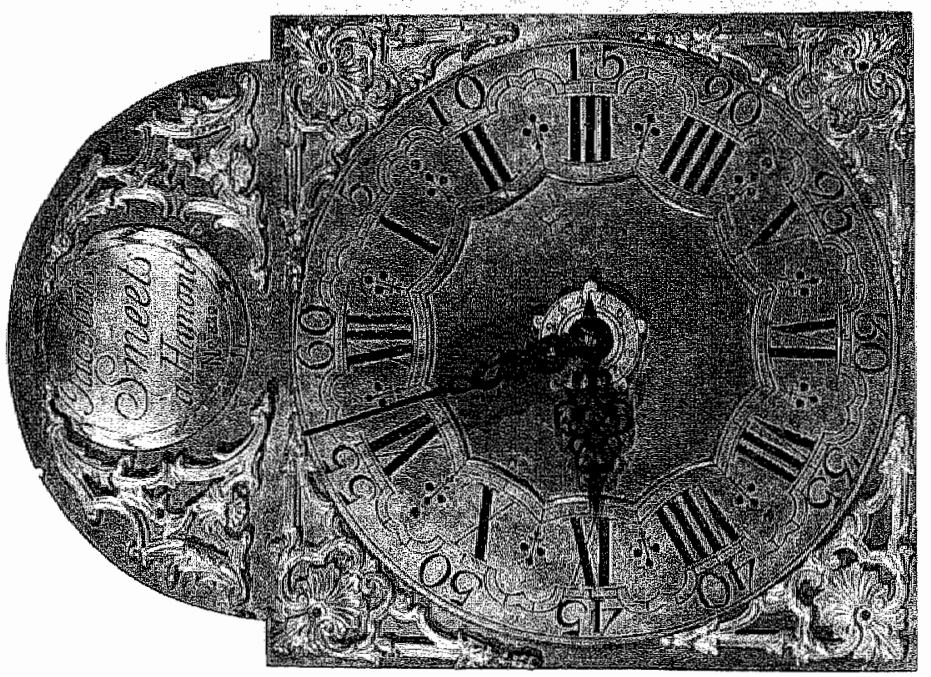

w

$\frac{8}{3}$

$\stackrel{3}{3}$

푭

है.

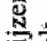

$\frac{2}{3}$

车

\&

哕

ह

语

y

32

25

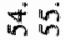




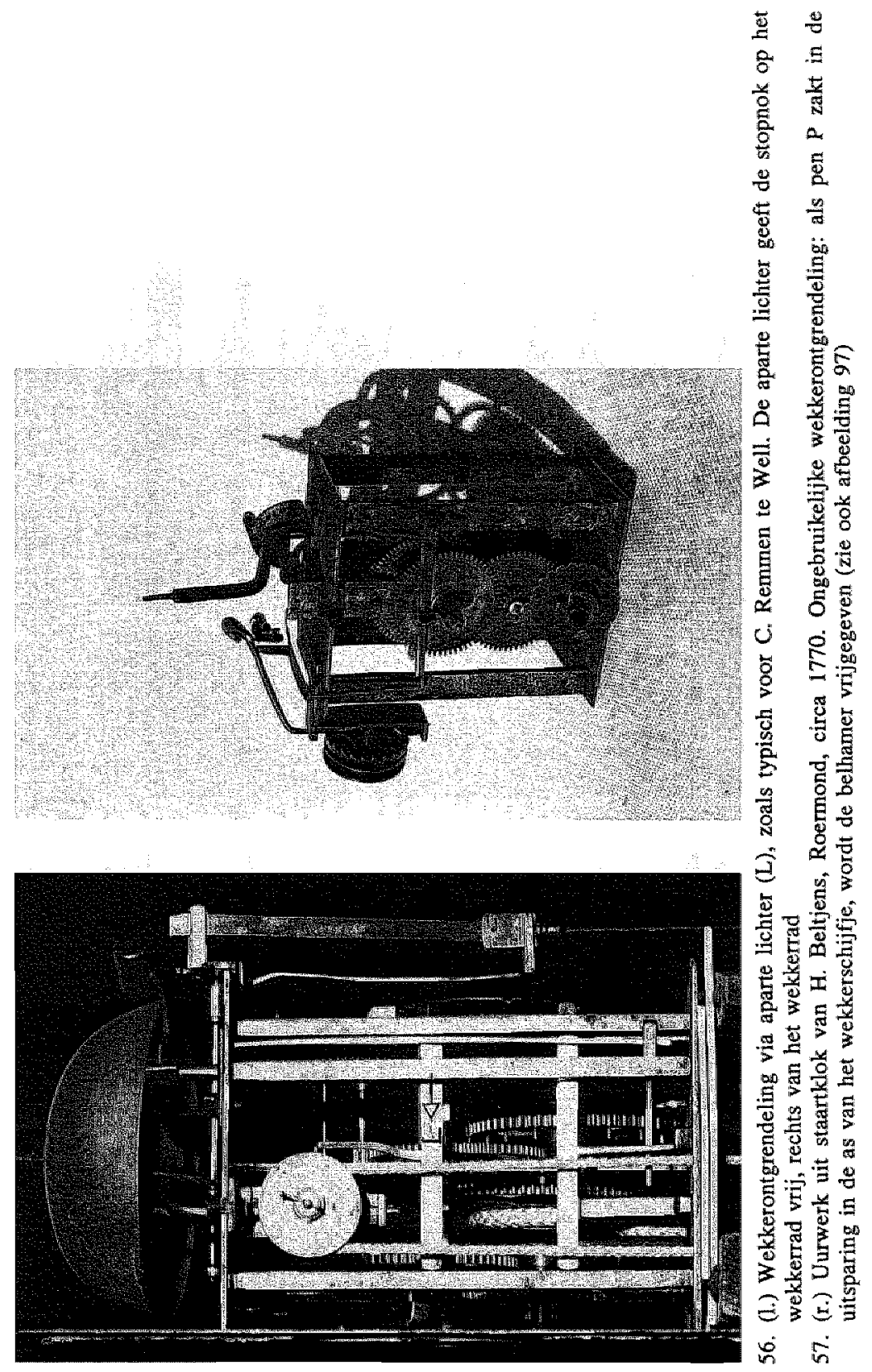


de wekker aflopen (zie afbeelding 57). Dit systeem werd verder niet in Limburgse uurwerken aangetroffen; het komt wel vaak voor bij Schwarzwald-klokken. Helaas is het wekkerwerk uit veel uurwerken verwijderd, toen goedkope losse wekkkers in zwang waren gekomen en menig bezitter blijkbaar terugschrok voor de herstelkosten. Daarom hebben veel uurwerken well nog de sporen van de wekker, namelijk bevestigingspunten van de lichter, het wekkerraadje en de wekkerhamer, maar niet meer de wekker zelf.

Technische innovaties, zoals de temperatuur-gecompenseerde slinger en de schaargang, werden slechts in enkele Limburgse klokken vastgesteld. Een gecompenseerde slinger komt voor bij twee wandregulateurs van J.W. Aerts te Tongeren, een wandregulateur van J.F. Nijs uit Roermond en een pendule van J. Wilmotte te Maastricht alsmede een staande klok van J.H. Bielen in Zonhoven $(0,7 \%)$. Een schaargang hebben de genoemde wandregulateur van Nijs en de pendule van Wilmotte $(0,3 \%)$ (zie afbeelding 58 en 59).
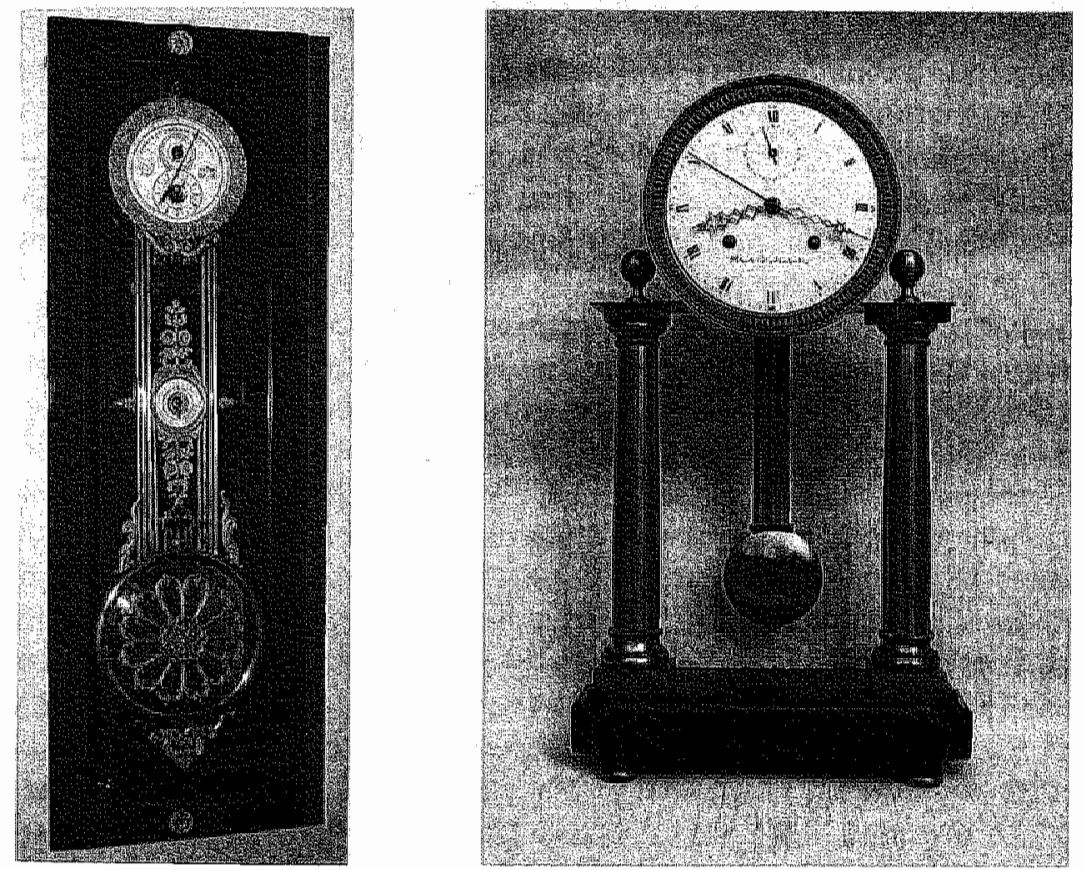

58. (1.) Compensatieslinger, uitgevoerd met messing en jzeren staven, circa $1830(\mathrm{~J} . \mathrm{W}$. Aerts, Tongeren)

59. (r.) Pendule met compensatieslinger, circa 1810 (J.S. Wilmotte, Maastricht) 
Soms is er dus sprake van acceptatie van recente innovaties. Dat gebeurde aan het einde van de 18de en in het begin van de 19de eeuw, al hebben zij zich zeker niet verbreid in het tempo, waarin de vindingen van Huygens en Clement in de laatste decennia van de 17 de eeuw navolging vonden. Ook vonden zij niet zo algemeen navolging als de 17 de-eeuwse vernieuwingen. Dat maakt het interessant nader in te gaan op het 17 de-eeuwse diffusieproces. Hoe heeft het zich voltrokken? Ten aanzien van de diffusie van de slinger moet worden opgemerkt dat Jan Vrijthoff uit Maastricht door zijn verblijf in Den Haag van belang is geweest voor de verspreiding van de slingertechniek in Maastricht en directe omgeving. Als fanatiek protestant zal hij echter weinig contacten hebben gehad met vakbroeders in de rest van de Zuidelijke Nederlanden. Deze laatsten zijn mogelijk met Huygens' innovaties in contact gekomen via Parijse connecties, ofwel direct uit Parijs - Huygens liet al vroeg slingeruurwerken naar Parijs brengen - of indirect langs een omweg via Luik. Het is in dit verband belangrijk te wijzen op het feit dat Huygens een presentexemplaar van zijn "Horologium oscillatorium" deed toekomen aan de Luikse wiskundige Sluse. ${ }^{43}$ Mogelijk heeft deze met uurwerkmakers uit zijn omgeving van gedachten gewisseld over Huygens' vondst en zo het idee van de slinger verspreid.Het is opvallend dat in de late 17 de eeuw in enkele jaren de toon werd gezet voor wat hier gemakshalve wordt aangeduid als de Limburgse klok. Hoe was het mogelijk dat uurwerkmakers in een regio zonder enige politieke of sociaaleconomische homogeniteit in korte tijd een bouwwijze accepteerden, die ze 150 jaar trouw bleven, en nog wel in een heel kort tijdsbestek? Ons onderzoek heeft geen gegevens opgeleverd om deze vraag te kunnen beantwoorden. Uit de overgeleverde uurwerken kan men op eenvoudige wijze onderlinge verschillen bepalen, maar nimmer homogeniseringstendenzen afleiden. Ondanks trouw aan het eertijds geïntroduceerde systeem vergaten de Limburgse uurwerkmakers niet eigen accenten te zetten. Het Limburgs uurwerk is niet eenvormig. Het gaat om een samenhangend geheel met wisselende kenmerken van onder andere de wijzerplaat, het slagwerk en de decoratieve elementen. Het is een type met luxe- en

${ }^{43}$ C. Andriesse 1994, p. 258. René François (de) Sluse (Visé 1622-Luik 1685) was kanunnik te Luik en had als wiskundige naam gemaakt met zijn tangentenmethode en "parels van De Sluse". 
eenvoudige versies. Het is geen eenvormig massaproduct, maar een product met individuele kenmerken, waarbij duurzaamheid en betrouwbare werking op de eerste plaats kwamen. De beste technieken om duurzaamheid en precisie te bereiken die omstreeks 1700 bestonden, werden algemeen geaccepteerd en vervolgens stug vastgehouden, wat er verder ook aan innovaties optrad. Waarschijnlijk heeft de consument hierin een doorslaggevende rol gespeeld. Hij verlangde voor de flinke som geld die een uurwerk in de $18 \mathrm{de}$ eeuw kostte een instrument dat ook zijn kindskinderen nog precies zou informeren over het voortschrijden van de tijd.

In welk opzicht onderscheidt het Limburgse type zich van die in omringende landstreken? Wanneer we de Limburgse uurwerken op basis van de bovenvermelde kenmerken vergelijken met de producten van de omringende landstreken, kunnen we het volgende vaststellen: ze onderscheiden zich duidelijk van de Friese, Hollandse en Bergische klokken qua opbouw en uitwoering van de uurwerken en de kasten. De verschillen met de Friese klokken en met de daarop gelijkende klokken uit Groningen zijn evident; uurwerktechnisch gezien: tot laat in de 18de eeuw hebben de Friese klokken als echappement de spillegang met korte slinger. Ze hebben voor de uitlichting van het slagwerk de zogeheten "bokkepoot". Bij de opbouw van het uurwerk vallen de getorste of geprofileerde messing hoekstijlen op, evenals de dikke tandwielen. De wijzerplaten zijn meestal bont beschilderd. De uurwerken zijn praktisch allemaal als wandklok uitgevoerd, stoelklok of staartklok. Alleen in Groningen komt af en toe een staand horloge voor. De Hollandse klokken in strikte zin, Zaanse klokken, staande horloges vooral afkomstig uit Amsterdam, en de zogenaamde "Amsterdammertjes"44 verschillen met de Limburgse door de luxe-uitwoering van uurwerk en kast. De tandwielen van de Zaanse uurwerken lijken veel op die van de Friese stoelklokken, maar zijn gevat in een strippenframe. Ze hebben een horizontale spillegang met korte slinger. De Amm sterdamse uurwerken zijn meestal weekwerken tussen platines met allerlei aanduidingen van de kalender, van getijden, van de maanfasen en van andere astronomische fenomenen. Vaak zijn ze voorzien van scheepjesmechanieken, tijds-equatie en speelwerken. De kasten zijn belijmd met kostbare houtsoorten. Kortom, het zijn zeer luxe

\footnotetext{
${ }^{4}$ Dit zijn wandklokken uit Amsterdam met een rijk geprofileerde kap en korte staart. De kast is gefineerd met luxehoutsoorten.
} 
objecten. In thet Bergische Land, de streek rond Solingen in Duitsland, werden uurwerken geproduceerd, die net als de Limburgse veel ijzeren componenten bevatten. Gaand werk en slagwerk werden daar echter naast elkaar gemonteerd, niet achter elkaar, zoals bij de Limburgse en Luikse uurwerken. De klokkasten vertonen enige gelijkenis met de Limburgse.

Veel onduidelijker en vaak zelfs geheel afwezig is het onderscheid met de klokken uit delen van Noord-Brabant, ${ }^{45}$ de westelijk of zuidelijk van Limburg gelegen Belgische provincies, Noord-Frankrijk (Frans-Vlaanderen), het Rijnland en de streek rond Aken (D). Hoewel de klokken uit de stad Luik vaak verfijnder zijn dan de plattelandsklokken, gemaakt in het Limburgse, en de klokken langs de Belgische kust soms Engelse invloed verraden, hebben ze toch gezamenlijke kenmerken. De Limburgse klok lijkt een subtype van een uurwerktype dat wordt aangetroffen in eén groot Zuid-Nederlands gebied. Met "Limburgse klok" wordt dan ook niet zozeer een geheel eigen type klok bedoeld, het is veeleer een sobere en degelijke Zuid-Nederlandse klok, gemakt in het gebied van de beide Limburgen.

Enkele onderdelen van de Limburgse klok, zoals de wijzerplaat en de klokkast, verdienen afzonderlijke behandeling omdat daarbij de lokale en regionale varianten duidelijker naar voren komen.

\subsubsection{Ontwikkeling van de wijzerplaat}

De wijzerplaat verschaft ons door haar vorm aanwijzingen over de datering en door het gebruikte materiaal over de herkomst van een Limburgse klok. Na de gotiek en de renaissance - tijdvakken waaruit te weinig Limburgse uurwerken zijn bewaard om gefundeerde uitspraken te doen - waren de wijzerplaten aanvankelijk vierkant van vorm (zie afbeelding 60). Dit was gebruikelijk in de periode $1650-1715$ en kwam tot 1740 incidenteel nog voor. Daarvan werden tien voorbeelden aangetroffen. Vanaf circa $1715 \mathrm{kwa}-$ men de getoogde wijzerplaten met tinnen cijferring en dito adresplaatje en hoekornamenten in zwang (zie afbeelding 61). Een vijftal oorspronkelijk vierkante platen, waarop later een toog is gezet,

\footnotetext{
"s In "s-Hertogenbosch werkten sommige klokkenmakers volgens de Hollandse stijl, anderen volgens de Zuid-Nederlandse. Zie I. Zeeman 1977, p. 402 .
} 

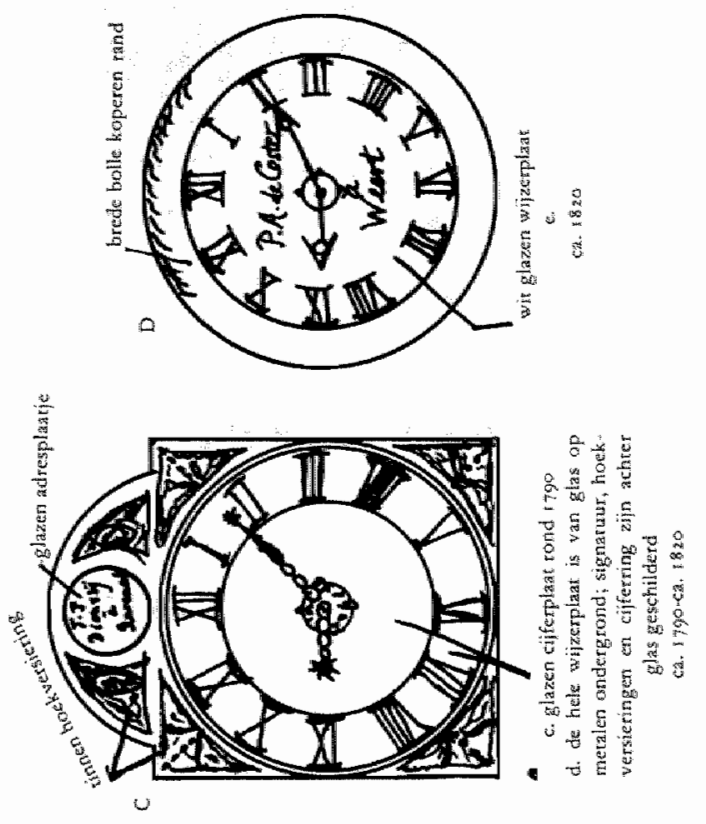

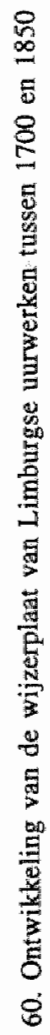
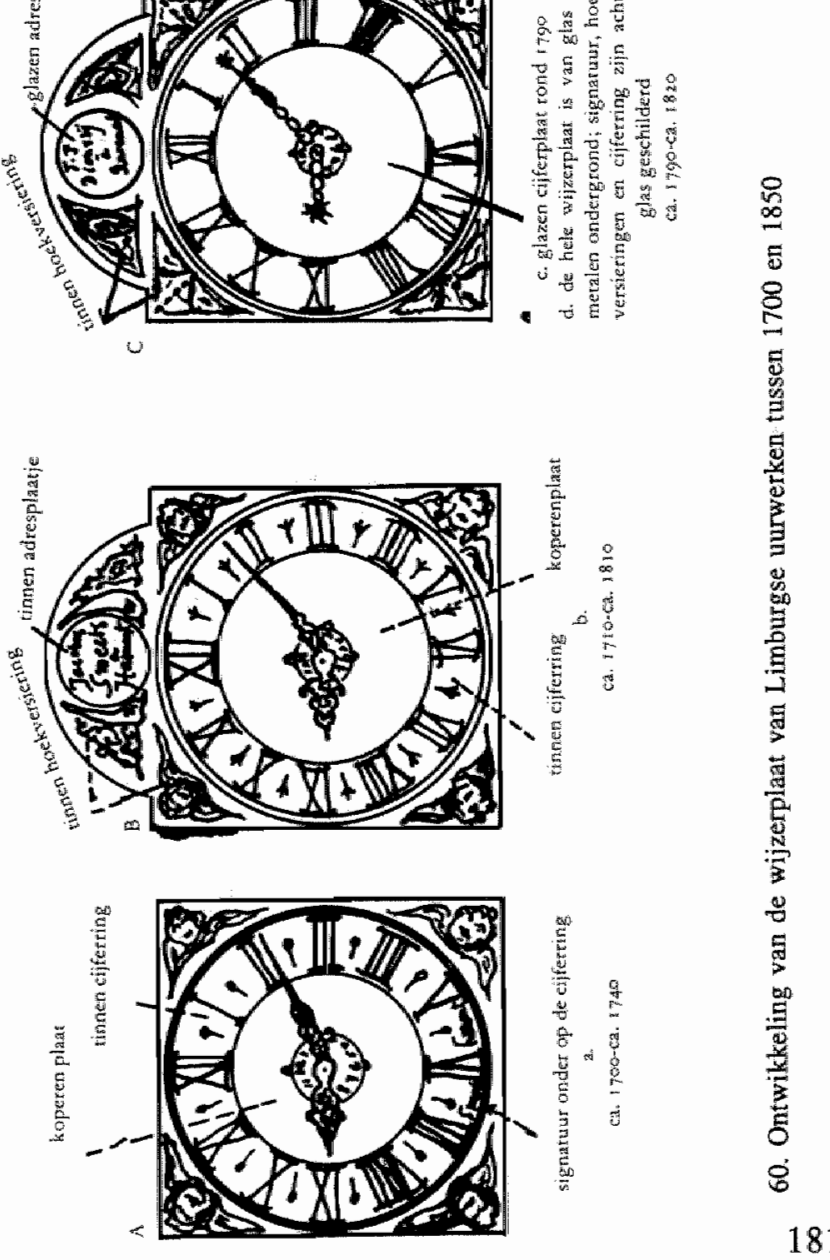
werd aangetroffen. Het getoogde type werd tot ver in de 19 de eeuw toegepast. De variatie is enorm. De wensen van de opdrachtgever, technische noodzaak en het kostenaspect speelden een rol. De tinnen cijferringen zijn soms $(3,8 \%)$ aan de binnenzijde geschulpt. De halfuurtekens vertonen een grote verscheidenheid van vorm. De grondvorm is ofwel de Franse lelie of het ruiten- of het klaverteken van het kaartspel. Sommige opdrachtgevers waren tevreden met een éénwijzerig uurwerk. De cijferringen voor éénwijzerige uurwerken hebben aan de binnenrand van de cijferring een kwartierindeling. De ruimte tussen twee uurcijfers is dan in vieren gedeeld, zodat de kwartieren globaal worden aangeduid, en niet in vijf, zoals op cijferringen voor tweewijzerige wurwerken, waarop de minuten worden aangeduid.

Soms werd een tin-loodlegering gebruikt voor de toog- en hoekstukjes in plaats van tin. Dat was goedkoper. Het is niet precies getalsmatig uit te drukken hoeveel keer "zuiver" tin werd aangetroffen en hoeveel keer een legering. Te weinig uurwerken mochten van de eigenaar op dit aspect worden onderzocht. Hoe eenvoudiger het uurwerk en hoe recenter vervaardigd, des te meer lood werd er in de legering gebruikt, lijkt het. Sommige luxeklokken ${ }^{46}$ hebben toog- en hoekstukjes en een adresplaatje van messing; de cijferring werd echter nooit van messing vervaardigd, behalve in de $17 \mathrm{de}$ eeuw, zoals blijkt uit de lantaarnklok van Muys en het Haagse klokje van Vrijthoff. Van circa 1790 tot circa 1850 hebben de getoogde wijzerplaten in plaats van een cijferring en adresplaatje van tin of een tin-loodlegering er een van glas met een zwart-witte achterglasschildering; $13 \%$ van de 691 hier beschreven huisuurwerken heeft dit type wijzerplaat en dateert dus uit deze periode. In de periode $1790-1820$ werd soms $(2,9 \%)$ de gehele getoogde wijzerplaat overdekt met een, vaak polychrome, achterglasschildering. ${ }^{47}$ De ontwikkeling van de getoogde wijzerplaat leidde ten langen leste tot het ontstaan van een heel nieuw type wijzerplaat. De

\footnotetext{
${ }^{46}$ Bij klokken van François de Beefe, Maastricht en Amold de Nève, Maastricht.

${ }^{47}$ Het betreft uwrwerken wan J. Beeckman, Meldert (1x), J.M. Beltjens, Roermond (2x), I.F. van Boom, Venlo (1x), P.A. de Coster, Weert $(1 x)$, F.T. Dionisy, Roennond (2x), J. Geelen, Neeritter (Ix), J. Gielissen, Neeritter (Ix), J. Keuller, Venlo (1x), M. Raetsen Jr., Heythuysen $(3 x)$, F. Schampers, Horst (1x), D. en M. Schoufs, Thorn (2x), J.B. Schoufs, Thorn $(1 x)$, Ch. Streel, Hamont (1x), D.L. Tonnaer, Thorn (1x), L. van de Winckel, Neeritter (1x). Het is derhalve een mode die voornamelijk in Midden- en Noord-Limburg voorkamt. In BelgischLuimburg werd zij minder angetroffen.
} 

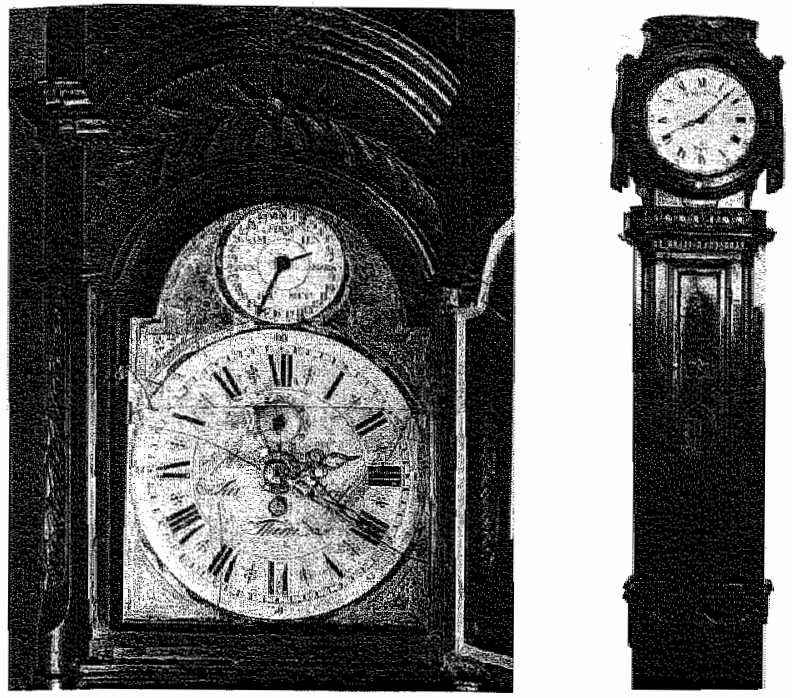

61. (1.) Getoogde glazen wijzerplaat, polychrome achterglasschildering, circa 1790 (J.B. Schoufs, Thorn)

62. (r.) Voorbeeld van een vroege, ronde wijzerplaat, circa 1790 (P.A. de Coster, Weert)

jongste wijzerplaten zijn rond, achterglasgeschilderd en voorzien van een messing rand. Omstreeks 1850 en later is deze vorm modieus. Het komt voor bij 5,5\%. De kop van deze klokken werd van boven recht of boogvormig afgesloten. Het deurtje vóór de wijzerplaat was vierkant met een ronde opening voor de wijzerplaat. Sommige Limburgse uurwerkmakers begonnen al vroeg met ronde wijzerplaten (zie afbeelding 62). De klokken met een ronde witglazen wijzerplaat en een ronde kop - de kop en de rand van het deurtje vóór de wijzerplaat volgen de ronding van de wijzerplaat zijn ouder dan de hierboven genoemde ronde witglazen platen met messing rand in een rechte kop; die met ronde kop dateren al van omstreeks 1800 . Er werden slechts vijf exemplaren $(0,7 \%)$ van aangetroffen in de beide Limburgen. ${ }^{48}$ Dit type klok kwam vooral, maar niet exclusief voor in Eindhoven en wijde omtrek. ${ }^{49}$ De ver

Het betreft hier uurwerken van I. Ceysens, Hasselt (1x), P.A. de Coster, Weert (2x), M.J. Hagen, Bree (1x), J.C. Schollberg, Weert (1x).

4" Dit type klok is niet exclusief voor Eindhoven en ongeving: een klok met dit model kop, wan de Akense klokkenmaker Sichmit $z_{t}$ bevindt zich in het Couvenmuseum te Aken. Daar werden dergelijke klokken waker gebouwd. In de tekeningenalbums van Matthias Soiron Jr. komt een tekening voor van een Louis XVI-klok met ronde kop, waarop twee duifjes en 
schillende modellen wijzerplaten sloten elkaar niet uit: diverse typen kwamen soms een tijdlang naast elkaar voor.

De stijl van de hoekornamenten zegt niet veel over de tijd van vervaardiging van de klok. Het lijkt erop, dat de doorsnee klokkenmaker de ornamenten gebruikte, die hij toevallig in voorraad had. Er zijn zeer veel typen hoek- en toogornamenten met internationaal voorkomende voorstellingen, zoals de vier jaargetijden, bloemen, hoornen des overvloeds, gevleugelde cherubijnenkopjes, rocailles en loofwerk tussen parelranden. In de toog komen onder andere zeepaardjes, dolfijnen, Indiaanse halffiguren en portretmedaillons voor (zie afbeelding 63). Bijna alle modellen die Pholien ${ }^{50}$ afbeeldt kan men op Limburgse uurwerken aantreffen. Er zijn er slechts enkele die hij niet afbeeldt. Typisch voor Nederlands-Noord-Limburg zijn de grote gietstukken met putti die het adresplaatje vasthouden en hoekstukjes in de vorm van een vrouwelijke halffiguur met geprononceerde borsten. De klokken van de familie Remmen uit Well hebben dergelijke ornamenten vaak.

De toog - en hoekstukjes zeggen niet veel over de plaats van fabricage van een uurwerk. De meeste typen toog- en hoekstukjes komen in het hele gebied van de beide Limburgen en in omringende gebieden voor. Sommige typen, zoals de dolfijnen als toogstukje en de putti met kroon als hoekstukje, zijn Engels van oorsprong, maar zij werden naar believen nagegoten, ofwel door tingieters ofwel door de uurwerkmakers zelf, die immers meestal een smidsvuur hadden, zodat het nagieten eenvoudig was.

De adresplaatjes zijn bij een wijzerplaat met tinnen cijferring meestal ook van tin; bij achttien klokken $(2,6 \%)$ met tinnen cijferring werden messing adresplaatjes aangetroffen. Dat was vooral het geval op uurwerken uit Nederlands-Noord- en Zuid-Limburg. In Noord-Limburg kwam dit tweemaal voor bij J. Becker uit Venray en L. Hockx uit Venlo en telkens éénmaal bij W. Feyen uit Neder-

guirlandes met de rekst: "Oorlogie kast gesien tot Aken, met 2 duijfkens boven op" ${ }^{\text {" R.A.M.x. }}$ Handschriftencollectie, inw.nr. 100, album II, nr. 59. Eem Zuid-Duitse versie, einde $18 d e$ eeuw, gesigneerd: Franz Xaver Liebherr, Immenstadt, wordt afgebeeld in Tessmar-Pfohl 1993, p. 16. De kast is wan gemarmerd zachthout met vergulde sculptures in een mengeling van Louis XVen Louis XVI-stijl. Het uurwerk lonpt een jaar. Een andere klok van dit model, ggetekend "Le Lion / à Louvain" bevond zich in een Belgische antiekzaak (1.986). Een vergelijkbare klok vit Utrecht beeldt $J$. Zeeman 1977 af op pp. 301-303. De desbetreffende klok is vervaardigd door de vit Duitsland afkomstige Johann Hinrich Wiedeking.

${ }^{50}$ F. Pholien 1933 , p. 45 , fig. 29 en 30 . Alleen de nts. 26 en 46 heb ik niet waargenomen. 


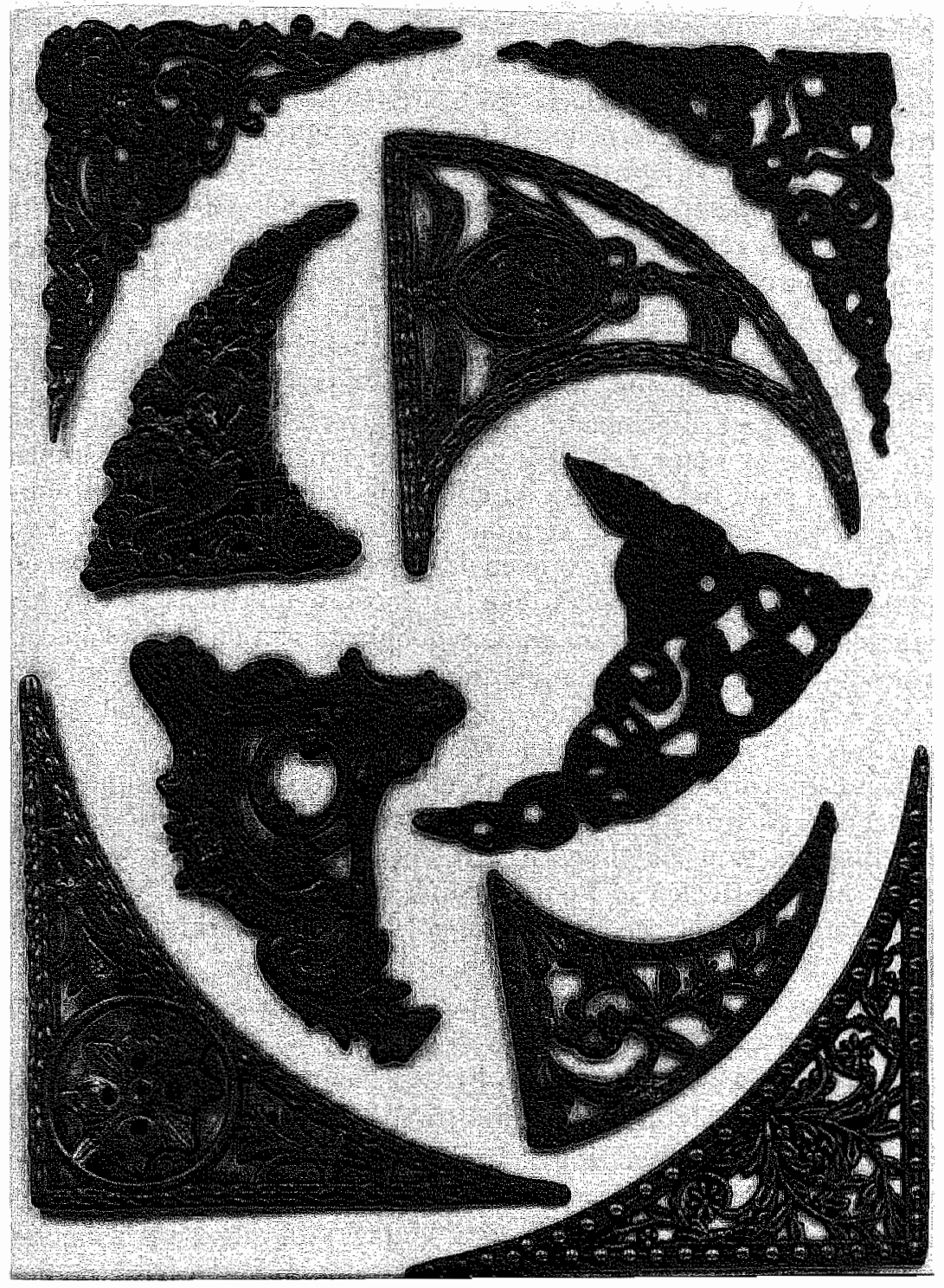

63. Hoek- en toogomamenten, aan te treffen op Limburgse uurwerken. N.B. De stijl van de hoek-en toogstukjes alleen is niet woldoende voor de datering van een klok, daar ze nog lang werden gebruikt 
weert, P.A. Gielissen uit Nederweert, J. Poeijn uit Venlo en C. Remmen uit Well. In Zuid-Limburg was de verdeling: viermaal bij I.H. ( $=J$. Haertmans uit Beek?), tweemaal bij A. de Nève uit Maastricht en telkens éénmaal bij E. Bachgus uit Maastricht, A. Fraiture uit Maastricht, I.H.S. ergens in Zuid-Limburg woonachtig en Chr. Mommer uit Zuid-Limburg (?). Toch zijn de messing adresplaatjes geen Nederlands-Limburgse exclusiviteit, er werd ook een aangetroffen op een klok van $\mathrm{R}$. Vanintbrouck uit Hasselt; op Luikse weekwerken komt het frequent voor.

Wijzerplaten met een glazen cijferschijf hebben glazen adresplaatjes. Ronde en getoogde, volledig glazen wijzerplaten hebben uiteraard geen apart adresplaatje; bij deze wijzerplaten staat het adres op de glazen plaat zelf. Bij vierkante wijzerplaten met tinnen cijferring staat het adres op de cijferring, zoals voorkomt bij uurwerken van J. Smeets uit Hamont en L. Mijnis te Maastricht. Een apart concentrisch plaatje binnen de cijferring werd aangetroffen op onder andere een uurwerk van $L$. Joosten uit Maaseik. In het algemeen worden de naam en de woonplaats van de klokkenmaker vermeld. Soms is er alleen een monogram of een monogram met één of meer van de volgende gegevens: plaatsnaam, jaartal, serienummer of typische symbolen. Met IWK wordt hoogstwaarschijnlijk Johan Werner Kleinjans te Doenrade bedoeld; I.H. is mogelijk Johannes Haertmans te Beek; $M: R: H: H:$ is geïdentificeerd als Mathias Raetsen Heythuysen. I.B. met $\sim$ en drie sterretjes staat voor Jacobus Becker te Venray. Bijna zonder uitzondering worden de plaatsnamen in een Franse versie vermeld, voorafgegaan door het Franse voorzetsel "à". Dat gebeurde zowel vóór, tijdens, als ná de Franse overheersing van de beide Limburgen tussen 1795 en 1815. Alleen W.Wessels in Geleen gebruikt het Nederlandse voorzetsel "tot" en de Nederlandse beroepsnaam "orloismaecker". De meeste van zijn collega's gebruiken het Franse "(h)orlogeur" of "(h)orloger". Een enkeling gebruikt het voorzetsel "in" vóór de plaatsnaam, zoals bijwoorbeeld Johan Werner Kleinjans die "in Doenraet" woonde.

Behalve de naam en de woonplaats van de uurwerkmaker werden soms ook, zoals reeds werd aangestipt, het jaartal on het fabricagenummer vermeld. Opmerkelijk is dat sommigen in dit opzicht heel consequent zijn, met name Jan Remmen te Well en Jacobus 
Becker te Venray. ${ }^{51}$ Enkele bijzondere opschriften zijn vermelding waard. Zo signeerde F. de Beefe eens: "François de Beefe / Orlogeur de la ville / de Maestricht / à Maestricht". Het betreffende uurwerk is waarschijnlijk kort na zijn benoeming tot stadsuurwerkmaker gemaakt (1750), toen hij trots was op die benoeming. Een ander merkwaardig opschrift is enigszins politiek gekleurd. Zo lezen wij: "Dyonisius, horloger / à Ruremonde dans / Le Limbourg hollandais"! Dit moet betrekking hebben op de nieuw gecreëerde provincie Nederlands-Limburg in 1839. Misschien mogen we uit deze tekst concluderen, dat Dionisy als zoon van een magistraat Oranje-gezind was en - in tegenstelling tot veel streekgenoten, die petities ondertekenden voor de hereniging van de beide Limburgen - tevreden was over het herstel van het Nederlands regime in zijn woonplaats. Vaak is het opschrift fraai gegraveerd, waarschijnlijk door een specialist, een beroepsgraveur. In Rekem en Gulpen werden in de late $17 \mathrm{de}$ en in de 18de eeuw joodse graveurs aangetroffen, die hun bedrijf geruime tijd overeind wisten te houden en nauwelijks bijbanen hadden. In Midden- en Noord-Limburg kwamen geen joodse graveurs voor. ${ }^{52}$ Misschien is het daarom geen toeval, dat de fraaie middengravures op de wijzerplaat daar ontbreken. Soms is de gravering en de vlakverdeling wat onbeholpen, zoals bij de klokken van G. Janssen uit Sint-Odiliënberg, wat allicht op doe-het-zelfwerk duidt (zie afbeelding 64).

Het materiaal, gebruikt voor de vervaardiging van de wijzerplaat, geeft wèl een aanwijzing voor de herkomst: een wijzerplaat van effen geschilderd ijzer duidt op een herkomst van boven de lijn Roermond-Heythuysen-Weert. Daaronder zijn er wijzerplaten van messing. Vlakbij de genoemde lijn zijn de messing platen geheel onversierd, maar wel gepolijst, of soms voorzien van eenvoudige ingeponste versieringen, soms een patroon van cirkeltjes met een puntje, soms een grote zespuntige ster met als middelpunt de wijzeras. Het zijn versieringen met volkskundige motieven, sterk regionaal bepaald. Buiten de Limburgen kwam deze versieringstechniek waarschijnlijk weinig voor. Ik ken slechts één wijzerplaat met een dergelijke versiering buiten het Limburgse, te weten een

\footnotetext{
sll Voor meer klokkenmakers die serienummers plaatsten en het belang daarvan voor een schatting van de productieomvang van uurwerken zie hoofdstuk $\mathbf{X}$, paragraaf 9.3.2.

s2 J. Jansen $1988, \mathrm{pp}, 85-87$.
} 

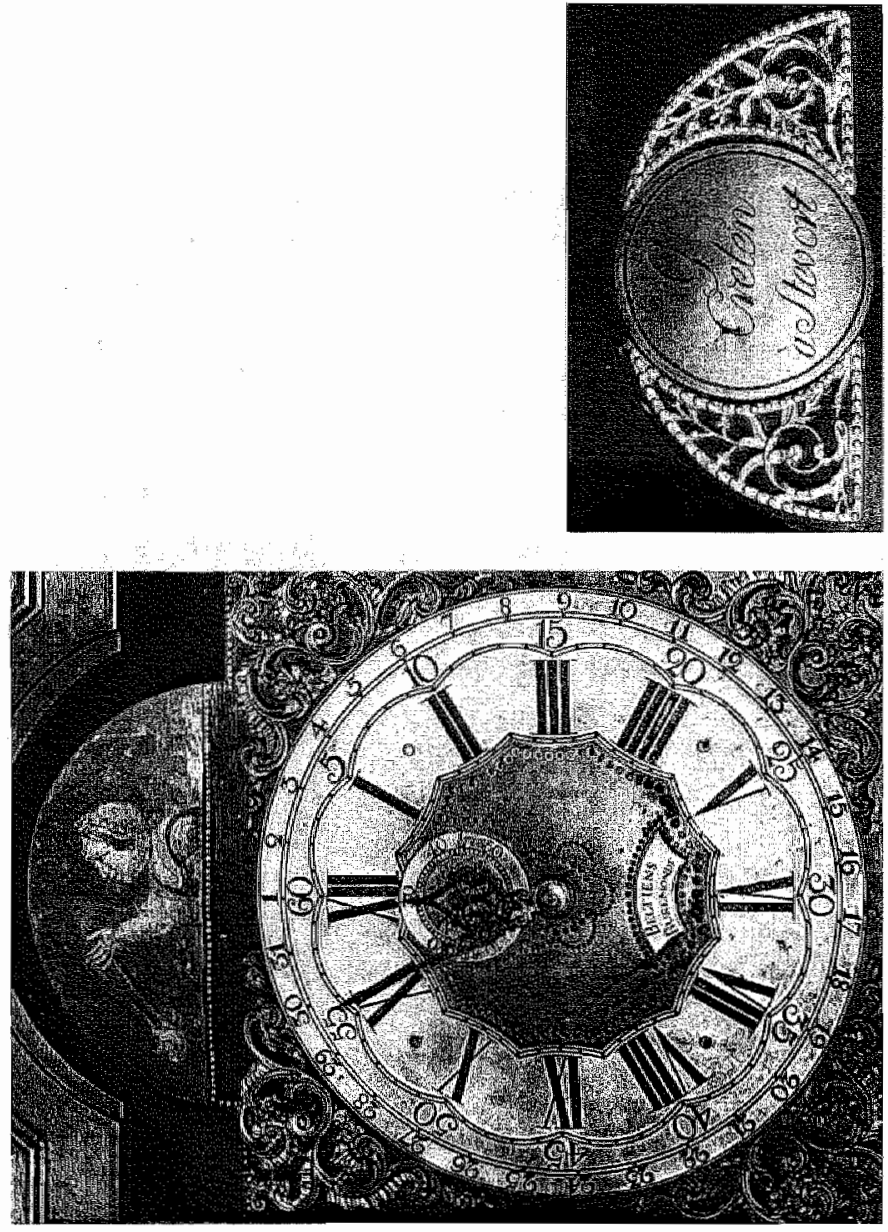

3
8
8
8
0
$\frac{5}{5}$

a

$\div$

这

焉

$\frac{4}{0}$

$\pm$

记

8

量

용

$\sum^{2}$

50

के

8

$\$$

동

를

8

1

롱

2

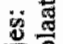

E

量

3

马률

隶

昰

I 
wijzerplaat uit Bornem in de provincie Antwerpen. ${ }^{53}$ Meer naar het zuiden vindt men meestal een mooie middengravure. Deze zijn vaak virtuoos en heel stijlzuiver uitgevoerd. De stijl hiervan, bijvoorbeeld Lodewijk XV of Lodewijk XVI, kan iets zeggen over de datering. Noodzakelijk is het niet. Louis XV-versieringen werden nog lang na diens dood aangebracht; Louis XVI-ornamenten werden ook nog gebruikt nadat deze koning al was onthoofd. Een bijzonderheid vertonen de wijzerplaten van Hermanus Petrus Beltjens uit Roermond: de togen van zijn wijzerplaten zijn beschilderd met een polychrome voorstelling in olieverf (zie afbeelding 65). Dat is uniek voor deze contreien.

De maten van de wijzerplaten vertonen aanzienlijke verschillen. De hoogte laat het volgende beeld zien:

Tabel 5. Hoogte wijzerplaat in $\mathrm{mm}$ bij verschillende typen klokken $\mathrm{N}=83^{54}$

\begin{tabular}{lccr}
\hline & Staande klok & Wandklok & Totalen \\
\hline $200-225$ & & 1 & 1 \\
$225-250$ & 1 & 2 & 3 \\
$250-275$ & 2 & 1 & 1 \\
$275-300$ & 2 & 4 & 2 \\
$300-325$ & 2 & 2 & 6 \\
$325-350$ & 6 & 2 & 8 \\
$350-375$ & 19 & 1 & 21 \\
$375-400$ & 17 & 3 & 18 \\
$400-425$ & 14 &. & 17 \\
$425-450$ & 1 &. & 1 \\
$450-475$ & 1 & 16 & 1 \\
$475-500$ & 4 & 327 & 83 \\
\hline Totalen & 67 & 61 & 370 \\
Gemiddelde & 381 & & 52 \\
Standarddeviatie & 44 & &
\end{tabular}

Uit de tabel blijkt dat de wijzerplaten van staande klokken gemiddeld $38,1 \mathrm{~cm}$ hoog zijn en die van wandklokken $32,7 \mathrm{~cm}$. Wat de wandklokken aangaat is de spreiding zeer groot. De staande klokken vertonen enige standaardisatie. Vijftig van de 67 staande

${ }^{5}$ Afbeelding van wijzerplaat van unwerk door L. van Roy uit Bornem. Zie J. Weyns 1974, p. 339, afb. CCXLVI.

${ }^{4}$ Gegevens van een aselecte steekproef wan klokken, die nawwkeurig konden worden opgemeten. 
Grafiek 4. Hoogte yan wijzerplaten in $\mathrm{mm}$ tussen $1720 \mathrm{en} 1860$

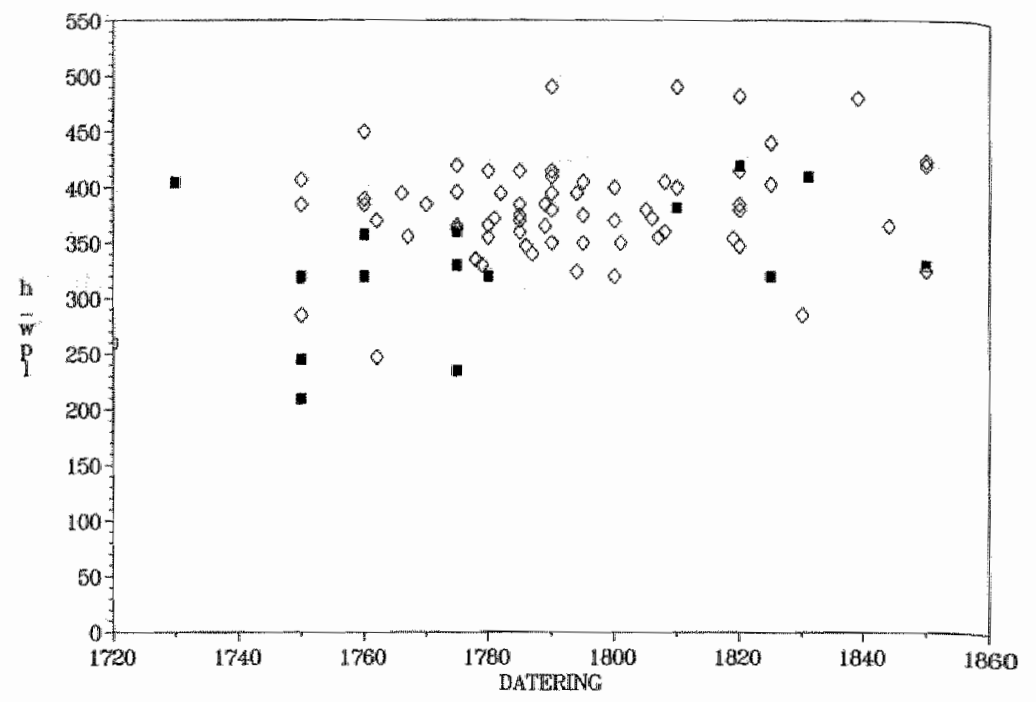

Grafiek 5. Verhouding hoogte wijzerplaathoogte uurwerk tussen 1720 en 1860

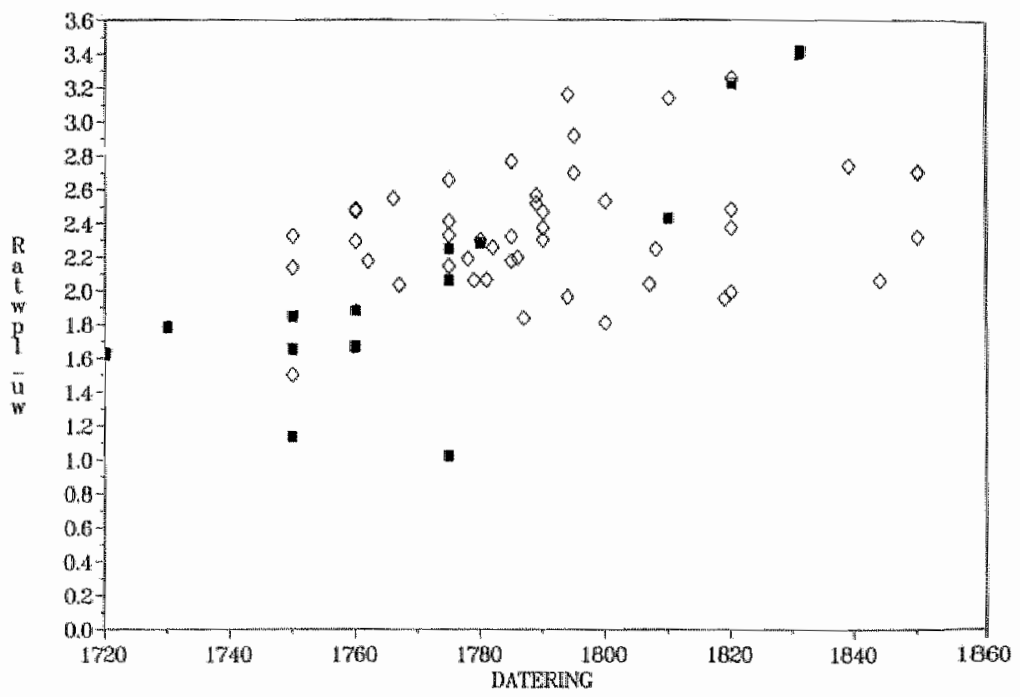

$\vartheta$ sk $=$ staande klok, $\mathbf{E}$ wk=wandklok 
klokken hebben een wijzerplaat tussen 35 en $42,5 \mathrm{~cm}$ hoog. Deze norm werd omstreeks 1800 verlaten. Bij de 19 de-eeuwse wijzerplaten komen hogere waarden voor ( $>45 \mathrm{~cm}$ ) dan bij de 18de-eeuwse: zij zijn gemiddeld $48 \mathrm{~cm}$ hoog, zowel bij een dagwerk als bij een weekwerk met platines (zie grafiek 4 en 5). Na 1780 komt het voor dat de wijzerplaat meer dan 2,5 maal hoger is dan het uurwerk; vóór 1780 is dat niet het geval.

De ronde witglazen wijzerplaten van uurwerken met slagwerk meten gemiddeld $34 \mathrm{~cm}$ in doorsnee; de wijzerplaten van wekkerklokjes waren gemiddeld slechts $28 \mathrm{~cm}$ hoog. Deze geringe hoogte kan drie oorzaken hebben: het uurwerkje achter de wijzerplaat was kleiner dan de volledige uurwerken met slagwerk, de plaats dichtbij de slaapstede, zodat voor de afleesbaarheid geen grote wijzerplaat nodig was en tenslotte materiaalbesparing: het ging om het goedkoopste type uurwerk.

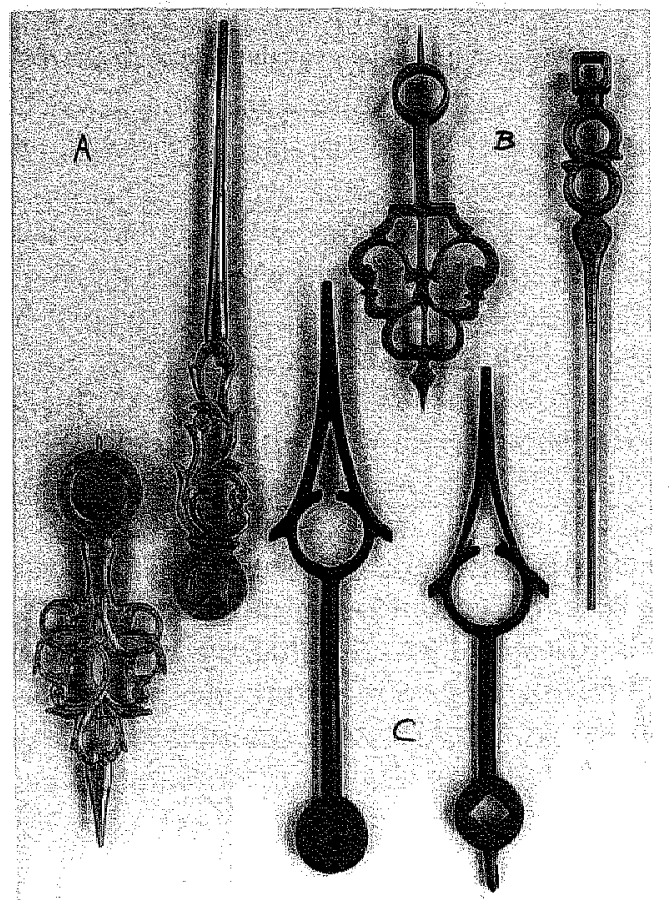

66. Wijzertypen, ann te treffen op Limburgse uurwerken: a. tijk versierd, uitgezaagd en geciseleerd (gebruikt van \pm 1685 tot \pm 1825 ); b. typische Noord-Limburgse uurwijzer (Remmen en omgeving; gebruikt van \pm 1750 tot \pm 1800 ); c. Bréguet-wijzer in gebruik van \pm 1795 tot \pm 1850 
Er is een grote variatie in wijzervormen vastgesteld. ${ }^{55}$ Een veel voorkomend type is type A van afbeelding 66, eerst uitgezaagd en dan nog eens geciseleerd. Rond 1800 komt de zogeheten Bréguetwijzer op. Deze eindigt in een pijlvorm (type C op afbeelding 66). Een variant hierop is het type, waarbij de wijzers eindigen in de vorm van een schaar, die als het ware de tijd in stukjes knipt. ${ }^{56}$ In Noord-Limburg komt het type B voor (zie afbeelding 66). De wijzers zijn van ijzer als de wijzerplaat van messing is, maar van messing als de wijzerplaat van ijzer of van glas is (zie tabel 6). Die "materiaalafwisseling" doet zich bij $77 \%$ van de op dit onderdeel nauwkeurig bestudeerde uurwerken voor. $\mathrm{Bij} 23 \%$ van de uurwerken is het material van de wijzers hetzelfde als dat van de wijzerplaat. Bijzondere combinaties van materialen, zoals papier en ijzer, email en messing of hout en messing zijn uiterst zeldzaam. Ze komen elk één keer voor.

Tabel 6. Materiaal van de wijzers bij verschillende materialen van de wijzerplaat $\mathrm{N}=108^{57}$

\begin{tabular}{|c|c|c|c|}
\hline \multirow[t]{2}{*}{ Wijzerplaat } & \multicolumn{2}{|c|}{ Wijzers } & \multirow[t]{2}{*}{ Totaal } \\
\hline & Messing & Uzer & \\
\hline Emaill & 1 & . & 1 \\
\hline Glas & 8 & 2 & 10 \\
\hline Hout & $\mathbb{1}$ & . & $\mathbb{1}$ \\
\hline Messing & 14. & 46 & 60 \\
\hline Papier & . & 1 & 1 \\
\hline IJzer & 28 & 7 & 35 \\
\hline Totalen & 52 & 56 & 108 \\
\hline
\end{tabular}

Bij een messing wijzerplaat zijn de wijzers meestal (76\%) van ijzer; bij een ijzeren of glazen wijzerplaat zijn ze meestal (79\%) van messing. Het is opmerkelijk dat deze verhoudingen ongeveer gelijk blijken te zijn. Het gebruik van contrasterende materialen komt de afleesbaarheid van de wijzerplaat zeer ten goede. Afwij-

${ }^{55}$ F. Pholien 1933, p. 42, fig. 24-27.

${ }^{36}$ Over de vraag of de wijzers en andere wijzerplaatonderdelen eigen werk waren of van anderem werden betrokken, zie hoofdstuk $\mathrm{IX}$, paragraaf 9.3.1.

${ }^{57}$ Gebaseerd op een aselect sample van 108 aurwerken, die door de auteur nauwkeurig konden worden bestudeerd en opgemeten. Het is een subgroep van de 691 hwisuurwerken van tabel 5. 
kingen van het vastgestelde patroon zijn wellicht terug te voeren op individuele smaak of mode.

\subsubsection{De kasten van staande klokken: opbouw en decoratie}

De klokkasten bestaan uit twee of drie delen, te weten de kop, het smallere middendeel en de basis. Middendeel en basis vormen meestal, in $90 \%$ van de gevallen, één geheel, soms zijn het twee losse delen. Ze werden niet door de uurwerkmakers zelf vervaardigd, maar door schrijnwerkers die in samenspraak met de klant materiaal, vorm en versiering van de klokkast bepaalden, al heeft met name de vorm van de wijzerplaat grote invloed op de vorm van de kop. Onder het bovenste lijstwerk van de kop zijn soms ajour gestoken ornamenten aangebracht, zodat de klank van de bel(len) zich goed kan verspreiden ( 57 van de 691 onderzochte huisuurwerken, dus ruim $8 \%$ ). Als houtsoort treffen we bijna altijd $(97 \%)$ eiken aan, zelden olmen $(1,75 \%)$ of een combinatie van beide houtsoorten $(0,45 \%)$. Latere kasten zijn ook wel eens van vruchtenhout, met name kersenhout, vervaardigd $(0,8 \%)$. Het hout werd meestal gevernist; een kleurige beschildering of fineerwerk komt praktisch nooit voor. De enige klokkast met fineerwerk die werd aangetroffen, is die met een uurwerk met vierkante wijzerplaat van Leonardus Mijnis uit Maastricht ${ }^{58}$ (zie afbeelding 46 en 71). Polychroom beschilderde kasten werden in het onderzoeksgebied niet aangetroffen bij staande klokken. Wel hebben enkele consoleklokken zo'n beschildering, namelijk één van Arnold de Nève $^{59}$ uit Maastricht, enkele van François de Beefe, eveneens uit Maastricht afkomstig, ${ }^{60}$ en één tafelklokje van Johannes Reinerus Beltjens uit Roermond ${ }^{61}$ (zie afbeelding 67 ). Een tafelklokje van Jacobus Joosten uit Maaseik is zwart geschilderd met gouden lijstjes en rocailles ${ }^{62}$ (zie afbeelding 68). De achterwand van de klokken is altijd van een niet-edele zachte houtsoort; als men een andere houtsoort aantreft, gaat het om een vervanging bij restauratie.

\footnotetext{
${ }^{54}$ Zie appendix $\mathbb{I}$, Mijnis, Leonardus, Marstricht, klok a.

Zie appendix II, Neve, Amoldus de, Maastricht, klok $f$.

60 Zie appendix II, Beefe, François de, Maastricht., klok p.

${ }^{61}$ Zie appendix II, Bieltjens, Johanmes Reinenus, Roemmond, klok b.

${ }^{62}$ Zie appendix II, Joosten, Jacobus, Maaseik, klok k.
} 


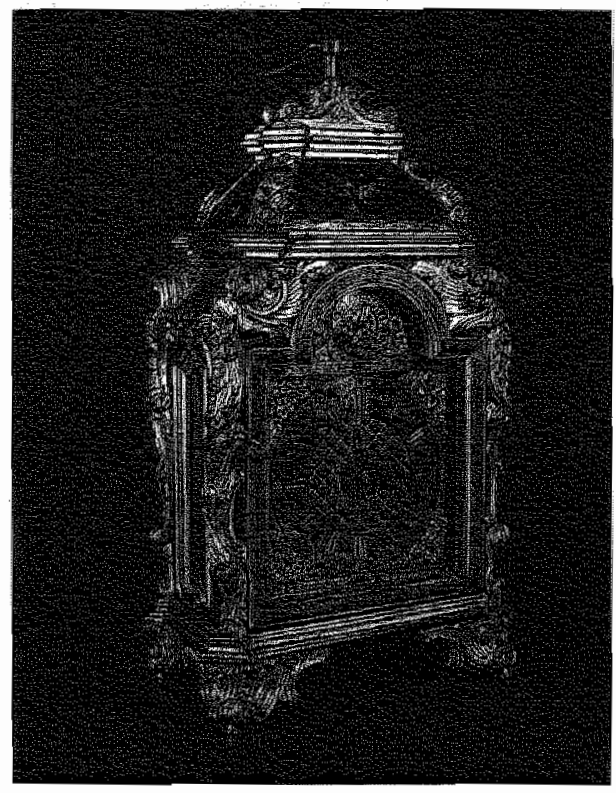

67. Tafelklok, circa 1800 (J.R. Beltjens, Roermond)

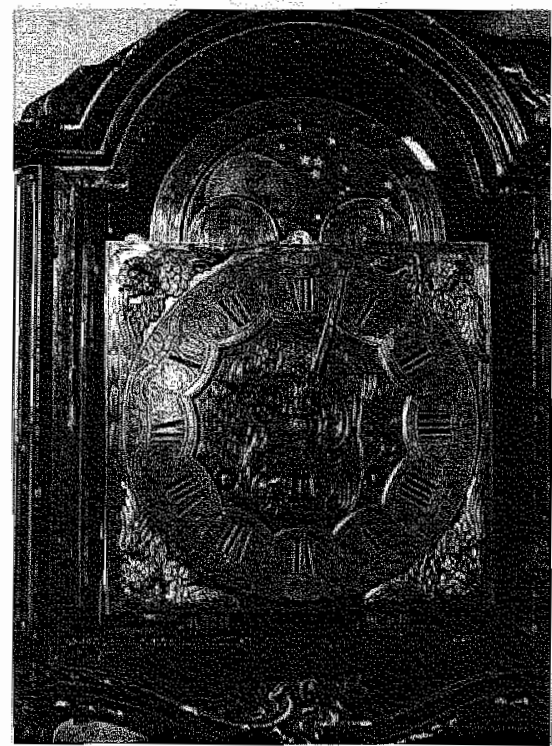

68. Tafelklok, circa 1780 (Jacobus Joosten, Maaseik) 

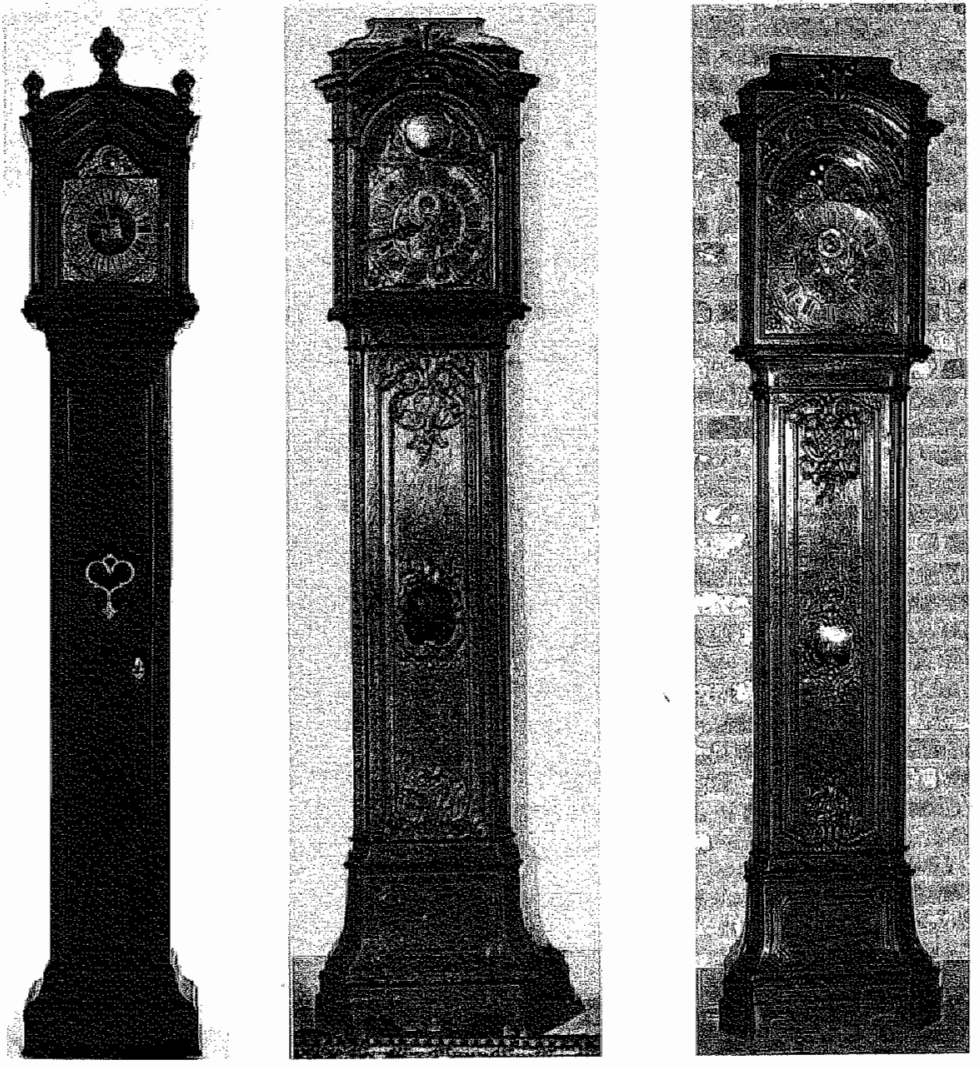

69. (1.) Voorbeeld van een klokkast uit Noord-Limburg, derde kwart 18de eeuw (foto H.M. Hulsteijn)

70. (m.) Régence-klokkast, circa 1750 (Fr. de Beefe, Maastricht)

71. (r.) Régence-klokkast, circa 1750 (Fr. de Beefe, Maastricht) 

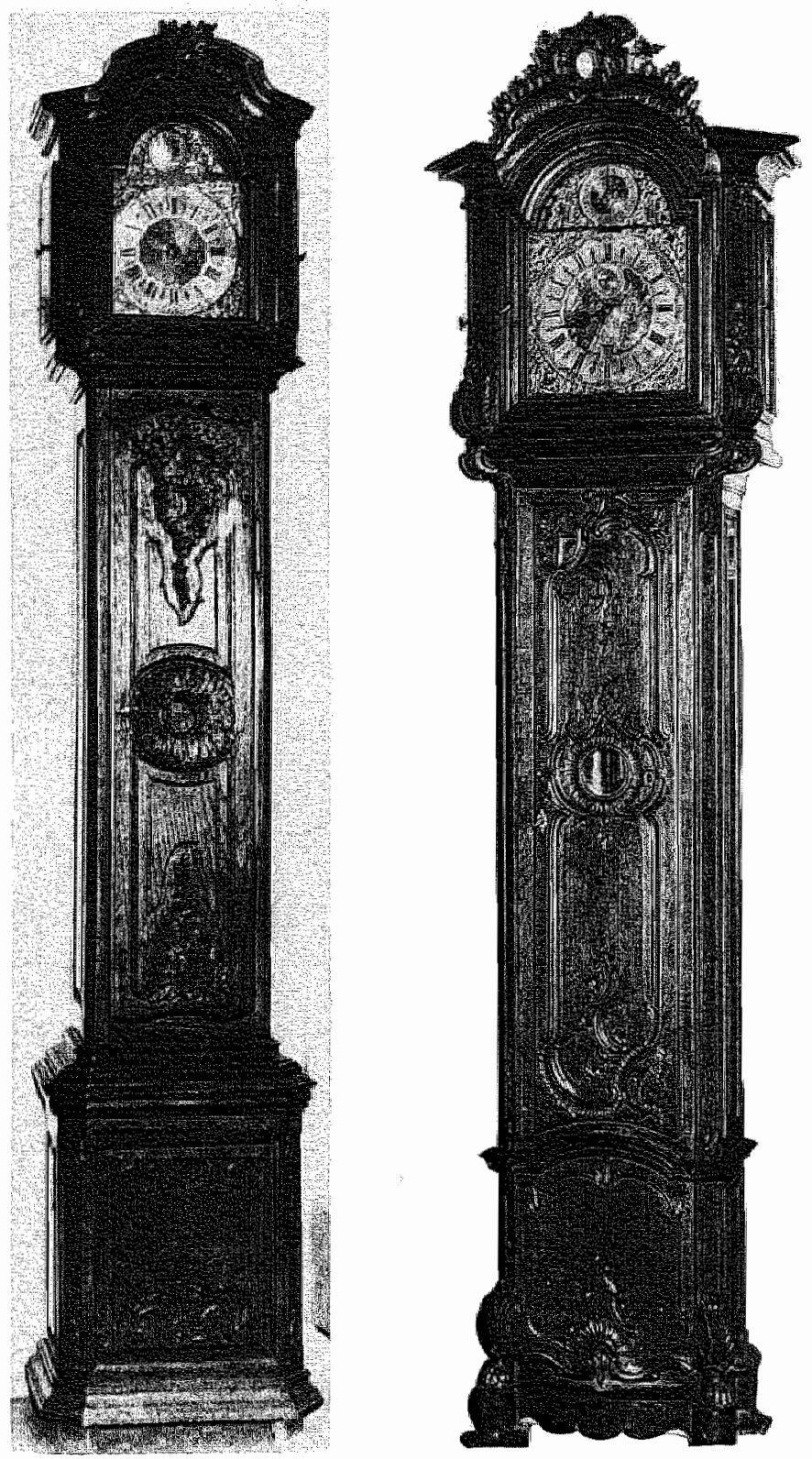

72. (1.) Louis XV-klokkast, circa 1775 (W. Wessels, Geleen)

73. ( $\mathrm{r}_{\text {. }}$ Louis XV-klokkast, circa 1775 (Amold de Nève, Maastricht) 
De decoratie van de klokkasten beperkt zich in Nederlands-NoordLimburg meestal tot paneel- en lijstwerk (zie afbeelding 69). Meer naat het zuiden toe worden de kasten voorzien van vlak steekwerk in een min of meer rustieke interpretatie van de Franse meubelstijlen: Lodewijk XIV (zie afbeelding 46 en 47), Régence (zie afbeelding 70 en 71), Lodewijk XV (zie afbeelding 72 en 73), Lodewijk XVI (zie afbeelding 74 en 75), Empire (zie afbeelding 76 en 77). Daarbij moeten we niet uit het oog verliezen, dat deze stijlen vele jaren, soms wel 25 jaar, na hun bloeiperiode in Frankrijk pas op het Limburgse platteland werden toegepast. Hoe luxer de kast en hoe dichter deze bij de stad Luik ontstond, des te stijlzuiverder is hij: Luik beleefde in de 18 de eeuw een enorme opbloei van het eiken gesculpteerde meubel. ${ }^{63}$ De invloed van Luik op de meubelkunst in het algemeen en op de klokkasten in het bijzonder was in de hele Zuidelijke Nederlanden en aangrenzende gebieden zo groot, dat in allerlei studies wordt gesproken van "Luiks", ook als het gaat om meubels en klokkasten die ver van buiten de stad Luik en het prinsbisdom zijn vervaardigd. Een enkele keer treffen we biedermeier(zie afbeelding 78) en Louis-Philippe-kenmerken aan (zie afbeelding 79). De mate van versiering kan het hele gamma doorlopen van sober tot uitbundig. De afstand tot Luik is bepalend. In het algemeen kan men. stellen: hoe noordelijker de herkomst van een klok, des te strakker de kast, hoe zuidelijker, des te uitbundiger. Het kastonderdeel waar de schrijnwerkers de meeste aandacht aan besteedden was de deur vóór de slinger. Het bovenste gedeelte van deze slingerdeur en vooral ook het snijwerk rond het slingervenster getuigen vaak van virtuositeit. Soms krijgt men zelfs de indruk, dat de slingerdeur door een specialist en niet door de kastenmaker zelf is vervaardigd, zoals bij de slingerdeur van de staande klok van De Beefe $^{64}$ in Museum het Spaans Gouvernement te Maastricht (zie afbeelding 80 ). Het kwalitatief betere steekwerk op veel slingerdeuren werd zeer verschillend geinterpreteerd. Het verleidde een auteur tot de volgende opmerking over een klokkast met een uurwerk van. Laurens van Stralen uit Zepperen: "Net zoals een hele reeks andere meubelen werd ook deze klokkekast in de loop der jaren bijgesculpteerd, zodat ze er nu wat rijkelijker uitziet dan op het moment van haar geboorte. Dit verklaart ook waarom het snijwerk

53. Philippe 1977, passim.

${ }^{4}$ Zie appendix II, Beefe, François de, Matastricht, klok n $_{\text {. }}$ 

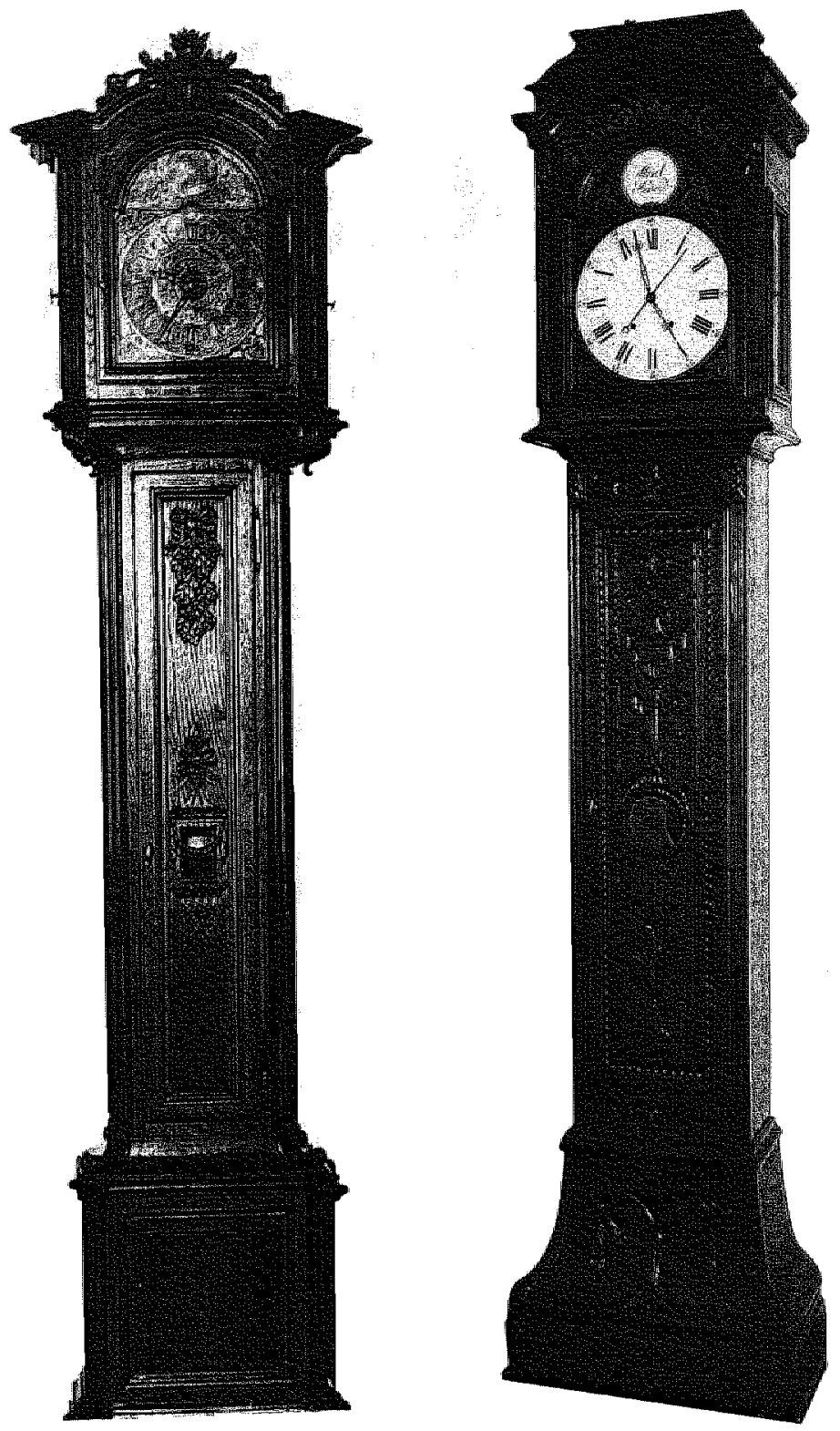

74. (1.) Louis XVI-klokkast, circa 1790 (M. Sleegel, Elsloo)

75. (r.) Lonis XVI-klokkast, circa 1825 (Ch. Streel, Hamont) 

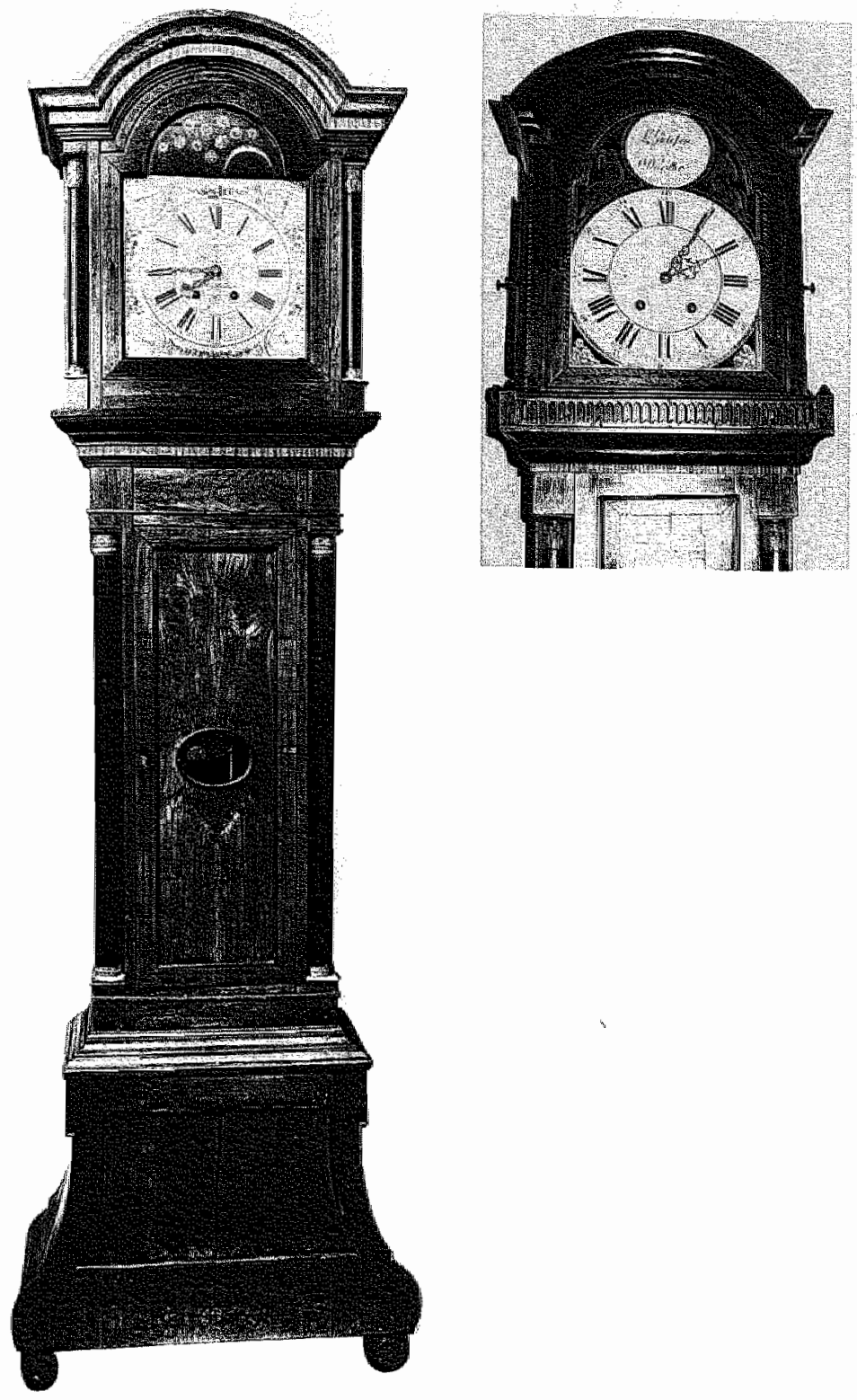

76. (1.) Empire-klokkast, circa 1820 (M. Raetsen Jr., Heythuysen)

77. (r.) Empire-klokkast, circa 1820 (L. Gielissen, Neeritter) 

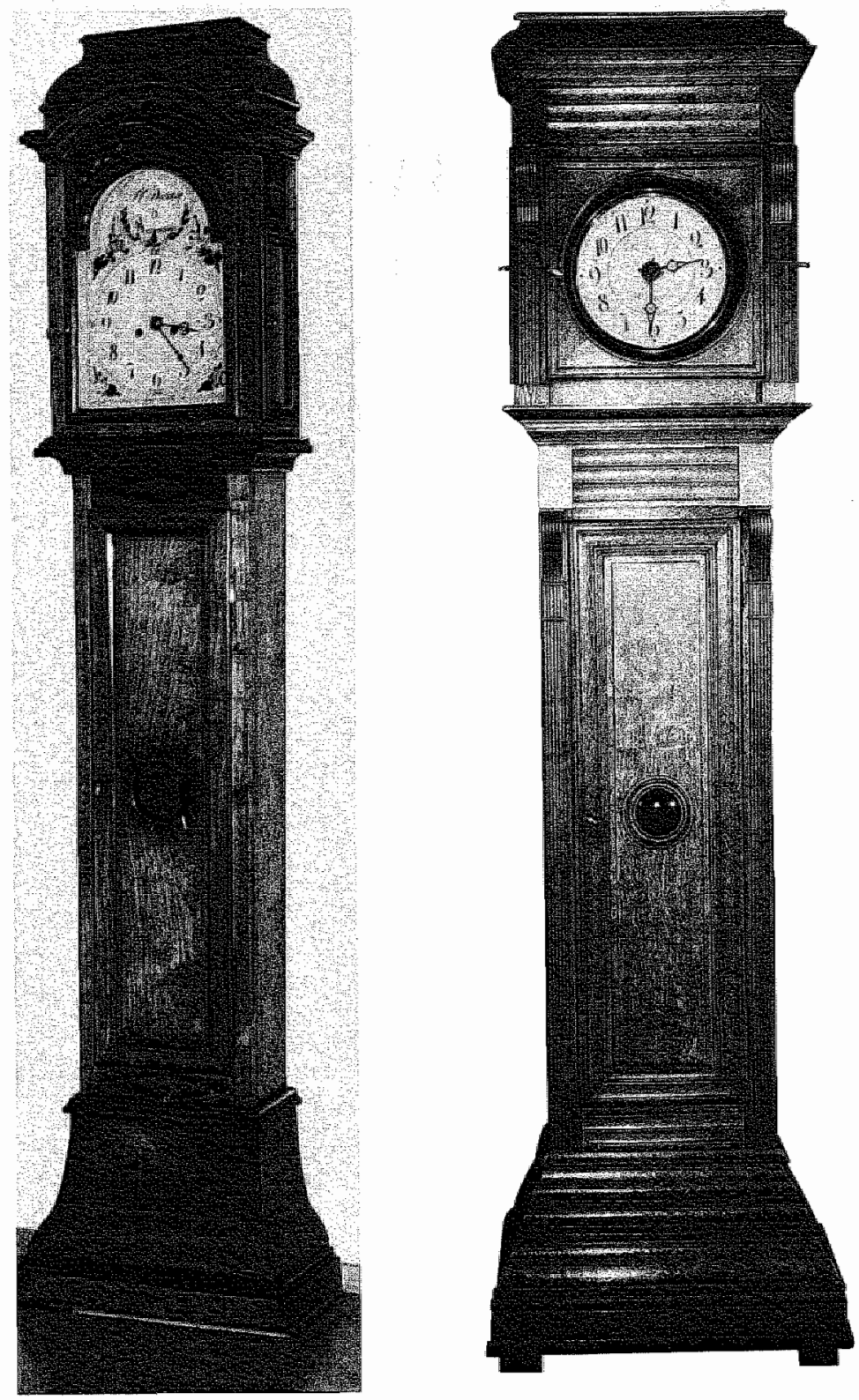

78. (1.) Biedermeier-kjokkast, circa 1835 (T.F. Dionisy, Roenmond)

79. (r.) Louis-Philippe-klokkast, circa 1860 (G. Creten, Sint-Truiden) 
op het deurtje veel uitbundiger overkomt dan het steekwerk op de voet" ${ }^{55} \mathrm{Mij}$ is evenwel geen enkele klok bekend, die zo'n latere bewerking heeft ondergaan. Zoiets had minstens een aantal keren moeten leiden tot stijlverschillen tussen kast en deur. Dit komt echter nooit voor. De maker van het deurtje en de bouwer van de kast hebben hun meubelstijl aan elkaar aangepast. Beide onderdelen stammen steeds uit dezelfde tijd. De artistieke en technische vaardigheden van de maker van het deurtje steken soms ver uit boven die van de bouwer van de klokkast. In plaats van aan latere bewerking dient veeleer te worden gedacht aan toelevering. Dit gebruik is ook elders aangetroffen en soms goed gedocumenteerd. Zo spreekt Helmut Krieg in een artikel over de kasten van de Bergische klokken over toelevering van kopbekroningen door gespecialiseerde sculpteurs aan kastenmakers. ${ }^{66}$

Een decoratief elementje, dat tijdens de Louis XV-periode vaak in Maastricht op klokkasten en andere meubels voorkomt, maat ook in architectonische versieringen, is een rocaille met een stukje muurwerk of ruïne (zie afbeelding 81). Behalve Franse stijlornamenten komen ook folkloristische elementen voor, zoals gevlochten knopen, levensbomen en vogels (zie afbeelding 82).

Een drietal kasten met uurwerk ${ }^{67}$ van Matthias Raetsen Sr. uit Heythuysen vertoont een bijzonderheid. Opvallend aan deze kasten zijn de slingerdeuren met ajour steekwerk van rocailles en bloemen over de gehele oppervlakte van de slingerdeur, waarachter glas is geplaatst. De stijl is een rustieke versie van de Lodewijk XV-stijl (zie afbeelding 83). Waarschijnlijk zijn deze kast(deuren) van één en dezelfde schrijnwerker, die ook aan andere uurwerkmakers leverde. Een vergelijkbare slingerdeur hebben een klok van Antonij van Bussel uit Asten, gebouwd omstreeks $1780^{68}$ en een ongesigneerde klok met maanfasenaanduiding in privébezit te Maastricht, die in dezelfde tijd is te dateren.

Eveneens heel eigen decoratievormen, gebaseerd op de Louis XIVstijl, zijn aangebracht op twee klokkasten met een timpaanvormige kop, beide zeker van dezelfde onbekende schrijnwerker. Het is onduidelijk waar ze vandaan komen en aan welke urwerkmaker ze

${ }^{65}$ Sint-Truiden in de 18 de eeuw 1993, nr. 83, p. 185, ondertekend W(alter).S(cheelen).

${ }^{66}$ H. Krieg 1989, Teil I, pp. 2766-2767.

${ }^{63}$ Bién is gedateerd 1781 en genummerd 53 . De twee andere zijn niet gedateerd. Zij dragem de rnummers 73 en 86 en zullen dus één à twee jaar na 1781 zijn gemaakt.

J. Zeeman 1977, pp. 407 en 412. 

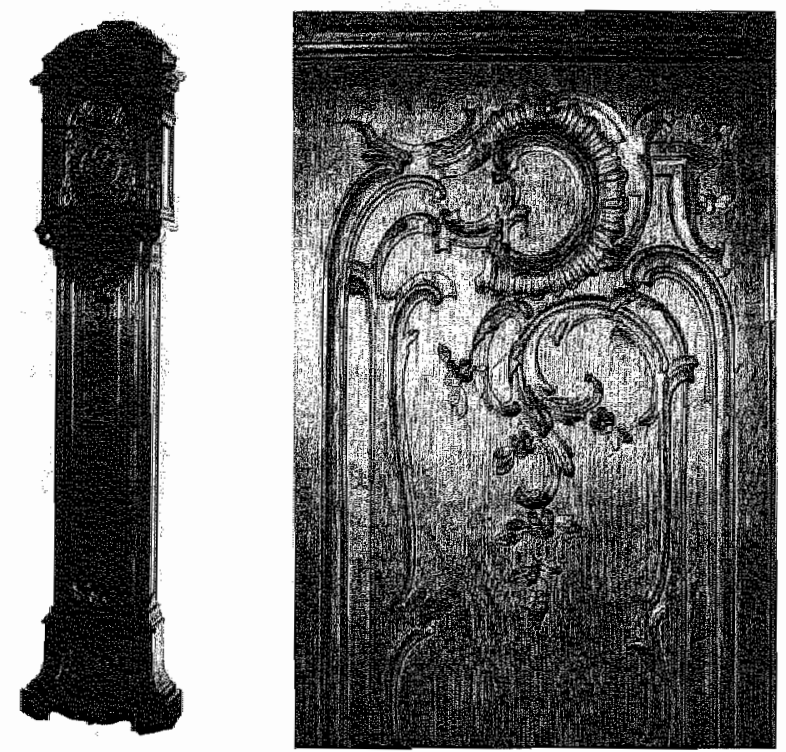

80. (1.) Rijk gestoken slingerdeur, circa 1750 (Fr. de Beefe, Maastricht)

81. (r.) "Maastrichts motiefje": stukje murwerk in rocalle, zie pijl, circa 1775 (Arnold de Nève, Maastricht)
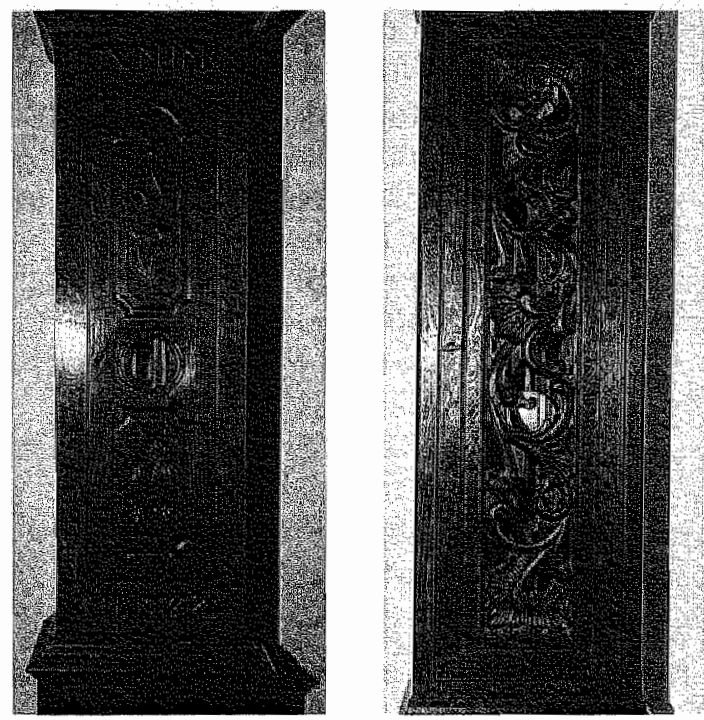

82. (1.) Klokkast met folkloristische motieven: levensboom, bloempjes, anno 1814 83. (r.) Ajour gestoken slingerdeur, 1781 (M. Raetsen. Sr., Heythuysen) 
zijn geleverd. In de ene kast zit nog het oorspronkelijke uurwerk, maar dit is niet gesigneerd. In de andere zit een uurwerk van $V$ an den Wijngaert uit Weert, dat er duidelijk niet in past. De beide kasten zijn in de slingerdeur gedateerd, respectievelijk 1762 en 1759. Vage verhalen van de huidige eigenaars over de pedigree van de klokken wijzen naar de omgeving van Venlo. Vergelijking met de kop van de kast van de Hockx-klok in het Goltziusmuseum te Venlo spreekt deze verhalen niet tegen (zie afbeelding 84 en 85 ). Soms vindt men uurwerken in hoekkasten, secretaires, kleerkasten en zelfs één in een bedstede ingebouwd. Deze bedstede met ingebouwd uurwerk bevond zich in het zogeheten Schoutenhuis, Hoofdstraat 14 te Schaesberg (gemeente Landgraaf). ${ }^{69}$ Dit zeer fraaie historische pand werd in de jaren zestig van deze eeuw in strijd met de bepalingen van de monumentenwet afgebroken. Het uurwerk was volgens een zegsman, die het nog in situ heeft gezien, van een Akense klokkenmaker. Het snijwerk van de bedstede wijst volgens de foto inderdaad naar Aken (zie afbeelding 86). In Akense stijl zijn ook enkele klokkasten van Wilhelmus en Theodorus Wessels uit Geleen. Dergelijke zeer luxeproducten, die ik combinatiemeubels zou willen noemen, vindt men in de rest van Nederland vrijwel niet. Enkele zijn gesigneerd door Joannes Balthasar Schoufs en door Dominicus en Mathias Schoufs te Thorn, die ze wellicht hebben gemaakt in opdracht van zeer vermogende stiftdames, waarvan velen uit het Rijnland afkomstig waren (zie afbeelding 87 en 88). In de steden Aken en Luik kwamen combinatiemeubels regelmatig voor.

Soms ook is een uurwerk ingebouwd in een schoorsteenboezem of een lambrizering. ${ }^{70}$ In de Hervormde pastorie van Beek (Nederlands-Limburg) is een staande klok met uurwerk van Nicolas Guilbert uit Maastricht in een gangmuur ingebouwd. De klokkast. bestaat slechts uit een voorfront en het uurwerk bevindt zich in een holte in de muur.

De klokkasten zijn, zoals reeds opgemerkt, het werk van schrijnwerkers. Namen zijn nauwelijks bekend omdat zij hun werk in de regel niet signeerden. Door rekeningen in de boedel van

\footnotetext{
69 J. Jongen 1950, pp. 111-112.

${ }^{20}$ In schoorsteenboezem: Vrusschemigerweg 34, Heerlen. Dit pand is in 1967 afgebroken woor een steriele nieuwbouwwijk! In lambrizering, nog aanwezig: café Forschelen, Thom (uurwerk van D. en $H_{\text {. }}$ Schoufs).
} 

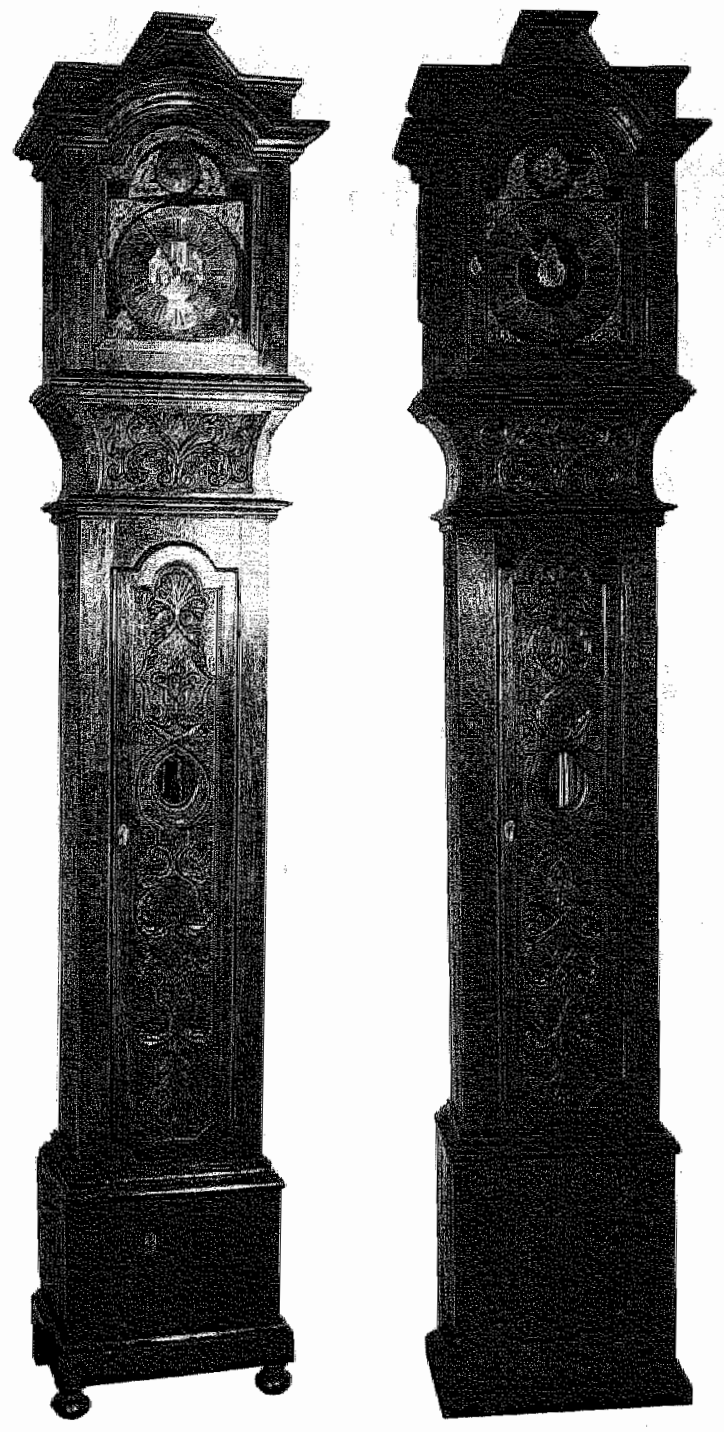

84. (1.) Slingerdeur met rustieke Lonis XIV-motieven, gedateerd in de deur 1759 (urwerk niet origineel)

85. (r.) Slingerdeur met rustieke Louis XIV-motieven, gedateerd in de deur 1762 , vermoedelijk van dezelfde schrijnwerker als bij afbeelding 86 (uurwerk niet gesig. neerd) 


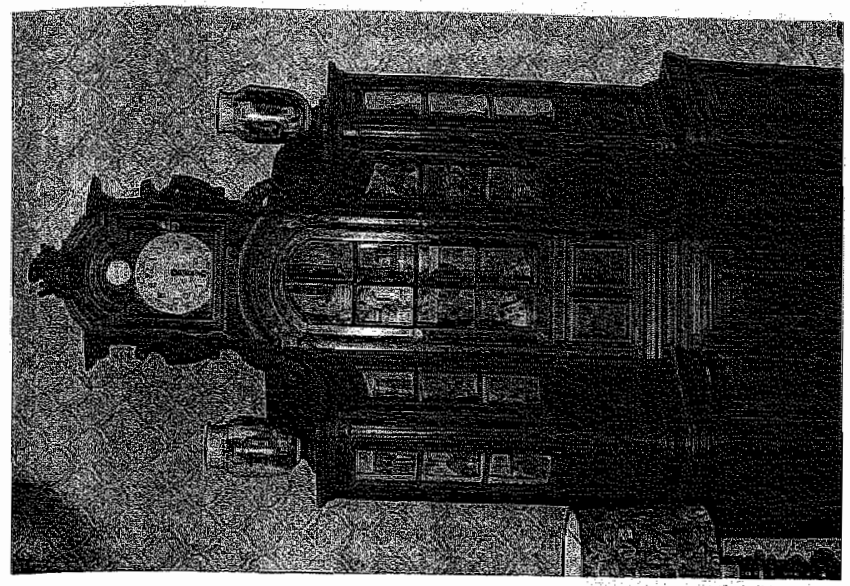

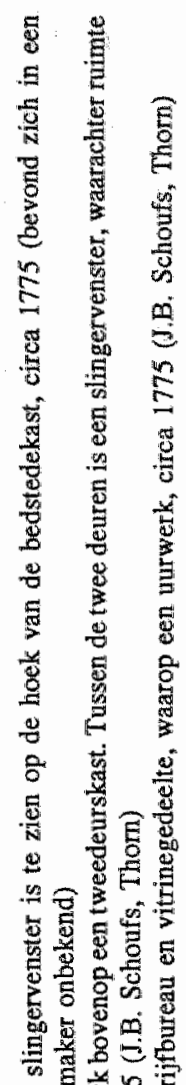

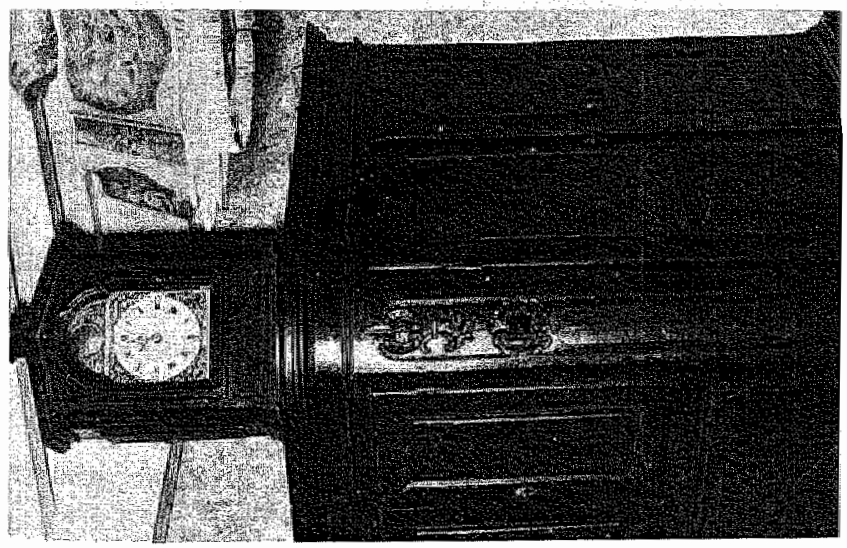
总索点焉 结芯 总与喝 on 要量 대 焉哥 它管 8

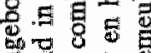
흘

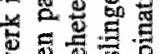
. 马然员 20

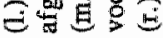
$\infty \quad \infty$ 
Joannes Brienen te Venray weten we, dat hij bij de plaatselijke timmerman Gradus Litjens klokkasten liet maken. Ook had hij een klokkast laten maken door een zekere Antonius Schadde uit Goch voor drie rijksdaalders en dertig stuivers. Gerardus Janssen heeft waarschijnlijk kasten laten maken door zijn schoonfamilie Cloudt te Sint-Odiliënberg. Een drietal vrijwel identieke kasten met Louis XVI-strik op de slingerdeur en met een kop, die veel te ruim is voor het Janssen-uurwerk, dat op een aangepast voetstuk staat, is mogelijk door deze familie gemaakt. Zij vormen een vroeg voorbeeld van seriewerk. De klokkast met een uurwerk van Petronella van den Wijngaert uit Weert, welke zich in de raadzaal van het stadhuis in Weert bevindt, behoort duidelijk tot dezelfde serie. Hoe dit is te verklaren, is vooralsnog onduidelijk. Het uurwerk in laatstgenoemde klokkast past wel goed (zie afbeelding 89 en 90). De kersenhouten kast met veel messing sierlijsten en uurwerk van T.F. Dionisy uit Roermond in het Gemeentemuseum te Roermond draagt "estampilles" van een schrijnwerker. Helaas zijn deze niet te ontcijferen. Mathias Soiron Jr. (1748-1834) ${ }^{71}$ noemt een paar namen van mogelijk klokkasten bouwende schrijnwerkers: Dumoulin en Minjolet.

Hoe de schrijnwerkers aan de ontwerpen voor hun kasten kwamen, is evenmin bekend. Waarschijnlijk hebben zij interieurprenten of kasten die zij uit hun omgeving kenden als voorbeelden gebruikt. Een bekend architect als genoemde Soiron, die ook interieurs ontwierp, legde hele tekenboeken aan met onder andere klokkasten, die hij ergens had gezien en die hem aanspraken. Het is denkbaar dat hij nit dit archief putte, als iemand hem een ontwerp voor een klok vroeg (zie afbeelding 91). Maar hij zal natuurlijk ook wel zelf ontwerpen hebben gemaakt. Van de vijf tekeningen van klokkasten in het tweede album zijn er drie zeker nagetekend, te weten: II, 58 "Model van oorlogiekast gezien bij Bertran aen O:L:V:poort... te Luijk gemakt", II, 59 "Oorlogie kast gesien tot Aken" en II, 60 "ongeveer $t$ model van eene oorlogie kast gezien by Eymael in de Staet". Bij de laatste tekent hij aan: "Dog is den zelven niet elegant maer staet seer materieel of swaar". De twee andere tekeningen lijken ontwerpen van hemzelf. $\mathrm{Zij}$ hebben uitvoerige maatopgaven

\footnotetext{
${ }^{71}$ R.A.M., Handschriftencollectie, inv,nr. 100, Mathias Soiron, album II, nrs. 55, 56, 58, 59, 60: tekeningen van klokkasten.
} 

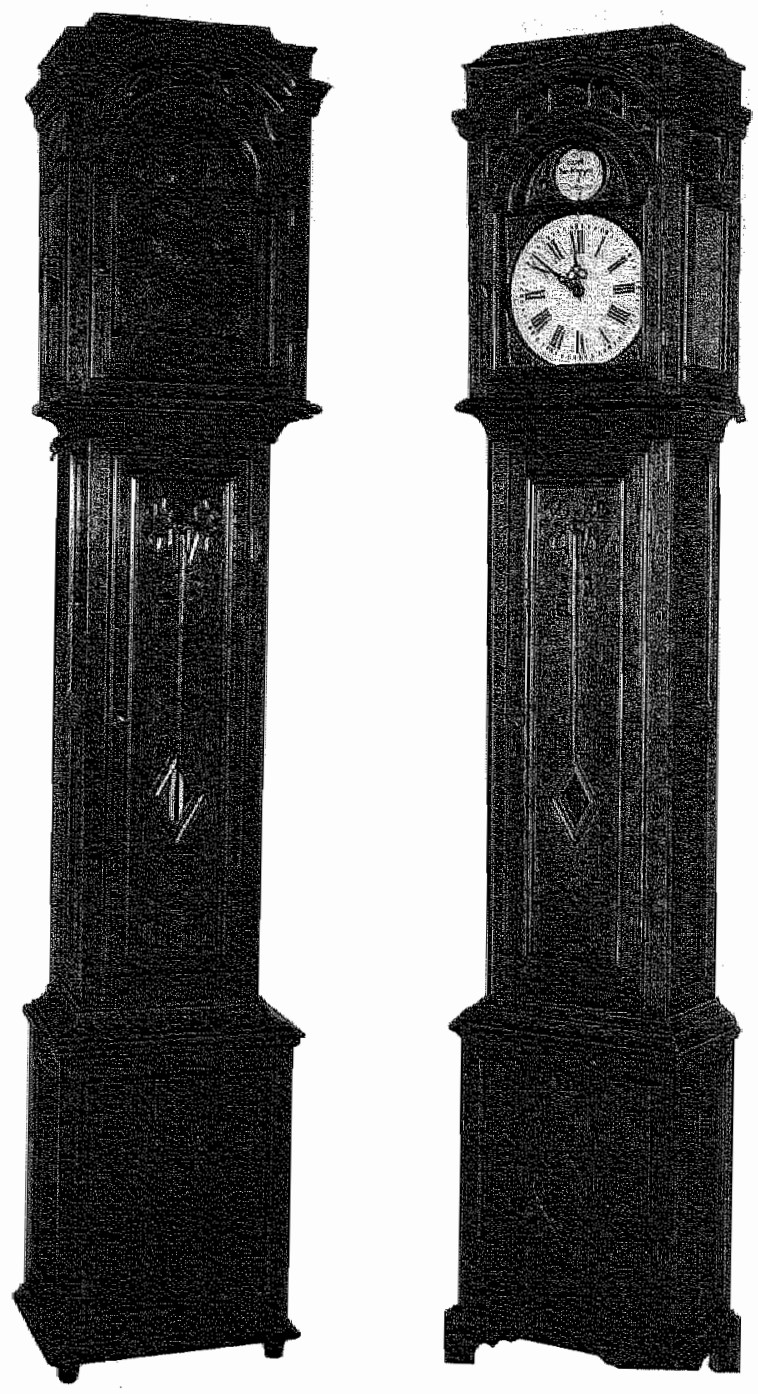

89. (1.) Staande klok met uurwerk van G. Janssen, Sint-Odiliënberg, anno 1807. De kop is te groot voor het urwerk, maar de "stoel" waar het uurwerk op staat, is op de maat van het uurwerk. Er zijn meer praktisch identieke klokkasten met Janssen-klokken en genoemde opstelling, zodat we kumnen concluderen dat het originele klokken zijn en. geen latere samenvoegingen

90. (r.) Staande klok met uurwerk van Petronella van den Weyngaart, Weert, circa 1800. De klokkast is praktisch identiek aan de kast van afbeelding 89 . Het uwrwerk van Van den Weyngaart past goed in de kast. Afbeelding 89 en 90 lijken te wijzen op "massafabricage" van klokkasten rond 1800 


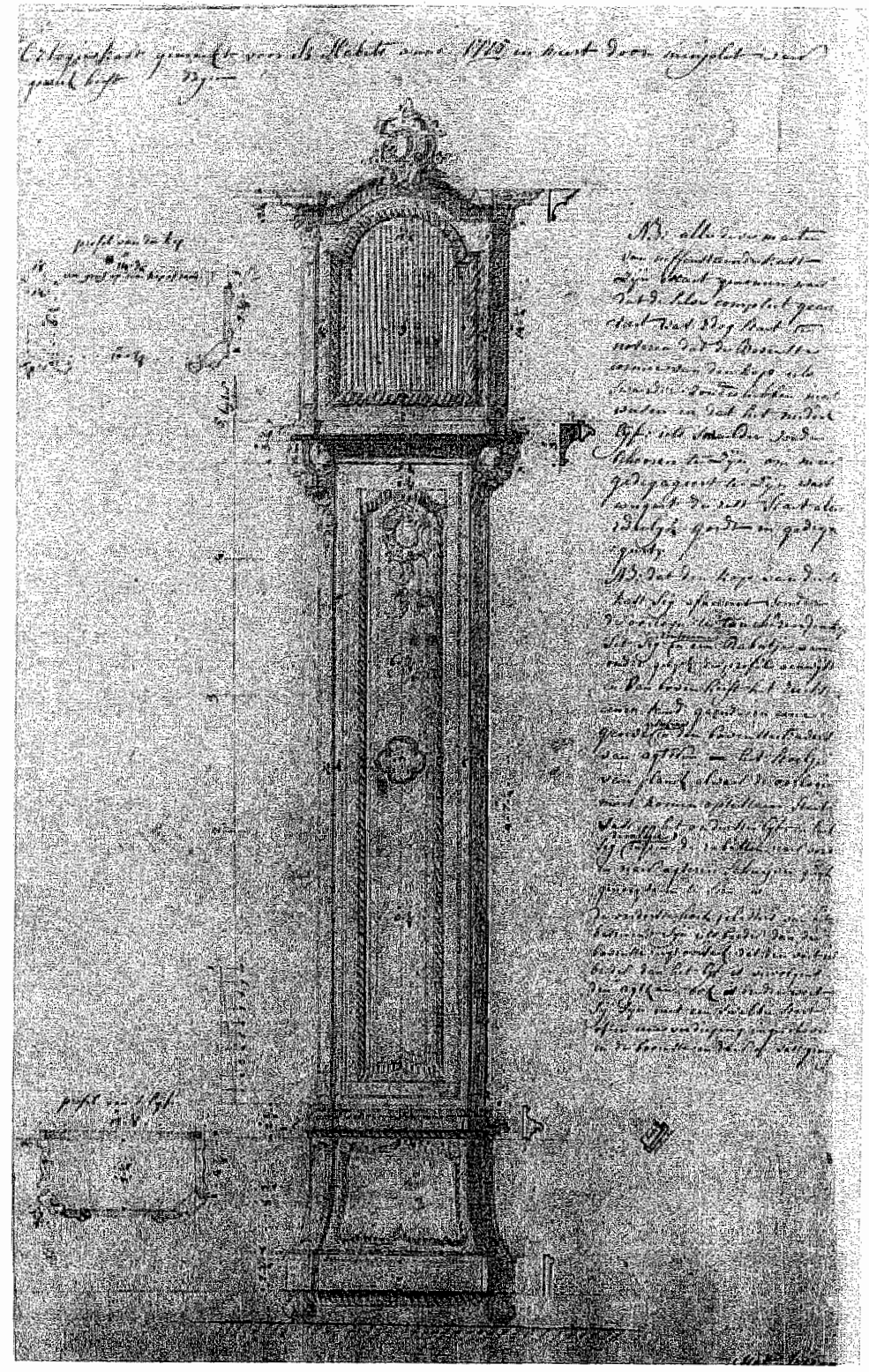

91. Tekening van een kast voor een Limburgse staande klok door de architect M. Soiron, Matrastricht, circa 1785 (R.A.M., Handschriftencollectie, inw.nr. 100, album II, nr. 56) 
en andere details, zoals vermelding van de opdrachtgever en de uitvoerend schrijnwerker. Dit zijn de tekeningen II, 55: "Oorlogie kast gemakt voor Hr Mutter door Dumouli[n] in 1784" in Lodewijk XVI-stijl en in Lodewijk XV-stijl de tekening II, 56: "Orlogie kast gemaekt voor Hr Habets anno 1775 in Meert door Minjolet waer op gewerk heeft ... dagen". Ook staan er veel opmerkingen in de marge, zowel van technische als van esthetische aard: "NB: dat de kop van dese kast sig afneemt sonder de oorlogie te toucheren" en "... dat de bovenste corniche van den kop iets swaerder soude hebben moeten weesen en dat het middellijf iets smalder soude behooren te sijn". Hij maakte deze opmerkingen kennelijk nadat het ontwerp was uitgevoerd.

De hoogte van de Limburgse staande klok uit de periode 1740 tot 1850 ligt steeds rond de 2 meter $50(220-270 \mathrm{~cm})$. Anders dan elders was geen wijziging in de maat nodig. Het Amsterdamse staande horloge $\mathrm{e}^{72}$ bijvoorbeeld nam gedurende de periode van 1680 tot 1780 in hoogte toe van 1 meter 90 tot 3 meter 10 als gevolg van wijzigingen in het model. De aanvankelijk lage kast naar Engels model met vierkante wijzerplaat evolueerde naar het typisch Nederlandse model met getoogde kast met beelden bovenop, vaak extra hoog door een mechaniek onder de wijzerplaat. De Limburgse klok heeft blijkbaar een constantere opbouw; bedoeld voor een lage middenklasse uit de bevolking was zij minder an mode onderhevig.

Kijkt men naar de hoogte waarop de wijzeras zit - van belang voor de manier waarop het uurwerk wordt afgelezen -, dan valt op dat bij de Limburgse klok de wijzers ongeveer $20 \mathrm{~cm}$ hoger zijn aangebracht dan bij het Amsterdamse model (circa 210 tegen 190 $\mathrm{cm}$ ). De lengte van de Limburgers zal niet de oorzaak zijn van dit hoogteverschil, alhoewel in de 19 de eeuw de Limburgse dienstplichtigen zo'n zeven millimeter langer waren $(165 \mathrm{~cm})$ dan de overige Nederlandse dienstplichtigen. ${ }^{73}$

Om een of andere reden waren de maten van de Limburgse staande klok sterk afwijkend van het Amsterdamse staande horloge. Dit is niet alleen te zien aan de absolute hoogte, maar ook aan de relatie-

\footnotetext{
72 Bepaald aan de hand van afbeeldingen en gegevens varn 55 Amsterdamse staande horloges in 1. Zeeman 1977, pp. 1-141 en de afbeeldingen en gegevens van 17 Limburgse en Brabantse klokken uit genoemd boek, pp. 401-430, aangevuld met we hoogtemetingen van tabel 8 .

${ }^{73}$ W. Rutten 1995 , p. 150.
} 
ve hoogte van de wijzeras. Tussen 1740 en 1850 ligt deze bij de Limburgse staande klok gedurende de hele periode tussen 0,7 en 0,85 . Bij het Amsterdamse staande horloge neemt de relatieve hoogte af van rond de 0,85 in 1680 naar onder de 0,7 na 1750 omdat er steeds meer opbouw boven het wijzerwerk in het model van de kast werd ingevoerd. De vraag blijft, waarom de wijzeras bij de Limburgse staande klok zoveel hoger zat. Mogelijk zouden de inrichting en afmetingen van de huizen hiervoor een verklaring kunnen geven. Dat de afmetingen van het Amsterdamse staande horloge zoveel toenamen, werd mogelijk gemaakt door plaatsing in de hoge gangen en trappenhuizen van de Amsterdamse kooplui. De Limburgse staande klok werd blijkens boedelinventarissen in Nederlands-Noord-Limburg en het aanpalende Oost-Brabant bijna altijd in de woonkeuken ${ }^{74}$ geplaatst. Daarin was - in tegenstelling tot de weliswaar hoge, maar smalle Amsterdamse gangen - ruimte om afstand tot de klok te nemen. Zo kon iedereen, hoe groot of klein hij ook was, de tijd zonder enige inspanning aflezen. Hoewel er een luid tijdsein door de bel(len) van het slagwerk werd gegeven, hechtte men aan de mogelijkheid zich precies te kunnen informeren. Overigens kan men ook een technische reden aangeven voor de hoogte van de wijzeras. De Limburgse klokken zijn over het algemeen daguurwerken met één gewicht, dat zowel het gaande werk als het slagwerk aandrijft. Om het uurwerk circa dertig uur te laten lopen, is een grotere valhoogte yoor het gewicht vereist dan om een weekwerk met zijn twee gewichten aan darmsnaren, waarmee de meeste Amsterdamse staande horloges zijn uitgevoerd, een week te laten lopen.

Waarschijnlijk was ook voor de wandklokken de ruimte maatgevend. Hun mat loopt zeer sterk uiteen. Van iets meer dan $40 \mathrm{~cm}$ tot ruim 1,60 $\mathrm{m}$ toe. De hoogte van de ruimte, waarin de wandklok was opgehangen, zal doorslaggevend zijn geweest. Hoogstwaarschijnlijk werd de wandklok zo hoog gehangen, dat ook haar tijdsaanduiding in een oogopslag was af te lezen. Het was kennelijk wenselijk dat groot en klein zich op elk moment konden verge-

\footnotetext{
${ }^{74}$ A. Schuurman 1989 , pp. 196-197, constateert, dat in 1830 bij de boeren in Oost-Brabant de keuken bijn altijj ook slaapvertrek is, een gunstige plaats voor het uurwerk, dat praktisch gltijd van een wekker was woorzien. Echter ook in de woonkamer werd bij de boeren tot 1890 vakk geslapen. Cfr. G. Rooijakkers 1992, pp. 108 en 116 . Ook de boedelinventarissen van Brienen in Venray (zie hoofdstuk VIII, noot 40) en S.L. Joosten te Maaseik (zie hoofdstuk VIII, noot 38 ) vermelden bedden in keuken en woonkamer.
} 
wissen van de precieze tijd; in hoeverre leefwijze of arbeidsorganisatie daartoe aanleiding gaven, is nog niet onderzocht.

Tabel 7. Kasthoogte in mm bij verschillende typen Limburgse klokken $N=90$

\begin{tabular}{|c|c|c|c|}
\hline & Staande klok & Wandklok & Totaal \\
\hline $0-200$ & . & . & . \\
\hline $200-400$ & . & 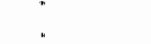 & . \\
\hline $400-600$ & . & 6 & 6 \\
\hline $600-800$ & . & 3 & 3 \\
\hline $800-1000$ & . & 1 & 1 \\
\hline $1000-1200$ & . &. & \\
\hline $1200-1400$ & . & . & . \\
\hline $1400-1600$ & . & . & . \\
\hline $1600-1800$ & . & $i$ & $i$ \\
\hline $1800-2000$ & . & . & . \\
\hline $2000-2200$ & 1 & . & 1 \\
\hline $2200-2400$ & 11 & . & 11 \\
\hline $2400-2600$ & 54 & . & 54 \\
\hline $2600-2800$ & 11 & * & $\mathbb{1 1}$ \\
\hline $2800-3000$ & 2 & . & 2 \\
\hline Gemiddelde hoogte & 2.497 & 681 & 2.275 \\
\hline Standaarddeviatie & 142 & 355 & 622 \\
\hline Totalen & 79 & 11 & 90 \\
\hline
\end{tabular}

7.2.6. Wandklokken: aantal, opbouw en vormgeving

Wandklokken zijn in veel geringere mate aangetroffen dan staande klokken: 65 wandklokken tegen 550 staande klokken. Een groot gedeelte van de wandklokken wordt gevormd door de zogeheten wekkerklokjes of "meidenklokken". Deze bestaan uit niet meer dan een wijzerplaat met daarachter een gaand werk met wekker (géen slagwerk!) in een dun metalen kastje, dat is voorzien van een draagoog en afstandspennen om de slinger ruimte te geven tussen wand en uurwerk. De oudste bewaarde exemplaren, van omstreeks 1770 , hebben een getoogde wijzerplaat, soms met één wijzer; de latere hebben een ronde witglazen wijzerplaat met messing rand en Bréguet-wijzers (zie afbeelding 92 en 93). De aanwezigheid hier en daar van meidenklokken is slechts verrassend omdat de kans dat zo'n eenvoudig klokje twee eeuwen overleefde niet groot mag worden geacht. Meidenklokken zijn waarschijnlijk in redelijk groten 

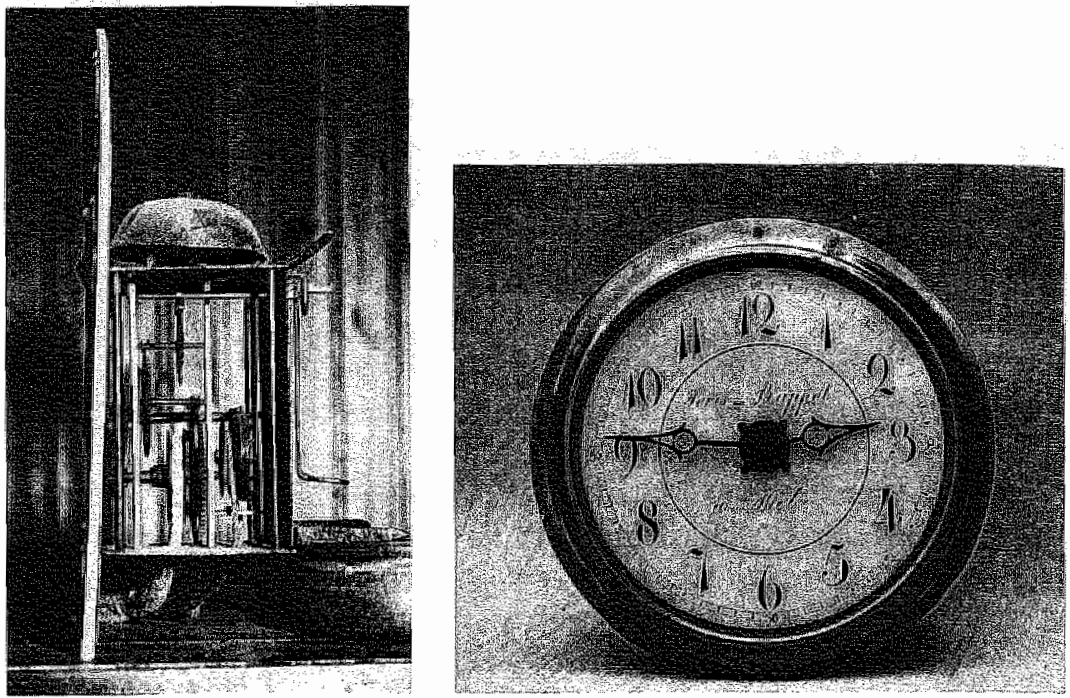

92. (1.) Wekker- of meidenklok met getoogde wijzerplaat. Deze wandklokken bevatten in. hun metalen kastje slechts een gaand werk met daarachter een wekkerwerk; ze hebben dus geen slagwerk. Eenwijzerig werk van circa 1775 (A.J. Smeets, Hamont)

93. (r.) Wekker- of meicienklak met ronde witglazen wijzerplaat, circa 1850 (J. Ruppol, Niel bij Sint-Truiden)
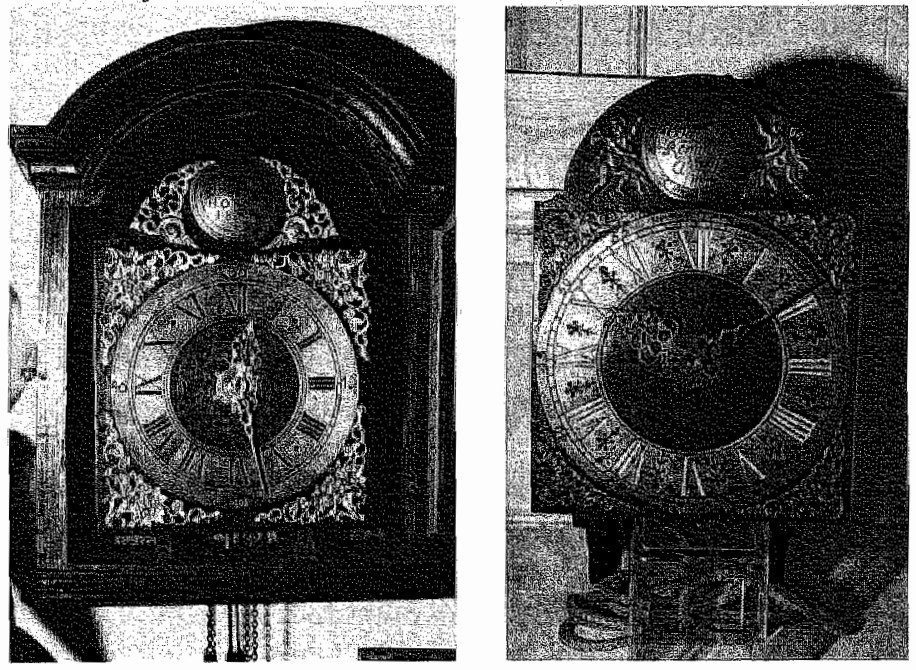

94. (1.) Wanduurwerk, anno 1801. In tegenstelling tot de meeste Limburgse wandklokken is dit uurwerk in een houten kastje geplaatst (G. Trommar, Horst)

95. (r.) Stoelklok uit Noord-Limburg, anno 1767 (C. Remmen, Weil). Stoelklokken komen slechts zelden voot in Limburg en dan alleen in Noord-Limburg. 
getale aangeschaft. De aanwezigheid van mannelijk en vrouwelijk personeel voor dag en nacht vormde op laat-18de-eeuwse agrarischambachtelijke bedrijven een probleem. Indien de situatie leidde tot een ongewenste zwangerschap van een der meiden, werd de werkgever er tenminste scheef op aangekeken. Eén van de mogelijke oplossingen was de slaapplaatsen van mannelijk en vrouwelijk inwonend personeel aan weerszijden van die van de werkgever en zijn echtgenote te projecteren. Frequent had dit tot gevolg dat één van beide groepen de wekker van het uurwerk in de keuken niet kon horen. Voor hen werd een eenvoudig, maar degelijk wekkerklokje aangeschaft.

Het weinig frequent voorkomen van wandklokken heeft de aandacht getrokken. Weyns merkt op: "Uit een boedellijst uit 1781 heb ik aangetekend: een wecker (1781, Goossens, Gierle). Naar het uitzicht van dat uurwerk hebben wij het raden. De wekkerinrichting van de staande klok heb ik terloops vernoemd. Was het klein, bijzonder als wekker gebouwd klokje reeds in 1781 bekend? Over vele zaken van dagelijks gebruik zijn wij nog weinig ingelicht. Het heeft er alle schijn van, dat de wekker pas omstreeks 1900 tot het volkshuisraad is gaan behoren". ${ }^{75}$ Ongetwijfeld is in de door Weyns geciteerde inboedell sprake van een getoogd wekker- of meidenklokje, zoals te zien op afbeelding 92 .

De losse wekker, zoals wij die kennen, is een laat-19de-eeuwse ontwikkeling. Hiervoor zijn waarschijnlijk twee oorzaken aan te wijzen. Enerzijds was er een ontwikkeling in de wooncultuur: men kreeg meer differentiatie in de huizen, de bedstedes verdwenen, er kwamen aparte slaapkamers, waar men het huisuurwerk op de gang of in de woonvertrekken niet kon horen. Hier had men echter ook de oude vertrouwde wandwekker kunnen ophangen. Een andere, gelijktijdige stimulans voor de losse, draagbare wekker was de opkomst van de trein en het daarmee ontstane toerisme en handelsverkeer: de reizigers wensten in den vreemde ook op tijd gewekt te worden. Vandaar dat tussen 1850 en 1900 de reiswekkers, draagbare uurwerkjes in een messing stelling met glazen deurtjes en een leren etui op de markt kwamen. Ze waren soms zeer luxe uitgevoerd en werden in Franrijk en Engeland gefabriceerd. Rond 1890 kwamen er goedkopere kleine, ronde wekkers met een vast slingertje met rolanker. Ze hadden geen bel of gong, maar de wekker-

3. Weyns 1974 , pp. $981-982$. 
hamer sloeg tegen het metalen kastje. Ze werden vervoerd in kartonnen doosje. Deze uurwerkjes kwamen wooral uit Frank Wekkers werden steeds meer en masse gefabriceerd en in st goedkopere uitvoeringen. Dit gold vooral voor de huiswekkers voomamelijk in Duitsland werden vervaardigd. ${ }^{76}$

Naast de genoemde wandwekkerklokken zijn hangklokken aa troffen in een houten kastje, dat de vorm heeft van een kop van staande klok. Hierin zit meestal een volledig uurwerk, dus: g: werk, slagwerk en wekkerwerk (zie afbeelding 94). In Nederla Noord-Limburg komen deze "kopjes" met enige regelmaat , Soms werden ze later aangevuld met een middendeel en basi een staande klok. Dat er om te beginnen alleen een "kopje" , besteld, wordt bevestigd door de boedelinventaris ${ }^{77}$ van Joa Brienen te Venray uit 1788. Daarin is sprake van losse uurwer uurwerken met een bovenkastje en hele staande klokken. ${ }^{78}$

In Nederlands-Noord-Limburg komt ook nog een soort stoel voor: een zwaar uitgevoerd uurwerk met ankergang en lange sli en voorzien van slagwerk en wekkerwerk, omsloten door metalen kastje op een houten console en meestal afgedekt doo: houten tentdakje, zoals een Ruempol-klok. Het metalen kastje deze klokken verschilt van de "meidenklokken" hierin, da deurtjes scharniertjes hebben aan de achterwand, terwijl die vi meidenklokken uitsteeksels hebben die draaien in gaatjes i boven- en onderplaat van het uurwerkgestel. Daarenboven zi deurtjes van de Noord-Limburgse stoelklokken aan de bovei onderkant in een vorm uitgezaagd. Noch de wijzerplaten, nor kastjes, noch de consoles hebben een bonte beschildering a Friese stoelklokken. De ijzeren wijzerplaten zijn zwart, do groen, donkerblauw of meniekleurig geverfd. De consoles he een houtkleur onder vernis (zie afbeelding 95). Soms werd stoelklok, maar dan zonder dakje, in een staande kast gehang in de achterwand van zo'n kast ingewerkt (zie afbeelding 96: In en misschien rond Roermond schijnt men een soort staartkl hebben gemaakt. Hiervan heb ik overigens maar één exempl

\footnotetext{
${ }^{76}$ Mogelijk kan men ook in de zogenaamde rijtnighorloges, de "perdules d"officier "capucines" (officiersklokken) dure voorlopers van de latere, goedkope wekker zien.

${ }^{77}$ R.A.M., Schepenbank Venray, evacuatienummer 3956 , boedelinventaris van Brienen.

${ }^{78}$ Cfr. hoofdstuk $\mathrm{X}$, paragrabf 10.1 .
} 

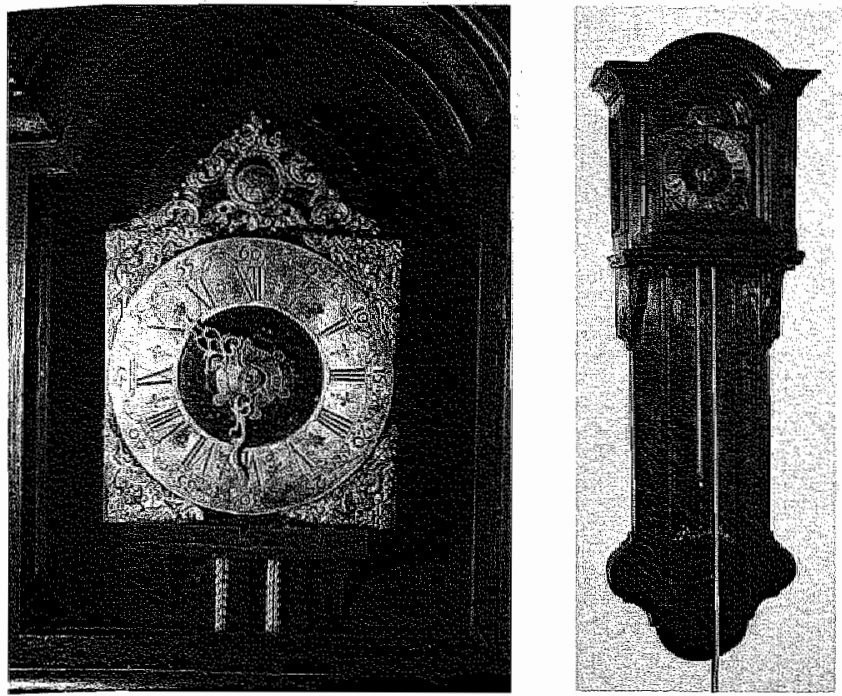

96. (1.) Staande klok, waarin een stoelklok in de achterwand is ingewerkt, anno $1779(\mathbf{N}$, Trommar, Horst)

97. (r.) Staartklok met wekkerklok, circa 1770 (H. Beltjens, Roermond), (zie ook afbeelding 57)
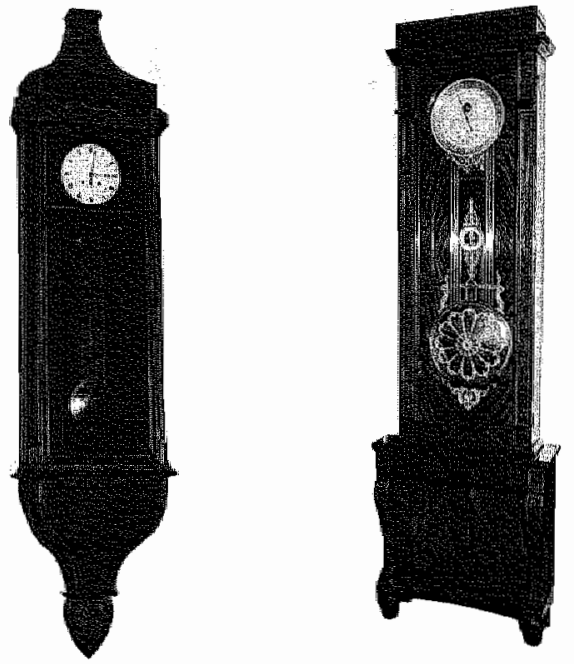

98. (.) Wandregulateur met compensatieslinger van ijzeren en messing staven, circa 1820 (J.F. Nijs, Roermond)

99. (r.) Staande regulateur met zeer rijk uitgevoerde compensatieslinger, een jaar lopend, circa 1830 (J.W. Aerts, Tongeren) 

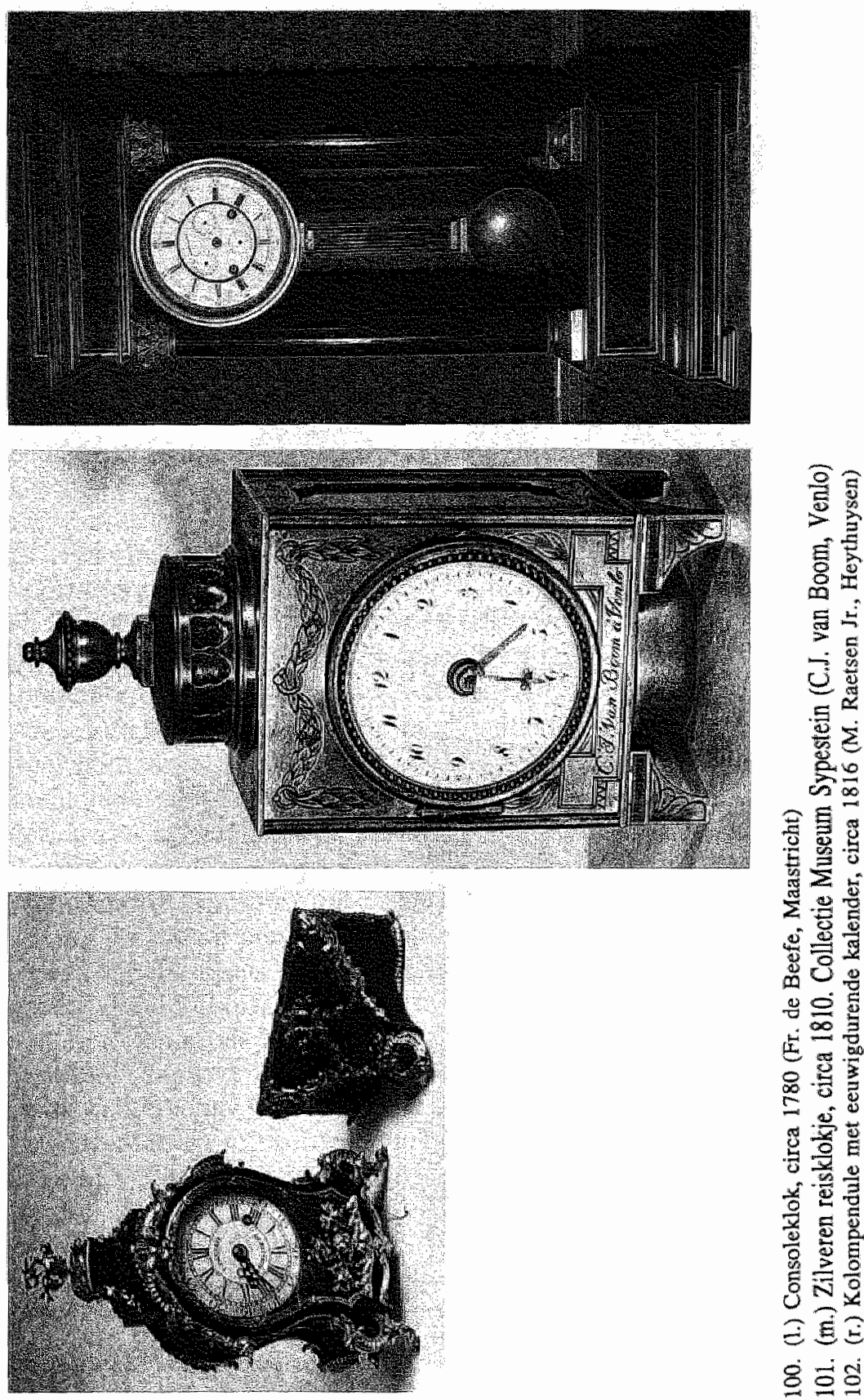

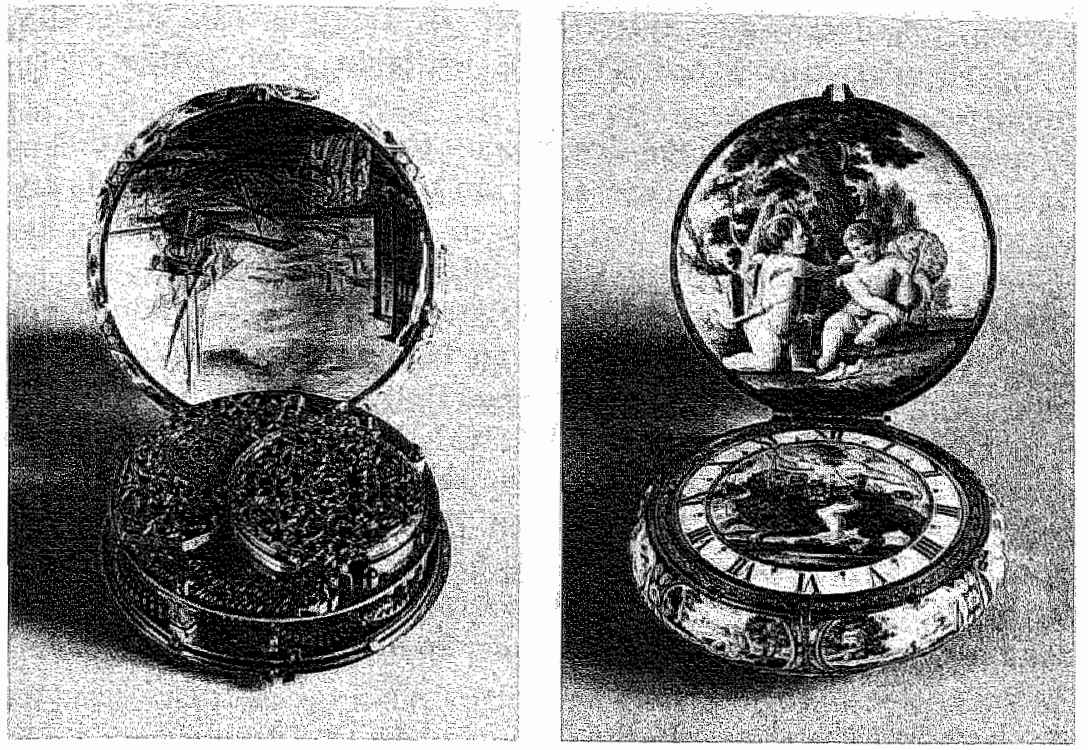

103a en b. Geëmailleerd zakhorloge, circa 1685, collectie Rijksmuseum (J. Vrijthoff den Jongen, Maastricht)
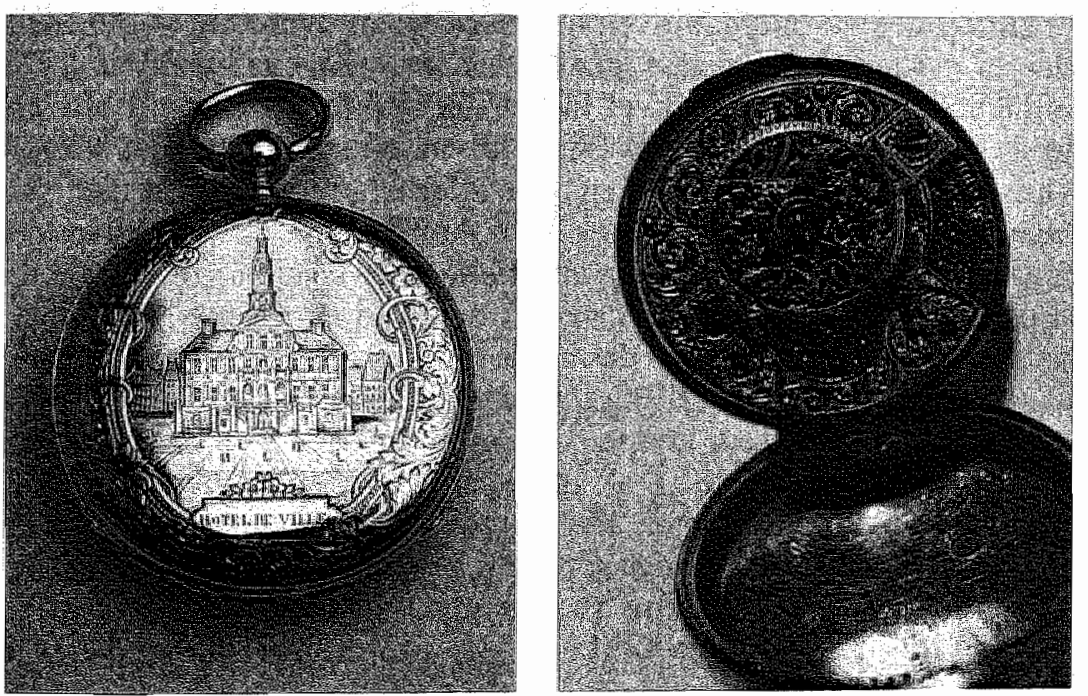

104. (1.) Gouden zakhorloge met gravering wan het stadhuis te Maastricht, circa 1850 (B. Arenz, Maastricht)

105. (r.) Zilveren zakhorloge, circa 1850 (T.F. Dionisy, Roermond) 
gezien met daarin een uurwerk van $H$. Beltjens (zie afbeelding 97). ${ }^{79}$ Verder zijn er alleen vage verhalen over zonder documentatie.

Wandregulateurs, zoals die van Nijs uit Roermond en van Aerts uit Tongeren, zijn zeer zeldzaam. Daaryan konden in totaal slechts drie worden opgespoord, één van Nijs en twee van Aerts, die bijna identiek zijn (zie afbeelding 98 en 99).

Consoleklokken (zie afbeelding 100), tafelklokken en pendules zijn zeldzaam. De tafelklokken, twee van Jacobus Joosten (zie afbeelding 68) en één van Joannes Reinerus Beltjens (zie afbeelding 67) lijken eigen werk; bij de reisklok van C.J. van Boom is dit zeer de vraag (zie afbeelding 101). Ook pendules (zie afbeelding 102) en zakhorloges (zie afbeelding 104 en 105) zijn over het algemeen geen eigen werk. Zij stammen alle, behalve een zakhorloge van $\mathrm{J}$. Vrijthoff den Jonge (zie afbeelding 103a en b), uit de 19 de eeuw, een tijd waarin de uurwerkmaker meer en meer een uurwerk-wederverkoper werd.

\subsubsection{Luxe- en utilitaire producten}

Wanneer we de overgebleven huisuurwerken overzien, is duidelijk dat er luxeproducten zijn gemaakt naast gewone, utilitaire. Dit onderscheid uitte zich zowel in het uurwerktechnisch gedeelte als in de uitvoering of zelfs afwezigheid van de kast. Voor het aflezen van de tijd is het aanbrengen van allerlei extra snufjes niet van belang. Het uurwerk wordt er alleen duurder van. Twee bellen met bijbehorende voorziening om die bellen afwisselend te bestemder tijd aan te slaan kost meer dan één bel. Een carillon was zo duur, dat deze voorziening in de beide Limburgen nawwelijks werd aangetroffen, in tegenstelling tot Amsterdam, waar vele rijke kooplieden zich deze luxe konden permitteren. Een weekwerk kostte meer dan een dagwerk. Ook de maanfasen- en datumaanduiding waren luxevoorzieningen. Van innovaties op uurwerktechnisch gebied kan men hierbij niet spreken. In technisch opzicht gaat het puur om luxe. Van belang is eigenlijk slechts de prijs en deze speelde in de Limburgen blijkbaar een grotere rol dan in de grote Hollandse steden.

${ }^{7}$ Over het slagwerk van deze klok zie p. 174. 
De grootste besparingen werden verkregen door het weglaten van het slagwerk (de zogenaamde meidenklokken of wekkerklokken) en het weglaten van een klokkast, zoals bij de meidenklok die slechts een metalen omhulsel kreeg. Eén wijzer was natuurlijk goedkoper dan twee wijzers met bijhorend minuutraderwerk. Smeets te $\mathrm{Ha}$ mont bouwde soms éénwijzerige wekkerklokjes. In zulke gevallen is sprake van een reductie van functies tot alleen de voor de gebruiker meest essentiële. Het zijn zuiver utilitaire producten, degelijk en zeer sober. $\mathrm{Zij}$ werden vooral aangetroffen in de armoedige Kempen en in de Peel. In Nederlands-Noord-limburg blijken als utilitaire producten onder meer een soort stoelklokken te zijn geproduceerd. Ook kwamen daar regelmatig kopjes als van een staande klok voor als wandklok (zie de vorige paragraaf). De staande klokken zijn vanwege de dure kast over het algemeen te rekenen tot de luxeproducten, behalve de zeer eenvoudige exemplaren. De combinatiemeubels, dat wil zeggen een combinatie van secretaire en klok, kleerkast en klok, vitrinekast en klok en bedstede en klok, zijn per definitie luxeproducten. Een decoratie met folkloristische of regionalistische elementen hoeft het predikaat luxeproduct niet te verhinderen. Samenvattend kunnen we dit overzichtje opstellen:

Luxeklokken

combinatiemeubels

staande klokken in

rijk bewerkte klokkasten

uurwerken met meer bellen

en/of meer aanduidingen
Utilitaire klokken

wekkerklokken

staande klokken in zeer

eenvoudige klokkasten.

stoelklokken; losse kopjes

Geleidelijk aan werd het huisuurwerk meer en meer een utilitair product, waarmee niet werd gepronkt. Het betekende uiteindelijk de doodsteek voor de uurwerkmakerij in de Limburgen. Rond 1850 was het gedaan met de productie van Limburgse klokken. Een enkeling als Peter Wessels maakte nog rond 1872 een staande klok in $18 \mathrm{de}$-eeuwse stijl, maar hij was een uitzondering. De Limburgse klokkenmakerij was ten onder gegaan door de opkomst van de goedkope Schwarzwald-klokken, die langs de deur werden gevent. Maar ook een veranderde smaak speelde een rol: de Franse pendules traden hoe langer hoe meer op de voorgrond in onze binnenhui- 
zen. ${ }^{80}$ Deze pendules werden reeds eind 18 de eeuw op een industriele schaal geproduceerd door de Japy-fabrieken in Frankrijk. De wekkerklokjes werden vervangen door en masse vervaardigde prototypen van onze huidige wekkers (zie paragraaf 7.2.6) Nieuwe slaapgewoonten, waarbij het gezin meer over heel het huis was verspreid, makten het wenselijk in verschillende vertrekken een wekker te plaatsen omdat een groot deel van het gezin de wekker in de staande klok niet meer kon horen. In die tijd werden waarschijnlijk al veel wekkerwerken uit staande klokken gesloopt. Daarvan vinden we nu nog slechts sporen in het binnenwerk. Toen ook in Duitsland en Zwitserland de industriële klokkenproductie doorbrak, kon het ambachtelijk vervaardigde Limburgse uurwerk de concurrentie helemal niet meer aan.

Opmerkelijk genoeg heeft geen uurwerkbouwer in onze streken ook maar enige poging gedaan tot massaproductie te komen of te industrialiseren. Zulke initiatieven werden vooral in bergachtige gebieden (Jura, Zwitserland, Zuidwest-Duitsland) aangetroffen. Waarom de allocatiefactoren daar zo gunstig waren, is onduidelijk. Ruimere aanwezigheid van bedrijfskapitaal in bergachtige streken ligt als verklaring niet voor de hand. Veeleer mag men denken aan de op het moment van introductie van massaproductie noodzakelijke keuze tussen agtarische en industriële activiteiten. In de $18 \mathrm{de}$ eeuw was de productie van uurwerken vaak een bijverdienste geweest voor plattelanders. In streken, zoals de beide Limburgen, waar vanaf 1820 de intensivering van de landbouw succesvol werd, ${ }^{81}$ werd waarschijnlijk meer verwacht van specialisatie in agrarische richting. In bergachtige streken, waar het klimaat ( $\mathrm{s}$ winters vaak maandenlange isolatie) en de terreinsgesteldheid niet bevorderlijk waren voor een redelijk rendement van extra inspanningen ten behoeve van de landbouw, zag men mogelijk meer in het uitbouwen van de ambachtelijke activiteiten tot hoofdberoep. Omdat massaproductie nodig was, werd het voortaan uitgeoefend op industrieel niveau. ${ }^{82}$

Van de technische kenmerken van de openbare uurwerken viel zeer weinig specifieks te melden. De vier oudste uurwerken die bewaard

\footnotetext{
A. Schmurman 1989, toonde dit aam voor werschillende regio's in Nederland, met name voor Oost-Brabant. In de beide Limburgen zal het net zo zijn geweest.

${ }^{8}$ J Jansen $1993 \mathrm{~b}$, pp. 150-182.

${ }^{82}$ D. Landes 1983 , pp. $257-259$. Landes wijst ook op het belang van pioniers die het voortouw nemen.
} 
bleven, zijn vele malen hersteld en gerenoveerd. Van het oude binnenwerk is hoegenaamd niets over. Alleen over de authenticiteit van het smeedijzeren raamwerk en de grondraderen bestaat zekerheid. Daaruit valt af te leiden dat de van elders bekende technieken uit de gotiek ook bij de oudste Limburgse torenuwrwerken grosso modo zijn toegepast. Of er al dan niet ooit sprake is geweest van bijzondere regionale kenmerken, onttrekt zich aan onze waarneming. Het staat slechts vast dat het in alle overgebleven voorbeelden gaat om eenvoudige instrumenten die geen astronomische data tot uitdrukking brachten en waaraan geen carillons of jacquemarts waren gekoppeld. Ook de jongere torenuurwerken uit de beide Limburgen onderscheidden zich niet van het standaardtorenuurwerk in West-Europa, zoals dit in de literatuur is beschreven.

Met de huisurwerken is het anders gesteld. Daarvan werden vele exemplaren aangetroffen en bestudeerd. Het waren oerdegelijke en hoogst betrouwbare apparaten die weinig onderhoudskosten vergden. Innovaties bij de vervaardiging van huisuurwerken uit het midden van de 17 de eeuw, zoals de slinger van Huygens en de ankergang van Clement, werden vrijwel onmiddellijk overgenomen. Tussen 1675 en 1725 ontwikkelde zich daaruit een type dat bijna ongevoelig was voor verdere innovaties. De rustende gang van Graham uit 1730 en de pennengang van Amant uit 1741 werden nauwelijks toegepast, latere vondsten pas na verloop van geruime tijd. Het Limburgse uurwerk is meestal van een wekkerwerk voorzien. Luid en duidelijk werd de Limburger 's ochtends uit zijn slaap gewekt. Van de diverse typen uurwerken was alleen de staande klok ruim vertegenwoordigd. De markt voor tafelklokken en zakhorloges werd verkend, maar niet voldoende perspectiefrijk geacht. Derhalve zijn er duidelijke aanwijzingen voor de functie van het Limburgse uurwerk: het was een dagwerk met terugwerkende ankergang, voorzien van een secondeslinger, een slagwerk met sluitschijf en een wekkermechanisme, het geheel geplaatst in een hoge, doorgaans sobere klokkenkast en voorzien van een forse wijzerplaat en flinke wijzers in messing of ijzer, in het bijzonder geschikt voor gebruik in lagere sociale strata, waar men behoefte had aan een uurwerk dat alle betrokkenen op tijd naar de werkplek riep.

Daarnaast kwamen luxeproducten voor die weliswaar nagenoeg dezelfde technische kenmerken hadden als de standaarduurwerken, maar wat vaker waren uitgevoerd als weekwerk met datum en 
dubbele bel. De klokkasten daarvan waren vaak rijk gesculpteerd. Enige neiging tot het tonen van hun status kan de bezitters ervan niet worden ontzegd. Een nadere analyse van productie en afzet zal wellicht duidelijk kunnen maken of de functie van deze luxeproducten niet vrijwel dezelfde was als die van de eenvoudige producten en dat het tonen van status van ondergeschikt belang was. 


\section{Hoofdstuk VIII}

\section{De Limburgse uurwerkmakers}

\subsection{De identificatie van de uurwerkmakers}

Voor uurwerkmaker komt men in de archivalische bronnen allerlei benamingen tegen. Zo heette hij in Venlo rond 1575 "der Ohrwercker", ook Oerwercker geschreven. In Roermond wordt in 1609 zekere Mr. Henrick der Uhrmecker vermeld. In de $18 \mathrm{de}$ eeuw vindt. men vaak de termen "orlosimaker", "horlogeur" en "horologiemaeker". Op adresplaatjes van W. Wessels te Geleen komt soms de term "orloismaecker" voor. Deze laatste vier benamingen zijn deels afgeleid van het Romaanse "hor(o)loge". Dat woord had een brede betekenis. Horloge was nog tot in de 19 de eeuw het verzamelwoord voor uurwerk in het algemeen.

Een andere term is het van klok afgeleide woord "klokkenmaker". Dit woord betekent zowel in de archivalische bronnen als in deze studie uurwerkmaker. Het mag niet worden verward met klokkengieter, iemand die luidklokken giet. Dat was een ander vak, ook al was vooral in de aanvangsfase de band tussen luidklok en torenuurwerk sterk. Tot rond 1450 ontbeerde het uurwerk immers een buitenwijzerplaat en was men genoodzaakt het aantal slagen op de "uurklok" te tellen om de juiste tijd te weten."

Wij zullen in deze studie de term uurwerkmaker hanteren. Alleen diegenen, die blijkens overgebleven producten of een expliciete vermelding in de bronnen, dat zij uurwerken produceerden, daadwerkelijk met het vervaardigen van een of meer typen mechanische uurwerken bezig waren, worden met die term aangeduid. $\mathrm{Zij}$ die zich uitsluitend met reparatiewerkzaamheden bezighielden zijn uitgesloten. $\mathrm{Zij}$ heten hierna uurwerkherstellers of uurwerkverkopers.

${ }^{1}$ Cfr. hoofdstuk I, pp. 7-9. 


\subsection{De ontwikkeling van het vak}

\subsubsection{De makers van torenuurwerken}

Het mechanisch uurwerk is waarschijnlijk tot ontwikkeling gekomen in het laatste kwart van de 13de eeuw. Gewoonlijk situeert de literatuur de vinding in het monastieke milieu: de kloosters, ${ }^{2}$ waar voor een goede "timing" en spreiding van de koorgebeden over het etmaal een betrouwbare tijdmeter zeer van pas kwam. Vanuit de kloosters, die een mechanisch uurwerk bezaten, zou de uurwerktechniek langzaam zijn verspreid, waarschijnlijk via smeden en slotenmakers, die bij de bouw en het onderhoud van de eerste uurwerken waren ingeschakeld. ${ }^{3}$ Een snelle verspreiding van uurwerken vond plaats, toen de bestuurders van de steden de openbare tijdmeting als een belangrijke taak waren gaan zien. Omdat er aanvankelijk zeer weinig uurwerkmakers waren, moest een stadsbestuur, als een uurwerk werd aangeschaft, een beroep doen op een expert uit een andere stad, streek of land. Zo'n expert vertrok weer zodra het uurwerk was geïnstalleerd, nadat hij een plaatselijke smid, slotenmaker of goud- en zilversmid had geleerd hoe het geleverde uurwerk moest worden onderhouden. De uurwerkmakers van deze eerste periode waren "reizende specialisten"." Bewijzen voert men voor deze ontwikkeling nauwelijks aan en zijn ook moeilijk te geven. In onze regio, waar de geschiedenis van het mechanisch uurwerk systematisch is onderzocht, bezaten kloosters en religieuze instellingen uitermate zelden een torenuurwerk. De paar uitzonderingen, het O.-L.-Vrouwekapittel en het Servaaskapittel te Maastricht en de abdij van Munsterbilzen schaften veel later hun torenuurwerk aan dan de besturen van de steden met meer dan een regionale economische functie. Uit niets kan worden afgeleid dat het Servaaskapittel de aanschaf van een stadsuurwerk subsidieerde omdat het een toremuurwerk wenste vanwege zijn nut voor de organisatie van religieuze plechtigheden. Op het grondgebied van het kapittel werden jaarmarkten gehouden; de stad organiseerde weekmarkten. Het markt-organisatorisch belang - beheersing van transactiekosten door institutionalisering - gold voor beide.

\footnotetext{
${ }^{3}$ Zie hoofidstuk I.

${ }^{3}$ G. Dohrn-van Rossum 1992, p. 170.

4. Dohrn-van Rossum 1992, pp. 177-182.
} 
Ook komt het hier in de 14de eeuw niet voor, dat een uurwerkmaker uit het monastieke milieu afkomstig is. In de $14 \mathrm{de}$ en $15 \mathrm{de}$ eeuw waren het in onze streken vakmensen die nogal eens tevens actief waren op andere deelgebieden van de mechanica, zoals het beheer en onderhoud van het stedelijk geschut. Het is zaak naar de feiten te kijken. Bij het eerste uurwerk van Maastricht (1367) kan men het aantrekken van een specialist slechts vermoeden. ${ }^{5}$ De naam en de herkomst van de maker zijn ons niet overgeleverd. Zeker is dat het uurwerk - helaas niet zo best - werd onderhouden door een plaatselijke goudsmid, Willem(me) van Zechen uit de Wolfstraat: ${ }^{6}$ Veel beter zijn we geinformeerd met betrekking tot het eerste stadsuurwerk van Venlo. Dit werd in 1389 geleverd door Hendrik van Thoiren uit Maastricht, dat op een afstand van tachtig kilometer van Venlo ligt. Omdat Van Thoiren zijn materialen moest meenemen, zal het hem meerdere dagen hebben gekost om in Venlo te geraken. Of hij nu het schip of paard en kar als vervoermiddel koos, meer dan een paar kilometer per uur kwam hij niet vooruit. ${ }^{7}$ Dat beperkte de straal, waarbinnen Van Thoiren opdrachten kon uitvoeren tot zo'n honderd kilometer. ${ }^{8}$ Hoe dan ook, Van Thoiren moest zijn vakkennis doorgeven. Voor een reparatie overkomen kon hij niet. $\mathrm{Na}$ aflevering van het uurwerk leerde hij Jan (de) Goutsmeyt uit Venlo hoe het uurwerk moest worden onderhouden. Hij ging weer terug naar Maastricht, waar hij moest vaststellen dat het aantal opdrachten voor uurwerken in de regio die hij kon bedienen niet groot was. Neveninkomsten waren gewenst. Van Thoiren bekleedde verschillende stedelijke ambten en oefende in Maastricht diverse beroepen uit: zo was hij van 1382 tot 1400 "koeremeister" (keurmeester). In 1395 waren Henric van Thoiren en Meister Otte "der stat werkluide van den donre", dat wil zeggen opzichters van de donderbussen, de stedelijke kanonnen, die vanwege de slechte kwaliteit buskruit tot 1420 onbetrouwbaar bleven. ${ }^{9}$ Herhaaldelijk spatten ze uiteen als een schot werd gelost. Van 1396 tot 1400 werkte hij aan een nieuw stadsuurwerk. In 1400 leverde hij aan de

\footnotetext{
${ }^{5}$ Zie hoofdstuk II, paragraaf 2.1.1.

${ }^{6}$ Nadere gegevens omtrent in de tekst gemoemde Limburgse uurwerkniakers in appendix II.

${ }^{7}$ F. Braudel 1987, p. 406.

${ }^{8}$ G. Dohm-van Rossum 1992, p. 179, noemt afstanden van twee tot vier dagreizen normal voor de klokkenmakers die interregionaal, werkten.
}

${ }^{9}$ L. White Ir. 1962, p. 101. 
stad Maastricht vervolgens twee nieuwe kanonnen op houten affuiten.

Dat Henric van Thoiren als uurwerkmaker tevens geschutmeester was, is geen uitzondering. Integendeel, meer vroege uurwerkmakers bekleedden dit ambt. In Rijssel (Lille) was Pierre Demileville, bijgenaamd "del orloge" in 1381 stadsuurwerkmeester; eind 14debegin 15 de eeuw was hij belast met het onderhoud van het stadsgeschut. Hij leverde enkele kanonnen aan de gemeente en maakte buskruit. Een collega "orlogeur", Jacques Yolens, trad in 1409 op als opzichter van de kanonnen in dezelfde stad. Hij maakte in 1412 zelfs draagbare vuurwapens van gietijzer. In Namen waren begin 15 de eeuw drie opeenvolgende opzichters van het kasteeluurwerk tevens opzichter van het stadsgeschut. Van de eerste van dit drietal, "maittre Colart le canonnier", is bekend dat hij alle metaalvakken beheerste en buskruit kon bereiden. ${ }^{10}$

Cipolla constateerde meermaals het samengaan van uurwerkmaken en optreden als geschutmeester. Hij citeert de benaming "magister bombardarum et horologiorum" en daarop lijkende varianten. "In de toenmalige samenleving waren mensen met hoge mechanischtechnische kennis en vaardigheid zeldzaam. Het was niet verwonderlijk, dat zij betrokken raakten bij alle vindingen die mechanisch-technisch inzicht vroegen, zoals uurwerken, buskruit en geschut. ${ }^{12}$ Het bleef nog lang zo. In Hasselt is het fenomeen nog aan het eind van de 16de eeuw aantoonbaar: daar was de uurwerkmaker Maarten Deeckens (genoemd van 1574 tot 1618) jarenlang stadsartilleriemeester. Hij handelde in buskruit en ingrediënten voor de vervaardiging daarvan, met name salpeter.

Het is opmerkelijk, maar niet uniek, dat bij de twee vroegste uilifwerken in de beide Limburgen goudsmeden als "stadsunrwerkmaker", de persoon belast met het onderhoud van het stadsuurwerk, werden aangesteld. Het ging om meer dan het smeren en opwinden van het uurwerk. Dagelijks moest de foliot 's morgens en 's avonds worden bijgesteld of omgewisseld, zolang men ongelijke uren hanteerde. Toen de gelijke uren in zwang waren gekomen, verviel dat werk, maar de uurwerken moesten toch vaak worden bijgesteld

${ }^{10}$ C. Gaier 1973, pp. 249-251.

"C. Cipolla 1967, p. 50.

${ }^{12}$ De combinatie buskruit en geschut dateert van kort na 1325. In de slag bij Crécy in 1346 schijnen voor het eerst kanornen in een veldslag te zijn gebruikt. 
vanwege de gebrekkige resultaten van de folliot als tijdregelaar. Ook dit vergde mechanisch inzicht en fijnmechanische vaardigheid. De goudsmeden behoorden tot de weinigen met zulk inzicht. Wie op dit vlak zijn sporen had verdiend, kon rekenen op een nevenverdienste in de uurwerkmakerij. Dohrn-van Rossum constateert, dat de uurwerkmakerij niet uit één bepaalde tak van de metaalnijverheid is voortgekomen: "Schmiede, Waffenschmiede und Goldschmiede haben die Uhrentechnik am Anfang des 14. Jahrhunderts beherrscht und für verschiedene Uhrentypen angewandt ${ }^{\prime \prime}{ }^{13} \mathrm{Als}$ men de grote gesmede torenuurwerken van die tijd beziet, is men geneigd zich er een grofsmid als onderhoudsmonteur bij voor te stellen, maar klaarblijkelijk zocht men bij voorkeur een metaalbewerker die de fijnmechanische technieken beheerste.

Voorlopig lag in de betrokkenheid van velen en hun bereidheid allerlei klussen aan te vatten een voorname bron van verbreiding en behoud van technische kennis en vaardigheden. Veel later, vanaf de 16de-17de eeuw, kwam er in heel wat steden een scheiding tussen de uurwerkmakers, die in het smedenambacht bleven, en de gouden zilversmeden, die een apart ambacht hadden gevormd. Pas in de tweede helft van de 19 de eeuw zouden de twee beroepen weer naar elkaar toe groeien en uiteindelijk worden gecombineerd tot de huidige juwelier-horloger. In de Limburgen kunnen we een paar facetten van deze specialisatietendens, die tussen 1300 en 1800 zoals alle met techniek verbonden ontwikkelingen zeer traag verliep, volgen. Langzamerhand kwamen er in steeds meer plaatsen uurwerken en mensen, meestal werkzaam in de metaalsector, die kleinere reparaties en het dagelijks onderhoud konden verrichten. Er ontstonden kleine concentraties gespecialiseerde constructeurs van torenuurwerken vanaf het midden van de 15 de eeuw. Deze waren gedurende de 16 de eeuw vooral gevestigd in Hasselt. Het betrof de families Colen (Koelen), Bla(e)sen en Deeckens. ${ }^{14}$ Een vroege gespecialiseerde torenuurwerkbouwer uit onze streken met grote faam was Henri van Nuys $(t)$, ook uit Hasselt. Hij leverde in het begin van de Tachtigjarige Oorlog verscheidene grote torenuurwerken met speelwerken aan Hollandse steden: aan Delft in 1570 voor het stadhuis. Dit werd in 1661 verplaatst naar de toren van de Nieuwe Kerk. Het kreeg bij die gelegenheid een nieuwe

G. Dohrn-van Rossum 1992, p. 170.

14. J. Leunis 1958 , passim. 
messing speeltrommel, gegoten door Fr. Hemony, die ook een nieuw carillon hierbij leverde. De speeltrommel werd afgewerkt en in het uurwerk geplaatst door $J$, van Call, die tevens een slinger aanbracht. Dit geheel is nog altijd in functie (zie afbeelding 34). Aan Leiden leverde Van Nuys(t) een dergelijk uurwerk voor het stadhuis in 1578 (dit is door brand in 1923 verloren gegaan). In 1578 sloot hij met het Goudse stadsbestuur een overeenkomst voor de levering van een torenuurwerk voor de hoofdkerk. Dit is wegens Van Nuys' overlijden in 1579 of 1580 niet gerealiseerd.

Van de torenuurwerkmaker werd niet alleen technische kennis gevergd. Het moest ook een kapitaalkrachtig man zijn. Bij de bouw van zo'n monumentaal uurwerk waren zeer veel mensen betrokken: Beeson noemt een getal van meer dan zeshonderd personen die te Perpignan in 1356 direct of indirect waren betrokken bij de bouw van een torenuurwerk en het gieten van een bijhorende luidklok. ${ }^{15}$ Zo'n onderneming kostte veel geld, zoveel, dat soms zelfs de opdrachtgevende stad in geldnood kwam en de uurwerkmaker moest vragen het geld voor te schieten. Zo leende Maarten Deeckens (1574-1618) aan de stad Sint-Truiden de som van duizend gulden Brabants voor de betaling van een door hem geleverd torenuurwerk. Omgekeerd eisten de opdrachtgevers bij grote projecten soms van de uurwerkmaker, dat hij zijn hele have en goed als borg stelde uit vrees voor een faillissement van de man tijdens de bouw van het uurwerk. In dit verband zij gewezen op de overeenkomst tussen het kapittel van Sint-Servaas te Maastricht en Johan Dierix Wenneme$\operatorname{ker}^{16}$ in 1555.

In de loop van de 17 de en gedurende de 18 de eeuw nam Luik wat betreft de fabricage van torenuurwerken de plaats van Hasselt over. Mogelijk hing dit samen met het feit, dat in de loop van de $17 \mathrm{de}$ eeuw de Luikse jjzerfabrikanten zich een monopoliepositie hadden verworven. $\mathrm{Zij}$ legden beslag op de gehele ijzerproductie van het land tussen Sambre en Maas en Luxemburg. Hierdoor lagen de prijzen van deze grondstoffen constant op een hoog niveau. Concurrentie was slechts mogelijk via het drukken van de transportkosten en besparen op de kosten van het betalingswerkeer. Voorall bij de honderden kilo's wegende torenuurwerken waren dit factoren van betekenis. Omdat de Luikse uurwerkmakers de transportkosten voor

${ }^{\text {ts }}$ C. Beeson 1982, p. 79.

${ }^{16}$ Zie appendix II onder Wennemeker, Johan Dierix. 
grondstoffen konden uitsparen en profiteren van gunstige leverancierskredieten, waren zij allicht in staat de Hasseltse concurrentie uit te schakelen. ${ }^{17}$ Er ontstonden uurwerkmakersbedrijven die van geslacht op geslacht werden voortgezet. In de $17 \mathrm{de}$ eeuw was de familie Moës actief; ${ }^{18}$ in de loop van de 18 de eeuw werd de familie De Beefe befaamd als constructeur van torenuurwerken. $\mathrm{Zij}$ leverde niet alleen in de regio, onder andere in Hasselt en Maastricht, maar zelfs tot in Portugal, met name in Lissabon en Mafra. ${ }^{19}$

In de Limburgen traden in de nadagen van het Ancien Régime maar twee torenuurwerkmakersgeslachten op, die aan de hoogste technische en financiële eisen voldeden. Beide opereerden vanuit ver van Luik gelegen plaatsen voor nogal geïsoleerde markten. In Well was aan het eind van de 17 de eeuw en gedurende de $18 \mathrm{de}$ eeuw de familie Remmen actief. Zij leverde heel wat uurwerken in Nederlands-Noord-Limburg en de aangrenzende Nederrijn, zoals voor het kasteel te Arcen en de kerken van Bergen, Hunsel, Maasbree, Well en Kevelaer (D), waat zelfs twee torenuurwerken werden geplaatst. ${ }^{20}$ In Hamont was in de 18de eeuw de familie Smeets actief, met name Jan Smeets en zijn zoon Antonius Jacobus. Het schijnt dat dit bedrijf op bescheidener leest was geschoeid dan dat van de Remmens. Jan Smeets was vooral bezig met torenuurwerken, zijn zoon meer met huisuurwerken. ${ }^{21}$ Naast genoemde specialisten waren ook mindere goden betrokken bij de werkzaamheden aan torenuurwerken. Veel "gewone" klokkenmakers vonden een neveninkomen in het onderhoud en de modernisering van torenuurwerken.

De vraag naar torenuurwerken was bescheiden. De uurwerkmakers konden, hoe succesvol ook, van de $16 \mathrm{de}$ tot de $18 \mathrm{de}$ eeuw waarschijnlijk niet van de torenuurwerkmakerij alleen leven. Zij waren aangewezen op nevenactiviteiten. Zo was Van Nuyst niet alleen uurwerkmaker, maar ook messenmaker. Personen die het ambt van stadsuurwerkmaker bekleedden, dat hen verplichtte dagelijks het uurwerk op te winden en regelmatig te smeren en kleine reparaties

${ }^{17}$ G. Hansotte 1975 , pp. $281-282$ en p. 289. Voor pogingen de monopoliepositie van de Luikenaars te doorbreken zie R. Evrard 1952, passim.

${ }^{12}$ Zie hoofdstuk II, paragraaf 2.2.1, O.-L.-Vrouwekerk: Artus en zijn zoon Anold Moës, 1642; hoofdstuk II, paragraaf 2.2.3, Sint-Servaaskerk: Lambert Moës, 1679.

${ }^{19}$ F. Pholien 1933, pp. 77-82. Voor de actiwiteiten in Mafra: A. Lehr 1984, passim.

20. Zie Remmen in appendix II. Een torenuurwerk van Comelis Remmen bevindt zich in het Klokkenmuseum te Schoonhoven; een ander in het poortgebouw van kasteel Arcen.

${ }^{2 .}$ Cfr. appendix $I$. 
te verrichten, combineerden dit gewoonlijk met andere werkzaamheden. We zagen reeds de combinatie stadsuurwerkmaker/stadsgeschutmeester. ${ }^{22}$ Maar het kon ook gebeuren dat de landbouw, de horeca of een ander ambacht mede instonden voor het dagelijks brood van het gezin. ${ }^{23}$ Wat betreft het dagelijks onderhoud van torenuurwerken ontmoetten de uurwerkmakers nogal eens concurrentie van kosters, organisten en schoolmeesters.

\subsubsection{De makers van huisuurwerken}

Eind 14de eeuw werd het huisuurwerk met slagwerk en wekkerwerk ontwikkeld. De aandrijving geschiedde aanvankelijk door middel van gewichten, zodat het uurwerk niet verplaatsbaar was zonder de gang te verstoren. De gewichten indiceerden bevestiging aan een wand, zodat zij ruimte hadden om te zakken. Na de uitvinding van de opwindveer rond het midden van de $15 \mathrm{de}$ eeuw in Vlaanderen of Bourgondië kon men tafelklokken en zelfs draagbare uurwerken gaan maken. Deze ontwikkelingen leidden tot een eerste productdiversificatie. Voor zulke producten was een grotere markt dan voor torenuurwerken, hoewel ook deze markt aanvankelijk beperkt was tot afzet bij vorsten en hoge adel. ${ }^{24}$ Een eerste uitbreiding kreeg de uurwerkmakerij in de 16de eeuw. Lang zou dit niet duren. De diepe economische crisis die zich in het laatste kwart van deze eeuw in het Maasdal manifesteerde en twee generaties aanhield, leidde er tot een scherpe teruggang van vraag en aanbod in het laatste kwart van de $16 \mathrm{de}$ en de eerste helft van de $17 \mathrm{de}$ eeuw. ${ }^{25}$ $\mathrm{Na}$ een generatie, waarin de uurwerkmakers het moeilijk hadden, werd het beroep tussen 1600 en 1650 kennelijk aantrekkelijker. Het oudst bewaard gebleven huisuurwerk in de Limburgen dateert uit 1653 , te weten de messing lantaarnklok met astronomische aanduidingen van Jan Muys. De markten waren verengd van interlokale tot een bijna puur plaatselijke omvang. Pas eind $17 \mathrm{de}$ eeuw werden de huisuurwerken bereikbaar voor de burgerij. Parallel met de eerste signalen van economisch herstel nam het aantal uurwerkma-

\footnotetext{
${ }^{22}$ Zie dit hoofolstuk, paragraaf 8.2 .1 .

${ }^{3}$ Cifr. pp. 239-243.

24 A. Chapuis 1954, passim.

2 J. Jarsen 1990 , pp. 141-163.
} 
kers weer toe. In meerdere steden, zoals Maastricht, Roermond, Venlo en Sint Truiden konden de uurwerkmakers een gespecialiseerde beroepsgroep gaan vormen en van de uurwerkmakerij leven. Mensen als Vrijthoff den Jonge, François de Beefe, de families Jonckers, Joosten en Beltjens, om er enkelen te noemen, hebben vrij zeker alléén van het klokkenmaken kunnen leven.

Tabel 8. Aantal vermelde Limburgse uurwerkmakers naar 25-jarige periode

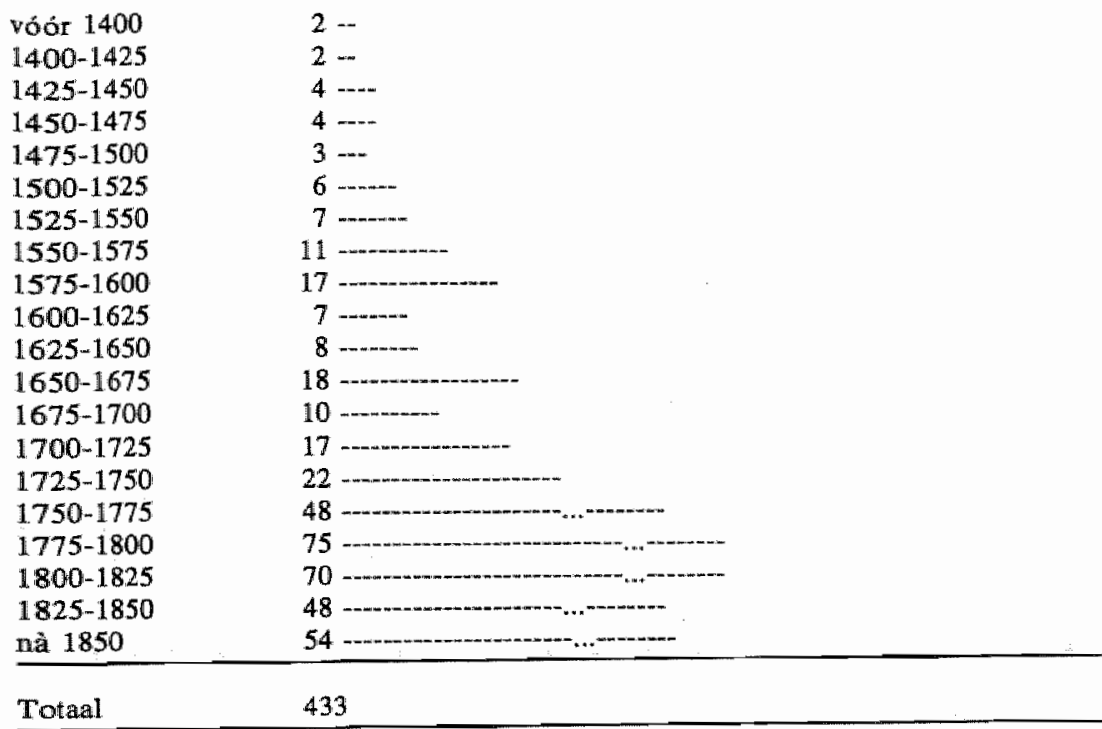

Bron:: tabel 4.

De snelle toename van het gezinsinkomen ten plattelande als gevolg van een verbetering van de productiviteit in de akkerbouw leidde vanaf 1750 tot een ware "boom". Tussen 1750 en 1850 is het aantal uurwerkmakers in de Limburgen bijna viermaal groter dan in de voorafgaande eeuw.

Vraag en aanbod verplaatsten zich naar het platteland. Het was een ingewikkeld proces. Aan de vraagzijde speelde de lange periode van vrede en de gunstige conjunctuur in deze contreien een rol, die voordien zo zeer van oorlogsgeweld te lijden hadden gehad. 
Jansen ${ }^{26}$ stelde een sterke groei vast in de akkerbouw en een regelmatige stijging van het nominale inkomen per agrarisch gezin tussen 1725 en 1783. Daarmee gepaard ging een sterke toename in het gebruik van consumptiegoederen als tabak, brandewijn, wijn, zout, zeep en kolen. Ook de verkeersintensiteit nam in deze periode toe. Geleidelijk ontstond ook vraag naar duurzame consumptiegoederen, zoals bedden, kachels en tafelgerei. Die onwikkeling is voor het westelijk deel van Limburg en het aan het noordelijk deel van Nederlands-Limburg aansluitend Oost-Brabant gedetailleerd onderzocht. De uitkomsten zijn zo consistent dat zij voor de hele regio, die hier wordt bestudeerd, relevant mogen worden geacht.

Weyns schetst voor de $18 \mathrm{de}$ en begin 19de eeuw een toestand in Vlaanderen, dus inclusief Belgisch-Limburg, waarin aanvankelijk zeer weinig bedden, bestek en kachels in de volkswoning en de boerderij werden aangetroffen; vanaf het midden van de $18 \mathrm{de}$ eeuw constateert hij een toename van deze goederen. ${ }^{27}$ Schuurman trof in 1830 in Oost-Brabant in $50 \%$ van de boedels de term "ledikant" aan en in $100 \%$ "bed". $\mathrm{Zij}$ moeten in de voorafgaande dertig à veertig jaar zijn aangeschaft. Bestek wordt in 1830 in $92 \%$ van de OostBrabantse inboedels vermeld. Een kachel is in 1830 in Oost-Brabant in $42 \%$ van de inboedels vertegenwoordigd. Dat is ruim twee keer zoveel als in Oost-Groningen en anderhalve keer zo vaak als in de Zaanstreek, al was ook daar natuurlijk overal een stookplaats. ${ }^{28}$ Het tafelbestek nam in de loop van de 18 de eeuw toe, met name de vork, die voordien slechts sporadisch voorkwam. Deze toename kan worden verklaard door een streven naar hygiënischer eetgewoonten, dringend gewenst in een tijd waarin veel besmettelijke darm- en maagaandoeningen, zoals dysenterie, voorkwamen. Ook kan de overschakeling van brij- en papachtige gerechten naar vaster voedsel een rol hebben gespeeld. Op een kachel kan men bakken en braden, op een open vuur zijn potages en soepen troef. Dat beide factoren een rol speelden, blijkt uit het feit dat ook de lepel in de $18 \mathrm{de}$ eeuw een veel grotere verspreiding kende onder alle bevolkingslagen. Deze tendenzen werden bevestigd in een

\footnotetext{
${ }^{26}$ J. Jansen 1979, pp. 114-127.

${ }^{27} \mathrm{~J}$. Weyns 1974, zie voor bedden pp. 321-353, voor bestek, met name de vork. pp. 562-567 en voor kachels pp. 125-139.

${ }^{28}$ A. Schuurman 1989 , respectievelijk p. 72, p. 84 , p. 101 met tabel 3.27 .
} 
analyse van boedelinventarissen uit Oirschot ${ }^{29}$ uit de periode 1650 1779. De geciteerde werken zijn gebaseerd op boedelinventarissen, opgemaakt na het overlijden van de laatste partner uit het huwelijk, waarvan de leden de beschreven spullen hadden aangeschaft. De boedelinventarissen werden soms wel dertig, veertig jaar na de aankoop opgesteld en geven dus niet precies aan, wanneer een voorwerp in zwang kwam.

In het hiervoor genoemde rijtje van duurzame consumptiegoederen past het huisuurwerk heel goed, zeker op het platteland. De rationeel werkende boer die zijn inkomen wilde vergroten, diende er onder meer voor te zorgen op de markt te zijn op het uur dat de verkoopprijzen het hoogst waren. Dat verreweg de meeste Limburgse uurwerken een zeer luid wekkermechanisme hebben (c.q. hadden), is in dat licht bezien geen toeval. De boeren lagen in de $18 \mathrm{de}$ eeuw ook voor op de stedelingen wat bezit van huisuurwerken betreft, zoals Schuurman heeft aangetoond door analyse van inboedelinventarissen van vergelijkbare sociale groepen in steden en op het platteland. ${ }^{30}$ Heel de familie moest samen met het huispersoneel worden gewekt en aan regelmaat gewend raken. Om tal van redenen dreigde het bezit van een huisuurwerk een plattelandszaak te worden. Er was een grote behoefte aan zo'n instrument omdat torenuurwerken er vaak ontbraken of zo ver weg waren dat ze niet konden worden afgelezen of zelfs maar gehoord. De introductie van pluri-activiteit in de vorm van combinatie van agrarische en ambachtelijke activiteiten, de intrede in een geldeconomie door meer oriëntatie op de markt en betaling van lonen per tijdseenheid vergden een ingrijpende verandering van levensstijl - de noodzakelijke regelmaat in levensritme kon door het uurwerk worden gestuurd - en tenslotte was er een snel stijgende koopkracht die, na vanaf 1725 vooral op voedings- en genotmiddelen gericht te zijn geweest, rond 1750 de vraag naar durzame consumptiegoederen prikkelde.

Dat de aanwezigheid van een groeiende markt voor uurwerken ten plattelande tevens de productie ervan in de dorpen stimuleerde was evenmin verwonderlijk. Voor een deel maakte het de economische cirkel rond. De behoefte van menig agrariër aan bijverdiensten in

29 "Het gebruik van tafellbestek in Oirschot: een voorbeeld", in: H. van Koolbergen 1.988, pp. 33-40.

A. Schuurman 1989 , pp. $270-272$. 
de wintermaanden kon mede worden vervuld door voor een dire omgeving goederen te leveren, zoals uurwerken, waaraan : behoefte was. Bovendien kon men door eenvoudige, efficiënte wil zeggen luid bellende en secuur lopende - uurwerken te leve in een betrekkelijk eenvoudige uitvoering voldoen aan de specifi. vraag van de boer tegen de prijs die hij ervoor over had. Die heel wat lager dan het bedrag dat stedelijke uurwerkmakers als Beefe, De Nève, Jonckers en Schoufs vroegen voor de luxe-uurw ken die zij leverden aan rijke burgers, stadsbesturen en de Thor hoogadellijke stiftsdames. In de beide Limburgen leidde dit a tussen 1750 en 1800 tot een hausse in de uurwerkmakerij, in bijzonder op het platteland, waar het grootste koperspotent was. ${ }^{31}$ In die halve eeuw was $60 \%$ van de uurwerkmakers op platteland gevestigd.

Schuurman en Weyns stelden de veranderingen in het gebruik duurzame consumptiegoederen post factum vast. Zij constateer de resultaten in het eerste kwart van de 19de eeuw. De door gebruikte gegevens geven het productiejaar aan; wanneer hoogtepunt van de productie van huisuurwerken tussen 1775 1825 ligt, betekent dit niet dat de klok eerder werd gekocht dan bed, de kachel of de vork! De afwijkende chronologie dw: niettemin de zaak precies te volgen.

Tabel 9a. Aantal uurwerkmakers steden/platteland

\begin{tabular}{lccc}
\hline & Total & $\begin{array}{l}\text { Negen } \\
\text { steden }^{32}\end{array}$ & Platteland \\
\hline $1700-1725$ & 17 & 9 & 8 \\
$1725-1750$ & 24 & 17 & 7 \\
$1750-1775$ & 48 & 18 & 30 \\
$1775-1800$ & 75 & 31 & 44 \\
$1800-1825$ & 70 & 41 & 29 \\
$1825-1850$ & 48 & 28 & 20 \\
\hline
\end{tabular}

${ }^{31}$ In andere streken kwam de toename van uurwerken op het platteland wat later op gas de boedelinwentarissen van Normandische boeren rond Caen stijgt de aanwezigheir klokken in de huisraad van $20 \%$ tot $40 \%$ tussen $1760-1789$ en 1813-1822. Cfr. Chr. $\mathrm{C}$ reault, J.A. Dickinson and Th. Wien 1994, p. 102.

${ }^{32}$ Hasselt, Maastricht, Tongeren, Sint-Truiden, Sittard, Maaseik, Roemond, Venlo en 1 
Tabel $9 \mathrm{~b}$. Uurwerkmakers in diverse steden

\begin{tabular}{|c|c|c|c|c|c|}
\hline & Hasselt & Maastricht & Tongeren & Sint-Truiden & \\
\hline $1700-1725$ & - & 3 & 3 & - & \\
\hline $1725-1750$ & 2 & 4 & 3 & - & \\
\hline $1750-1775$ & 1 & 7 & 3 & 1 & \\
\hline $1775-1800$ & 6 & 11 & 4 & 1 & \\
\hline $1800-1825$ & 5 & 16 & 1 & 5 & \\
\hline \multirow[t]{2}{*}{$1825-1850$} & 6 & 9 & 1 & - & \\
\hline & Sittard & Maaseik & Roermond & Venlo & Weent \\
\hline $1700-1725$ & 1 & 1 & - & 1 & - \\
\hline $1725-1750$ & - & 1 & 3 & 3 & 1 \\
\hline $1750-1775$ & - & 2 & 1 & 1 & 2 \\
\hline $1775-1800$ & 1 & 2 & 2 & 1 & 3 \\
\hline $1800-1825$ & 1 & 1 & 3 & 4 & 5 \\
\hline $1825-1850$ & 3 & 2 & 1 & 5 & 1 \\
\hline
\end{tabular}

Bron tabellen $9 \mathrm{a}$ en $9 \mathrm{~b}$ : Appendix $\mathrm{nL}$

Wanneer de aantalen uurwerkmakers in het onderzoeksgebied in de periode 1750-1800 op het platteland worden vergeleken met de steden, dan wordt de bovenvermelde explosieve toename van uurwerkmakers in de tweede helft van de 18 de eeuw vooral op het platteland cijfermatig onderschreven. In de steden is het aantal uurwerkmakers in de tweede helft van de 18 de eeuw nog niet dubbel zo groot als in de eerste helft van de eeuw; op het platteland was het vervijfvoudigd. Tussen 1750 en 1800 was $60 \%$ van de uurwerkmakers in de Limburgen op het platteland woonachtig. In de eerste helft van de 19 de eeuw verschoof het evenwicht weer ten gunste van de steden. In de jaren 1800-1850 was nog slechts $42 \%$ van de uurwerkmakers op het platteland gevestigd. De verhoudingen waren weer zoals een eeuw tevoren. Dat past in het kader van de algemene verschuiving van ambachtelijke en industriële activiteiten van het platteland naar de stad. ${ }^{33}$ Daar zijn diverse redenen voor aan te halen. We vermelden er hier slechts twee. Vooreerst maakte de Franse wetgeving in 1796 een einde aan economischinstitutionele verschillen tussen stad en platteland: de gilden, tienden en herendiensten werden afgeschaft. De belastingdruk werd

${ }^{33}$ C. Wijnen 1995, pp. 44-61. 
meer uniform. In plaats van de lagere transactiekosten op het platteland traden nu de schaalvoordelen van de stad met haar groter afzetgebied op de voorgrond. ${ }^{34}$ Van minstens zo groot belang was, dat onder meer door de verdwijning van tienden en herendiensten de verdiensten uit landbouwactiviteiten groter werden; een verdere intensivering van de landbouw vond plaats: voor nevenactiviteiten was minder tijd. Specialisatie deed zijn intrede. Wie koos voor het beroep van uurwerkmaker was in de stad beter op zijn plaats. ${ }^{35}$

Een stimulans voor de sterke toename van het aantal uurwerkmakers was sind 1750 ook de mogelijkheid tot gebruik van half afgewerkte componenten, zoals voorgegoten tandwielen, die men wel zelf nog moest uitfraisen. Dit hielp de kosten laag te houden door toeleveranciers in te schakelen. Zo kocht de uurwerkmaker $\mathrm{J}$. Brienen te Venray messing raderen van een zekere Fölling uit Kleef. ${ }^{36}$ Het waren halffabrikaten in de meest letterlijke zin van het woord. Het was niet mogelijk helemaal afgewerkte en perfect passende onderdelen te kopen voor uurwerken die niet in serie werden vervaardigd, maar die van streek tot streek een eigen karakter hadden. $\mathrm{Na}$ het uitfraisen van de tanden kwam voor de lokale ambachtsman nog het delicate werk om de ideale ingrijping van de tandwielen, de "engrenage", te bewerkstelligen.

Het hier beschreven fenomeen van toelevering deed zich ook elders in Europa voor. Volgens W. Pryce and T. Davies ${ }^{37}$ kwamen ook in Wales in de late 18de eeuw half afgewerkte onderdelen op de markt. Lage loonkosten waren daarbij van belang. Vrij algemeen zijn de economisch-historici van oordeel dat de allocatie van delen van de nijverheid, in het bijzonder textiel en metaal, op het platteland in de 18 de eeuw samenhangt met de lage lonen aldaar, waar het in de 18 de eeuw gebruik was in de wintermaanden, als er op de boerderij niet veel te doen was, een bijverdienste te zoeken. Die hoefde niet veel op te brengen. Het ging er maar om wat extra inkomen te verwerven. Wel moest men in een paar maanden tijd

${ }^{34} \mathrm{~J}$ Jansen, manuscript, p. 16.

${ }^{35}$ J. Jansen 1994, pp. 277-291; idem 1993a, pp. 127-144, met name pp. 135-136.

3f R.A.M., Schepenbank Venray, evacuatienummer 3956, boedelinventaris van Joannes Brienen.

${ }^{37}$ W. Pryce and T. Davies 1985 , p. 20 : "The clock maker, however, would probably have obtained his raw materials and (later in the eighteenth century) semi-finished parts by other means". 
zijn producten gereed hebben. Doorwerken in het drukke voorjaar leverde verliezen op.

Een ogenblik moeten we ook nog stilstaan bij de hiervór al genoemde gildedwang. Men had ten plattelande geen last van stedelijke reglementeringen en gildedwang. Dat gold in het bijzonder voor de textielnijverheid, die sinds 1750 onder meer Aken ontvluchtte, ${ }^{38}$ maar ook voor de uurwerkproductie. Juist in de jaren 1750-1795 zijn er aanwijzingen voor een verscherpte gildedwang in de steden, die de toevloed van nieuwe uurwerkmakers daarheen moest afremmen. Zo gingen enkele Zuid-Nederlandse steden van immigrerende uurwerkmakers de naleving van de bepalingen met betrekking tot leerbrief en proefstuk streng controleren. Het initiatief tot dergelijk ingrijpen ging gewoonlijk uit van aldaar reeds gevestigde branchegenoten.

Door de magistraat van Brussel werden op verzoek van de plaatselijke uurwerkmakers in 1750 en 1766 ordonnanties uitgevaardigd, die het nieuwkomers lastig maakten zich in de stad te vestigen. De Brusselse uurwerkmakers vormden, sinds de $17 \mathrm{de}$ eeuw, samen met de slotenmakers één ambacht. Om dit ambacht van "den onderganck ende ruïne" te redden, bepaalde de Brusselse magistraat in 1750 dat iedereen die vrijmeesterhorlogemaker wilde worden voortaan een proefstuk moest maken, hetzij een klein of een groot horloge, in aanwezigheid van de ambachtsdekens. In 1766 werd dit nog aangescherpt met de eis, dat het uurwerk "geheel gestelt ende ganschelyk volmaeckt" moest zijn op het moment van de beoordeling, wat wilde zeggen dat het uurwerk dan helemaal afgewerkt en afgeregeld moest zijn. ${ }^{39}$ In 1752 deden de Antwerpse uurwerkmakers een, overigens vergeefse, poging in dezelfde richting. Dat in Antwerpen de eisen niet werden aangescherpt, had in het oog springende gevolgen: in 1738 waren er in de stad vijf meesteruurwerkmakers, vier knechten en één leerjongen, maar tegen het einde van de $18 \mathrm{de}$ eeuw telde men niet minder dan 42 meesters en 63 leerjongens. In 1794 lieten zich vier nieuwe meesters inschrijven en in 1795 zelfs vijf! ${ }^{40}$ In Brugge golden reeds sedert 1714 strikte bepalingen betreffende het maken van een proefstuk, te weten "een camer oorlogie ofte pendule". Dit werkte blijkbaar zo remmend, dat er van

3* C. Wijnen 1995, ibidem.

A. Stroobants 1993d, pp. 82-84.

4 A. Stroobants 1993a, pp. 60-70. 
1750-1796 in het geheel geen nieuwe uurwerkmakers werden opgenomen. Het stadsbestuur werd daarom iets soepeler. Degenen die alleen zakhorloges maakten, repareerden en verkochten, hoefden het smedenambacht niet te verwerven omdat hun beroep als een "vrij conste en negotie" werd beschouwd. ${ }^{41}$ Of dit leidde tot een toename van het aantal "horlogers" of tot een wijziging in de wijze, waarop immigranten zich bij aankomst in de stad presenteerden, weten we niet. Er zijn geen lijsten van niet-leden van een gilde met aanduiding van hun beroep. De stad Gent voerde daarentegen een liberaal beleid ten anzien van nieuwe uurwerkmakers. Via een decreet werd aan steeds meer kandidaat-horlogemakers op hun verzoek vrijstelling van leerjaren en van poorterschap verleend. Veel hielp het niet. Er waren in de eerste helft van de $18 \mathrm{de}$ eeuw 24 uurwerkmakers in de stad en in de tweede helft 23. Dankzij het gevoerde beleid was er hooguit geen sprake van achteruitgang. ${ }^{42}$ Soortgelijke ordonnanties zijn in de beide Limburgen niet gevonden, behalve een ordonnantie van 1773 uit Venlo. Daarin werden de eisen om in het smedenambacht te worden opgenomen verscherpt, met name werden "eenen behoorlijcken leerbrieff" en een "proeff" vereist. Of het voorschrift ook voor de uurwerkmakers gold is niet duidelijk. Voor verschillende vakrichtingen binnen het ambacht worden de proeven opgesomd, maar voor uurwerkmakers wordt geen proef genoemd. Wel werd uitdrukkelijk onderscheid gemaakt tussen de horlogemakers die een smidsvuur en blaasbalg hadden, en zij die dit niet hadden. De laatste categorie werd uit het smedenambacht gezet en in het Sint-Lucasgilde, het kunstenaarsgilde, ondergebracht. Het is de vraag of deze groep voor ons interessant is. $\mathrm{Zij}$ verkochten mogelijk alleen geïmporteerde zakhorloges. ${ }^{43}$

Tenslotte zij hier melding gemaakt van een besluit van een gilldebestuur. In Roermond probeerde het smedenambacht in 1744 Godefridus Andriessens, die waarschijnlijk van buiten Roermond kwam, te beletten "horlogiewerk" te maken. De Roermondse magistraat gaf Andriessens enig respijt. Hoe het is afgelopen, is niet bekend. ${ }^{44} \mathrm{Op}$ grond van deze twee min of meer toevallige berichten kunnen we zeker niet concluderen, dat er in de "Limburgse" steden door de

\footnotetext{
${ }^{41}$ A. Stroobants 1993 b, pp. $71-82$.

12 A. Stroobants $1993 \mathrm{c}$, pp. 84-88.

43 A. Flament 1913 a, pp. 57-59 en 65-67.

${ }^{14}$ G.A.R., Oud-archief, donderdagse protocollen, inv.nt. 33, d.d. 17.09.1744.
} 
ambachten systematisch een politiek is gevoerd, die de vestiging van uurwerkmakers in de steden afremde, hooguit kunnen we zeggen dat pogingen in die richting niet ontbraken. Mogelijk verklaart dit de toename van het aantal uurwerkmakers in Hasselt en Maastricht tegen het einde van de 18 de eeuw. In de meeste andere steden was het getal uurwerkmakers overigens zo gering, dat het probleem zich niet stelde. Economische omstandigheden domineerden in onze streken voorshands de allocatiefactoren.

De uurwerkmakers op het platteland waren tot ver in de 19de eeuw genoodzaakt een nevenberoep uit te oefenen. De combinatie van beroepsactiviteiten met heel verschillende achtergrond kwam tussen 1750 en 1914 veel voor, al veranderde zij tussentijds van karakter. Tot $1800-1815$ vulde de boer de lege tijd in de wintermaanden met enige ambachtelijke activiteiten. Rond het midden van de $19 \mathrm{de}$ eeuw waren het juist de ambachtsman en de slecht betaalde vertegenwoordigers van de sector maatschappelijke dienstverlening die van een lapje grond sociale zekerheid haalden: de dorpsschoolmeester cumuleerde de functies van onderwijzer, organist en klokkensteller; daarbij had hij vaak nog wat grond, zodat zijn gezin in ieder geval te eten had. Vooral in de ambachtelijke sfeer was specialisatie zeldzaam, zoals blijkt uit een overzicht van beoefenaars van voor het leger nuttige beroepen ${ }^{45}$ uit 1815 . De timmerlieden, rademakers, smeden, slotenmakers, gieters, metselaars, bakkers, kleermakers en schoenmakers oefenden hun specifiek beroep uit en waren daarnaast ook boer en/of dagloner. Zo staat bij Herten onder Roermond een hele opsomming van ambachten/beroepen: 3 timmerlieden, 1 wagenmaker, 3 smeden, 2 kleermakers, 1 schoenmaker, 2 klompenmakers, 2 bierbrouwers, 8 kroeghouders (cabaretiers), 24 schippers, 1 schoolmeester en daaronder als opmerking: allen zijn daarbij nog landbouwer. Onder Haelen, eveneens vlakbij Roermond, staat de aantekening: niemand behalve de hoefsmid heeft een eigen werkplaats en allen zijn tevens boer. In Schinnen heet het na de opsomming van de ambachtslieden: zijn allen dagloners behalve de smeden. Bij Hoesselt, vlakbij Bilzen, wordt na opsomming van de ambachtslieden vermeld: dezen zijn

*s Algemeen Rijksarchief, 's-Gravenhage, Archief Ministerie vam Oorlog, archief van de kwartiermeester generaal en generale staf, inv.nr. 220-223, "Nombre des différentes espèces d'artisans, tels que de menuisers, de charrons, de maréchaux, sernuriers, fondeurs, maģons, boulangers, tailleurs, cordonniers etc." [1815]. 
allen dagloners. Men kon ze inhuren voor een overeengekomen tijd en beloning. Hetzelfde geldt voor nagenoeg alle andere genoemde plattelandsgemeenten.

Over het algemeen worden in deze bron geen klokkenmakers vermeld, ook niet in plaatsen waarvan we weten dat er in 1815 uurwerkmakers waren. Dat hangt samen met het doel van de enquête. De kwartiermeester-generaal wilde weten, waar hij eventueel troepen kon onderbrengen en welke infrastructuur aanwezig was voor hun verpleging, het onderhoud van de wapenen en de instandhouding van de transportmiddelen. Uurwerkmakers spelen daarin geen rol en worden slechts bij toeval vermeld. Alleen in Thorn wordt één uurwerkmaker genoemd en in Sint-Truiden twee. Onder de uitvoerig genoemde slotenmakers en smeden schuilen vermoedelijk heel wat parttime uurwerkmakers. Uit andere hoofde weten we dat dergelijke combinaties in de ambachtelijke sfeer veelvuldig voorkwamen. Op het Limburgse platteland werd tot in de 19de eeuw de combinatie smid-klokkenmaker frequent aangetroffen. Voorbeelden daarvan vormden Janssen in Sint-Odiliënberg, Houtappels in Nederweert en Kuijpers in Stevensweert. Raetsen te Heythuysen, Haertmans in Beek en Kleinjans in Doenrade waren zowel slotenmaker als uurwerkmaker. Zeer frequent was de koppeling van ambacht en dienstverlening, niet verwonderlijk in een gewest, waar de dienstensector zwarar onderbezet was. Zo was de combinatie caféhouder-uurwerkmaker geliefd. Voorbeelden vormen: Hendrick Sijmkens te Kinrooi, Ch. Streel in Hamont, P.M. Dirix te Weert en G.H. Vrencken te Echt. Van het bedrijf van één van hen, Dirix te Weert, is een foto bewaard (zie afbeelding 106). De combinatie winkelier-uurwerkmaker treft men aan bij Brienen te Venray en Van de Winckel in Neeritter. Beiden hadden ze een aanzienlijk debiet. Boer-klokkenmaker was slechts ogenschijnlijk een zeldzaamheid, zoals J.A. Kleinjans te Oirsbeek, Bins te Hamont en Van Poll te Ell laten zien ${ }^{46}$ Vaak zijn de agrarische activiteiten niet expliciet vermeld omdat het bewerken van een lapje grond werd verondersteld. Een dergelijke achterwaartse binding gold als normaal.

\footnotetext{
${ }^{46}$ Een zeer goed beeld van een boer, die tevens klokkenmaker was, wordt geschetst in: W. Pryce and T. Davies 1985. Dit boek is gebaseerd op het bewaard gebleven Account Book van Samuel Roberts, een boer-uurwerkmaker in Wales $( \pm 1720-1800)$.
} 

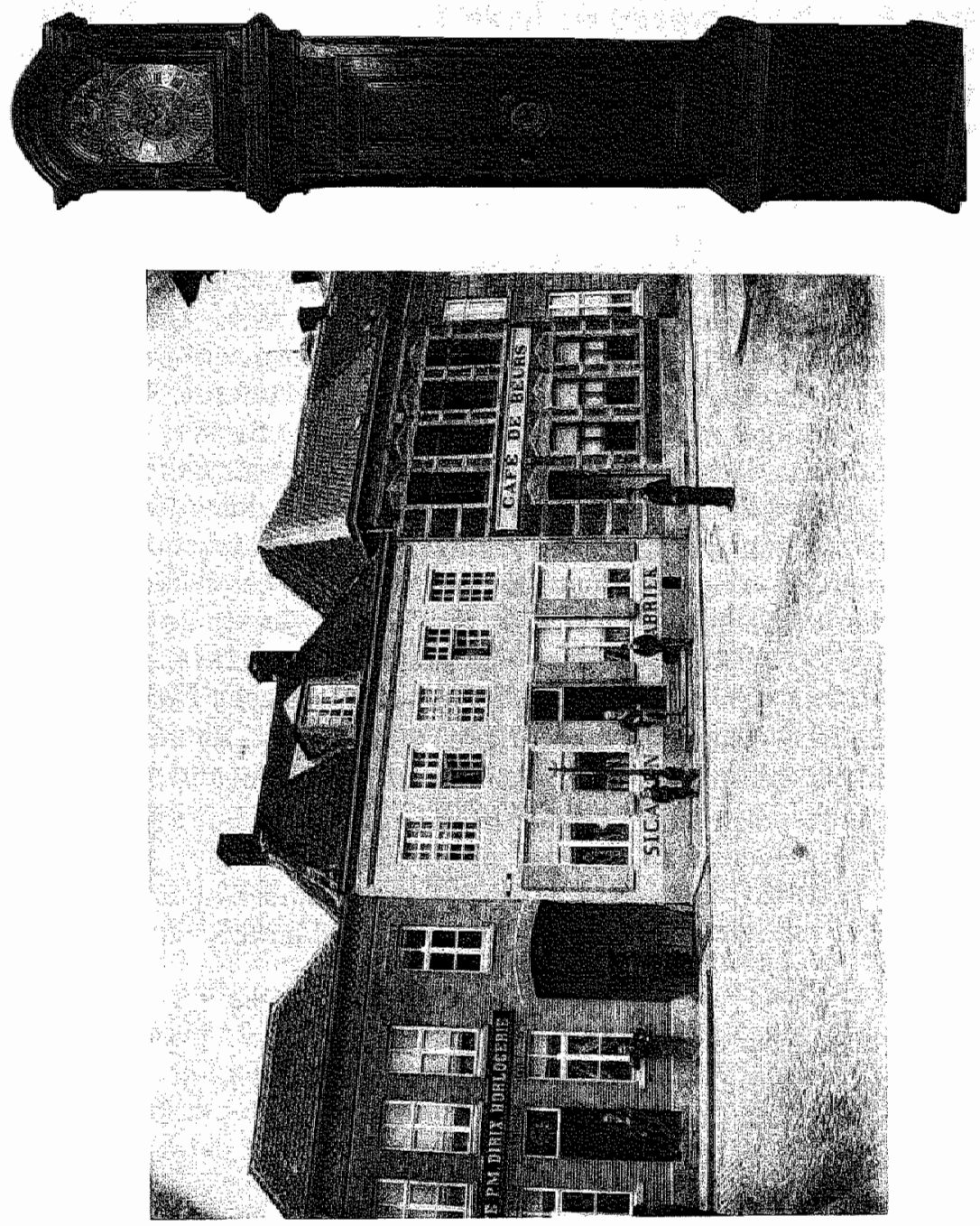

106. (1.) Café annex klokkenzaak van P.M. Dirix, Langstraat, Weert, circa 1890. Voordien stond op deze plek het 16de-eeuws huis "De Golden Cop", waarin Dirix ook al was gevestigd

107. (r.) Staande klok in 18de-eeuwse stijl, gedateerd 1878 (P.W. Wessels, Geleen) 
Opmerkelijk zijn combinaties van houtwerwerkende beroepen en uurwerkmakerij. Een voorbeeld van het samengaan van wieldraaier en uurwerkmaker vormt G. Trommar te Horst. Timmerman-uurwerkmaker waren Stiggeneer in Swalmen, J. Kessels in Baarlo en Schampers in Horst. Van elk van deze timmerlieden is echter slechts één klok, respectievelijk één zakhorloge, bewaard. Mogelijk hebben ze die voor eigen gebruik gemaakt en kochten ze het uurwerk van een klokkenmaker, waaraan ze vaker klokkasten leverden, om vervolgens hun eigen naam op het uurwerk te zetten. Gezien de uitzonderlijk geringe productie blijft het de vraag of men kan spreken van een combinatie van beroepen, temeer daar het uurwerk hoogstwaarschijnlijk geen eigen werk is.

De uurwerkmakerij werd bij voorkeur gecombineerd met werkzaamheden in de metaal- en houtsector en de economische dienstverlening. Enige verwantschap van de activiteiten was een pre: het betekende een daling van transactiekosten. Vanzelfsprekend leverden hoofdbezigheden in de metaalsector wat extra knowhow op. De vaardigheid om zowel uurwerk als klokkenkast te vervaardigen verstevigde de concurrentiepositie. Het bezit van een winkel of café versterkte de band met de markt. Het laatste genoot de voorkeur. In deze sfeer vinden we dan ook zeer vroege combinaties. Mr. Salomon de Bochstey (alias Boechten) was omstreeks 1560 behalve uurwerkmaker waard in "de Moriaen" te Tongeren; de uurwerkmaker Richard van Intbrouck verkocht in 1754 zijn huis "De Saligmaker" in de Kapelstraat te Hasselt samen met een brandewijnketel en het stokersgereedschap. Hij zal niet alleen voor eigen behoeften hebben gestookt. Op grond van het bovenstaande kunnen we het volgende overzicht opstellen van beroepencombinaties van uurwerkmakers, die meer dan eens optreden:

uurwerkmaker-smid uurwerkmaker-slotenmaker uurwerkmaker-caféhouder uurwerkmaker-boer uurwerkmaker-timmerman uurwerkmaker-wieldraaier uurwerkmaker-winkelier uurwerkmaker-brandewijnstoker 
Meer dan de helft van de Limburgse uurwerkmakers had in de late 18 de eeuw een tweede beroep. De uurwerkmakerij bleef in Limburg een nevenberoep. Dat was ook in de eerste helft van de 19 de eeuw vaak nog zo, althans ten plattelande. Daarna verdween het fenomeen even snel als het was opgekomen. $\mathrm{Na} 1850$ was er geen droog brood meer aan te verdienen. In het tweede kwart van de 19 de eeuw kregen de uurwerkmakers in deze streken sterke concurrentie van de Schwarzwald-klokken. Deze grotendeels houten wandklokken waren licht van gewicht, zodat één man er enkele tientallen op zijn rug kon torsen en uitventen. Daarbij waren ze door serieproductie in de huisindustrie laag in prijs. Ook sprak de vormgeving blijkbaar aan. De opkomst van de pendules en de schoorsteengarnituren zette de Limburgse uurwerkmakerij verder onder druk, zeker sinds vanaf 1807 de Franse pendules op industriële wijze werden geproduceerd door Japy Frères. ${ }^{47}$ Toen vervolgens ook nog in de Duitse landen de klokkenfabricage op industriële wijze werd opgezet en daardoor goedkope wandregulateurs op de markt kwamen, kreeg de Limburgse ambachtelijke uurwerkmakerij de doodsteek. Het had geen zin door te gaan. Allerlei andere bijverdiensten loonden beter. In een tijd dat er wat meer werd gebouwd, kon de timmerman zich beter als aannemer opwerpen, terwijl de smid vanwege de aandacht die het beslaan van paarden kreeg als hoefsmid, tevens grofsmid, goed de kost kon verdienen. In café en winkel zorgden graan- en boterhandel voor wekelijkse inkomsten. Dat kon van de handel in klokken bepaald niet meer worden gezegd.

Globaal kan men stellen, dat de Limburgse klokkenproductie rond 1850 tot stilstand kwam. Slechts incidenteel werden nog staande klokken in de oude trant vervaardigd, bijvoorbeeld door Petrus Wilhellmus Wessels te Geleen in 1878 . Het was een uitzondering die de regel bevestigde (zie afbeelding 107). Zoals gewoonlijk, waren er ook nu slachtoffers. De marginale uurwerkmakers op het platteland moesten terugschakelen naar hun vroegere agrarische activiteiten en het incidenteel repareren van uurwerken.

\footnotetext{
"Ftéderic Japy had al in 1779 een bedrijf, waarin hij op industriêle wijze "ébauches" (onafgewerkte uurwerken) maakte. In 1801 had hij al driehonderd man in dienst en produceerde honderdduizend ebauches per jaar. In $1807 \mathrm{kwamen}$ zijn zonen in de zalak, die nog grootschaliger gingen werken. Zie A. Smith (ed.) 1979, pp. 235-236.
} 
De klokkenmakers in de steden pasten zich beter aan. Zij werden wederverkopers van fabrieksproducten, reparateurs en juweliers, wat ze in feite nog zijn, hoewel de meesten het repareren weer uitbesteden aan thuiswerkers. Deze ontwikkelingen laten zich al aflezen uit de tabellen $9 a$ en $9 b$. Sedert 1800 daalde het aantal uurwerkmakers ten plattelande snel. In 1850 was er nog slechts hier en daar een over, terwijl de grotere handelssteden een ruim aantall wederverkopers van uurwerken herbergden. Geen enkele van de oude uurwerkmakersfamilies ten plattelande, zoals de Raetsens, de Remmens, de Wesselsen, de Petersen, ging zich in een stad vestigen om zich aan de nieuwe situatie aan te passen. Sommigen gingen op de oude voet verder met een nog lagere productie dan voorheen; de meesten schakelden over op andere beroepen. Alleen enkele Trommars vestigden zich in de tweede helft van de 19de eeuw in steden en werden horloger-juwelier. In deze contreien kon men niet, zoals in Engeland, overstappen naar nieuwe beroepen in de industrie, aanvankelijk de machinebouw voor de textielindustrie, later de stoommachinebouw en de machinebouw in het algemeen. Textielfabrikanten vroegen in Engeland al in 1771 naar klokkenmakers met kennis van tandwieloverbrengingen, vooral degenen die tandwielen uit hout of metaal konden snijden. In 1791 was er door de zuigkracht van de Noord-Engelse katoenindustrie zelfs in Londen een tekort aan uurwerkmakers. ${ }^{48}$ De industriële revolutie had de beide Limburgen vón 1850 nog niet bereikt. Alleen aan de periferie van het gebied was in Vaals, Eijsden, Monschau en Verviers sprake van textielnijverheid op industriële schaal. Luik en omgeving kwamen door Cockerills activiteiten in een stroomversnelling. Over het aantrekken van uurwerkmakers door deze industrieën is echter niets bekend.

\subsection{De sociale positie van de uurwerkmakers}

Gedurende het Ancien Régime kon en mocht een vakman in een stad slechts functioneren binnen één der gilden of, zoals deze corporaties in de Limburgse steden soms heetten, de ambachten. ${ }^{49}$

\footnotetext{
${ }^{48}$ H. Lintsen (hoofdred.) 1992-1995, deel IV, pp. 37-38.

${ }^{40}$ Im Marstricht waren drie gilden, te weten het apothekers-, het chinurgijns- en het schippersgilde. De andere 20 corporaties - 21 na de afsplitsing in 1662 van de goud- en zilversmeden -
} 
Vanwege het geringe aantal uurwerkmakers waren er in deze contreien geen specifieke uurwerkmakersgilden. Trouwens ook in belangrijke uurwerkcentra als Parijs, Neurenberg, Blois, Genêve en Londen kwamen er pas relatief laat aparte klokkenmakersgilden tot stand als afsplitsingen van de smedengilden. ${ }^{50}$ In Maastricht scheidden de goud- en zilversmeden zich in 1662 af van het smedengilde. De uurwerkmakers bleven echter, zolang de ambachten bestonden, lid van het smedenambacht, althans in theorie. De praktijk was veel genuanceerder. Verscheidene uurwerkmakers, ${ }^{51}$ die tussen 1747 en 1793 het burgerschap van Maastricht verwierven, werden bij de eedaflegging gepresenteerd door meesters van diverse ambachten en werden daar ook lid van. Het smedenambacht was daar niet bij. Een uurwerkmaker kon zelfs functioneren binnen het brouwersambacht! De mening van Ubachs, ${ }^{52}$ dat het presenterende ambacht niets zegt over het werkelijk uitgeoefende beroep, wordt bevestigd. Zo'n handelwijze lijkt haaks te staan op het principe, dat het ambacht zijn leden bestaanszekerheid verschafte door uitsluiting van concurrentie en beunhazerij. Met name de kwaliteitscontrole ontbrak. Welke leerbrief zou een uurwerkmaker/brouwer moeten overleggen en welk proefstuk kon hij maken?

Hoe was het tot deze opstelling van de ambachten gekomen? Sinds het midden van de $17 \mathrm{de}$ eeuw was met de lokale handel ook het gilde ingrijpend van karakter veranderd. Nu men niet meer voor internationale markten werkte, maar voor kopers uit de eigen stad of de directe omgeving die aan de winkeldeur verschenen, had kwaliteitscontrole nauwelijks meer zin. ${ }^{53}$ Knoeierijen brachten niet langer de afzet van de hele groep vaklieden in de stad in gevaar, maar diskwalificeerden alleen de knoeier. Het kwaad strafte zichzelf. Een ander belang van het gilde bleef evenwel overeind: sociale zekerheid diende het te blijven bieden, zij het op een andere manier, bijvoorbeeld door zich op te werpen als onderlinge verze-

heetten ambachten. Zie H. Lorijn 1980 en P. Ubachs 1992, pp. 232-245.

${ }^{90}$ Parijs 1544, Neurenberg 1565, Blois 1600, Genève 1601, Londen 1631. In Augsburg blevert ze in het smedengilde, welliswar met eigen bevoegdheden. In Luik poogde men in 1781 tot een apart gilde te komen, hetgeen nooit gelukt is. Zie F. Pholien 1933, pp. 100-103.

${ }^{51}$ Te weten: François de Beefe, 1747, kremerambacht; François N. Guilbert, 1752, brouwers ambacht; Arnold de Nève, 1758, goudsmitsambacht; Emanuel Bach, 1777, kremerambacht; Gerard Hamaide, 1777, kremerambacht; J.F.N. Hamoir, 1791, kremerambacht; Guillaume A. Fraiture, 1793, kremerambacht. Zie P. Ubachs 1993.

${ }^{52}$ P. Ubachs 1990, p. 43.

${ }^{53}$ M. Prak 1994, pp. 20-21. 
kering, die bij ziekte, invaliditeit en overlijden uitkeringen verstrekte ${ }^{54}$ Onder die omstandigheden kon men beter lid worden van een ambacht met goed gevulde $\mathrm{kas}^{55}$ dan zich aansluiten bij een kleine groep weinig welgestelden als de smeden, die het beter verdienende deel van hun achterban, de goud- en zilversmeden, inmiddels hadden verloren. Van zulke lieden had men alleen last: de leden van verschillende vakrichtingen binnen zo'n ambacht beloerden elkaar angstvallig om te verhinderen dat een nieuwkomer op hun bescheiden markt penetreerde, zoals bleek uit de boven geciteerde Venlose ordonnantie van 1773. In Venlo werd om die reden in 1773 een scheiding bewerkstelligd tussen de horlogemakers die een smidsvuur en blaasbalg hadden en zij die dit niet hadden. De laatste categorie werd uit het smedenambacht gezet en in het Sint-Lucasgilde, het kunstenaarsgilde, ondergebracht. ${ }^{56}$ Van een verdeling van de weerstandskas werd niet gerept.

Nadelen had het nieuwe systeem genoeg. Een nieuw lid maakte de spoeling voor de zittenden dunner, tenzij hij de kas stevig spekte. In Maastricht overheerste in de late $18 \mathrm{de}$ eeuw kennelijk het financiële aspect: elk gilde probeerde zo veel mogelijk geld te halen uit de aanmelding van nieuwe leden. De entreegelden gingen voortdurend omhoog.

De gillden haalden met hun ruime interpretatie van het aannemingsteglement vooral kapitaalkrachtige personen in huis. Daar hoorde kennelijk menig uurwerkmaker bij. Binnen de ambachten namen uurwerkmakers vaak een prominente plaats in, onder meer als bestuurder. ${ }^{57} \mathrm{Zij}$ waren vaak ook in de belangrijkste winkelstraten van de Limburgse steden gevestigd. Zo woonden Liefsoens en later L. Joosten te Hasselt in de Kapelstraat. Te Roermond huisde Beltjens op de Markt en Dionisij in de Brugstraat. Te Venlo stond het huis van Van Boom op de Markt. In Maastricht vinden we Vrijthoff en De Beefe in de Grote Staat. De laatste verhuisde later naar de Markt. Jacob Joosten en Severin Joosten waren gevestigd in Maaseiks belangrijkste winkelstraat: de Boschstraat. Het café annex horlogerie van P.M. Dirix lag aan de Markt te Weert.

54 J. vam Genabeek 1994, pp. 63-91, vooral pp. 75-89; M. de Ridder 1994, pp. 107-121.

35 J. van Genabeek 1994, p. 80 , geeft aan dat de gilden gemiddeld enige duizenden guldens aan obligaties hadden. De Amsterdamse gilden echter bezaten drie keer zoveel als de andere. 56 Zie noot 42.

${ }^{57}$ J. Leunis 1958 , pp. 297-298. 
In het stadsbestuur van de grotere steden hadden gewoonlijk geen uurwerkmakers zitting. In enige steden dienden zij bij bepaalde gelegenheden wel als (bestuurs-)lid van het smedenambacht te worden geraadpleegd. Alleen een klein stadje als Hamont had verscheidene keren een uurwerkmaker als burgemeester. Vader en zoon Smeets vervulden die functie meermalen. Ook op het platteland trof men uurwerkmakers aan als burgemeester. Mathias Raetsen Jr. bekleedde dit ambt binnen het dorp Heythuysen.

Sommige uurwerkmakers waren zeer gefortuneerd. Martin Deeckens van Hasselt kon in 1606 een lening van duizend gulden, in die tijd een som gelijk aan bijna een kilo goud, verstrekken aan de stad Sint-Truiden. De Vrijthoffs in Maastricht deden in de 17de-18de eeuw herhaaldelijk grondaankopen. Jacobus Joosten in Maaseik bezat volgens de delingsakte van de erfenis na het overlijden van zijn vrouw in 1819 zeer veel grond alsmede de hoeve Swevershof te Kessenich benevens meerdere huizen te Maaseik. Wilhelmus Wessels te Geleen was volgens de boedelverkoop na zijn overlijden in 1816 zeker niet onbemiddeld. Mathias Raetsen Sr. te Heythuysen kon zich in 1805 permitteren een remplaçant voor zijn dienstplichtige zoon te huren. Lambrecht Blaesen was gehuwd met een dochter uit het Hasseltse magistraatsgeslacht Squaden. ${ }^{58}$

Naast deze voorbeelden van "fortuin" zijn er ook gevallen wan uurwerkmakers die het niet voor de wind is gegaan. Hermanus Petrus Beltjens te Roermond failleerde in 1808. Zouden zijn klokken met beschilderde toog, die hij als enige Limburgse klokkenmaker heeft gemaakt, niet zo in de smaak zijn gevallen? Joannes Balthasar Schoufs uit Thorn kon in 1809 zijn schulden aan collegauurwerkmaker J.W. Leurs uit Sittard niet betalen en moest land te Maasbracht verhypothekeren om tenminste een deel van zijn schulden te kunnen aflossen.

Wanneer men het reilen en zeilen van Joannes Brienen te Venray bekijkt, krijgt men de indruk dat hij het ene gat stopte met het andere: hij sloot verscheidene leningen bij familieleden en mensen in en om Venray. Ook leefde hij sterk op groothandelskrediet. Zijn nalatenschap speelde met moeite quitte en dat alleen omdat verscheiden schuldeisers genoegen namen met een korting op hun vorderingen. ${ }^{59}$

\footnotetext{
58. Voor de familie Squaden zie G. Caluwaerts 1989, vooral pp. 64-65.

${ }^{59}$ Zie dit hooldstuk, paragraaf 8.4 .
} 
Ook Arnoldus Zelen te Venray boekte in zakelijk opzicht weinig succes. In 1788 had hij het klokkenmakersgereedschap uit de boedel van Brienen gekocht voor een bedrag van driehonderd gulden Kleefs. Daarna en misschien daardoor raakte hij zo in de schulden, dat zijn goederen en die van zijn moeder, die borg voor hem had gestaan, op 20 april 1790 openbaar werden verkocht. ${ }^{60}$ De familie Van Pol kan als een "sociale daler" worden aangemerkt: Joannes van Pol kon lezen en schrijven, althans een behoorlijke handtekening zetten. Zijn kleinkinderen, de kinderen van zijn zoon Peter van Pol, konden op één na hun naam niet schrijven. Zij waren - behalve Hendrik en Cornelius - niet meer werkzaam in de uurwerkmakerij, maar in de landbouw.

De uurwerkmakerij was een kostbare aangelegenheid met flinke risico's. Daarom deed de oude vertrouwde tactiek om het familievermogen bijeen te houden en langzaam van geslacht op geslacht uit te bouwen ook bij de uurwerkmakers opgang. Heel wat Limburgse uurwerkmakers behoorden tot echte uurwerkmakersfamilies, die minstens drie generaties uurwerkmakers hebben voortgebracht. Het betreft de families Remmen in Well en Boxmeer, Trommar in Horst, Raetsen in Heythuysen, Van Pol in Kelpen, Ell, Thorm en Buggenum, Joosten in Maaseik, Hasselt en Rekem, Schoufs in Thorn, Beltjens in Roermond, Pe(e)ters in Zutendaal en Opglabbeek, Wessels in Geleen, Jonckers in Maastricht, Vrijthoff in Maastricht, Valkenburg en Den Haag, De Beefe in Thimister, Luik, Maastricht, Aken en Mechelen, Bla(e)sen en Colen (Koelen) in Hasselt en De(ec)kens in Tongeren en Hasselt.

Nogal vaak is sprake van regionalisering van het bedrijf. Met een broer of zoon twintig, dertig kilometer verderop kon men meer klanten bedienen en het familievermogen verruimen. Van de hiervóór genoemde families greep precies de helft naar dit wapen.

Een tweede techniek om het bezit te consolideren, een op vermogensworming gerichte huwelijkspolitiek, bekend van de adel en de boeren uit de late Middeleeuwen en de Moderne Tijd, treft men eveneens aan. Tussen welgestelde uurwerkmakers werd vaak onderling getrouwd. Zo was Franciscus Beltjens gehuwd met Josephine van der Hoeven; C.J. van Boom met C.E. Keuller en later nog met M.C. Wassenbergh. Beide echtgenotes waren afkomstig uit een uurwerkmakersmilieu (zie afbeelding 108). De bepalin-

${ }^{60}$ Zie appendix II onder Zelen, Arnoldus. 


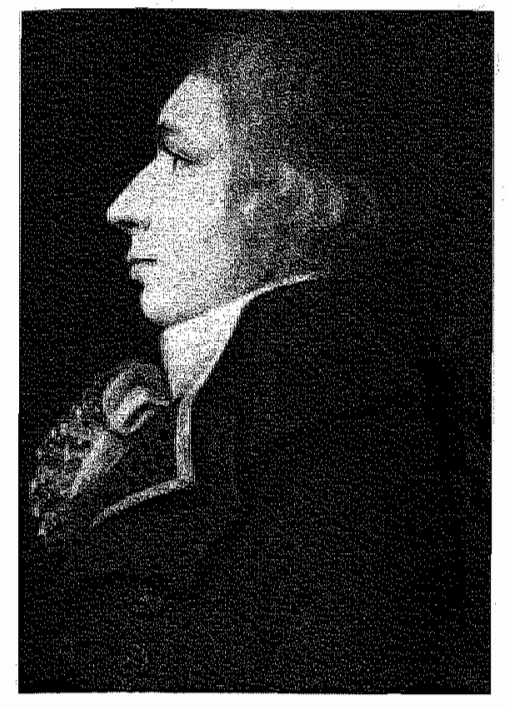

108. Pastelportret van C.J. wan Boom, Venlo, circa 1790

gen in de gildereglementen van diverse steden, die het verkrijgen van burgerschap en het lidmaatschap van een gilde via huwelijk met een weduwe of dochter van een gevestigd gildelid vergemakkelijkten, bevorderden het huwen van uurwerkmakers binnen de eigen beroepsgroep.

Opmerkelijk is de aanwezigheid van vrouwen in de uurwerkmakerij. Twee vrouwen worden op Limburgse wijzerplaten genoemd, te weten de dochter van G. Creten te Sint-Truiden en Petronella van de Weyngaert te Weert. De eerstgenoemde komt voor in de signatuur op een uurwerk van G. Creten en luidt: "G. Creten, Fille et fils à S. Trond". Dit uurwerk is gedateerd 1850 en bevindt zich te Wittem. Ook het reparatie-inschrift van Creten op de sluitschijf van het uurwerk met speeltrommel in de toren van het stadhuis van Sint-Truiden vermeldt de dochter. ${ }^{61}$ De tweede, Petronella van de Weyngaert (1741-nà 1796) uit Weert, heeft enkele klokken gesigneerd. $\mathrm{Zij}$ heeft blijkbaar als zelfstandige onderneemster het atelier voortgezet van haar vader Mathias van de Weyngaert, die was overleden in 1792. Dit blijkt uit de nummering van de klokken: haar klokken dragen geen nummer lager dan 498 , het eerst bekende

${ }^{61}$ Zie hoofdstuk IV, paragraaf 4.3. 
product van haar. De totale productie van haar atelier was niet groot, mogelijk slechts een twintigtal uurwerken. Van haar levensloop weten we hoegenaamd niets. Naar haar motieven kunnen we slechts raden. Zeker is slechts dat haar producten in technisch opzicht niet bij die van haar vader ten achter staan. Er is bijna geen andere vrouwelijke zelfstandige uurwerkmaakster in België en Nederland aangetroffen.

8.4. Joannes Brienen te Venray: enige aspecten van de bedrijfsvoering van een uurwerkmaker-winkelier eind 18 de eeuw

De algemene sociaal-economische karakteristieken van de uurwerkmakers kunnen worden aangevuld met een beknopt overzicht van een bedrijfsgeschiedenis, al is het slechts aan de hand van éen enkel dossier, omvattend de boedelinventaris van Joannes Brienen te Venray en enkele uitwoerige documenten betreffende de afwikkeling van zijn erfenis. ${ }^{62}$ Het begint hoopvol. Brienen hield boek: "In den lessenaar bevonden een annotie Boeck geteekent Litt. A, een dito geteekent Litt. B, een dito geteekent Litt. C, een dito geteekent Litt. D, allnog 3 memorie Boeckskens en andere papieren door den executeur naer te sien". ${ }^{63}$ Wat zou het een rijke bron van informatie zijn geweest als deze administratie bewaard was gebleven.

In feite kennen we zelfs de geboortedatum en geboorteplaats van Brienen niet met zekerheid. Afgaande op de datum van zijn eerste huwelijk, 1774, en de geboortejaren van zijn kinderen, 1778 en 1781 , moet hij omstreeks 1750 zijn geboren, allicht in Venray of onmiddellijke omgeving. De familienaam Brienen komt al vanaf 1564 in Venray voor. ${ }^{64}$ In het doopregister van Venray treffen we Johannes niet aan, of het moet zijn dat de pastoor de naam anders spelde. In Venray werd op 15 februari 1751 een Joannes Brijns geboren, zoon van Peter Brijns en Joanna Rongen. Het is niet onmogelijk, dat Brijns gelijkgesteld moet worden met Brienen. Nog in de 19 de eeuw werd een familienaam in de doopboeken soms verbasterd. Hyperacribie is nogal eens de oorzaak. Hier zou dat een

${ }^{62}$ Behalve van Brienen hebben we ook boedelinventarissen van Jacobus Joosten te Maaseik en van Wilhelmus Wessels te Geleen. Ze komen in hoofdstuk IX ter sprake.

63 R.A.M., Schepenbank Venray, evacuatiemummer 3956.

${ }^{54}$ R.A.M., Schepenbank Venray, evacuatienimmer 3893. 
ij in plaats van de dialectische ie en een genitief $-s$ in plaats van de uitgang -en kunnen zijn.

Wel vonden we de data van de beide huwelijken terug van Joannes Brienen. Hij huwde voor de eerste keer te Venray op 19 april 1774 met Joanna Maria van Gerven. Na haar overlijden trouwde hij voor de tweede maal eveneens te Venray op 7 juli 1788 met Maria Agnes Kerkmans. Na een kort ziekbed overleed hij op 31 augustus 1788, zeven weken na zijn tweede huwelijk. Aanvankelijk was hij behandeld door de "medicine doctor" Gerard Raymaekers, die op 8 mei 1777 te Duisburg was afgestudeerd. ${ }^{65}$ Daama werd een zekere doctor M. Oomen, die verder niet kon worden getraceerd, geconsulteerd. Oomen rekende voor tien visites zes gulden en twaalf stuiver. Behalve door deze medisch geschoolden werd Brienen ook behandeld door de chirurgijn Gerardus Roeffs, die hem aderliet, een "visicatoor" (vesicans) toediende en schoor. De apotheker P.A. Knapen leverde geneesmiddelen, vooral "mixturen", maar ook opiumpillen. ${ }^{66}$ Brienen stierf met achterlating van twee onmondige kinderen. Eigenlijk had er al na het overlijden van zijn eerste vrouw een uitvoerige boedelinventaris moeten worden opgesteld ten behoeve van de momboors van de onmondige kinderen. $\mathrm{Nu}$ werd de inventaris opgesteld op verzoek van dr. Raymaekers. Niet vanwege de rekening van één gulden en vier stuivers, maar omdat hij net als verscheidene anderen aan Brienen geld had geleend. Dr. Raymaekers had Joannes Brienen op 22 juli 1779 tweehonderd gulden geleend en was bang die niet terug te krijgen. Daarom lieten hij en negen anderen - waaronder diverse leveranciers - van 3 tot 11 september 1788 beslag leggen op de roerende goederen, actiën en kredieten van de weduwe van Joannes Brienen.

Brienen had een goed voorziene winkel aan de Markt in Venray in een huis met smidse, dat was gehuurd van de weduwe Van Gerven. $\mathrm{Hij}$ vervaardigde, repareerde en verkocht niet alleen klokken, maar handelde ook in huishoudelijke artikelen, zoals porselein en aardewerk, koloniale waren - waaronder koffie en chocolade -, zeep, blauwsel, verf, ijzerwaren en nog veel meer. In een dorp als Venray, dat een verzorgende functie had voor de omringende Peelregionen, kon zo'n winkel floreren. Brienen schijnt zich ook een zekere

\footnotetext{
${ }^{65}$ Generale lyst der doctoren 1819, nr. 66, p. 181.

De rekeningern van deze personen zijn bij de stukken betreffende de boedel van Brienen gevoegd.
} 
luxe te hebben gepermitteerd: hij had een "clavecingel" (klavecimbel). Zijn huis was aangekleed met gordijnen, negen ingelijste platen en een landkaart. ${ }^{67}$ Verder was er een "glasere kastje met porcelain" en een spiegel met gouden rand. Ook was er ruimschoots tinnen bestek, een olie- en azijnstel en een drinkservies.

Toch was het niet allemaal goud wat blonk. Brienen had nogal wat geld geleend; veel winkelvoorraad was nog niet aan de leveranciers betaald.

Tabel 10. Leningen aangegaan door Joannes Brienen, Venray

\begin{tabular}{llll}
\hline Lener & Woonplaats & Datum lening & Bedrag \\
\hline Gradus Roefs & Venray & 1777 & 250 gulden Kleefs \\
L. van Dijk & Venray & $?$ & 300 gulden Kleefs \\
Ger. Boogarts & Venray & 17.11 .1782 & 200 gulden Kleefs \\
Dr. Raymaekers & Venray & 22.07 .1779 & 200 gulden Kleefs \\
Corn. Driesen & Venray & 01.10 .1785 & 400 gulden Kleefs \\
R. Baltissen & Horst & 09.06 .1780 & 200 gulden Kleefs \\
A.M. Brienen & Venray & $?$ & 600 gulden Kleefs \\
G. Biorgraaf & Vierlingsbeek & $?$ & 100 gulden Kleefs \\
\hline & & & 2250 gulden Kleefs \\
\hline
\end{tabular}

De openstaande rekeningen van leveranciers beliepen 2.159 gulden 5 stuivers voor onder andere snuiftabak, jenever, bier, een klokkast, peperkoek, olie en zeep. Met inbegrip van de kosten voor de medische behandeling, de begrafeniskosten en de gerichtskosten beliepen de totale vorderingen 4.804 gulden 14 stuivers Kleefs, terwijl de opbrengst van de boedelverkoop en de invordering van openstaande rekeningen bij klanten 4.803 gulden 8 stuivers opleverden.

Het valt op dat Brienen klokken leverde op krediet. Van P.J. van Verssen in Nijmegen en zekere Thijm te Venray was telkens nog 110 gulden Kleefs te vorderen voor een staande klok. Hendrik Brienen moest zelfs nog tweehonderd gulden betalen voor een staande klok. Bij andere uurwerken wordt aangetekend "uyt de hand gekogt". Onder de inkomsten worden slechts zeven uurwerken vermeld, terwijl volgens de boedelinventaris veertien uurwerken

${ }^{67}$ R.A.M., Schepenbark Venray, evacuatienummer 3956, boecielinventaris Joannes Brienen: "9 schilderie van papier met een land caart". 
voorradig waren. Mogelijk zijn de opbrengsten van de andere klokken onder de meubiliaire goederen gerekend. De niet gespecificeerde opbrengst hiervan beliep 1.897 gulden 17 stuivers Kleefs. De zeven verkochte uurwerken brachten met het horlogemakersgereedschap en het smidsgereedschap 911 gulden en 3 stuivers op, dat is $22 \%$ van de totale inkomsten. De winkelvoorraad bracht 912-192 op. De voorraad zout leverde 92-1 op.

Het nadelig saldo van 1 gulden en zes $1 / 4$ stuivers $^{6 \%}$ gaf enkele schuldeisers aanleiding kleine kortingen op hun vorderingen te accepteren, zoals onder meer blijkt uit een beverig geschreven briefje: "Goede vrint. beken ontfangen te hebbe van Peeter van Dick (= Dijck, R.M.) uijt den boedel van J:Briene de somma van 9 gulde hollans; beken voldaen te weesen; als het anders niet sijn kan is 't ons als een ander. Johanna Gossens de huijsvrouw van Jacobus Geene. Catwijck den 21 Januari 1790".

De leveranciers waar Brienen zijn waren van betrok, kwamen niet alleen van Venray. Hij betrok goederen uit een groot gebied van Nijmegen en Kleef in het noorden tot Venlo in het zuiden, van 'sHertogenbosch in het westen tot Geldern en Krefeld in het oosten. Soms kocht een leverancier ook een klok van Brienen, zoals Van de Wielen uit Cuijk, die er 22 gulden Kleefs aan besteedde.

Brienen deed flinke zaken volgens de gebruiken van de tijd. Hij gaf en nam handelskrediet voor een flinke termijn. Ongellkkig genoeg had hij geen onroerend goed dat als onderpand kon dienen voor op lange termijn aangetrokken gelden, zodat zijn plotselinge dood tot ernstige moeilijkheden aanleiding gaf. In normale omstandigheden, zonder de kosten voor huwelijk, medische zorg, begrafenis en een juridische procedure, was zijn balans ruim in evenwicht geweest. Het ruime afzetgebied, dat samenviel met de regio waaruit goederen werden betrokken en een straal van zo'n vijftig kilometer had, had het bedrijf een serieuze basis kunnen bieden. Afnemers en leveranciers vielen deels samen. 's Mans markt kende enige dynamiek. Tegen catastrofale gebeurtenissen was een dergelijk bedrijf evenwel niet opgewassen.

\footnotetext{
${ }^{68}$ R.A.M., Schepenbank Venray, evacuatienummer 3871, Rekeninge, Bewijs et reliqua van soodaenigen ontfank ende uijtgaeve als P. Gijskens in qualiteyt als curateur over den naergelaetenen boedel van $\mathrm{J}$. Brienen salr. gehad heeft in de volgende jaaren. 15 september 1792. Op dit stuk is de tabel van leningen en de tekst daarna gebaseerd.
} 
De prijsstelling wan de uurwerken bij Brienen is niet erg helder. Er waren eenvoudige en gecompliceerdere uurwerken in voorraad, uurwerken zonder kast, uurwerken met gedeeltelijke kast en uurwerken in staande kast. Elke soort had zijn eigen prijs. Toen Brienen nog leefde, had hij aan Van der Wielen te Cuyck, één van zijn leveranciers, een uurwerk verkocht voor 22 gulden. Het wordt in de rekening niet gespecificeerd, maar kan nauwelijks meer dan een los uurwerk zijn geweest. In de rekening van een vrachtrijder wordt een "orlosie met cast" genoemd; de waarde van het uurwerk wordt opgegeven als tien gulden, die van de kast als twintig gulden. Daarentegen verkocht Brienen aan P.J. van Verssen te Nijmegen een staande klok voor 110 gulden, evenals aan een zekere heer Thijm te Venray. Hendrikus Brienen, waarschijnlijk een familielid, had een staande klok van tweehonderd gulden bij hem gekocht. Dat was de "top of the bill".

Op de openbare verkoop gingen vier uurwerken van de hand. J.H. Brienen, mogelijk identiek met de genoemde Hendrikus Brienen, kocht een uurwerk met kast voor 36 gulden en een onvoltooid uurwerk eveneens voor 36 gulden. Zekere C. Mulders kocht een "orloge" voor 46 gulden; Jan Poels moest 68 gulden neerleggen voor een "orlloge". Wegens de summiere omschrijwingen valt er geen lijn te ontdekken in de prijzen van de uurwerken. Zoals reeds vermeld werden niet alle voorradige klokken verkocht. De belangstelling voor de publieke verkoop was zeer plaatselijk. Hoewel de woonplaatsen van de kopers over het algemeen niet worden genoemd, is dit af te leiden uit de familienamen. De weduwe hield niets over: de opbrengst was zelfs te gering om alle schulden te delgen.

De torenuurwerken werden in de Middeleeuwen en in de vroege Nieuwe 1rja vervaardigd door in steden gevestigde uurwerkmakers. In het begin waren het personen die hun sporen ook verdienden bij heel andere toepassingen van de mechanica dan alleen het uurwerk, met name bij het in gereedheid brengen van het stedelijk geschut. In de 15 de en 16de eeuw ging het om enkele geslachten van uurwerkmakers, afkomstig uit nijverheidssteden die van de fabricage en het onderhoud van torenuurwerken hun specialiteit maakten. De combinatie van het vervaardigen van torenuurwerken en huisuurwerken komen we pas in de $17 \mathrm{de}$ en $18 \mathrm{de}$ eeuw tegen, en dan zowel in stedelijke als in plattelandsmilieus. 
Huisuurwerken werden zowel in stedelijke kring vanaf het midden van de 17 de eeuw vervaardigd als op het platteland vanaf het midden van de 18 de eeuw. De stedelijke uurwerkmakers vervaardigden zonder uitzondering aanvankelijk luxere producten dan die welke op het platteland waren gevestigd. In de 18de eeuw was het aantal dorpelingen dat zich met uurwerkfabricage bezighield opmerkelijk genoeg aanzienlijk groter dan het aantal in steden gevestigde uurwerkmakers. In het eerste kwart van de 19 de eeuw nam het aantal uurwerkmakers en handelaars in klokken en horloges in de steden weer de overhand.

De uurwerkmaker op het platteland was zelden een specialist. Gewoonlijk combineerde hij de uurwerkmakerij met andere bezigheden: de landbouw, de metaalnijverheid, heel zelden de houtbewerking die hem ook in staat stelde de klokkenkast te vervaardigen, en enige vormen van dienstverlening, zoals het houden van café of winkel, wat de verkoop vergemakkelijkte. Ofwel de tijdsbesteding - de boer had in de winter weinig om handen - of een bepaalde vakkennis dan wel voordelen bij het binnendringen op de markt lijken de voornaamste redenen yoor de gevonden combinaties van beroepen.

Van het gros van de uurwerkmakers is maar een geringe productie bekend. Vaak zijn hooguit twee à drie uurwerken van een en dezelfde maker overgebleven. Bij hen gaat het waarschijnlijk om een incidentele bijverdienste. Enkele uurwerkmakershuizen fabriceerden echter twee of drie generaties lang een groot aantal - soms zelfs ruim duizend - huisuurwerken en kwamen daardoor tot enige wellstand. Het was echter een vak met risico's. Het kon financieel ook goed mislopen. 


\section{Hoofdstuk IX}

\section{De productie van Limburgse huisuurwerken}

\subsection{De opleiding}

In de periode dat de ons bekende Limburgse huisuurwerken werden vervaardigd - van circa 1650 tot circa 1850 - waren er geen opleidingen in schoolverband tot uurwerkmaker net zo min als die voor enig ander ambacht bestonden.

De uurwerkmakers moesten in de praktijk hun vaardigheid aanleren en ontwikkelen. Onder leiding van ervaren uurwerkmakers leerden zij uurwerken onderhouden en bouwen. $\mathrm{Zij}$ fungeerden tijdens hun leertijd als hulpje van een ervaren meester. Dat proces kwam nog moeizaam op gang ook. Omdat er aanvankelijk zo weinig uurwerkmakers waren, werden die van heinde en verre ontboden voor het uitvoeren van opdrachten. Daar was enige educatieve inspanning bij inbegrepen. Wanneer de reizende uurwerkmaker ergens een stadsuurwerk had vervaardigd en geplaatst, moest hij een plaatselijke smid, slotenmaker of goudsmid leren het geleverde uurwerk te onderhouden en kleine reparaties te verrichten. Beroepsgeheimen werden bij die gelegenheid niet prijs gegeven. Enige diffusie van. kennis vond niettemin plaats. De uurwerkmakerskunst sijpelde maar langzaam door tot een grotere groep mensen. Wel werd zulke kennis van generatie op generatie overgedragen. Hij nam evenwel maar heel langzaam, stap voor stap, toe.

In de 16de en 17de eeuw, toen er meer gevestigde uurwerkmakers waren, kon men in de leer gaan bij een meesteruurwerkmaker. Daarvoor moest men wel de vleugels uitslaan en in staat zijin een leergeld te betalen. Zo ging Jan Comans uit Maastricht in 1572 voor vier jaar in de leer bij Lambrecht Bla(e)sen(s) in Hasselt; ${ }^{1}$ hij zou Jan gedurende vier jaar alle kneepjes van het uurwerkmakersen smidsvak leren, zonder geheim. Comans moest betalen voor het onderricht en de mondkost. Melot Moreau uit Wonck ging in 1660 voor zes jaar in de leer bij Joannes Muys in Maastricht; Johan

J. Leunis 1958 , pp. 293-294.

${ }^{2}$ Zie appendix II onder Muys, Joannes; leercontract G.A.M., Notariëlle archieven, inw.nt. 1146, notaris $L$. de Vaulx, d.d. 26.05.1660. 
Vrijthoff den Jonge werkte vanaf 1665 vijf jaar als leerling bij zijn stadgenoot Jean Durand te Maastricht. ${ }^{3} \mathrm{Na}$ afsluiting van zijn Maastrichtse leertijd bezocht hij Frankrijk en Engeland. Regelmatig was hij in Den Haag. Het staat vast, dat hij er contacten onderhield met de uurwerkmakers rond Huygens. Hij maakte er kennis met diens belangrijke innovatie, de slinger.

Sommige meesters hadden vaker een leerling. Durand had in 1664 al een zekere Samuel Dro(u)ssade voor vier jaar als leerling aangenomen. Er waren weinig mogelijkheden aan een leercontract te komen. De meester moest voldoende werk hebben om een leerling in huis te halen, daarbij het risico lopend een concurrent op te leiden. Voor de opleiding en kost en inwoning diende de leerling te betalen. Lang niet iedere aspirant had ouders, die hiertoe in staat waren. Als een meester een zoon had met aanleg voor het uurwerkmakersvak haalde hij liever niet ook nog een leerling in huis. Van specialisatie, waarbij de ene medewerker het smeedwerk, de ander het fraiswerk en een derde de montage voor zijn rekening nam, was in de Limburgse ateliers waarschijnlijk nooit sprake. Zoals bij alle ambachten werkte ook in de uurwerkbranche de meester met een handlanger. Gaandeweg konden de rollen worden verwisseld. Als de meester wat ouder werd, moest hij het fijne werk nogal eens aan een medewerker overlaten. Dan had hij een knecht nodig, geen leerjongen. Vaak is het rollenpatroon onduidelijk. Jean Michel Joosten was in 1808 bij Van Nierbeck in Sint-Truiden in de leer of inmiddels all tot knecht opgeklommen. ${ }^{5}$

Het (smeden-)ambacht bemoeide zich ook met het leerlingwezen, zoals overigens met de hele bedrijfsvoering en productie. Een leerling moest worden aangemeld en ingeschreven bij het ambacht. Verder waren er voorschriften over het aantal leerlingen en knechten dat een meester mocht hebben, over het aantal leerjaren, over de arbeidsvoorwaarden en over de omstandigheden waarin men van meester mocht veranderen. Daarnaast had het ambacht zich tot taak

${ }^{3}$ G.A.M. Notariële archieven, inv.nr. 1237, minuten notaris G. Bruysterbosch, akte d.d. 15.04.1665.

4.A.M., Notariële archieven, inv.nr. 1236, minuten notaris G. Bruysterbosch, akte d.d. 20.05.1664. Durant, een Hugenoot uit Roven, was sinds \pm 1659 in Maastricht, waar hij blijkbaar whg een goede naam verwierf. Waat Droussade vandaan kwam, is onbekend. Later, \pm 1670 , duikt iemand met die naam op in Londen. Zie F. Britten 1977, p. 445.

s S.A.St.-Tr., Volkstelling St. Truiden 1808, nr. 350. 
gesteld om de vakbekwaamheid van de leerlingen na beëindiging van de opleiding te testen door middel van een proefstuk. ${ }^{6}$

Vaak werd bij een notaris een leercontract opgesteld. Vanaf de 16de eeuw zijn enkele van deze contracten bewaard gebleven. Zij stipuleren de verplichtingen van beide partijen exact. Het was gewoon dat de leerling moest betalen voor kost en inwoning alsook voor het onderricht: "voor leergelt, cost dranck ende anderssints". De meester verplichtte zich dan wel geen vakgeheimen voor zich te houden. ${ }^{8}$

Afgaande op de bewaard gebleven leercontracten was de leertijd in de beide Limburgen vier tot zes jaar. Na afloop van de leertijd kon de meester zijn leerling niet langer aan zich binden. Dat was elders wel anders. Volgens Pryce en Davies duurde de opleiding in de grotere Engelse steden ongeveer zeven jaar, waarna men nog eens twee jaar als "journeyman" moest werken. Op het Engelse platteland was men hierin niet zo strikt. Meestal verviel daar de tweejaarlijikse "journeyman"-periode. De aanvangsleeftijd was doorgaans veertien jaar."

Gewoonlijk werd het vak in de familie overgeleverd. ${ }^{10}$ In het vorige hoofdstuk zijn verschillende uurwerkmakersfamilies opgesomd. Een jongen uit zo'n familie leerde het vak van zijn vader en eventueel. zijn broers op een informele wijze zonder betaling. Wanneer een zoon zich echter al zelfstandig had gevestigd, kon hij wel degelijk geld vragen voor de opleiding van een broer, zoals blijkt uit het leercontract tussen Philip Vrijthoff en zijn broer Johan. ${ }^{11}$ In mei 1679 kwamen zij voor de notaris overeen, dat Johan zijn broer Philip aannam als leerknecht voor vijf jaar om hem "de conste ende weetenschappe van orlogiemaecken ende andersints" te leren. Philip moest voor leergeld en voor kost en inwoning driehonderd gulden Maastrichter koers betalen, tweehonderd gulden meteen en na twee jaar nog eens honderd gulden. Dat was een redelijke overeenkomst, maar waar moest de jonge halfwees Philip dit geld vandaan halen?

\footnotetext{
${ }^{6}$ H. Lorijn 1980, pp. 35-38.

Zie contract tussen Johan Vrijthoff den Jonge en zijn broer Philip, 1679, hieronder.

${ }^{8}$ Zie noot 1.

W. Pryce and T. Davies 1985, p. 39.

${ }^{10}$ In de steden resulteerden de gunstige bepallingen voor verkrijging van een ambacht voor kinderen van een ambachtslid erin, dat een vak lang in dezelfide familie bleef.

"I. G.A.M., Notariële Archieven, inv,nr. 1313, minuten notaris J. Aussems, contract d.d. 25.05.1679.
} 
Zijn broer Lambertus was weliswaar mede aansprakelijk, maar kennelijk niet overmatig bemiddeld. Ook de moeder van de drie jongens, Christina Latomus, kon zoveel geld niet vrijmaken. Haar vierde zoon Herman was daartoe wel in staat. Die wilde er echter zeker van zijn dat hij er onder geen beding ooit een stuiver bij zou inschieten. De boedel van de moeder moest als borg worden aangemerkt. Wij krijgen de volgende curieuze constructie. Koopman Herman Vrijthoff leent tweehonderd gulden à $6,25 \%$ rente aan zijn moeder op voorwaarde dat hij het restant van de lening bij haar overiijden vooraf uit de boedel mag halen. Ma draagt het geld over aan de meerderjarige zoon Lambertus, die op zijn beurt uit naam van de minderjarige Philip broer Johan de som bezorgt, die deze verlangde voor de eerste twee jaar van Philips opleiding. ${ }^{12}$

De lezer krijgt de neiging de wenkbrauwen te fronsen bij het zien van zo'n familieverhouding. Ten onrechte wellicht. Over de honderd gulden die na twee jaar moesten worden betaald, wordt nergens gerept. Die zou men te zijner tijd wel weten te vinden. Het doel van de ingewikkelde regeling was waarschijnlijk te voorkomen dat de zorg voor een passende opleiding van een halfwees, die men algemeen deelde, ooit zou leiden tot familietwisten. Geen lid van de familie mocht ooit kunnen zeggen, dat hij in het bijzonder voor de opvoeding van het jongere broertje had moeten opdraaien: Johan niet, Lambertus niet, Herman evenmin. Zelfs moeder Christina moest, zolang zij leefde, buiten schot blijven.

Een meesteruurwerkmaker kon van uurwerken, die hij onder handen kreeg voor reparatie, soms wat leren: Samuel Roberts uit Wales ${ }^{13}$ tekende zo nu en dan uurwerken na. Hij vermeldde het telkens uitdrukkelijk in zijn aantekenboek. Het was niet ongebruikelijk na te apen. Zo is er een tekening bewaard gebleven van Joseph Trommar (1827-1896) uit Horst met het opschrift: "Repetiesie werk voor 1 vierkantige klok afgeteekendt naar den kapalaan zijn klok in Sevenum. Jozef Trommar". Het tekeningetje geeft een detail weer van de constructie van een zaagslagwerk. ${ }^{14}$ Terloops zij hier verwezen naar de Maastrichtse architect Soiron, die soms klokkasten naar

12 G.A.M., Notariële Archieven, inv.nr. 1477, minuten notaris W. Deckers, contract d.d. 27.05.1679. Dank aan prof. A. Gehlen te Heerlen voor toelichting bij deze akte.

${ }^{13}$ W. Pryce and T. Davies 1985, pp. 348 en 351.

${ }^{14}$ R.A.M., Prentencollectie, inv.nr. 343, ongedateerd. 
eigen ontwerp liet uitwoeren, maar ook het werk van anderen als voorbeeld nam." ${ }^{15}$

De invloed van boeken bij de opleiding zal waarschijnlijk miniem, zoniet nihil zijn geweest. Huygens' boek "Horologium oscillatorium" was voer voor geleerden, die Latijn konden lezen en kennis van mathematica hadden. De 18 de-eeuwse werken van de Encyclopedisten en van Berthoud waren ook slechts voor enkelingen weggelegd. Pas in de 19 de eeuw komen leer- en handboeken voor klokkenmakers in de moderne zin op de markt.

De kennis van de slinger is waarschijnlijk snel verspreid door het nabouwen van concrete voorbeelden als de "Haagse klokjes" van Salomon Coster en andere uurwerkmakers uit de omgeving van Huygens. Het blijft opmerkelijk dat deze techniek in de Limburgen desondanks al zo vroeg algemeen werd. De diffusie van innovaties kon in half-primitieve samenlevingen dankzij nabootsingen zeer snel verlopen. Dat was al in de 12 de eeuw het geval. Zo was de nieuwe muzieknotatie van Guido van Arezzo, gestorven omstreeks 1050 , al kort na 1100 in Sint-Truiden bekend, blijkens de antekeningen van abt Rodulf, die ze zelf gebruikte. ${ }^{16}$ Eveneens snel ging de verspreiding van textielmachines. In 1810 kwamen ze vrijwel gelijktijdig in bedrijf in Vaals, Verviers en Hasselt. Vaak echter drongen belangrijke vernieuwingen en uitvindingen slechts zeer langzaam door. Dat was vooral het geval als vindingen aanvankelijk niet erg praktisch leken. Het prototype van de stoommachine dateert uit 1690; de eerste toepassing is van Newcomen in 1715 . Watts toepassing is van 1776 , bijna een eeuw later. ${ }^{17}$ Nabootsing vereist dat de bruikbaarheid van een vinding evident is. De receptie in de Limburgen van de slinger in combinatie met de ankergang kan als zeer snel worden aangemerkt. Het was dan ook een der weinige vindingen uit de $17 \mathrm{de}$ eeuw, waarvan het nut onmiddellijk evident was. Des te verwonderlijker is het, dat de Friese uurwerkmakers zo laat op de ankergang met lange slinger overstapten.

${ }^{\text {is }}$ Zie hoofdstuk VII, paragraaf 7.2.5.

${ }^{16}$ E. Lavigne 1986, pp. 241-242.

i7 1690, niet-atmosferische stoommachine van Denis Papin (1647-1712). Atmosferische stoommachine van Newcomen rond 1715. In 1776 eerste exemplaar van James Watt (17361819). 


\subsection{De grondstoffen}

De uurwerkmaker verwerkte ijzer, messing, tin en llood. IJzer gebruikte hij voor de kooiconstructie, het gestel, voor de strips of platines, waarin de tandwielen draaien, en voor de lichters en de assen. Voor de tandwielen werd het makkelijker te bewerken en niet roestende messing aangewend, evenals voor de platines van weekwerken. De wijzerplaten konden van ijzer of messing zijn, evenals de wijzers. Tin werd gebruikt voor cijferringen, adresplaatjes en hoekversieringen. Lood kwam van pas voor gewichten, voor de ringen die het touw of de ketting strak moesten houden en voor hoekstukjes. Deze grondstoffen konden de Limburgse uurwerkmakers zonder veel moeite betrekken omdat ze sinds de Middeleeuwen in ruime hoeveelheden niet al te ver weg werden geproduceerd en er goede distributienetwerken bestonden. De prijs van deze producten was vrij stabiel, mede omdat de metaalhandel in Luik in de 17 de en 18 de eeuw monopoloïde vormen had aangenomen. ${ }^{18}$ Het is nochtans twijfelachtig of dit op de prijs van de uurwerken veel invloed had: de hoeveelheid erin verwerkte metalen is gering.

IJzer werd geproduceerd in talloze valleien in de Ardennen en de Eifel. Dichtbij het Limburgse lag een groot productiegebied in het Land van Franchimont ten oosten van Luik. ${ }^{19}$ Van daaruit waren de transportkosten evenwel hoog. Na de crisis aan het einde van de 16de eeuw komt het land tussen Sambre en Maas en Luxemburg op als gebied met ijzerindustrie. De fenderies fabriceerden staafijzer, de platineries plaatijzer. ${ }^{20}$ Staal werd in Wallonië niet geproduceerd. De wapensmeden, uurwerkmakers, slotensmeden en allen die ijzer gebruikten, hardden het gewoonlijk zelf naar behoefte door cementatie. ${ }^{21}$ In de boedelinventarissen van de uurwerkmakers treft men gewoonlijk gereedschap voor het smidsvuur aan. Dat de uurwerkmakers het harden beheersten blijkt uit de grote hardheid van assen en ankers van oude uurwerken. Restaurateurs hebben nu vaak de grootste moeite deze onderdelen te bewerken, zelfs met gebruikmaking van de modernste hulpmiddelen.

17. Cfr. hoofdstuk VIII, paragraafi 8.2.1 en noot 17.

19 A. Joris et J. Kupper 1975 , pp. 131-159, met name p. 139.

${ }^{20} \mathrm{G}$. Hansotte 1975, pp. 269-294, met mame pp. 270-272, 275-276, 281-282

21 G. Hansotte 1975, p. 283. 
Messing was in de omtrek gemakkelijk te krijgen. Het was een legering van koper en galmei: zinkerts. Het productiegebied verschoof nogal eens: soms lag het direct bij de galmeimijnen, dan weer vlakbij de kopercentra. Dinant was in de Middeleeuwen het centrum van de koperindustrie in West-Europa. Het was beroemd vanwege zijn "dinanderie". Aken nam deze centrumpositie over na de totale verwoesting van Dinant door hertog Philips van Bourgondië in 1466. Rond Aken lagen diverse galmeimijnen. De Altenberg bij Moresnet zou de meeste faam verwerven. ${ }^{22}$ In Aken verviel deze industrie weer rond 1589 volgens sommigen als gevolg van godsdiensttwisten. Veel waarschijnlijker is, dat de verplaatsing van de handelsroutes de doorslaggevende factor was. De handelsstroom Antwerpen-Keulen-Neurenberg-Venetië over land werd in het laatste kwart van de 16 de eeuw vervangen door een zeeroute. ${ }^{23}$ In het bijzonder luxeproducten die in kleine hoeveelheden werden meegegeven op een groot transport kregen te maken met scherpe wijzigingen in de transactiekosten, zodat men genoodzaakt was het platteland op te zoeken, waar de lonen lager waren en de hinderlijke gildereglementen ontbraken. ${ }^{24}$ Veel koperslagers gingen naar Stolberg, dat in de $18 \mathrm{de}$ eeuw de belangrijkste messingfabrieken van heel Europa herbergde. Zij bereikten een jaarproductie van 2.000 ton per jaar, ${ }^{25}$ voor die tijd heel veel. Toen in het begin van de 17 de eeuw de Staten-Generaal zeggingschap kregen in ZuidLimburg met als gevolg de mogelijkheid op bepaalde transacties de in- en uitvoerrechten te ontwijken, ${ }^{26}$ vestigden zich enkele koperfabrikanten in Vaals ${ }^{27}$ en Eijsden. ${ }^{28} \mathrm{Zij}$ fabriceerden staven, draad en platen van messing, evenals gebruikswoorwerpen uitgevoerd in dat metaal.

Tin werd aanvankelijk uit Engeland geimporteerd; ${ }^{29}$ men had het nodig om brons, een legering van koper en tin, te kunnen vervaardigen, maar ook voor het maken van tinnen onderdelen van

${ }^{22}$ In de 19 de en begin 20 ste ceuw leverde Altenberg cen kwart tot eenderde van de totale Europese productie. Cfr. R. Cameron 1971, pp. 2811-285.

${ }^{23}{ }_{\text {H. }}$ van der Wee 1963, deel II, pp. 18-25; J. Israel 1990, pp. 3-7; J. Jansen 1990, p. 160.

${ }_{24}^{24}$ H. Kisch 1965, pp. 265 en 270.

${ }^{25}$ J. van Hall 1981, pp. 215-228, met name p. 227 , noot 44 .

26 C. Wijnen 1995, pp. 44-61.

${ }^{27}$ W. Alberts 1974 , deel II, p. 65 .

28. J. van Hall 1981, pp. 215-228, met name p. 227 , noot 44 .

29 A. Joris et J. Kupper 1975 , p. 138. 
wijzerplaten was het onontbeerlijk en daarom beschikbaar voor de vakhandel.

Rond Moresnet en Stolberg werden naast zink- ook loodertsen gedolven; de plaatsnaam Plombières, in het Duits Bleyberg, verwijst nog naar dit voormalig Oost-Belgisch productiecentrum. Het Stolbergse bekken was zo rijk dat John Cockerill er de grondslagen voor de moderne, industriële mijnbouw ging leggen. ${ }^{30}$ In de omtrek van de loodmijnen, onder andere in Gemünd, Düren, Dolhain bij Limbourg en Goé ontstonden loodgieterijen. ${ }^{31}$ Er is zeker sinds de 16 de tot de 18 de eeuw in de Eifel en de Ardennen een goede infrastructuur geweest voor metalnijverheid. Hierdoor kon ook een gunstig klimaat ontstaan voor de uurwerkmakerij. Deze vorm van metalverwerking bleef al vlug niet beperkt tot de Eifel en Walloniê, maar breidde zich onder meer uit naar de beide Limburgen. We hebben gezien, dat Hasselt in de 16de en 17 de eeuw bekend was om zijn torenuurwerkmakers. In Sittard was in 1623 een gilde van messensmeden. ${ }^{32}$ Begin 18 de eeuw was er in Geleen een "gilde van den eyseren", waarin veel metaalbewerkers verenigd waren, die allerlei ijzeren gereedschappen vervaardigden. ${ }^{33}$ Aan het einde van de 18 de eeuw werden er in Brunssum jaarlijks 200.000 pond $^{1 j} z^{34}$ verwerkt tot hangsloten, scharen, hengsels, kaarsensnuiters, passers en dergelijke. ${ }^{35}$ Ook het Rijnland profiteerde. Toen er, waarschijnlijk aan het einde van de $18 \mathrm{de}$ eeuw, half-afgewerkte componenten voor uurwerken op de markt kwamen, werden deze door Joannes Brienen in Venray uit Kleef betrokken. In Zuid-Limburg kon men hiervoor terecht in Luik, zoals blijkt uit de volgende advertentie uit 1772: "Wirix, rue Neuvice, au Canon d'Or, à Liège, avertit qu'il vend toute sorte de garnitures d'horloge comme cadrans, coins, aiguilles, cloches (timbres), roues, etc., etc., tout à juste prix ${ }^{13}{ }^{36}$ Gretig werd deze mogelijkheid tot beperking van kosten aangegrepen. Séverin Lambert Joosten in Maaseik had volgens zijn boedelbeschrijving uit 1811 verschillende fournituren in voorraad.

\footnotetext{
${ }^{30}$ S. Pasleau 1995, passim.

${ }^{31}$ W. Alberts 1974 , deel II, p. 40.

32. P. van Luyyn 1993 , p. 113.

33 W. Alberts 1974 , deel II, p. 65.

34. Men kan hier mijtis inzlens spreken wan een plattelandsindustrie.

${ }^{35}$ De Grand Callendrier de Herve pour 1792 is de bron zowel voor de beweringen hierover van

S. Ernst 1837-1852, deel I, p. 139, als voor die van A. Flament 1913b, pp. 81-82.

${ }^{36}$ Giazette de Liège, 27 janvier en ller mai 1772, geciteerd door F. Pholien 1933, p. 60.
} 
Als gewoonlijk spendeerde de notaris er niet veel woorden aan: "plusieurs plaques d'étain; cinq cadrans de montre en étain; cinque plaques de pendule en cuivre; sept clochettes de pendule de metal; une partie de verres de montre; cinquante ressorts de montres". ${ }^{37}$ Grondstoffen waren in voldoende mate en tegen lage transport- en distributiekosten beschikbaar. Deze gunstige omstandigheid was bevorderlijk voor de mogelijkheid in de Limburgen een productiecentrum van eenvoudige, niet te dure uurwerken te doen ontstaan, maar het lage aandeel van kosten van grondstoffen in de totale productiekosten beperkte het afzetgebied, behalve voor de zeer zware torenuurwerken, tot de regio. Er was voor een uurwerkmaker regelmatig lonend werk, maar niet zoveel dat hij er permanent de kost mee kon verdienen.

\subsection{De productie}

\subsubsection{Werkplaats en gereedschap}

Zoals gezegd, bevatten de Limburgse huisuurwerken verschillende onderdelen van ijzer. De klokkenmakers hadden net als de smeden en slotenmakers een smidse met smidsvuur, blaasbalg, aambeeld en de nodige tangen en hamers om het ijzer te bewerken. In hun geval was ook een passer vereist voor het uitzetten van de tandwielen en een set vijlen voor het (bij-)vijlen van de tanden. Deze basisuitrusting gebruikten de Limburgse uurwerkmakers tot begin $19 \mathrm{de}$ eeuw. Sévérin Lambert Joosten, die zijn woonhuis annex winkel en werkplaats in de Boschstraat te Maaseik had, had zijn smidse met een scherm tegen de vonken, blaasbalg en aambeeld op zolder staan! $!^{38}$ Of anderen meer oog hadden voor brandgevaar is niet duidelijk. Het was zo evident dat de uurwerkmaker temperaturen van meer dan $1.000{ }^{\circ} \mathrm{C}$ nodig had, dat de notarissen er weinig woorden aan vuil maakten. In de inboedelinventaris van Joannes Brienen te Venray van 1788 is sprake van "een cleijn isere ballans

${ }^{37}$ R.A.H., Notariaat Maaseik, notaris Ignace Voss, microfilm mr. 1462343, nr. 85.

${ }_{38}^{98}$ R.A.H., Notariaat Maaseik, notaris. Ignace Voss, microfilm nr. 1462343, akte nr. 85, d.d. 24 juli 1811 . 
in de smis" ${ }^{39}$ Vermeldingen in de inboedel van Wilhelmus Wessels die na zijn overlijden in 1816 werd geveild, tonen eenzelfde beeld. In de verkooplijst" is sprake van een "smehamer", "kleen smitsgetuijg", "smitsgetuijg", een "aveld" (aambeeld), een "blaasbalk", vijlen, verschillende partijen ijzer en "schruijf" (schroeven). De laatste bleken overigens relatief duur, waarschijnlijk omdat ze nog met de hand waren vervaardigd.

In de loop der eeuwen werden aan deze basisuitrusting natuurlijk allerlei gespecialiseerde gereedschappen toegevoegd naargelang de uurwerktechniek zich ontwikkelde. Met name moet hier worden genoemd de radersnijmachine met verdeelschijf. Ook zou men kunnen denken aan de engrenagepasser en ander specialistisch gereedschap, dat door de oude klokkenmakers vaak zelf werd bedacht en vervaardigd. Deze gereedschappen waren relatief duur. In de lijst van opbrengsten op de genoemde boedelverkoop van Brienen wordt vermeld: "Van Arnold Zelen orlogiemaker voor 't orlogie gereedschap uijt de hand gekogt... 300 gulden".

Naast het smidsgereedschap kwamen in de boedel van Wessels ook speciale uurwerkmakersgereedschappen aan bod. Het werd in drie partijen verkocht, helaas niet nader gespecificeerd. Gezien de afwerking van de klokken van Wilhelmus Wessels zal er zeker een radersnijmachine met verdeelschijf bij zijn geweest. Genoemde zaken werden praktisch allemaal gekocht door zijn zoon Peter Wessels, die zijn beroep hiermee op traditionele wijze kon voortzetten. Op de veiling van de inboedel van Wessels waren kennelijk geen andere liefhebbers. Het horlogemakersgereedschap was er dan ook niet duur: de lotnummers 74,75 en 76 brachten respectievelijk $1,77,1,18$ en 1,47 franc op. De duurdere gereedschappen zullen daar niet bij zijn geweest, wellicht had Peter die al eerder van zijn vader overgenomen of verkregen uit de nalatenschap van zijn broer Theodorus, die een week eerder dan vader Willem was gestorven. Het smidsgereedschap was veel duurder. Zo betaalde Peter voor het aambeeld 60,43 franc en voor de blaasbalg 3,55 franc. In totaal kocht hij voor 81,71 franc aan gereedschappen. Aan materiaal, zoals klokkentinkens ( $=$ bellen), ijzerwerk en schroeven gaf hij nog eens 30,89 franc uit (zie afbeelding 109).

\footnotetext{
${ }^{39}$ R.A.M. Schepenbank Venray, evacuatienummer 3956, imboedel wan Joannes Brienen, 1788. ${ }^{40}$ R.A.M., Notariële archieven, inv.nr. 376, minuutakten wan notaris J.M. Luijten te Geleen, akte nr. 16, d.d. 1 manrt 1816.
} 
De inboedelinventaris van Sévérin Lambert Joosten te Maaseik uit 1811 vermeldt de radersnijmachines (tours à fendre des roves) expliciet. Hier ontbreekt evenwel de verkooplijst, zodat we de waarde niet kennen.

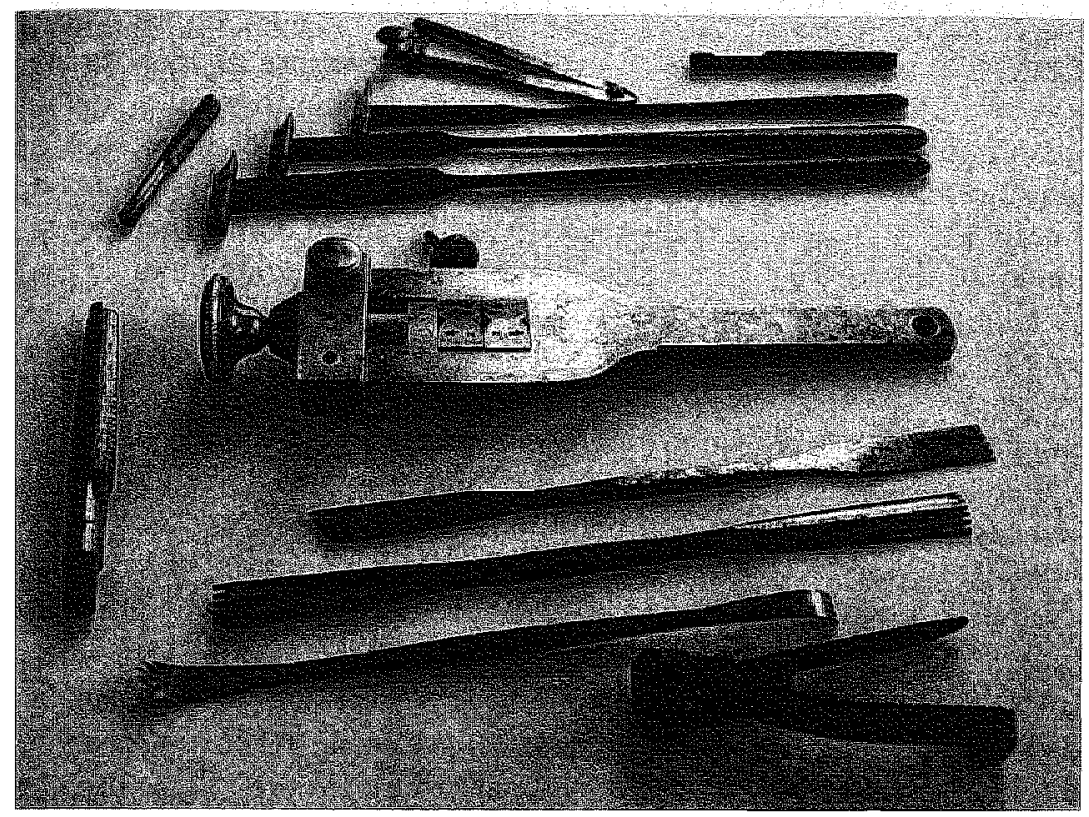

109. Gereedschap van C.J. van Boom, Venlo, gemerkt: C.I.V.B.

\subsubsection{Zelfbouw of assemblage/toelevering?}

Het is duidelijk, dat de hele outillage was gericht op het zelf vervaardigen van klokken en niet op het doorverkopen van gekochte producten of het assembleren van onderdelen. Deze laatste productiemethode veronderstelde Weyns: "Wij moeten ons het werk van die vaklieden zo voorstellen, dat zij meestal de onderdelen goeddeels elders betrokken en het uurwerk hoofdzakelijk slechts ineenstaken". ${ }^{41}$ Dit is een ongefundeerde stelling, want er was geen industrie of huisindustrie die deze onderdelen kant en klaar kon leveren. Er werden geen standaarduurwerken gemaakt. Het was tot

41 J. Weyns 1974, deel III, p. 973. 
circa 1850 niet mogelijk onderling uitwisselbare onderdelen voor machines te leveren. ${ }^{42}$ Ten aanzien van precisie-onderdelen voor uurwerken bestond deze situatie zelfs tot in de 20 ste eeuw.

Ook wordt soms gesuggereerd, dat de namen op de Limburgse uurwerken slechts de verkoper aanduiden van producten uit de stad Luik of het Luikerland. Dit acht ik in tegenspraak met de uitrusting, die de signeerders van uurwerken aantoonbaar hebben gehad. De veronderstelling is ook onlogisch. Als er productie op grotere schaal van kant en klare uurwerken had plaatsgevonden, had het niet voor de hand gelegen dat de producenten hun producten via smeden, slotenmakers en dergelijke in kleine gehuchten aan de man brachten. Men had dan als distributiekanaal handelaren of goud- en zilversmeden in de steden genomen, zoals dat voor zakhorloges al vanaf het begin van de $18 \mathrm{de}$ eeuw het geval was. Het spreekt boekdelen dat in de jaren tachtig van de 18 de eeuw de pogingen van Nicolas Jacquet om in Luik een "manufacture d'horlogerie" op te zetten mislukten. Of deze manufactuur huisuurwerken of zakhorloges zou moeten gaan maken, wordt overigens uit de stukken niet duídelijk. ${ }^{43}$ Thomassin noemt in zijjn "Mémoire statistique du département de l'Ourte", begonnen in 1806, geen fabrieksmatige productie van uurwerken. Integendeel, hij geeft aan dat in 1788 in het departement van de Ourthe voor tachtigduizend francs aan "objets d'horlogerie" uit Parijs en Genève werden ingevoerd. ${ }^{44}$ De auteur is bepaald niet karig met zijn informatie. Zo sleept hij de metaalnijverheid in Brunssum er met de haren bij. ${ }^{45}$ Als er iets was geweest dat maar enigszins leek op uurwerkindustrie had hij dat zeker gemeld.

Ook de verplichting "eene groote, 't zij eene clijne horologie" als proefstuk te vervaardigen en de stringente eisen ten aanzien van de voltooiing van de opleiding alvorens als uurwerkmaker in een stad te worden opgenomen, wijzen op het zelf vervaardigen van uurwerken. ${ }^{46}$ Daarbij komen in de steden de gildenvoorschriften, waarin werd bepaald dat van elders afkomstige producten niet mochten

\footnotetext{
${ }^{42}$ H. Lintsen (hoofdred.) 1992-1995, deel IV, pp. 37-38.

${ }^{43}$ F. Pholien 1933, pp. 102-104.

\$4 L. Thomassin 1879, p. 400: Aperçu de la valeur des exportations et des importations du département de l'Ourte, en 1788 etc.

${ }_{45}^{45}$ L. Thomassin 1879 , pp. 459 en 460.

${ }^{4}$ Zie hoofdstuk VIII, noot 39 en moot 41 .
} 
worden verkocht, tenzij ze niet ter plaatse konden worden gemaakt. Ook was het aan ambachtsleden verboden goederen en waren in te kopen met het doel ze door te verkopen. Dat mochten alleen de leden van het kremersambacht, maar daar hoorden de uurwerkmakers niet bij. ${ }^{47}$ Er zijn nog meer argumenten om de stelling, dat de Limburgse uurwerkmakers al in de $17 \mathrm{de}$ en $18 \mathrm{de}$ eeuw voornamelijk wederverkopers waren, te ontkrachten.

In het proces, dat de ene Johannes Vrijthoff ${ }^{48}$ in 1689 tegen de andere voerde over de toevoeging aan hun naam van het epitheton "den Jongen" of "le Jeune", zodat identieke signeringen ontstonden, komen in de replieken niet alleen concurrentie-overwegingen naar voren, maar is ook duidelijk sprake van beroepstrots. De ene Johan troeft de andere af met de sneer, dat "alle kenners weten, dat hij suppliant (Johan, *1651) soo wel in sijn konst niet en is geavanceert dat hij rescribent (Johan, *1646) sijn wercken op des suppliants naam soude konnen ofte willen debuiteren". Men was duidelijk trots op zijn werk. De passage zou wezenlijk anders zijn verwoord, als het alleen maar om doorverkoop van andermans producten had gegaan.

Het feit, dat er in de boedelinventaris van Brienen sprake is van " 2 dito onvolmaekte" (dit wil zeggen "onvoltooide") uurwerken, waarbij het woord "dito" nadrukkelijk slaat op een eerder genoemd "hangende huijs orlogie sonder kastje", wijst op het zelf vervaardigen van het mechanisch deel van uurwerken en niet op het doorverkopen van kant en klare of geassembleerde producten.

Ook het gebruik van de term "maken" in de zin van "vervaardigen" in teksten, die handelen over de levering of aanschaf van een huisuurwerk wijst in de richting van zelf produceren. Zo wordt in de verkoopovereenkomst tussen W. Wessels en Bernard Wauters van 7 juni 1762 gesproken over een klok, die "thien rixdaelders" waard moest zijn en die voor 1 november 1762 moest worden "gemaakt". ${ }^{9}$ De overeenkomst tussen W. Wessels en J. Vroemen, landmeter te Geleen, spreekt van "maken" en ook hier is ver-

${ }^{47}$ H. Lorijn 1980 , p. 48 , nr, 137 en p. 49, nr. 140. Dit zijn weliswaar Maastrichtse voorbeelden, maar ook in andere steden gold het algemene principe wan de ambachten, dat de verkoper ook de producent moest zijn.

${ }^{48}$ Zie appendix II onder Johannes Vrijthoff den Jongen.

${ }^{49}$ R.A.M., Landen van Overmaas, inv.nr. 1321, verkoopakte d.d. juni 1762. 
vaardigen bedoeld en nijet repareren. ${ }^{50}$ Soms verplichtte men zich ook een geleverd uurwerk te onderhouden, zoals in genoemd accoord tussen Wessels en Vroemen.

De bewering van Wilhelmus Wessels in een petitie om vermindering van patentrecht wit 1797, dat hij alleen oude klokken repareerde en schoonmaakte, ${ }^{51}$ moeten we met een flinke korrel zout nemen. Ze werd genit tegen een instantie die hem meer belasting liet betalen, als hilj zei producent te zijn. Zijn zonen Peter en Theodorus Eligius gaven in de Franse tijd als beroep niet op "horlogemaker", maar "landbouwer" of "werkman" om aan het patentrecht te ontkomen. Hun gemengd inkomen rechtvaardigde zulk gedrag min of meer. Pas na 1810 wordt van hen weer het beroep "horlogier" vermeld. Wel kan Wilhelmus in 1797 iets minder hebben geproduceerd vanwege zijn leeftijd en zijn slechte ogen. Hij beroept zich hier uitdrukkelijk op. Verder klaagt hij dat hij van dorp naar dorp moet gaan voor zijn werk en dat het zo weinig oplevert. Hij heeft het allemaal wel erg somber voorgesteld. Zelfs met zijn ogen zal het wel meegevallen zijn, immers ook voor repareren en schoonmaken heeft men goede ogen nodig. Hij moet lang nadien nog klokken hebben geproduceerd, want er zijn van hem klokken bekend, gedateerd 1806 en 1810 . Bij zijn overlijden had hij veertien uurwerken in voorraad.

Het bovenstaande wil echter niet zeggen, dat de Limburgse uurwerkmakers geen enkel kant en klaar gekocht onderdeel benutten. Dat kwam zelfs veel voor. Tinnen en loden ornamenten, die makkelijk waren na te gieten, waren kant en klaar te koop in Luik. ${ }^{52}$ Ook werden misschien de wijzers gekocht, hoewel er zeker ook eigen werk bij was, bijvoorbeeld de wijzers van de leden van de familie Remmen. Voor de knap uitgevoerde gravering van de naamplaatjes en het middenpart van de wijzerplaat deed men een beroep op

\footnotetext{
${ }^{90}$ Th. Dorten 1900, p. 67: "Op heden den 17 Juni 1760 sco hebben wi alles gelijck gemaekt vant maecken der klocke soo, hebben wij naar goedwinden van ons beyden als dat een ieder noch sal geven een botelle wijn, wellcke wij met den eersten zullen verdrencken, waarbij geconditioneert is allsdat Wetsels mijne klocke noch moet onderhouden dry gantse jaeren [:] tot waerheyt een ieder onderteekent op dagh en dato voors. waatbij ick noch den brandewijn moet geven ofte twee kannen bier "t sij voomiddagh den brandewijn, naer middagh " de klock gerepareert word". Ondertekend door Jacobus Vroemen/Wilhelmus Wetsels.

${ }^{51}$ R.A.M., Frans Archief, inv.nr. 4049 "patentrechten nr. 929 N10, d.d. 5 Fructidor an VI ( 22 angustus 1797). Hij krijgt verlaging tot de achtste klasse van de patentrechten.

${ }^{32}$ F. Pholien 1933, pp. 59-60.
} 
gespecialiseerde vakmensen. Bij de naamplaatjes van Gradus Janssen uit Sint-Odiliënberg, die door hem zelf werden gegraveerd, is aan het povere resultaat duidelijk te zien dat het om eigen werk gaat (zie ook afbeelding 64). Voor de glazen cijferplaten en adresplaatjes deed men zeker een beroep op toeleveringsbedrijven, waaronder Delarivière-Deprez in Luik. De bronzen bellen ${ }^{53}$ van het slagwerk betrok men van een bronsgieter. De klokkasten waren het werk van goede schrijnwerkers en beeldhouwers.

De late 18de eeuw vormde een overgangsperiode. Niemand deed nog alles zelf, zoals in de 17 de eeuw nog het geval was geweest, maar ook was er geen enkele uurwerkmaker die louter assembleerde. Joannes Brienen maakte gebruik van halffabrikaten, voorgegoten messing wielen, die hij zelf nog moest bewerken tot goed passende tandwielen. ${ }^{54} \mathrm{De}$ "parttime" klokkenmakers op het platteland probeerden uit vrij weinig grondstoffen en halffabrikaten met inzet van al hun vernuft en arbeid een product te maken, dat niet al te kostbaar was voor de koper, maar de verkoper toch aardig wat opleverde. Dat was hier evenzeer het geval als in Wales. ${ }^{55}$ Reparatie en onderhoud van (toren-)uurwerken was voor de uurwerkmakers een voor de hand liggende bron van neveninkomsten.

De Limburgse uurwerken werden niet vervaardigd in een puttingout-systeem, waarbij bepaalde gezinnen één bepaald onderdeel fabriceerden, anderen de volgende onderdelen van het productieproces voor hun rekening namen, waarna alles in een fabriekje werd afgewerkt. Voor zoiets is geen enkele aanwijzing gevonden, noch op de uurwerken zelf, noch in enig archiefstuk. De betrekkelijk geringe aantallen Limburgse klokken die zijn gemaakt en de grote individualiteit van de uurwerken wijzen ook niet in die richting, maar op individuele vakmensen of kleine familiebedrijfjes, die de voornaamste onderdelen, zoals tandwielen en anker, zelf vervaardigden en samen met eventueel van elders betrokken wijzers en

\footnotetext{
${ }^{53}$ In de Lijst wan boedelverkoop van W. Wessels genoemd onder n., 12: "twee klokkentinkens $^{\text {s; }}$ nrs. 16 en 90 spreken van "tinken". Ik neem aan dat dit een onomatopee is voor een tinkelende bel. Veel bellen op uurwerken van A.J. Smeets, Hamont, vertonen een ingekraste $X$. Wellicht heeft hij dit als kenmerk gebruikt bij de belgieter woor de bellen, die hij had uitgezocht.

${ }^{54}$ R.A.M., Schepenbank Venray, evacuatienummer 3956, inboedel Joannes Brienen, uitstałande rekeming van Theodonus Folling te Kleef voor " $81 / 2$ pond koopere raadere". Van hem betrok hij ook koperen bellen: "horlogie klocke".

${ }^{s 5}$ W. Pryce and T. Davies 1.985, passim.
} 
bellen in een door een timmerman vervaardigde kast bijeen brachten tot een compleet uurwerk. We moeten ons geen moderne voorstellingen maken van productiemethoden, zoals grote series, standaardmaten en verwisselbare onderdelen. Gezien de verspreiding van de bewaard gebleven uurwerken werd slechts voor een beperkt gebied rond de woonplaats geproduceerd. Een enkeling vervulde een regionale functie. Van Brienen is bekend dat hij klokken per kar naar Nijmegen en Cuyck heeft laten brengen. ${ }^{56}$

\subsubsection{Productie-omvang}

Hoe werd geproduceerd? Hoelang werkte men aan een uurwerk? Hoeveel uurwerken produceerde een uurwerkmaker in zijn leven? Deze vragen zijn niet eenvoudig te beantwoorden omdat we geen gedetailleerde informatie hebben, zoals in het aantekenboek van Samuel Roberts wordt aangetroffen of in werkplaatshandleidingen kan worden verwacht. Toch zijn enkele antwoorden mogelijk op basis van de gegevens die genummerde uurwerken kunnen opleveren. Daarbij doen zich twee moeilijkheden voor. We weten vooreerst niet hoe werd genummerd. Begon een uurwerkmaker bij het nummer één? Of startte hij bijvoorbeeld met nummer honderd om meer expertise te suggereren? Zowel het een als het ander kan zijn voorgekomen. Van Alexius Remmen is het nummer één bewaard en enkel andere nummers onder de tien. Van anderen zijn alleen hoge nummers bekend. Ook weten we niet of het laagste of hoogste nummer dat is aangetroffen, het laagste of hoogste serienummer van een bepaalde klokkenmaker of atelier was. Van J. Peeters te Zutendaal is een klok bekend met het serienummer 1022; van A.J. Smeets te Hamont het nummer 1052. Brian Loomes vermeldt veel hogere serienummers: 2343,2826 en zelfs 3063 . Hij vindt dit reële aantallen ${ }^{57}$ Op grond van de hoogste in Limburg aangetroffen serienummers schatte ik in een artikel uit 1989 het aantal klokken

\footnotetext{
${ }^{36}$ R.A.M., Schepenbank Venray, evacuatienummer 3956, inboedel Joannes Brienen, onbetaalde rekening van de worman voor deze transporten: 1785, 24 februari "naer nimwege cen orlosie met een cast de werde van de orlosi 10 gld. den cast 20 gld."; 1785,20 april "'maer nimege metgenomen een taefel orlosie [...] noch naer Cuck een orlosie gebrocht"; 1786, 22 juli "een orlosie naer nimwege".
}

${ }^{37}$ B. Loomes 1976a, pp. 68-89. 
dat een Limburgse uurwerkmaker kon vervaardigen op $1100 .^{58}$ Dat was veel te hoog geschat. Nadere bestudering en analyse van de klokken uit de ateliers van Peeters en Smeets toonde aan, dat de familie Peeters een doorlopende ateliernummering hanteerde, zodat het aantal van 1022 niet alleen door J. Peeters is gemaakt, maar mede door zijn vader Thomas Sr. en zijn broer Mathieu, totdat deze zich zelfstandig vestigde in Opglabbeek. Hetzelfde bleek het geval bij A.J. Smeets te Hamont: hij zette de nummering voort, die door zijn vader Jan Smeets was begonnen. Ook Petronella van den Wijngaert te Weert zette de ateliernummering van haar vader voort. Gelukkig zijn er vergelijkingsmogelijkheden. De Welshman Samuel Roberts schijnt in een periode van veertig jaar circa zeshonderd klokken te hebben gemaakt in de tijd die overbleef naast het uitoefenen van zijn boerenbedrijf. Hiervan zijn er 102 teruggevonden. Van de 18de-eeuwse klokkenmaker James Wilson, die in Belfast werkzaam was, wordt gezegd dat hij in 42 jaar circa 588 klokken heeft gemaakt. ${ }^{59}$ Dat zijn veertien à vijftien uurwerken per jaar, waarvan een maand of vier à vijf volledig aan uurwerkmaken werd besteed en wellicht een maand of twee, drie parttime, alles bijeen zo'n 120 à 150 werkdagen. Globaal komt men dan op een dag of tien per uurwerk, maximaal een honderdtal werkuren. Was dat ook in Limburg het geval?

Voorzichtigheid is geboden. Het maakte natuurlijk verschil met hoevelen men in een atelier werkte, of men klokkenmaken als voltijds beroep uitoefende, welke leeftijd men bereikte en hoe de vraag naar klokken zich ontwikkelde. De productietijd van een klok zal waarschijnlijk nogal variabel zijn geweest. Naarmate er meer opties moesten worden ingebouwd in een uurwerk, zoals datum, slagwerk met dubbele bel, wekkerwerk, gangduur van een week, etcetera. duurde de productie langer. Samuel Roberts had een halfklare voorraad. Hij kon als het moest in één dag een klok voltooien. ${ }^{60}$ Brienen hanteerde een vergelijkbare werkwijze, zoals we zagen.

Als we het gemiddelde van vijftien klokken per jaar van Samuel Roberts ook aanhouden voor de Limburgse klokkenmakers, dan komen we voor een man als A.J. Smeets uit op een aantal van 750

P. Mestrom 1989, p. 119.

${ }^{59}$ W. Seaby 1983, pp. 133-155. Zie ook de getallen door B. Loomes genoend.

A. Davies 1985 , pp. 49-75, met name p. 53. 
klokken. Hij leefde immers van 1730 tot 1802 , heeft dus ongeveer vijftig jaar klokken kunnen bouwen. Dit klopt met de nummering. De nummers tot ongeveer 250 moeten waarschijnlijk aan zijn vader worden toegeschreven. Dat deze niet meer huisuurwerken produceerde, komt omdat hij zich veel meer met torenuurwerken heeft beziggehouden. Wilhelmus Arnoldus Wessels te Geleen, die 86 jaar is geworden, kan in een actieve periode van ongeveer zestig jaar dus wel negenhonderd klokken hebben gebouwd. Dit getal klinkt onwaarschijnlijk hoog. Er zijn 23 klokken van Wessels opgespoord, beduidend minder dan de 102 van de 600 door Samuel Roberts gebouwde nurwerken. Van Wessels' productie bleef nog geen 3\% bewaard, tegen $17 \%$ van Roberts. De vraag rijst hoe zoveel klokken, die toch degelijk gemaakte en geliefde objecten waren, die van generatie op generatie vererfden, verloren konden gaan? Zijn de Limburgers terughoudend met het tonen van hun familiebezit uit vrees voor diefstal? Is de mobiliteit hier groter dan in Wales, zodat oproepen de huidige bezitters moeilijk bereiken? Besteedde Wessels minder tijd aan de uurwerkmakerij dan Roberts? Was de concurrentie groter, de markt kleiner? Vragen genoeg. Zonder volledige boekhouding is geen antwoord mogelijk, hooguit hier en daar een suggestie.

Hoewel de klokken meestal op bestelling werden geproduceerd, zoals blijkt uit het "Account Book" van Samuel Roberts en uit het accoord tussen W. Wessels en J. Vroemen, ${ }^{61}$ zal een kiene klokkenmaker in slappe tijden wel een paar klokken of minstens wat onderdelen in voorraad hebben gemaakt. Meer genoemd "Account Book" spreekt hiervan en ook de voorraad klokken in de boedels van Joannes Brienen en Wilhelmus Wessels is een indicatie in die richting.

Samenvattend: een productie van veertien à vijftien uurwerken per jaar is wel het maximum dat kon worden gehaald. Waarschijnlijk zal het over een heel werkzaam leven gemeten aanzienlijk minder zijn geweest. Gewoonlijk ging veel mogelijke productietijd verloren. Daar waren goede redenen voor. Naast de verkoop, de reparatie en het onderhoud bij particulieren, hadden verscheidene klokkenmakers inkomsten uit het onderhoud en de reparatie van torenuurwerken, vaak met de officiële titel van stadsklokkenmaker. De uurwerkmaker die de uurwerken van meerdere dorpen moest onder-

${ }^{61}$ Zie noot 50 . 
houden, was heel wat tijd kwijt met het lopen naar de te onderhouden uurwerken. Wilhelmus Wessels, die onder meer de uurwerken van Heerlen, Voerendaal en Welten onderhield, wijst er in een brief aan de hoofdbank Heerlen op, dat hij telkens zes uur reistijd kwijt is om naar één van de genoemde plaatsen te gaan. ${ }^{62} \mathrm{Zij}$ besteedden maar een deel van de tijd die voor de uurwerkmakerij beschikbaar was aan de productie van nieuwe uurwerken.

Niet meer dan enkele procenten van de met name bekende uurwerkmakers haalden een productie van tien of meer uurwerken per jaar. Het gros van de in appendix II opgesomde uurwerkmakers vervaardigde, als we mogen afgaan op het aantal bewaarde en achterhaalde producten, hooguit zo nu en dan een uurwerk. Er zijn er wel erg veel bij, waarvan geen enkel of hooguit één à twee producten bewaard bleven. Aan die uurwerken zijn geen grote kwaliteitsverschillen te ontdekken met de producten van die uurwerkmakers, waarvan er aanzienlijk meer zijn bewaard.

Of de klokkenmakers veel onderlinge handelsrelaties hadden, is bij gebrek aan bedrijfsarchieven niet uit te maken. Mij is slechts één geval onder ogen gekomen: in een notariële akte van 1809 bekent. de Thornse klokkenmaker Joannes Schoufs 355,50 francs schuldig te zijn aan Jean Guillaume Leurs, klokkenmaker te Sittard, wegens geleverde "marchandises". ${ }^{63}$ Helaas vermeldt de akte niet om welke koopwaar het hier ging, noch wanneer deze was ingekocht. Misschien waren het goud- en zilverwaren. J.G. Leurs wordt immers in de inwonerslijst van Sittard uit 1801 "orfèvre" genoemd. Het kan zijn dat Schoufs vóór de Franse revolutie dergelijke luxe-artikelen doorverkocht aan rijke klanten als de Thornse stiftdames en was hij na de Franse bezetting met zijn handel blijven zitten omdat de klantenkring als gevolg van de opheffing van het stift wegviel. Mogelijk heeft Joannes Brienen zaken gedaan met een klokkenmaker in Nijmegen. In de jaren 1785-1786 liet hij twee staande klokken en één tafelklok naar Nijmegen brengen. ${ }^{64}$ Het kunnen evenwel aankopen van particulieren zijn geweest, die elkaar naar Venray verwezen.

\footnotetext{
${ }^{62}$ G.A. Heerlen, Landen wan Overmaas, inw.nr. 6374, anno 1761. De genoemde ururwerken kwamen ten laste van de hoofdbank Heerlen. Cfr. appendix III onder Heerlen, Voerendaal, Welten.

${ }^{63}$ R.A.H., Notariaat Maaseik, notaris Van de Borne, vol. 4583, akte nr. 244, d.d. 10 juli 1809. Vriendelijk medegedeeld door de heer M. Kunnen, Kinrooi.

4 Zie noot 56 .
} 


\subsubsection{Zakhorloges}

Bij zakhorloges ligt de zaak heel anders. Ze waren aanvankelijk het product van enkele stedelijke specialisten, zoals de Vrijthoffs in Maastricht. Van hun productie is weinig overgebleven. Evenmin is duidelijk of de vervaardiging in Maastricht is doorgezet en zo ja hoelang. Zakhorloges lijken nooit op het Limburgse platteland te zijn vervaardigd. In ieder geval is de bedrijfsorganisatie bij eventuele Limburgse stedelijke bowwers van zakhorloges niet geëvolueerd als in Engeland. Al zeer vroeg is daar sprake van een ver doorgevoerde werkwerdeling. ${ }^{65}$ Waarschijnlijk werden alle zakhorloges hier al omstreeks 1730 ingevoerd als min of meer afgewerkte producten. De Venlose verordening van 1773 , waarin sprake is van "horlosiemakers met en zonder smidsvuur" schijnt te wijzen op het naast elkaar voorkomen van vervaardigers en wederverkopers van uurwerken. ${ }^{66}$

Het is niet bekend, waar de hier verhandelde zakhorloges vandaan kwamen. Misschien waren zij merendeels afkomstig uit de Jura of Luik en in mindere mate uit Engeland. Dorsch beweert in zijn "Statistique du département de la Roer", dat ze uit Genève en de comté Vallangin bij Neuchatel komen. ${ }^{67}$ Volgens hem zijn de meeste uurwerkmakers meer reparateurs van zakhorloges dan echt makers van uurwerken, met uitzondering van enkele "artistes" in Aken, Burscheid, Keulen en Krefeld. Uit het huidige Limburg noemt hij in de rubriek "horlogerie" alleen Sittard. ${ }^{68}$ of het daarbij on een handelaar gaat die alleen horloges doorverkocht, is onduidelijk. Heel de afzet van horloges in Limburg ligt trouwens in het duister. Er is slechts één expliciet geval bekend van verkoop van Engelse zakhorloges in Limburg. Het betreft een zekere William Howell, die rond 1775 in Venlo was beland met een voorraad horloges en juwelen. ${ }^{69}$ Soms waren joden bij de handel in zakhorloges betrokken. De weinige documenten daarover leveren niet veel helderheid. Het komt voor dat een joods handelaar in tweedehands

${ }^{65}$ In de 17de eeuw waren in Engeland al speciale klovenmakers, kastmakers, wijzermakers, etc. De eerste specialisten waren de makers van spiraalveren.

${ }^{65}$ Zie hoofdstuk VIII, paragraaf 2 , noot 17 .

${ }^{67}$ A. Dorsch 1804, pp. 393-394.

${ }^{68}$ A. Dorsch 1804, p. 372 .

Zie hoofdstuk X. 
goederen gerechtelijk werd aangesproken vanwege het bezit van een gestolen horloge. Een andere keer maakt de rechter zich zorgen over de vraag of een jood die enkele kostbare horloges in bezit had en verstoken was van liquide middelen, als landloper mocht worden uitgewezen. ${ }^{70}$ Het lijkt allemaal meer op individuele activiteiten dan op systematische handelspraktijken, laat staan op de uitoefening van een hoofdberoep.

Pas heel laat, rond het midden van de 19 de eeuw, wordt het beeld duidelijker. Rond 1850 betrok F.N. Trommar in Horst zijn zakhorloges van de Rotterdamse firma Delosie. Via de verkoop van vaak kostbaar uitgevoerde zakhorloges was de horloger-constructeur geëvolueerd naar de horloger-juwelier, zoals wij die heden ten dage kennen: een zakenman die in een chique juwelierszaak fabrieksmatig vervaardigde klokken en horloges doorverkoopt, die hij vaak niet eens zelf kan repareren.

De opleiding van uurwerkmakers was louter een opleiding in de praktijk. Het was geen sinecure. De afspraken tussen de leermeester en de ouders van de leerling werden nauwgezet vastgelegd.

Bij de vervaardiging van klokken deed de uurwerkmaker veel zelf, althans zolang de werkzaamheden op het terrein van de mechanica lagen. Slechts tegen het einde van de 18 de eeuw bereiken ons berichten over de inkoop van onderdelen en halffabrikaten, die allemaal nog de nodige bewerkingen moesten ondergaan. Grondstoffen en halffabrikaten werden zo dicht mogelijk bij huis gezocht, in het Luikerland of in het Rijnland. Het staat echter buiten kijf dat het ten verkoop aanbieden van door derden gefabriceerde producten op het vlak van staande klokken en andere huisuurwerken niet voorkwam. De Limburgse uurwerkmaker was - behalve als het om zakhorloges ging - geen tussenhandelaar of assembleur.

De omvang van de productie kon sterk wisselen, zoals blijkt uit de genummerde uurwerken. De uurwerkmakers arbeidden naar het schijnt gemiddeld twee à drie weken aan het vervaardigen van een uurwerk zonder de kast. Veertien à vijftien uurwerken was de maximale productie die een getenommeerd huis in een jaar kon halen. Dan besteedde de uurwerkmaker ongeveer de helft van zijn arbeidstijd aan het maken van uurwerken. Bij zo'n kleine jaarproductie mag het niet verbazen dat voornamelijk voor de lokale markt

${ }^{70}$ Mededelingen I.C.G.M. Jansen. 
werd gewerkt. Een enkeling vond afzet tot dertig of veertig kilometer van zijn woonplaats.

Evenals in het vorig hoofdstuk kwam in dit hoofdstuk tot uitdrukking dat tegen het einde van het Ancien Régime de markt voor uurwerken diepgaand veranderde. Anders dan in de Middeleeuwen, toen specialisten op het terrein van mechanica voornamelijk in opdracht van stadsbesturen openbare uurwerken vervaardigden ter plaatsing op of nabij pleinen waar het gros van de handelsactiviteiten zich afspeelde, zijn het in de $18 \mathrm{de}$ en begin $19 \mathrm{de}$ eeuw beoefenaren van meerdere beroepen die ten plattelande huisuurwerken vervaardigden ten behoeve van een brede particuliere markt. Deze markt bestond in het bijzonder - naar het schijnt uit personen die behoefte hadden aan een wekkersignaal en aan het gemakkelijk kunnen aflezen van de tijd in een ruimte, waarin zich veel personen bevonden: zij hoefden slechts naar boven te kijken. Voordat daaruit indringende conclusies worden getrokken, dient zeker nog naar de afzet te worden gekeken in het volgende hoofdstuk. 


\section{Hoofdstuk X}

\section{De verkoop en verspreiding van Limburgse uurwerken}

\subsection{De sociale aspecten van de verspreiding}

Het bezit van de eerste, grote torenuurwerken was volgens de gespecialiseerde literatuur en de gegevens van dit onderzoek beperkt tot grote en middelgrote steden, rijke kapittels en abdijen. De eerste huisuurwerken en draagbare horloges konden alleen koningen en hoge adel zich veroorloven. Zij lieten er zich graag mee afbeelden op schilderijen; zij beschouwden hun uurwerk kennelijk als statussymbool. ${ }^{1}$

Wanneer Margaretha van Male, de echtgenote van Philips de Stoute van Bourgondië, van het ene kasteel naar het andere trok, nam zij steeds op één van haar wagens haar "orloge" mee. In haar gevolg bevond zich een Vlaamse of Hollandse uurwerkmaker die voor onderhoud en herstel moest zorgdragen. De man zal er werk genoeg aan hebben gehad. De toenmalige uurwerken waren allerminst bestand tegen schokken en stoten. Philips de Stoute liet te Atrecht twintig uurwerken ineens kopen. ${ }^{2}$ Dit grote aantal had hij mogelijk nodig om in zijn verschillende kastelen een uurwerk te kunnen plaatsen of om ze ten geschenke te geven.

Jacoba van Loon-Heinsberg, van 1446 tot 1451 abdis van Thorn, bleek bij haar overlijden in 1466 in Mechelen in het bezit te zijn van een rijke inboedel, waartoe ook een uurwerk behoorde. Helaas weten wij niet of ze dit al in Thorn had, noch waar of door wie het was vervaardigd. ${ }^{3}$ Langzamerhand sijpelde het bezit van uurwerken door naar lagere echelons in de maatschappij, zij het mondjesmaat. De rentmeester van kasteel Blitterswijk (Nederlands-Noord-Limburg) bezat kennelijk al in 1585 een draagbaar uurwerk. Hij werd in dat jaar onderweg naar Hemmen overvallen en moest zijn mantel, horloge, schoenen, neusdoeken en dolk afstaan. ${ }^{4}$ In de boedelin-

\footnotetext{
1 A. Chapuis 1954, passim.

${ }^{2}$ J. Lecat 1985, p. 60.

${ }^{3} \mathrm{E}$. Koch 1994, bijlagen op diskette: Thorn, nr. 68.

${ }^{4}$ Middelleenwse kastelen in Limburg 1996, p. 193.
} 
ventaris, opgemaakt op 25 februari 1670 in het sterfhuis van Elisabeth Moeitz, de echtgenote van Johan Balthasar Renthelin, wordt bij het "iser werck" een uurwerk, "ein horologium", vermeld. Elisabeth Moeitz stamde uit een rijke Venlose familie. Het sterfhuis lag in Het Venn bij Venlo. De aard van het uurwerk wordt niet nader omschreven in de inventaris. ${ }^{5}$ Begin 18 de eeuw komen staande klokken nog slechts voor in kasteelinboedels; kort daarna worden zij in Limburg ook aangetroffen in die van rijke burgers en pastorieën. ${ }^{6}$ Ook de bellangstelling van steden voor uurwerken valt tot in de 18 de eeuw tegen, laat staan dat rijke kapittels en abdijen uurwerken bezaten.

De laat-middeleeuwse uurwerkmarkt was zeer klein. In het hier onderzochte gebied lijkt een schatting van één uurwerk per 1.000 $\mathrm{km}^{2}$ omstreeks 1500 realistisch. Een klein groepje uurwerkmakers, geconcentreerd in één of twee steden, aanvankelijk Maastricht en Hasselt, volstond om aan de vraag te voldoen. Tientallen namen van personen die dagelijks bemoeienis hadden met de torenuurwerken konden worden opgespoord. Het is vaak niet uit te maken wie van hen echt uurwerkmakers waren en wie slechts het intensieve dagelijkse onderhoud konden verrichten, maar de echte uurwerkmakers waren zeker ver in de minderheid. Van een beroepsgroep die uit de uurwerkmakerij zijn levensonderhoud kon puren, was tussen 1367 en 1500 geen sprake. In de 16de en 17de eeuw was het weinig beter. Maar langzaam breidde het aantal torenuurwerken zich uit. Opmerkelijk is vooral dat een aantal kleine dorpen rond Hasselt en Sint-Truiden er een kreeg. Uit spaarzame berichten is bekend dat daar tot 1560 nogal wat wede werd geteeld, de grondstof voor blauwe verven. Het laat zich aanzien dat de bereiding van blauw verfpigment uit wede in de dorpen plaats vond. $^{7}$ Of dit gecompliceerde productieproces een dusdanige arbeidsdifferentiatie vergde, dat regulering van de dagindeling met behulp van een uurwerk nodig was, is niet bekend. Het zeer spaarzame bronnenmateriaal kan er voor onze streek geen helderheid

${ }^{5}$ G.A.V., Schepenarchief Venlo, inv.nr. 2745. Zie voor de tekst van de inventaris P. Geuskens 1996 , pp. $85-89$.

J. Weyns 1974 , p. 975.

${ }^{7}$ Wede, Isatis tinctoria, bevat relatief weinig kleurstof, die er door middel van een intensieve bewerking moest worden uitgehaald. De ballen met pigment werden op de markt verkocht. Na de 16 de eeuw ondervond wede sterke concuntentie van indigo dat meer pigment bevat. $T$. Derry and 'T. Williams 1960, pp. 266-267. 
over verschaffen. Een grootschaliger vergelijkend onderzoek zal nodig zijn om de samenhang tussen deze vorm van intensieve landbouw en tijdmeting aan te tonen.

Pas in de 18 de eeuw ontstond er een ruime markt voor uurwerken. $\mathrm{Na} 1750$ breidt het klokkenbezit en dus ook het aantal klokkenmakers zich explosief uit: ook voor de gewone man wordt een klok een begeerd en bereikbaar voorwerp, waarmee hij zijn interieur wil tooien. Dat eenvoudige mensen zich een klok konden veroorloven, blijkt uit de namen van klokkopers op de openbare boedelveilingen van Brienen in 1788 en van Wessels in 1816 . Zij wijzen niet op een elitair koperskorps, maar op boeren en ambachtslieden. Dat zij klokken nodig hadden, hield verband met de doorbraak van de geldeconomie. ${ }^{8}$

Dit beeld wordt bevestigd door Schuurman. ${ }^{9}$ Zich baserend op 18de-eeuwse gegevens poneert hij: "In klokkenbezit lopen de boeren duidelijk voor op de stedelingen. Mogelijk hebben zij er meer behoefte aan, wanneer zij te ver verwijderd wonen van een kerkklok. ... De klok blijkt in zijn oorspronkelijke verspreiding bij uitstek een plattelandsvoorwerp te zijn". Deze constatering zal ook voor de beide Limburgen gelden, gezien het feit dat er slechts in een kleine $30 \%$ van de dorpen aanwijsbaar een torenuurwerk was ${ }^{10}$ en de hoge frequentie van uurwerkmakers op het plattelland. ${ }^{11} \mathrm{Wij}$ zagen dat de combinatie van agrarische en nijverheidsactiviteiten op het platteland een nauwgezette dagindeling en regulering van de arbeidstijd vereisten. Vooral in streken met veel verspreide bebouwing was het huisuurwerk populair. Waar de huizen dicht opeen in een dorpskern stonden, nam het aantal torenuurwerken toe. De verspreiding van de klok ging in de 19 de eeuw in verhevigde mate door. Op grond van analyses van boedelinventarissen concludeert Schuurman, dat in 1830 in praktisch elk huishouden in de drie onderzochte regio"s, te weten de Zaanstreek, Oost-Groningen en Oost-Brabant, een klok is. ${ }^{12}$ Oost-Brabant ligt zo dicht tegen de Limburgen aan qua geografie en mentaliteit, dat het niet onverantwoord lijkt Schuurmans constateringen voor die regio ook voor de

\footnotetext{
${ }^{8}$ F. Braudel 1987; P. Servais 1982, pp. 269-272; C. Leonard and B. Mironov (eds.) 1994, pp. 11-21 en 47-63.

${ }^{9}$ A. Schuurman 1989 , p. 271.

${ }^{10} \mathrm{Cfr}$. hoofdstuk VI.

"CfT. hoofdstuk VIII.

${ }^{12}$ A. Schuurman 1989 , p. 115.
} 
Limburgen geldend te achten. Langs indirecte weg, door een schatting te maken wan de markt, kunnen we er een bevestiging van vinden. We moeten dan niet kijken naar het geringe aantal overgeblewen unrwerken.

Schuurman stelt dat de staande klok nooit een grote verspreiding heeft gehad, gezien haar prijs. ${ }^{13}$ Dat kan juist zijn en het bevestigt het eerder uitgesproken vermoeden, dat er meer hangklokken verloren zijn gegaan dan staande klokken, waardoor we een vertekend beeld krijgen, als we alleen afgaan op de bewaard gebleven exemplaren uit de beide Limburgen, voor het merendeel staande klokken. Wel leveren de productienummers op de klokken van sommige uurwerkmakers ons een aanwijzing. Het staat vast dat enige uurwerkateliers in een periode van zo'n zestig jaar achthonderd tot duizend uurwerken afzetten. Het gemiddelde zal zonder twijfel veel lager hebben gelegen. Wellicht kwam het nauwelijks boven een honderdtal per atelier uit. Gezien het grote aantal uurwerkmakers dat tussen 1750 en 1825 volgens tabel 4 actief was, mag niettemin een productie van zo'n twintigduizend stuks worden verondersteld. Gezien de gezinsomvang - zo'n vijf personen per huishouden - en het totaal aantal inwoners in de beide Limburgen rond de overgang van de $18 \mathrm{de}$ en de $19 \mathrm{de}$ eeuw betekent dit, dat in ieder geval tweederde deel van de gezinshoofden in deze tijd een uurwerk aanschafte. De afzet was immers in hoge mate regionaal gebonden. Gewoonlijk leverde de klokkenmaker alleen het uurwerk, maar soms zal hij ook een complete staande klok in voorraad hebben gehad. $\mathrm{Bij}$ de veertien klokken op de veiling ${ }^{14}$ van de nalatenschap van Wilhelmus Wessels was er slechts één klok met kast, misschien het huisuurwerk van Wessels zelf. Deze klok werd voor 52,40 franc gekocht door Joannes Mathis Lemmens, schoenmaker te Geleen en voogd van Wessels' kleindochter Elisabeth, een dochter van Theodorus Wessels. Hij deed deze aankoop misschien om de klok voor zijn pupil te bewaren of haar in de familie te houden. Misschien werd het begin 19de eeuw gebruikelijk, dat er door de klokkenmakers complete staande klokken werden aangeboden; Peter Wessels kocht op genoemde veiling niet minder dan zes olmen en een

${ }^{13}$ A. Schuurrman 1989 , p. 89 .

${ }^{14}$ R.A.M., Notariële archieven, inv.nr. 376, minuutakten van notaris J.M. Luijten te Geleen, akte nr. 16 , d.d. I maart 1816 . 
es, mogelijk om zelf kasten bij zijn uurwerken te leveren. ${ }^{15}$ Deze tendens werd al waarneembaar aan het eind van de 18 de eeuw: blijkens de boedelinventaris van Joannes Brienen te Venray in 1788 kon men bij hem kiezen uit losse uurwerken, uurwerken in een hangkastje en uurwerken in hele kasten. ${ }^{16}$ De mogelijkheid om eerst een los uurwerk dan wel een uurwerk in een hangkastje of een wandklok te kopen en dit later uit te bouwen tot een staande klok was geschapen vanwege de grote kosten van een complete staande klok, die vooral vanwege de kast duur was. Deze praktijk kwam niet alleen voor in Nederlands-Noord-Limburg, maar ook in het Bergische Land (D). Helmut Krieg vermeldt over de klokkasten aldaar: "Der Kauf einer Stand- oder Wanduhr bedeutete auch für den Bürger des bergischen Landes, der im 18. und 19. Jahrhundert in gesicherten Verhältnissen lebte, eine Anschaffung, die nicht immer leicht fiel. Um nun die Kosten so niedrig wie möglich zu halten, wurden die Uhren in der Mehrzahl nur in Form eines Uhrenkopfes geliefert, wobei oft genug infolge Mangels an Bargeld Naturalien in Zahlung gegeben wurden. Hatte der Erwerber sich nach einiger Zeit finanziell erholt und hatte er unbedingt den Wunsch, eine Standuhr, ein Statussymbol in damaliger Zeit, zu besitzen, so beauftragte er einen örtlichen Schreiner, zu dem Uhrenkopf einen passenden Unterkasten zu bauen". ${ }^{17}$

\subsection{De prijs van een klokkast}

Een klokkast was relatief duur: de bovengenoemde staande klok met kast in de veiling Wessels kostte 52,40 franc, terwijl de gemiddelde prijs van de 13 losse uurwerken 9 franc bedroeg. De kast kostte dus bijna zes keer zoveel als het uurwerk en bijna de helft van de koe uit de nalatenschap van Wessels. Ook de opbrengsten van staande klokken in de boedelveiling van J. Brienen te Venray in 1788 geven duidelijke indicaties van de kostbaarheid van klokkasten. Op genoemde veiling brachten staande klokken 110 tot 200 Kleefse guldens op; losse uurwerken deden 36 tot 46 Kleefse

\footnotetext{
${ }^{15}$ R.A.M., Notariële archieven, inw.nr. 376, minuutakten wan notaris J.M. Luijten te Geleen, akte $\mathrm{nr} .16$, d.d. 1 maart $1816, \mathrm{mr}$. 146 van de veilinglijst.

${ }^{16}$ R.A.M., Schepenbank Venray, evacuatienummer 3956, inboedel van Joannes Brienem, 1788.

${ }^{17}$ H. Krieg 1989, Teil II, pp. 3877 en 3878.
} 
guldens en een uurwerk met hangkastje 68 Kleefse guldens. De verhouding tussen kosten van uurwerk en kosten van de kasten is hier één : drie. De kostbaarheid van een klokkast blijkt ook uit het aantekenboekje van Jan Gijbels uit Laak bij Houthalen. Hij leverde in 1791 een "horolosiecas" van eikenhout voor 28 gulden, terwijl zijn dagloon 15 stuivers bedroeg. De waarde van de klokkast was gelijk aan een loon van 37 dagen, meer dan zes volle werkweken. ${ }^{18}$ Een timmerman die de vier wintermaanden vulde met het bouwen van klokkasten kwam nog niet aan drie kasten per jaar. De uurwerkmaker zette drie- tot vijfmaal zoveel uurwerken ineen.

Het uurwerk was niet alleen een nuttig voorwerp, het was ook een statussymbool. Een klok werd nogal eens als bruidsgeschenk gegeven, zoals te zien is aan initialen en namen van echtparen op klokkasten. Zo kregen Renerus Helgers uit Geleen en Ida Martens vit Beek, die in 1783 trouwden, een klok, vervaardigd door Wilhelmus Wessels, ${ }^{\| 9}$ blijkens een inscriptie aan de binnenkant van de
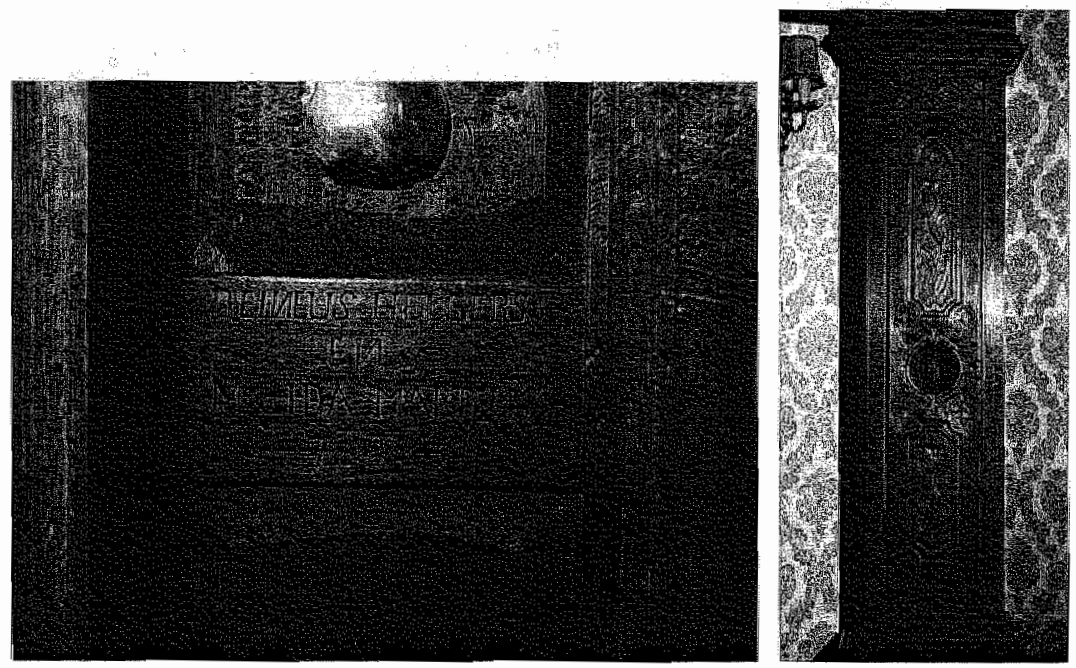

110. (1.) Inscriptie bimnenin klokkast (uurwerk W. Wessels, Geleen)

111. (r.) Inscriptie buiten op klokkast (uurwerk F. van der Hoeven, Venlo)

\footnotetext{
${ }^{18}$ N. Martens 1955, pp. 261-267.

19 Zie appendix II. Dit is klok e. van Wilhelmus Wessels. De inscriptie luidt: "Reineus (sic) Helgers / en / M : Ida Martens / 1783".
} 
klokkast (zie afbeelding 110). Regel was echter dat de initialen van een echtpaar en het jaartal van trouwen aan de buitenkant van de klokkast werden uitgestoken. Zo is op klok c. van Van der Hoeven, Venlo (z.a.) uitgestoken "I.V.D.H / A.M.D.E.L / . ANNO 1807.", dat wil volgens de huidige bezitter zeggen: I. van den Homburg en Anne Marie D(?): echtelieden (zie afbeelding 111). In het Centraal Huwelijksregister in het Rijksarchief te Maastricht is helaas geen echtpaar te vinden, waarvan de initialen en het jaartal overeenkomen met deze op de bovengenoemde klokkast. Verwonderlijk is dit niet. Sinds de invoering van het Echtreglement door de Staten-Generaal had zich in Noord-Brabant en Limburg het gebruik ontwikkeld de administratieve afwikkeling van het huwelijk lang vóór het kerkelijk huwelijk te doen plaatsvinden. Pas op de dag van de kerkelijke inzegening van het huwelijk werden huwelijksgeschenken in ontvangst genomen.

Over de handelsgebruiken zijn wij slecht geïnformeerd. Uit de boedelpapieren van Joannes Brienen blijkt, dat hij een paar klokken bij mensen thuis had staan. Dit kan verschillende redenen hebben gehad, op proef, op krediet - hij nam zelf royaal groothandelskrediet - of in consignatie voor wederverkoop. Het is het enige document waaruit duidelijk wordt, dat tussen levering en betaling geruime tijd kon zitten. Harde conclusies zijn er niet uit te trekken.

\subsection{De verkoop van zakhorloges}

Zakhorloges lijken tot het eind van de $17 \mathrm{de}$, misschien het eerste kwart van de 18 de eeuw het werk te zijn van degene, die het horloge heeft gesigneerd. Daarna werden het kant en klaar geïmporteerde producten, die van een verkopersnaam werden voorzien. Door hun geringe omvang konden zij gemakkelijk worden vervoerd en soms zelfs gesmokkeld. Het is niet met zekerheid bekend waar ze vandaan kwamen. Wellicht kwamen ze eind 18 de eeuw goeddeels uit de Jura. Rond 1850 bestelde F.N. Trommar (z.a.) in Horst zijn zakhorloges in Rotterdam bij de firma Delosie. Omdat we, behalve van Trommar, geen sporen van bedrijfsarchieven hebben aangetroffen, blijft de herkomst van de zakhorloges verder hoogst onzeker.

Bij toeval weten we echter, dat rond 1775 een Engelse horlogemaker, te weten William Howell uit Hearn in Kent, in Venlo en 
omstreken zakhorloges en juwelen trachtte te slijten. Hij was met zijn vrouw Mary en een voorraad horloges en sieraden naar Den Haag getogen. Aan contant geld en koopwaar hadden zij voor 260 pond sterling bij zich. Omdat de verkoop tegenviel en het leven in 's-Gravenhage duur was, reisden de Howells per trekschuit naar Delft. Tijdens dit tochtje raakten zij in gesprek met een Schotse korporaal, Thomas Tyrer, die in Venlo in garnizoen lag. Deze ried hen aan hun geluk in Venlo te beproeven, waar de handel wrij en het leven goedkoop was. Hij bood hen voorlopig onderdak aan. De Howells gingen op zijn voorstel in. Toen ze een week te gast waren geweest bij Tyrer, werd Howell ontboden bij de schout van Venlo, Joannes van den Vaero. ${ }^{20} \mathrm{Hij}$ vroeg hem met hulp van Tyrer als tolk of hij burger van Venlo wilde worden. Toen Howell zei dat hij dit met zijn vrouw wilde overleggen, ried Van den Vaero hem aan zich vanwege de kosten op het platteland te vestigen. Hij bood een stuk grond te koop aan in Grubbenvorst voor duizend gulden Kleefs. Howell ging op het aanbod in en betaalde in natura, te weten een "extraordinaire goude repetitie horologie" ter waarde van 330 gulden Hollands, een dito zonder repetitie ter waarde van 130 gulden Hollands, een ring met diamant ter waarde van 50 gulden Hollands en een paar zilveren schoengespen ad 7 gulden Hollands, in totaal dus 517 gulden Hollands, ruim 1000 gulden Kleefs. Daarbij gaf hij nog een koppel zadelpistolen. Howell bouwde een huis op de heidegrond, gelegen op "het Hennekes en Swevers" bij het "oude Witteveld", conform het contract. Hij voelde zich alras bedrogen omdat hij volgens informanten minstens driemaal te veel yoor de waardeloze grond zou hebben betaald. Howell spande een procedure aan voor het Hof van Gelre in Venlo.

Van den Vaero verdedigde zich tegen de aantijgingen door te stellen dat de grond beter was dan Howell wilde doen voorkomen, door te stellen dat er geen sprake was van verkoop, maar van ruil en door de horloges en de juwelen lager te laten taxeren dan de prijzen, genoemd door Howell. Voor de taxatie van de horloges schakelde hij drie Venllose uurwerkmakers in, te weten: Leonardus Hockx (1720-1815), J. Poeijn (1695?-nà 1774) en F.H. Wassenbergh, tot nu toe onbekend. De taxaties van het gouden repetitie-

\footnotetext{
${ }^{20}$ Voor de familite Van den Vaero zie J. Verzij1 1964, pp. 125-128. Joannes van den Vaero was scholtis van 1767 tot 1781 . Hij was geboren te Grubbenvorst en bewoonde het kasteeltje de Gun te Swolgen.
} 
horloge in twee "doorwerckte ofte doorlughtige kaste" variëren van 315 tot 325 gulden Kleefs. Het andere, Franse (volgens Hockx) in één kast werd geschat op 168 tot 178 gulden 10 stuivers Kleefs. Howell wees erop dat het helemaal niet bewezen was, dat de schout Howells horloges had laten taxeren en als dat wel zo was, dan was het onjuist alleen het materiaal en niet het vakwerk te waarderen. De diamanten ring en de zilveren gespen werden getaxeerd door de Venlose zilversmeden Petrus Reijnders, Johannes F. van Carlo en de tot nu toe onbekende V.N. Lacroix. Laatstgenoemde taxeerde de sieraden inclusief de pistolen op 42 gulden Kleefs. Horloges en sieraden met pistolen samen werden geschat op 525 tot 546 gulden Kleefs, ongeveer de helft van wat Howell ze waard achtte. ${ }^{21}$ Het proces duurde tot 11 juli 1775 . Toen deed het hof de volgende uitspraak: "... 't Hoff verclaart het coop contract door den impetrant (Howell) met den gedaagden (Van den Vaero) ingegaan de dato 7 september 1773 ende all hetgene daeruyt ende aan is gevolght, Nul, craghteloos ende van geender waarde, releveerende dienvolgens ende stellende den impetrant in geheel ten opzighte van gesegt contract ende sequeelen vandien, condemneert den gedaagden aan den impetrant promptelijk te restitueeren tegens overneemen van het erve in actis vermeld ende het huijs daarop staande, de beijde goude horologien, mitsgaders diamanten ringh ende een paar zilvere gespen, uit cragte van voornoemd coopcontract bij hem gedaagden ontfangen, voorts aan den impetrant te betaalen duijzent guldens Cleefs voor het huijs op gesegt erf door den impetrant gestelt, condemneerende verners den gedaagden zoo in de gereserveerde als andere costen van den processe ter taxatie ende moderatie van den Hove". Howell werd volkomen in het gelijk gesteld. De proceskosten die Van den Vaero moest betalen, werden door het hof op 16 augustus 1775 vastgesteld op "twe hondert ende eenen guldens ende twe ende een quart deniers brabants, inbegreepen het specie gelt" ${ }^{22}$

Het proces zegt meer over de relatie tussen het Hof van Gelre en de schout, dan over de horlogehandel te Venlo. Erg bloeiend kan die niet zijn geweest. Howell kon niet uit de opbrengst van verkochte goederen financieren, maar moest zijn toevlucht nemen tot

${ }^{21}$ R.A.M., Hof van Gelre te Venlo, inv.nr. 4, vonnissemboek, proces Howell, William contra Vaero, J.v.d., 1773-1775. Met dank aan dr. G. Venner voor attendering op dit stuk.

22 R.A.M. , Hof van Gelre te Venilo, inv.nr. 4, vonnissenboek. 
betaling in natura. Waarschijnlijk is hij, na voor een redelijk bedrag van zijn huis te zijn afgekomen, uit de regio Venlo vertrokken en heeft hij elders een betere markt gezocht. Dat zal niet gemakkelijk zijn geweest. De gebeurtenissen in Den Haag en Venlo laten zien, dat de levensstandaard zowel de omvang van de transactiekosten als de bestedingen van het koopkrachtig publiek bepaalde. Wie met dure Engelse producten kwam aandragen, leed altijd verlies, hetzij omdat zijn handeltje tegen te hoge kosten in stand moest worden gehouden, hetzij omdat de kopers veel lagere prijzen wensten te bedingen. Het was zaak de koopwaar te betrekken uit een regio met een lager kostenniveau dan gebruikelijk in de streek waar de koopman zijn afzet zocht. De voorkeur voor horloges uit de Jura, waarvan Dorsch ${ }^{23} 25$ jaar later gewag maakt, is begrijpelijk.

De eerste stappen op weg naar een georganiseerde handel in horloges waren moeilijk. Weldra werd het beter. In het midden van de 19 de eeuw is de branche in Limburg gevestigd, gewoonlijk bij goud- en zilversmeden.

Alleen welgestelden konden zich in de begintijd van het mechanisch uurwerk een huisuurwerk permitteren. Het allereerste huisuurwerk in Limburg waarvan wij weet hebben, werd aangeschaft door een zeer vermogende, hoogadellijke dame in het midden van de 15 de eeuw. Zelfs in de eerste decennia van de 18 de eeuw was de uurwerkmarkt nog heel klein. Rond 1750 breidde het uurwerkbezit zich sterk uit. Het koperspubliek moest op het platteland worden gezocht, in het bijzonder in kringen waar agrarische en ambachtelijke activiteiten werden gecombineerd om in het levensonderhoud te voorzien. Dat gebeurde vooral door gezinshoofden die te weinig grond bezaten om een groot gezin te kunnen onderhouden en hun kinderen een aanvaardbare toekomst te bezorgen: de lagere middenklasse van de agrarische samenleving.

Met de hoge aanschafkosten van een uurwerk had dit koperspubliek grote moeite. Soms werd in fasen gekocht: eerst een naakt uurwerk of een uurwerk met alleen het houten bovenstuk en pas geruime tijd later de klokkenkast. De behoefte aan een eigen uurwerk moet heel aanzienlijk zijn geweest. Dit moet wel hebben samengehangen met de bedrijfsorganisatie bij agrariërs die waren aangewezen op het combineren van activiteiten, want terzelfdertijd werden in diverse

${ }^{33}$ A. Dorsch 1804, p. 394. 
dorpen eindelijk ook torenuurwerken geplaatst, waarvan men de tijd kon aflezen als men even de deur uitging.

Meer vooraanstaande figuren, die voor de vervulling van hun taken nu eens hier, dan weer daar verbleven, zoals de schout van Venlo, voorzagen zich van een zakhorloge. De markt daarvoor was erg klein. 


\section{Hoofdstuk XI}

\section{Conclusies}

\subsection{Het openbare uurwerk}

Op een aantal punten biedt het gedetailleerd onderzoek naar de evolutie van de openbare tijdmeting middels torenuurwerken in het kleine, territoriaal sterk versnipperde en in economisch opzicht bepaald niet voorlijke Limburg, zoals beschreven in de voorgaande hoofdstukken, duidelijkheid. Een vijftal punten willen we aanstippen:

1. De diffusie van het mechanisch uurwerk verliep, evenals in de grote Europese steden, in de grotere Limburgse steden redelijk snel. In de 14 de en 15 de eeuw kregen de meeste Limburgse steden met vierduizend inwoners of meer een stadsuurwerk. Roermond, dat met zevenduizend inwoners in 1400 bijna half zo groot was als Maastricht en groter dan Venlo, Tongeren en SintTruiden, vormt mogelijk een uitzondering. In de kleinere steden en de dorpen vergde het echter veel meer tijd: het duurde tot in de 16de eeuw vóór alle Maassteden een uurwerk hadden. De plattelandsstadjes wachtten er gewoonlijk nog langer op. In de dorpen was het openbaar uurwerk tot 1650 zeer zeldzaam. Daar nam in de 18 de eeuw het aantal openbare uurwerken wel flink toe, maar er bleef samenhang bestaan met de ruimtelijke ordening van het dorp. Was er merendeels verspreide bebouwing, lag er om het kerndorp een krans van gehuchten of is er sprake van een straatdorp, telkens wanneer niet het overgrote deel van de inwoners het tijdsignaal kon volgen, liet men het torenuurwerk achterwege. De maatschappelijke invloed van het mechanisch uurwerk, waarover Mumford, ${ }^{1}$ Cipolla, ${ }^{2}$ O. Mayr,${ }^{3}$ Landes $^{4}$ en Le Goff ${ }^{5}$ spreken, was waarschijnlijk heel wat beperkter en trager dan zij het voorstellen. Het gaat klaarblijkelijk niet om

\footnotetext{
${ }^{1}$ L. Mumford 1934, pp. 12-18.

${ }^{2}$ C. Cipolla 1967.

${ }^{3}$ O. Mayt 1986.

${ }^{4}$ D. Landes 1983.

s. le Goff 1.960; idem 1985.
} 
een fundamentele verandering van het maatschappijbeeld, evenmin om innovaties die voorwaarden schiepen voor blijvende economische groei of het ontstaan van een kapitalistische economische orde en ook niet om een grondige wijziging van de fundamenten van het Westers denken, zoals deze auteuts veronderstelden. Zo'n brede impact zou tenminste veronderstellen dat eenieder de zegeningen van de openbare tijdmeting kon genieten. Daar was geen sprake van: zelfs in de belangrijkste steden worden tot 1550 hoogstens één à twee uurwerken aangetroffen, voorshands niet voorzien van een wijzerplaat, de uurslag slechts in een deel van de stad hoorbaar, regelmatig defect, soms langere tijd buiten bedrijf. In Tongeren en Venlo, waar twee uurwerken vlakbij elkaar waren opgesteld, wist men tenminste enige bedrijfszekerheid te bereiken, evenals in Maastricht, waar er wel vier waren. Meer uurwerken gaf echter nieuwe problemen. In Maastricht was het in de 17 de eeuw nog onduidelijk wie de standaardtijd leverde, het stadhuis of de Sint-Servaas.

2. De tijdmeting was sedert de 14 de eeuw in de grotere stedelijke centra een taak van de stadsbesturen. De landsheren bemoeiden zich tot diep in de 17 de eeuw nimmer met enig aspect van de openbare tijdmeting. Een mogelijke uitzondering vormt het kapittel van Sint-Servaas, dat in een klein deel van de stad als suzerein optrad en verantwoordelijk was voor de Maasbrug, een essentieel onderdeel van de belangrijkste verkeersader over land, zodat het er soms belangen vertegenwoordigde die parallel liepen met die van de stad. Op zijn grondgebied werden deels de jaarmarkten gehouden. In 1367 gaf het kapittel de stad een aanzienlijk subsidie voor de aanschaf van een uurwerk. Veel machtiger heren, zoals de bisschop van Luik, de hertog van Brabant, de graven van Gelre, Gulik en Kleef, lieten zich aan de openbare tijdmeting in hun bezittingen in het Maasdal niets gelegen liggen, althans daar werd geen spoor van teruggevonden. Hetzelfde gold voor de hertogen van Bourgondië, die weliswaar een uurwerk meesleepten door hun landen, zodat ze zelf over een tijdsaanduiding beschikten, maar - zover we weten - zich niet bekommerden om enige harmonisatie van de tijd in hun landen of intensivering van het aantal afleespunten. Alleen de koning van Pruisen, die in 1713 een gedeelte van Nederlands-NoordLimburg in bezit kreeg, vormt wellicht een uitzondering. Sinds 1650 , ruim drie en een halve eeuw na de uitvinding van het 
mechanisch uurwerk, bevorderde hij her en der de plaatsing, zonder evenwel in zijn landen tot een dekkend net te geraken. Het vroege (14de-15de eeuw) stadsuurwerk is te beschouwen als een kenmerk van een geslaagde stadsstichting naast stadsrechten, stadsmuren en marktrechten. De stedelijke uurwerken waren slechts vanaf de markt goed zichtbaar. Doorslaggevend voor het bepalen van de functie van het uutwerk was de zichtbaarheid niet. Het ging niet om klok kijken, de torenuurwerken waren nog lang niet overal voorzien van een wijzerplaat. Men luisterde naar het tijdsignaal. De akoestische tijdsindicatie, zoals uur-/halfuur$/ \mathrm{kwartier}$ - en halfkwartierslag was zeer belangrijk, maar lang niet altijd in de hele stad te horen. Alleen als het uur werd geslagen op de banklok, zoals in Namen, Fosses en Doornik ${ }^{6}$ gebeurde, kon het hele bangebied dit in theorie horen, zich ernaar richten en op den duur een tijdsbesef ontwikkelen. Of dit ook in Limburg gebruikelijk was en waar dan wel weten we niet. Vanuit Limburg zijn er geen berichten over. Over het algemeen kon daar met behulp van de tijdsindicatie op het openbaar uurwerk of met een speciaal luidklokje alleen het gebeuren op de markt worden geregeld.

3. In de 16 de en 17 de eeuw vond er een geleidelijke toename plaats van het aantal stadsuurwerken en andere openbare uurwerken. $\mathrm{Zij}$ werden geplaatst aan stadspoorten, enkele kloosters, kastelen en kerken. Merkwaardig genoeg had vrijwel geen enkel klooster of kerkelijke instelling tot omstreeks 1600 een openbaar uurwerk, zelfs niet als deze instellingen, zoals de kapittels van Maastricht en Tongeren en de adellijke stiften en kloosters te Thorn, Roermond, Houthem, Susteren en Herckenrode, zich veel beter een openbaar uurwerk konden permitteren dan de lokale overheden. Religieus-rituele gebeurtenissen bleef men nog lang met luidklokken regelen. Hetzelfde gold voor de adel: pas vanaf het midden van de 18 de eeuw plaatsten enkele edellieden een uurwerk in het front van het poortgebouw of op de voorgevel van hun kasteel. De toename zal hebben samengehangen met een grotere behoefte aan tijdmeting. In de laatste decennia van de 17 de eeuw en in de loop van de 18de eeuw werd de slinger toegepast bij nieuwbouw en ombouw van uurwerken, bijvoorbeeld het nieuwe stadhuisuurwerk en de ombouw van het uur-

${ }^{6}$ Over uurslag op de banklok bericht C. Parart 1976, pp. 170-171. 
werk van de Sint-Servaaskerk te Maastricht. Daardoor ontstond meer precisie en voor het eerst enige synchronisatiemogelijkheid, zij het alleen binnen de eigen stad. ${ }^{7}$ Sinds het marktschip en de postkoets er een dienstregeling op na hielden, was het zaak de plaatselijke tijd goed in de gaten te houden en vaak op de openbare klok te kijken. Een horloge in de vestzak werleende wel. status, maar bepaald geen zekerheid dat men op tijd kwam. Het was met name zaak dat op knooppunten van wegen, bij aanlegplaatsen van buurtschepen en op halteplaatsen van koetsdiensten uurwerken aanwezig waren.

4. In de loop van de 19de eeuw werd de openbare tijdmeting een minder belangrijke taak voor de gemeentelijke overheden vanwege de verspreiding van uurwerken en het verdwijnen van de plaatselijke tijd. Voor de kerkbesturen werd het anders. Die zorgden allemaal dat ze een torenuurwerk kregen. De kerktorens van oudere kerken, die vaak eigendom waren van de burgerlijke gemeenten, werden soms zelfs door de kerkbesturen overgenomen met de last van onderhoud van het uurwerk. Ook kwamen er uurwerken aan fabrieken en stations. Publieke gebeurtenissen, kerkelijke diensten, arbeidstijden en het verkeer vonden woor het eerst in de geschiedenis nauwkeurig op tijd plaats.

5. Op het platteland is in het derde kwart van de 18 de eeuw nog maar $30 \%$ van de dorpen aanwijsbaar in het bezit van een openbaar uurwerk, vele daarvan ook nog maar sinds kort. Onze bronnen zijn lacuneus, misschien waren het er enige meer. Voor Dohrn-van Rossum begon al kort na 1450 de verspreiding van het mechanisch uurwerk over praktisch alle dorpen van de Nederlanden en Duitsland. ${ }^{8}$ Hij citeert Antonio de Beatis uit 1517-1518 en Guicciardini uit 1567: "ende boven. al, dat veel Urwercken soo in't ghemeyn als in sonderheydt zijn niet alleenlijc in alle steden, maer oock in alle dorpen, vlecken ende treffelijcke huysen". ${ }^{9}$ Dohrn-van Rossum liet zich kennelijk door Guicciardini misleiden. Wat de beide Limburgen aangaat, was dit in elk geval een schromelijke overdrijving. Het gold wellicht in de directe omgeving van enkele Brabantse en Vlaamse steden,

\footnotetext{
${ }^{7}$ Een goed beeld van de verwarting die het tijdsverschil tussen de verschillende wurwerken in een stad als Delft nog aan het eind wan de 19 de eeuw kon weroorzaken, schetst A. Beekman 1887, p. 30 .

${ }^{8}$ G. Dohm-van Rossurn 1992, p. 146.

${ }^{9}$ Hier in de versia van de uitgave Amsterdam, 1612, p. 30.
} 
zoals Brussel, Brugge en Gent, en in streken met een zó vooruitstrevende landbouw, dat de commercialisatie van veeteelt en tuinbouw om zich heen begon te grijpen, zodat de boer of zijn echtgenote regelmatig naar de markt moesten. Maar zelfs dan moesten de omstandigheden voor de aanschaf van een torenuurwerk gunstig zijn. Naar alle waarschijnlijkheid was aan deze voorwaarde alleen voldaan, als er in de nabijgelegen stad een klokkenmakerstraditie bestond, zodat de uurwerken het niet al vlug begaven. In afgelegen streken gaf nog lang alleen de zonnewijzer het tijdsverloop aan. Het plaatsen van een openbaar uurwerk werd er pas urgent, toen vele dorpelingen een huisuurwerk hadden en een standaardtijd, waarmee men de eigen klok kon gelijkzetten, node werd gemist.

Het belang van het mechanisch uurwerk en van de techniek in het algemeen voor de ontwikkeling van de middeleeuwse maatschappij is door vroegere historici vaak onvoldoende onderkend. Verscheidene moderne cultuur- en techniekhistorici hebben in de laatste zes decennia getracht deze tekortkoming te herstellen. Zij hebben dat vaak zeer beeldend gedaan zonder grondig voorafgaand onderzoek en met de nodige overdrijving. Zo is het industriële tijdperk volgens Mumford, één der eersten die het belang van de ontwikkeling van de techniek in de Middeleeuwen inzag, begonnen met de introductie van het mechanisch uurwerk. ${ }^{10}$ Het was pure intuïtie van de auteur. Met evenveel recht had Mumford de klok kunnen vervangen door de molen; in sommige opzichten had dit zelfs meer voor de hand gelegen. Immers ook de molen is een machine met tandradoverbrengingen en diverse vernuftige constructies, zoals verschillende omwentelingssnelheden van de molenstenen en luiwerken voor het hijsen. $\mathrm{Na}$ de $10 \mathrm{de}$ eeuw was er in Europa een plotselinge uitbreiding in de molenbouw. ${ }^{11}$ Voor de toegepaste mechanica was de molen later zeer belangrijk vanwege de omzetting van een roterende beweging in een lineaire, die bijvoorbeeld in houtzaagmolens en stampmolens werd toegepast. De molens waren talrijk en lange tijd ruimer verspreid dan uurwerken. Ze waren gemakkelijk toegankelijk en hun werking was voor belangstellenden eenvoudig te observeren. Windmolens en watermolens waren een voorbeeld van hoe bij ambachtelijke activiteiten man-

\footnotetext{
${ }^{10}$ L. Mumford 1934, pp. 12-18.

$" 1$ C. Cipolla 1967, p. 21.
} 
kracht kon worden vervangen door een andere krachtbron, net als later met de stoommachine het geval was. Door hun aantal en hun goed zichtbare werkwijze hadden de molens invloed op het technisch bewustzijn van mensen.

Het wurwerk, aanvankelijk alleen als torenuurwerk aanwezig, was veel minder verbreid en, geplaatst in hoge torens, slechts voor een enkeling in zijn essentiële werking gade te slaan. Klokken konden echter worden geminiaturiseerd; zij raakten op den duur meer verspreid in de vorm van huisuurwerk en zakhorloge. Pas toen kon eenieder die dat wilde hun precieze werking bekijken. Daarbij ontwikkelden zij zich onder pressie van astronomen en door toedoen van geleerden als Huygens en Hooke in de $17 \mathrm{de}$ eeuw tot precisie-instrumenten, wat hun status verhoogde. Fundamentele vernieuwingen als de slinger, het balanswiel met spiraalveer en verbeterde echappementen, zoals het ankerechappement, werden niet door klokkenmakers bedacht, maar door mensen geïnteresseerd in mechanica. De klokkenmakers speelden pas een rol bij het zoeken maar grotere precisie in de 18de eeuw bij de ontwikkeling van de scheepschronometer. Eerst door de toepassing als precisieinstrument droeg de klok bij tot de mechanisering van het wereldbeeld van filosofen en geleerden.

Dat de mechanische klok kon uitgroeien tot een serieus en gewaardeerd instrument, is toe te schrijven aan de tijd en de maatschappij, ${ }^{12}$ waarin zij ontstond: ze vond een warm onthaal in de nieuwe steden. De vraag rijst, waarom de stadsbesturen zoveel waarde hechtten aan het bezit van een uurwerk en dat, zeker in de 14 de en 15de eeuw, op of vlakbij marktplaatsen op een hoog punt aanbrachten, zodat zijn signaal tenminste tijdens het voltrekken van handelstransacties kon worden gehoord en van het midden van de 15 de eeuw af de tijd aan de ene wijzer kon worden afgelezen. Er kan slechts worden gedacht aan een bescheiden rol in het sociaaleconomisch proces.

Het ligt in de rede deze ontwikkeling te plaatsen in het verlengde van de door Witold Kula in zijn studie over het ingewikkelde middeleeuwse systeem van maten en gewichten ${ }^{13}$ zo beeldend

\footnotetext{
${ }^{12}$ In een andere maatschappij, zoals de Chinese, liep de inheemse ontwikkeling van de klok (Su Sung) en de westerse invoering van de klok (jezuieten in de 17de eeuw) op niets uit. De uitvindirug wan Su Sung raakte in vergetelheid; de westerse uurwerken werden als curieuze speeltjes beschouwd. Zie C. Cipolla 1967, pp. 80-102 en D. Landes 1983, pp. $17 \times 52$.

${ }^{13}$ W. Kula 1986, pp. 102-110.
} 
beschreven theorie van de rechtvaardige prijs, die de handelstransacties sedert het einde van de 13 de eeuw domineerde, in de verwachting langs die weg de schadelijke gevolgen van het stedelijk handels- en distributiesysteem op te vangen.

Van de 12 de tot de 14de eeuw waren overal in Europa steden gegrondvest. De stedelingen genoten veel vrijheden en voordelen, maar werden tevens geconfronteerd met één zeer ernstig probleem. Zelfs in jaren dat de oogsten in Europa meer dan matig waren, werd slechts weinig meer leeftocht geproduceerd dan nodig was voor het in leven houden van de bevolking van Europa, de stedelingen inbegrepen. Bairoch ${ }^{14}$ schat het gemiddelde inkomen per hoofd van de bevolking rond het jaar 1500 op een equivalent van 2.500 $\mathrm{kcal}$, alle industriëlle productie inbegrepen. Een volwassene had echter al $2.000 \mathrm{kcal}$ aan voedsel nodig. Het inkomensoverschot was gering. Een bescheiden misoogst van lokale omvang kon dadelijk het gevaar van een hongersnood oproepen. In ieder geval leidde hij tot een dusdanige stijging van de kosten van levensonderhoud, dat het met aardse goederen minst gezegende deel van de bevolking in ernstige moeilijkheden kwam. De middeleeuwse stad was spoedig een woelige stad: een kleine economische calamiteit leidde al vlug tot relletjes of erger, waarbij de stadsbesturen hardhandig op hun verantwoordelijkheden werden gewezen. Het was zeer in hun belang een commerciële systematiek te ontwerpen die garandeerde dat eenieder naar billijkheid voor zijn goede geld de leeftocht kreeg die hij nodig had. Eenvoudige trucjes, zoals bij stijgende graanprijzen het brood naar rato lichter maken, maar voor dezelfde prijs als voorheen verkopen, volstonden al spoedig niet meer. Als de bakkers het hele gelag moesten betalen, zag men die spoedig op de stoep van het stadhuis, schreeuwend en tierend.

De theologen werden te hulp geroepen. Zij maakten de zaak niet eenvoudiger. Op instigatie van Thomas van Aquino beschouwden zij sedert het laatste kwart van de 13 de eeuw de prijs van een goed als een intrinsiek kenmerk van dat goed, die door toedoen van mensen niet mocht worden veranderd, tenzij zondig. ${ }^{15}$ In beginsel was de inkoopprijs gelijk aan de verkoopprijs. Maar waar moest de handelaar dan van leven? Hij begon met de maat te knoeien. De molenaar kreeg zijn vergoeding door een - flinke - schep van het

${ }^{14}$ P. Bairoch 1976, p. 277.

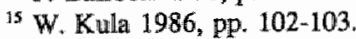


meel af te halen. Een nieuwe bron van conflicten was geboren. De Brabaritse en Vlaamse stedem losten die op door vast te leggen dat de som van een bepaald aantal kleine maateenheden groter was dan het vermenigvuldigingsgetal aangaf. Het verschil was de beloning van de molenaar. Op een dergelijke basis kon ook de bakker worden beloond: een nauwkeurig vastgelegd percentage van het verbakken meel vormde zijn brutowinst. Op dezelfde wijze konden ook andere ambachtslieden hun inkomen veiligstellen. Met zo'n techniek had de doe-het-zelver altijd een voordeel. Wie op de markt en gros inkocht, kon van het gekochte merkelijk langer leven dan wanneer hij woor het bedrag, dat hij op de markt had kunnen besteden, bij ambachtslieden en detail zijn waar haalde.

Het gevecht werd verlegd naar de marktplaats. Kloosters, instellingen woor sociale zorg, edelen en notabelen die zich konden permitteren in eigen huis hun leeftocht te bereiden, waren altijd bereid een hogere groothandelsprijs te accepteren dan de detaillist kon bieden. Het was zaak te voorkomen dat die van de markt werd verdreven. Men kon de bakker een voorkeursrecht van koop geven: tot een bepaald uur mocht alleen hij in zijn behoeften voorzien. Maar dan moest men ook de boeren dwingen op tijd op de markt te verschijnen en paal en perk stellen aan eindeloos loven en bieden. Tot in detail diende de marktorganisatie te worden geregeld en belangrijker nog, de naleving van de regels diende strikt en vooral stipt te worden gecontroleerd. Het uurwerk maakte zoiets mogelijk. Het voorzag in een grote behoefte, aanvankelijk op de markt van levensmiddelen, spoedig ook op die van kaarsen en hout, na niet te lange tijd ook op die van gelooid leer. De gecompliceerde regelingen dienaangaande, die tussen 1350 en 1795 bovendien herhaaldelijk werden aangescherpt, kunnen hier onmogelijk in extenso worden besproken. Het onderzoek is niet alleen uiterst tijdrovend - alleen voor het tijdvak $1583-1750$ is er een register op de Raadsverdragen van Maastricht ${ }^{16}$-, maar overstijgt ook het thema van deze studie. Er wordt steeds opnieuw geageerd tegen het opkopen van granen door handelaren en gros vóór en tijdens de markturen. Heel de organisatie is in het geding. Telkens wanneer graanschaarste dreigde, kwam het stadsbestuur er op terug en vulde het de regelingen aan. Alleen al in het tijdvak 1583-1750 tenminste 25 maal. Zelden werden bij dergelijke aangelegenheden wijzigingen

${ }^{16}$ G.A.M., Ond-archief, Raadsverdragen, inw.nr. 90, pp. 974-980. 
aangebracht die verband hielden met de tijdsindeling van het marktgebeuren; hoogst incidenteel werd het signaal dat het verloop van het handelsproces moest aangeven gewijzigd. In Maastricht werd tenminste vanaf 1380 het verloop van de handel in granen geregeld door het luiden van een "schelle". ${ }^{17}$ Dat bleef eeuwenlang zo, minstens tot in de 17de eeuw. Het marktschema blijft lang in nevelen gehuld. Uit 17 de-eeuwse recessen ${ }^{18}$ blijkt dat het volgende tijdschema werd gehanteerd: gewone burgers mochten graan kopen van negen tot elf uur; de bakkers en brouwers waren tussen elf en twaalf uur aan de beurt, pas na twaalf uur mochten de zogenaamde "voorcoopers", de graanhandelaren op de markt verschijnen. Vóór negen uur mocht niemand proberen de aanbieders enig graan te ontfutselen, ook niet buiten de stadspoort.

Het signaal werd gegeven door een "schelle". Dat was in 1586 nog zo. ${ }^{19}$ Pas in de $17 \mathrm{de}$ eeuw wordt het woord "graanklokje" gebruikt voor dit tuig. De schelle is wellicht een komvormig klokje met een duidelijk eigen timbre, dat we ons niet te klein moeten voorstellen. De komvorm is niet uitzonderlijk: alle bellen van slagwerken van huisuurwerken hebben deze vorm. In een grotere maat komen ze nog voor in een 18 de-eeuws carillon dat zich in kasteel Born bevindt. ${ }^{20} \mathrm{De}$ schel heeft mogelijk aan de Lakenhal, waar zich ook een stadsuurwerk bevond, gehangen. $\mathrm{Na}$ het gereedkomen van het nieuwe stadhuis werd daar een graanklokje geïnstalleerd met een meer gebruikelijke klokvorm. Het hangt daar nog steeds in een lichtwenster in de koepel.

De schelle en het latere graanklokje werden met de hand geluid en niet door het slagwerk van het stadswurwerk aangeslagen. Wel was de nabijheid van een stadsuurwerk hoogst gewenst voor de autoriteiten die de markt regelden. Dankzij de aanwezigheid van een torenuurwerk konden zij er zeker van zijn de eindeloze discussies met de aanwezige kopers en verkopers over de exactheid van hun signaal in hun voordeel te beslechten. Op die wijze was het ook mogelijk ontduikers van de regeling, die zich verweerden met

\footnotetext{
${ }^{17}$ Raadswerdragen wan Mastricht $1367-1428,1992$, p. 61, nr. 82, d.d. 26 november 1380: "... Item so en sal niemant voer den marct eir die schelle luidt eynich koren verkoupen opden kore taillhans vorseit".

${ }^{18}$ Recueil der recessen 1680 , art. MII-VIII.

${ }^{19}$ G.A.M., Oud-archief, Raadsverdragen, inw.nr. 61, d.d. 9 september 1586.

20. Zie appendix IIII onder Born.
} 
de mededeling "ik kan Uw signaal niet horen", in de kraag te vatten. Het onmiddellijk voorafgaand luide signaal van de klok van het uurwerk was immers overal op de markt te horen, ook achter de lakenhal of aan de zijkanten van het stadhuis. Met een uurwerk kon het stadsbestuur niet alleen de uitvoering van zijn beleid afdwingen, maar ook flexibel inspelen op veranderende omstandigheden.

Het was zaak ervoor te zorgen dat het uurwerk naar behoren functioneerde: op onderhoud werd niet bezuinigd. Als het kon werd zelfs niet geaarzeld een tweede uurwerk te plaatsen, zodat men zich in geval van nood kon behelpen (Tongeren, Venlo, Maastricht). Waar de markt niet van betekenis was, zoals in de vele mislukte stadsstichtingen, of slechts fungeerde als onbetekenende nevenmarkt van een nabijgelegen centrale plaats, kon men het voorlopig zonder uurwerk doen: een zonnewijzer of een zandloper volstond. De invloed van de centralle markten was zo groot, dat zij prijsverschillen die binnen de regio dreigden te ontstaan in de kortste keren wegwerkten. ${ }^{21}$

Intussen was het wel zaak de bevolking te wennen aan de regulerende werking van het stedelijk uurwerk. Een carillon, een paar jacquemarts, bewezen uitstekende diensten om de mensen op het uurwerk te attenderen, ook buiten de markttijden. Langzamerhand drong door dat openbare tijdmeting in allerlei omstandigheden van nut kon zijn. Zo kon men met behulp ervan de verplichte wachtdiensten regelen, ten plattelande uitwassen bij de herendiensten indammen, kerkelijke diensten beter op tijd laten verlopen, enige synchronisatie in verkeersdiensten bewerkstelligen en dergelijke meer. De eerste helft van de 16 de eeuw liet een bescheiden uitbreiding van het kleine net van openbare uurwerken zien. In kleinere steden, hier en daar op het platteland, een enkele keer op een torentje van een klooster werd een uurwerk geplaatst.

De economische teruggang, mede als gevolg van de zware oorlogslasten vanaf 1568 tot $1713,{ }^{22}$ en de zware schulden waarin de dorps- en stadsbesturen zich moesten steken om oorlogsschaden te vergoeden ${ }^{23}$ en verdedigingswerken intact te houden, ${ }^{24}$ maakten aan

${ }^{21}$ W. Christaller 1933, pp. 252-262.

${ }^{22}$ Te weten: de Tachigigarige oorlog (1568-1648), de Frans-Staatse corlog (1672-1678) en de Spaanse Successie-ootlog (1702-1713).

${ }^{2}$ M. Gutmann 1980, pp. $50-53$.

${ }^{24}$ L. Morreau 1979, passim. 
deze prille uitbouw rap een einde. Het werd zelfs een kunst de middelen te vinden om de bestaande uurwerken passend te onderhouden. De kosten liepen zeer hoog op. De revolutionaire technische verbeteringen van het uurwerk door Huygenst vinding van de slinger gaf sinds de tweede helft van de 17 de eeuw nieuwe stimulansen voor uitbreiding van het aantal uurwerken en vernieuwing van bestaande. Dat deed ook de lichte opleving van de economie vanaf 1650 , toen de oorlogen wat meer op afstand werden gevoerd en de fronten gewoonlijk niet meer boven de lijn Namen-Antwerpen kwamen, zodat de beide Limburgen meer en meer etappegebied werden, waar aan de levensmiddelenwoorziening en de fouragering van het leger goed was te verdienen. De opleving van het openbare uurwerk kreeg een flinke steun in de rug vanaf het moment dat het huisuurwerk meer en meer in zwang kwam. De burgers en de boeren die over een eigen uurwerk beschikten, hadden grote behoefte aan een standaardtijd. Tot in het midden van de 20 ste eeuw was het gebruik die van de kerktoren af te lezen. Wilde er in een dorp of stad enige uniformiteit in tijdmeting zijn en wilde het huisuurwerk dienen voor de doelen waarvoor het was aangekocht, dan was een openbaar uurwerk in de nabijheid bijna onontbeerlijk. Eind 17 de eeuw zette een hausse in de plaatsing van torenuurwerken in. Keurig werd de lijn van de welvaartsgroei gevolgd: eerst de Haspengouw, dan het Maasdal, vervolgens het Pruisisch deel van Opper-Gelder. De achterstandsgebieden - de door territoriale versnippering van elke verkeersmogelijkheid verstoken Landen van Overmaas, de arme zandstreken in de Kempen en de door afwateringsproblemen geplaagde Roerstreek - volgden als laatste, zeer mondjesmaat.

Kort samengevat luidt onze conclusie ten aanzien van de openbare tijdmeting in het algemeen: in tegenstelling tot wat Cipolla c.s. hebben beweerd, had de openbare tijdmeting nooit meer dan een beperkte functie. De nauwkeurige analyse van een weinig geurbaniseerde, dun bevolkte en in economisch opzicht niet overmatig gezegende regio als de beide Limburgen verschaft in dit opzicht meer duidelijkheid dan de analyse van Europa's meest vooraanstaande stedengordels. 


\subsection{Het huisuurwerk}

De grote stappen voorwaarts op uurwerkgebied vonden plaats in het midden van de 17 de eeuw en in de loop van de 18 de eeuw. De 17 de-eewwse vondsten van slinger en ankergang vonden in Limburg toepassing. De 18 de-eeuwse ontwikkelingen, pennengang en gecompenseerde slinger, hebben hier nooit opgang gemaakt. De uurwerken werden veel nauwkeuriger en betrouwbaarder, maar bovenal ontstond er een snel groeiende vraag naar uurwerken. $\mathrm{Nu}$ ging het niet meer om openbare uurwerken, maar vooral om huisuurwerken. De documentatie die ons daarover ter beschikking staat is nogal eenzijdig. Er zijn vrij veel uurwerken bewaard gebleven, maar de schriftelijke documentatie is heel beperkt. Dientengevolge kan ten aanzien van technisch-historische aspecten heel wat meer zekere kennis worden geboden dan ten aanzien van economische en sociaal-historische kwesties. Niettemin is het noodzakelijk daar de nodige aandacht aan te besteden.

Het eerste wat opvalt is, dat de overgebleven huisuurwerken opmerkelijk vaak op het platteland worden aangetroffen. $\mathrm{Zij}$ stonden er eertijds in de centrale ruimte van de boerderij, de keuken. Het waren overwegend staande uurwerken, waarop vanuit elk punt van deze ruimte de tijd zeer eenvoudig kon worden afgelezen. De diffusie deed zich voor vanaf 1725 en was vooral in de tweede helft van de 18 de eeuw sterk. Mede omdat ook de uurwerkmakers voor een aanzienlijk deel op het platteland waren gevestigd, dient ter verklaring van de toename van het uurwerkbezit en het aantal uurwerkmakers vooral naar de ontwikkeling van het platteland te worden gekeken. Daar sprongen twee aspecten in het oog. Zelfs in betrekkelijk achtergebleven gebieden, zoals de Landen van Overmaas, is sprake van commercialisatie van de landbouw. Meer en meer oriënteerden boer en boerin zich op nabijgelegen stedelijke markten. Zelfs vanuit Oirsbeek en omgeving trokken de boeren met graan naar Aubel om het daar te verkopen; de boerinnen trotseerden weer en wind om boter op stedelijke markten af te zetten. Servais en Jansen wezen in diverse publicaties op dit verschijnsel. ${ }^{25}$ Het begon in het oude hertogdom Limburg en breidde zich sterk uit.

${ }^{25}$ P. Servais 1983; J. Jansen 1992; J. Jansen 1993a. 
Nog vóór 1800 waren via de Landen van Overmaas en MiddenLimburg ook de Kempen en Noord-Limburg bereikt. ${ }^{26}$

Tegelijk wordt op boerderijen in allerlei delen van de beide Limburgen heel wat pluri-activiteit aangetroffen. Vooral de combinatie van agrarische inspanningen en vervaardiging van textiel was geliefd. Maar daarnaast zijn er boeren die strohoeden gaan vervaardigen, zoals langs de Jeker het geval was, of zich parttime met metaalnijverheid bezighouden. De streek tussen Geleen en Brunssum leverde er voorbeelden van. De nodige andacht is in de voorgaande pagina's besteed aan het samengaan van landbouw en uurwerkmakerij. Her en der in de beide provincies werden er voorbeelden van gevonden, zij het nimmer in concentraties in één of enkele dorpen, zoals bij de andere genoemde activiteiten het geval was.

Zowel de marktoriëntatie als de pluri-activiteit vergden aanpassingen van de organisatie van de gezinsbedrijven ten plattelande. De werkzaamheden van de gezinsleden en van het eventueel inwonend dienstpersoneel moesten nauwkeuriger dan voorheen op elkaar worden afgestemd. De wens de markt te bereiken, had tot gevolg dat men vanwege de deplorabele toestand van de wegen, die voor veel tegenslag konden zorgen, goed op de tijd moest letten. Binnen het agrarisch-ambachtelijk bedrijf moesten de activiteiten ten behoeve van het ene bedrijfsonderdeel worden afgestemd op die ten behoeve van het andere. Ook in dit opzicht was een tijdsindeling noodzakelijk. Ten slotte was het terwille van een eerlijke beloning van de werkzaamheden van knechten en meiden en voor het bepalen van de prijs van een ambachtelijk vervaardigd product nodig de gewerkte uren redelijk nauwkeurig vast te stellen. Kennelijk verwachtten velen voor deze doeleinden het heil van een uurwerk, mits het betrouwbaar was, weinig onderhoud vergde en ieder lid van de familiaire bedrijfsorganisatie wekte op de door de bedrijfsleider gewenste tijd. Het uurwerk moest goed lopen, eenvoudig kunnen worden bediend en van een wekkerwerk zijn voorzien. Aan de behoefte aan een goed lopend uurwerk met wekker hebben de Limburgse uurwerkmakers perfect voldaan. $\mathrm{Zij}$ bouwden een uurwerk, meestal in een staande kast geplaatst, dat zó goed aan de wensen van de kopers voldeed, dat vijf generaties lang, van omstreeks 1680 tot 1850 toe, nauwelijks meer innovaties voorkwamen.

26 J. Jansen 1993b. 
Technisch gezien was het Limburgs uurwerk een op de regionale behoefte toegesneden combinatie van oude techniek en zinvolle toepassing van nieuwe ontwikkelingen ellders. De bouwwijze van het uurwerk en de uitvoering van de klokkasten verschilt niet wezenlijk van de klokken uit andere delen van de Zuidelijke Nederlanden.

Hoe zag het Limburgse huisuurwerk eruit? Het heeft zich ontwikkeld uit het gotische huisuurwerk tussen hoekstijlen via de renaissancistische lantaarnklok. Vanaf 1685 , na de uitvinding van de slinger en de ankergang, vond het Limburgse huisuurwerk zijn definitieve vorm. Opmerkelijk is de vroege toepassing van de slinger, wat mogelijk moet worden toegeschreven aan de bemiddelende rol van de Vrijthoffs, die zowel in Maastricht als in Den Haag werkzaam waren, net in de periode dat er de eerste slingeruurwerken werden vervaardigd. Zij verwerkten in hun producten vanaf 1685 de nieuwe vinding.

De typische kenmerken van het Limburgs daguurwerk zijn de volgende:

a. Het zijn bijna altijd dagwerken, dat wil zeggen uurwerken die circa dertig uur lopen na het optrekken van het gewicht.

b. Het mechanisme is gevat in een "kooi", bestaande uit een onderen bovenplaat, verbonden door rechthoekige ijzeren stijlen op de vier hoeken zonder enige versiering. Het gaande werk is vóór het slagwerk geplaatst.

c. Het echappement is een "terugwerkende" ankergang. Als men nauwkeurig naar de grote wijzer kijkt, ziet men deze bij elke slingerbeweging even terugwijken voordat hij verder gaat in de klokrichting. Deze gang is minder gunstig dan de later ontwikkelde rustende gangsystemen, al zijn de gangresultaten van de terugwerkende ankergang bij een goed geconstrueerde en onderhouden klok met gewichtsaandrijving uitstekend.

d. Ze hebben een één meter lange secondeslinger van draadijzer, waaraan een messing met lood verzwaarde slingerlens. $\mathrm{De}$ slinger is opgehangen aan een slingerveer. Ze hebben bijna nooit een secondewijzer.

e. De meeste hebben een slagwerk, gewoonlijk met sluitschijf en slaan op een luide bel. Alleen de zogenaamde meidenklok of wekkerklok heeft géén slagwerk, maar achter het gaande werk een wekkermechanisme. 
f. Er is meestal een wekkermechanisme (geweest), haaks ten opzichte van de andere tandwielen gemonteerd. Het wekkerschijfje, om de tijd van aflopen van de wekker in te stellen, is bijna altijd van messing.

g. Ze hebben één gewicht aan een koord of ketting, die als een eindeloze lus volgens het principe van Huygens is aangebracht. In vele opzichten stonden degelijkheid en betrouwbaarheid voorop.

Ook aan het gebruiksgemak was gedacht. De wijzeras bevindt zich gemiddeld $20 \mathrm{~cm}$ hoger dan bij de Amsterdamse staande horloges. Het mag zijn dat de Limburgers kort vóór 1800 iets langer waren dan de Amsterdammers, maar het ging bij lange na niet om $20 \mathrm{~cm}$. De Limburger wilde graag over het hoofd van anderen heen op het uurwerk kunnen kijken. Bij opstelling op een centrale plaats in het huis, meestal de werk- en leefkeuken, was de tijd steeds voor iedereen die zich in het vertrek bevond zichtbaar, als de wijzeras wat hoger zat dan $220 \mathrm{~cm}$. De hoogte van de staande klokkasten bleef in alle perioden constant rond de twee meter vijftig. Overigens kan men ook een technische reden aangeven voor de hoogte van de wijzeras. De Limburgse klokken zijn over het algemeen daguurwerken met één gewicht, dat zowell het gaande werk als het slagwerk aandrijft. Om het uurwerk circa dertig uur te laten lopen, is een grotere valhoogte voor het gewicht vereist dan om een weekwerk met zijn twee gewichten aan darmsnaren, waarmee de meeste Amsterdamse staande horloges zijn uitgevoerd, een week te laten lopen.

De klokkasten waren meestal van eikenhout. De kasten hadden nooit een polychrome beschildering of fineerwerk, de decoratie bestond uit lijst- en paneelwerk, vaak in combinatie met steekwerk in de verschillende Lodewijkstijlen, aangevuld met motieven uit de volkskunst. Het gaat om een sober product van groot nut voor de bezitter. Degelijkheid hoeft geen luxe in te houden. De Limburgse klok is eerder een gebruiksvoorwerp dan een statussymbool. De Limburgse klokken zijn duidelijk te onderscheiden van de NoordNederlandse klokken. Die weerspiegelen de status van de bezitter veel meer en zijn niet zo nadrukkelijk afgestemd op het nut voor de gebruiker. Het mag nauwelijks verbazen dat de aard van het Limburgse uurwerk en de nadruk op zijn gebruikersnut worden weerspiegeld in de karakteristiek van de uurwerkmakers die kon worden opgesteld. 
De $18 \mathrm{de}$ - en 19de-eeuwse huisuurwerkmaker verschilde hemelsbreed van zijn laat-middeleeuwse en vroeg-moderne voorganger. De middeleeuwse torenuurwerkmakers waren veelal reizende specialisten. Na de geleidelijke toename van het aantal uurwerken vestigden zij zich vanaf het midden van de 14 de eeuw in de steden, waar zij voorlopig tot het smedenambacht behoorden. Opmerkelijk is dat verscheidene uurwerkmakers uit de late Middeleeuwen niet alleen stadsuurwerkmeester waren, maar ook stadsgeschutmeester, zoals Van Thoiren in Maastricht. Deze combinatie van ambten kwam ook voor in Hasselt, Lille en Namen. Cipolla stelde ze eveneens vast in verschillende Italiaanse steden. De vroegste torenuurwerkmakers waren in alle aspecten van de mechanica thuis. De gebrekkige uurwerktechniek verhinderde een participatie van niet-deskundigen. De uurwerkmakers namen in het stedelijk ambacht vaak een prominente plaats in. Hun ateliers en winkels lagen gewoonlijk aan de drukste winkelstraten.

Dit alles gold allerminst voor diegenen die het dagelijks onderhoud van het uurwerk verzorgden. Nadat in het begin goud- en zilversmeden waren belast met het smeren en stellen van het torenuurwerk, werden in de $16 \mathrm{de}$ eeuw gaandeweg meer en meer personen ingeschakeld die door de aard van hun werk, bijvoorbeeld als koster of beiaardier, toch geregeld in de toren of in de kerk moesten zijn.

De 18de-eeuwse huisuurwerkmaker was een heel ander persoon. Rond 1750 woonden de meeste uurwerkmakers op het platteland. Door agrarisch-technische en economische ontwikkelingen was daar een grote markt voor uurwerken ontstaan. Een voordeel was, dat men ten plattelande geen last had van beperkende gildenbepalingen, al deden in de 18 de eeuw de gilden ook in de steden in het Maasdal nauwelijks moeite zich vestigende uurwerkmakers iets in de weg te leggen. De uurwerkmakers op het platteland waren geen voltijdse uurwerkmakers, ze verrichtten allen nevenwerkzaamheden. Deze situatie zou voortduren tot het midden van de 19 de eeuw, het moment dat er geen markt meer was voor ambachtelijk vervaardigde uurwerken. Onduidelijk is vaak of de uurwerkmakerij een bijverdienste was of het hoofdberoep uitmaakte, waarvan de opbrengsten langs andere wegen werden aangevuld om ook op momenten dat de afzet van uurwerken stagneerde, het hoofd boven water te kunnen houden. Beide situaties zijn voorgekomen. Er zijn nogal wat uurwerkmakers aangetroffen die vrijwel zeker gedurende 
heel hun leven maar enkele uurwerken hebben vervaardigd. Daar konden zij zeker niet van leven. Aan de andere zijde van de schaal vinden wij de echte klokkenmakersfamillies, zoals Joosten, Peeters, Raetsen, Remmen en Wessels. Zij leverden soms meer dan twee eeuwen lang uurwerkmakers. Hun bedrijf werd generaties lang voortgezet. Een tweetal uurwerkmakers wist tenminste enige jaren lang de bedrijfscontinuilteit te verzekeren door dochters bij de leiding van het bedrijf te betrekken. ${ }^{27}$ In zulke gevallen ligt het voor de hand in de uurwerkmakerij een hoofdberoep te zien.

De weinige gegevens over de financiële positie van uurwerkmakers tonen aan dat de tussenpositie - nu eens afhankelijk van inkomsten uit de uurwerkmakerij, dan weer sterk leunend op het nevenberoep - tamelijk verbreid was. Slechts een enkele uurwerkmaker was uitgesproken welgesteld. De documenten betreffende de nalatenschap van Joannes Brienen te Venray uit 1786 maken evenwel duidelijk dat de omvang van de activiteiten zo sterk wisselde, dat het bezit van onroerend goed onontbeerlijk was om de wisselvalligheden des levens in financieel opzicht te kunnen doorstaan. Weerstandskracht was te meer noodzakelijk omdat de kosten van een staand uurwerk in hoge mate werden bepaald door de prijs van de kast. Die was soms zesmaal hoger dan die van het uurwerk zelf. Sommige klanten konden zich niet meteen een hele staande klok veroorloven. Dus werd op krediet geleverd. Ook was het mogelijk voorlopig alleen een uurwerk met kop te kopen, waar later een kast onder kon worden gebouwd.

Over de technische aspecten van de uurwerkmakerij in de late $18 \mathrm{de}$ eeuw zijn we weer heel wat beter geïnformeerd, maar ook niet tot in de finesses.

De Limburgse unrwerkmakers hadden tot in het begin van de 19de eeuw in het algemeen een werkplaats met smidsvuur. Voor het snijden van tandwielen worden in de boedelinventarissen herhaaldelijk radersnijmachines genoemd. Daarnaast had men allerlei gereedschappen, als vijlen, tangen etcetera. Het horlogemakersgereedschap was het kostbaarste deel van de boedel van een uurwerkmaker. Het smidsvuur en de gereedschappen tonen aan dat de uurwerkmaker zelf de uurwerken vervaardigde. Het ging niet om pure assemblage of wederverkoop van kant en klare uurwerken. Ook de gebruikte term bij het bestellen van een uurwerk: "maak een uur-

${ }^{2 \pi}$ De dochter van $\mathrm{G}$. Creten te Sint-Truiden en Petronella van den Weyngaert in Weert. 
werk voor mij", wijst op eigen maaksel, evenals de passage in de boedelinventaris van Brienen te Venray die rept van "een onvolmaekte horlogie", een uurwerk dat nog niet helemaal klaar was. Dit betekent ook weer niet, dat ze alles zelf hebben gemaakt. Er is vanaf 1775 gebruikgemaakt van fournituren als hoekstukjes, wijzers, witglazen wijzerplaten en adresplaatjes en bellen die van derden werden betrokken. De klokkasten waren in het algemeen het werk van schrijnwerkers, die misschien op hun beurt weer onderdelen als de slingerdeur en de kopversiering van speciale houtsnijders betrokken.

Kennelijk hebben we bij de uurwerkmaker te doen met een kleine zelfstandige die zijn bedrijf naar bevind van zaken organiseerde. Afhankelijk van de eigen vaardigheid, de marktomstandigheden en de mogelijkheid werk bij derden uit te besteden werden besluiten genomen. Als gevolg van de pluri-activiteit en het uitblijven van innovaties is een gemiddelde productie van vijftien uurwerken per jaar per uurwerkmaker als de hoogst haalbare aan te nemen. Het aantal uurwerkmakers dat een dergelijke productie haalde was waarschijnlijk heel gering. Het heeft geen zin ten aanzien van de Limburgse uurwerkmakerij van proto-industrialisatie te spreken. De uurwerkmakers in de beide Limburgen hebben de overstap naar industriële productie nooit gemaakt, in tegenstelling tot hun collegae in Friesland, het Schwarzwald of de Franche Comté. In het tweede kwart van de 19 de eeuw verdween de Limburgse uurwerkmakerij langzaam maar zeker door de concurrentie van industrieel vervaardigde uurwerken. De beroepsaanduiding uurwerkmaker of horlogemaker wordt sindsdien in Limburg alleen gebruikt voor reparateurs en restaurateurs. 


\section{Summary}

This book presents the findings of historical research into the mechanical clocks and their makers in the present Belgian and Dutch provinces of Limburg from 1367, the year when mention was made for the first time of a clock in this area, untill about 1850 , the end of the handicrafted production of Limburg clocks.

The angle of incidence from which the subject has been researched is especially a social-economic historical one, which does not mean that important technical aspects fail to appear.

Two components are distinguished: the public clocks and the house clocks and their makers.

The first six chapters are consecrated to the public clocks. Questions arose like: who in the late Middle Ages took the initiative, the sovereign lord, the municipalities, the ecclesiastical leadership? What was the use of such an expensive acquisition? How did the tower clocks spread geographically? How did the number of tower clocks develope in ecclesiastical circles? How in governmental institutions?

After a chapter in which some hypotheses about the origin and spread of the mechanical clock are described and some major notions are explained, chapter II deals in detail with the tower clocks in Maastricht, the largest town in the two Limburgs and the cradle of tower clocks in the region. The two following chapters deal with the attention given to public timekeeping in the other Limburg towns, which in the late Middle' Ages can be considered as commercial or industrial towns. Chapter III concerns the towns in the present Dutch Limburg; chapter IV reviews those in Belgian Limburg. Chapter V deals with the establishments of towns in the Middle Ages which did not result in settlements worthy of the name town, the grey zone between town and country. Chapter VI is concerned with aspects of the countriy in Dutch and Belgian Limburg. Both countries comprise a zone of meagre sand soil and one with fertile löss. Attention is given to differences in level of prosperity between these areas.

From the first six chapters it can be concluded:

1. The diffusion of the mechanical clock had a reasonably quick progress in the larger towns. In the 14 th and 15 th centuries most of the Limburg towns with 4000 or more inhabitants acquired a 
town clock. In the smaller towns it took until the 16th century before at least the towns near the Meuse got a clock. The country towns had to wait for it even longer. In the villages the public clock was still very tare about 1650 . In the 18 th century the number of public clocks increased, limited however by the spatial structure of the village. When the major part of the inhabitants could not hear the time signal from their houses, the tower clock was omitted. But also in the towns not nearly everybody could enjoy the blessings of public timekeeping. Until 1500 even in the most important towns at most one or two clocks were found, initially without dial, the striking of the hours being audible only in a minor part of the city, often with regular interuptios. Sometimes the clocks were out of order for a longer period of time.

2. Timekeeping since the 14th century in the larger urban settlements was a task of the communities. The sovereign lords never charged themselves with it until far in the 17th century. A possible exception is the chapter of Saint Servatius, which in a rather small part of Maastricht, acted as suzerain. Mighty lords, like the bishop of Liège, the duke of Brabant and the counts of Guelders, Julich and Cleve, did not care about public timekeeping in their possessions in the Meuse valley. The same can be said of the dukes of Burgundy and their successors in rights, who did not even care about any harmonization of the clock time in their lands. It was the king of Prussia, having obtained possession in 1713 of a part of Dutch Northern Limburg, who promoted the placing of clocks here and there, without obtaining full coverage in his lands, however.

The town clocks were well visible only from the market places. Conclusive for determining the function of clocks was not their visibility. In the beginning most of the tower clocks were not provided with dial plates. People listened to the time signal. The acoustical time indication was by far not allways audible all over the town. In general, by means of the time indication on the public clock or the ringing of a special bell only the trade on the market place was regulated, many rules prevailing which had to be strictly observed. A time signal was of vital importance there. For the rest of society the function of the tower clock was less important than well-known authors like Cipolla, Landes, Mayr and Le Goff supposed. Nevertheless, the early (14th - 15th 
century) town clock can be regarded as a mark of identification of the successful establishment of a town, together with municipal rights, town walls and market rights.

3 . In the 16 th and 17 th centuries the number of public clocks gradually increased. They were installed on town gates and on some cloisters, castles and church towers. Most of the church institutions had no public clocks until 1600 , even if these institutions, such as the chapters of Maastricht and Tongeren and the noble abbeys and convents of Thorn, Roermond, Houthem, Susteren and Herckenrode, could afford a public clock more easily than many municipalities. The same can be said of the nobility: only from the middle of the 18 th century some noblemen placed a clock in the gate front or the façade of their castles, which can be explained from a growing need of timekeeping. Since the market barge and the post coach were bound by a time schedule, it was necessary to keep one's eye to the public clock. At cross-roads, at landing stages of local ship services and stopping places of post coaches clocks appeared. Trade and traffic felt the need for some synchronization of timekeeping. Application of the pendulum was a first step in this direction.

4. During the 19th century public timekeeping became a less important task for the local authorities because of the increased spread of house clocks and the disappearance of local time. Also for the church councils things changed. They had to synchronize their summons for the divine service with the time indication on the clocks of the faithfull. They all took care to get a church clock. The church towers of older churches, which were often owned by the municipality, were taken over, with the attendant trouble of maintaining the clock. Clocks also appeared at factories and railway stations.

5 . In the country, in the third quarter of the 18 th century, only $30 \%$ of the villages proved to be in the possession of a public clock, many villages having only recently got a public clock of their own. Dohm - van Rossum assumes that the spread of the mechanical clock over nearly all the villages of the Low Countries and Germany started already shortly after 1450 . In this connection he quotes Antonio de Beatis from 1517/18 and Guicciardini from 1567. Concerning the two Limburgs this is surely very exaggerated. In remote regions only a sun dial indicated the passing of time still for a long time. Installing a public clock only became 
urgent when many villagers had a house clock and a standard time with which their own clocks could be synchronized was dearly missed. Besides, more social and economic institutions had a need of synchronized time.

As to the technical characteristics of the public clocks only few specific matters can be indicated. The four oldest clocks which have survived have been repaired and modified many times. Of the original inner works practically nothing has been retained. Only the authenticity of the wrought iron cage and the biggest toothed wheels can be relied upon. From this it can be concluded that the techniques known from elsewhere to have been used in the Gothic have also been applied in the oldest Limburg tower clocks, possibly with some variations. Whether regional characteristics have existed is not clear. It only stands firm that they were simple instruments without astronomical dials, carillons or jacks. Also the more recent tower clocks from the two Limburgs are not distinguishable from the standard tower clock in Western Europe, as described in literature.

The second part deals with the house clocks.

When did private persons become interested in having a house clock? How did the possession of house clocks spread over the social layers? These questions are dealt with in the chapters VII $X$. A striking finding is that the existing house clocks were often found in the country. The diffusion took place from 1725 onwards, and was especially strong in the second halve of the 18 th century. Because also a large part the clock makers had established themselves in the country, which accounts for the increase in the number of clocks and clock makers, the developments in the country have been reviewed. Two aspects leap to the eye: the commercialisation of agriculture, notably the orientation on nearby urban markets and the increasing plurality of work. Above all the combination of agricultural activities and textile production was a favourite one. Besides there were farmers who part-time occupied themselves with the metal industry. The region between Geleen and Brunssum is an example of this. Striking also is the combination of agriculture and clock making. All over the two Limburgs examples were found, but they never concentrated in one or a few villages as was the case with the other mentioned activities. Both the market orientation and the plurality of activities demanded adaptations in the organization 
of the family farms in the country. The activities of members of the family and of personel living with them had to be tuned carefully to one another. All activities had to start on time; meals were taken together and work was finished at the same time. This made time indication necessary. Also, to ensure a fair reward for the labour of personel and to assess the price of a handicraft product it was necessary to determine the hours devoted to the different kinds of work as accurately as possible. The house clock had to function well, had to be simple in use and be provided with an alarum. The Limburg clock makers perfectly satisfied the demands for such a clock.

What did the Limburg house clock look like? Since 1685, when pendulum and ancre escapement were applied, the Limburg clock had the following characteristics:

a. It was nearly allways a 30 -hour going time piece.

b. The mechanism was set in a "bird-cage" made of an upper and under plate connected by rectangular iron bars on the corners, without any decoration. The going train was fitted in front of the striking train.

c. The escapement was a recoiling ancre escapement, which means that the big hand goes back a little at every pendulum movement before it proceeds in clock direction. This escapement is less favourable than the later resting escapements, but in a well built and maintained clock with weight traction it performs excellently.

d. They had an one-second pendulum, a wire pendulum rod nearly one meter long. Attached to it was a brass, lead-weighted pendulum bob. The pendulum was attached to a pendulum spring. It hardly ever had a seconds hand.

e. Most clocks had a striking mechanism, mostly with a locking plate, striking the hour on a loudly sounding bell. Only the socalled "servants clock" or "alarum clock" did not have a striking train, but behind the going train an alarum.

f. It mostly had an alarum, fitted square to the toothed wheels. The alarum disc to set the time of alarum was nearly allways made of brass.

g. It had one weight attached to a rope or chain which in accordance with Huygens's principle had been fitted as an endless loop. In many respects solidity and reliability were aimed at. 
The clock cases were mostly made of oak wood. They never had a polychrome painting and were never veneered. The decoration consisted of mouldings and panel work, often combined with sculpture work in the different Louis styles, filled up with motives from folkloristic art. It was a sober product of great use to its owner, without extreme luxury, but often tastefully decorated. The Limburg clock was rather a utilitarian object than a status symbol. In this respect it differed from the clocks found in the Western provinces. These reflected much more the social level of the owner and were less aimed at utility.

It is not amazing therefore that the kind of the Limburg clock and the emphasis on utility are refelected in the characteristics of the clock makers which are described in chapter VIII.

The 18th- and 19th-century makers of house clocks differred in many respects from their late-medieval and early-modern predecessors. The first medieval makers of tower clocks were itinerant specialists. After the number of clocks had increased they settled down in the towns from the middle of the 14th century, where they belonged to the smith's trade and executed several mechanical activities. Several clock makers in the late Middle Ages were not only in charge of the town clock, but also of the urban artillery. This combination of offices occurred not only in Maastricht, but also in Hasselt, Lille, Namur en several Italian cities. The early clock technique prevented the participation of non-experts. The clock makers often occupied a prominent place in the urban arts and crafts. Their workshops and shops were usually situated in the business quarters of the town.

All this did not apply to those who provided for the daily maintenance of the tower clock. In the beginning gold- and silversmiths were charged with the oiling and setting of the clock. Since the 16 th century gradually persons were gradually involved who by the very kind of their office, e.g. as verger or carillon player, had to come regularly to the tower or the church.

The 18th-century maker of house clocks was quite another person. About 1750 most of the clock makers were to be found in the country, where due to agrarian-technical and economical developments a large market for clocks had come into existence. An advantage sometimes was the fact that in the country there were no restrictive regulations for the crafts, though in the 18 th century also in the cities of the Meuse valley the crafts caused hardly any 
trouble to hinder the settling of clock makers. The country clock makers had no full-time jobs: they all had additional work to do. This situation was to last until the middle of the 19th century, the moment when the market for handicrafted clocks dissappeared. Often it is not clear whether clock making was a by-job or the main job whose yields had to be suppleted in one way or another in order to survive when the selling of clocks stagnated. Both situations occurred. There were quite a number of clock makers who during all their lives made only a few clocks. They certainly could not have subsisted on that alone. Against this may be set the fact that there were whole families of real clock makers, like Joosten, Raetsen, Remmen and Wessels. Their workshops were continued for generations, sometimes for longer than two centuries. Two clock makers assured the continuity of the trade, at least for a some years, by implicating their daughters. In such cases it is obvious that clock making was the main job. Data on the financial position of clock makers demonstrate that their interjacent position, now depending on earnings from clock making, then again leaning on the by-job, was widespread. Only a few clock-makers were definitely in easy circumstances.

Documents relating to the estate of Joannes Brienen in Venray from 1786 make it clear that the range of activities changed so much that the possession of a real estate was indispensable for being able to resist financially the vicissitudes of live. Endurance was necessary the more so as the price of an standing clock was fixed to a high degree by the price of the clock case. This could be up to six times higher than that of the clock work itself. Many customers could not afford a complete standing clock at the same time, and they could buy a clock on credit. It was also possible to buy a clock with only the head of the clock case to which later on the rest of the case could be fitted.

About the technical aspects of clock making at the end of the 18th century there is no detailed information. Chapter IX deals with these aspects. In general the Limburg clock makers had a forge until the first decades of the 19th century. For wheel cutting lathes were used. Besides they had tools of all kinds, such as files, pairs of tongs and so on. The clock making tools were the most expensive part in the estate of clock makers. The forge and the tools prove that the clock maker made the clocks himself. It was not the pure assembling of ready-made components or the mere selling of 
the clocks. This does not mean that the clock makers made all parts themselves. From about 1775 ready-made parts were used such as sprandles, hands, white-painted glass dials, tin chapter rings and bells, which were bought from third parties. The clock cases were made by joiners, whereas maybe such parts as the door in front of the pendulum and the sculptured finial of the head were ordered from specialist carvers.

It is evident that the clock maker was a little entrepreneur who organised his business as circumstances required. Dependent on his own skill, the market situation and the possibilities to board out work he took his decisions. As a result of the numerous activities and the lack of innovation an average production of 15 clocks per year can be assumed to be the highest attainable. The number of clock makers who actually attained this production was probably very small. It is not justified with regard to Limburg clock making to speak of proto-industrialization. The clock makers in the two Limburgs never stepped over to industrial production, in contrast with their colleagues in Friesland, the Black Forest or the Franche Comté.

Chapter X deals with the sale and spread of Limburg clocks. The market for clocks in the Middle Ages and long afterwards was very limited. Only the very rich could afford a house clock. The very first house clock in Limburg, of which we know the origin, was bought by a lady belonging to the highest nobility in the middle of the 15th century. Even in the first decades of the 18th century the market for clocks was very limited. About 1750 the number of clocks increased to a large extent. The customers were found in the country, especially in circles where agrarian and handicraft activities were combined to earn a living: the lower middle class of the agrarian society.

In the second quarter of the 19th century Limburg clock-making disappeared as a consequence of the competition by industrially made clocks. The professional name of clock maker or watch maker was since then used for repairers and restorers. 
APPENDIX I. Lijst van uurwerkmakers per locatie chronologiseh geordend

Voor de levensbeschrijving van onderstaande uurwerkmakers de door hen gemakte produeten wordt verwezen naar appendix II op de bijgevoegde diskette.

\begin{tabular}{|c|c|c|c|c|}
\hline NAAM & VOORNAAM & GEE. & OVERL. & WERKZ. \\
\hline \multicolumn{5}{|c|}{ Onbekende plasts } \\
\hline Gillesen & Joannes & - & - & 1750 \\
\hline Bachgus & Emanuel & - & - & 1790 \\
\hline \multicolumn{5}{|l|}{ Alken } \\
\hline Creten & G. & - & - & 1820 \\
\hline \multicolumn{5}{|l|}{ Baarlo } \\
\hline Kessels & Joachim & 1738 & 1791 & 1776 \\
\hline \multicolumn{5}{|l|}{ Beek } \\
\hline Ha(e)rtmans & Joannes & 1735 & 1807 & 1765 \\
\hline \multicolumn{5}{|l|}{ Beek-Genhout } \\
\hline Smedts & Leendert & - & - & 1735 \\
\hline \multicolumn{5}{|l|}{ Bicringen } \\
\hline Hondt & Petrus wan & - & - & 1790 \\
\hline Snyers & Pierre Casimir & 1788 & 1832 & 1812 \\
\hline \multicolumn{5}{|l|}{ Beverllo } \\
\hline Puts: & Michel & - & - & 1765 \\
\hline Put(s) & Pierre & 1752 & $=$ & 1775 \\
\hline Delosie & Pierre & 1779 & - & 1795 \\
\hline \multicolumn{5}{|l|}{ Borgloon } \\
\hline Stafue & Pascal & 1752 & - & 1780 \\
\hline Briers & Henry Viator & 1815 & - & 1840 \\
\hline Vapossen & Albert & - & “ & 1825 \\
\hline Cuetern & Mathieu & 1827 & - & 1850 \\
\hline \multicolumn{5}{|l|}{ Biree } \\
\hline Thonis & Jan & - & - & 1634 \\
\hline Pingen & Michael & - & - & 1661 \\
\hline Willems & Claes & - & - & 1705 \\
\hline Beekman & François? & - & - & 1783 \\
\hline H国gen & M.J. & - & - & 1800 \\
\hline Beekmuan & & - & - & 1850 \\
\hline \multicolumn{5}{|c|}{ Broekhuixen (baj Rimburg) } \\
\hline Louppen & M. (Matthijs?) & - & - & 1791 \\
\hline \multicolumn{5}{|l|}{ Buggenun } \\
\hline Pol & Cornelius van & 1824 & 1875 & 1874 \\
\hline \multicolumn{5}{|l|}{ Doenrade } \\
\hline Kleinjans & Johan Werner & 1752 & 1812 & 1787 \\
\hline \multicolumn{5}{|l|}{ Donk } \\
\hline Cellis & & - & . & 1790 \\
\hline \multicolumn{5}{|l|}{ Fecht } \\
\hline Frencken & & - & . & 1705 \\
\hline Frehmel & Laurens: & 1820 & - & 1850 \\
\hline Vren(c) ken & Gerardus Hubertus & 1839 & 1916 & 1865 \\
\hline
\end{tabular}




\begin{tabular}{|c|c|c|c|c|}
\hline NAAM & VOORNALI & GEB. & QVERL. & WER \\
\hline \multicolumn{5}{|l|}{ Eijodete } \\
\hline Smits & Arnold & $*$ & - & 1796 \\
\hline \multicolumn{5}{|l|}{ Ekse! } \\
\hline Ceystiseng & & - & - & 1750 \\
\hline Coysens & Jan Mathias & 1763 & 1819 & 1787 \\
\hline \multicolumn{5}{|l|}{ Ei } \\
\hline Pol & Joananes van & 1766 & 1851 & 1795 \\
\hline Pol & Chrigtiquus van & 1799 & - & 1832 \\
\hline \multicolumn{5}{|l|}{ Elstoo } \\
\hline Sleegel (Schleegel) & Matthijs alias Mathis & - & - & 1780 \\
\hline \multicolumn{5}{|l|}{ Geleen } \\
\hline Messels & Wilhelmus Amoldus & 1730 & 1816 & 1750 \\
\hline Emmelen & Joanunes & - & $>1796$ & 1767 \\
\hline Wessels & Theodorus Estigius & 1767 & 1816 & 1790 \\
\hline Wessels & Peter & 1772 & 1855 & 1796 \\
\hline Wersels & Petrins Wilhelmus & 1815 & 1895 & 1840 \\
\hline Wesisels: & Jan Willen & 1813 & 1900 & 1849 \\
\hline Wessels & Jan Leonaurdus & 1823 & 1904 & 1850 \\
\hline \multicolumn{5}{|l|}{ Gemep } \\
\hline Klock & Jackop & - & - & $\$ 1660$ \\
\hline Klowkesmith & Peter & - & - & 1737 \\
\hline Camps & Willem & $*$ & $=$ & 1748 \\
\hline Coijk & Willibrond wan & 1796 & - & 1843 \\
\hline Adriatens & Antorot & 1800 & - & 1843 \\
\hline Raay & Conenraad vall & 1817 & - & 1843 \\
\hline Adriaens & Willem $J . \mathrm{H}$ & 1842 & 1878 & \\
\hline \multicolumn{5}{|l|}{ Genoelselderen } \\
\hline Geuten & S. & - & - & 1825 \\
\hline \multicolumn{5}{|l|}{ Hamont } \\
\hline Smeets & Jan & 1696 & 1766 & 1728 \\
\hline Sineets & Antonins Jacobus & 1730 & 1802 & 1765 \\
\hline Mertens & Theodome & 1756 & 1812 & 1777 \\
\hline Simons & Jean Jacques & 1757 & 1816 & 1780 \\
\hline Buns (Biens) & Henry & 1773 & 1816 & 1800 \\
\hline Strael & Carolus Franciscus & 1787 & 1861 & 1810 \\
\hline Streel & Jacolbuis (Jacques) & 1823 & 1863 & 1850 \\
\hline \multicolumn{5}{|l|}{ Hassell } \\
\hline Colen (Koelen) & Bartholomaeus I (Mewris) & . & - & 1451 \\
\hline Colen & Vaes I (Servatius) & - & - & 1494 \\
\hline $\mathbb{D}$ lest & Hendrik van & - & - & 149.4 \\
\hline Voes & Mt. & - & - & 1506 \\
\hline Blategen & $\operatorname{san}$ & - & . & 1509 \\
\hline Colen & Mewis II & w. & - & 1514 \\
\hline Colent & Vaes II (Servatius) & * & - & 1534 \\
\hline Messmeilckars & Drles & - & - & 1545 \\
\hline Nuys $(t)$ & Heari van & - & 1580 & 1549 \\
\hline Bla(e)sen & Lambrecht & * & - & 1558 \\
\hline
\end{tabular}




\begin{tabular}{|c|c|c|c|c|}
\hline NAAMI & VOORNAAM & GEM. & OVERL. & WERK Z. \\
\hline Deeckerns (Dekens) & Maarten (Martin) & - & - & 1574 \\
\hline Bilasen & Heinrick & * & - & 1575 \\
\hline Sporckels & Jaspar & - & 1583 & 1580 \\
\hline \multirow[t]{2}{*}{ Jansisen } & Kerst (alias Christiaen der & & & \\
\hline & Smeed) & - & - & 1585 \\
\hline Minne & $\operatorname{Jan}$ & - & 1602 & 1586 \\
\hline Beringhs & Gerardus & - & - & 1600 \\
\hline Deeckens & Geert & - & 1632 & 1600 \\
\hline Liefsoens & Hubrecht St. & - & 1625 & 1602 \\
\hline Noelinams & $\operatorname{Jan}$ & - & 1652 & 1625 \\
\hline Liefsoens & Huibrecht Jr. & 1606 & 1657 & 1630 \\
\hline Noelmans & Frans & 1617 & 1665 & 1640 \\
\hline Braunts (Broniws) & Herman & - & - & 1658 \\
\hline Sme (e) $)(\mathrm{s})$ & Jacobr & $*$ & 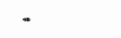 & 1729 \\
\hline Intbronck & Richardus van & - & - & 1730 \\
\hline Ceyssen: & $F^{2}$ & - & - & 1770 \\
\hline Gerarts (Geraets) & Michael & 1751 & 1831 & 1775 \\
\hline Theunissen & Joseph & - & - & 1775 \\
\hline Gewels & M. & - & - & 1783 \\
\hline Augustinus & Johannes & 1763 & 1790 & 1785 \\
\hline Ullix & Ivo & - & - & 1788 \\
\hline Joostem & Leonard Guillaume & 1762 & 1849 & 1795 \\
\hline Magchiels & c. & - & - & 1800 \\
\hline Jans & Joseph & 1764 & 1814 & 1814 \\
\hline Thonissen & Mathien I. & \pm 1787 & 1819 & 1814 \\
\hline Ceysens & Joseph & 1790 & $\lfloor 873$ & 1820 \\
\hline Gerarts (Geraets) & Joarnnes Michael Gaspar & 1791 & 1859 & 1820 \\
\hline Bielen & & - & - & 1825 \\
\hline Joosten & Amoldus Jacobus & 1.798 & 1856 & 1825 \\
\hline Lambrechts & Josephus Gerarcus Eduardus & 1806 & - & 1827 \\
\hline Joosten en Zn. & & - & - & 1845 \\
\hline Joosten & Marcel & - & - & 1850 \\
\hline Jans & Henri & - & - & 1850 \\
\hline Loets & Wouter & - & - & $?$ \\
\hline \multicolumn{5}{|c|}{ Heer (Geneente Maastrichth) } \\
\hline Lespinasse & Jean Noe de & 1734 & 1803 & 1755 \\
\hline \multicolumn{5}{|l|}{ Heerlen } \\
\hline Beeckers & Jacob & $=$ & - & 1679 \\
\hline Howtem & Joannes van & - & - & 1693 \\
\hline Kolen & Wilhelmus & - & - & 1696 \\
\hline Brischou & Guillaume & 1.754 & - & 1786 \\
\hline Brink & Samuel ten & - & - & 1811 \\
\hline \multicolumn{5}{|l|}{ Herk-de-Stad } \\
\hline Clingernans & Mattheus & - & - & 1446 \\
\hline Jaspers & Pieter & 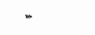 & - & 1665 \\
\hline Joris & Lambricht & - & - & 1665 \\
\hline Schonaers & Armold & - & - & 1852 \\
\hline Reck & $S$ & - & - & 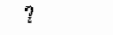 \\
\hline
\end{tabular}




\begin{tabular}{|c|c|c|c|c|}
\hline WAM & NOOMNAAM & CWR. & OVERL. & WERK $Z_{*}$ \\
\hline \multicolumn{5}{|l|}{ Hewdien } \\
\hline Hotid: & Petrus wan & - & - & 1790 \\
\hline \multicolumn{5}{|l|}{ Heytlinuysen } \\
\hline Retisen & Thorstas & 1724 & 7784 & 1750 \\
\hline Rnctsen & Hentriews: & 1735 & 1813 & 1760 \\
\hline Raetsery & Matthias Sr. & 1745 & 1816 & 1770 \\
\hline Retretsen & Johannes & 1774 & 1848 & 1795 \\
\hline Raetsen & Matthilas $\mathrm{Jr}$. & 1785 & 1844 & 1810 \\
\hline Raetsen & Pieter Ios Fubert & 1822 & 1900 & 1850 \\
\hline Rejunen & Henricus & 1826 & 1907 & 1850 \\
\hline \multicolumn{5}{|l|}{ Horst } \\
\hline Trommar & Nicolatas & - & 1794 & 1768 \\
\hline Grosffeli & Ferdinam(d)t & 1757 & $>1799$ & 1775 \\
\hline Trommar & Gerard & 1769 & - & 1790 \\
\hline Schampers & Frans & 1777 & 1857 & 1800 \\
\hline Trommar & Johannes $\mathrm{Sr}_{\text {r. }}$ & 1772 & 1848 & 1800 \\
\hline Trommrnar & Joannes $\mathrm{Jr}$ & 1798 & 1.876 & 1825 \\
\hline Tromemar & Franciscus Nicolaras & 1809 & 1894 & 1830 \\
\hline Trommmar & Joseph & 1827 & 1896 & 1850 \\
\hline \multicolumn{5}{|l|}{ Intlervoont } \\
\hline Pol & Joanyes van & 1766 & 1851 & 1816 \\
\hline \multicolumn{5}{|l|}{ Kelpen } \\
\hline Pol & Joanthes van & 1766 & 1851 & 1800 \\
\hline Pol & Petrus van & 1791 & 1859 & 1813 \\
\hline \multicolumn{5}{|l|}{ Kinrooy } \\
\hline Symkens & Hendrilk & 1764 & $<1808$ & 1790 \\
\hline \multicolumn{5}{|l|}{ Kleine Brogel } \\
\hline Faas & Dirk & - & - & 1770 \\
\hline \multicolumn{5}{|l|}{ Klelne Spauwen } \\
\hline Nulens (Nilens) & Mathijs & - & - & 1825 \\
\hline \multicolumn{5}{|l|}{ Leuth (bi) Venlo) } \\
\hline Noten & P.J & - & - & 1775 \\
\hline \multicolumn{5}{|l|}{ Limbunrg } \\
\hline Momnuer & Christiean & - & - & 1762 \\
\hline Poorten & H.T(er?) & - & - & 1764 \\
\hline K. & P. & - & $*$ & 1770 \\
\hline K. & G.D. & - & - & 1772 \\
\hline \multicolumn{5}{|l|}{ Lommel } \\
\hline Booms & Adolf & - & .. & 1789 \\
\hline Lampen & Matthias & - & ".' & 1800 \\
\hline \multicolumn{5}{|l|}{ Lutterade } \\
\hline Wessells & Peter & 1685 & 1753 & 1713 \\
\hline \multicolumn{5}{|l|}{ Manstbracht } \\
\hline Weijs & Gerard de & - & $\infty$ & 1810 \\
\hline \multicolumn{5}{|l|}{ Mangeik } \\
\hline Vuaht & Pieter van (dler Custer) & ” & $\approx$ & 1600 \\
\hline Alers & Corsi & - & - & 1619 \\
\hline
\end{tabular}




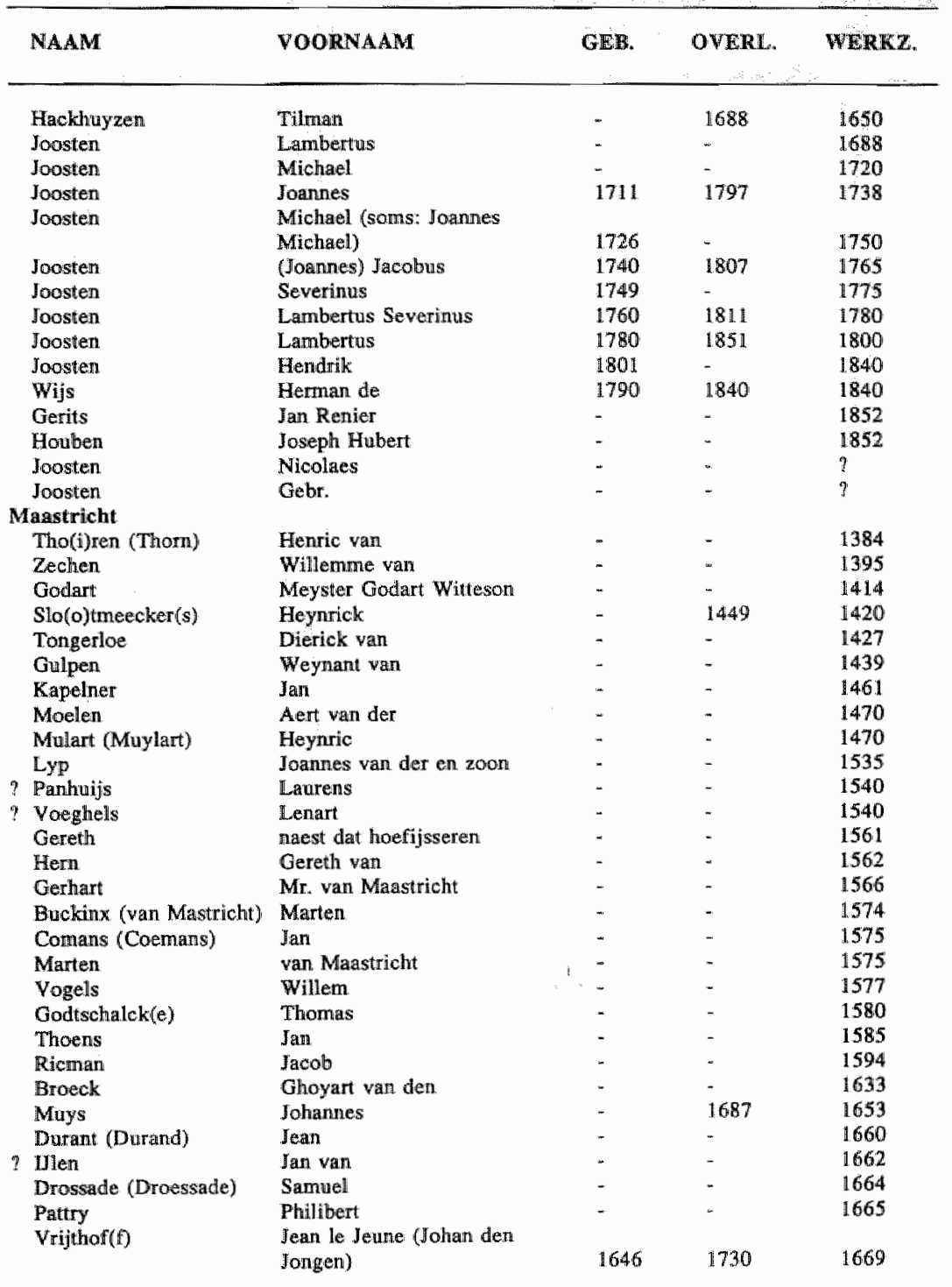




\begin{tabular}{|c|c|c|c|c|}
\hline WAAM & VODWNAAMI & GEB & OVERI & WERK $Z$. \\
\hline \multirow[t]{2}{*}{ Wrijthof(f) } & Jean le Jevme Gothan den & & & \\
\hline & Jongen) & 1651 & 1716 & 1670 \\
\hline Maurilissetn: & Jacob & $\omega$ & 1733 & 1678 \\
\hline Vrijthoff & Philippus & 1664 & $>1683$ & 1680 \\
\hline Vrijthioff & Jollannes Lambertus & 1657 & $<1715$ & 1685 \\
\hline Smissen & Johamness van der & - & - & 1700 \\
\hline Mijnis (Minis, Menis) & Leonardus & - & 1726 & 1710 \\
\hline Vrijthoff & Johanmes Hermanus & 1689 & - & 1720 \\
\hline Mijnis & Willen Sr. & - & 1737 & 1726 \\
\hline Mijnis & Willem li. & - & - & 1733 \\
\hline Neve & Armold de & 1712 & 1776 & 1740 \\
\hline Perrier & $?$ & - & - & 1740 \\
\hline Beefe & François de & 1718 & 1794 & 1745 \\
\hline Guilbert & Francoiss Micolas & 1720 & - & 1750 \\
\hline Penkert & Johan Ulrich & 1720 & - & 1750 \\
\hline Vrijthoff & Johannes Bernardus & 1724 & 1800 & 1750 \\
\hline Theuwissen & Jacobas & 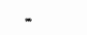 & . & 1758 \\
\hline Jon(c)kers & Jean Sebastiaan & 1739 & 1826 & 1760 \\
\hline Bach & Emanuel & 1735 & - & 1770 \\
\hline Sabrouskit & N. & - & - & 1771 \\
\hline Croissant & Nicolas & 1749 & - & 1774 \\
\hline Beefe & François Denis de & 1759 & 1794 & 1775 \\
\hline Detriche & & - & - & 1775 \\
\hline Hamaide & Gierard & 1744 & 1813 & 1775 \\
\hline Neve & Franciscus: Winandus de & 1747 & 1820 & 1775 \\
\hline Neve & Francischs Dominicus de & 1750 & 1811 & 1775 \\
\hline Beefe & Aegidius Nicolaas de & 1750 & - & 1780 \\
\hline Woasmer (Wasmeer) & Antonius: & 1767 & - & 1790 \\
\hline Fraiture & Ambroise & - & $<1802$ & 1793 \\
\hline Fraiture & Joseph & 1768 & 1813 & 1795 \\
\hline Fraiture & Guillewme Antoine & - & 1808 & 1795 \\
\hline Saint & $\mathrm{HI}, \mathrm{I}$ & - & - & 1795 \\
\hline Beckers & Willielmus Jacobus & 1773 & 1812 & 1800 \\
\hline Fraiture & François & 1774 & 1844 & 1800 \\
\hline Wilmottle & Joarnes: Stephanus & 1771 & 1841 & 1800 \\
\hline Donssert & Frederique Guillatume & 1770 & - & 1801 \\
\hline Goos & J. & 1783 & - & 1802 \\
\hline Bayet & & - & . & 1807 \\
\hline Wagemans & Lodewijk Servaas & 1778 & $\ldots$ & 1810 \\
\hline Jonckers & Micolaus Liambertus & 1781 & 1862 & 1810 \\
\hline Gillard & Mathieu Leonard Joseph & 1782 & $\infty$ & 1810 \\
\hline Bertrisnd & Willem Hendrik & 1783 & 1866 & 1810 \\
\hline Bourdonix & Jeary lacques & 1786 & - & 1810 \\
\hline Hamoir & Jean François Nicolas & 1788 & 1856 & 1815 \\
\hline Beckers & Leonard & 1782 & 1855 & 1816 \\
\hline Scheepers & Joseph & $*$ & - & 1818 \\
\hline Binge & Pieter Theodorus: & 1798 & - & 1820 \\
\hline
\end{tabular}




\begin{tabular}{|c|c|c|c|c|}
\hline NAAM & VOORNAMM & GEB. & OVERL. & WERKZ. \\
\hline Rutten & Franciscus Dominicus & 1790 & 1864 & 1820 \\
\hline Hamoir & Theodoor Michiel & 1796 & - & 1825 \\
\hline Scholberg & Cornelis Josephus & 1801 & 1871 & 1828 \\
\hline Arenz & Benediet & 1803 & 1881 & 1835 \\
\hline Bril & Andreas & 1816 & 1895 & 1840 \\
\hline Delconmune & Nicolas & - & - & 1840 \\
\hline Doppler & Lambertus Nicolaus & 1817 & 1887 & 1840 \\
\hline Bertrand & Jan Williem & 1818 & 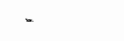 & 11845 \\
\hline Schöpping & August Hermann Wilhelm & 1816 & - & 1847 \\
\hline Wesley & Henry & 1819 & na 1884 & 1849 \\
\hline Jonakers & Hubert & 1820 & - & 1849 \\
\hline Arenz & Albert & 1833 & 1906 & 1850 \\
\hline Horsmans & Henricus: & 1834 & 1899 & 1850 \\
\hline Jonckers & Joannes, Carolus, Hubertus & 1821 & 1888 & 1850 \\
\hline Scherzinger & Roman & 1.823 & - & 1850 \\
\hline Jonckers & J.L.J.". & - & - & 1855 \\
\hline Mulder & Th. of $\mathrm{J}$. & - & - & 1855 \\
\hline Rutten & J. & 1830 & - & 1855 \\
\hline Mulder & Theodorns Adrianus Franciscus & - & - & 1874 \\
\hline Bemmel & L.N. van & - & - & 1875 \\
\hline Jonckers & J.H.H.T. & - & - & 1875 \\
\hline Raeven & (G. (of L.) A.J. & - & - & 1875 \\
\hline Horstruans & Guillaume Henri & - & - & 1880 \\
\hline \multicolumn{5}{|l|}{$\begin{array}{l}\text { Hotstrins } \\
\text { Meeuwen }\end{array}$} \\
\hline $\operatorname{Max}$ & Gaspard & 1833 & 1910 & 1855 \\
\hline \multicolumn{5}{|l|}{ Meldert } \\
\hline Beeckman & J. & - & & 1825 \\
\hline \multicolumn{5}{|c|}{ Millen (bij Tongeren) } \\
\hline Valkenborck & Jean & - & - & $?$ \\
\hline \multicolumn{5}{|l|}{ Molenbeersel } \\
\hline \multirow{2}{*}{\multicolumn{5}{|c|}{ Mook }} \\
\hline & & & & \\
\hline Hanssen & Andries & 1672 & - & 1700 \\
\hline \multicolumn{5}{|l|}{ Nederweert } \\
\hline Smeets & M. & s. & - & 1720 \\
\hline Gielissen & P.A. & - & . & 1778 \\
\hline Goossens & Mr. & - & - & $₫ 780$ \\
\hline Hobus & M. & - & - & 1780 \\
\hline Hobus & Godefridus & - & 1794 & 1782 \\
\hline Feyen. & Wilhelmnas & - & - & 1794 \\
\hline Michiels & Godefridus & 1766 & - & 1794 \\
\hline Houtappels & Wilhelmus & 1770 & 1846 & 1795 \\
\hline \multicolumn{5}{|l|}{ Neeritter } \\
\hline Winckel & Lambert van de & 17.42 & 1804 & 1782 \\
\hline Geelen & J. & - & - & 1810 \\
\hline Gielissen & L. & - & - & 1820 \\
\hline
\end{tabular}




\begin{tabular}{|c|c|c|c|c|}
\hline NAM & VOORNAAM & GEB. & OVERL. & WIRKKZ: \\
\hline \multicolumn{5}{|l|}{ Nertpell } \\
\hline Jaten & & - & . & 1800 \\
\hline \multicolumn{5}{|l|}{ Niel (hi) stont-Truiden) } \\
\hline Leaw Lectw & H. $\operatorname{van}$ & - & - & 1775 \\
\hline Ruppol & Jorís & - & - & 1810 \\
\hline \multicolumn{5}{|l|}{ Noorbeek } \\
\hline Stiellen & Joan & - & - & 1773 \\
\hline \multicolumn{5}{|l|}{ Oirgbeels } \\
\hline Kleiry & Joannes Arnoddus & 1795 & . & 1819 \\
\hline \multicolumn{5}{|l|}{ Ool } \\
\hline \multicolumn{5}{|l|}{ Opglabberk } \\
\hline Pe(e)ters & Matthieo: & 1772 & 1848 & 1800 \\
\hline Pe(e)ters & N.L. $=M . !$ & 1772 & 1848 & 1800 \\
\hline Peresters & $\operatorname{Ian}$ & 1809 & $>1874$ & 1838 \\
\hline Percesturs & P.J. (-Jan?) & $m$ & - & $?$ \\
\hline \multicolumn{5}{|l|}{ Owerpell } \\
\hline Lquentur & M. & - & - & 1850 \\
\hline \multicolumn{5}{|l|}{ Peer } \\
\hline Nouten & Aert & - & - & 1589 \\
\hline Crifns & Adrien Martin & 1758 & 1836 & 1790 \\
\hline \multicolumn{5}{|l|}{ Posterholt } \\
\hline Posterholt & den Horlogennaker wan & - & - & 1710 \\
\hline Borgh & Hendrik van den & 1735 & 1766 & 1760 \\
\hline \multicolumn{5}{|l|}{ Puth-Schingmen } \\
\hline Franken & & - & - & 1800 \\
\hline Dieteran & (Peter) Nicolaas & 1833 & 1918 & 1860 \\
\hline \multicolumn{5}{|l|}{ Rekeni } \\
\hline Joosten & Jacob Willem & 1801 & 1867 & 1835 \\
\hline \multicolumn{5}{|l|}{ Rimburg } \\
\hline Loogen & Jan Willem &. & 1857 & 1825 \\
\hline Loogen & Willem Joseph & 1826 & - & 1850 \\
\hline \multicolumn{5}{|l|}{ Roermond } \\
\hline Robijns & Tilman ( $=V_{\text {an }}$ Stefensweert?) & - & 1599 & 1588 \\
\hline S1. Stefensweert & Mr. Tilmaru van & $\infty$ & 1599 & 1599 \\
\hline Vuscht & Derick wan & - & - & 1600 \\
\hline Broatbyl & Marcus & - & - & 1629 \\
\hline Berentsen van Thiel & Johan & - & - & 1634 \\
\hline Gruter & Gerar: & * & - & 1670 \\
\hline Simons & Phillppus Jacobus & 1655 & 1734 & 1675 \\
\hline Nicolnes & Steven & - & - & 1684 \\
\hline Doux & Franquis le & $*$ & $=$ & 1732 \\
\hline Beltiens & Hertunanus & 1593 & 1778 & 1735 \\
\hline Andritssens & Godefridus & - & - & 1744 \\
\hline Belt jens & Joannes Reinerus & 1730 & 1803 & 1755 \\
\hline Belt Hens & Hermanus Petrus & 1763 & 1839 & 1790 \\
\hline Diconisy & Theodorus Franciscus & 1764 & 1855 & 1790 \\
\hline
\end{tabular}




\begin{tabular}{|c|c|c|c|c|}
\hline NAAM & VOORNAAM & GEB: & OVERL. & WERRZ. \\
\hline Beltjens & (Joames) Franciscus & 1.776 & 1846 & 1800 \\
\hline Nijs & Joannes Franciscus & 1776 & 1857 & 1800 \\
\hline Beltjens & Jean Michel & 1.781 & 1870 & 1810 \\
\hline Beltjens & Michel Antonins Hubertus & 1799 & 1870 & 1825 \\
\hline Burgers (Burgens) & Petrus Matthias & 1798 & 1865 & 1830 \\
\hline Beltjens & Henricus (m.H.R.?) & 1810 & - & 1835 \\
\hline Maesen & Gerard & 1809 & . & 1835 \\
\hline Hoten & Gottschallc & 1817 & - & 1840 \\
\hline Scholberg & Comelis Josephus & 1801 & 1871 & 1845 \\
\hline Janssens & Frans Hubert & 1824 & - & 1850 \\
\hline Wilms & Gustave & 1833 & .. & 1860 \\
\hline Scholberg & Constantius Hubartus Johannes & 1835 & - & 1860 \\
\hline Regter & Quirinus C. & 1821 & - & 1868 \\
\hline Scholberg & Leopold Johan Hubert & 1841 & - & 1870 \\
\hline Voldentberg & Peter P. & 1842 & - & 1870 \\
\hline Bussel & Petrus Johannes van & $18: 55$ & - & 1877 \\
\hline Regter & Herman Juilius & 1853 & - & 1880 \\
\hline Eyck & Jacobus Martînas & 1859 & - & 1885 \\
\hline Trommar & Frans Nicolaas & 1874 & - & 1888 \\
\hline Regter & Hubertus & 1861 & - & 1890 \\
\hline Croonenberg & Theodoras Hubertus & 1865 & - & 1890 \\
\hline Schumidt & Max Wolter & 1870 & - & 1890 \\
\hline Eynde & A. van de & - & - & 1890 \\
\hline \multicolumn{5}{|l|}{ Rosmeer } \\
\hline Dechen (Doyen) & Hubert & 1728 & * & 1760 \\
\hline Mertens & Joannes & - & - & 1790 \\
\hline \multicolumn{5}{|l|}{ Schinmen } \\
\hline Hagen & MuJ. & - & - & 1810 \\
\hline \multicolumn{5}{|l|}{ Sevenum } \\
\hline Raemaeckers & R. & - & - & 1785 \\
\hline \multicolumn{5}{|l|}{ Sittard } \\
\hline ? Moris & Lemart & - & - & 1712 \\
\hline Leurs & Jan Willem (Jean Guillanme) & 1767 & 1839 & 1790 \\
\hline Ancion & Jean Lambert & 1795 & - & 1812 \\
\hline Dewever & Jan Leonard & 1795 & 1872 & 1818 \\
\hline Schmidtnagel & Gerard Jos & 1816 & - & 1847 \\
\hline Horen. & Gottschalc & 1817 & - & 1847 \\
\hline Dewever & Jan Joseph Godfried & 1823 & 1885 & 1847 \\
\hline \multicolumn{5}{|l|}{ Sint-Odiliënberg } \\
\hline Jansser & Gerardus & 1759 & 1827 & 1789 \\
\hline \multicolumn{5}{|l|}{ Sint-Truiden } \\
\hline Smets & Gerard & - & - & 1750 \\
\hline Dumont & Medard & 1746 & 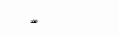 & 1774 \\
\hline Nieuwenbo(u)rg(h) & Jean Baptista van & 1750 & 1821 & 1.775 \\
\hline Nierbe(e)ck & Jean Chretien van & 1778 & - & 1800 \\
\hline Mancor(s) & Simon & 1781 & - & 1805 \\
\hline Dumont & Theodore & 1782 & - & 1808 \\
\hline
\end{tabular}




\begin{tabular}{|c|c|c|c|c|}
\hline NANM & VOORNAAW & GEW. & OVERL. & WERKZ. \\
\hline Dumont & Henti & 1786 & - & 1808 \\
\hline Niewenbo(u)rg(h) & Henuri Joseph van & 1784 & - & 1810 \\
\hline Vanetmen & Melchior Jacgues & 1823 & - & 1850 \\
\hline \multicolumn{5}{|l|}{ Stein. } \\
\hline $\mathrm{S}(\mathrm{ch})$ leedgel & Mathi(j)s & - & - & 1780 \\
\hline Camp & I. op den & - & - & 1800 \\
\hline Ruskens & $\mathrm{G}$ & - & $\infty$ & 1825 \\
\hline \multicolumn{5}{|l|}{ Stewensweert } \\
\hline \multirow[t]{2}{*}{ Robijns } & \multirow{2}{*}{$\begin{array}{l}\text { Tilmain (ster smyet Mr. } \\
\text { Tilman vam St. Stefensweent?) }\end{array}$} & & & \\
\hline & & - & - & 1578 \\
\hline Kuijpers & Theodorus: & 1750 & 1820 & 1790 \\
\hline \multicolumn{5}{|l|}{$\begin{array}{l}\text { Mutupers } \\
\text { Stewoot }\end{array}$} \\
\hline Creteri & Gilis: & 1797 & - & 1836 \\
\hline \multicolumn{5}{|l|}{ Stisteren } \\
\hline Rouers & Matthias & 1747 & 1802 & 1770 \\
\hline \multicolumn{5}{|l|}{ Swalmen } \\
\hline Stigeneer (Stignaitre) & Prederik & 1799 & 1838 & 182.1 \\
\hline \multicolumn{5}{|l|}{ Tessenderlo } \\
\hline Vliegen & Henry & - & $*$ & 1775 \\
\hline \multicolumn{5}{|l|}{ Thorn } \\
\hline Schoufs & Jacobus $\mathrm{Sr}$. & 1730 & 1792 & 1759 \\
\hline Schoufs & Joannes Balthasar & 1765 & 1815 & 1788 \\
\hline Schoufs: & Mathias & 1777 & 1853 & 1800 \\
\hline Schoufs: & Dominicus & 1772 & 1839 & 1800 \\
\hline Schoufs & Jacobus Antonius Jr. & 1794 & - & 1814 \\
\hline Schorifs & Clement & 1797 & $<1854$ & 1825 \\
\hline Tonnaier & Dominianue Lambert. & 1816 & 1870 & 1840 \\
\hline Pol & Hendrik van. & 1826 & $>1874$ & 1867 \\
\hline \multicolumn{5}{|l|}{ Tongeren } \\
\hline Dekens (Decani) & Janne:s (Jolinannes) & - & - & 1413 \\
\hline Dekens & Thomas Sr. (alias Maes Dekens) & - & - & 1477 \\
\hline Moes & Meester & - & - & 1506 \\
\hline Ho(e)len & Ghijsbrecht & - & - & 1510 \\
\hline Dekens & Thomas $\mathrm{J}$ & - & - & 1515 \\
\hline Ho(e)len & Ghi,js: & - & - & 1550 \\
\hline Bochstey (Boechten) & Salomon de & - & - & 1560 \\
\hline Lenart & wan Tongeren & - & 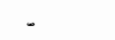 & 1562 \\
\hline Hoelen & Michtiel & - & 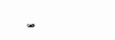 & 1565 \\
\hline Eijeken & Peter van der & - & - & 1580 \\
\hline Mellarts (wan Meldent) & Johamies: & * & $\infty$ & 1594 \\
\hline Keyen & Johitannes: & * & 1667 & 1638 \\
\hline Keyen & Matthiys & - & - & 1665 \\
\hline Adam. & Hubertus & - & - & 1667 \\
\hline Hendrick & dent Forologienaeker & - & - & 1690 \\
\hline Von $(c)$ kern & Willem & - & - & 1700 \\
\hline Willems & M. & - & . & 1700 \\
\hline Hansmins (Huysmans) & Nicolas (Claus) & 1672 & - & 1709 \\
\hline
\end{tabular}




\begin{tabular}{|c|c|c|c|c|}
\hline NAAM & YOORNAAM & GEB & OVERL & WERKR. \\
\hline Marchant & Lawrent & - & - & 1726 \\
\hline Huysmans (Elausmans) & Jahannes Wilhelmus & . & - & 1748 \\
\hline Vrints & Hobertus & . & - & 1749 \\
\hline Dumon & $\mathbb{D}$ & - & - & 1750 \\
\hline Gerets & Wilhelmus & - & * & 1,751 \\
\hline Maquoy & Henricus: & - & - & 1763 \\
\hline Even & H. & - & - & 1775 \\
\hline Petershem & Johannes Lambertus: & - & -. & 1777 \\
\hline Mertens & Martinus & - & - & 1783 \\
\hline Laminne & Matthias & - & w & 1789 \\
\hline Aerts & Jean Guillanme (Jan Willem) & 1786 & 1864 & 1813 \\
\hline Smolders & M.C. & - & - & 1830 \\
\hline \multicolumn{5}{|l|}{ Tongerlo } \\
\hline Soors & Jacob & * & - & 1850 \\
\hline \multicolumn{5}{|l|}{ Vaalis } \\
\hline Schoeler & Winand & - & - & 1668 \\
\hline Promper & Jean Hubert & 1786 & 1856 & 1810 \\
\hline Prompeler & Jacob Hubert & 1814 & m & 1856 \\
\hline \multicolumn{5}{|l|}{ Valkenburg aal de Geul } \\
\hline Vrijthoff & Lambertus & 1690 & 1769 & 1716 \\
\hline \multicolumn{5}{|l|}{ Veldwezelt } \\
\hline Flardy & P. & - & .. & 1825 \\
\hline \multicolumn{5}{|l|}{ Venlo } \\
\hline Goutsmeyt & Jan & - & - & 1389 \\
\hline Bartscherre & Peter & - & - & 1449 \\
\hline Coster van Breije & Wilhelm & - & - & 1532 \\
\hline Jan & den Derwercker (Ohrwercker) & - & $\omega$ & 1574 \\
\hline Raeil & Hendrik van & * & - & 1582 \\
\hline Janssen & Pasquier & - & - & 1651 \\
\hline Terpoorten & Derick & - & - & 1705 \\
\hline Pelt & Matthijs wan & - & - & 1735 \\
\hline Poeljin & Joannes (Michael?) & - & - & 1735 \\
\hline Terpoorten & Bermardus & - & - & 1749 \\
\hline Hoeckx (Hockx) & Leonard & 1720 & 1815 & 1750 \\
\hline Hoeven & Johannes Ferdinand van der & 1750 & 1812 & 1780 \\
\hline Boom & Christiaan Jozef wan & 1774 & 1859 & 1800 \\
\hline Wassenberg(h) & Jan Frans & 1779 & 1840 & 1800 \\
\hline Kentler & Joseph Jacob & 1779 & 1861 & 1810 \\
\hline Grinten & Jan Willem Jacob van der & 1790 & 1840 & 1812 \\
\hline Boom & Joseph Frans van & 1806 & 1844 & 1830 \\
\hline Kenller & Auguste & 1808 & 1867 & 1830 \\
\hline Gruyter & Ferdinand Johannes de & 1806 & - & 1840 \\
\hline Brandt & Comelis wan den & - & - & 1842 \\
\hline Grinten & Johannes Josephus Wilhelm var & 1823 & 1900 & 1847 \\
\hline Keijzer & Auguste & 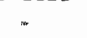 & - & 18.50 \\
\hline
\end{tabular}




\begin{tabular}{|c|c|c|c|c|}
\hline NAMM & VOORNAMA & GEB. & OVERL. & WERKX. \\
\hline \multicolumn{5}{|l|}{ Vemray } \\
\hline Onckels & Jarn & $=$ & - & 1655 \\
\hline Beckers & Hendrick & - & - & 1750 \\
\hline Becker & Jacobus & • & $\approx$ & 1760 \\
\hline Briene(n) (Bnijnen) & Joannes & \pm 1750 & 1788 & 1774 \\
\hline Beckers & Petrus Joannes & 1748 & 1821 & 1775 \\
\hline Ysermans & Willem & - & - & 1785 \\
\hline Zelen & Arnold & - & . & 1788 \\
\hline Dijok & Martinus valn & - & - & 1820 \\
\hline Welter & Alexander & - & - & 1820 \\
\hline Kayck & Matys wan & $\infty$ & - & 1829 \\
\hline Trommar & Prancisters? & 1803 & - & 1830 \\
\hline \multicolumn{5}{|l|}{ Weert } \\
\hline Herleine & Wijman & - & 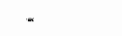 & 1594 \\
\hline Weyngaent (Wingat) & Mathias wan de(n) & - & 1792 & 1738 \\
\hline Greg(r)oir(e) & Nicolas Joseph & - & 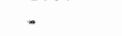 & 1760 \\
\hline Smeets & $\mathrm{M}$ & - & - & 1770 \\
\hline Coster & Petrus Andreas de & 1751 & $>1796$ & 1775 \\
\hline Wijngaed (Weijnggert) & Petronella varn den. & 2741 & - & 1790 \\
\hline Geneygen & & - & - & 1800 \\
\hline Truyens & $\mathbb{P}, \mathrm{G}_{n}$ & - & - & 1808 \\
\hline Bocken & Reinier & - & - & 1810 \\
\hline Dellaive & Jean Nicolas & 1772 & 1843 & 1810 \\
\hline Howtakkers & Jakob & 1790 & 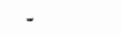 & 1820 \\
\hline \multirow{6}{*}{$\begin{array}{l}\text { Scholberg } \\
\text { Jansen } \\
\text { Dirix } \\
\text { Regter } \\
\text { Schneken } \\
\text { Dirix }\end{array}$} & Cornells Josephus & 1801 & 1871 & 1825 \\
\hline & Bonaventura Joseph & 1806 & 1882 & 1835 \\
\hline & J.M. en Zn & - & - & 1850 \\
\hline & Quirimes $\mathrm{C}$. & 1.821 & - & 1850 \\
\hline & J.A.J & * & - & 1850 \\
\hline & Petrus Mathias & 1835 & - & 1860 \\
\hline \multicolumn{5}{|c|}{ Well } \\
\hline Remment (alias Lenssen) & $\operatorname{Jan} S_{r}$ & \pm 1660 & 1716 & 1688 \\
\hline Remment & Comelis & \pm 1700 & 1775 & 1725 \\
\hline Remment & Rembout (alias Remigins) & \pm 1700 & 1758 & 1725 \\
\hline Remment & $\operatorname{Ian}$ Peter & 1738 & 1795 & 1765 \\
\hline Remmen & A lexius Cornelius & 1740 & 1822 & 1770 \\
\hline Remmen & Petrus & 1770 & 1841 & 1800 \\
\hline Bouten & $\mathrm{T}$ & $\infty$ & - & 1851 \\
\hline \multicolumn{5}{|l|}{ Wellen } \\
\hline Lutet: & P.J. & . & - & 1828 \\
\hline \multicolumn{5}{|l|}{ Weyer } \\
\hline Jooken & J. & - & - & 1850 \\
\hline \multicolumn{5}{|l|}{ Wijle } \\
\hline Ackermatns & Hermanus & - & - & 1756 \\
\hline Brouwers: & Joannes Anton & - & - & 1791 \\
\hline \multicolumn{5}{|l|}{ Wonck } \\
\hline Moteau & Melot & - & - & 1660 \\
\hline
\end{tabular}




\begin{tabular}{|c|c|c|c|c|}
\hline NAAM & VOORNAAM & GER. & OVERL & WERKZ. \\
\hline \multicolumn{5}{|l|}{ Zepperea } \\
\hline Straelen & Laurens; van & - & - & 1775 \\
\hline \multicolumn{5}{|l|}{ Zonlhoven } \\
\hline Bielen & $\mathrm{H}$ & - & * & 1600 \\
\hline Bielen & F. & - & - & 1750 \\
\hline Pearters: & Johan & - & - & 1755 \\
\hline Bielen & Jean & 1753 & 1813 & 1775 \\
\hline Dellosie & P.J. & - & - & 1775 \\
\hline Bielen & J.H. & - & . & 1800 \\
\hline Bielen & Hendrik & 1763 & - & 1800 \\
\hline Willems & $\mathbf{F}$ & $\cdots$ & - & 1800 \\
\hline Bielen & Jan Arnold & 1808 & 1879 & 1835 \\
\hline \multicolumn{5}{|c|}{ Zuid-Limburg } \\
\hline Schlipper & Ger. & - & - & 1751 \\
\hline Steijn & de horlogiemaker & - & - & 1760 \\
\hline \multicolumn{5}{|l|}{ Zutendaal } \\
\hline Pe(e)ters & Thomas Sr. & 1732 & 1806 & 1756 \\
\hline Pe(e)ters & $\mathbf{F}_{n}$ & - & - & 1775 \\
\hline Pe(e)ters & Matthieu & 1772 & 1848 & 1795 \\
\hline Pe(e)ters & Jacques & 1785 & 1837 & 1810 \\
\hline Pe(e)ters & Thomas Jr. & 1811 & - & 1835 \\
\hline
\end{tabular}




\section{Curriculum vitae}

Peter Theodorus Rudolf Mestrom werd geboren op 10 januari 1941 te Posterholt. Aan het Bisschoppelijk College te Roermond volgde hij het gymnasium van 1953 tot 1959 , in welk jaar hij het diploma Gymnasium A behaalde. Daarna heeft hij aan de Katholieke Universiteit Nijmegen klassieke talen en letteren gestudeerd. Deze studie werd voltooid met het behalen van het doctoraaldiploma op 7 maart 1967. Na enige jaren leraar klassieke talen te zijn geweest, is hij vervolgens in enkele wetenschappelijke bibliotheekfuncties werkzaam geweest. 